\title{
Hazardous Waste Management
}

This chapter has been revised extensively as a result of the publication of the new AFI 32-7042 of 21 April 2009. Review it carefully in its entirety.

\section{Other Environmental Issues/EMS}

Checklist items have been added to O7.30, O7.40, and O7.60 to account for the release of DOD Instruction 4715.17, Environmental Management Systems, dated 15 April 2009.

\section{Other Environmental Issues/P2: Solid Waste}

This chapter has been revised as a result of the publication of the new AFI 32-7042 of 21 April 2009. Review it carefully in its entirety.

\section{Pesticide Management}

There are significant changes throughout this chapter occasioned by the release of new versions of AFI 321053 and AFI 32-1074. The chapter must be carefully reviewed in its entirety.

PM.53 has been added to address Armed Forces Pest Management Board Technical Guide No. 45, Storage and Display of Retail Pesticides, dated November 2006.

\section{POL}

Numerous checklist items have been revised due to the update of AFI 23-201. Search the MSWord document using the phrase "23-201" (without quotation marks) to review the changes.

PO.40 has been revised extensively. Each checklist item within this topic heading should be carefully reviewed.

\section{Solid Waste Management}

This chapter has been revised extensively as a result of the publication of the new AFI 32-7042 of 21 April 2009. Review it carefully in its entirety.

\section{Storage Tanks}

The Storage Tank chapter has been updated to account for new AFI 23-204; the definitions of org tank types have changed.

Checklist items ST.11.1.OCAF and ST.90.9.OCAF have been updated to account for the revision of AFI 23-201.

ST.90 has been revised extensively; every checklist item under this topic heading should be reviewed carefully. 
OCONUS Compliance Assessment Protocols Air Force Supplement

David A. Krooks

July 2008

Revised September 2009

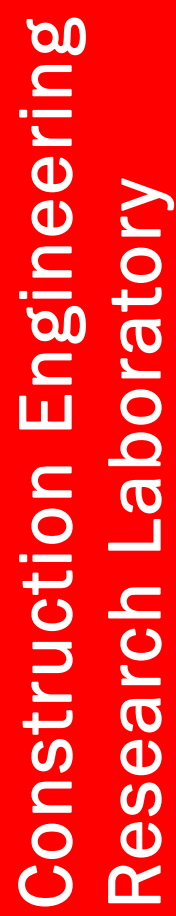





\section{OCONUS Compliance Assessment Protocols - Air Force Supplement}

David A. Krooks

Construction Engineering Research Laboratory (CERL)

U.S. Army Engineer Research and Development Center

2902 Newmark Dr.

Champaign, IL 61822-1076

Final Report

Approved for public release; distribution is unlimited.

Prepared for Headquarters, Air Force Center for Engineering and the Environment, TDN 3300 Sidney Brooks, Bldg. 532

Brooks City-Base, TX 78235-5112

Under MIPR F1JFAA8319G001 


\begin{abstract}
This environmental compliance assessment manual is based on Air Force Instructions and Department of Defense documents that apply to installations overseas. It is intended for use by the United States Air Force and should be used in conjunction with a manual based on the Final Governing Standards for the relevant host nation.
\end{abstract}

DISCLAIMER: The contents of this report arenot to beused for advertising, publication, or promotional purposes. Citation of trade names does not constitute an official endorsement or approval of the use of such commercial products. All product names and trademarks cited are the property of their respective owners. The findings of this report are not to be construed as an official Department of the Army position unless so designated by other authorized documents. 


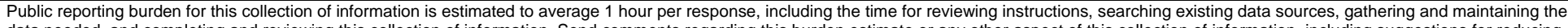

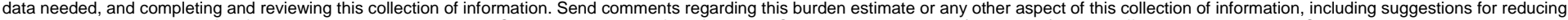

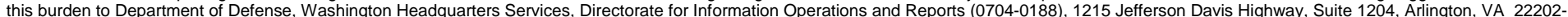

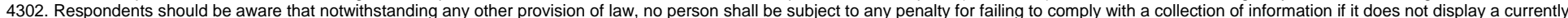
valid OMB control number. PLEASE DO NOT RETURN YOUR FORM TO THE ABOVE ADDRESS.
1. REPORT DATE (DD-MM-YYYY)
2. REPORT TYPE
3. DATES COVERED (From - To)

$17-07-2008$

Final

\section{TITLE AND SUBTITLE}

OCONUS Compliance Assessment Protocols - Air Force Supplement

Fin TYPE

5a. CONTRACT NUMBER

5b. GRANT NUMBER

5c. PROGRAM ELEMENT

\section{AUTHOR(S)}

David A. Krooks, Ph.D.

\section{5d. PROJECT NUMBER}

MIPR

5e. TASK NUMBER

5f. WORK UNIT NUMBER

F1J FAA8319G001

7. PERFORMING ORGANIZATION NAME(S) AND ADDRESS(ES)

U.S. Army Engineer Research and Development Center (ERDC)

Construction Engineering Research Laboratory (CERL)

PO Box 9005,

Champaign, IL 61826-9005

8. PERFORMING ORGANIZATION REPORT NUMBER

ERDC/ CERL SR-08-11

Revised September 2009

\section{SPONSORING I MONITORING AGENCY NAME(S) AND ADDRESS(ES)}

Headquarters, Air Force Center for Engineering and the Environment, TDN

3300 Sidney Brooks, Bldg. 532

Brooks City-Base, TX 78235-5112

10. SPONSOR/MONITOR'S ACRONYM(S) AFCEE/TDN

11. SPONSOR/MONITOR'S REPORT NUMBER(S)

12. DISTRIBUTION I AVAILABILITY STATEMENT

Approved for public release; distribution is unlimited.

\section{SUPPLEMENTARY NOTES}

\section{ABSTRACT}

This environmental compliance assessment manual is based on Air Force Instructions and Department of Defense documents that apply to installations overseas. It is intended for use by the United States Air Force and should be used in conjunction with a manual based on the Final Governing Standards for the relevant host nation.

\section{SUBJECT TERMS}

environmental compliance, Environmental Compliance Assessment and Management Program, environmental compliance laws and regulations, environmental compliance checklists, protocols

\begin{tabular}{|c|c|c|c|c|}
\hline \multicolumn{3}{|c|}{ 16. SECURITY CLASSIFICATION OF: } & \multirow{2}{*}{$\begin{array}{l}\text { 17. LIMITATION } \\
\text { OF ABSTRACT } \\
\text { SAR }\end{array}$} & \multirow{2}{*}{$\begin{array}{l}\text { 18. NUMBER } \\
\text { OF PAGES } \\
650\end{array}$} \\
\hline $\begin{array}{l}\text { a. REPORT } \\
\text { Unclassified }\end{array}$ & $\begin{array}{l}\text { b. ABSTRACT } \\
\text { Unclassified }\end{array}$ & $\begin{array}{l}\text { c. THIS PAGE } \\
\text { Unclassified }\end{array}$ & & \\
\hline
\end{tabular}

19a. NAME OF RESPONSIBLE PERSON

19b. TELEPHONE NUMBER (include area code) 


\section{Comment Form}

Comments and questions regarding the OCAP-AF Protocols can be addressed to:

David A. Krooks, Ph.D.

e-mail david.a.krooks@usace.army.mil

phone 217-373-3432, 1-800-USACERL (ext. 3432), or

FAX 217-373-3430

DSN: 312-643-3432/3430

Please include the following information with your comment(s):

User Name:

Affiliation (installation, command, etc.):

email:

Phone:

FAX:

\begin{tabular}{|c|c|l|l|}
\hline $\begin{array}{c}\text { Page } \\
\#\end{array}$ & $\begin{array}{c}\text { Checklist } \\
\text { item \# }\end{array}$ & Line \# & Comments \\
\hline & & & \\
& & & \\
\hline
\end{tabular}





\section{FOREWORD}

This compliance assessment manual is for use by the U.S. Air Force overseas. Air Force Instructions cited in this document are current through Air Force (AF) Product Announcement 17-09, dated 17 August 2009.

The research was performed for the Headquarters, Air Force Center for Environmental Excellence (HQ AFCEE), under Military Interdepartmental Purchase Request (MIPR) number F1JFAA8319G001, dated 14 November 2008. The HQ AFCEE technical monitor was Ms. Karen Winnie, HQ AFCEE/TDNC.

The research was performed by the Business Processes Branch (CN-B), Installations Division (CN), of the Construction Engineering Research Laboratory (CERL). The Principal Investigator was Dr. David A. Krooks, CN-B; Ms. Susan J. Bevelheimer, CN-B, was Associate Investigator. Ms. Michelle J. Hanson is Chief, CN-B. Dr. John Bandy is Chief, CN. Dr. Ilker R. Adiguzel is the Director of CERL.

CERL is an element of the U.S. Army Engineer Research and Development Center (ERDC), U.S. Army Corps of Engineers. The Commander and Executive Director of ERDC is COL Gary Johnston. The Director of ERDC is Dr. James R. Houston. 


\section{NOTICE}

This manual is intended as general guidance for personnel at Air Force (AF) facilities. It is not, nor is it intended to be, a complete treatise on environmental laws and regulations. Neither the United States Government nor any agency thereof, nor any of their employees, makes any warranty, expressed or implied, or assumes any legal liability or responsibility for the accuracy, completeness, or usefulness of any information contained herein. For any specific questions about, or interpretations of, the legal references herein, consult appropriate counsel. 


\begin{tabular}{|clc|}
\hline \multicolumn{3}{|c|}{ PROTOCOL SECTIONS } \\
\hline Section & \multicolumn{1}{|c|}{ Title } & Page \\
\hline 1 & Air Emissions Management & $1-1$ \\
2 & Cultural Resources Management & $2-1$ \\
3 & Hazardous Materials Management & $3-1$ \\
4 & Hazardous Waste Management & $4-1$ \\
5 & Natural Resources Management & $5-1$ \\
6 & Other Environmental Issues & $6-1$ \\
7 & Pesticide Management & $7-1$ \\
8 & Petroleum, Oils, and Lubricants (POL) Management & $8-1$ \\
9 & Solid Waste Management & $9-1$ \\
10 & Storage Tank Management & $10-1$ \\
11 & Toxic Substances Management & $11-1$ \\
12 & Wastewater Management & $12-1$ \\
13 & Water Quality Management & $13-1$ \\
\hline
\end{tabular}


Table 1

\section{Previsit Questionnaire}

\section{Installation:}

\section{Installation POC:}

Telephone Number (DSN and Commercial):

Fax Number (DSN and Commercial):

\section{E-mail:}

Date:

\begin{tabular}{|c|c|c|}
\hline General & YES & NO \\
\hline \multicolumn{3}{|l|}{$\begin{array}{l}\text { Do host nation authorities inspect the installation (or parts of it) or show particular interest in it in } \\
\text { some other way? }\end{array}$} \\
\hline \multicolumn{3}{|l|}{$\begin{array}{l}\text { Has the installation received notifications of noncompliance, complaints, or enforcement actions } \\
\text { from host nation agencies at the national, state, or local level? } \\
\text { If yes, what is the nature of the noncompliance, complaints, etc.? }\end{array}$} \\
\hline \multirow{4}{*}{\multicolumn{3}{|c|}{$\begin{array}{l}\text { Has the installation ever received a significant finding as a result of an external environmental } \\
\text { compliance assessment? }\end{array}$}} \\
\hline & & \\
\hline & & \\
\hline & & \\
\hline \multicolumn{3}{|l|}{ Is the installation currently the subject of litigation that concerns environmental issues? } \\
\hline \multicolumn{3}{|l|}{ Has the installation ever been the subject of litigation that concerns environmental issues? } \\
\hline \multicolumn{3}{|l|}{ Are there contaminated sites (old spill sites, dumps, etc.)? } \\
\hline \multicolumn{3}{|l|}{ a) Suspected? What is the suspected contaminant? } \\
\hline \multicolumn{3}{|l|}{ b) Validated? What is the contaminant? } \\
\hline \multicolumn{3}{|l|}{ c) Under assessment? What is the contaminant? } \\
\hline \multicolumn{3}{|l|}{ d) Under remediation? What is the contaminant? } \\
\hline \multicolumn{3}{|l|}{ Has the installation been identified for closure? } \\
\hline $\begin{array}{l}\text { Has the installation inherited quantities of undisposed waste or material? If yes, what and how } \\
\text { much? }\end{array}$ & & \\
\hline
\end{tabular}




\begin{tabular}{|c|c|c|}
\hline Air Emissions Management & YES & NO \\
\hline $\begin{array}{l}\text { Does the installation have an individual responsible for managing the air emissions program? } \\
\text { If yes, who? }\end{array}$ & & \\
\hline $\begin{array}{l}\text { Does the installation have any SOPs specific to air emissions issues? } \\
\text { If yes, pertaining to what? } \\
\text { (Please provide copies for review.) }\end{array}$ & & \\
\hline $\begin{array}{l}\text { Has the installation performed an air emissions inventory? } \\
\text { If yes, where is the copy kept and when was the inventory performed? }\end{array}$ & & \\
\hline $\begin{array}{l}\text { Does the installation have N/SM fossil-fuel-fired steam generating units with a heat input capac- } \\
\text { ity greater than } 100 \mathrm{MBtu} / \mathrm{h} \text { ? } \\
\text { (Please list the units and their size here or on the back of this page or attach a separate sheet.) }\end{array}$ & & \\
\hline $\begin{array}{l}\text { Does the installation have N/SM steam generating units or electric utility steam generating units } \\
\text { with a heat input capacity greater than } 100 \mathrm{MBtu} / \mathrm{h} \text { ? } \\
\text { (Please list the units and their size here or on the back of this page or attach a separate sheet. }\end{array}$ & & \\
\hline $\begin{array}{l}\text { Does the installation have steam generating units or electric utility or thermal heating units rated } \\
\text { greater than 100,000 Btu, whether N/SM or existing? } \\
\text { (Please list the units and their size here or on the back of this page or attach a separate sheet.) }\end{array}$ & & \\
\hline $\begin{array}{l}\text { Does the installation have any N/SM incinerators that burn more than } 50 \text { tons/day or more than } \\
10 \text { percent sewage sludge? } \\
\text { (Please list the units and their size here or on the back of this page or attach a separate sheet.) }\end{array}$ & & \\
\hline Does the installation operate any of the following: & & \\
\hline a) paint booths? & & \\
\hline b) rotary presses? & & \\
\hline c) carpentry shops? & & \\
\hline d) surface coating facilities? & & \\
\hline e) chemical dry cleaning plants? & & \\
\hline $\begin{array}{l}\text { Does the installation have any air emissions sources that are subject to continuous emissions } \\
\text { monitoring? } \\
\text { What are these sources? }\end{array}$ & & \\
\hline Are heated degreaser baths part of any industrial process on the installation? & & \\
\hline Are any of the installation's heating plants inspected by host nation authorities? & & \\
\hline $\begin{array}{l}\text { Does open burning occur on the installation? } \\
\text { If yes, for what purpose? }\end{array}$ & & \\
\hline
\end{tabular}




\begin{tabular}{|l|l|l|}
\hline Air Emissions Management & YES & NO \\
\hline $\begin{array}{l}\text { Has the installation received complaints from host nation individuals or agencies about its air } \\
\text { emissions? }\end{array}$ & & \\
What was the nature of the complaint? & & \\
\hline Have host nation agencies or authorities made any inquiries regarding air emissions? & & \\
\hline What was the nature of these inquiries? & & \\
\hline Additional observations: & \\
\hline
\end{tabular}




\begin{tabular}{|c|c|c|}
\hline Cultural Resources Management & YES & NO \\
\hline \multicolumn{3}{|l|}{$\begin{array}{l}\text { Does the installation have an individual responsible for the cultural resources management pro- } \\
\text { gram? If yes, who? }\end{array}$} \\
\hline \multicolumn{3}{|l|}{ Does the installation have any SOPs specific to cultural resources issues? } \\
\hline \multicolumn{3}{|l|}{ If yes, pertaining to what? } \\
\hline \multicolumn{3}{|l|}{ (Please provide copies for review.) } \\
\hline \multirow{2}{*}{\multicolumn{3}{|c|}{$\begin{array}{l}\text { Has an inventory of historic properties been conducted? } \\
\text { (Please provide a copy.) }\end{array}$}} \\
\hline & & \\
\hline \multicolumn{3}{|l|}{ Does the installation have a Cultural Resources Management Plan? } \\
\hline \multicolumn{3}{|l|}{ If yes, what is the date of the most recent signed plan? } \\
\hline \multicolumn{3}{|l|}{ (Please provide a copy.) } \\
\hline \multicolumn{3}{|l|}{$\begin{array}{l}\text { Are construction/demolition projects on potentially historic buildings coordinated with the envi- } \\
\text { ronmental office? }\end{array}$} \\
\hline \multicolumn{3}{|l|}{$\begin{array}{l}\text { Have human artifacts or human remains ever been discovered as part of routine installation op- } \\
\text { erations? }\end{array}$} \\
\hline \multicolumn{3}{|l|}{ If yes, what types of artifacts/remains? } \\
\hline \multicolumn{3}{|l|}{$\begin{array}{l}\text { Is the installation in control of any archaeological collection that may contain human remains, } \\
\text { funerary objects, or sacred objects? }\end{array}$} \\
\hline \multicolumn{3}{|l|}{$\begin{array}{l}\text { Has any host nation authority shown a particular interest in any on-installation } \\
\text { cultural/archaeological resource? }\end{array}$} \\
\hline \multicolumn{3}{|l|}{ If yes, which resources? } \\
\hline \multicolumn{3}{|l|}{$\begin{array}{l}\text { Has the installation received complaints from host nation individuals or agencies about cultural } \\
\text { resources issues? }\end{array}$} \\
\hline \multicolumn{3}{|l|}{ What was the nature of the complaint? } \\
\hline \multicolumn{3}{|l|}{ Have host nation agencies or authorities made any inquiries regarding cultural resources? } \\
\hline \multicolumn{3}{|l|}{ What was the nature of these inquiries? } \\
\hline Additional observations: & & \\
\hline
\end{tabular}




\begin{tabular}{|c|c|c|}
\hline Hazardous Materials Management & YES & NO \\
\hline \multicolumn{3}{|l|}{$\begin{array}{l}\text { Does the installation have an individual responsible for managing the hazardous materials pro- } \\
\text { curement and distribution program? }\end{array}$} \\
\hline \multicolumn{3}{|l|}{ If yes, who? } \\
\hline \multicolumn{3}{|l|}{ Does the installation have any SOPs specific to hazardous materials issues? } \\
\hline \multicolumn{3}{|l|}{ If yes, pertaining to what? } \\
\hline \multicolumn{3}{|l|}{ (Please provide copies for review.) } \\
\hline \multirow{2}{*}{\multicolumn{3}{|c|}{$\begin{array}{l}\text { Does the installation have clearly defined procedures for reporting hazardous material spills? } \\
\text { If yes, please provide a copy. }\end{array}$}} \\
\hline & & \\
\hline \multirow{2}{*}{\multicolumn{3}{|c|}{$\begin{array}{l}\text { Do any installation personnel transport hazardous materials on public roads? } \\
\text { If yes, where are the training records? }\end{array}$}} \\
\hline & & \\
\hline \multicolumn{3}{|l|}{ What kind of spill response capabilities does the installation have? } \\
\hline \multicolumn{3}{|l|}{ Does the installation store hazardous materials in any of the following: } \\
\hline \multicolumn{3}{|l|}{ a) storage rooms inside buildings? } \\
\hline \multicolumn{3}{|l|}{ b) storage buildings or warehouses? } \\
\hline \multicolumn{3}{|l|}{ c) outdoor storage areas? } \\
\hline \multirow{2}{*}{\multicolumn{3}{|c|}{$\begin{array}{l}\text { Does the installation have a battery shop? } \\
\text { Where is it? }\end{array}$}} \\
\hline & & \\
\hline \multirow{2}{*}{\multicolumn{3}{|c|}{$\begin{array}{l}\text { Does the installation have acid storage facilities? } \\
\text { Where are they? }\end{array}$}} \\
\hline & & \\
\hline \multirow{2}{*}{\multicolumn{3}{|c|}{$\begin{array}{l}\text { Does the installation have any hazardous substance USTs? } \\
\text { Where are they located? }\end{array}$}} \\
\hline & & \\
\hline \multirow{2}{*}{\multicolumn{3}{|c|}{$\begin{array}{l}\text { Does the installation store compressed gas cylinders? } \\
\text { If yes, in what type of facility? }\end{array}$}} \\
\hline & & \\
\hline \multicolumn{3}{|l|}{ Have host nation agencies or authorities made any inquiries regarding hazardous materials? } \\
\hline \multicolumn{3}{|l|}{ What was the nature of these inquiries? } \\
\hline Additional observations: & & \\
\hline
\end{tabular}




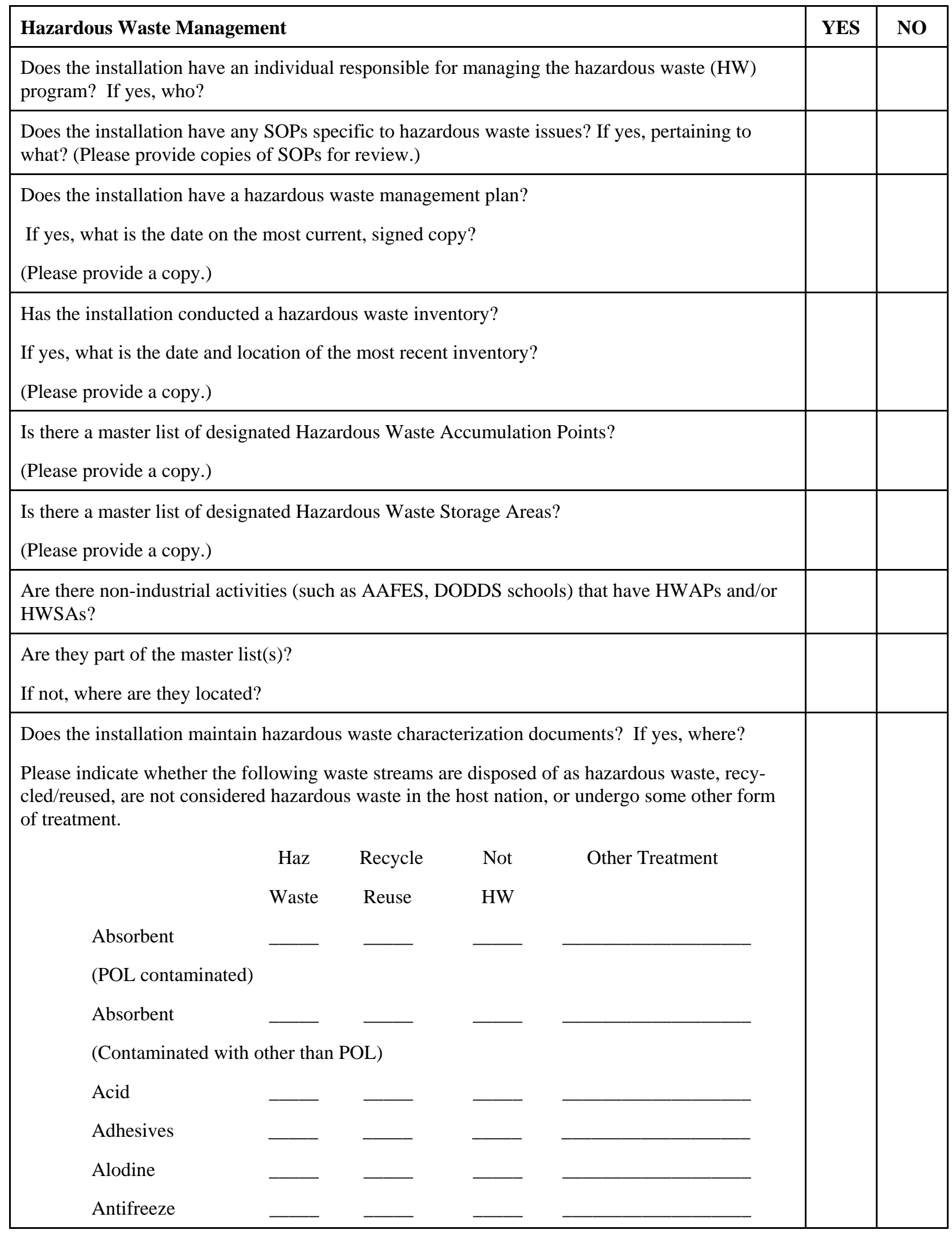




\begin{tabular}{|c|c|c|c|c|c|c|}
\hline \multicolumn{5}{|c|}{ Hazardous Waste Management } & YES & NO \\
\hline & Haz & Recycle & Not & Other Treatment & & \\
\hline & Waste & Reuse & HW & & & \\
\hline \multicolumn{7}{|l|}{ Asbestos } \\
\hline \multicolumn{7}{|l|}{ Asphalt } \\
\hline \multicolumn{7}{|l|}{ Blast media } \\
\hline \multicolumn{7}{|l|}{ Batteries, alkaline } \\
\hline \multicolumn{7}{|l|}{ Batteries, cadmium } \\
\hline \multicolumn{7}{|l|}{ Batteries, gel cell } \\
\hline \multicolumn{7}{|l|}{ Batteries, lead acid } \\
\hline \multicolumn{7}{|l|}{ Batteries, lithium } \\
\hline \multicolumn{7}{|l|}{ Batteries, } \\
\hline \multicolumn{7}{|l|}{ magnesium } \\
\hline \multicolumn{7}{|l|}{ Batteries, NiCad } \\
\hline \multicolumn{7}{|l|}{ Brake Fluid } \\
\hline \multicolumn{7}{|l|}{ Compressed gases } \\
\hline \multicolumn{7}{|l|}{ Corrosives } \\
\hline \multicolumn{7}{|c|}{ Decontaminating Agents } \\
\hline \multicolumn{7}{|l|}{ (e.g., STB) } \\
\hline \multicolumn{7}{|l|}{ Floor dry/absorbent } \\
\hline \multicolumn{7}{|l|}{ (contaminated/used) } \\
\hline \multicolumn{7}{|l|}{ Fuel (contaminated) } \\
\hline \multicolumn{7}{|l|}{ Fuel filters } \\
\hline \multicolumn{7}{|l|}{ Firing range sand } \\
\hline \multicolumn{7}{|l|}{ Fluorescent bulbs } \\
\hline \multicolumn{7}{|l|}{ Hydraulic fluid } \\
\hline \multicolumn{7}{|l|}{ Inks } \\
\hline \multicolumn{7}{|l|}{ Lubricating oil } \\
\hline \multicolumn{7}{|l|}{ Mixed waste fuel } \\
\hline \multicolumn{7}{|l|}{ NBC filters } \\
\hline \multicolumn{7}{|l|}{ Oil cans/bottles } \\
\hline (empty) & 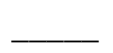 & & & & & \\
\hline
\end{tabular}




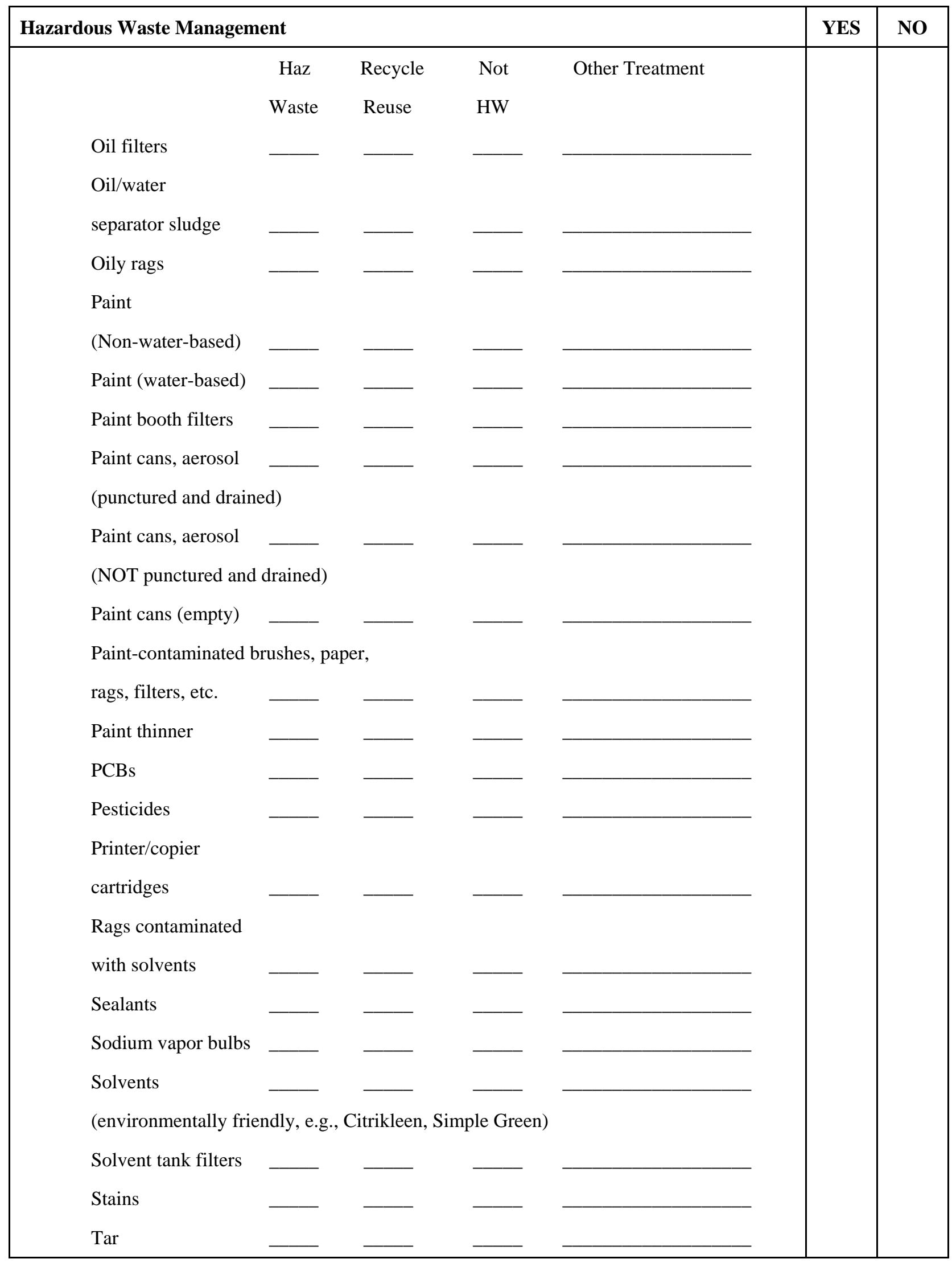




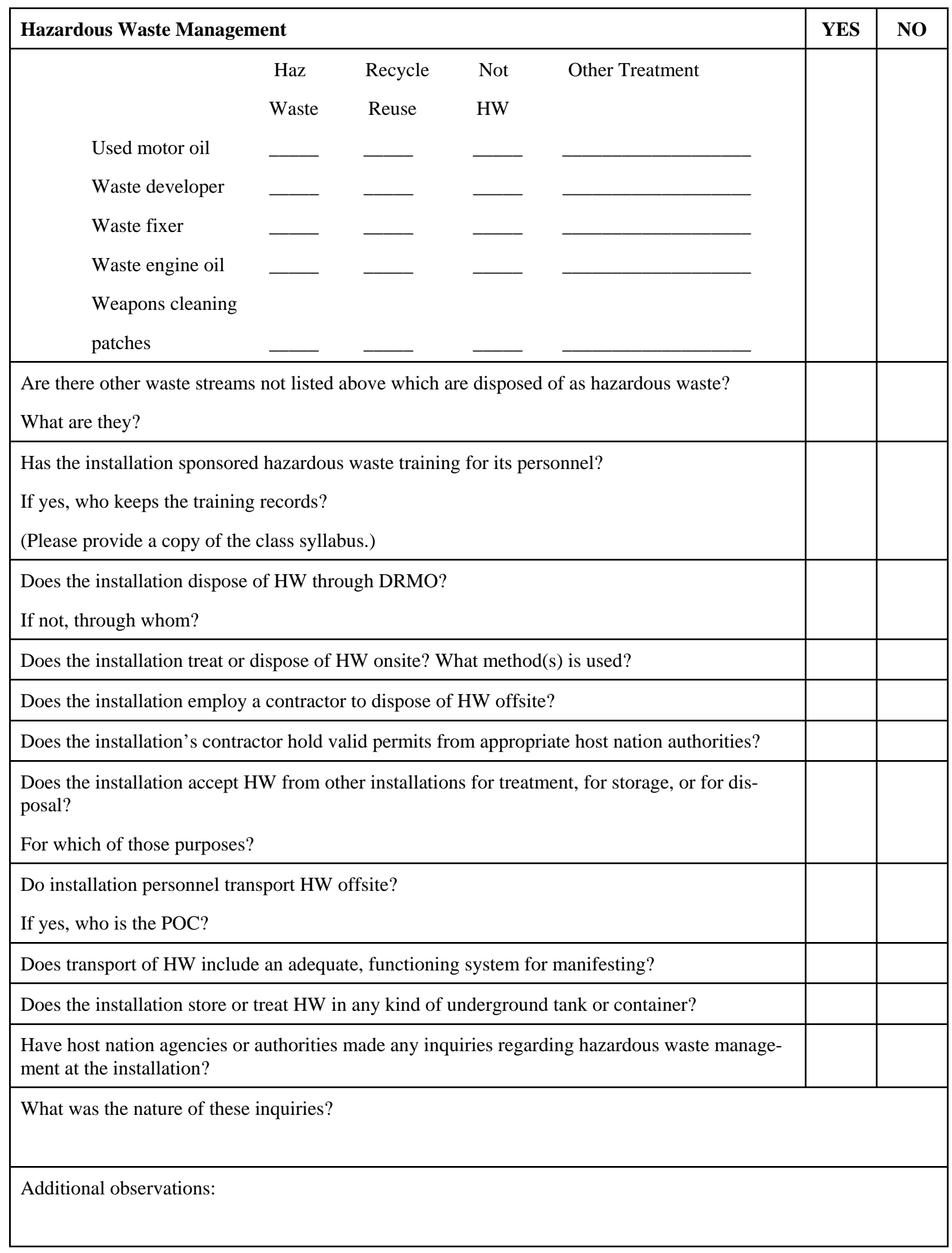




\begin{tabular}{|c|c|c|}
\hline Natural Resources Management & YES & NO \\
\hline \multicolumn{3}{|l|}{$\begin{array}{l}\text { Does the installation have an individual responsible for the natural resources management pro- } \\
\text { gram? }\end{array}$} \\
\hline \multicolumn{3}{|l|}{ If yes, who? } \\
\hline \multicolumn{3}{|l|}{ Are appropriate personnel trained for natural resources-related responsibilities? } \\
\hline \multicolumn{3}{|l|}{ Does the installation have any SOPs specific to natural resources issues? } \\
\hline \multicolumn{3}{|l|}{ If yes, pertaining to what? } \\
\hline \multicolumn{3}{|l|}{ (Please provide copies of SOPs for review.) } \\
\hline \multirow{2}{*}{\multicolumn{3}{|c|}{$\begin{array}{l}\text { Does the installation have a Natural Resources Management Plan? If yes, what is the date on the } \\
\text { most current, signed version? } \\
\text { (Please provide a copy for review.) }\end{array}$}} \\
\hline & & \\
\hline \multicolumn{3}{|l|}{ Does the installation have any of the following? (Indicate location and size.) } \\
\hline \multicolumn{3}{|l|}{ a) Wetlands } \\
\hline \multicolumn{3}{|l|}{ b) Floodplains } \\
\hline \multicolumn{3}{|l|}{ c) Forest resources } \\
\hline \multicolumn{3}{|l|}{ d) Agricultural (grazing) resources } \\
\hline \multicolumn{3}{|l|}{ e) Recreational resources } \\
\hline \multicolumn{3}{|l|}{ Are there structures (e.g., dams) on installation-controlled water resources? } \\
\hline \multirow{2}{*}{\multicolumn{3}{|c|}{$\begin{array}{l}\text { Does the installation have any endangered species? } \\
\text { If yes, what species? Where? }\end{array}$}} \\
\hline & & \\
\hline \multirow{3}{*}{\multicolumn{3}{|c|}{$\begin{array}{l}\text { Does the installation have an Endangered Species Management Plan? } \\
\text { If yes, what is the date on the most recent signed copy? } \\
\text { (Please provide a copy for review.) }\end{array}$}} \\
\hline & & \\
\hline & & \\
\hline \multirow{2}{*}{\multicolumn{3}{|c|}{$\begin{array}{l}\text { Has any host nation authority shown a particular interest in any on-installation natural resource? } \\
\text { If yes, which resource(s)? }\end{array}$}} \\
\hline & & \\
\hline \multirow{2}{*}{\multicolumn{3}{|c|}{$\begin{array}{l}\text { Is there any surface water to be found within the installation's perimeter? } \\
\text { Of what type is it (lake, river, pond, creek, etc.)? }\end{array}$}} \\
\hline & & \\
\hline \multicolumn{3}{|l|}{ Is the installation located above or very near an aquifer? } \\
\hline \multirow{2}{*}{\multicolumn{3}{|c|}{$\begin{array}{l}\text { Does a species that the host nation has identified as endangered or threatened have habitat within } \\
\text { the boundaries of the installation? } \\
\text { If yes, what species? }\end{array}$}} \\
\hline & & \\
\hline Does the installation engage in the destruction of ordnance by explosion or burning? & & \\
\hline
\end{tabular}




\begin{tabular}{|l|l|l|}
\hline Natural Resources Management & YES & NO \\
\hline If yes, what method is used? & & \\
\hline $\begin{array}{l}\text { Have host nation agencies or authorities made any inquiries regarding natural resources on the } \\
\text { installation? }\end{array}$ & & \\
\hline What was the nature of these inquiries? & \\
\hline Additional observations: & \\
\hline
\end{tabular}




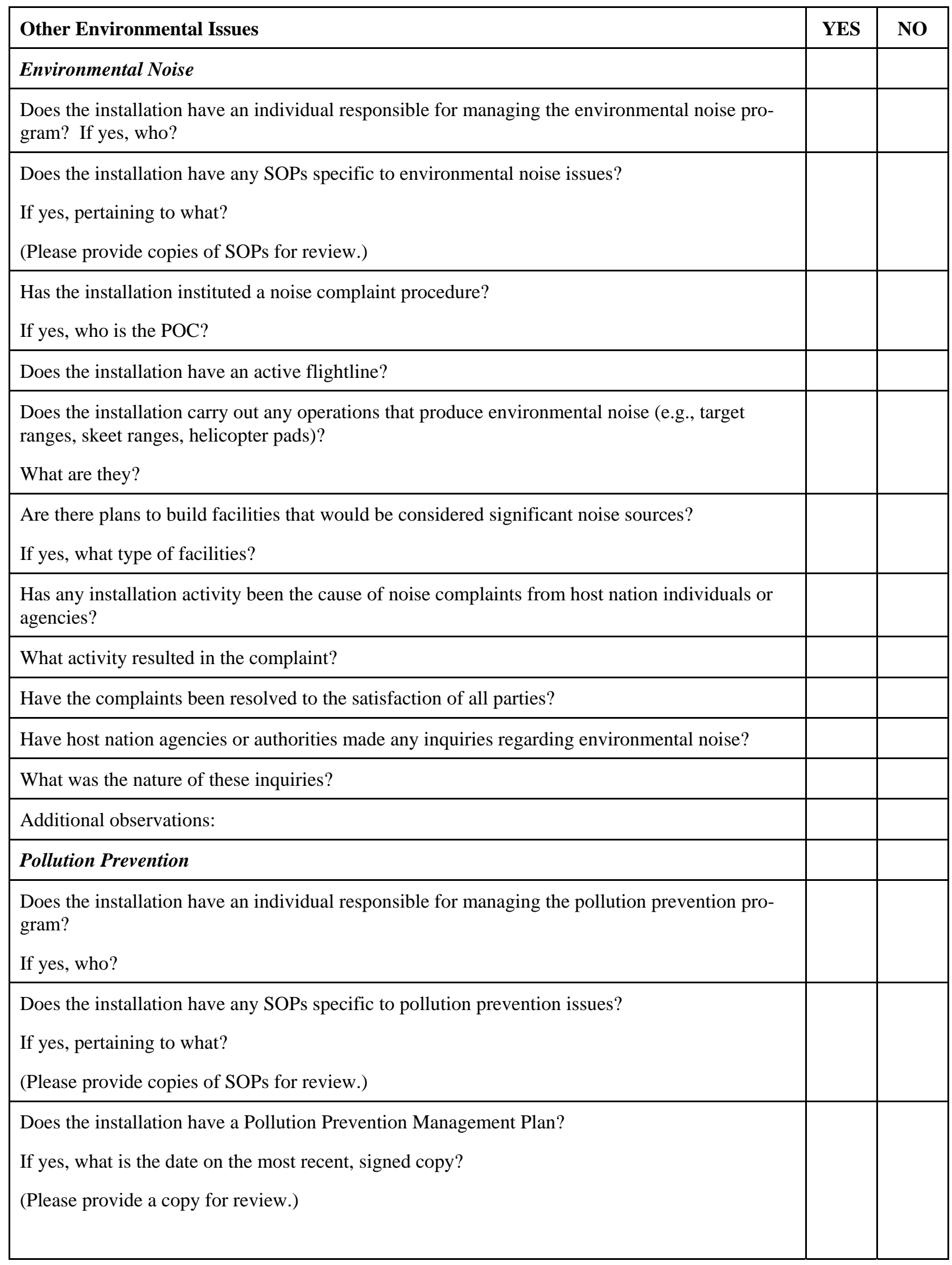




\begin{tabular}{|l|l|l|}
\hline Other Environmental Issues & YES & NO \\
\hline Pollution Prevention (continued) & & \\
\hline Does the installation have an affirmative procurement program? & & \\
\hline If yes, what materials are included in it? & & \\
\hline Does the installation use chlorofluorocarbons (CFCs) or halons? & & \\
\hline Does the installation recycle/reclaim CFCs or halons? & & \\
\hline $\begin{array}{l}\text { Does the installation have a solid waste recycling program? } \\
\text { If yes, what is recycled? }\end{array}$ & & \\
\hline $\begin{array}{l}\text { Does the installation have a current inventory of hazardous materials? } \\
\text { If yes, what is the most recent date and where is a copy located? }\end{array}$ & & \\
\hline Has the installation implemented a Hazardous Materials Pharmacy Program? & $\begin{array}{l}\text { Has the installation conducted Pollution Prevention Opportunity Assessments at any of its facili- } \\
\text { ties? If yes, where? }\end{array}$ & \\
\hline Program Management & $\begin{array}{l}\text { Are environmental surveys and construction site clearances conducted before the selection of } \\
\text { construction sites? }\end{array}$ & \\
\hline $\begin{array}{l}\text { Is sufficient funding requested by the installation to perform required environmental compliance } \\
\text { activities? }\end{array}$ & & \\
\hline
\end{tabular}




\begin{tabular}{|c|c|c|}
\hline Pesticides Management & YES & NO \\
\hline $\begin{array}{l}\text { Does the installation have an individual responsible for the pesticides management program (e.g., } \\
\text { a pest management coordinator)? } \\
\text { If yes, who? }\end{array}$ & & \\
\hline $\begin{array}{l}\text { Does the installation have any SOPs specific to pesticide management issues? } \\
\text { If yes, pertaining to what? } \\
\text { (Please provide copies of SOPs for review.) }\end{array}$ & & \\
\hline $\begin{array}{l}\text { Does the installation have an Integrated Pest Management Plan? } \\
\text { If yes, what is the date on the most recent, signed copy? } \\
\text { (Please provide a copy for review.) }\end{array}$ & & \\
\hline Are the pesticides in use on the installation approved for use in the host nation? & & \\
\hline Are restricted-use pesticides in use on the installation? & & \\
\hline Is pest management accomplished by contract? & & \\
\hline $\begin{array}{l}\text { Are any installation personnel certified applicators? } \\
\text { If yes, who? }\end{array}$ & & \\
\hline $\begin{array}{l}\text { Does the installation's Pest Management Facility drain to a holding tank, a septic system, a sani- } \\
\text { tary sewer, or to a stormwater system? } \\
\text { If yes, to which? }\end{array}$ & & \\
\hline $\begin{array}{l}\text { Does the installation's Pest Management Facility have backflow prevention devices that are both } \\
\text { of an appropriate type and operational? }\end{array}$ & & \\
\hline $\begin{array}{l}\text { Is the installation's Pest Management Facility located closer than } 200 \mathrm{ft} \text { to surface water, existing } \\
\text { wells and cisterns, or 100-yr flood plains? }\end{array}$ & & \\
\hline $\begin{array}{l}\text { Is the installation's Pest Management Facility located uphill from sources of potable water or } \\
\text { from structures that are occupied continuously? }\end{array}$ & & \\
\hline Is the installation's Pest Management Facility located over an aquifer? & & \\
\hline Does the installation include a golf course? & & \\
\hline $\begin{array}{l}\text { Have host nation agencies or authorities made any inquiries regarding pesticide use on the instal- } \\
\text { lation? }\end{array}$ & & \\
\hline \multicolumn{3}{|l|}{ What was the nature of these inquiries? } \\
\hline Additional observations: & & \\
\hline
\end{tabular}




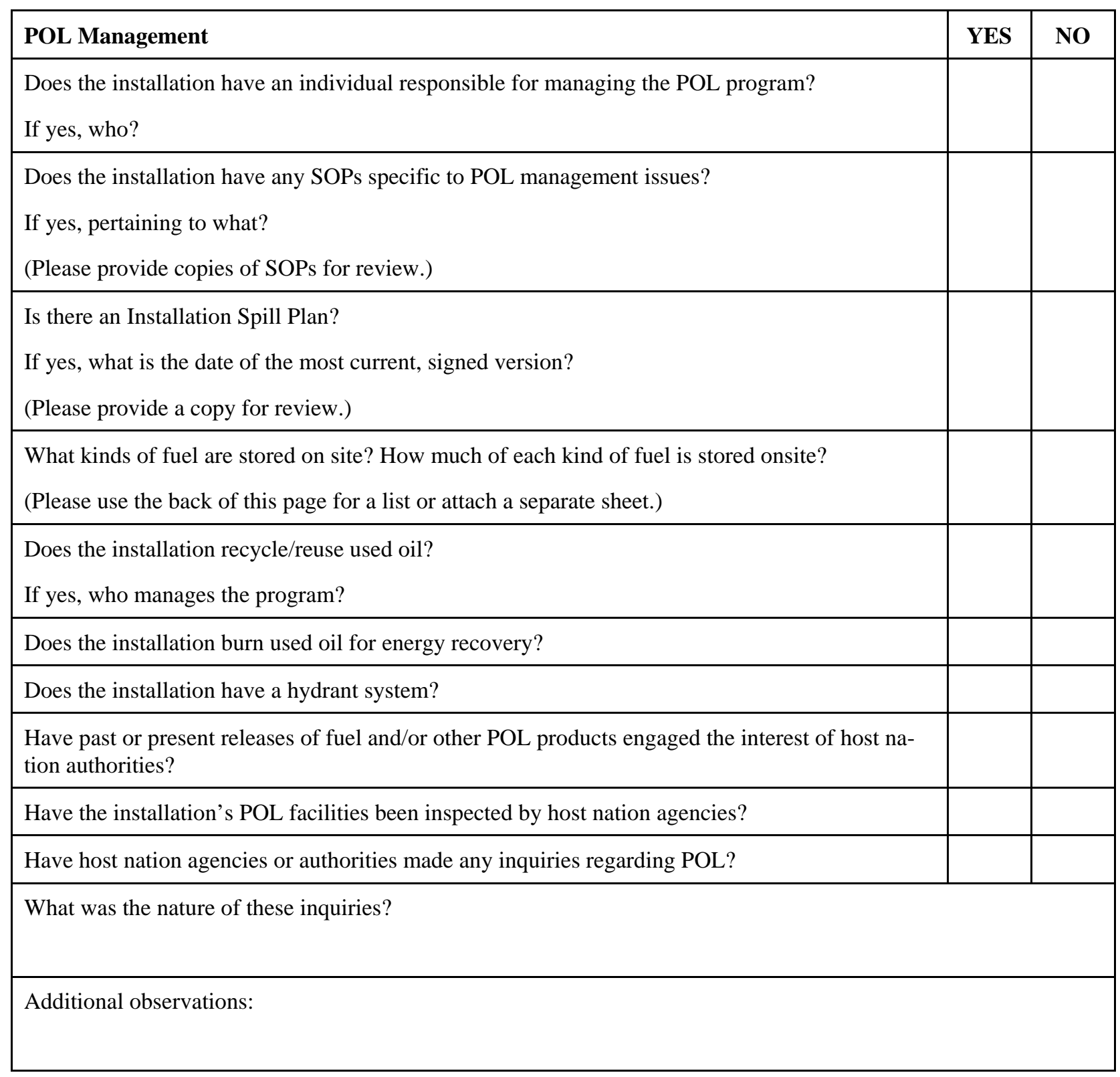




\begin{tabular}{|c|c|c|}
\hline Solid Waste Management & YES & NO \\
\hline $\begin{array}{l}\text { Does the installation have an individual responsible for managing the solid waste program? } \\
\text { If yes, who? }\end{array}$ & & \\
\hline $\begin{array}{l}\text { Does the installation have any SOPs specific to solid waste issues? } \\
\text { If yes, pertaining to what? } \\
\text { (Please provide copies for review.) }\end{array}$ & & \\
\hline $\begin{array}{l}\text { Does the installation have a Solid Waste Management Program? } \\
\text { (Please provide a copy for review.) }\end{array}$ & & \\
\hline Does the installation have a solid waste management facility onsite? & & \\
\hline Does the installation operate an official or unofficial landfill at this time? & & \\
\hline Has the installation operated an official or unofficial landfill in the past? & & \\
\hline Has the installation formally closed a landfill? & & \\
\hline Has the installation simply stopped using a landfill rather than close it formally? & & \\
\hline Does the installation collect and dispose of solid waste itself? & & \\
\hline Are collection and disposal contracted out to a host nation firm? & & \\
\hline Does that firm hold valid permits from appropriate host nation authorities? & & \\
\hline Does the installation dispose of any solid waste by open burning? & & \\
\hline $\begin{array}{l}\text { Has runoff from a land disposal site been the cause of complaints from host nation individuals or } \\
\text { agencies? }\end{array}$ & & \\
\hline What was the nature of the complaints? & & \\
\hline Does the installation operate an incinerator for the disposal of municipal solid waste? & & \\
\hline Does the installation compost sludge from a domestic wastewater treatment plant? & & \\
\hline Does the installation currently dispose of asbestos onsite? & & \\
\hline Has the installation ever disposed of asbestos onsite? & & \\
\hline Is there an active hospital or clinic on the installation? & & \\
\hline How much infectious medical waste does the hospital/clinic generate? & & \\
\hline $\begin{array}{l}\text { Does the installation dispose of infectious medical waste itself? } \\
\text { What method of collection and disposal is used? }\end{array}$ & & \\
\hline Are collection and disposal of such waste contracted out to a host nation firm? & & \\
\hline $\begin{array}{l}\text { Does that firm hold valid permits from appropriate host nation authorities for the category (or } \\
\text { categories) of waste that it receives? }\end{array}$ & & \\
\hline Does the installation store infectious medical waste prior to disposal? & & \\
\hline
\end{tabular}




\begin{tabular}{|l|l|l|}
\hline Solid Waste Management & YES & NO \\
\hline $\begin{array}{l}\text { Does the installation treat infectious medical waste prior to disposal? } \\
\text { By what process(es)? }\end{array}$ & & \\
\hline Do installation personnel transport infectious medical waste offsite? & & \\
\hline $\begin{array}{l}\text { Have host nation agencies or authorities made any inquiries regarding solid waste management } \\
\text { (including medical waste)? }\end{array}$ & & \\
\hline What was the nature of these inquiries? & \\
\hline Additional observations: & \\
\hline
\end{tabular}




\begin{tabular}{|c|c|c|}
\hline Storage Tank Management & YES & NO \\
\hline $\begin{array}{l}\text { Does the installation have an individual responsible for the storage tank management program? } \\
\text { If yes, who? }\end{array}$ & & \\
\hline $\begin{array}{l}\text { Does the installation have any SOPs specific to storage tank management issues? } \\
\text { If yes, pertaining to what issues? } \\
\text { (Please provide copies of SOPs for review.) }\end{array}$ & & \\
\hline $\begin{array}{l}\text { Does the installation have an inventory of aboveground storage tanks? } \\
\text { If yes, please provide a copy, including information on the contents of the tanks. }\end{array}$ & & \\
\hline Is the aboveground storage tank inventory complete and up-to-date? & & \\
\hline $\begin{array}{l}\text { Does the installation have an inventory of underground storage tanks? } \\
\text { If yes, please provide a copy, including information on the contents of the tanks. }\end{array}$ & & \\
\hline Is the underground storage tank inventory complete and up-to-date? & & \\
\hline $\begin{array}{l}\text { Does the installation maintain tank tightness testing records? } \\
\text { If yes, where are the records located? }\end{array}$ & & \\
\hline $\begin{array}{l}\text { Does the installation maintain tank monitoring records. } \\
\text { If yes, where are the records located? }\end{array}$ & & \\
\hline $\begin{array}{l}\text { Does the installation have a UST removal/upgrade program? } \\
\text { If yes, please provide copies of documentation on where tanks have been removed/upgraded and } \\
\text { where future removals/upgrades are planned. }\end{array}$ & & \\
\hline $\begin{array}{l}\text { Does the installation have ASTs whose design and/or construction do not currently meet recog- } \\
\text { nized U.S. industry standards? }\end{array}$ & & \\
\hline $\begin{array}{l}\text { Do any ASTs present a risk of failure? } \\
\text { If yes, which? }\end{array}$ & & \\
\hline $\begin{array}{l}\text { Are any ASTs inadequately maintained? } \\
\text { If yes, which? }\end{array}$ & & \\
\hline $\begin{array}{l}\text { Does the installation have any ASTs that are no longer in use but have not been formally closed } \\
\text { or removed? } \\
\text { If yes, how many, what size, where? }\end{array}$ & & \\
\hline $\begin{array}{l}\text { Does the installation have any ASTs with a capacity greater than } 660 \text { gal that do not have proper } \\
\text { secondary containment that is impermeable to petroleum products? } \\
\text { If yes, how many and what size? }\end{array}$ & & \\
\hline
\end{tabular}




\begin{tabular}{|c|c|c|}
\hline Storage Tank Management & YES & NO \\
\hline \multicolumn{3}{|l|}{$\begin{array}{l}\text { Does the installation have any pipeline systems whose design and/or construction do not cur- } \\
\text { rently meet recognized U.S. industry standards? }\end{array}$} \\
\hline \multicolumn{3}{|l|}{ Has the installation had a confirmed release of a hazardous substance or POL from an AST? } \\
\hline \multicolumn{3}{|l|}{ What substance? } \\
\hline \multicolumn{3}{|l|}{ How much? } \\
\hline \multicolumn{3}{|l|}{ Does the installation use USTs for the storage of any of the following substances: } \\
\hline \multicolumn{3}{|l|}{ a) POL? } \\
\hline \multicolumn{3}{|l|}{ b) hazardous materials? } \\
\hline \multicolumn{3}{|l|}{ c) hazardous waste? } \\
\hline \multicolumn{3}{|l|}{$\begin{array}{l}\text { Does the installation have any USTs whose design and/or construction do not currently meet } \\
\text { recognized U.S. industry standards? }\end{array}$} \\
\hline \multirow{2}{*}{\multicolumn{3}{|c|}{$\begin{array}{l}\text { Does the installation have any USTs that are not double-walled? } \\
\text { If yes, which and what size? }\end{array}$}} \\
\hline & & \\
\hline \multirow{2}{*}{\multicolumn{3}{|c|}{$\begin{array}{l}\text { Are there USTs onsite that present a risk of failure? } \\
\text { If yes, which? }\end{array}$}} \\
\hline & & \\
\hline \multicolumn{3}{|l|}{ Does the installation have any leaking USTs that have not been removed from service? } \\
\hline \multicolumn{3}{|l|}{ Does the installation have any USTs that are no longer in use but have not been properly closed? } \\
\hline \multicolumn{3}{|l|}{ Has the installation had a confirmed release of a hazardous substance or POL from a UST? } \\
\hline \multicolumn{3}{|l|}{ What substance? } \\
\hline \multicolumn{3}{|l|}{ What quantity? } \\
\hline \multicolumn{3}{|l|}{$\begin{array}{l}\text { Have past or present releases of hazardous substances or POL attracted the attention of host na- } \\
\text { tion authorities? }\end{array}$} \\
\hline \multicolumn{3}{|l|}{ Have host nation agencies or authorities made any inquiries regarding USTs on the installation? } \\
\hline \multicolumn{3}{|l|}{ What was the nature of these inquiries? } \\
\hline Additional observations: & & \\
\hline
\end{tabular}




\begin{tabular}{|c|c|c|}
\hline Toxic Substances Management & YES & NO \\
\hline PCBs & & \\
\hline Is the installation located in a country where PCTs are regulated along with PCBs? & & \\
\hline $\begin{array}{l}\text { Does the installation have an individual responsible for the PCB management program? } \\
\text { If yes, who? }\end{array}$ & & \\
\hline $\begin{array}{l}\text { Does the installation have any SOPs specific to PCB issues? } \\
\text { If yes, pertaining to what? } \\
\text { (Please provide copies of SOPs for review.) }\end{array}$ & & \\
\hline $\begin{array}{l}\text { Has the installation done a PCB inventory? } \\
\text { If yes, please provide a copy for review. }\end{array}$ & & \\
\hline $\begin{array}{l}\text { Has the installation tested all electrical equipment that is likely to contain PCBs for PCB concen- } \\
\text { trations? }\end{array}$ & & \\
\hline $\begin{array}{l}\text { Does the installation use any electrical equipment that contains PCBs in concentrations greater } \\
\text { than } 50 \text { ppm? }\end{array}$ & & \\
\hline $\begin{array}{l}\text { Does the installation use any electrical equipment that contains PCBs in concentrations greater } \\
\text { than } 500 \text { ppm? }\end{array}$ & & \\
\hline $\begin{array}{l}\text { Does the installation store any electrical equipment that contains PCBs in concentrations greater } \\
\text { than } 50 \mathrm{ppm} \text { ? }\end{array}$ & & \\
\hline $\begin{array}{l}\text { Does the installation store any electrical equipment that contains PCBs in concentrations greater } \\
\text { than } 500 \text { ppm? }\end{array}$ & & \\
\hline $\begin{array}{l}\text { Does the installation service any electrical equipment that contains PCBs in concentrations } \\
\text { greater than } 50 \text { ppm? }\end{array}$ & & \\
\hline $\begin{array}{l}\text { Does the installation service any electrical equipment that contains PCBs in concentrations } \\
\text { greater than } 500 \text { ppm? }\end{array}$ & & \\
\hline $\begin{array}{l}\text { Does the installation replace such equipment at the end of its service life with equipment that } \\
\text { does not contain PCBs? }\end{array}$ & & \\
\hline $\begin{array}{l}\text { Does the installation dispose onsite of PCBs and/or equipment that contains or is contaminated } \\
\text { with PCBs? }\end{array}$ & & \\
\hline $\begin{array}{l}\text { Does the installation dispose of PCBs through DRMO? } \\
\text { If no, what method of disposal is used? }\end{array}$ & & \\
\hline Do installation personnel transport PCBs off-installation? & & \\
\hline Asbestos & & \\
\hline $\begin{array}{l}\text { Does the installation have an individual responsible for managing the asbestos program? } \\
\text { If yes, who? }\end{array}$ & & \\
\hline
\end{tabular}




\begin{tabular}{|c|c|c|}
\hline Toxic Substances Management & YES & NO \\
\hline \multicolumn{3}{|l|}{ Asbestos (continued) } \\
\hline \multicolumn{3}{|l|}{ Does the installation have any SOPs specific to asbestos issues? } \\
\hline \multicolumn{3}{|l|}{ If yes, pertaining to what (e.g., brake pad disposal)? } \\
\hline \multicolumn{3}{|l|}{ (Please provide copies of SOPs for review.) } \\
\hline \multicolumn{3}{|l|}{ Does the installation dispose of ACM from building renovation/demolition onsite? } \\
\hline \multicolumn{3}{|l|}{ If yes, who does the disposal and where? } \\
\hline \multicolumn{3}{|l|}{ If no, how and where does disposal occur? } \\
\hline \multicolumn{3}{|l|}{ Has the installation conducted a complete asbestos survey? } \\
\hline \multicolumn{3}{|l|}{ If yes, what the date of the most recent survey? } \\
\hline \multicolumn{3}{|l|}{ (Please provide a copy for the assessment team.) } \\
\hline \multirow{2}{*}{\multicolumn{3}{|c|}{$\begin{array}{l}\text { Has the installation prepared, coordinated, and executed an Asbestos Management Plan? } \\
\text { (Please provide a copy for review.) }\end{array}$}} \\
\hline & & \\
\hline \multicolumn{3}{|l|}{ Are there facilities onsite that are known to contain or are suspected of containing ACM? } \\
\hline \multicolumn{3}{|l|}{$\begin{array}{l}\text { Has the installation tested any friable materials that are likely to contain asbestos to discover if in } \\
\text { fact the material does contain asbestos? }\end{array}$} \\
\hline \multicolumn{3}{|l|}{ Does the friable material actually contain asbestos? } \\
\hline \multicolumn{3}{|l|}{ Does the installation have any sites where damaged asbestos is found? } \\
\hline \multicolumn{3}{|l|}{ Does the installation have any sites where friable asbestos is found? } \\
\hline \multicolumn{3}{|l|}{ Does the installation have any sites where asbestos abatement is either planned or on-going? } \\
\hline \multicolumn{3}{|l|}{ Does the installation have an active in-house asbestos removal team? } \\
\hline \multicolumn{3}{|l|}{$\begin{array}{l}\text { Is the installation renovating or demolishing any structures where ACM may be disturbed or re- } \\
\text { moved? }\end{array}$} \\
\hline \multirow{2}{*}{\multicolumn{3}{|c|}{$\begin{array}{l}\text { Is the installation currently storing any asbestos-containing waste material for disposal? } \\
\text { If yes, what ACM and what quantity? }\end{array}$}} \\
\hline & & \\
\hline \multicolumn{3}{|l|}{$\begin{array}{l}\text { Are any sites on the installation currently being monitored for concentrations of airborne asbestos } \\
\text { fibers? }\end{array}$} \\
\hline \multicolumn{3}{|l|}{$\begin{array}{l}\text { Have any monitoring results indicated concentrations greater than } 0.2 \text { fibers per cubic centime- } \\
\text { ter? }\end{array}$} \\
\hline \multirow{2}{*}{\multicolumn{3}{|c|}{$\begin{array}{l}\text { Does the installation dispose of asbestos containing waste material? } \\
\text { What type? What quantity? }\end{array}$}} \\
\hline & & \\
\hline Does the installation have an active waste disposal site where ACM is being disposed of? & & \\
\hline
\end{tabular}




\begin{tabular}{|l|l|l|}
\hline Toxic Substances Management & YES & NO \\
\hline
\end{tabular}

\begin{tabular}{|c|c|}
\hline Asbestos (continued) & \\
\hline $\begin{array}{l}\text { Does the installation have an inactive waste disposal site where ACM has been disposed of in the } \\
\text { past? }\end{array}$ & \\
\hline Radon & \\
\hline $\begin{array}{l}\text { Does the installation have an individual responsible for managing the radon program? } \\
\text { If yes, who? }\end{array}$ & \\
\hline $\begin{array}{l}\text { Does the installation have any SOPs specific to radon issues? } \\
\text { If yes, pertaining to what? } \\
\text { (Please provide copies of SOPs for review.) }\end{array}$ & \\
\hline Is the installation located in an area likely to be associated with high radon levels? & \\
\hline Has initial radon screening been conducted on the installation? & \\
\hline Did any initial screening sample show a radon level greater than $4 \mathrm{pCi} / \mathrm{L}$ ? & \\
\hline Has mitigation been conducted on buildings where radon levels exceed $4 \mathrm{pCi} / \mathrm{L}$ ? & \\
\hline Lead-Based Paint & \\
\hline $\begin{array}{l}\text { Does the installation have an individual responsible for managing the lead-based paint (LBP) } \\
\text { program? } \\
\text { If yes, who? }\end{array}$ & \\
\hline $\begin{array}{l}\text { Does the installation have any SOPs specific to LBP issues? } \\
\text { If yes, pertaining to what? } \\
\text { (Please provide copies of SOPs for review.) }\end{array}$ & \\
\hline $\begin{array}{l}\text { Has the installation conducted LBP surveys? } \\
\text { If yes, where are the survey results located? } \\
\text { If no, which facilities have not had a survey? }\end{array}$ & \\
\hline Has the installation identified any existing or potential LBP hazards? & \\
\hline $\begin{array}{l}\text { Is LBP currently being used on the installation in the course of maintenance or construction? } \\
\text { In what amounts? }\end{array}$ & \\
\hline Are any buildings with LBP hazards being demolished or renovated? & \\
\hline Are there plans to demolish or renovate any buildings with LBP hazards? & \\
\hline Has the installation ever had a case of elevated levels of lead in the blood? & \\
\hline Do any persons on the installation currently have elevated levels of lead in the blood? & \\
\hline
\end{tabular}




\begin{tabular}{|l|l|l|}
\hline Toxic Substances Management & YES & NO \\
\hline Describe how demolition/renovation wastes that might contain LBP or asbestos are managed. & & \\
\hline $\begin{array}{l}\text { Have host nation agencies or authorities made any inquiries regarding PCBs, asbestos, radon, or } \\
\text { LBP on the installation? }\end{array}$ & & \\
\hline What was the nature of these inquiries? & \\
\hline Additional observations: & \\
\hline
\end{tabular}




\begin{tabular}{|c|c|c|}
\hline Wastewater Management & YES & NO \\
\hline $\begin{array}{l}\text { Does the installation have an individual responsible for managing the wastewater program? } \\
\text { If yes, who? }\end{array}$ & & \\
\hline $\begin{array}{l}\text { Does the installation have any SOPs specific to wastewater issues? } \\
\text { If yes, pertaining to what? } \\
\text { (Please provide copies of SOPs for review.) }\end{array}$ & & \\
\hline Where are the facility drain plans located? & & \\
\hline Does the installation operate a wastewater treatment plant? & & \\
\hline What sort of certification does the operator have? & & \\
\hline Does the installation discharge into a publicly owned treatment works? & & \\
\hline $\begin{array}{l}\text { Does the installation engage in pretreatment of industrial wastewater prior to discharge to a } \\
\text { wastewater treatment plant? }\end{array}$ & & \\
\hline $\begin{array}{l}\text { Does the installation have any oil/water separators? } \\
\text { If yes, please provide a current list to the assessment team. }\end{array}$ & & \\
\hline Does the installation conduct any effluent monitoring? For what substances? & & \\
\hline $\begin{array}{l}\text { Have the installation's point source dischargers exceeded FGS standards for any of the following } \\
\text { within the last } 12 \text { months? }\end{array}$ & & \\
\hline a) Total Suspended Solids? & & \\
\hline b) $\mathrm{pH}$ ? & & \\
\hline c) $\mathrm{BOD}_{5}$ ? & & \\
\hline $\begin{array}{l}\text { If yes, which parameters? } \\
\text { For what length of time? }\end{array}$ & & \\
\hline Has the DWTP received slug discharges that have seriously impaired operations? & & \\
\hline Has the DWTP ever been killed? If yes, how and when? & & \\
\hline Does the installation discharge effluent from electroplating facilities? & & \\
\hline Has the installation surveyed stormwater discharge within the last year? & & \\
\hline $\begin{array}{l}\text { Has stormwater run-off from the installation resulted in complaints from host nation individuals } \\
\text { or authorities? } \\
\text { What was the nature of the complaints? }\end{array}$ & & \\
\hline Is the installation subject to ground- or surface water monitoring for any reason? & & \\
\hline $\begin{array}{l}\text { Has the installation received water pollution complaints from individuals and/or host nation wa- } \\
\text { ter pollution control authorities? }\end{array}$ & & \\
\hline
\end{tabular}




\begin{tabular}{|c|c|c|}
\hline Wastewater Management & YES & NO \\
\hline \multicolumn{3}{|l|}{ What was the nature of those complaints? } \\
\hline \multicolumn{3}{|l|}{ Have host nation agencies or authorities made any inquiries regarding wastewater? } \\
\hline \multicolumn{3}{|l|}{ What was the nature of these inquiries? } \\
\hline Additional observations: & & \\
\hline
\end{tabular}




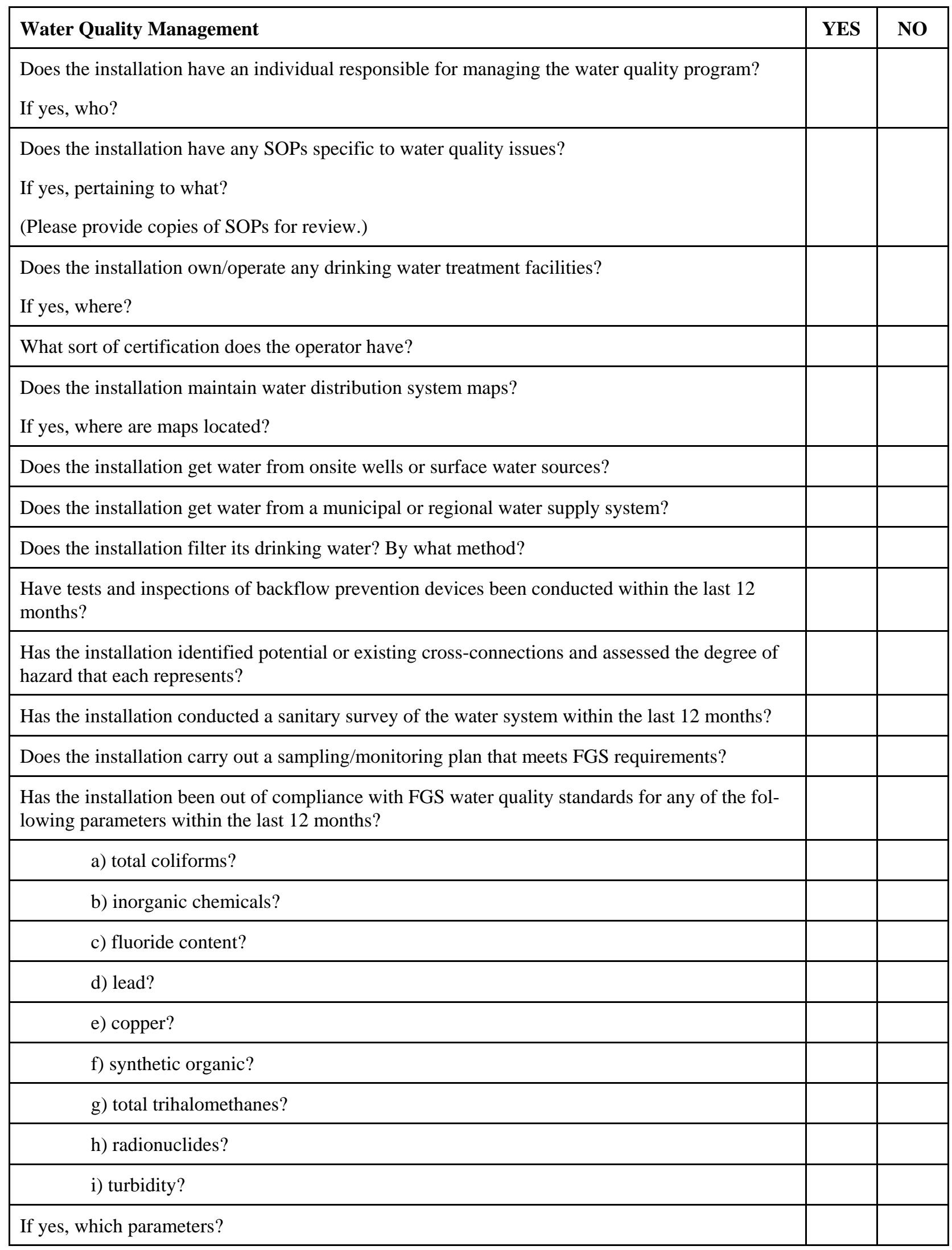




\begin{tabular}{|l|l|l|}
\hline Water Quality Management & YES & NO \\
\hline For what length of time? & & \\
\hline $\begin{array}{l}\text { Does the installation maintain a disinfectant residual throughout the water system? } \\
\text { If yes, what is the level of residual disinfectant? }\end{array}$ & & \\
\hline $\begin{array}{l}\text { Has the installation conducted proper notification in the event of noncompliance with water qual- } \\
\text { ity standards? }\end{array}$ & & \\
\hline Does the installation have any underground injection wells existing or planned? & & \\
\hline Does the installation manage recreational waters (i.e., beaches, swimming pools)? & & \\
\hline $\begin{array}{l}\text { Has the installation received complaints about water quality from host nation individuals or agen- } \\
\text { cies? }\end{array}$ & & \\
\hline What was the nature of those complaints? & & \\
\hline Have host nation agencies or authorities made any inquiries regarding drinking water? & \\
\hline What was the nature of these inquiries? & \\
\hline Additional observations: & \\
\hline
\end{tabular}


ATTENTION: The following records should be available for review by the assessment team either prior to the assessment or immediately upon arrival at the installation.

(NOTE: Not all installations will have, or are even required to have, all of the following documents.)

\section{General}

- Detailed maps of the installation indicating street names and building numbers. Enough for one for every member of the assessment team

- A telephone list

- Copies of open enforcement actions (OEAs) issued to the installation in any of the following areas

\section{Air Emissions Management}

- A list of steam-generating units and boilers and their size, fuel used, and locations

\section{Cultural Resources Management}

- Any cultural or archeological resources surveys

- Management plans for cultural and archeological resources

- A list of properties included on the host nation's equivalent of the National Register

\section{Hazardous Materials Management}

- A list of hazardous material storage/use areas

- A waste minimization plan

\section{Hazardous Waste Management}

- The Hazardous Waste Management Plan

- A list of hazardous wastes generated at the installation

- A list of waste generation/storage areas

- Manifests

\section{Natural Resources Management}

- The endangered species survey

- The Natural Resources Management Plan

- Any land management plans

\section{Other Environmental Issues}

Environmental Impacts

- Recent environmental analyses (EAs), environmental impact statements (EISs), environmental studies, environmental reviews

Environmental Noise Management 
- Installation Compatible Use Zone (ICUZ) documentation

- Noise complaints

Cleanup (Restoration)

- Cleanup documentation

Pollution Prevention

- The Pollution Prevention Management Plan

- Any recycling plans

Program Management

- The A-106 Pollution Abatement Plan

\section{Pesticides Management}

- The Pesticide Management Plan

- A list of pesticide storage sites

- Application records

- Documentation of certifications for applicators

- Contracts for pesticide application

\section{Petroleum, Oils, and Lubricants (POL) Management}

- The installation spill plan

- A list of POL storage areas

\section{Solid Waste Management}

- Any contracts with waste haulers

- All documentation pertaining to landfill operation or closure

- Records on groundwater sampling resulting from monitoring wells

\section{Storage Tank Management}

- List of organizational fuel tanks

- List of support tanks authorized to receive fuel

- Records of all spills and leaks and associated site assessment/cleanup activities

- Tank custodian training records

- Underground storage tank (UST) inventory

- UST integrity test results

- Upgrading and/or closure plans and site contamination reports after tank removals 


\section{Toxic Substances Management}

- The PCB inventory

- The PCB annual report

- The results of the asbestos survey

- The Asbestos Management Plan

- Radon survey results

- Lead-based Paint Management Plan

\section{Wastewater Management}

- Maps of the storm, sanitary, and industrial sewers

- A list of maintenance shops/operations, including wash facilities

- Locations of holding ponds, sedimentation pits, and open/end-of-pipe discharge points

\section{Water Quality Management}

- Copies of drinking water test results 
Table 2

Logic Table

\begin{tabular}{|c|c|c|c|c|}
\hline & \multicolumn{4}{|c|}{ Sections } \\
\hline Major Activities/Operations & $\begin{array}{c}\text { Air Emissions } \\
\text { Management } \\
1\end{array}$ & $\begin{array}{c}\text { Cultural } \\
\text { Resources } \\
\text { Management } \\
2\end{array}$ & $\begin{array}{c}\text { Hazardous } \\
\text { Materials } \\
\text { Management } \\
3\end{array}$ & $\begin{array}{c}\text { Hazardous } \\
\text { Waste Man- } \\
\text { agement } \\
4\end{array}$ \\
\hline 1. Incinerators & - & & & - \\
\hline 2. Heat/Power Production & - & & & - \\
\hline 3. AGE Operation & - & & • & - \\
\hline 4. Aircraft Operations & - & & & \\
\hline 5. Aircraft Maintenance & & & - & - \\
\hline 6. Fuel Storage & - & & - & \\
\hline 7. Surface Coating Operations & - & & • & • \\
\hline 8. Sanitary Wastewater & & & & \\
\hline 9. Stormwater Runoff & & & & \\
\hline 10. Sludge Disposal & • & & & \\
\hline 11. POL Dispensing & - & & & \\
\hline 12. Wastewater Treatment & & & & \\
\hline 13. Vehicle Maintenance & • & & $\bullet$ & • \\
\hline 14. Shop Activities & - & & • & - \\
\hline 15. Solid Waste Generation & & & & \\
\hline 16. Water Supply & & & & \\
\hline 17. Toxic/Hazardous Materials Use & & & - & \\
\hline 18. Firefighting Training & • & & & \\
\hline 19. PCB Electrical Equipment & & & & \\
\hline 20. Pesticide/Herbicide Use & & & & - \\
\hline 21. Environmental Noise & & & & \\
\hline 22. Emergency Planning & & & • & • \\
\hline 23. Asbestos Removal & & & & \\
\hline 24. Underground Storage Tanks & - & & - & - \\
\hline 25. Remodeling Activities & & • & & \\
\hline 26. Construction Activities & & - & & \\
\hline 27. Soil Removal & & - & & \\
\hline
\end{tabular}




\begin{tabular}{|c|c|c|c|c|}
\hline \multirow[b]{2}{*}{ Major Activities/Operations } & \multicolumn{4}{|c|}{ Sections } \\
\hline & $\begin{array}{c}\text { Natural } \\
\text { Resources } \\
\text { Management } \\
5 \\
5\end{array}$ & 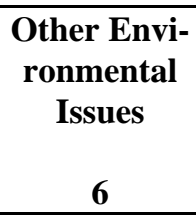 & $\begin{array}{c}\text { Pesticide } \\
\text { Management } \\
\\
7 \\
\end{array}$ & 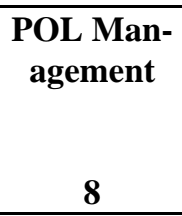 \\
\hline \multicolumn{5}{|l|}{ 1. Incinerators } \\
\hline 2. Heat/Power Production & & & & • \\
\hline 3. AGE Operation & & & & - \\
\hline 4. Aircraft Operations & & • & & • \\
\hline 5. Aircraft Maintenance & & • & & • \\
\hline 6. Fuel Storage & & & & • \\
\hline 7. Surface Coating Operations & & - & & \\
\hline \multicolumn{5}{|l|}{ 8. Sanitary Wastewater } \\
\hline 9. Stormwater Runoff & & & • & - \\
\hline 10. Sludge Disposal & & • & & \\
\hline 11. POL Dispensing & & & & • \\
\hline \multicolumn{5}{|l|}{ 12. Wastewater Treatment } \\
\hline 13. Vehicle Maintenance & & • & & • \\
\hline 14. Shop Activities & & - & & \\
\hline 15. Solid Waste Generation & & • & & \\
\hline \multicolumn{5}{|l|}{ 16. Water Supply } \\
\hline 17. Toxic/Hazardous Materials Use & & - & & \\
\hline 18. Firefighting Training & & & & • \\
\hline \multicolumn{5}{|l|}{ 19. PCB Electrical Equipment } \\
\hline 20. Pesticide/Herbicide Use & & & • & \\
\hline 21. Environmental Noise & & • & & \\
\hline 22. Emergency Planning & & & & • \\
\hline \multicolumn{5}{|l|}{ 23. Asbestos Removal } \\
\hline 24. Underground Storage Tanks & & & & • \\
\hline 25. Remodeling Activities & • & & & \\
\hline 26. Construction Activities & $\cdot$ & & & \\
\hline 27. Soil Removal & - & & & \\
\hline
\end{tabular}




\begin{tabular}{|c|c|c|c|c|}
\hline \multirow[b]{2}{*}{ Major Activities/Operations } & \multicolumn{4}{|c|}{ Sections } \\
\hline & $\begin{array}{c}\text { Solid Waste } \\
\text { Management } \\
9 \\
\end{array}$ & $\begin{array}{c}\text { Storage Tank } \\
\text { Management } \\
10 \\
\end{array}$ & $\begin{array}{c}\text { Toxic } \\
\text { Substances } \\
\text { Management } \\
11\end{array}$ & $\begin{array}{c}\text { Wastewater } \\
\text { Management } \\
12 \\
\end{array}$ \\
\hline 1. Incinerators & • & & & \\
\hline 2. Heat/Power Production & - & • & & - \\
\hline 3. AGE Operation & & - & & \\
\hline \multicolumn{5}{|l|}{ 4. Aircraft Operations } \\
\hline 5. Aircraft Maintenance & & & & - \\
\hline 6. Fuel Storage & & • & & \\
\hline 7. Surface Coating Operations & & & & • \\
\hline 8. Sanitary Wastewater & & & & • \\
\hline 9. Stormwater Runoff & & & & • \\
\hline 10. Sludge Disposal & • & & & - \\
\hline \multicolumn{5}{|l|}{ 11. POL Dispensing } \\
\hline 12. Wastewater Treatment & & & & - \\
\hline 13. Vehicle Maintenance & - & & • & • \\
\hline 14. Shop Activities & • & & & • \\
\hline 15. Solid Waste Generation & - & & & \\
\hline \multicolumn{5}{|l|}{ 16. Water Supply } \\
\hline 17. Toxic/Hazardous Materials Use & & & - & \\
\hline 18. Firefighting Training & & & & - \\
\hline 19. PCB Electrical Equipment & & & - & \\
\hline 20. Pesticide/Herbicide Use & & & & • \\
\hline \multicolumn{5}{|l|}{ 21. Environmental Noise } \\
\hline \multicolumn{5}{|l|}{ 22. Emergency Planning } \\
\hline 23. Asbestos Removal & & & • & \\
\hline 24. Underground Storage Tanks & & • & & \\
\hline 25. Remodeling Activities & - & & - & \\
\hline 26. Construction Activities & • & & - & \\
\hline 27. Soil Removal & & & & \\
\hline
\end{tabular}




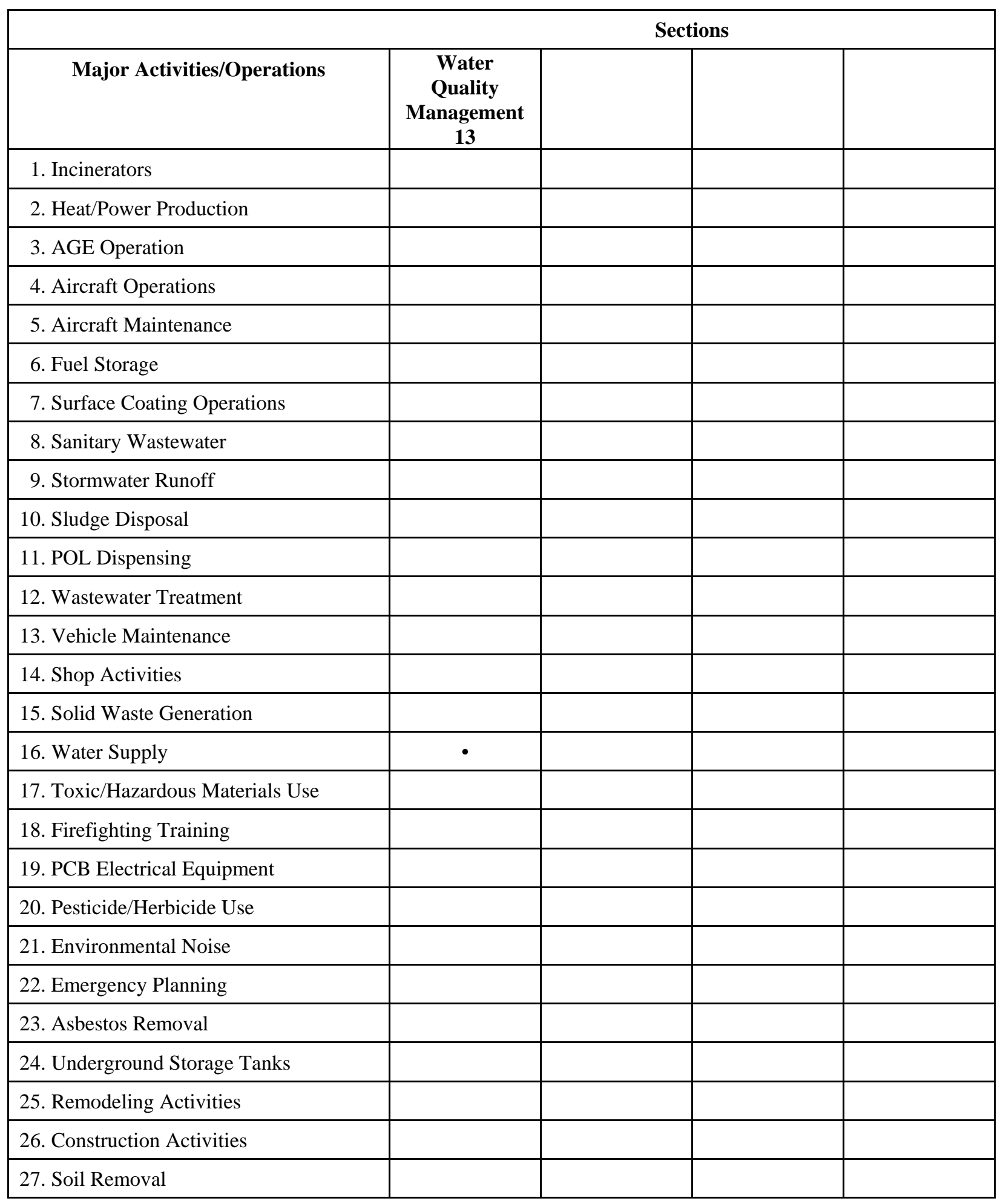


Table 3

\section{ECAMP Core Data}

(AFI 32-7045, Attachment 5)

To facilitate Air Force-wide data collection and assessment, each compliance assessment will include the collection of the following information in the format specified below. ECAMP Analysis Data in Bold print is the subset of data that will be submitted to AFCEE from external assessments.

\section{REQUIRED FIELD NAME}

MAJCOM

BASE

COUNTRY

STATE

FIND DATE

PROTOCOL

FINDING NUMBER

QUESTION NUMBER

SOURCE

RATING

REPEAT FINDING?

CARRYOVER FINDING

PREVIOUS FINDING NUMBER

BLDG NUMBER

LOCATION

FINDING TITLE

FINDING DETAIL

CITATION

OTHER CRITERIA

MEDIA BY LAW

FINDING ID CODE

RESPONSIBLE ORG

RESPONSIBLE ORG POC

POC PHONE NUM

SUGGESTED ACTION

CORRECTIVE ACTION

CORRECTIVE ACTION COST

A-106 PROJECT NUMBER

STATUS

ESTIMATION COMPLETION DATE

ACTUAL COMPLETION DATE

ROOT CAUSE

LAST UPDATE

\section{REQUIRED FIELD TYPE}

TEXT

TEXT

TEXT

TEXT

DATE(DD/MMM/YYYY)

TEXT

TEXT

TEXT

TEXT

TEXT

YES/NO

YES/NO

TEXT

TEXT

TEXT

TEXT

MEMO

TEXT

TEXT

TEXT

TEXT

TEXT

TEXT

TEXT

MEMO

MEMO

CURRENCY

TEXT

MEMO

DATE(DD/MMM/YYYY)

DATE(DD/MMM/YYYY)

TEXT

DATE(DD/MMM/YYYY)

\begin{tabular}{c} 
REQUIRED FIELD TYPE \\
\hline 50 \\
50 \\
$\mathbf{5 0}$ \\
$\mathbf{5 0}$ \\
11 \\
50 \\
50 \\
50 \\
50 \\
$\mathbf{5 0}$ \\
$\mathbf{1}$ \\
1 \\
50 \\
50 \\
100 \\
100 \\
unlimited \\
$\mathbf{1 4 0}$ \\
140 \\
$\mathbf{5 0}$ \\
$\mathbf{5 0}$ \\
60 \\
50 \\
50 \\
unlimited \\
unlimited \\
8 \\
50 \\
unlimited \\
11 \\
11 \\
$\mathbf{5 0}$ \\
11 \\
\end{tabular}


Table 4

\title{
Finding Identification Codes for Use OCONUS
}

\author{
(Based on AFI 32-7045, Attachment 3)
}

\section{Air Emissions}

AE01 Emissions Limits Or Operational Requirements Not Met

AE02 Construction Permits Missing

AE03 Permit Conditions Not Met

AE04 Sources Not Permitted

AE05 Operating Permit Incomplete

AE06 Emission Inventory Inaccurate

AE07 ODC Management Deficiency

AE08 Gasoline/Fuels Management

AE09 Vehicle Emissions Testing

AE10 Solvent Degreaser Deficiency

AE11 Other (please indicate on the finding sheet the nature of the finding)

\section{Cultural Resources Management}

CR01 Inadequate Historic Properties Management

CR02 Inadequate Religious/Heritage Access

CR03 Inadequate Archaeological/Native American Site Management

CR04 Inadequate Collection Management and Curation

CR05 Inadequate/Lacking Survey/Plans

CR06 Other (please indicate on the finding sheet the nature of the finding)

\section{Hazardous Materials Management}

$\begin{array}{ll}\text { HM01 } & \text { Inadequate Storage Cabinet } \\ \text { HM02 } & \text { Inadequate Storage Room } \\ \text { HM03 } & \text { Storage Building Deficiency } \\ \text { HM04 } & \text { Inadequate Outside Storage } \\ \text { HM05 } & \text { Improper Storage Practice } \\ \text { HM06 } & \text { Compressed-Gas Storage Deficiency } \\ \text { HM07 } & \text { Bulk-Acid Storage Deficiency } \\ \text { HM08 } & \text { Fire Protection Deficiency } \\ \text { HM09 } & \text { Personnel Protective Equipment Deficiency } \\ \text { HM10 } & \text { Inadequate HAZCOM Program } \\ \text { HM11 } & \text { Improper/Lacking Reporting (EPCRA/Release) } \\ \text { HM12 } & \text { Inadequate Emergency Response Planning }\end{array}$




\section{Finding Identification Codes for Use OCONUS}

(Based on AFI 32-7045, Attachment 3)

\section{Hazardous Materials Management (continued)}

HM13 Laboratory Management Deficiency

HM14 Transportation Deficiency

HM15 Other (please indicate on the finding sheet the nature of the finding)

\section{Hazardous Waste Management}

HW01 Accumulation Point Deficiency

HW03 HWSA Deficiency

HW04 Lack of Characterization

HW05 Transportation/Manifest Deficiency (except LDR)

HW06 Unpermitted/Improper Disposal

HW07 Unpermitted/Treatment

HW08 Inadequate Waste Minimization

HW09 Program Planning Deficiency

HW10 Waste Analysis Characterization Planning Deficiency

HW11 Facility-Wide Records Deficiency

HW12 AFI/Procedural Records Deficiency

HW13 Training Deficiency

HW15 Other (please indicate on the finding sheet the nature of the finding)

\section{Natural Resources Management}

NR01 Inadequate/Lacking Integrated Natural Resource Management Plan

NR02 Ecosystem Management Deficiency

NR03 Land Management Deficiency

NR04 Range Management Deficiency

NR05 Forestry/Silviculture Management Deficiency

NR06 Agriculture/Grazing Management Deficiency

NR07 Wetlands Deficiency

NR08 Flora and Fauna Management Deficiency

NR09 Threatened and Endangered Species Management Deficiency

NR10 Other (please indicate on the finding sheet the nature of the finding)

\section{Other Environmental Issues:}

Environmental Noise

EO04 Inadequate/Lacking ICUZ

EO05 Inadequate Management of Noise Complaints 


\section{Finding Identification Codes for Use OCONUS}

(Based on AFI 32-7045, Attachment 3)

Other Environmental Issues Noise (continued)

EO06 Range Noise Management Deficiency

EO07 Noise Other (please indicate on the finding sheet the nature of the finding)

Cleanup (Restoration)

IR06 Other

Pollution Prevention

PP01 Inadequate/Lacking Opportunity Assessment/Pollution Prevention Planning

PP02 Inadequate Recycling Program

PP03 Inadequate/Lacking Waste Minimization

PP04 Inadequate Hazardous Substance Control and Reduction

PP05 Improper Management of ODCs

PP06 Inadequate Energy Conservation

PP07 Inadequate/Lacking Affirmative Procurement

PP08 Other (please indicate on the finding sheet the nature of the finding)

Program Management

EO08 Improper Management of Ranges

EO09 Inadequate A-106 Pollution Abatement Plan

EO10 Environmental Baseline Study Deficiency

EO11 Compliance Tracking/Reporting Deficiency

EO12 Environmental Protection Committee Deficiency

EO13 Inadequate WIMS-ES Management

EO14 Program Management Other (please indicate on the finding sheet the nature of the finding)

\section{Pesticides Management}

PM01 DOD Applicator Certification Deficiency

PM02 Inadequate/Lacking Integrated Pest Management Plan

PM03 Inadequate/Lacking Application Records

PM04 Inadequate Storage Structures

PM05 Improper Storage Practices

PM06 Inadequate/Lacking Pesticide Inventory

PM07 Contractor Application Deficiency

PM08 Unapproved Pesticide Use

PM09 Application Equipment Deficiency 


\section{Finding Identification Codes for Use OCONUS}

(Based on AFI 32-7045, Attachment 3)

\section{Pesticide Management (continued)}

PM10 Inadequate Residue/Container Disposal

PM11 Other (please indicate on the finding sheet the nature of the finding)

\section{POL Management}

PO01 Spill Plan Deficiency

PO02 Inadequate Spill Training

PO03 Spill Cleanup Deficiency

PO04 Inadequate Spill Equipment

PO05 Service Stations Deficiency

PO06 Marine Oil Transfer Deficiency

PO07 Inadequate Loading Areas

PO08 Inadequate Pipelines

PO09 Inadequate Used Oil Management

PO10 Other (please indicate on the finding sheet the nature of the finding)

\section{Solid Waste Management}

$\begin{array}{ll}\text { SW01 } & \text { Improper/Unpermitted Disposal } \\ \text { SW02 } & \text { Landfill Management Deficiency } \\ \text { SW03 } & \text { Resource Recovery Facility Deficiency } \\ \text { SW04 } & \text { Improper/Unpermitted Storage } \\ \text { SW05 } & \text { Dumpster/Receptacle Deficiency } \\ \text { SW06 } & \text { Special Waste Materials Deficiency } \\ \text { SW07 } & \text { Medical Waste Deficiency } \\ \text { SW08 } & \text { Overseas Waste Deficiency } \\ \text { SW09 } & \text { Inadequate/Lacking Disposal Records } \\ \text { SW10 } & \text { Other (please indicate on the finding sheet the nature of the finding) } \\ \text { orage Tank Management } \\ \text { ST01 } & \text { AF Tank Management } \\ \text { ST02 } & \text { AST Installation Deficiency } \\ \text { ST03 } & \text { AST Containment Deficiency } \\ \text { ST04 } & \text { AST Spill Reporting/Cleanup Deficiency } \\ \text { ST05 } & \text { UST Installation Deficiency } \\ \text { ST06 } & \text { UST Notification Deficiency } \\ \text { ST07 } & \text { UST Leak Testing Deficiency }\end{array}$




\section{Finding Identification Codes for Use OCONUS}

(Based on AFI 32-7045, Attachment 3)

\section{Storage Tank Management (continued)}

ST08 UST Removal Deficiency

ST09 UST Spill/Leak Reporting/Cleanup Deficiency

ST10 Other (please indicate on the finding sheet the nature of the finding)

\section{Toxic Substances Management}

\section{PCBs}

TS01 Labeling Deficiency

TS02 Inadequate/Lacking Inventory

TS03 Storage Deficiency

TS04 PCB Inspection Deficiency

TS05 PCB Spill/Leaking Equipment

TS06 Documentation Deficiency

TS07 Exceeding 1 Yr Storage Time

TS08 Equipment Management Deficiency

TS09 PCB Other (please indicate on the finding sheet the nature of the finding)

Asbestos

TS10 Labeling Deficiency

TS11 Inadequate Container Management

TS12 Inadequate Personnel Certification/Training

TS13 Abatement Site Management Deficiency

TS14 Inadequate/Lacking Survey/Plans

TS15 Disposal Deficiency

TS16 Improper Management of ACM

TS17 Asbestos Other (please indicate on the finding sheet the nature of the finding)

Radon Mitigation

TS18 Inadequate/Lacking Sampling

TS19 Inadequate/Lacking Documentation

TS20 Improper Notification

TS21 Radon Other (please indicate on the finding sheet the nature of the finding)

Lead-Based Paint (LBP) Management

TS22 Inadequate/Lacking Survey/Required Investigation

TS23 Improper Sampling

TS24 Inadequate/Lacking Documentation 


\section{Finding Identification Codes for Use OCONUS}

(Based on AFI 32-7045, Attachment 3)

Toxic Substances Management $L B P$ (continued)

TS25 Improper Notification

TS26 LBP Training Deficiency

TS27 LBP Other (please indicate on the finding sheet the nature of the finding)

\section{Wastewater Management}

WW01 Unpermitted Discharge

WW02 Noncompliance with Discharge Permit

WW03 Monitoring/Sampling Deficiency

WW04 Discharge Monitoring Record Keeping Deficiency

WW05 Oil/Water Separator Deficiency

WW06 Collection System (e.g., lift stations, sewer lines, etc.) Deficiency

WW07 Improper Wastewater Treatment Plant Operation

WW08 Improper Sewage Sludge Disposal

WW09 Inadequate Treatment Plant Operator Training/Certification

WW10 Underground Injection Well (e.g., septic tanks) Management Deficiency

WW11 Fire Training Pit Deficiency

WW12 Storm Water Management Deficiency

WW13 Nonpoint Source Management Deficiency

WW14 Other (please indicate on the finding sheet the nature of the finding)

\section{Water Quality Management}

$\begin{array}{ll}\text { WQ01 } & \text { Unpermitted Water Supply System } \\ \text { WQ02 } & \text { Noncompliance With Withdrawal Permit } \\ \text { WQ03 } & \text { Inadequate Water Source Protection } \\ \text { WQ04 } & \text { Exceeding Water Quality Standard } \\ \text { WQ05 } & \text { Monitoring/Sampling Deficiency } \\ \text { WQ06 } & \text { Notification/Record Keeping Deficiency } \\ \text { WQ07 } & \text { Water Tank/Reservoir Deficiency } \\ \text { WQ08 } & \text { Filtration/Chlorination Facility Deficiency } \\ \text { WQ09 } & \text { Distribution System Deficiency } \\ \text { WQ10 } & \text { Backflow Prevention Deficiency } \\ \text { WQ11 } & \text { Water Plan Operator Training/Certification Deficiency } \\ \text { WQ12 } & \text { Water Quality Monitoring Record Keeping Deficiency } \\ \text { WQ13 } & \text { Other (please indicate on the finding sheet the nature of the finding) }\end{array}$


Table 5

\section{Root Cause Codes}

(AFI 32-7045, Attachment 4)

\section{Plans and Implementation}

\section{PA ECAMP}

PA1 Assessments of inspections are not conducted by trained and qualified professionals

PA2 Inadequate or conflicting guidance exists for conducting assessments or inspections

PA3 Appropriate review and follow-up of self-assessment and/or inspection program are not conducted.

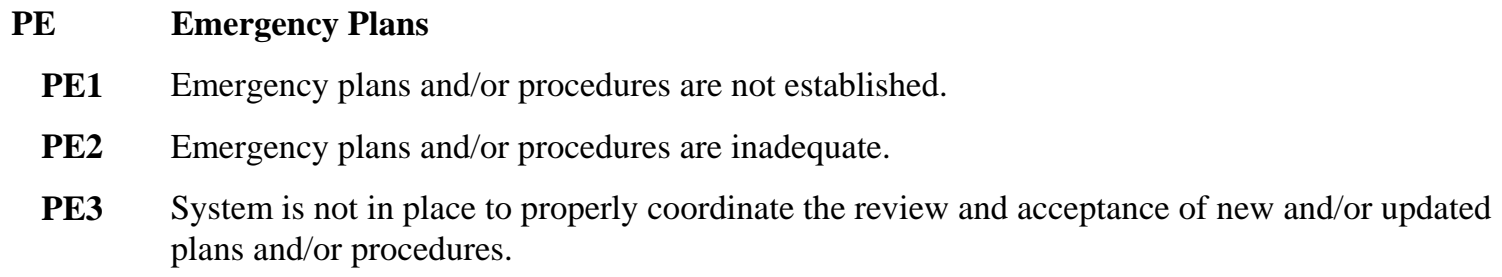

PE1 Emergency plans and/or procedures are not established.

PE2 Emergency plans and/or procedures are inadequate.

PE3 System is not in place to properly coordinate the review and acceptance of new and/or updated plans and/or procedures.

PE4 Emergency plans and/or procedures are not effective and/or properly implemented.

PM Management Action Plans (MAPs)

PM1 MAPs are not established.

PM2 MAPs are inadequate.

PM3 System is not in place to properly coordinate the review and acceptance of new and/or updated MAPs.

PM4 MAPs are not effective and/or properly implemented.

PP

\section{Environmental Management Plans}

PP1 Environmental management plans and/or procedures are not established.

PP2 Environmental management plans and/or procedures are inadequate.

PP3 System is not in place to properly coordinate the review and acceptance of new and/or updated plans and/or procedures.

PP4 Plans and/or procedures are not effective and/or properly implemented.

\section{PD Documentation/Regulations Tracking/Recordkeeping}

PD1 System not in place to track new or changing regulations.

PD2 New regulatory requirements are not being incorporated into standard operating procedures.

PD3 Regulations are misinterpreted or unknown.

PD4 Document control system and record retention policy does not exist or is inadequate.

\section{PC Compliance Tracking and Reporting}

PC1 Tracking system for key regulatory compliance deadlines does not exist or is inadequate.

PC2 No formal mechanisms exist to investigate, report, correct, track, or monitor environmental problems and incidents. 


\section{Training and General Awareness}

TC Continuing Education

TC1 Personnel not trained

TC2 Personnel trained but course content inadequate

TC3 Insufficient skills to execute procedures properly (individual has received the proper training but is not proficient in skills)

TM Mandated

TM1 Personnel not trained

TM2 Personnel trained but course content inadequate

TM3 Personnel trained but did not fully understand requirement

TM4 Training not properly documented

TG General Awareness

TG1 Personnel not trained

TG2 Personnel trained but course content inadequate

TG3 Personnel trained but did not fully understand requirement

\section{Command Emphasis/Oversight}

\section{CO Management Organization and Oversight Implementation}

CO1 Known deficient item, facility, or equipment, not formally identified for action/funding (not acting on a known deficiency)

CO2 Higher priority mission requirements took precedence

CO3 Insufficient skills to execute procedures properly (individual has received the proper training but is not proficient in skills)

CO4 Procedures have been developed and implemented but are not being followed

CO5 Inadequate manning

CO6 Environmental management does not participate at key strategic and operations planning meetings

CO7 Line manager(s) does not show commitment and/or responsibility for minimizing environmental impacts within operations area.

CO8 Environmental responsibilities are not clearly defined and understood by personnel.

\section{Contract Management}

CM1 Contract documents are inadequate (e.g. specifications, statements of work do not hold contractor accountable for noncompliance with environmental requirements).

CM2 Contract documents are adequate but contractor does not fulfill requirements.

CR Roles and Responsibilities

CR1 Personnel understood requirement, but simply forgot to act.

CR2 Environmental responsibilities are not clearly defined in job descriptions.

CR3 Environmental responsibilities are not included in performance standards. 


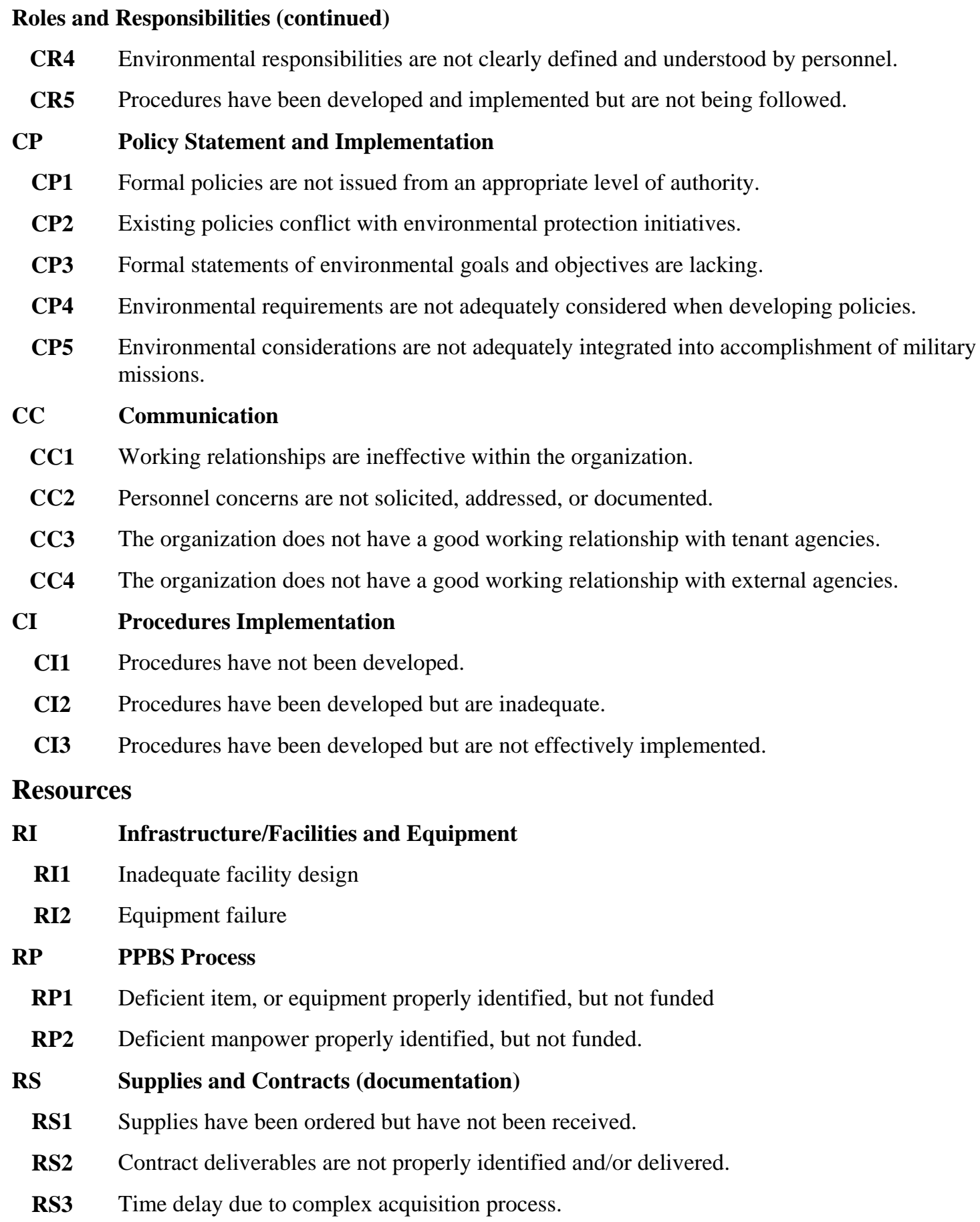

CR4 Environmental responsibilities are not clearly defined and understood by personnel.

CR5 Procedures have been developed and implemented but are not being followed.

CP Policy Statement and Implementation

CP1 Formal policies are not issued from an appropriate level of authority.

CP2 Existing policies conflict with environmental protection initiatives.

CP3 Formal statements of environmental goals and objectives are lacking.

CP4 Environmental requirements are not adequately considered when developing policies.

CP5 Environmental considerations are not adequately integrated into accomplishment of military missions.

\section{Communication}

CC1 Working relationships are ineffective within the organization.

CC2 Personnel concerns are not solicited, addressed, or documented.

CC3 The organization does not have a good working relationship with tenant agencies.

CC4 The organization does not have a good working relationship with external agencies.

CI Procedures Implementation

CI1 Procedures have not been developed.

CI2 Procedures have been developed but are inadequate.

CI3 Procedures have been developed but are not effectively implemented.

\section{Resources}

RI Infrastructure/Facilities and Equipment

RI1 Inadequate facility design

RI2 Equipment failure

RP PPBS Process

RP1 Deficient item, or equipment properly identified, but not funded

RP2 Deficient manpower properly identified, but not funded.

RS Supplies and Contracts (documentation)

RS1 Supplies have been ordered but have not been received.

RS2 Contract deliverables are not properly identified and/or delivered.

RS3 Time delay due to complex acquisition process.

\section{External Factors}

EU Unforeseen Accident

EW Weather Related

EA Animal Activity

EV Acts of Vandalism

EG Acts of God 


\section{Glossary of Acronyms}

\begin{tabular}{|c|c|}
\hline Acronym & Expansion \\
\hline AAFES & Army/Air Force Exchange Service \\
\hline ACM & asbestos-containing material \\
\hline ACWM & asbestos-containing waste material \\
\hline $\mathrm{AF}$ & Air Force \\
\hline AFCEE & Air Force Center for Environmental Excellence \\
\hline AFI & Air Force Instruction \\
\hline AFJ & Air Force Joint [Publication] \\
\hline AFM & Air Force Manual \\
\hline AFMAN & Air Force Manual \\
\hline AFOSH & Air Force Occupational Safety and Health \\
\hline AFP & Air Force Pamphlet \\
\hline AFPD & Air Force Policy Directive \\
\hline AFPMB & Armed Forces Pest Management Board \\
\hline AFR & Air Force Regulation \\
\hline AFTO & Air Force Technical Order \\
\hline AGE & aerospace ground equipment \\
\hline AST & aboveground storage tank \\
\hline AUL & authorized users list \\
\hline BASH & Bird Aircraft Strike Hazard \\
\hline BCE & Base Civil Engineer \\
\hline BEE & Bioenvironmental Engineer \\
\hline BFMO & Base Fuels Management Officer \\
\hline BES & Bioenvironmental Engineering Services \\
\hline BRAC & Base Realignment and Closure \\
\hline CAA & Clean Air Act \\
\hline CATEX & categorical exclusion \\
\hline CDC & Child Development Center \\
\hline CE & Civil Engineering \\
\hline CECORS & Civil Engineering Contract Reporting System \\
\hline CEM & continuous emissions monitoring \\
\hline CEP & Civil Engineering Programmer \\
\hline CERCLA & Comprehensive Environmental Restoration, Compensation and Liability Act \\
\hline CERL & Construction Engineering Research Laboratory \\
\hline CFC & chlorofluorcarbon \\
\hline
\end{tabular}




\begin{tabular}{|c|c|}
\hline Acronym & Expansion \\
\hline CFR & Code of Federal Regulations \\
\hline CPSA & Consumer Product Safety Act \\
\hline DBOF & Defense Business Operations Fund \\
\hline DCM & Deputy Commander for Maintenance \\
\hline DeCA & Defense Commisary Agency \\
\hline DESCIM & Defense Environmental Security Corporate Information Management \\
\hline DFO/DFR & Defense Fuel Office/Defense Fuel Region \\
\hline DLA & Defense Logistics Agency \\
\hline DOD & Department of Defense \\
\hline DODD & DOD Directive \\
\hline DODDS & Department of Defense Dependents Schools \\
\hline DODI & DOD Instruction \\
\hline DOE & Department of Energy \\
\hline DOPAA & description of proposed action and alternatives \\
\hline DOT & Department of Transportation \\
\hline DRMO & Defense Reutilization and Marketing Office \\
\hline DRMS & Defense Reutilization and Marketing Service \\
\hline DWTP & domestic wastewater treatment plant \\
\hline EA & environmental analysis \\
\hline EC & Environmental Coordinator \\
\hline ECAMP & Environmental Compliance Assessment and Management Program \\
\hline EEA & Environmental Executive Agent \\
\hline $\mathrm{EHO}$ & Environmental Health Officer \\
\hline EIAP & Environmental Impact Analysis Process \\
\hline EIS & environmental impact statement \\
\hline EMO & Environmental Management Office \\
\hline EPC & Environmental Protection Committee \\
\hline EPCRA & Emergency Planning and Community Right-to-Know Act \\
\hline EPF & Environmental Planning Function \\
\hline ERDC & Engineer Research and Development Center \\
\hline FGS & Final Governing Standards \\
\hline FMF & Fuels Management Flight \\
\hline FMFC & Fuels Management Flight Commander \\
\hline FMT & Fuels Management Team \\
\hline FOIA & Freedom of Information Act \\
\hline
\end{tabular}




\begin{tabular}{|c|c|}
\hline Acronym & Expansion \\
\hline FONSI & Finding of No Significant Impact \\
\hline GOCO & government-owned contractor-operated \\
\hline GSA & General Services Administration \\
\hline HAZCOM & Hazard Communication \\
\hline HAZMAT & hazardous material \\
\hline HAZMART & Hazardous Material Pharmacy Office \\
\hline HAZWOPER & Hazardous Waste Operations and Emergency Response \\
\hline $\mathrm{HM}$ & hazardous materials \\
\hline HMIS & Hazardous Materials Information System \\
\hline HMMP & Hazardous Materials Management Process \\
\hline HMTA & Hazardous Materials Transportation Act \\
\hline HPP & HAZMAT Pharmacy Program \\
\hline HQ & Headquarters \\
\hline HUD & Housing and Urban Development \\
\hline HVAC & Heating, Ventilating, and Air-conditioning \\
\hline HWAP & hazardous waste accumulation point \\
\hline HWPS & hazardous waste profile sheet \\
\hline HWSA & hazardous waste storage area \\
\hline IAPMO & International Association of Plumbing and Mechanical Officials \\
\hline IC & Installation Commander \\
\hline ICUZ & installation compatible use zone \\
\hline IMPAC & International Merchant Purchase Authorization Card \\
\hline IOSC & Installation On-Scene Coordinator/Commander \\
\hline IPM & integrated pest management \\
\hline IPMIS & Integrated Pest Management Information System \\
\hline IRT & Installation Response Team \\
\hline ITP & Industrial Toxic Project \\
\hline JCS & Joint Chiefs of Staff \\
\hline LBP & lead-based paint \\
\hline LCCA & Lead Contamination Control Act \\
\hline LFM & Liquid Fuels Maintenance \\
\hline LTI & lead toxicity investigation \\
\hline MAJCOM & Major Command \\
\hline MAP & Management Action Plan \\
\hline MFH & military family housing \\
\hline
\end{tabular}




\begin{tabular}{|c|c|}
\hline Acronym & Expansion \\
\hline MILCOM & military construction \\
\hline MIPR & military interdepartmental purchase request \\
\hline MOA & Memorandum of Agreement \\
\hline MOGAS & motor gasoline \\
\hline MP & Management Practice \\
\hline MSDS & material safety data sheet \\
\hline MSHA & Mine Safety and Health Administration \\
\hline MSW & municipal solid waste \\
\hline MSWLF & municipal solid waste landfill \\
\hline NATO & North Atlantic Treaty Organization \\
\hline NFPA & National Fire Protection Association \\
\hline NOI & notice of intent \\
\hline NPDES & National Pollutant Discharge Elimination System \\
\hline NPS & nonpoint (or nonstationary) source \\
\hline O\&M & Operations and Maintenance \\
\hline OCAP & OCONUS Compliance Assessment Protocols \\
\hline OCONUS & Outside of the Continental United States \\
\hline ODC & ozone-depleting chemical \\
\hline ODS & ozone-depleting substance \\
\hline OEA & open enforcement action \\
\hline OEBGD & Overseas Environmental Baseline Guidance Document \\
\hline OPR & Office of Primary Responsibility \\
\hline OSHA & Occupational Safety and Health Administration \\
\hline PAO & Public Affairs Officer \\
\hline PCB & polychlorinated biphenyl \\
\hline PCMS & Project by Contract Management System \\
\hline PDC & Programming, Design, and Construction (System) \\
\hline $\mathrm{PH}$ & Public Health \\
\hline POL & petroleum, oil, and lubricant \\
\hline PPE & personal protective equipment \\
\hline PPMP & Professional Pest Management Personnel \\
\hline QA/QC & quality assurance/quality control \\
\hline QC\&I & quality control and inspection \\
\hline QRP & qualified recycling program \\
\hline RAC & risk assessment code \\
\hline
\end{tabular}




\begin{tabular}{ll} 
Acronym & Expansion \\
\hline RCRA/HSWA & Resource Conservation and Recovery Act/Hazardous and Solid Waste Amendments \\
RCS & Report Control Symbol \\
RDF & refuse-derived fuel \\
ROA & Range Operating Agency \\
RRR & Resource Recovery and Recycling (Program) \\
SJA & Staff Judge Advocate \\
SOFA & Status of Forces Agreement \\
SOP & standard operating procedure \\
SOS & sources of supply \\
TIM & Technical Information Memorandum \\
TO & Technical Order \\
TSDF & treatment, storage, and disposal facility \\
UFC & Unified Facilities Criteria \\
ULV & ultra-low volume \\
UPC & Uniform Plumbing Code \\
USACERL & U.S. Army Construction Engineering Research Laboratories \\
USAF & U.S. Air Force \\
USC & U.S. Code \\
USEPA & U.S. Environmental Protection Agency \\
UST & underground storage tank \\
VHAP & volatile hazardous air pollutant \\
VOC & volatile organic compound \\
VOL & volatile organic liquid \\
WIMS & Work Information Management System \\
WIMS-ES & Work Information Management System-Environmental Subsystem \\
&
\end{tabular}




\title{
SECTION 1
}

\section{AIR EMISSIONS MANAGEMENT}

\section{Overseas ESOHCAMP}

\author{
September 2009
}

\section{A. Service-specific Regulations and Policies}

- HQ USAF/ILEV Memorandum, Revised Environmental Quality Metrics, 14 February 2005, requires immediate implementation across the AF (including overseas installations and government-owned/contractor-operated (GOCO) facilities of Under Secretary of Defense Memorandum, Revised Pollution Prevention and Compliance Metrics, dated 12 October 2004.

- Air Force Instruction (AFI) 32-7040, Air Quality Compliance and Resource Management, 27 August 2007; applicable portions of this instruction are implemented overseas (i.e., outside the U.S., its territories and possessions) in accordance with international agreements and the applicable Final Governing Standards (FGS) or the Overseas Environmental Baseline Guidance Document (OEBGD).

\section{B. DOD Directives and Instructions}

- Under Secretary of Defense Memorandum, Revised Pollution Prevention and Compliance Metrics, dated 12 October 2004, publishes pollution prevention (P2) metrics and definitions. Implementation begins in 2005. The following goals are established in the memorandum:

1. Manage air pollutant emissions to protect public health, meet clean air standards, and maximize operational flexibility

2. Make appropriate investments to promote the attainment of air quality standards and enhance the training/operations flexibility in maximizing use of air resources

3. Leverage energy conservation opportunities.

\section{Service-specific/DOD Definitions}

- Emission - release of pollutants into the air from a source (Attachment 2, Under Secretary of Defense Memorandum, Revised Pollution Prevention and Compliance Metrics, 12 October 2004).

- Nonrecurring Compliance Investment - fiscal year costs listed on Exhibit PB-28 (Funds Budgeted for Environmental Quality) of the Presidential Budget for the Clean Air Act. These costs represent Class I/II projects and planning efforts (already out of compliance/will be out of compliance at a specified date in the future) to achieve compliance (Attachment 2, Under Secretary of Defense Memorandum, Revised Pollution Prevention and Compliance Metrics, 12 October 2004).

- Nonrecurring Pollution Prevention Investment - fiscal year costs listed on Exhibit PB-28 (Funds Budgeted for Environmental Quality) of the Presidential Budget for the CAA. These costs represent Class I/II pollution prevention projects (already out of compliance/will be out of compliance at a specified date in the future) (Attachment 2, Under Secretary of Defense Memorandum, Revised Pollution Prevention and Compliance Metrics, 12 October 2004).

- Overseas - outside any territory, possession, or commonwealth of the United States. This does not include contingency operations, training deployments, or the operations of military vessels and aircraft (Attachment 2, Under Secretary of Defense Memorandum, Revised Pollution Prevention and Compliance Metrics, 12 October 2004). 
- Overseas Installations - permanent, base force structure facilities under the operational control of the Secretary of a military department or the Department of Defense that is located outside the United States and outside any territory, commonwealth or possession of the United States. Installations overseas do NOT include temporary, contingency operation or deployment support facilities. Tenants on overseas installations should report through their component headquarters reporting systems (Attachment 2, Under Secretary of Defense Memorandum, Revised Pollution Prevention and Compliance Metrics, 12 October 2004).

(NOTE: Include Government-owned, Contractor-operated [GOCO] installations.)

\section{Additional Records To Review}

- None

E. Additional Physical Features To Inspect

- None

F. Guidance for Checklist Users

\section{REFER TO CHECKLIST ITEMS:}

Missing Checklist Items/Positive Findings

General

Non-Nuclear Steam-, Heat-, or Power-Generating Units

Nonmedical Incinerators

Motor Vehicles

Dry Cleaning Machines

Vapor Recovery Systems

Volatile Organic Compounds

Fugitive Emissions
AE.2.1.OCAF and AE.2.2.OCAF

AE.5.1.OCAF through AE.5.7.OCAF

AE.10.1.OCAF through AE.10.4.OCAF

AE.20.1.OCAF and AE.20.2.OCAF

AE.30.1.OCAF

AE.50.1.OCAF

AE.70.1.OCAF

AE.90.1.OCAF through AE.90.4.OCAF

AE.110.1.OCAF through AE.110.6.OCAF 


\begin{tabular}{|c|c|}
\hline \multicolumn{2}{|r|}{$\begin{array}{c}\text { COMPLIANCE CATEGORY: } \\
\text { AIR EMISSIONS MANAGEMENT } \\
\text { Overseas ESOHCAMP }\end{array}$} \\
\hline $\begin{array}{l}\text { REGULATORY } \\
\text { REQUIREMENTS: }\end{array}$ & $\begin{array}{l}\text { REVIEWER CHECKS: } \\
\text { September } 2009\end{array}$ \\
\hline $\begin{array}{l}\text { AE.2 } \\
\text { MISSING CHECKLIST } \\
\text { ITEMS/POSITIVE } \\
\text { FINDINGS }\end{array}$ & \\
\hline $\begin{array}{l}\text { AE.2.1.OCAF. Installations } \\
\text { must comply with all applica- } \\
\text { ble regulatory requirements } \\
\text { not contained in this checklist } \\
\text { (a finding under this checklist } \\
\text { item will have the citation of } \\
\text { the applied regulation as a } \\
\text { basis of finding) [Added } \\
\text { March 2002]. }\end{array}$ & $\begin{array}{l}\text { Determine whether any new regulations concerning air emissions management } \\
\text { have been issued since the finalization of the manual. } \\
\text { Determine whether the installation has activities or facilities that are regulated but } \\
\text { not addressed in this checklist. } \\
\text { Verify that the installation is in compliance with all applicable and newly issued } \\
\text { regulations. }\end{array}$ \\
\hline $\begin{array}{l}\text { AE.2.2.OCAF. Installations } \\
\text { should go above and beyond } \\
\text { environmental statutory and } \\
\text { regulatory compliance (MP) } \\
\text { [Added March 2002]. }\end{array}$ & $\begin{array}{l}\text { Determine whether the installation has gone above and beyond simply complying } \\
\text { with environmental requirements. } \\
\text { (NOTE: This checklist item is used only to write positive findings.) }\end{array}$ \\
\hline
\end{tabular}




\begin{tabular}{|c|c|}
\hline \multicolumn{2}{|r|}{$\begin{array}{l}\text { COMPLIANCE CATEGORY: } \\
\text { AIR EMISSIONS MANAGEMENT } \\
\text { Overseas ESOHCAMP }\end{array}$} \\
\hline $\begin{array}{l}\text { REGULATORY } \\
\text { REQUIREMENTS: }\end{array}$ & $\begin{array}{l}\text { REVIEWER CHECKS: } \\
\text { September } 2009\end{array}$ \\
\hline $\begin{array}{l}\text { AE.5 } \\
\text { GENERAL }\end{array}$ & \\
\hline $\begin{array}{l}\text { AE.5.1.OCAF. Installations } \\
\text { must meet requirements con- } \\
\text { tained in MAJCOM supple- } \\
\text { ments to AFIs and policy } \\
\text { documents (a finding under } \\
\text { this checklist item will have } \\
\text { the citation of the MAJCOM } \\
\text { document as a basis of find- } \\
\text { ing) [Moved June 2003]. }\end{array}$ & $\begin{array}{l}\text { Determine whether the requirements in MAJCOM supplements to AFIs and pol- } \\
\text { icy documents are within the scope of the environmental compliance assessment. } \\
\text { Verify that the installation is in compliance with MAJCOM requirements. } \\
\text { [Formerly checklist item number AE.10.2.OCAF.] }\end{array}$ \\
\hline $\begin{array}{l}\text { AE.5.2.OCAF. All installa- } \\
\text { tions that must report energy } \\
\text { reduction in accordance with }\end{array}$ & $\begin{array}{l}\text { Determine whether the installation is required to report energy reduction in accor- } \\
\text { dance with EO } 13123 \text {. }\end{array}$ \\
\hline $\begin{array}{l}\text { Executive Order (EO) 13123, } \\
\text { Greening the Government } \\
\text { through Efficient Energy } \\
\text { Management must report spe- } \\
\text { cific information on a calen- } \\
\text { dar year basis (HQ } \\
\text { USAF/ILEV Memorandum, } \\
\text { Revised Environmental Qual- } \\
\text { ity Metrics, } 14 \text { February 2005, } \\
\text { para 1; Under Secretary of } \\
\text { Defense Memorandum, Re- } \\
\text { vised Pollution Prevention } \\
\text { and Compliance Metrics, 12 } \\
\text { October 2004; Attachment 1, } \\
\text { paras II.c.2 and II.d.2 through } \\
\text { II.d.4) [Added March 2005]. }\end{array}$ & $\begin{array}{l}\text { Verify that the installation reports: } \\
\text { - energy reduction as BTU per Gross Square Foot (BTUs/GSF); energy man- } \\
\text { agement data reported to the Office of the Deputy Under Secretary of De- } \\
\text { fense (Installations \& Environment) to meet the requirements of EO 13123, } \\
\text { Greening the Government Through Efficient Energy Management } \\
\text { - cost of air pollution management as reported in President's Budget (Exhibit } \\
\text { PB-28) in Thousands of Dollars (\$): } \\
\text { - nonrecurring compliance investment, Clean Air Act } \\
\text { - nonrecurring pollution prevention investment, Clean Air Act. } \\
\text { (NOTE: Potential sources of data include the President's Budget [Exhibit PB-28] } \\
\text { and the DOD Annual Energy Management Report.) } \\
\text { (NOTE: Begin collecting this data in Calendar Year 2005.) }\end{array}$ \\
\hline $\begin{array}{l}\text { AE.5.3.OCAF. All installa- } \\
\text { tions that have facilities that } \\
\text { must measure and meet air } \\
\text { pollution requirements de- } \\
\text { fined by the Final Governing } \\
\text { Standards or international } \\
\text { treaties must report specific } \\
\text { information on a calendar } \\
\text { year basis (HQ USAF/ILEV } \\
\text { Memorandum, Revised Envi- } \\
\text { ronmental Quality Metrics, } 14 \\
\text { February 2005, para 1; Under } \\
\text { Secretary of Defense Memo- }\end{array}$ & $\begin{array}{l}\text { Determine whether the installation has facilities that must measure and meet air } \\
\text { pollution requirements defined by the Final Governing Standards or international } \\
\text { treaties. } \\
\text { Verify that the installation reports, in tons ( } 2000 \mathrm{lb} / \mathrm{ton}) \text {, the amount of regulated } \\
\text { air pollutant emissions identified by the FGS. } \\
\text { (NOTE: Begin collecting this data in Calendar Year 2005.) }\end{array}$ \\
\hline
\end{tabular}




\begin{tabular}{|c|c|}
\hline \multicolumn{2}{|r|}{$\begin{array}{c}\text { COMPLIANCE CATEGORY: } \\
\text { AIR EMISSIONS MANAGEMENT } \\
\text { Overseas ESOHCAMP }\end{array}$} \\
\hline $\begin{array}{l}\text { REGULATORY } \\
\text { REQUIREMENTS: }\end{array}$ & $\begin{array}{l}\text { REVIEWER CHECKS: } \\
\text { September } 2009\end{array}$ \\
\hline $\begin{array}{l}\text { randum, Revised Pollution } \\
\text { Prevention and Compliance } \\
\text { Metrics, } 12 \text { October 2004; } \\
\text { Attachment 1, paras II.c.2 and } \\
\text { II.d.2 through II.d.4) [Added } \\
\text { March 2005]. }\end{array}$ & \\
\hline $\begin{array}{l}\text { AE.5.4.OCAF. Installation } \\
\text { organizations planning to } \\
\text { purchase equipment that will } \\
\text { generate air emissions which } \\
\text { have potential permitting, } \\
\text { authorization or registration } \\
\text { requirements should first co- } \\
\text { ordinate with the installation } \\
\text { environmental function (MP) } \\
\text { [Added July 2008]. }\end{array}$ & $\begin{array}{l}\text { Verify that installation organizations planning to purchase equipment that will } \\
\text { generate air emissions which have potential permitting, authorization, or registra- } \\
\text { tion requirements first coordinate with the installation environmental function. } \\
\text { (NOTE: Degreasers, generators, boilers, and painting or abrasive equipment are } \\
\text { examples of equipment that that will generate air emissions which have potential } \\
\text { permitting, authorization or registration requirements.) } \\
\text { (NOTE: This MP is found at AFI 32-7040, para 1.3.15.) }\end{array}$ \\
\hline $\begin{array}{l}\text { AE.5.5.OCAF. Tenant or- } \\
\text { ganizations and other DOD } \\
\text { services on Air Force installa- } \\
\text { tions or on joint installations } \\
\text { where the Air Force is the } \\
\text { lead component must meet } \\
\text { specific responsibilities (AFI } \\
\text { 32-7040, para 1.3.16) [Added } \\
\text { July 2008]. }\end{array}$ & $\begin{array}{l}\text { Verify that tenant organizations and other DOD services on Air Force installa- } \\
\text { tions or on joint installations where the Air Force is the lead component coordi- } \\
\text { nate any actions which affect air quality (to include construction activities and } \\
\text { installation of applicable equipment) with the installation environmental function. } \\
\text { Verify that tenant organizations and other DOD services on Air Force installa- } \\
\text { tions or on joint installations where the Air Force is the lead component maintain } \\
\text { records to demonstrate compliance with Air Quality Compliance and Resource } \\
\text { Management Program requirements. } \\
\text { (NOTE: AAFES is considered a tenant organization.) }\end{array}$ \\
\hline $\begin{array}{l}\text { AE.5.6.OCAF. Installation } \\
\text { environmental functions must } \\
\text { perform specific planning } \\
\text { functions (AFI 32-7040, para } \\
\text { 2.1.4) [Added July 2008]. }\end{array}$ & $\begin{array}{l}\text { Verify that, as a minimum, installation environmental functions perform the fol- } \\
\text { lowing planning actions: } \\
\text { - as early as practicable, coordinate closely as appropriate with all applicable } \\
\text { organizations (MAJCOM Air Program Manager, Civil Engineer Flights, } \\
\text { Bioenvironmental Engineering, logistics functions, regulatory authorities, } \\
\text { Metropolitan Planning Organizations, etc.) on plans for new construction, } \\
\text { modification or replacement of emissions-related equipment, and on other } \\
\text { requirements that will impact the installation's air emissions } \\
\text { - actively compare the installation Air Emissions Inventory (AEI) and upcom- } \\
\text { ing changes in installation emission levels against regulatory thresholds and } \\
\text { emerging regulatory requirements to assure uninterrupted mission capability } \\
\text { and continued compliance } \\
\text { - maintain an updated summary of all permit requirements, with a comparison } \\
\text { to the regulatory requirements and schedules } \\
\text { - identify and document insignificant/exempt sources not subject to permitting } \\
\text { program requirements } \\
\text { - track and assess for their potential impact on installation operations }\end{array}$ \\
\hline
\end{tabular}




\begin{tabular}{|c|c|}
\hline \multicolumn{2}{|r|}{$\begin{array}{c}\text { COMPLIANCE CATEGORY: } \\
\text { AIR EMISSIONS MANAGEMENT } \\
\text { Overseas ESOHCAMP }\end{array}$} \\
\hline $\begin{array}{l}\text { REGULATORY } \\
\text { REQUIREMENTS: }\end{array}$ & $\begin{array}{l}\text { REVIEWER CHECKS: } \\
\text { September } 2009\end{array}$ \\
\hline $\begin{array}{l}\text { AE.5.7.OCAF. Installations } \\
\text { must submit their most recent } \\
\text { AEI in electronic format to } \\
\text { AFIOH and their parent } \\
\text { Command within } 30 \text { days of } \\
\text { final AEI report completion } \\
\text { (AFI 32-7040, para 3.2) } \\
\text { [Added July 2008]. }\end{array}$ & $\begin{array}{l}\text { - ensure that any new or emerging regulatory requirements are incorporated } \\
\text { into appropriate program elements } \\
\text { - report identified impacts of new or emerging regulatory requirements } \\
\text { through the chain of command. } \\
\text { [Author's Note: AFI 32-7040, para 3.2, requires that overseas installations con- } \\
\text { duct AEIs only in accordance with FGS or host nation agreements. However, } \\
\text { USAFEI 32-7040, para 2.1, requires each installation to conduct an initial emis- } \\
\text { sions source survey of all emissions sources for which it has environmental com- } \\
\text { pliance responsibility.] } \\
\text { Verify that the installation submits its most recent AEI in electronic format to } \\
\text { AFIOH and their parent Command within } 30 \text { days of final AEI report completion. } \\
\text { (NOTE: AFIOH is the AEI repository custodian for the Air Force.) } \\
\text { [Author's Note: AFI 32-7040, para 3.2, requires that overseas installations con- } \\
\text { duct AEIs only in accordance with FGS or host nation agreements. However, } \\
\text { USAFEI } 32-7040 \text {, para 2.1, requires each installation to conduct an initial emis- } \\
\text { sions source survey of all emissions sources for which it has environmental com- } \\
\text { pliance responsibility.] }\end{array}$ \\
\hline
\end{tabular}




\begin{tabular}{|l|l|}
\hline \multicolumn{2}{|c|}{$\begin{array}{c}\text { COMPLIANCE CATEGORY: } \\
\text { AIR EMISSIONS MANAGEMENT } \\
\text { Overseas ESOHCAMP }\end{array}$} \\
REGULATORY \\
REQUIREMENTS:
\end{tabular}




\begin{tabular}{|c|c|}
\hline \multicolumn{2}{|r|}{$\begin{array}{l}\text { COMPLIANCE CATEGORY: } \\
\text { AIR EMISSIONS MANAGEMENT } \\
\text { Overseas ESOHCAMP }\end{array}$} \\
\hline $\begin{array}{l}\text { REGULATORY } \\
\text { REQUIREMENTS: }\end{array}$ & $\begin{array}{l}\text { REVIEWER CHECKS: } \\
\text { September } 2009\end{array}$ \\
\hline $\begin{array}{l}\text { AE.20 } \\
\text { NONMEDICAL } \\
\text { INCINERATORS }\end{array}$ & \\
\hline $\begin{array}{l}\text { AE.20.1.OCAF. [Moved } \\
\text { June 2003; Deleted July } \\
\text { 2008]. }\end{array}$ & $\begin{array}{l}\text { Deleted at the request of the sponsor. } \\
\text { [Formerly checklist item number AE.20.5.OCAF.] }\end{array}$ \\
\hline $\begin{array}{l}\text { AE.20.2.OCAF. [Moved } \\
\text { June 2003; Deleted July } \\
\text { 2008]. }\end{array}$ & $\begin{array}{l}\text { Deleted at the request of the sponsor. } \\
\text { [Formerly checklist item number AE.20.6.OCAF.] }\end{array}$ \\
\hline
\end{tabular}




\begin{tabular}{|c|c|}
\hline \multicolumn{2}{|r|}{$\begin{array}{c}\text { COMPLIANCE CATEGORY: } \\
\text { AIR EMISSIONS MANAGEMENT } \\
\text { Overseas ESOHCAMP }\end{array}$} \\
\hline $\begin{array}{l}\text { REGULATORY } \\
\text { REQUIREMENTS: }\end{array}$ & $\begin{array}{l}\text { REVIEWER CHECKS: } \\
\text { September } 2009\end{array}$ \\
\hline $\begin{array}{l}\text { AE.30 } \\
\text { MOTOR VEHICLES }\end{array}$ & \multirow{3}{*}{$\begin{array}{l}\text { Deleted at the request of the sponsor. } \\
\text { [This checklist item was moved to AE.70.1.OCAF.] }\end{array}$} \\
\hline $\begin{array}{l}\text { AE.30.1.OCAF. } \\
\text { July 2008]. }\end{array}$ & \\
\hline $\begin{array}{l}\text { AE.30.2.OCAF. } \quad \text { [Moved } \\
\text { June 2003]. }\end{array}$ & \\
\hline
\end{tabular}




\begin{tabular}{|l|c|}
\hline \multicolumn{2}{|c|}{$\begin{array}{c}\text { COMPLIANCE CATEGORY: } \\
\text { AIR EMISSIONS MANAGEMENT } \\
\text { Overseas ESOHCAMP }\end{array}$} \\
\hline \multicolumn{1}{|c|}{$\begin{array}{c}\text { REGULATORY } \\
\text { REQUIREMENTS: } \\
\text { September 2009 }\end{array}$} \\
$\begin{array}{l}\text { AE.50 } \\
\text { DRY CLEANING } \\
\text { MACHINES } \\
\begin{array}{l}\text { AE.50.1.OCAF. [Moved } \\
\text { June 2003; Deleted July } \\
\text { 2008]. }\end{array}\end{array}$ & $\begin{array}{l}\text { Deleted at the request of the sponsor. } \\
\text { [Formerly checklist item number AE.60.1.OCAF.] }\end{array}$ \\
\hline
\end{tabular}




\begin{tabular}{|l|c|}
\hline \multicolumn{2}{|c|}{$\begin{array}{c}\text { COMPLIANCE CATEGORY: } \\
\text { AIR EMISSIONS MANAGEMENT } \\
\text { Overseas ESOHCAMP }\end{array}$} \\
\hline \multicolumn{1}{|c|}{$\begin{array}{c}\text { REGIEWER CHECKS: } \\
\text { REQUIREMENTS: } \\
\text { September 2009 }\end{array}$} \\
$\begin{array}{l}\text { AE.70 } \\
\text { VAPOR RECOVERY } \\
\text { SYSTEMS } \\
\begin{array}{l}\text { AE.70.1.OCAF. [Moved } \\
\text { June 2003; Deleted July } \\
\text { 2008]. }\end{array}\end{array}$ & $\begin{array}{l}\text { Deleted at the request of the sponsor. } \\
\text { [Formerly checklist item number AE.30.2.OCAF.] }\end{array}$ \\
\hline
\end{tabular}




\begin{tabular}{|l|l|}
\hline \multicolumn{2}{|c|}{$\begin{array}{c}\text { COMPLIANCE CATEGORY: } \\
\text { AIR EMISSIONS MANAGEMENT } \\
\text { Overseas ESOHCAMP }\end{array}$} \\
\hline \multicolumn{2}{|c|}{ REGULATORY } \\
REQUIREMENTS: \\
\hline $\begin{array}{l}\text { September 2009 } \\
\text { AE.90 }\end{array}$
\end{tabular}




\begin{tabular}{|c|c|}
\hline & $\begin{array}{c}\text { COMPLIANCE CATEGORY: } \\
\text { AIR EMISSIONS MANAGEMENT } \\
\text { Overseas ESOHCAMP }\end{array}$ \\
\hline $\begin{array}{l}\text { REGULATORY } \\
\text { REQUIREMENTS: }\end{array}$ & $\begin{array}{l}\text { REVIEWER CHECKS: } \\
\text { September } 2009\end{array}$ \\
\hline $\begin{array}{l}\text { AE.110 } \\
\text { FUGITIVE EMISSIONS }\end{array}$ & \\
\hline $\begin{array}{l}\text { AE.110.1.OCAF. [Moved } \\
\text { June 2003; Deleted July } \\
\text { 2008]. }\end{array}$ & $\begin{array}{l}\text { Deleted at the request of the sponsor. } \\
\text { [Formerly checklist item number AE.50.1.OCAF.] }\end{array}$ \\
\hline $\begin{array}{l}\text { AE.110.2.OCAF. [Moved } \\
\text { June 2003; Deleted July } \\
\text { 2008]. }\end{array}$ & $\begin{array}{l}\text { Deleted at the request of the sponsor. } \\
\text { [Formerly checklist item number AE.50.2.OCAF.] }\end{array}$ \\
\hline $\begin{array}{l}\text { AE.110.3.OCAF. [Moved } \\
\text { June 2003; Deleted July } \\
\text { 2008]. }\end{array}$ & $\begin{array}{l}\text { Deleted at the request of the sponsor. } \\
\text { [Formerly checklist item number AE.50.3.OCAF.] }\end{array}$ \\
\hline $\begin{array}{l}\text { AE.110.4.OCAF. [Moved } \\
\text { June 2003; Deleted July } \\
\text { 2008]. }\end{array}$ & $\begin{array}{l}\text { Deleted at the request of the sponsor. } \\
\text { [Formerly checklist item number AE.50.4.OCAF.] }\end{array}$ \\
\hline $\begin{array}{l}\text { AE.110.6.OCAF. [Moved } \\
\text { June 2003; Deleted July } \\
\text { 2008]. }\end{array}$ & $\begin{array}{l}\text { Deleted at the request of the sponsor. } \\
\text { [Formerly checklist item number AE.50.6.OCAF.] }\end{array}$ \\
\hline
\end{tabular}




\section{Appendix 1-1}

Deleted July 2008 in consequence of the deletion of MPs without citable regulatory sources. 


\section{Appendix 1-2}

Deleted July 2008 in consequence of the deletion of MPs without citable regulatory sources. 


\section{SECTION 2}

\section{CULTURAL RESOURCES MANAGEMENT}

\section{Overseas ESOHCAMP}

September 2009

\section{A. Service-specific Regulations and Policies}

- Air Force Instruction (AFI) 32-7062, Air Force Comprehensive Planning, 1 October 1997, requires installations to develop and maintain maps that address specific environmental issues, including (among others) natural and cultural resources issues.

\section{B. DOD Directives and Instructions}

- None

C. Service-specific/DOD Definitions

- None

D. Additional Records To Review

- Base Environmental Maps

E. Additional Physical Features To Inspect

- None

F. Guidance for Checklist Users

REFER TO CHECKLIST ITEMS:

Missing Checklist Items/Positive Findings

CR.2.1.OCAF and CR.2.2.OCAF

General

CR.10.1.OCAF through CR.10.5.OCAF

Inventories and Documents

CR.30.1.OCAF 


\begin{tabular}{|c|c|}
\hline & $\begin{array}{c}\text { COMPLIANCE CATEGORY: } \\
\text { CULTURAL RESOURCES MANAGEMENT } \\
\text { Overseas ESOHCAMP }\end{array}$ \\
\hline $\begin{array}{l}\text { REGULATORY } \\
\text { REQUIREMENTS: }\end{array}$ & $\begin{array}{l}\text { REVIEWER CHECKS: } \\
\text { September } 2009\end{array}$ \\
\hline $\begin{array}{l}\text { CR.2 } \\
\text { MISSING CHECKLIST } \\
\text { ITEMS/POSITIVE } \\
\text { FINDINGS }\end{array}$ & \\
\hline $\begin{array}{l}\text { CR.2.1.OCAF. Installations } \\
\text { must comply with all applica- } \\
\text { ble regulatory requirements } \\
\text { not contained in this checklist } \\
\text { (a finding under this checklist } \\
\text { item will have the citation of } \\
\text { the applied regulation as a } \\
\text { basis of finding) [Added } \\
\text { March 2002]. }\end{array}$ & $\begin{array}{l}\text { Determine whether any new regulations concerning cultural resources manage- } \\
\text { ment have been issued since the finalization of the manual. } \\
\text { Determine whether the installation has activities or facilities that are regulated but } \\
\text { not addressed in this checklist. } \\
\text { Verify that the installation is in compliance with all applicable and newly issued } \\
\text { regulations. }\end{array}$ \\
\hline $\begin{array}{l}\text { CR.2.2.OCAF. Installations } \\
\text { should go above and beyond } \\
\text { environmental statutory and } \\
\text { regulatory compliance (MP) } \\
\text { [Added March 2002]. }\end{array}$ & $\begin{array}{l}\text { Determine whether the installation has gone above and beyond simply complying } \\
\text { with environmental requirements. } \\
\text { (NOTE: This checklist item is used only to write positive findings.) }\end{array}$ \\
\hline
\end{tabular}




\begin{tabular}{|c|c|}
\hline \multicolumn{2}{|r|}{$\begin{array}{c}\text { COMPLIANCE CATEGORY: } \\
\text { CULTURAL RESOURCES MANAGEMENT } \\
\text { Overseas ESOHCAMP }\end{array}$} \\
\hline $\begin{array}{l}\text { REGULATORY } \\
\text { REQUIREMENTS: }\end{array}$ & $\begin{array}{l}\text { REVIEWER CHECKS: } \\
\text { September } 2009\end{array}$ \\
\hline $\begin{array}{l}\text { CR.10 } \\
\text { GENERAL }\end{array}$ & \\
\hline $\begin{array}{l}\text { CR.10.1.OCAF. [Moved } \\
\text { March 2002]. }\end{array}$ & Moved to CR.2.1.OCAF. \\
\hline $\begin{array}{l}\text { CR.10.2.OCAF. Installations } \\
\text { must meet requirements con- } \\
\text { tained in MAJCOM supple- } \\
\text { ments to AFIs and policy } \\
\text { documents (a finding under } \\
\text { this checklist item will have } \\
\text { the citation of the MAJCOM } \\
\text { document as a basis of find- } \\
\text { ing). }\end{array}$ & $\begin{array}{l}\text { Determine whether the requirements in MAJCOM supplements to AFIs and pol- } \\
\text { icy documents are within the scope of the environmental compliance assessment. } \\
\text { Verify that the installation is in compliance with MAJCOM requirements. }\end{array}$ \\
\hline $\begin{array}{l}\text { CR.10.3.OCAF. } \quad \text { [Moved } \\
\text { March 2002]. }\end{array}$ & Moved to CR.2.2.OCAF. \\
\hline $\begin{array}{l}\text { CR.10.4.OCAF. [Deleted } \\
\text { July 2008]. }\end{array}$ & Deleted July 2008 at the request of the sponsor. \\
\hline $\begin{array}{l}\text { CR.10.5.OCAF. } \quad \text { [Moved } \\
\text { June 2003]. }\end{array}$ & Moved to CR.30.1.OCAF. \\
\hline
\end{tabular}




\begin{tabular}{|c|c|}
\hline & $\begin{array}{c}\text { COMPLIANCE CATEGORY: } \\
\text { CULTURAL RESOURCES MANAGEMENT } \\
\text { Overseas ESOHCAMP }\end{array}$ \\
\hline $\begin{array}{l}\text { REGULATORY } \\
\text { REQUIREMENTS: }\end{array}$ & $\begin{array}{l}\text { REVIEWER CHECKS: } \\
\text { September } 2009\end{array}$ \\
\hline $\begin{array}{l}\text { CR.30 } \\
\text { INVENTORIES AND } \\
\text { DOCUMENTS } \\
\text { CR.30.1.OCAF. Installations } \\
\text { must develop base environ- } \\
\text { mental maps that address par- } \\
\text { ticular topics (AFI 32-7062, } \\
\text { Attachment 7) [Moved June } \\
\text { 2003]. }\end{array}$ & $\begin{array}{l}\text { Verify that the installation is developing the following maps: } \\
\text { - Map A: Natural and Cultural Resources } \\
\text { - Map A-1: Areas of Critical Concern } \\
\text { - historic preservation and archeology } \\
\text { - threatened and endangered species } \\
\text { - wetlands and floodplains } \\
\text { - lakes, rivers, streams, and water bodies } \\
\text { - soil borings and soil types } \\
\text { - Map A-2: Management Areas } \\
\text { - geology, including surface features } \\
\text { - topography and physiology [sic] } \\
\text { - hydrology } \\
\text { - vegetation types } \\
\text { - forest (commercial timber) } \\
\text { - agriculture grazing/crops } \\
\text { - fish and wildlife } \\
\text { - prime and unique soils } \\
\text { - grounds categories } \\
\text { - climate and weather } \\
\text { - Bird Aircraft Strike Hazard (BASH) } \\
\text { - outdoor recreation } \\
\text { - pest management } \\
\text { (NOTE: Standards and specifications for preparing most of these products are } \\
\text { found in the Air Force Master Statement of Work.) } \\
\text { - Map B-1: Environmental Regulatory Issues } \\
\text { - hazardous waste generation points } \\
\text { - hazardous facilities } \\
\text { - solid waste generation points } \\
\text { - solid waste disposal locations } \\
\text { - fuel storage tanks } \\
\text { - cleanup (restoration) sites } \\
\text { - Map B-2: Environmental Emission Sources } \\
\text { - air emissions } \\
\text { - wastewater discharge } \\
\text { - stormwater discharge } \\
\text { - drinking water supply sources } \\
\text { - electromagnetic and radiation sources } \\
\text { - radon sources. } \\
\text { Map Bironental } \\
\text { B }\end{array}$ \\
\hline
\end{tabular}




\begin{tabular}{|c|c|}
\hline \multicolumn{2}{|c|}{$\begin{array}{c}\text { COMPLIANCE CATEGORY: } \\
\text { CULTURAL RESOURCES MANAGEMENT } \\
\text { Overseas ESOHCAMP }\end{array}$} \\
\hline $\begin{array}{c}\text { REGULATORY } \\
\text { REQUIREMENTS: }\end{array}$ & $\begin{array}{c}\text { REVIEWER CHECKS: } \\
\text { September 2009 }\end{array}$ \\
\hline & [Formerly checklist item number CR.10.5.OCAF.] \\
\hline
\end{tabular}




\title{
SECTION 3
}

\section{HAZARDOUS MATERIALS MANAGEMENT}

\section{Overseas ESOHCAMP}

\author{
September 2009
}

\section{A. Service-specific Regulations and Policies}

- Air Force Manual (AFM) 67-1, Storage and Related Operations, requires that the installation have a comprehensive list of all chemicals used or generated onsite.

- Air Force Instruction (AFI) 32-7086, Hazardous Materials Management, 1 November 2004, establishes procedures and standards that govern the management of hazardous materials (HAZMAT) throughout the Air Force (AF). It applies to all AF personnel (at classified and unclassified operations) who authorize, procure, issue, use, or dispose of HAZMAT in the course of their official duties; it also applies to those who manage, monitor, or track any of the preceding processes, whether the processes are performed by government or contractor personnel. AFI 32-7086 is applicable to all installations, except where international agreements require modified policy.

(NOTE: Throughout AFI 32-7086, the term “AF Form 3952” refers to either the hard copy of the AF Form 3952 or the standardized Air Force HAZMAT tracking system authorization data entry screens. The electronic data entry screens may or may not appear similar to the hard copy of the AF Form 3952. However, the standardized Air Force HAZMAT tracking system must be able to produce a hard copy of the AF Form 3952 in accordance with the AF Form 3952 authorization data requirements detailed in Attachment 2 to AFI 32-7086.)

- AFI 91-301, Air Force Occupational and Environmental Safety, Fire Prevention, and Health (AFOSH) Program, 1 June 1996, outlines the AF's Occupational and Environmental Safety, Fire Prevention, and Health Program. It specifically requires the Bioenvironmental Engineering Services (BES) to maintain material safety data sheets (MSDSs) and other related information.

- AFOSH STD 91-501, Air Force Consolidated Occupational Safety Standard, 16 September 2002, Chapter 22, Flammable and Combustible Liquids, addresses the storage (inside/outside), use, and handling of flammable and combustible liquids in containers or tanks of 60 gal or less and in portable tanks up to 660 gal capacity. It also includes storage in fuel tanks of two gal or less located on small gasoline-powered equipment such as lawnmowers and snow-blowers. It does not apply to petroleum products in fuel tanks of motor vehicles, aircraft, boats, other watercraft, large portable or stationary engines, petroleum products in portable tanks over 660 gal, alcoholic beverages when packed in individual glasses, plastic, metal or ceramic containers not exceeding $4 \mathrm{~L}$ in volume, medicines, foodstuffs and cosmetics, special purpose vehicles designed and maintained for the storage and transportation of flammable or combustible liquids, or liquids having no flashpoint which may not burn under normal conditions.

- Air Force Instruction (AFI) 90-821, Hazard Communication, 30 March 2005, describes the Air Force Hazard Communication (HAZCOM) Program that puts into effect the requirements of the Occupational Safety and Health Administration (OSHA) Hazard Communication Standard 29 CFR 1910.1200 for the Air Force (AF). Unless otherwise noted, the guidance and procedures outlined in AFI 90-821 apply to all U.S. Air Force military and civilian personnel, direct-hire foreign nationals, and indirect hire foreign employees at Air Force installations within the U.S., its territories, and in foreign countries, and geographically separated units (GSU). GOCO operations located either outside the regulatory jurisdiction of the continental U.S. or in U.S. territories not covered by the Occupational Safety and Health Act comply with AFI 90-821 in response to AF Federal Acquisition Regulation Supplement Clause 52.223-9004. 
AFI 90-821 is intended to minimize the incidence of chemically induced occupational illnesses and injuries in the workplace by establishing guidance for training employees on the health and physical hazards associated with, and proper preventive measures to be taken when, using or handling hazardous chemicals in work area/shop(s). This program is commonly referred to as the HAZCOM Program; it is not to be confused with other separate and distinct entities such as Hazardous Waste Operations and Emergency Response (HAZWOPER) and the Hazardous Materials (HAZMAT) Management Program (HMMP). HAZCOM is a performance-based program with separate training requirements, and successful implementation can be measured only by evaluating worker awareness of work area/shop hazards.

AF HAZCOM Program requirements apply to any chemical hazard, with the exceptions listed below, that is known to be present in work area/shop(s) in such a manner employees may be exposed under normal conditions of use or in a foreseeable emergency. AF HAZCOM Program requirements do not apply to the following:

1. hazardous wastes regulated under the Resource Conservation and Recovery Act (RCRA)

2. hazardous substances subject to a remedial action or removal action under the Comprehensive Environmental Response, Compensation, and Liability Act (CERCLA)

3. tobacco or tobacco products

4. wood or wood products that will not be processed

5. articles (see definition)

6. food or alcoholic beverages

7. drugs in final form, such as nonprescription and prescription, dry pelletized drugs, e.g., pills or caplets

8. cosmetics

9. consumer products in normal consumer use, such as vehicle propane tanks, copier toner, etc. (i.e., material usage in the workplace is for the purpose intended by the chemical manufacturer or importer of the product, and the use results in a duration and frequency of exposure which is not greater than the range of exposures that could reasonably be experienced by consumers when used for the purpose intended).

(NOTE: Whether consumer product materials are subject to the AF HAZCOM Program and require training requires a case-by-case judgment by the supervisor in consultation with Bioenvironmental Engineering (BE). For example:

- personnel who use window cleaner fluid to clean infrequently will not require this training; however, maintenance personnel using the same window cleaner daily will require training

- patrons using automotive cleaners at the auto skills center will not require training; however, auto skills center employees and LRS transportation personnel using the same cleaner as part of their job will require training.)

10. nuisance particulates such as copier toner

11. ionizing and nonionizing radiation

12. biological hazards

13. munitions.

\section{B. DOD Directives/Instructions}

- DOD 4145.19-R-1, Storage and Materials Handling, Chapter 5, Section 4, Hazardous Commodities, dated September 1979, addresses the storage and handling of compressed gases and other hazardous commodities. This document is incorporated by reference in the Overseas Environmental Baseline Guidance Document (OEBGD) and in Final Governing Standards (FGS) derived from it. It is cited here when existing AF documents do not include its provisions.

\section{Service-specific/DOD Definitions}

- Approved - listed and approved by Underwriter's Laboratory, Inc., Factory Mutual Engineering Corporation, the Bureau of Mines, the National Institute of Occupational Safety and Health, the American National Standards Institute, the National Fire Protection Association (NFPA), or other nationally recognized agencies which list, ap- 
prove, test, or develop specifications for equipment to meet fire protection, health, or safety requirements (AFOSH STD 91-501, Attachment 1).

- Article - a manufactured item, other than fluid or particle, that (AFI 90-821, para 2.2.5):

1. is formed to a specific shape or design during manufacture

2. has end-use function(s) dependent in whole or in part upon its shape or design during end use

3. under normal conditions of use does not release more than very small quantities, e.g., minute or trace amounts of hazardous chemicals (as determined under 29 CFR 1910.1200(d)), and does not pose a physical hazard or health risk to employees.

- Authorized Users List (AUL) - the list of all completed AF Form 3952 authorizations, as recorded in the standardized Air Force HAZMAT tracking system, for installation-level work areas to use specific HAZMAT in specific processes (so long as the conditions described in the AF Form 3952 authorization remain unchanged) (AFI 327086, Attachment 1).

- Blanket Authorization - the blanket authorization approves the use of a particular unit of issue of an HAZMAT independent of process. Each of the AF Form 3952 Authorizing Offices (CE, SE, and BE) will make an independent determination of whether or not to provide a blanket authorization for a specific HAZMAT and HAZMAT container size. Each of the offices providing a blanket authorization must also specify a maximum draw amount for the HAZMAT and HAZMAT container size. Blanket authorizations must identify specific NSNs and specific qualified products under that NSN, or specific material and container size. In addition, users must stay within the maximum draw amounts specified on their AF Form 3952 for the blanket authorization to remain valid. It is not necessary for all three (CE, SE, and BE) authorizations to be of the same type (blanket or activity-specific). However, all three offices must authorize (or review for contractor submittals) the request before the requestor can obtain the HAZMAT (AFI 32-7086, Attachment 1).

- Chemical - any element, chemical compound or mixture of elements, or compounds (AFI 90-821, Attachment 1).

- Chemical Manufacturer - an employer with a work area where chemical(s) are produced for use or distribution (AFI 90-821, Attachment 1).

- Combustible Liquid - a liquid having a closed cup flashpoint at or above $100^{\circ} \mathrm{F}\left(37.8^{\circ} \mathrm{C}\right)$. Combustible liquids are categorized as Class II or Class III liquids and they are further subdivided as follows (AFOSH STD 91-501, para 22.1.2. and Attachment 1):

1. Class II liquids are those having a flashpoint at or above $100^{\circ} \mathrm{F}\left(37.8^{\circ} \mathrm{C}\right)$ and below $140^{\circ} \mathrm{F}\left(60^{\circ} \mathrm{C}\right)$

2. Class IIIA liquids are those having flashpoints at or above $140^{\circ} \mathrm{F}\left(60^{\circ} \mathrm{C}\right)$ and below $200^{\circ} \mathrm{F}\left(93.35^{\circ} \mathrm{C}\right)$, except any mixture having components with flashpoints of $200.5^{\circ} \mathrm{F}\left(93^{\circ} \mathrm{C}\right)$

3. Class IIIB liquids are those having flashpoints at or above $200^{\circ} \mathrm{F}\left(93^{\circ} \mathrm{C}\right)$.

(NOTE: AFOSH STD 91-501 does not cover Class IIIB liquids. Where the term "Class III liquids” is used in checklist items derived from it, the term means only Class IIIA liquids.)

- Container - any bag, barrel, bottle, box, can, cylinder, drum, reaction vessel, storage tank, or the like that contains a hazardous chemical. For purposes of AFI 90-821, pipes or piping systems and engines, fuel tanks, or other operating systems in a vehicle are not considered to be containers (AFI 90-821, Attachment 1).

- Data Field - the smallest element (numeric or alphanumeric) of data in the standardized Air Force HAZMAT tracking system. It has a finite length and number of characters (AFI 32-7086, Attachment 1).

- ESOH-MIS - an AF approved automated system to store and maintain all information associated with environment, safety, and occupational health surveillance data and work area/shop requirements (AFI 90-821, Attachment 1). 
- Employee - a worker who may be exposed to hazardous chemicals under normal operating conditions or in foreseeable emergencies. Office workers who encounter hazardous chemicals only in nonroutine, isolated instances are not covered (AFI 90-821, Attachment 1).

- Exposure - the intensity, frequency, and length of time personnel are subjected to a hazard (AFI 90-821, Attachment 1).

- Fire Area - an area of a building separated from the remainder of the building by construction having a rated fire resistance of at least 1 and having all communicating openings properly protected by an assembly having a fire resistance rating of at least $1 \mathrm{~h}$.

[Author's Note: This definition was provided in Attachment 1 to AFOSH STD 91-43, which AFOSH STD 91501 replaces. Although AFOSH STD 91-501, para 22.4.4 explicitly refers the reader to its own Attachment 1 for a definition of "fire area," that term is not defined in the Attachment. The old definition is provided here for convenience only.]

- Flammable Liquid - a liquid with a closed cup flashpoint below $100{ }^{\circ} \mathrm{F}\left(37.8^{\circ} \mathrm{C}\right)$ and having a vapor pressure not exceeding 40 pounds per square inch, guage (psig) $(2068 \mathrm{~mm} \mathrm{Hg})$ at $100{ }^{\circ} \mathrm{F}\left(37.8^{\circ} \mathrm{C}\right)$. Flammable liquids are categorized as Class I liquids, and are further subdivided as follows (AFOSH STD 91-501, para 22.1.1.1. and Attachment 1):

1. Class IA are those that have a flashpoint below $73^{\circ} \mathrm{F}\left(22.8^{\circ} \mathrm{C}\right)$ and have a boiling point below $100{ }^{\circ} \mathrm{F}$ $\left(37.8^{\circ} \mathrm{C}\right)$.

2. Class IB are those that have a flashpoint below $73^{\circ} \mathrm{F}\left(22.8^{\circ} \mathrm{C}\right)$ and have a boiling point at or above 100 ${ }^{\circ} \mathrm{F}\left(37.8^{\circ} \mathrm{C}\right)$.

3. Class IC are those that have a flashpoint at or above $73^{\circ} \mathrm{F}\left(22.8^{\circ} \mathrm{C}\right)$ and below $100{ }^{\circ} \mathrm{F}\left(37.8^{\circ} \mathrm{C}\right)$.

- General Laboratories - a room or rooms or buildings where research, testing, analysis, or investigation takes place.

[Author's Note: This definition was provided in Attachment 1 to AFOSH STD 91-43, which AFOSH STD 91501 replaces. Although AFOSH STD 91-501, para 22.5.1.1 explicitly refers the reader to its own Attachment 1 for a definition of "general laboratory," that term is not defined in the Attachment. The old definition is provided here for convenience only.]

- Hazard Communication (HAZCOM) - the OSHA Hazard Communication Standard found in 29 CFR 1910.1200 requires supervisors to inform the workers they supervise of the occupational safety and heath hazards of chemicals used in the workplace and the proper procedures and equipment to use to minimize the risks of injury or sickness (AFI 32-7086, Attachment 1).

- Hazard Warning - any words, pictures, symbols, or combination thereof appearing on a label or other appropriate form of warning which convey the specific physical and health hazard(s), including target organ effects, of the chemical(s) in the container(s) (AFI 90-821, Attachment 1).

- Hazardous Chemical (HAZMAT) - any chemical that is a physical or health hazard and requires an MSDS as defined in AFI 32-7086, Hazardous Materials Management, and all Class I and Class II ozone-depleting substances (ODS); also known as hazardous material or HAZMAT (AFI 90-821, Attachment 1).

- Hazardous Material (HAZMAT) - for purposes of AFI 32-7086, the term HAZMAT includes all items (including medical supply items with the exception of drugs in their finished form and pharmaceuticals in individuallyissued items) covered under the Emergency Planning and Community Right-to-Know Act (EPCRA) (or other host nation, federal, state, or local) reporting requirement, the Occupational Safety and Health Administration (OSHA) Hazard Communication (HAZCOM) Standard, and all Class I and Class II Ozone Depleting Substances (ODS). It does not include munitions or hazardous waste (AFI 32-7086, para 1.3 and Attachment 1). 
- Hazardous Material Management Process (HMMP) - a standard methodology used to manage and track the procurement and use of HAZMAT to support Air Force missions, protect the safety and health of personnel on Air Force installations and communities surrounding Air Force installations from misuse of HAZMAT, minimize Air Force use of HAZMAT consistent with mission needs, and to maintain Air Force compliance with environmental requirements for HAZMAT usage. The HMMP is composed of three interdependent programs: the HAZMAT Pharmacy Program (IHMP), the Weapon System Hazardous Material (HAZMAT) Program (WSHP), and the ODS Program (ODSP) (AFI 32-7086, Attachment 1, and AFI 90-821, Attachment 1).

- Hazardous Material Management Process (HMMP) Teams - at each level (HQ USAF, MAJCOM, and installations) the Environmental Protection Committee (EPC) or Environmental, Safety, and Occupational Health Committee (ESOHC) chair will establish a cross-functional HMMP team. Civil Engineering (CE) will lead the team. The HMMP team will report to the EPC or ESOHC chair. The HMMP team will include, but is not limited to, representatives from CE (representing Environmental and Fire), Maintenance (weapon systems), Logistics Readiness (with Supply expertise), Contracting, Surgeon General (SG) (Bioenvironmental Engineering or BE), Safety (SE), Legal (JA), Communications and Information (SC or CS), and the HAZMART supervisors. Other functional representatives such as Finance, Requirements, Plans, Manpower, Public Affairs, HAZMAT users, and tenant organizations are also members of the team, as required. Contracted functions may have contractor representation on the HMMP team (AFI 32-7086, Attachment 1).

- Hazardous Waste - any material subject to the hazardous waste manifest requirements of Environmental Protection Agency specified in 40 CFR Part 262 and meets the definition in 40 CFR 261.3 according to AFI 32-7042, Solid and Hazardous Waste Compliance (AFI 32-7086, Attachment 1).

- HAZMART - a HAZMART is the "customer service desk" for the IHMP, and is the only entity on an installation authorized to issue government-owned HAZMAT. At a minimum, a HAZMART is a facility or location where customers can receive support for obtaining HAZMAT, and where HAZMAT are managed and tracked. A HAZMART is intended to be the primary location on an installation where LRS personnel stock, store, issue, and distribute HAZMAT. Each installation must have at least one primary HAZMART established by, and accountable to, the LRS commander. The HMMP team may designate additional unit-controlled supply activities as HAZMARTs, performing all the functions of the primary HAZMART. The HAZMART responsibilities include the receipt and entry of data on Government-wide Purchase Card purchases of HAZMAT and the receipt and entry of data on contractor usage of HAZMAT (AFI 32-7086, Attachment 1).

- HAZMART - as the customer service desk for the IHMP, it is the only entity on an installation authorized to issue government-owned HAZMAT. At a minimum, a HAZMART is a facility or location where customers can receive support for obtaining HAZMAT, and where HAZMATs are managed and tracked. A HAZMART is intended to be the primary location on an installation where LRS personnel stock, store, issue, and distribute HAZMAT. Each installation must have at least one primary HAZMART established by, and accountable to the LRS Commander. The HMMP team may designate additional unit-controlled supply activities as HAZMARTs performing all the functions of the primary HAZMART. The HAZMART responsibilities include the receipt and entry of data on Government-wide Purchase Card purchases of HAZMAT, and the receipt and entry of data on contractor usage of HAZMAT (AFI 90-821, Attachment 1).

- Health Hazard - includes materials which are carcinogens, toxic or highly toxic agents, reproductive toxins, irritants, corrosives, sensitizers, hepatotoxins, nephrotoxins, neurotoxins, agents which act on the hematopoietic system, and agents which damage the lungs, skin, eyes, or mucous membranes (AFI 90-821, Attachment 1).

- Health-Related Laboratories - a room or rooms located in any part of a building providing patient care and intended to serve activities engaged in investigation, diagnosis, or treatment. Also, rooms or buildings used to conduct research, analysis, or investigation of occupational health problems.

[Author's Note: This definition was provided in Attachment 1 to AFOSH STD 91-43, which AFOSH STD 91501 replaces. Although AFOSH STD 91-501, para 22.5.1.1 explicitly refers the reader to its own Attachment 1 for a definition of "health-related laboratory," that term is not defined in the Attachment. The old definition is provided here for convenience only.] 
- Immediate Use Materials - any hazardous chemical that will be under the control of and used only by the person who transfers it from a labeled container and only within the work shift in which it is transferred (AFI 90-821, Attachment 1).

- Installation - for purposes of the Federal HAZCOM standard and AFI 90-821, an installation is a single geographic location with one or more work area/shops. The AF does not constitute one installation and must have programs that address hazards at each installation (AFI 90-821, Attachment 1).

(NOTE: 29 CFR 1910.1200 uses the term “workplace” instead of "installation.”)

- Installation HAZMAT Management Program (IHMP) - an Air Force standardized program for authorizing, procuring, issuing, and tracking of HAZMAT. This program was previously called the HAZMAT Pharmacy Program (HPP) (AFI 32-7086, Attachment 1).

- Label - any written, printed, or graphic material, displayed on or affixed to containers of hazardous chemicals (AFI 90-821, Attachment 1).

- Laboratory - a facility where relatively small quantities of hazardous materials are used on a nonproduction basis. Use of hazardous materials must meet all of the following conditions (AFI 90-821, Attachment 1):

1. chemical manipulations are carried out on a laboratory scale with all work with substances in containers designed to be easily and safely manipulated by one person

2. Multiple chemical procedures or chemicals are used

3. Procedures involved are not part of a production process, nor in any way simulate a production process;

4. Protective laboratory practices and equipment are available.

- Laboratory Standard - OSHA, 29 CFR 1910.1450, Occupational Exposure to Hazardous Chemicals in Laboratories. See AFOSH Standard 48-22, Occupational Exposure to Hazardous Chemicals in Laboratories (AFI 90821, Attachment 1).

- Management Practice (MP) - practices that, although not mandated by law, are encouraged to promote safe operating procedures.

- Material Safety Data Sheet (MSDS) - written or printed material concerning a hazardous chemical that is prepared according to 29 CFR 1910.1200 (AFI 90-821, Attachment 1).

- Medical Supply Items - those items purchased through the Medical Dental Division of the Air Force Working Capital Fund as required in AFMAN 23-110, USAF Supply Manual, Volume 5, Air Force Medical Materiel Management System-General (AFI 32-7086, Attachment 1, and ).

- Nonroutine Tasks - those tasks included within a work area/shop's normal activities but performed infrequently (e.g., cleaning a solvent tank and changing the solvent) and temporary duties outside an individual's normal Air Force Specialty Code or job series (AFI 90-821, para 2.9.1).

- Ozone Depleting Substance (ODS) - refers to Class I and Class II ODS, as defined by the Montreal Protocol on Substances that Deplete the Ozone Layer (AFI 32-7086, Attachment 1, AFI 90-821, Attachment 1).

- Partially Decentralized Operation - the operating concept of the IHMP. It consists of at least one facility or location, known as a HAZMART, that serves as the "customer service desk" for the IHMP; with the other IHMP activities (Bioenvironmental Engineering, Civil Engineering, Safety, Contracting, Maintenance, and other, unitcontrolled HAZMARTs, etc.) operating from their own organizations (AFI 32-7086, Attachment 1).

- Physical Hazard - includes materials for which there is scientifically valid evidence it is a combustible liquid, a compressed gas, explosive, flammable, an organic peroxide, an oxidizer, pyrophoric, unstable (reactive) or waterreactive (AFI 90-821, Attachment 1). 
- Process - a uniquely defined "unit of work" bounded by (1) ESOH regulatory drivers, and (2) hazard recognition, evaluation, and control. Shops provide the TO number, title, page, and paragraph information that identify the work "step" in an overall process. However, this information is captured only as a "driver" for the identified process; TO "steps” are not the sole determinants in defining a process (AFI 32-7086, Attachment 1).

- Process-specific Authorization - one of the two types of BE, SE, or CE approvals to authorize the use of a given HAZMAT. Process-specific authorizations approve the use of a particular HAZMAT in a given process in specified amounts (AFI 32-7086, Attachment 1).

- Produce - to manufacture, process, formulate, blend, extract, generate, emit, or repackage (AFI 90-821, Attachment 1).

- Protected - protected with automatic sprinklers installed according to NFPA Standard 13, Standard for the Installation of Sprinkler Systems (AFOSH STD 91-501, para 22.6.1).

- Recovered Material - partially used, waste materials, and by-products recovered or diverted from solid waste, excluding those materials and by-products generated from, and commonly reused within, an original manufacturing process (AFI 32-7086, Attachment 1).

- Recycle - the process that transforms recovered materials into new or usable products (AFI 32-7086, Attachment 1).

- Report Owner - any organization requiring data from the HAZMAT data system to complete required reports (AFI 32-7086, Attachment 1).

- Requiring Document - the document that requires the use of the requested HAZMAT in a work area. The requiring document will be a TO, owner/operator manual, work specification, or drawing (AFI 32-7086, Attachment 1).

- Responsible Party - someone who can provide additional information on the hazardous chemical and appropriate emergency procedures if necessary. This party is generally a manufacturer's representative (AFI 90-821, Attachment 1).

- Trade Secret - any confidential formula, pattern, process, device, or information or compilation of information that is used in an employer's business and that gives the employer an opportunity to obtain an advantage over competitors who do not know or use it (AFI 90-821, Attachment 1).

- Use - to package, handle, react, emit, extract, generate as a by-product or transfer (AFI 90-821, Attachment 1).

- User - anyone or any organization utilizing hazardous material in the performance of their Air Force mission (AFI 32-7086, Attachment 1).

- Water-reactive Substances - the following lists some common water-reactive substances (AFOSH STD 91-501, para 22.4.1.3.):

1. Alkali metals (lithium [Li], potassium (kalium [K]), sodium (natrium [Na]), cerium [Ce])

2. Calcium

3. Hydrides

4. Phosphorous trichloride

5. Phospohorous pentasulfide.

- Work Area - a definable location where personnel perform work. This can be outdoors (e.g., an aircraft trim pad) or indoors; administrative or industrial; or any installation-level location where a hazardous material is used in the performance of a specific process. Synonymous with work center (AFI 32-7086, Attachment 1). 
- Work Area/Shop - a room or defined space in an installation where hazardous chemicals are produced or used, and where employees are present (AFI 90-821, Attachment 1).

(NOTE: Employees who often work outside the physically defined work area, such as pest management personnel during pesticide application or aircraft maintainers that take chemicals to the flightline, will have their hazards addressed as part of the work area/shop program.)

\section{Additional Records To Review}

- HAZMART records

- The written Hazard Communication Plan

\section{E. Additional Physical Features To Inspect}

- HAZMART

- Storage areas for flammable/combustible liquids

- Laboratories

- Areas (other than Military Family Housing) where small gasoline-powered equipment is stored 


\section{F. Guidance for Checklist Users}

REFER TO CHECKLIST ITEMS:

Missing Checklist Items/Positive Findings

General

Pharmacy Program

Training

Hazard Communication

Releases

General Operating Requirements

Documentation

Transportation

Flammable/Combustible Liquids

Handling

Training

General Storage Requirements

Storage Cabinets

Storage Inside Buildings

Storage Rooms

Storage Buildings

Ventilation in Dispensing Areas

Outdoor Storage

Industrial Storage Areas

Military Exchanges, Commissaries, and Asso- ciated Retail Stores

Laboratories

Small Gasoline Powered Equipment

Compressed Gases

Bulk Acid Storage
HM.2.1.OCAF and HM.2.2.OCAF

HM.3.1.OCAF through HM.3.10.OCAF

HM.4.1.OCAF through HM.4.21.OCAF

HM.20.1.OCAF

HM.21.1.OCAF through HM.21.17.OCAF

HM.30.1.OCAF

HM.40.1.OCAF through HM.40.3.OCAF

HM.50.1.OCAF through HM.50.4.OCAF

HM.70.1.OCAF

HM.90.1.OCAF through HM.90.3.OCAF

HM.100.1.OCAF

HM.110.1.OCAF through HM.110.6.OCAF

HM.120.1.OCAF through HM.120.6.OCAF

HM.130.1.OCAF and HM.130.2.OCAF

HM.140.1.OCAF through HM.140.4.OCAF

HM.150.1.OCAF through HM.150.4.OCAF

HM.160.1.OCAF through HM.160.6.OCAF

HM.170.1.OCAF through HM.170.5.OCAF

HM.180.1.OCAF through HM.180.3.OCAF

HM.190.1.OCAF through HM.190.6.OCAF

HM.200.1.OCAF through HM.200.7.OCAF

HM.210.1.OCAF through HM.210.4.OCAF

HM.220.1.OCAF through HM.220.4.OCAF

HM.230.1.OCAF 


\section{COMPLIANCE CATEGORY: \\ HAZARDOUS MATERIALS MANAGEMENT \\ Overseas ESOHCAMP}

\begin{tabular}{|c|c|}
\hline $\begin{array}{l}\text { REGULATORY } \\
\text { REQUIREMENTS: }\end{array}$ & $\begin{array}{l}\text { REVIEWER CHECKS: } \\
\text { September } 2009\end{array}$ \\
\hline $\begin{array}{l}\text { HM.2 } \\
\text { MISSING CHECKLIST } \\
\text { ITEMS/POSITIVE } \\
\text { FINDINGS }\end{array}$ & \\
\hline $\begin{array}{l}\text { HM.2.1.OCAF. Installations } \\
\text { must comply with all applica- } \\
\text { ble regulatory requirements } \\
\text { not contained in this checklist } \\
\text { (a finding under this checklist } \\
\text { item will have the citation of } \\
\text { the applied regulation as a } \\
\text { basis of finding) [Added } \\
\text { March 2002]. }\end{array}$ & $\begin{array}{l}\text { Determine whether any new regulations concerning hazardous materials manage- } \\
\text { ment have been issued since the finalization of the manual. } \\
\text { Determine whether the installation has activities or facilities that are regulated but } \\
\text { not addressed in this checklist. } \\
\text { Verify that the installation is in compliance with all applicable and newly issued } \\
\text { regulations. }\end{array}$ \\
\hline $\begin{array}{l}\text { HM.2.2.OCAF. Installations } \\
\text { should go above and beyond } \\
\text { environmental statutory and } \\
\text { regulatory compliance (MP) } \\
\text { [Added March 2002]. }\end{array}$ & $\begin{array}{l}\text { Determine whether the installation has gone above and beyond simply complying } \\
\text { with environmental requirements. } \\
\text { (NOTE: This checklist item is used only to write positive findings.) }\end{array}$ \\
\hline
\end{tabular}




\begin{tabular}{|c|c|}
\hline & $\begin{array}{c}\text { COMPLIANCE CATEGORY: } \\
\text { HAZARDOUS MATERIALS MANAGEMENT } \\
\text { Overseas ESOHCAMP }\end{array}$ \\
\hline $\begin{array}{l}\text { REGULATORY } \\
\text { REQUIREMENTS: }\end{array}$ & $\begin{array}{l}\text { REVIEWER CHECKS: } \\
\text { September } 2009\end{array}$ \\
\hline $\begin{array}{l}\text { HM.3 } \\
\text { GENERAL }\end{array}$ & \\
\hline $\begin{array}{l}\text { HM.3.1.OCAF. Installations } \\
\text { must meet requirements con- } \\
\text { tained in MAJCOM supple- } \\
\text { ments to AFIs and policy } \\
\text { documents (a finding under } \\
\text { this checklist item will have } \\
\text { the citation of the MAJCOM } \\
\text { document as a basis of find- } \\
\text { ing) [Moved June 2003]. }\end{array}$ & $\begin{array}{l}\text { Determine whether the requirements in MAJCOM supplements to AFIs and pol- } \\
\text { icy documents are within the scope of the environmental compliance assessment. } \\
\text { Verify that the installation is in compliance with MAJCOM requirements. } \\
\text { [Formerly checklist item number HM.10.2.OCAF.] }\end{array}$ \\
\hline $\begin{array}{l}\text { HM.3.2.OCAF. The installa- } \\
\text { tion must have an HMMP } \\
\text { team that consists of represen- } \\
\text { tatives from certain organiza- } \\
\text { tions (AFI 32-7086, paras } \\
1.4 .2 \text { and 1.11.1.1) [Moved } \\
\text { June 2003; Revised January } \\
\text { 2005; Citation Revised Janu- } \\
\text { ary 2005]. }\end{array}$ & $\begin{array}{l}\text { Verify that the EPC or ESOHC chair has formally chartered a cross-functional } \\
\text { team led by CE. } \\
\text { Verify that the membership of the HMMP team consists of representatives from at } \\
\text { least the following organizations: } \\
\text { - Civil Engineering (CE, representing environmental and fire protection) } \\
\text { - Surgeon General (SG; Bioenvironmental Engineering or BE) } \\
\text { - Safety (SE) } \\
\text { - Communications and Information (SC or CS) } \\
\text { - Legal (JA) } \\
\text { - Maintenance } \\
\text { - Logistics Readiness (with supply expertise), } \\
\text { - Contracting } \\
\text { - HAZMART supervisors. } \\
\text { (NOTE: Other functional representatives such as Finance, Requirements, Plans, } \\
\text { Manpower, Public Affairs, HAZMAT users, and tenant organizations are also } \\
\text { members of the HMMP team, as required. Contracted functions may have con- } \\
\text { tractor representation on the HMMP team.) } \\
\text { Verify that the team charter specifically identifies HMMP team members. } \\
\text { [Formerly checklist item number HM.20.1.OCAF.] }\end{array}$ \\
\hline $\begin{array}{l}\text { HM.3.3.OCAF. The installa- } \\
\text { tion HMMP team must carry } \\
\text { out specific responsibilities } \\
\text { (AFI 32-7086, paras 1.4.3.5 } \\
\text { and 1.11.2) [Moved June } \\
\text { 2003; Revised January 2005; } \\
\text { Citation Revised January }\end{array}$ & $\begin{array}{l}\text { Verify that the installation HMMP team regularly schedules and holds meetings at } \\
\text { least quarterly to address HMMP issues. } \\
\text { (NOTE: Suggested topics of discussion are: } \\
\text { - resource [funding and personnel] review, validation, and tracking } \\
\text { - support Agreements } \\
\text { - metrics } \\
\text { - contract HAZMAT requirements }\end{array}$ \\
\hline
\end{tabular}




\begin{tabular}{|c|c|}
\hline & $\begin{array}{c}\text { COMPLIANCE CATEGORY: } \\
\text { HAZARDOUS MATERIALS MANAGEMENT } \\
\text { Overseas ESOHCAMP }\end{array}$ \\
\hline $\begin{array}{l}\text { REGULATORY } \\
\text { REQUIREMENTS: }\end{array}$ & $\begin{array}{l}\text { REVIEWER CHECKS: } \\
\text { September } 2009\end{array}$ \\
\hline 2005]. & 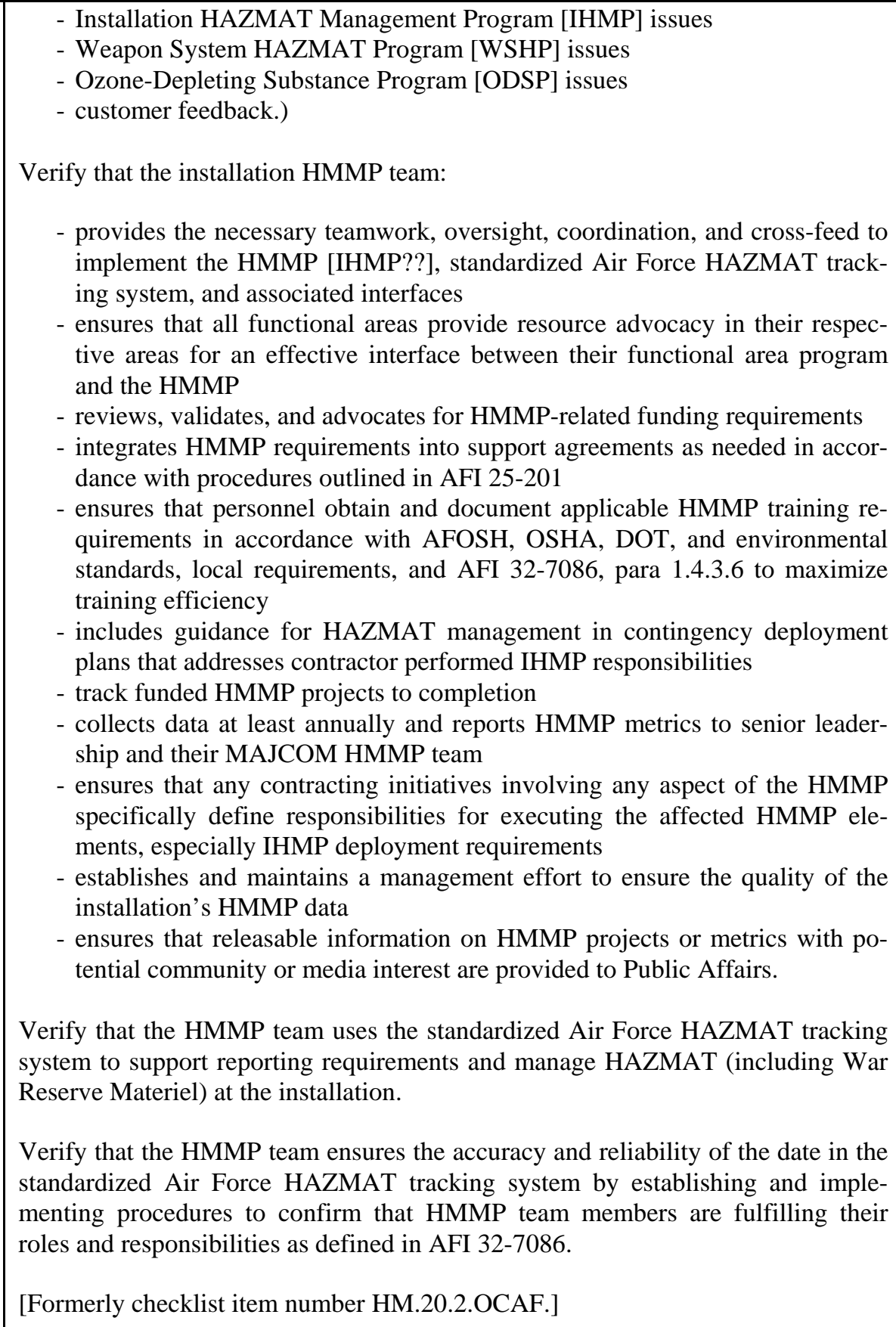 \\
\hline $\begin{array}{l}\text { HM.3.4.OCAF. The installa- } \\
\text { tion HMMP team must fullfill } \\
\text { specific resposibilities in ad- } \\
\text { dition to those specified in }\end{array}$ & $\begin{array}{l}\text { Verify that the installation HMMP team: } \\
\text { - ensures personnel meet all installation-level responsibilities for executing the } \\
\text { IHMP }\end{array}$ \\
\hline
\end{tabular}




\section{COMPLIANCE CATEGORY: HAZARDOUS MATERIALS MANAGEMENT Overseas ESOHCAMP}

\begin{tabular}{c|c} 
REGULATORY & REVIEWER CHECKS: \\
REQUIREMENTS: & September 2009
\end{tabular}

AFI 32-7086, paras 1.4.2 and 1.11.2 (AFI 32-7086, paras 2.10.1.1 through 2.10.1.16) [Added January 2005].
- determines for each requested potentially hazardous material whether it meets the HAZMAT definition in AFI 32-7086, para 1.3. and, therefore, must be tracked using the standardized Air Force HAZMAT tracking system

- establishes and implements procedures for HAZMAT reduction, recycling, reuse, or shelf-life control, including reducing HAZMAT disposal through reduction, recycling, reuse, shelf-life control, etc.

- assesses customer satisfaction periodically (e.g., spot-check the time required to process AF Forms 3952) and makes improvements whenever possible

- ensures that any contracting initiatives involving any aspect of the IHMP specifically define responsibilities for executing the affected IHMP elements in accordance with AFI 32-7086

- develops local GPC procedures for HAZMAT purchases to implement the requirements of AFI 32-7086, para 2.5.6, and ensures that the Contracting Office implements these procedures and includes them in the GPC training and guidance

- ensures that appropriate IHMP requirements described in AFI 32-7086, para 2.6, are accounted for in deployment planning

- ensures that the Unit Deployment Managers (UDMs) include in the appropriate installation contingency deployment plans the HAZMAT deployment planning requirements described in AFI 32-7086, para 2.6, and assists the UDMs in executing those requirements during actual deployments

- ensures that HAZMAT management functions performed by contractors at the home station will be accomplished during deployment, either by inclusion in the contract or by assigning the responsibilities to government personnel qualified to perform the functions

- determines and documents the procedures for effective tracking of HAZMAT from cradle to grave, for facilitating work center inspections for unauthorized HAZMAT, and for supporting the free-issue of unused HAZMAT

- establishs, documents, and implements a schedule for and procedures to review and revalidate each AF Form 3952

- develops and executes procedures to ensure all hazardous materials brought onto the installation by contractors are properly managed in accordance with AFI 32-7086, para 2.5.5.2

- works with the Contracting Office to develop and implement procedures to:

- ensure that contracts for HAZMART operations or that involve the use of HAZMAT on the installation include FAR clause 52.223-3, AFFARS clause 5352.223.9003, and appropriate installation-specific contract requirements

- define how contractors submit AF Form 3952 authorization requests

- determine which of the materials identified in contractor AF Forms 3952 meet the Air Force definition of a HAZMAT in AFI 32-7086, para 1.3

- provide the contractors with the results of the AF Form 3952 reviews

- require contractors to report the authorized HAZMAT usage data to the HAZMART, in specified formats and at specified intervals

- provides the installation responses to HAZMAT data calls 


\section{COMPLIANCE CATEGORY: \\ HAZARDOUS MATERIALS MANAGEMENT \\ Overseas ESOHCAMP}

\begin{tabular}{|l|}
\hline REGULATORY \\
REQUIREMENTS: \\
\hline \\
\\
\\
\\
HM.3.5.OCAF. Each instal- \\
lation must have at least one \\
primary HAZMART estab- \\
lished by, and accountable to, \\
the Logistics Readiness \\
Squadron (LRS) commander \\
(AFI 32-7086, para 2.3.1) \\
[Added January 2005]. \\
HM.3.6.OCAF. The installa- \\
tion HAZMART must carry \\
out specific functions (AFI \\
32-7086, paras 2.4.1 through \\
2.4.15) [Added January \\
2005].
\end{tabular}

\section{REVIEWER CHECKS: September 2009}

- provides inputs on appropriate HAZMAT requirements to the Contracting Office for inclusion in the contract Quality Assurance Surveillance Plans and the contract Quality Assurance Personnel training

- reviews the installation Self-Help program to ensure that the IHMP tracks and reports HAZMAT issued through the Self-Help store

- reviews and assesses the validity of changes to the standardized Air Force HAZMAT tracking system requested by installation personnel and forwards validated change requests to the MAJCOM HMMP team

- ensures that there is an installation-wide free-issue, reuse, and redistribution program for HAZMAT

- supports LRS in the development and implementation of HAZMAT transportation security plans and training (see AFI 32-7086, paras 2.7. and 2.10.3, if applicable).

Verify that the installation has at least one primary HAZMART established by, and accountable to, the LRS commander.

(NOTE: Those installations, such as Geographically Separated Units, that have IHMP support from another location do not require a HAZMART.)

(NOTE: This requirement applies whether the HAZMART is operated by the government or by a contractor.)

Verify that the installation HAZMART:

- manages the receipt, storage, issue, inspection, and distribution of HAZMAT

- immediately forwards to the HMMP team information on any requested material that is not currently loaded in the standardized Air Force HAZMAT tracking system and is potentially hazardous

- reviews submitted AF Form 3952 information and supporting materials for accuracy and completeness

- ensures that all requests for HAZMAT have prior authorization in accordance with AFI 32-7086, para 2.5, before issue

- enters HAZMAT transactions into the standardized Air Force HAZMAT tracking system, including, but not limited to, Government-wide Purchase Card (GPC), contractor purchased/used, contracting purchased transactions, and supply system transactions

- minimizes HAZMAT usage or waste by reusing/redistributing excess HAZMAT on base to other Air Force bases, or through the Defense Reutilization and Marketing Office (DRMO) Reutilization, Transfer, Donation, and Sales (RTDS) program

- determines, before ordering or purchasing HAZMAT, if it is possible to obtain the HAZMAT from the installation free-issue, reuse, and redistribution program, as the preferred HAZMAT source

- works with customers and suppliers to ensure they purchase HAZMAT in 


\section{COMPLIANCE CATEGORY: \\ HAZARDOUS MATERIALS MANAGEMENT \\ Overseas ESOHCAMP}

\begin{tabular}{|l|l|}
\hline REGULATORY & $\begin{array}{c}\text { REVIEWER CHECKS: } \\
\text { September } 2009\end{array}$ \\
\hline REQUIREMENTS: & \\
\hline & practical quantities to minimize waste, handling, and storage costs \\
- uses the Class I ODS Requisition SAO Approval process described in AFI \\
32-7086, para 4.6, to requisition Class I ODS \\
- uses bar coding, or an HMMP team-approved alternative procedure, on all \\
materials determined to be HAZMAT, in accordance with AFI 32-7086, \\
para 2.5 \\
- performs quality control functions to properly identify items as possible \\
HAZMAT to prevent inadvertent procurement or issue transactions for un- \\
authorized materials \\
- immediately notifies the HMMP team of any suspected or potential \\
HAZMAT that has not been properly coded as a HAZMAT \\
- works with the Time Compliance Technical Order (TCTO) monitor or the \\
Time Change monitor to ensure all HAZMAT contained in TCTO kits is \\
properly identified and controlled \\
- maintains and updates the HAZMART-specific and supply-specific \\
HAZMAT data fields in the standardized Air Force HAZMAT tracking sys- \\
tem as required in the Users Manual or On-Line Help \\
- assists users in identifying HAZMAT stock numbers and/or part numbers, \\
and finding appropriate MSDS \\
- submits required changes for the standardized Air Force HAZMAT tracking \\
system to the HMMP team for review and possible validation \\
- ensures copies of MSDSs not available in the existing MSDS inventory are \\
forwarded to either the installation SG OPR for MSDS management or di- \\
rectly to the central Air Force MSDS focal point.
\end{tabular}

(NOTE: Any IHMP task, including the HAZMAT authorization responsibilities, can be performed by contractors, provided the contract complies with applicable federal and military procurement policies, and supports IHMP deployment requirements. If any IHMP functional responsibilities are contracted out, they must remain within the purview of the individual functional office to which AFI 327086 assigns those responsibilities.)

(NOTE: Self-Help Customers do not require an AF Form 3952 to use a HAZMAT on Self-Help Projects, unless that HAZMAT requires a processspecific authorization.)

HM.3.7.OCAF. The installaVerify that, in addition to the functions detailed in AFI 32-7086, paras 2.4.1 through 2.4.15, the installation HAZMART:

out specific functions in addition to those detailed in AFI 32-7086, paras 2.4.1 through 2.4.15 (AFI 32-7086, paras 2.10.3.2.1, 2.10.3.2.2, 2.5.3.4, and 2.5.3.7) [Added January 2005].

- maintains and updates the HAZMAT-specific fields in the SBSS (e.g.; IEX Code 9 and requisition exception [REX] codes)

- conducts data queries as directed by the installation HMMP team.

Verify that the HAZMART does not procure or issue HAZMAT to a requestor unless the requestor is on the AUL for that HAZMAT.

Verify that the HAZMART maintains a file of all completed AF Forms 3952 in 


\section{COMPLIANCE CATEGORY: \\ HAZARDOUS MATERIALS MANAGEMENT \\ Overseas ESOHCAMP}

\begin{tabular}{|c|c|}
\hline $\begin{array}{l}\text { REGULATORY } \\
\text { REQUIREMENTS: }\end{array}$ & $\begin{array}{l}\text { REVIEWER CHECKS: } \\
\text { September } 2009\end{array}$ \\
\hline $\begin{array}{l}\text { HM.3.8.OCAF. Contractors } \\
\text { that operate a HAZMART } \\
\text { must comply with the re- } \\
\text { quirements of AFI } 32-7086 \text {, } \\
\text { para 2.4, to participate in and } \\
\text { enforce the HAZMAT au- } \\
\text { thorization procedures (AFI } \\
\text { 32-7086, para 2.5.5.1) [Added } \\
\text { January 2005]. }\end{array}$ & $\begin{array}{l}\text { either hard copy or electronic equivalent. } \\
\text { Verify that contractors that operate a HAZMART comply with the requirements } \\
\text { of AFI 32-7086, para 2.4, to participate in and enforce the HAZMAT authoriza- } \\
\text { tion procedures. } \\
\text { [Author's Note: See checklist item HM.3.6.OCAF. Presumably, a contractor that } \\
\text { operates a HAZMART must also meet the responsibilities listed in } \\
\text { HM.3.7.OCAF.] } \\
\text { (NOTE: Contractors operating a HAZMART do not require AF Form } 3952 \text { au- } \\
\text { thorizations to perform the HAZMART supply functions of ordering, receiving, } \\
\text { stocking, and storing HAZMAT.) }\end{array}$ \\
\hline $\begin{array}{l}\text { HM.3.9.OCAF. No one may } \\
\text { bring HAZMAT onto an in- } \\
\text { stallation, or use HAZMAT } \\
\text { on an installation, until they } \\
\text { have received all required } \\
\text { authorizations via the process } \\
\text { described in AFI 32-7086, } \\
\text { para 2.5 (AFI 32-7086, para } \\
\text { 2.5.1) [Added January 2005]. }\end{array}$ & $\begin{array}{l}\text { Verify that no one brings HAZMAT onto the installation, or uses HAZMAT on } \\
\text { the installation, until they have received all required authorizations via the process } \\
\text { described in AFI 32-7086, para } 2.5 \text {. } \\
\text { (NOTE: The IHMP tracks only those items determined to be a HAZMAT.) } \\
\text { (NOTE: Government organizations and contractors have different procedures for } \\
\text { obtaining authorization for HAZMAT use; see checklist items HM.4.17.OCAF } \\
\text { through HM.4.21.OCAF.) } \\
\text { (NOTE: HAZMARTs do not require authorizations to perform the HAZMART } \\
\text { supply functions of ordering, receiving, stocking, and storing HAZMAT.) }\end{array}$ \\
\hline $\begin{array}{l}\text { HM.3.10.OCAF. It is the } \\
\text { responsibility of contractors } \\
\text { and GPC holders to report } \\
\text { HAZMAT purchases and use } \\
\text { to the HAZMART (AFI 32- } \\
\text { 7086, para 2.4.5.2) [Added } \\
\text { January 2005]. }\end{array}$ & $\begin{array}{l}\text { Verify that contractors and GPC holders report HAZMAT purchases and use to } \\
\text { the HAZMART. } \\
\text { (NOTE: Appropriate penalties for the contractor, or administrative and discipli- } \\
\text { nary action for the latter, should be established.) }\end{array}$ \\
\hline
\end{tabular}




\begin{tabular}{|c|c|}
\hline & $\begin{array}{c}\text { COMPLIANCE CATEGORY: } \\
\text { HAZARDOUS MATERIALS MANAGEMENT } \\
\text { Overseas ESOHCAMP }\end{array}$ \\
\hline $\begin{array}{l}\text { REGULATORY } \\
\text { REQUIREMENTS: }\end{array}$ & $\begin{array}{l}\text { REVIEWER CHECKS: } \\
\text { September } 2009\end{array}$ \\
\hline $\begin{array}{l}\text { HM.4 } \\
\text { PHARMACY PROGRAM }\end{array}$ & \\
\hline $\begin{array}{l}\text { HM.4.1.OCAF. } \quad \text { [Moved } \\
\text { January 2005]. }\end{array}$ & $\begin{array}{l}\text { Moved and split into checklist item number HM.4.16.OCAF and HM.4.17.OCAF } \\
\text { as a result of the revision of AFI 32-7086 dated 01 November 2004. }\end{array}$ \\
\hline $\begin{array}{l}\text { HM.4.2.OCAF. } \quad \text { [Deleted } \\
\text { January 2005]. }\end{array}$ & Deleted as a result of the revision of AFI 32-7086 dated 01 November 2004. \\
\hline $\begin{array}{l}\text { HM.4.3.OCAF. CE has spe- } \\
\text { cific responsibilities with re- } \\
\text { spect to the IHMP (AFI 32- } \\
\text { 7086, paras 2.10.2.1 through } \\
\text { 2.10.2.9) [Moved June 2003; } \\
\text { Revised January 2005; Cita- } \\
\text { tion Revised January 2005]. }\end{array}$ & $\begin{array}{l}\text { Verify that CE: } \\
\text { - leads the HMMP team } \\
\text { - ensures that HAZMART facilities meet applicable ESOH requirements to } \\
\text { support the IHMP } \\
\text { - manages the Data Base Administration (DBA)/System Administration } \\
\text { (SA)/Information System Security Officer (ISSO) responsibilities for the } \\
\text { standardized Air Force HAZMAT tracking system } \\
\text { - provides LG, SG (Medical Logistics and BE), SE, and other personnel, } \\
\text { as appropriate, with operator training on the standardized Air Force } \\
\text { HAZMAT tracking system } \\
\text { - submits requested changes for the standardized Air Force HAZMAT } \\
\text { tracking system to the installation HMMP team for review and possible } \\
\text { validation } \\
\text { - maintains and updates CE-related HAZMAT data fields in the standardized } \\
\text { Air Force HAZMAT tracking system as required in the User's Manual or } \\
\text { On-Line Help } \\
\text { - assesses, at a minimum, environmental, fire protection, and emergency re- } \\
\text { sponse risks of, and control options for, materials } \\
\text { - participates in the HMMP team evaluation of materials that are poten- } \\
\text { tially hazardous, but are not loaded in the standardized Air Force } \\
\text { HAZMAT tracking system } \\
\text { - decides whether CE blanket or process-specific authorization is appro- } \\
\text { priate for material that the HMMP team determines meets the definition } \\
\text { of a HAZMAT } \\
\text { - for process-specific authorizations, evaluates each AF Form 3952 and } \\
\text { decides whether to authorize without additional restrictions, authorize } \\
\text { with additional restrictions or not authorize the request to use a } \\
\text { HAZMAT. } \\
\text { - at a minimum, assesses whether the authorized contractor HAZMAT } \\
\text { usage may cause violations of environmental, fire protection, or emer- } \\
\text { gency response requirements or create health and safety hazards (based } \\
\text { on the BE and SE inputs) before authorizing contractor usage of a par- } \\
\text { ticular HAZMAT in a specific process on the installation } \\
\text { - ensures HAZMAT on the installation is tracked by facility, quantity, and } \\
\text { process to support fire protection, ESOH, disaster response, and environ- } \\
\text { mental reporting requirements }\end{array}$ \\
\hline
\end{tabular}




\section{COMPLIANCE CATEGORY: \\ HAZARDOUS MATERIALS MANAGEMENT \\ Overseas ESOHCAMP}

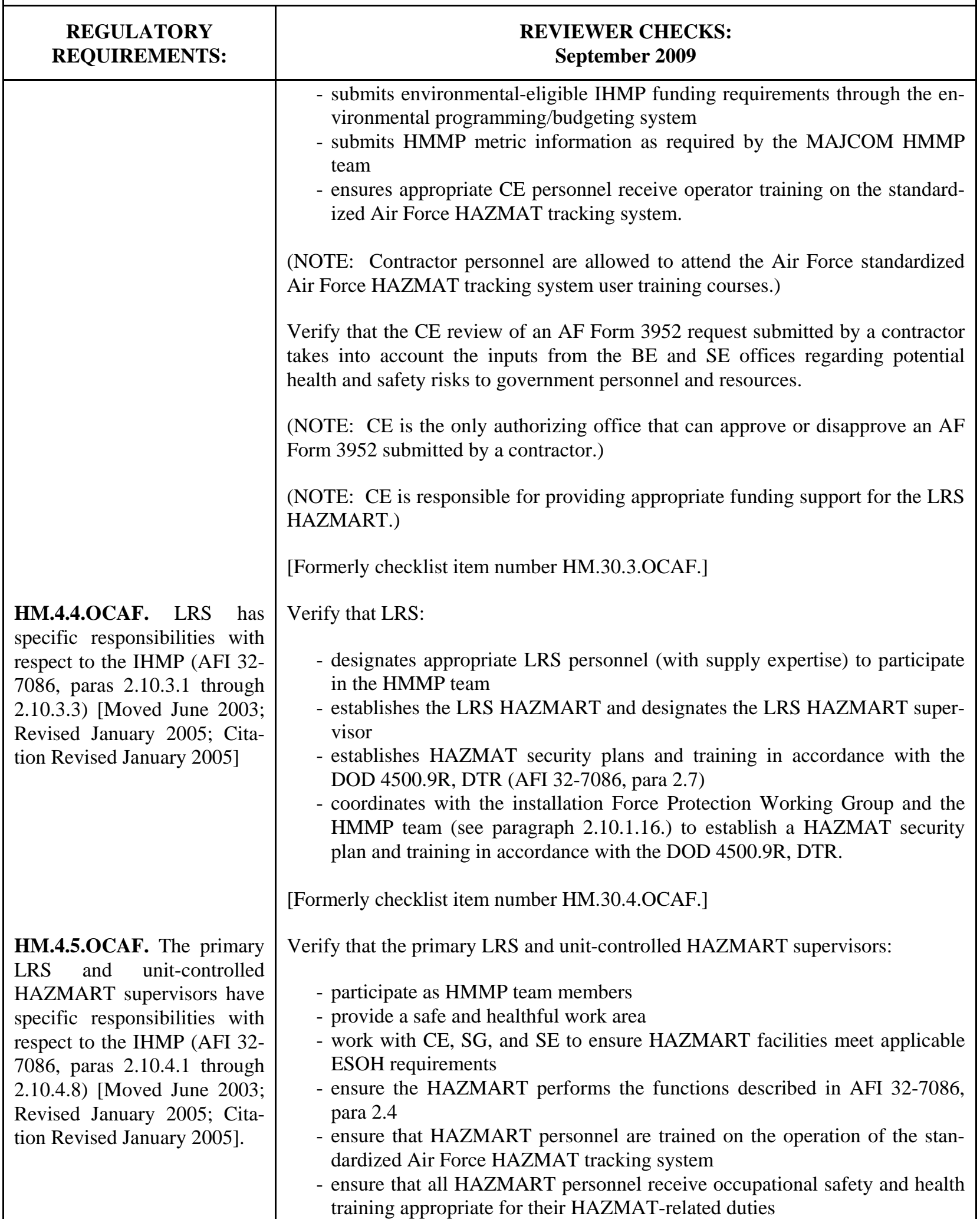




\begin{tabular}{|c|c|}
\hline & $\begin{array}{c}\text { COMPLIANCE CATEGORY: } \\
\text { HAZARDOUS MATERIALS MANAGEMENT } \\
\text { Overseas ESOHCAMP }\end{array}$ \\
\hline $\begin{array}{l}\text { REGULATORY } \\
\text { REQUIREMENTS: }\end{array}$ & $\begin{array}{l}\text { REVIEWER CHECKS: } \\
\text { September } 2009\end{array}$ \\
\hline $\begin{array}{l}\text { HM.4.6.OCAF. [Deleted } \\
\text { January 2005]. } \\
\text { HM.4.7.OCAF. SG has spe- } \\
\text { cific responsibilities with re- } \\
\text { spect to the IHMP (AFI 32- } \\
\text { 7086, paras 2.10.5.1 through } \\
\text { 2.10.5.10) [Moved June 2003; } \\
\text { Revised January 2005; Cita- } \\
\text { tion Revised January 2005]. }\end{array}$ & 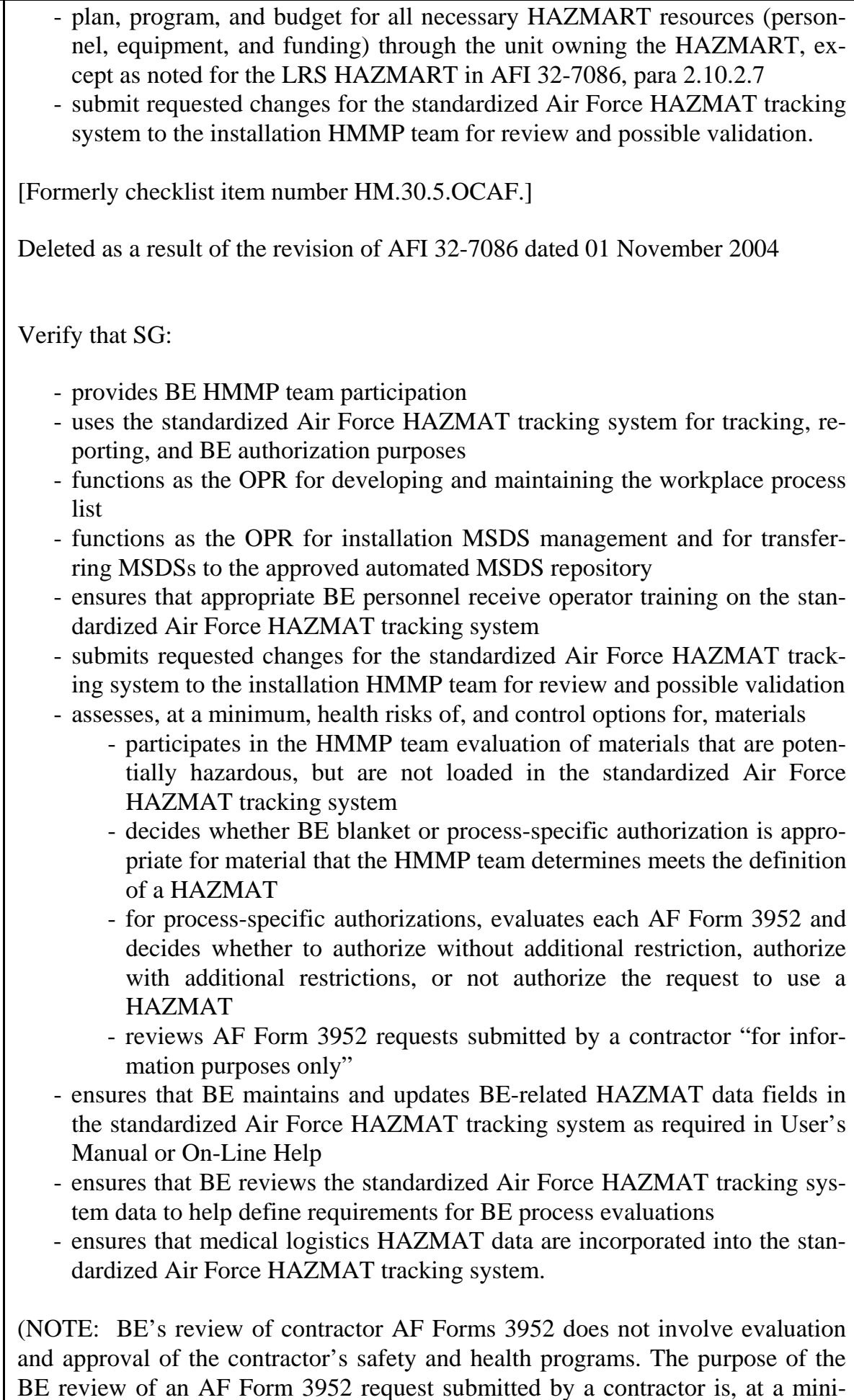 \\
\hline
\end{tabular}




\section{COMPLIANCE CATEGORY: \\ HAZARDOUS MATERIALS MANAGEMENT \\ Overseas ESOHCAMP}

\begin{tabular}{|c|}
\hline $\begin{array}{c}\text { REGULATORY } \\
\text { REQUIREMENTS: }\end{array}$ \\
\hline \\
\\
HM.4.8.OCAF. SE has spe- \\
cific responsibilities with re- \\
spect to the IHMP (AFI 32- \\
7086, paras 2.10.6.1 through \\
2.10.6.7) [Moved June 2003; \\
Revised January 2005; Cita- \\
tion Revised January 2005].
\end{tabular}

\section{REVIEWER CHECKS: \\ September 2009}

mum, to identify potential health risks to non-contractor personnel and resources and to advise $\mathrm{CE}$ and the Contracting Office on how to mitigate identified hazards from planned contractor HAZMAT usage.)

Verify that, for process-specific authorizations, BE evaluations of AF Forms 3952 include a review of HAZMAT-related work area surveys and identify conditions of use for HAZMAT.

[Formerly checklist item number HM.30.7.OCAF.]

Verify that SE:

- participates as an HMMP team member

- uses the standardized Air Force HAZMAT tracking system for tracking and authorization purposes

- ensures that appropriate SE personnel receive operator training on the standardized Air Force HAZMAT tracking system

- submits requested changes for the standardized Air Force HAZMAT tracking system to the installation HMMP team for review and possible validation

- advises HAZMART facilities on compliance with all applicable OSHA, AFOSH, and local standards

- assesses, at a minimum, the safety risks of, and control options for, HAZMAT

- participates in the HMMP team evaluation of materials that are potentially hazardous, but are not loaded in the standardized Air Force HAZMAT tracking system

- decides whether SE blanket or process-specific authorization is appropriate for material that the HMMP team determines meets the definition of a HAZMAT

- for process-specific authorizations, evaluates each AF Form 3952 and decides whether to authorize without additional restrictions, authorize with additional restrictions, or not authorize the request to use a HAZMAT

- reviews AF Form 3952 requests submitted by a contractor "for information purposes only"

- maintains and updates SE-related HAZMAT data fields in the standardized Air Force HAZMAT tracking system as required in User's Manual or OnLine Help.

Verify that, for process-specific authorizations, SE uses HAZMAT-related information from prior work area safety surveys in the AF Form 3952 review.

Verify that SE identifies conditions of HAZMAT use, and worker occupational safety training requirements that must be completed prior to HAZMAT use.

Verify that SE determines whether or not the process under review requires occupational safety analysis according to AFOSH Standard 91-119, Process Safety 


\section{COMPLIANCE CATEGORY: \\ HAZARDOUS MATERIALS MANAGEMENT \\ Overseas ESOHCAMP}

\begin{tabular}{c|c} 
REGULATORY & REVIEWER CHECKS: \\
REQUIREMENTS: & September 2009 \\
\hline
\end{tabular}

Management (PSM) of Highly Hazardous Chemicals.

(NOTE: SE's review of contractor AF Forms 3952 does not involve evaluation and approval of the contractor's safety and health programs. The purpose of the SE review of an AF Form 3952 request submitted by a contractor is, at a minimum, to identify potential safety risks to non-contractor personnel and resources and to advise CE and the Contracting Office on how to mitigate identified hazards from planned contractor HAZMAT usage.)

[Formerly checklist item number HM.30.8.OCAF.]

HM.4.9.OCAF. Work area supervisors have specific responsibilities with respect to the IHMP (AFI 32-7086, paras 2.10.7.1 through 2.10.7.15) [Moved June 2003; Revised January 2005; Citation Revised January 2005].
Verify that work area supervisors:

- comply with the installation IHMP

- participate in HMMP team meetings, as required, or to voice specific issues/concerns

- provide safe and healthful workplaces that comply with environmental requirements

- use AF Form 3952 to submit HAZMAT requirements to the HAZMART prior to obtaining the required HAZMAT from any source

- provide additional information to authorizing offices as requested to complete AF Forms 3952 (such as application methods, transfer methods, etc.)

- comply with all conditions of use identified on approved AF Forms 3952

- immediately notify the HAZMART of any changes to the conditions or processes as described on an approved AF Form 3952

- procure all HAZMAT using the process defined in AFI 32-7086, para 2.5., regardless of payment method (e.g.; SBSS; GPC; AF Form 9, Request for Purchase; etc.

- process all GPC purchases of HAZMAT through the HAZMART in accordance with AFI 32-7086, para 2.5.6.2

- provide work area personnel appropriate HAZMAT training (to include HAZCOM training)

- document all appropriate training on AF Form 55, Employee Safety and Health Record, or similar training documentation form

- ensure compliance with Air Force Technical Order (AFTO) requirements for use of HAZMAT until formally notified of a TO change to the requirements

- submit requests to eliminate a HAZMAT TO requirement on an AFTO Form 22, Technical Manual (TM) Change Recommendation and Reply, to the SM that controls the TO

- consider submitting the proposed TO change through the WSHP described in AFI 32-7086, Chapter 3

- maintain an inventory listing of all HAZMAT used or stored in the work area and ensure that all HAZMAT containers have appropriate labeling

- maintain only minimal quantities of HAZMAT in the work area and turn in excess HAZMAT to the HAZMART as soon as possible for reuse or redistribution

- avoid storing excess or expired products at the job site or in the work-area

- ensure, for those contracts for which the supervisor is responsible, that Qual- 


\section{COMPLIANCE CATEGORY: \\ HAZARDOUS MATERIALS MANAGEMENT \\ Overseas ESOHCAMP}

\begin{tabular}{|c|c|}
\hline $\begin{array}{l}\text { REGULATORY } \\
\text { REQUIREMENTS: }\end{array}$ & $\begin{array}{l}\text { REVIEWER CHECKS: } \\
\text { September } 2009\end{array}$ \\
\hline $\begin{array}{l}\text { HM.4.10.OCAF. The Con- } \\
\text { tracting Office has specific } \\
\text { responsibilities with respect to } \\
\text { the IHMP (AFI 32-7086, } \\
\text { paras 2.10.9.1 through } \\
\text { 2.10.9.6) [Moved June 2003; } \\
\text { Revised January 2005; Cita- } \\
\text { tion Revised January 2005]. }\end{array}$ & 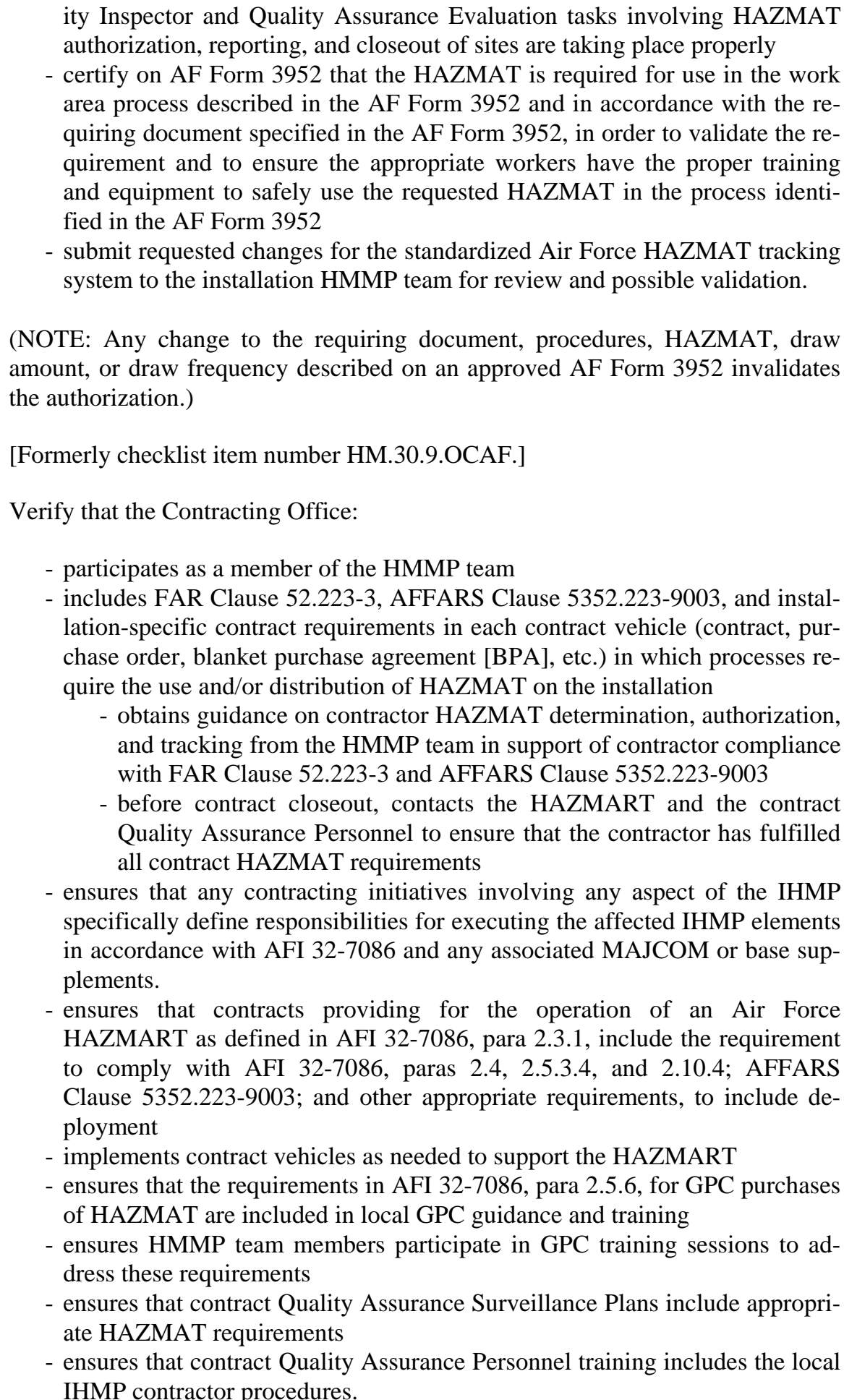 \\
\hline
\end{tabular}




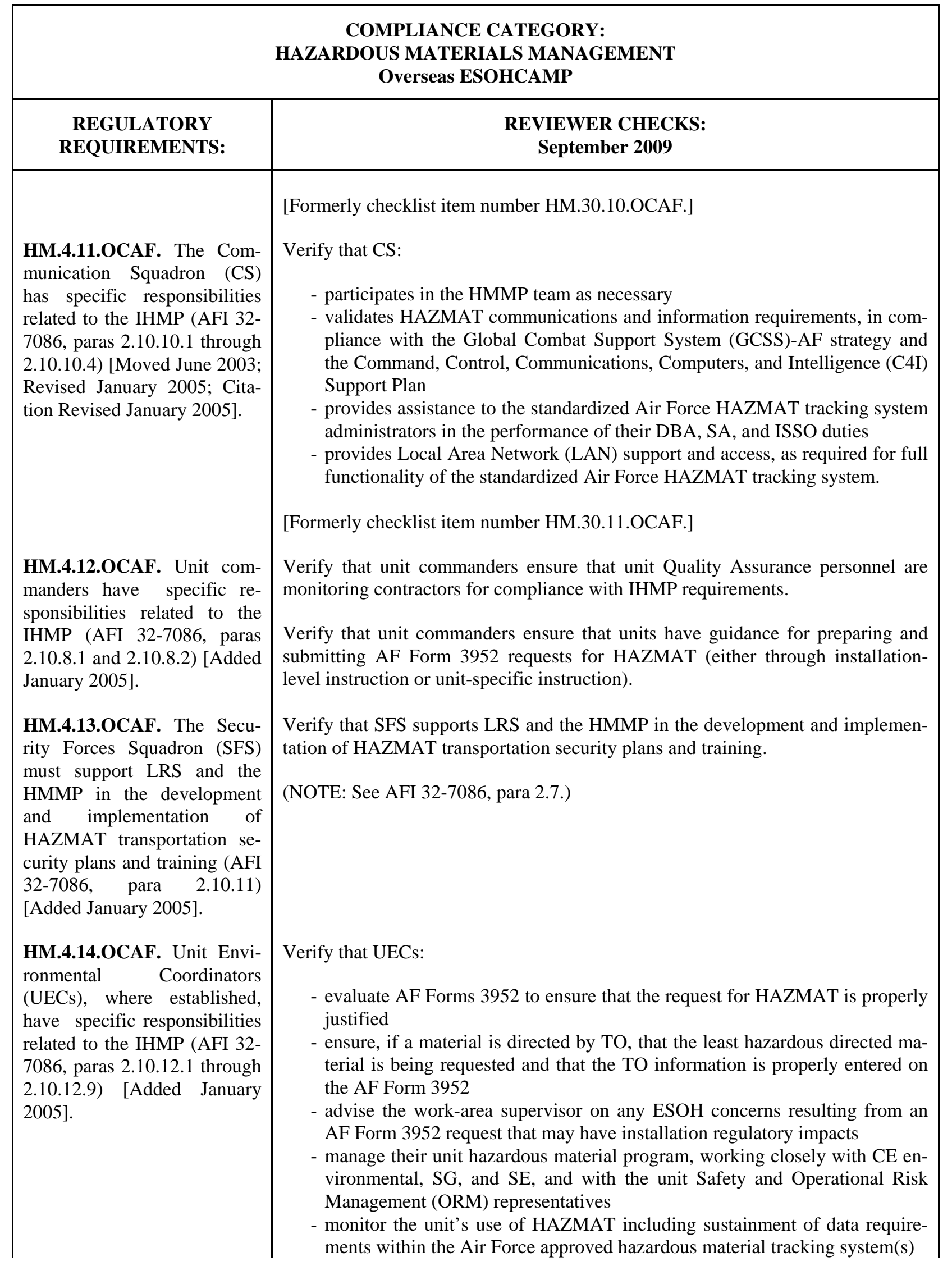




\section{COMPLIANCE CATEGORY: \\ HAZARDOUS MATERIALS MANAGEMENT \\ Overseas ESOHCAMP}

\begin{tabular}{|c|c|}
\hline $\begin{array}{c}\text { REGULATORY } \\
\text { REQUIREMENTS: }\end{array}$ & $\begin{array}{c}\text { REVIEWER CHECKS: } \\
\text { September 2009 }\end{array}$ \\
\hline & - emphasize hazardous material/environmental guidance to unit sup- \\
ply/material acquisition managers and supervisors \\
- review any unit-proposed HAZMAT process change or product substitutions \\
to ensure that all changes have been properly reviewed and approved \\
- review and coordinate with applicable offices on all unit HAZMAT-related \\
inputs to base environmental plans or ESOH program requirements \\
- serve as the unit focal point for HAZMAT environmental compliance \\
- support ESOH inspections such as ECAMP/ESOHCAMP assessments.
\end{tabular}

HM.4.15.OCAF. Installation Deployment Officers (IDOs) and UDMs must ensure that the HAZMAT deployment planning requirements described in AFI 32-7086, para 2.6, are included in the appropriate contingency deployment plans (AFI 32-7086, para 2.10.13) [Added January 2005].

HM.4.16.OCAF. Work area supervisors must use an $\mathrm{AF}$ Form 3952 and follow a specific procedure to request HAZMAT that is not currently loaded in the standardized Air Force HAZMAT tracking system (AFI 327086, paras 2.5.3.1, 2.5.3.1.2, 2.5.3.1.4, 2.5.3.1.5, 2.5.3.1.8, and 2.5.3.1.9) [Moved January 2005; Revised January 2005; Citation Revised January 2005].
(NOTE: Only the SM that controls a TO may make a change to the processes or HAZMAT requirements identified in the TO.)

Verify that IDOs and UDMs ensure that the HAZMAT deployment planning requirements described in AFI 32-7086, para 2.6, are included in the appropriate contingency deployment plans.

Verify that work area supervisors use an AF Form 3952 to initiate a request for HAZMAT.

(NOTE: AF Form 3952 is used for the first-time use of a HAZMAT in a Work Area; for the renewal of an AF Form 3952 authorization that is expiring; to submit revisions to an existing AF Form 3952 because of changes to the requiring document, procedures, HAZMAT, draw amount or draw frequency; and for use of the HAZMAT in a different process.)

Verify that work area supervisors submit the AF Form 3952 to the HAZMART (or local HMMP team specified workflow).

(NOTE: For any requested material that is not currently loaded in the standardized Air Force HAZMAT tracking system, the HMMP team determines whether it meets the HAZMAT definition in AFI 32-7086, para 1.3. If the HMMP team determines that the material does not meet the HAZMAT definition, the work area supervisor does not need an AF Form 3952 authorization to obtain the material. If the HMMP determines that the material does meet the HAZMAT definition, the HAZMART will load the material information into the standardized Air Force HAZMAT tracking system.)

Verify that, for HAZMAT that requires a process-specific authorization by one or more of the Authorizing Offices, the work area supervisor provides a copy of the one or more documents that require the use of the requested HAZMAT in the 


\section{COMPLIANCE CATEGORY: \\ HAZARDOUS MATERIALS MANAGEMENT \\ Overseas ESOHCAMP}

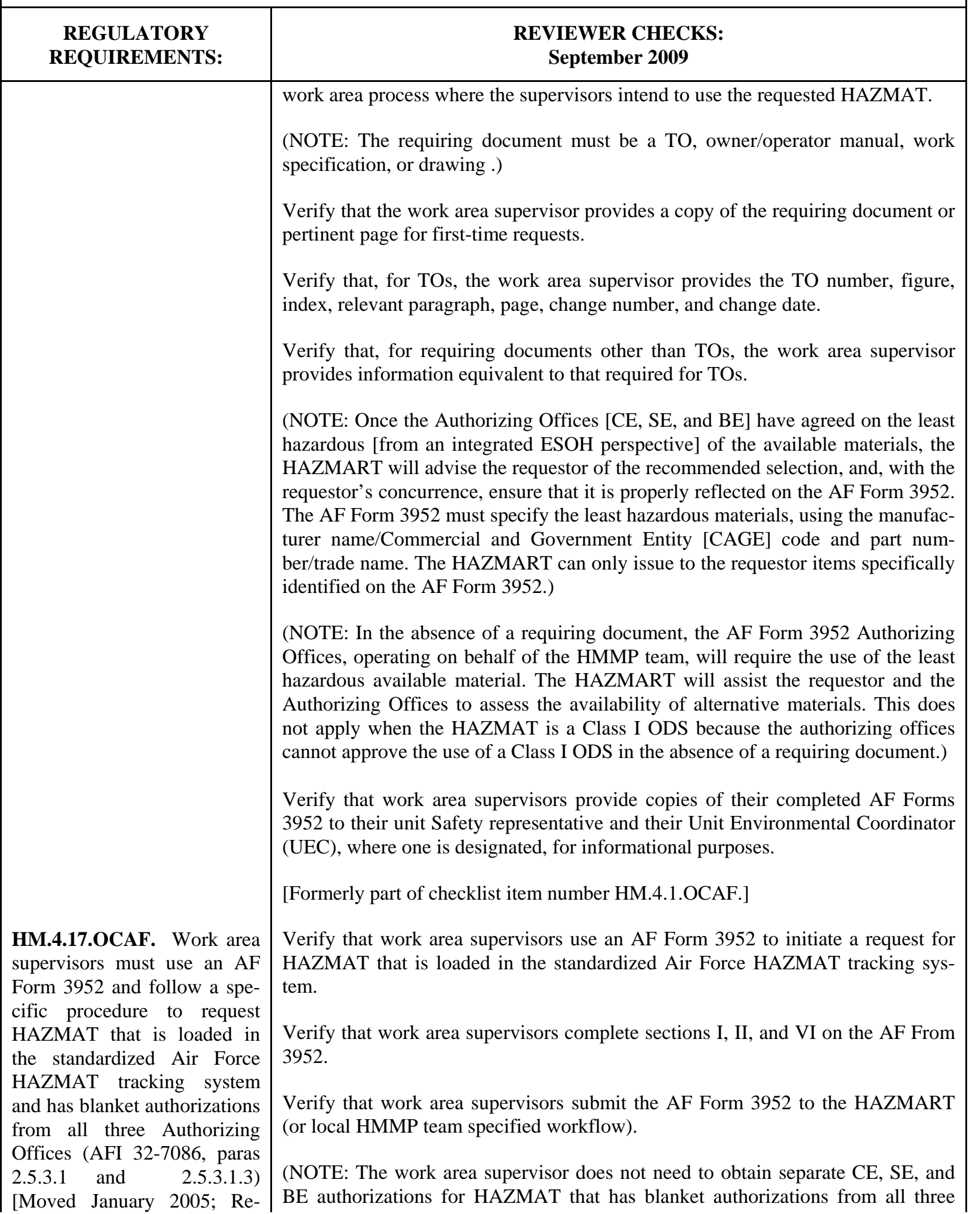




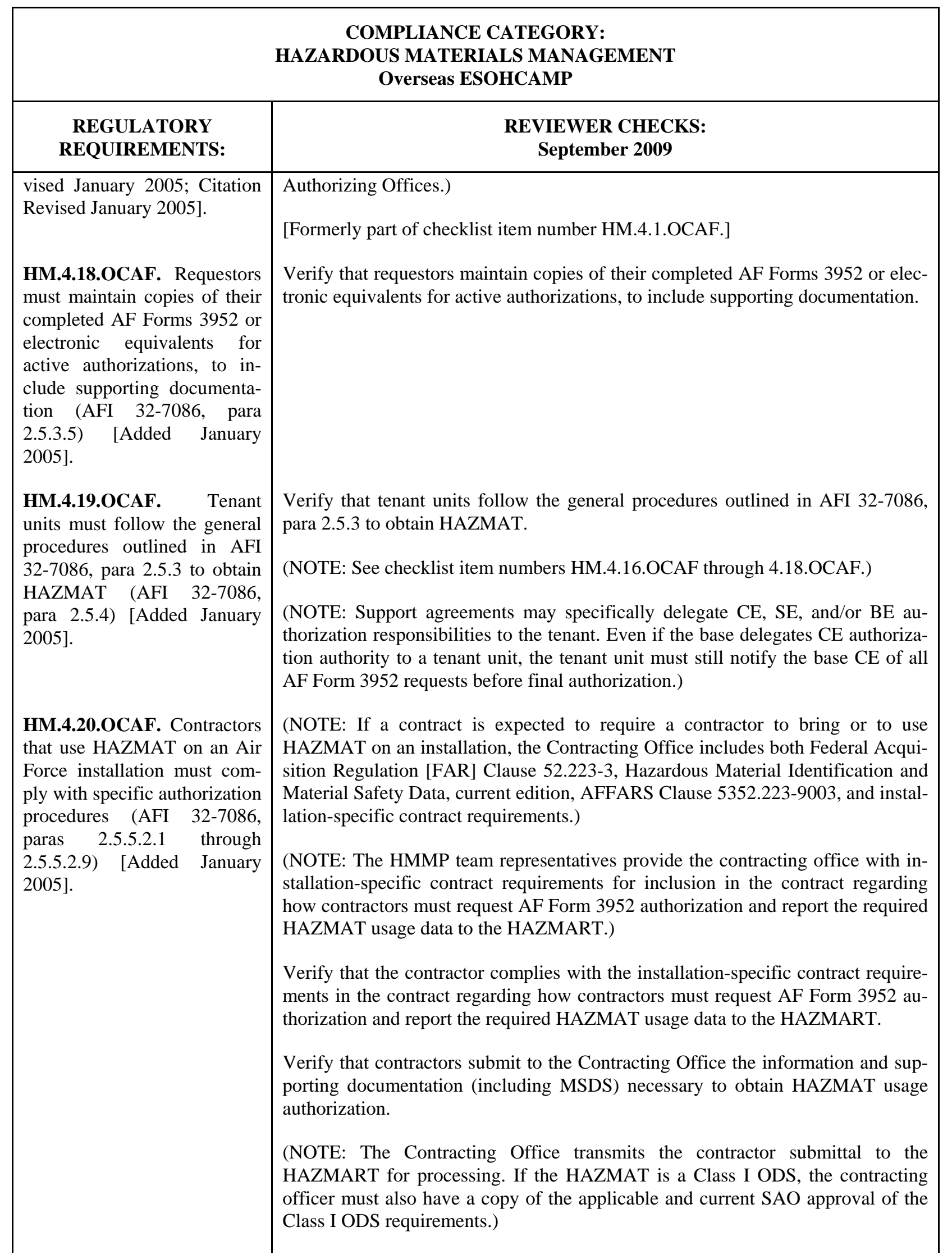




\section{COMPLIANCE CATEGORY: \\ HAZARDOUS MATERIALS MANAGEMENT \\ Overseas ESOHCAMP}

\section{REGULATORY REQUIREMENTS:}

HM.4.21.OCAF. Purchases of HAZMAT made using the GPC are subject to specific requirements (AFI 32-7086, paras 2.5.6.1 and 2.5.6.2) [Added January 2005].

\section{REVIEWER CHECKS: September 2009}

(NOTE: Contractors are not required to coordinate with a government UEC or Unit Safety Representative.)

(NOTE: For each contractor-identified HAZMAT that the HMMP team determines does not meet the Air Force definition of a HAZMAT, the IHMP requirements do not apply. The HMMP team will notify the Contracting Office that the contractor has authorization to bring and use that material on the installation without reporting usage.)

(NOTE: For each contractor-identified HAZMAT that the HMMP team determines does meet the Air Force definition of a HAZMAT, the Air Force requires $\mathrm{CE}$ authorization and SE and BE review of the AF Form 3952 information. The $\mathrm{CE}$ authorization is for environmental, fire protection concerns, and emergency response purposes only. The SE and BE reviews are "for information purposes only" and do not involve evaluation and approval of the contractor's safety and health programs. The purpose of the SE and BE review is to identify potential risks to government personnel and resources and advise CE and the Contracting Office on how to mitigate identified hazards from planned contractor HAZMAT usage. If the HAZMAT is a Class I ODS, CE must ensure there is an applicable and current SAO approval for the contract Class I ODS requirements before signing the AF Form 3952.)

(NOTE: The HAZMART ensures entry of the contractor supplied information into the standardized Air Force HAZMAT tracking system. This action includes the addition of the contractor to the AUL.)

Verify that the contractor reports data on the HAZMAT used during the performance of the contract at intervals and in the format specified by the HMMP team.

Verify that, if the contractor needs to bring a material on the installation that was not included in the original HAZMAT listing, the contractor first notifies the Contracting Office and then obtains prior authorization, if the HMMP team determines the material to be a HAZMAT.

Verify that individual cardholders obtain prior authorization before using the GPC to purchase HAZMAT.

Verify that, at the time of receipt, the individual cardholders process each authorized HAZMAT purchase (whether initial or recurring) through the HAZMART.

(NOTE: This allows the material to be reviewed for consistency with the authorization [amounts, MSDS, draw frequency, etc.], for barcoding [or approved equivalent], and for recording of receipt and issue in the standardized Air Force HAZMAT tracking system. )

(NOTE: HAZMART personnel are not required to deliver any GPC-purchased HAZMAT items.) 


\begin{tabular}{|c|c|}
\hline \multicolumn{2}{|c|}{$\begin{array}{c}\text { COMPLIANCE CATEGORY: } \\
\text { HAZARDOUS MATERIALS MANAGEMENT } \\
\text { Overseas ESOHCAMP }\end{array}$} \\
\hline $\begin{array}{c}\text { REGULATORY } \\
\text { REQUIREMENTS: }\end{array}$ & \multicolumn{1}{c|}{$\begin{array}{c}\text { REVIEWER CHECKS: } \\
\text { September 2009 }\end{array}$} \\
\hline & $\begin{array}{l}\text { (NOTE: Installation HMMP Teams may establish alternative reporting procedures } \\
\text { for GPC purchases of HAZMAT that have blanket approval from all three AF } \\
\text { Form 3952 Authorizing Offices [CE, SE, and BE].) }\end{array}$ \\
\hline
\end{tabular}




\begin{tabular}{|l|c|}
\hline \multicolumn{2}{|c|}{$\begin{array}{c}\text { COMPLIANCE CATEGORY: } \\
\text { HAZARDOUS MATERIALS MANAGEMENT } \\
\text { Overseas ESOHCAMP }\end{array}$} \\
\hline \multicolumn{1}{|c|}{$\begin{array}{c}\text { REVIEWER CHECKS: } \\
\text { REGULATORY } \\
\text { REQUIREMENTS: }\end{array}$} & \multicolumn{1}{c|}{$\begin{array}{c}\text { September 2009 } \\
\text { HM.20 } \\
\text { TRAINING } \\
\begin{array}{l}\text { HM.20.1.OCAF. [Deleted } \\
\text { June 2005]. }\end{array}\end{array}$} \\
\hline
\end{tabular}




\begin{tabular}{|c|c|}
\hline & $\begin{array}{c}\text { COMPLIANCE CATEGORY: } \\
\text { HAZARDOUS MATERIALS MANAGEMENT } \\
\text { Overseas ESOHCAMP }\end{array}$ \\
\hline $\begin{array}{l}\text { REGULATORY } \\
\text { REQUIREMENTS: }\end{array}$ & $\begin{array}{l}\text { REVIEWER CHECKS: } \\
\text { September } 2009\end{array}$ \\
\hline $\begin{array}{l}\text { HM.21 } \\
\text { HAZARD } \\
\text { COMMUNICATION }\end{array}$ & \\
\hline $\begin{array}{l}\text { HM.21.1.OCAF. Each Air } \\
\text { Force installation whose em- } \\
\text { ployees will potentially be } \\
\text { exposed to hazardous materi- } \\
\text { als must create a written haz- } \\
\text { ard communication program } \\
\text { that meets specific content } \\
\text { requirements (AFI 90-821, } \\
\text { para 2.3) [Added June 2005; } \\
\text { Citation Revised September } \\
\text { 2005]. }\end{array}$ & $\begin{array}{l}\text { Determine whether installation employees will potentially be exposed to hazard- } \\
\text { ous materials. } \\
\text { Verify that the installation has created a written hazard communication program } \\
\text { to support work area/shop implementation of the HAZCOM Program. } \\
\text { Verify that the written program includes installation-specific procedures to meet } \\
\text { the HAZCOM Program requirements and specifically includes: } \\
\text { - how MSDSs are accessible to employees } \\
\text { - container labeling procedures and requirements } \\
\text { - training requirements and procedures } \\
\text { - chemical inventory requirements } \\
\text { - procedures for informing employees regarding hazards of nonroutine tasks } \\
\text { and unlabeled pipes } \\
\text { - procedures for determining the hazard of a chemical (applies to only work } \\
\text { area/shops which produce hazardous chemicals). }\end{array}$ \\
\hline $\begin{array}{l}\text { HM.21.2.OCAF. Squadron } \\
\text { Commanders, or their desig- } \\
\text { nated representatives, must } \\
\text { approve written work } \\
\text { area/shop-specific training } \\
\text { prior to implementation in the } \\
\text { work area/shop and must } \\
\text { know the location of MSDSs } \\
\text { and training materials (AFI } \\
\text { 90-821, paras 1.8.1) [Added } \\
\text { June 2005]. }\end{array}$ & $\begin{array}{l}\text { Verify that Squadron Commanders, or their designated representatives, have ap- } \\
\text { proved written work area/shop-specific training prior to implementation in the } \\
\text { work area/shop. } \\
\text { Verify that Squadron Commanders, or their designated representatives, know the } \\
\text { location of MSDSs and training materials. }\end{array}$ \\
\hline $\begin{array}{l}\text { HM.21.3.OCAF. Supervisors } \\
\text { must ensure the appropriate } \\
\text { functionals review and ap- } \\
\text { prove the shop-specific haz- } \\
\text { ard training program for tech- } \\
\text { nical accuracy and complete- } \\
\text { ness prior to implementation } \\
\text { in the work area/shop (AFI } \\
\text { 90-821, paras } 2.7 \text { and 2.7.1) } \\
\text { [Added June 2005]. }\end{array}$ & $\begin{array}{l}\text { (NOTE: The work area/shop supervisor is responsible for ensuring all workers are } \\
\text { properly trained on the chemical hazards in their work area/shop.) } \\
\text { Verify that the appropriate functionals (i.e., PH, BE, base safety office, and fire } \\
\text { department) have reviewed and approved the shop-specific hazard training pro- } \\
\text { gram for technical accuracy and completeness prior to implementation in the work } \\
\text { area/shop. } \\
\text { (NOTE: Contract supervisors and contractors are trained according to their spe- } \\
\text { cific contract provisions.) }\end{array}$ \\
\hline
\end{tabular}




\section{COMPLIANCE CATEGORY: \\ HAZARDOUS MATERIALS MANAGEMENT \\ Overseas ESOHCAMP}

\section{REGULATORY REQUIREMENTS:}

HM.21.4.OCAF. Work area/shop supervisors have specific additional responsibilities with regard to the HAZCOM Program in their work areas/shops (AFI 90821, para 1.8.2.1 through 1.8.2.3 and 1.8.2.6 through 1.8.2.10) [Added June 2005; Revised September 2005; Citation Revised September 2005].

\section{REVIEWER CHECKS: September 2009}

(NOTE: Work area/shop supervisors are responsible for hazard communication in their work area/shops, but may designate an alternate to assist in daily program execution.)

Verify that work area/shop supervisors and their work area/shop HAZCOM Program designee obtain HAZCOM Program training.

Verify that work area/shop supervisors and their work area/shop HAZCOM Program designee ensure that all elements of HAZCOM training are conducted.

(NOTE: Public Health may be contacted for assistance.)

Verify that work area/shop supervisors and their work area/shop HAZCOM Program designee implement all elements of the AF HAZCOM Program in their work areas.

Verify that training is conducted by the work area/shop supervisor or another workplace designee selected by the supervisor.

Verify that work area/shop supervisors and their work area/shop HAZCOM Program designee develop and maintain a work area/shop-specific HAZCOM written program including a copy of the installation written HAZCOM Program and work area/shop-specific program elements.

Verify that work area/shop supervisors and their work area/shop HAZCOM Program designee implement AF HAZCOM program requirements for contractors in AF work areas/shops.

(NOTE: See checklist item number HM.21.16.OCAF.)

Verify that work area/shop supervisors and their work area/shop HAZCOM Program designee maintain or have access to an inventory of all hazardous materials used in the work area/shop.

Verify that, at least annually, the work area/shop supervisors and their work area/shop HAZCOM Program designee reconcile MSDSs on file (if files outside of HMIRS and ESOH-MIS are maintained) and the work area/shop hazardous chemical inventory.

Verify that all routine and nonroutine tasks are thoroughly described to include associated hazards and controls.

(NOTE: This description can be in the form of Technical Orders, Job Safety Analyses, BE survey letters, operating instructions, or specific task lists.)

Verify that work area/shop supervisors and their work area/shop HAZCOM Program designee conduct additional hazard communication training on contaminants 


\section{COMPLIANCE CATEGORY: \\ HAZARDOUS MATERIALS MANAGEMENT \\ Overseas ESOHCAMP}

\begin{tabular}{|l|}
\hline $\begin{array}{c}\text { REGULATORY } \\
\text { REQUIREMENTS: }\end{array}$ \\
\hline \\
HM.21.5.OCAF. An MSDS \\
must be immediately accessi- \\
ble for every item on the work \\
area/shop-specific hazardous \\
chemical inventory (AFI 90- \\
821, paras 1.8.2.8 and 2.5) \\
[Added June 2005, Revised \\
September 2007].
\end{tabular}

\section{REVIEWER CHECKS: September 2009}

as required by OSHA expanded standards such as asbestos, benzene, lead, etc.

(NOTE: Refer to BE survey letters to identify if expanded standards apply in a work area/shop.)

(NOTE: The September 2007 revisions are based on the Interim Change to AFI 90-821, Hazard Communication, memorandum dated 9 January 2007.)

Verify that OCONUS locations maintain documents consistent with 29 CFR 1910.1200(g), Hazard Communication.

(NOTE: If a document consistent with 29 CFR 1910.1200(g) cannot be obtained from the OCONUS supplier, a document meeting the intent of 29 CFR 1910.1200 (g) is acceptable.)

(NOTE: European Safety Data Sheets [SDSs] meet the intent of 29 CFR 1910.1200(g).)

Verify that an MSDS is immediately accessible (in either paper or electronic format) for every item on the work area/shop-specific hazardous chemical inventory.

Verify that the MSDS on file matches the manufacturer and part number/trade name of the material on-hand.

Verify that the MSDS preparation date is consistent with the date/lot of any material on-hand.

(NOTE: If a new MSDS is received, but the old material is still on-hand, the MSDS that matched the old material must be retained.)

(NOTE: MSDSs may be obtained from several sources. These include, but are not limited to, the chemical manufacturer or supplier, installation or unit HAZMART, DOD HMIRS online or CDROM, or through the ESOH-MIS. If the MSDS is not available from these sources, the BE Flight may be contacted for further assistance.)

Verify that all workers on all shifts know how to obtain an MSDS and have unrestricted direct access to MSDSs for their work area/shop during all shifts.

(NOTE: MSDSs may be maintained in the work area/shops in paper or electronic version. OSHA does not specifically prohibit any form of access as long as "no barriers to immediate employee access" are created. The location of MSDSs and/or means of access for any work area/shop is determined locally. The supervisor should consider how long it would take for a worker to obtain an MSDS if it were needed to respond to a spill or if a worker was accidentally splashed with a hazardous chemical.)

Verify that, if the primary means for MSDS access is electronic, a back-up system 


\section{COMPLIANCE CATEGORY: \\ HAZARDOUS MATERIALS MANAGEMENT \\ Overseas ESOHCAMP}

\section{REGULATORY REQUIREMENTS:}

HM.21.6.OCAF. Supervisors must ensure labels on containers of hazardous chemicals used in their work area/shop meet HAZCOM requirements, remain affixed to their containers, and are not obliterated or covered (AFI 90-821, paras 2.6.2 through 2.6.4) [Added June 2005].

\section{REVIEWER CHECKS: September 2009}

for MSDS access is established in case primary computer access is disrupted.

(NOTE: The back-up system may include, but is not limited to, paper copies, local computer files or CDs at another nonimpacted location, telephone, fax, or access through a nearby HAZMART or BE Flight. Local judgment must be used to determine an adequate back-up system on a case-by-case basis.)

(NOTE: BE or other qualified personnel will provide explanations or interpretations of the MSDS to supervisors and affected workers, as requested, for routine training and planning, and will be available during emergency situations to assist in interpretation of MSDSs.)

(NOTE: Where personnel must travel between work area/shops during a work shift [e.g., their work is carried out at more than one geographical location such as flight line operations], the MSDS may be kept at the primary work area/shop facility.)

Verify that where personnel travel between work area/shops during a work shift and the MSDSs are kept at the primary work area/shop facility, the supervisor ensures that personnel can immediately obtain the required information in an emergency.

(NOTE: It is the responsibility of chemical manufacturers, importers and commercial distributors to label containers of hazardous chemicals according to the OSHA's Federal HAZCOM standard. Accordingly, chemical containers entering the installation through the supply system or through local purchase should already be labeled. Supply receiving and HAZMARTs ensure incoming containers are properly labeled.)

Verify that labels on containers of hazardous chemicals used in the work area/shop meet HAZCOM requirements, remain affixed to their containers, and are not obliterated or covered.

Verify that, at minimum, the following information appears on container labels:

- the identity of the hazardous chemical(s) in the container

- appropriate hazard warnings that include information about the specific physical and health hazard(s), including target organ effects of the chemical(s) in the container.

(NOTE: Any combination of words, symbols, or pictures may be used to provide information about the specific physical and health hazard[s].)

(NOTE: The following materials are exempted from HAZCOM labeling requirements:

- any pesticide as such term is defined in the Federal Insecticide, Fungicide, and Rodenticide Act when subject to the labeling requirements of that Act

- any chemical substance or mixture as such terms are defined in the Toxic 


\section{COMPLIANCE CATEGORY: \\ HAZARDOUS MATERIALS MANAGEMENT \\ Overseas ESOHCAMP}

\section{REGULATORY REQUIREMENTS:}

HM.21.7.OCAF. Containers into which chemicals have been transferred are subject to labeling requirements (AFI 90-821, para 2.6.6) [Added June 2005].

HM.21.8.OCAF. Workers must be provided HAZCOM training (AFI 90-821, paras 1.2.1, 1.8.2.4, and 2.7.2) [Added June 2005; Citation Revised September 2005].

\section{REVIEWER CHECKS: September 2009}

Substances Control Act when subject to the labeling requirements of that Act

- any food, food additive, color additive, drug, cosmetic, or medical or veterinary device or product, including materials intended for use as ingredients in such products [e.g., flavors and fragrances], as such terms are defined in the Federal Food, Drug, and Cosmetic Act

- any distilled spirits [beverage alcohols], wine, or malt beverage intended for nonindustrial use, as such terms are defined in the Federal Alcohol Administration Act, and regulations issued under that Act, when subject to the labeling requirements of that Act and labeling regulations issued under that Act by the Bureau of Alcohol, Tobacco, and Firearms

- any consumer product or hazardous substance as those terms are defined in the Consumer Product Safety Act and Federal Hazardous Substances Act respectively, when subject to a consumer product safety standard or labeling requirement of those Acts, or regulations issued under those Acts by the Consumer Product Safety Commission

- agricultural or vegetable seed treated with pesticides and labeled in accordance with the Federal Seed Act and labeling regulations issued under that Act by the Department of Agriculture.)

(NOTE: If an employee transfers a chemical from a labeled container [e.g., a 55gal drum] into a portable container for the immediate use of the same employee who made the transfer, then the portable container does not need to be labeled according to HAZCOM requirements. Immediate use means that the hazardous chemical will be under the control of and used only by the person who transfers it from a labeled container and only within the work shift in which it is transferred.)

Verify that, if an employee who transfers a chemical from a labeled container into a portable container cannot maintain full control over the chemical or departs the work area/shop and if there is residual material left in the portable container, this material is either be disposed of under applicable local disposal regulations, returned to its original container, or labeled in accordance with applicable regulations.

Verify that, if a chemical is transferred from a labeled container into a portable container at a central distribution point, such as the installation or unit HAZMART, for use by other employees, the portable container is labeled by the HAZMART in accordance with HAZCOM requirements.

Verify that all employees who work in an environment where any chemical is known to be present in such a manner that employees may be exposed under normal conditions of use or in a foreseeable emergency, are provided information about the hazardous chemicals to which they are exposed.

Verify that workers are provided HAZCOM training prior to working with a material that could potentially create a health hazard and when work area/shop conditions or hazardous materials change. 


\section{COMPLIANCE CATEGORY: \\ HAZARDOUS MATERIALS MANAGEMENT \\ Overseas ESOHCAMP}

\section{REGULATORY REQUIREMENTS:}

HM.21.9.OCAF. Initial training must meet specific minimum requirements (AFI 90821, para 2.7.2.1) [Added June 2005].

HM.21.10.OCAF. Supplemental training must meet specific requirements (AFI 90-821, para 2.7.2.2) [Added June 2005].

HM.21.11.OCAF. Work area / shop supervisors must document both worker initial and

\section{REVIEWER CHECKS: September 2009}

Verify that workers receive comprehensive HAZCOM training from their supervisors at the time of their initial assignment in a work area/shop.

Verify that supplemental training for all potentially affected employees is provided whenever a new hazard is brought into the work area/shop or a new chemical is introduced.

Verify that, when workers change work area/shops either by assigned duties or location, initial work area/shop-specific training is reaccomplished to the extent needed to cover changes in working conditions and potential exposures.

Verify that initial training includes the following, at a minimum:

- identification of operations or processes in the work area/shop where hazardous chemicals are present or used, and the complete list of hazardous material used in association with work area/shop processes

- identification of relevant hazard categories associated with each chemical used (e.g., flammability, carcinogenicity, etc.) or the individual chemical hazards; including, but not limited to, those with specific regulatory requirements (e.g., asbestos, benzene, beryllium, cadmium, formaldehyde, and

- thedocation and contents of the work area/shop-specific written hazard communication program

- proper labeling of hazardous materials

- how to access and read MSDSs

- controls (engineering controls, administrative controls, and personal protective equipment) workers must use to minimize or eliminate exposure to hazardous chemicals specific to a task (e.g., the specific respirator for a specific spray painting process)

- emergency procedures, such as recognition of a spill or accidental chemical release (e.g., visual, odor, alarm) and escape procedures to include the locations of emergency eye wash stations, showers, and monitoring capabilities

- chemical hazards associated with nonroutine tasks (e.g., solvent tank change-out every three months).

Verify that supervisors refer to the installation BE work area/shop survey reports for specific control requirements.

Verify that supplemental training includes all the elements listed in AFI 90-821, para 2.7.2.1.

(NOTE: See checklist item HM.21.9.OCAF.)

(NOTE: Supervisors may use the AF Form 3952 or BE special survey letters as sources of information to meet this training requirement.)

Verify that work area/shop supervisors document both worker initial and supplemental HAZCOM training on AF Form 55 or in CAMS or in ESOH-MIS. 


\section{COMPLIANCE CATEGORY: \\ HAZARDOUS MATERIALS MANAGEMENT \\ Overseas ESOHCAMP}

\section{REGULATORY REQUIREMENTS:}

supplemental hazard communication training on AF Form 55 or in CAMS or in ESOHMIS (AFI 90-821, paras 1.8.2.5 and 2.7.4) [Added June 2005; Revised September 2005].

HM.21.12.OCAF. The written work area/shop hazard communication program must include a list of the hazardous chemicals known to be present in a work area/shop (AFI 90-821, para 2.8) [Added June 2005].

HM.21.13.0CAF. Supervisors must ensure work area/shop operating instructions (OIs), specific task lists, and Job Safety Analyses (JSAs) thoroughly describe nonroutine tasks and their associated hazards and controls (AFI 90-821, para 2.9.2) [Added June 2005].

HM.21.14.OCAF. When workers temporarily perform duties outside their normal jobs, the supervisor of the gaining activity must ensure these workers receive specific training prior to beginning the activity (AFI 90-821, para 2.9.3) [Added June 2005].

HM.21.15.OCAF. Specific, limited requirements must be met in work operations (such

\section{REVIEWER CHECKS: September 2009}

Verify that the information is accessible electronically or in hard copy.

(NOTE: This record should also include external HAZCOM training provided to AF supervisors and employees from contractor organizations, where applicable.)

Verify that the written work area/shop hazard communication program includes a list of the hazardous chemicals known to be present in a work area/shop.

(NOTE: The list may be compiled for the work area/shop as a whole or for specified and readily distinguishable portions of a work area/shop).

Verify that the identity that is used on the MSDS is cross-referenced to the inventory.

(NOTE: Where accessible, the inventory may be maintained in the ESOH-MIS.)

(NOTE: The inventory is a fundamental building block for a HAZCOM Program, and the nature of the chemicals on the inventory in a work area/shop determines the scope of the hazard communication program and training requirements appropriate for that work area/shop.)

Verify that work area/shop OIs, specific task lists, and JSAs thoroughly describe nonroutine tasks and their associated hazards and controls.

(NOTE: OIs do not need to be prepared if technical orders or other official documents adequately describe these tasks and associated hazards and controls.)

Verify that workers review these procedures before performing the nonroutine tasks.

Verify that, when workers temporarily perform duties outside their normal jobs, they receive the following training prior to beginning the activity:

- initial HAZCOM training for workers not previously trained

- work area/shop-specific training, as necessary, on work area/shop-specific chemical hazards and associated controls.

Verify that, in work operations (such as warehousing) where employees handle chemicals only in sealed containers that are not opened under normal conditions 


\section{COMPLIANCE CATEGORY: \\ HAZARDOUS MATERIALS MANAGEMENT \\ Overseas ESOHCAMP}

\section{REGULATORY REQUIREMENTS:}

as warehousing) where employees handle chemicals only in sealed containers that are not opened under normal conditions of use (AFI 90821, para 1.2.5) [Added June 2005; Citation Revised September 2005].

HM.21.16.OCAF. Specific requirements must be met when an AF work area/shop uses hazardous chemicals in a way that contractor employees may be exposed (AFI 90821, para 2.10) [Added June 2005].

HM.21.17.OCAF. Wing / Installation Commanders must assess the effectiveness of the HAZCOM Program in work area/shops where hazardous chemicals are stored, used, or handled (AFI 90-821, paras 1.6.1.1 and 2.7.5) [Added June 2005].

\section{REVIEWER CHECKS: September 2009}

of use, the following requirements are met:

- labels on incoming containers of hazardous chemicals are not removed or defaced

- MSDSs received with incoming shipments of sealed containers are maintained, and employees have access to the MSDSs

- if hazardous chemicals received do not have MSDSs, they are obtained as soon as possible

- supervisors train employees on the hazards of the chemicals in their work area/shop and to the extent necessary to protect them in the event of a spill or leak of a hazardous chemical from a sealed container.

Determine whether an AF work area/shop uses hazardous chemicals in a way that contractor employees (e.g., a painting contractor working in an industrial shop) may be exposed.

Verify that the work area/shop written hazard communication program and access to MSDSs is provided to the contractors.

(NOTE: The contractor is responsible for determining the adequacy of the HAZCOM information for assessments of contractor employees and is responsible for their own HAZCOM Program.)

Verify that the effectiveness of the HAZCOM Program is assessed in work area/shops where hazardous chemicals are stored, used, or handled.

Verify that the effectiveness of worker training is measured by assessing worker knowledge of basic hazard communication concepts to include, but not be limited to:

- what processes and chemicals present hazards in their work area/shop and the nature of the hazard

- how to access MSDSs for any chemical they use

- how to find information on an MSDS

- how to interpret the hazard symbols or wording on hazard labels and what precautions (e.g., engineering controls, personal protective equipment, etc.) they must use when working with hazardous chemicals. 


\begin{tabular}{|c|c|}
\hline & $\begin{array}{c}\text { COMPLIANCE CATEGORY: } \\
\text { HAZARDOUS MATERIALS MANAGEMENT } \\
\text { Overseas ESOHCAMP }\end{array}$ \\
\hline $\begin{array}{l}\text { REGULATORY } \\
\text { REQUIREMENTS: }\end{array}$ & $\begin{array}{l}\text { REVIEWER CHECKS: } \\
\text { September } 2009\end{array}$ \\
\hline $\begin{array}{l}\text { HM.30 } \\
\text { RELEASES }\end{array}$ & \\
\hline $\begin{array}{l}\text { HM.30.1.OCAF. [Moved } \\
\text { June 2003; Deleted July } \\
\text { 2008]. }\end{array}$ & $\begin{array}{l}\text { Deleted July } 2008 \text { at the request of the sponsor. } \\
\text { [Formerly checklist item number HM.50.1.OCAF.] }\end{array}$ \\
\hline
\end{tabular}




\begin{tabular}{|c|c|}
\hline \multicolumn{2}{|r|}{$\begin{array}{c}\text { COMPLIANCE CATEGORY: } \\
\text { HAZARDOUS MATERIALS MANAGEMENT } \\
\text { Overseas ESOHCAMP }\end{array}$} \\
\hline $\begin{array}{l}\text { REGULATORY } \\
\text { REQUIREMENTS: }\end{array}$ & $\begin{array}{l}\text { REVIEWER CHECKS: } \\
\text { September } 2009\end{array}$ \\
\hline $\begin{array}{l}\text { HM.40 } \\
\text { GENERAL OPERATING } \\
\text { REQUIREMENTS }\end{array}$ & \\
\hline $\begin{array}{l}\text { HM.40.1.OCAF. [Deleted } \\
\text { June 2005]. }\end{array}$ & $\begin{array}{l}\text { Deleted as a consequence of the release of AFI 90-821, Hazard Communication. } \\
\text { See the checklist items in HM.21. }\end{array}$ \\
\hline HM.40.2.OCAF. [Moved & Deleted at the request of the sponsor. \\
\hline $\begin{array}{l}\text { June 2003; Deleted July } \\
\text { 2008]. }\end{array}$ & [Formerly checklist item number HM.70.2.OCAF.] \\
\hline $\begin{array}{l}\text { HM.40.3.OCAF. [Moved } \\
\text { June 2003; Deleted July } \\
\text { 2008]. }\end{array}$ & $\begin{array}{l}\text { Deleted at the request of the sponsor. } \\
\text { [Formerly checklist item number HM.70.3.OCAF.] }\end{array}$ \\
\hline
\end{tabular}




\begin{tabular}{|c|c|}
\hline & $\begin{array}{c}\text { COMPLIANCE CATEGORY: } \\
\text { HAZARDOUS MATERIALS MANAGEMENT } \\
\text { Overseas ESOHCAMP }\end{array}$ \\
\hline $\begin{array}{l}\text { REGULATORY } \\
\text { REQUIREMENTS: }\end{array}$ & $\begin{array}{l}\text { REVIEWER CHECKS: } \\
\text { September } 2009\end{array}$ \\
\hline $\begin{array}{l}\text { HM.50 } \\
\text { DOCUMENTATION } \\
\text { HM.50.1.OCAF. The instal- } \\
\text { lation must have a compre- } \\
\text { hensive list of all chemicals } \\
\text { used or generated onsite and } \\
\text { an assessment of their hazards } \\
\text { (AFM 67-1, Volume 2, Part } \\
\text { Two, Chapters } 14 \text { and 21) } \\
\text { [Moved June 2003]. }\end{array}$ & $\begin{array}{l}\text { Verify that the installation has a comprehensive list of all chemicals used or gen- } \\
\text { erated onsite and an assessment of their hazards. } \\
\text { [Formerly checklist item number HM.80.1.OCAF.] }\end{array}$ \\
\hline $\begin{array}{l}\text { HM.50.2.OCAF. [Deleted } \\
\text { June 2005]. }\end{array}$ & $\begin{array}{l}\text { Deleted as a consequence of the release of AFI 90-821, Hazard Communication. } \\
\text { See the checklist items in HM.21. }\end{array}$ \\
\hline $\begin{array}{l}\text { HM.50.3.OCAF. [Deleted } \\
\text { June 2005]. }\end{array}$ & $\begin{array}{l}\text { Deleted as a consequence of the release of AFI 90-821, Hazard Communication. } \\
\text { See the checklist items in HM.21. }\end{array}$ \\
\hline $\begin{array}{l}\text { HM.50.4.OCAF. BES must } \\
\text { meet specific responsibilities } \\
\text { with respect to MSDSs (AFI } \\
\text { 91-301, paras 2.10.1.17 and } \\
\begin{array}{l}2.10 .1 .18 \text { ) [Moved June } \\
2003 \text { ]. }\end{array}\end{array}$ & $\begin{array}{l}\text { Verify that BES maintains a current copy of DOD List 6050.5-L, Hazardous Ma- } \\
\text { terial Information System (HMIS) Hazardous Item Listing, on compact disc. } \\
\text { Verify that BES maintains copies of other MSDSs for items: } \\
\text { - not listed in the HMIS } \\
\text { - locally purchased through base supply, medical supply, or civil engineering } \\
\text { supply channels. } \\
\text { Verify that BES maintains a file of MSDSs for all hazardous materials used in the } \\
\text { industrial facilities on the installation. } \\
\text { [Formerly checklist item number HM.80.4.OCAF.] }\end{array}$ \\
\hline
\end{tabular}




\begin{tabular}{|l|c|}
\hline \multicolumn{2}{|c|}{$\begin{array}{c}\text { COMPLIANCE CATEGORY: } \\
\text { HAZARDOUS MATERIALS MANAGEMENT } \\
\text { Overseas ESOHCAMP }\end{array}$} \\
\hline \multicolumn{2}{|c|}{$\begin{array}{c}\text { REVIEWER CHECKS: } \\
\text { September 2009 }\end{array}$} \\
REQUIREMENTS: & \\
HM.70 & \\
$\begin{array}{l}\text { TRANSPORTATION } \\
\text { HM.70.1.OCAF. [Moved } \\
\begin{array}{l}\text { June 2003; Deleted July } \\
\text { 2008]. }\end{array}\end{array}$ & $\begin{array}{l}\text { Deleted at the request of the sponsor. } \\
\text { [Formerly checklist item number HM.240.1.OCAF.] }\end{array}$ \\
\hline
\end{tabular}




\begin{tabular}{|c|c|}
\hline & $\begin{array}{c}\text { COMPLIANCE CATEGORY: } \\
\text { HAZARDOUS MATERIALS MANAGEMENT } \\
\text { Overseas ESOHCAMP }\end{array}$ \\
\hline $\begin{array}{l}\text { REGULATORY } \\
\text { REQUIREMENTS: }\end{array}$ & $\begin{array}{l}\text { REVIEWER CHECKS: } \\
\text { September } 2009\end{array}$ \\
\hline $\begin{array}{l}\text { HM.90 } \\
\text { FLAMMABLE/ } \\
\text { COMBUSTIBLE } \\
\text { LIQUIDS: } \\
\text { Handling }\end{array}$ & \\
\hline $\begin{array}{l}\text { HM.90.1.OCAF. Flamma- } \\
\text { ble/combustible liquids must } \\
\text { be handled according to spe- } \\
\text { cific procedures (AFOSH } \\
\text { STD 91-501, para 22.4.11) } \\
\text { [Citation Revised December } \\
\text { 2002]. }\end{array}$ & $\begin{array}{l}\text { Verify that the following procedures are followed when flammable/combustible } \\
\text { materials are handled: } \\
\text { - transfer of liquids from or into vessels, containers, or portable tanks within a } \\
\text { building takes place only by means of the following methods: } \\
\text { - a closed piping system } \\
\text { - safety cans } \\
\text { - a device drawing through the top } \\
\text { - from a container or portable tank by gravity through an approved self- } \\
\text { closing valve } \\
\text { - approved safety cans are used for transporting and dispensing flammable liq- } \\
\text { uids in quantities of } 19 \mathrm{~L} \text { ( } 5 \text { gal) or less } \\
\text { - flammable liquids are kept in covered containers when not actually in use } \\
\text { - Class I liquids are used only when there are no open flames or other sources } \\
\text { of ignition within the area or possible path of vapor travel. } \\
\text { Verify that no transfers are carried out by means of air pressure on the container } \\
\text { or portable tank. } \\
\text { Verify that safety cans and other portable containers of flammable liquids having } \\
\text { a flashpoint at or below } 80{ }^{\circ} \mathrm{F} \text { are painted red with some additional clearly visible } \\
\text { identification either in the form of a yellow band around the container or the name } \\
\text { of the contents conspicuously stenciled or painted on the container in yellow. } \\
\text { (NOTE: This provision does not apply to containers that are required by technical } \\
\text { data to be painted "tonedown;" such containers must be conspicuously stenciled } \\
\text { in black with the name of the contents.) } \\
\text { (NOTE: This provision does not apply to shipping containers.) }\end{array}$ \\
\hline $\begin{array}{l}\text { HM.90.2.OCAF. Functional } \\
\text { managers and/or supervisors } \\
\text { must ensure that appropriate } \\
\text { spill and containment control } \\
\text { materials are readily available } \\
\text { at storage or dispensing areas } \\
\text { for flammable/combustible } \\
\text { liquids (AFOSH STD 91-501, } \\
\text { paras 22.3 and 22.4.11.3) } \\
\text { [Citation Revised December }\end{array}$ & $\begin{array}{l}\text { Verify that appropriate spill and containment control materials are readily avail- } \\
\text { able at storage or dispensing areas for flammable/combustible liquids. }\end{array}$ \\
\hline
\end{tabular}




\begin{tabular}{|c|c|}
\hline \multicolumn{2}{|r|}{$\begin{array}{c}\text { COMPLIANCE CATEGORY: } \\
\text { HAZARDOUS MATERIALS MANAGEMENT } \\
\text { Overseas ESOHCAMP }\end{array}$} \\
\hline $\begin{array}{l}\text { REGULATORY } \\
\text { REQUIREMENTS: }\end{array}$ & $\begin{array}{l}\text { REVIEWER CHECKS: } \\
\text { September } 2009\end{array}$ \\
\hline 2002]. & \\
\hline $\begin{array}{l}\text { HM.90.3.OCAF. Functional } \\
\text { managers and/or supervisors } \\
\text { must ensure that personal } \\
\text { protective equipment (PPE) is } \\
\text { available and appropriately } \\
\text { worn when personnel handle } \\
\text { flammable or combustible } \\
\text { liquids (AFOSH STD 91-501, } \\
\text { para 22.3.1.6) [Citation Re- } \\
\text { vised December 2002]. }\end{array}$ & $\begin{array}{l}\text { Verify that PPE is available and appropriately worn when personnel handle flam- } \\
\text { mable or combustible liquids. }\end{array}$ \\
\hline
\end{tabular}




\begin{tabular}{|c|c|}
\hline & $\begin{array}{c}\text { COMPLIANCE CATEGORY: } \\
\text { HAZARDOUS MATERIALS MANAGEMENT } \\
\text { Overseas ESOHCAMP }\end{array}$ \\
\hline $\begin{array}{l}\text { REGULATORY } \\
\text { REQUIREMENTS: }\end{array}$ & $\begin{array}{l}\text { REVIEWER CHECKS: } \\
\text { September } 2009\end{array}$ \\
\hline $\begin{array}{l}\text { HM.100 } \\
\text { FLAMMABLE/ } \\
\text { COMBUSTIBLE } \\
\text { LIQUIDS: } \\
\text { Training }\end{array}$ & \\
\hline $\begin{array}{l}\text { HM.100.1.OCAF. Functional } \\
\text { managers and/or supervisors } \\
\text { must meet specific require- } \\
\text { ments with regard to training } \\
\text { of personnel (AFOSH STD } \\
\text { 91-501, para 22.3.1.4) [Re- } \\
\text { vised December 2002; Cita- } \\
\text { tion Revised December } \\
\text { 2002]. }\end{array}$ & $\begin{array}{l}\text { Verify that functional managers and/or supervisors: } \\
\text { - provide all workers and handlers of flammable or combustible liquids with } \\
\text { the appropriate level of training associated with tasks and associated hazards } \\
\text { related to the work environment } \\
\text { - ensure that personnel engaged in activities that involve the handling or use } \\
\text { of hazardous materials receive training per requirements of AFI 90-821, } \\
\text { Hazard Communication } \\
\text { - ensure that individuals involved in dispensing of flammable or combustible } \\
\text { liquids are instructed on the hazards of static electricity } \\
\text { - make sure that personnel who handle and store flammable or combustible } \\
\text { liquids are trained in fire prevention and protection as it relates to their par- } \\
\text { ticular duties. }\end{array}$ \\
\hline
\end{tabular}




\begin{tabular}{|c|c|}
\hline \multicolumn{2}{|r|}{$\begin{array}{c}\text { COMPLIANCE CATEGORY: } \\
\text { HAZARDOUS MATERIALS MANAGEMENT } \\
\text { Overseas ESOHCAMP }\end{array}$} \\
\hline $\begin{array}{l}\text { REGULATORY } \\
\text { REQUIREMENTS: }\end{array}$ & $\begin{array}{l}\text { REVIEWER CHECKS: } \\
\text { September } 2009\end{array}$ \\
\hline $\begin{array}{l}\text { HM.110 } \\
\text { FLAMMABLE/ } \\
\text { COMBUSTIBLE } \\
\text { LIQUIDS: } \\
\text { General Storage Require- } \\
\text { ments }\end{array}$ & \\
\hline $\begin{array}{l}\text { HM.110.1.OCAF. Flamma- } \\
\text { ble and combustible liquid } \\
\text { containers must meet specific } \\
\text { design and capacity standards } \\
\text { (AFOSH STD 91-501, para } \\
\text { 22.4.3.1) [Citation Revised } \\
\text { December 2002]. }\end{array}$ & $\begin{array}{l}\text { Verify that containers meet the design and capacity standards in Appendix 3-1. } \\
\text { (NOTE: Glass or plastic containers of no more than 1-gal capacity may be used } \\
\text { for Class IA or IB flammable liquids, if: } \\
\text { - such liquid would be rendered unfit for its intended use by contact with } \\
\text { metal or would excessively corrode a metal container so as to create a leak- } \\
\text { age, and } \\
\text { - the user's process would either require more than } 1 \text { pt of a Class IA liquid or } \\
\text { more than } 1 \text { qt of a Class IB liquid of a single assay lot to be used at one } \\
\text { time, or would require the maintenance of an analytical standard liquid of a } \\
\text { quantity which is not met by the specified standards of liquids available, and } \\
\text { the quantity of the analytical standard liquid required to be used in any one } \\
\text { control process exceeds } 1 / 16 \text { the capacity of the container allowed under } \\
\text { Appendix } 3-1 \text { for the class of liquid.) }\end{array}$ \\
\hline $\begin{array}{l}\text { HM.110.2.OCAF. Flamma- } \\
\text { ble/combustible materials that } \\
\text { are also water-reactive should } \\
\text { not be stored where fire pro- } \\
\text { tection sprinklers are in place } \\
\text { (MP). }\end{array}$ & $\begin{array}{l}\text { Verify that no flammable/combustible materials that are also water-reactive are } \\
\text { stored where fire protection sprinklers are in place. } \\
\text { (NOTE: This MP is suggested in AFOSH STD 91-501, para 22.4.1.3.) }\end{array}$ \\
\hline $\begin{array}{l}\text { HM.110.3.OCAF. Flamma- } \\
\text { ble/combustible liquids } \\
\text { should not be stored with ma- } \\
\text { terials that are water-reactive } \\
\text { (MP). }\end{array}$ & $\begin{array}{l}\text { Verify that no flammable/combustible liquids are stored with materials that are } \\
\text { water-reactive. } \\
\text { (NOTE: This MP is suggested in AFOSH STD 91-501, para 22.4.1.3.) }\end{array}$ \\
\hline $\begin{array}{l}\text { HM.110.4.OCAF. Storage of } \\
\text { flammable and combustible } \\
\text { liquids in office occupancies } \\
\text { is prohibited (AFOSH STD } \\
\text { 91-501, para 22.4.3.3) [Cita- } \\
\text { tion Revised December } \\
\text { 2002]. }\end{array}$ & $\begin{array}{l}\text { Verify that no flammable/combustible liquids are stored in office occupancies. } \\
\text { (NOTE: This prohibition does not apply to flammable/combustible liquids that are } \\
\text { required for maintenance and operation of building and operation of equipment.) } \\
\text { (NOTE: The term 'office occupancy' is not defined in AFOSH STD 91-501. } \\
\text { NFPA 30, to which the AFOSH STD frequently refers, defines the term as "A } \\
\text { building or structure or any portion thereof used for the transaction of business or } \\
\text { the rendering or receiving of services." This term is understood to include tents } \\
\text { and other covered areas that personnel regularly use as offices for the perform- }\end{array}$ \\
\hline
\end{tabular}




\begin{tabular}{|c|c|}
\hline \multicolumn{2}{|r|}{$\begin{array}{c}\text { COMPLIANCE CATEGORY: } \\
\text { HAZARDOUS MATERIALS MANAGEMENT } \\
\text { Overseas ESOHCAMP }\end{array}$} \\
\hline $\begin{array}{l}\text { REGULATORY } \\
\text { REQUIREMENTS: }\end{array}$ & $\begin{array}{l}\text { REVIEWER CHECKS: } \\
\text { September } 2009\end{array}$ \\
\hline $\begin{array}{l}\text { HM.110.5.OCAF. The stor- } \\
\text { age in office occupancies of } \\
\text { flammable/combustible liq- } \\
\text { uids required for maintenance } \\
\text { and operation of the building } \\
\text { and/or operation of equipment } \\
\text { must meet specific standards } \\
\text { (AFOSH STD 91-501, para } \\
\text { 22.4.3.3) [Citation Revised } \\
\text { December 2002]. }\end{array}$ & $\begin{array}{l}\text { ance of official duties.) } \\
\text { Verify that the liquids are stored in one of the following ways: } \\
\text { - in closed metal containers in a storage cabinet } \\
\text { - in a safety can } \\
\text { - in an inside storage room having no door that opens into that portion of the } \\
\text { building used by personnel. }\end{array}$ \\
\hline $\begin{array}{l}\text { HM.110.6.OCAF. [Deleted } \\
\text { February 1999]. }\end{array}$ & $\begin{array}{l}\text { This checklist item was deleted at the request of the sponsor as not primarily envi- } \\
\text { ronmental in nature. }\end{array}$ \\
\hline
\end{tabular}




\begin{tabular}{|c|c|}
\hline \multicolumn{2}{|r|}{$\begin{array}{c}\text { COMPLIANCE CATEGORY: } \\
\text { HAZARDOUS MATERIALS MANAGEMENT } \\
\text { Overseas ESOHCAMP }\end{array}$} \\
\hline $\begin{array}{l}\text { REGULATORY } \\
\text { REQUIREMENTS: }\end{array}$ & $\begin{array}{l}\text { REVIEWER CHECKS: } \\
\text { September } 2009\end{array}$ \\
\hline $\begin{array}{l}\text { HM.120 } \\
\text { FLAMMABLE/ } \\
\text { COMBUSTIBLE } \\
\text { LIQUIDS: } \\
\text { Storage Cabinets }\end{array}$ & \\
\hline $\begin{array}{l}\text { HM.120.1.OCAF. Flamma- } \\
\text { ble and combustible liquid } \\
\text { storage cabinets must meet } \\
\text { specific structural require- } \\
\text { ments (AFOSH STD 91-501, } \\
\text { paras 22.4.4 and 22.4.4.3) } \\
\text { [Revised December 2002; } \\
\text { Citation Revised December } \\
\text { 2002]. }\end{array}$ & $\begin{array}{l}\text { Verify that all flammable/combustible storage cabinets are listed/approved for the } \\
\text { specific class of storage. } \\
\text { Verify that flammable and combustible storage cabinets are designed and con- } \\
\text { structed to limit the internal temperature at the center of the cabinet and } 1 \text { in. }(2.5 \\
\mathrm{cm} \text { ) from the top of the cabinet to not more than } 325^{\circ} \mathrm{F}\left(162.8^{\circ} \mathrm{C}\right) \text {, when sub- } \\
\text { jected to a } 10 \text {-min fire test that simulates the fire exposure of the standard time- } \\
\text { temperature curve specified in NFPA } 251 \text {. } \\
\text { (NOTE: Listed cabinets that have been constructed and tested according to the } \\
\text { above requirements are acceptable.) }\end{array}$ \\
\hline $\begin{array}{l}\text { HM.120.2.OCAF. Flamma- } \\
\text { ble and combustible liquid } \\
\text { storage cabinets are subject to } \\
\text { specific limitations on their } \\
\text { contents (AFOSH STD 91- } \\
\text { 501, para 22.4.4) [Citation } \\
\text { Revised December 2002]. }\end{array}$ & $\begin{array}{l}\text { Verify that the following storage requirements are met: } \\
\text { - no more than } 120 \text { gal of Class I, Class II, and Class IIIA liquids are stored in } \\
\text { any cabinet } \\
\text { - the combined total of Class I and II liquids does not exceed } 60 \text { gal per cabi- } \\
\text { net. }\end{array}$ \\
\hline $\begin{array}{l}\text { HM.120.3.OCAF. [Deleted } \\
\text { July 2008]. }\end{array}$ & Deleted at the request of the sponsor. \\
\hline $\begin{array}{l}\text { HM.120.4.OCAF. No more } \\
\text { than three cabinets are permit- } \\
\text { ted in a single fire area } \\
\text { (AFOSH STD 91-501, para } \\
\text { 22.4.4) [Citation Revised De- } \\
\text { cember 2002]. }\end{array}$ & $\begin{array}{l}\text { Verify that no more than three cabinets (with contents of } 120 \text { gal or less) are lo- } \\
\text { cated in a single fire area. } \\
\text { (NOTE: This requirement does not apply to industrial areas.) } \\
\text { (NOTE: The limit of three cabinets in a single area may be increased where small } \\
\text { cabinets are used; however, the maximum amount of flammable storage cannot } \\
\text { exceed } 360 \text { gal.) } \\
\text { (NOTE: Additional cabinets may be located in the same fire area of an industrial } \\
\text { area if the additional cabinet, or group of not more than three } 120 \text {-gal cabinets, is } \\
\text { separated from other cabinets or group of cabinets by at least } 100 \mathrm{ft} \text {.) }\end{array}$ \\
\hline $\begin{array}{l}\text { HM.120.5.OCAF. Storage } \\
\text { cabinets for flamma- } \\
\text { bles/combustibles must meet } \\
\text { labelling } \quad \text { requirements }\end{array}$ & $\begin{array}{l}\text { Verify that cabinets are conspicuously labeled FLAMMABLE--KEEP FIRE } \\
\text { AWAY. } \\
\text { (NOTE: Additional guidance for marking storage containers is contained in }\end{array}$ \\
\hline
\end{tabular}




\section{COMPLIANCE CATEGORY: \\ HAZARDOUS MATERIALS MANAGEMENT \\ Overseas ESOHCAMP}

\begin{tabular}{|c|c|}
\hline $\begin{array}{l}\text { REGULATORY } \\
\text { REQUIREMENTS: }\end{array}$ & $\begin{array}{l}\text { REVIEWER CHECKS: } \\
\text { September } 2009\end{array}$ \\
\hline $\begin{array}{l}\text { (AFOSH STD 91-501, para } \\
\text { 22.4.4.1) [Citation Revised } \\
\text { December 2002]. }\end{array}$ & AFOSH STD 91-501, Chapter 20, Safety Color Coding, Labeling, and Marking.) \\
\hline $\begin{array}{l}\text { HM.120.6.OCAF. Storage } \\
\text { cabinets must meet venting } \\
\text { requirements (AFOSH STD }\end{array}$ & $\begin{array}{l}\text { (NOTE: Cabinets are not required to be vented for fire protection purposes; how- } \\
\text { ever, the following requirements do apply.) }\end{array}$ \\
\hline $\begin{array}{l}\text { 91-501, para 22.4.4.2) [Cita- } \\
\text { tion Revised December } \\
\text { 2002]. }\end{array}$ & $\begin{array}{l}\text { Verify that, if the cabinet is vented for any reason whatever, the cabinet inlet is } \\
\text { vented outdoors in a manner that will not compromise the specified performance } \\
\text { of the cabinet. } \\
\text { Verify that, if the cabinet is not vented, the vent opening is sealed with bungs sup- } \\
\text { plied with the cabinet or with bungs specified by the manufacturer of the cabinet. }\end{array}$ \\
\hline
\end{tabular}




\section{COMPLIANCE CATEGORY: \\ HAZARDOUS MATERIALS MANAGEMENT \\ Overseas ESOHCAMP}

\begin{tabular}{|l|}
\hline \multicolumn{1}{|c|}{ REGULATORY } \\
REQUIREMENTS: \\
\hline HM.130 \\
FLAMMABLE/ \\
COMBUSTIBLE \\
LIQUIDS: \\
Storage Inside Buildings \\
HM.130.1.OCAF. Specific \\
requirements must be met \\
when incidental storage of \\
flammable/combustible liq- \\
uids inside buildings is re- \\
quired (AFOSH STD 91-501, \\
paras 22.4.9, 22.4.9.1 through \\
22.4.9.3, 22.4.9.5, 22.4.9.7, \\
and paras 22.4.9.9 through \\
22.4.9.15) [Citation Revised \\
December 2002].
\end{tabular}

(NOTE: The requirements of this section apply both to storage buildings and to storage rooms inside buildings.)

Determine whether both of the following conditions are met:

- storage of flammable or combustible liquids inside a building is required

- such storage is incidental and not the primary purpose of the area.

Verify that the storage of flammable/combustible liquids does not physically obstruct a means of egress from the building or area.

Verify that flammable/combustible liquids are not so placed that a fire would prevent safe egress from the area.

Verify that containers are tightly sealed, except when the contents are being transferred, poured, or applied.

Verify that workers remove from the storage container only that portion of liquid required to accomplish a particular job.

Verify that leaking containers are removed to a safe location outside the building and that the contents are transferred to an undamaged container.

(NOTE: Flammable paints, oils, and varnishes in 1- to 5-gal containers, used for building maintenance purposes, may be stored temporarily in closed metal containers outside of approved storage cabinets or rooms, if kept at the job site for less than 10 calendar days.)

Verify that water-reactive materials are not stored in the same room with flammable/combustible liquids.

(NOTE: Small quantities may be stored in laboratories.)

Verify that the following requirements are met:

- if the storage building is $50 \mathrm{ft}$ or less from a building or line of adjoining property that may be built upon, the wall facing the building or property line is a blank wall with a fire-resistance rating of at least $2 \mathrm{~h}$

- any quantity of liquids may be stored as long as the storage arrangements outlined in Appendix 3-2 are met

- stacked containers are separated by pallets or dunnage when necessary to provide stability and prevent excess stress on container walls

- portable tanks stored over one tier high are designed to nest securely without 


\begin{tabular}{|c|c|}
\hline & $\begin{array}{c}\text { COMPLIANCE CATEGORY: } \\
\text { HAZARDOUS MATERIALS MANAGEMENT } \\
\text { Overseas ESOHCAMP }\end{array}$ \\
\hline $\begin{array}{l}\text { REGULATORY } \\
\text { REQUIREMENTS: }\end{array}$ & $\begin{array}{l}\text { REVIEWER CHECKS: } \\
\text { September } 2009\end{array}$ \\
\hline $\begin{array}{l}\text { HM.130.2.OCAF. The stor- } \\
\text { age of flammable/combustible } \\
\text { liquids in base supply ware- } \\
\text { houses is subject to specific } \\
\text { requirements (AFOSH STD } \\
\text { 91-501, para 22.4.9.8) [Added } \\
\text { December 2002]. }\end{array}$ & $\begin{array}{l}\text { dunnage } \\
\text { - adequate materials handling equipment is available to handle tanks safely at } \\
\text { the upper tier level } \\
\text { - no stack is closer than } 3 \mathrm{ft} \text { to the nearest beam, chord, girder, or other con- } \\
\text { struction member } \\
\text { - piles are } 3 \mathrm{ft} \text { below sprinkler deflectors or discharge points of water spray or } \\
\text { other fire protection system } \\
\text { - aisles are at least } 3 \mathrm{ft} \text { wide for access to all doors, windows, or standpipe } \\
\text { connections } \\
\text { - containers have clearly legible labels that identify contents and indicate haz- } \\
\text { ards. } \\
\text { Verify that the storage of of flammable/combustible liquids in base supply ware- } \\
\text { houses meets the requirements of Appendix 3-2, Indoor Container Storage. } \\
\text { Verify that buildings or portions of such buildings utilized for flammable/ com- } \\
\text { bustible storage are isolated by standard fire walls approved for the type and } \\
\text { quantity of liquids being stored. } \\
\text { (NOTE: Materials that create no fire hazard may be stored in the same area.) }\end{array}$ \\
\hline
\end{tabular}




\begin{tabular}{|c|c|}
\hline & $\begin{array}{c}\text { COMPLIANCE CATEGORY: } \\
\text { HAZARDOUS MATERIALS MANAGEMENT } \\
\text { Overseas ESOHCAMP }\end{array}$ \\
\hline $\begin{array}{l}\text { REGULATORY } \\
\text { REQUIREMENTS: }\end{array}$ & $\begin{array}{l}\text { REVIEWER CHECKS: } \\
\text { September } 2009\end{array}$ \\
\hline $\begin{array}{l}\text { HM.140 } \\
\text { FLAMMABLE/ } \\
\text { COMBUSTIBLE } \\
\text { LIQUIDS: } \\
\text { Storage Rooms } \\
\text { HM.140.1.OCAF. Indoor } \\
\text { flammable/combustible stor- } \\
\text { age rooms must meet specific } \\
\text { standards (AFOSH STD 91- } \\
\text { 501, para 22.4.5.1, 22.4.6.1, } \\
\text { 22.4.8) [Citation Revised De- } \\
\text { cember 2002]. }\end{array}$ & $\begin{array}{l}\text { Verify that the installation's flammable/combustible inside storage rooms have: } \\
\text { - walls that meet the specifications of NFPA Standard } 251 \text { and have the fire- } \\
\text { resistive rating for their use } \\
\text { - liquid tight joints where the walls join the floor } \\
\text { - self-closing fire doors (NFPA 80). } \\
\text { Verify that the storage room does not open into any portion of a building that is } \\
\text { used by the public. } \\
\text { Verify that openings to other rooms or buildings have noncombustible liquid-tight } \\
\text { raised sills or ramps at least } 4 \text { in. in height or that the floor of the storage area is at } \\
\text { least } 4 \text { in. lower than the surrounding floors. } \\
\text { Verify that, if a sill or ramp is not present, the room has an open grated trench that } \\
\text { drains to a safe area. } \\
\text { Verify that wooden shelving, racks, dunnage, scuffboards, and floor overlay are at } \\
\text { least } 1 \text {-in. thick. } \\
\text { Verify that, where other portions of the building or other properties are exposed, } \\
\text { windows are protected as required by NFPA Standard } 80 \text {. } \\
\text { Verify that electrical wiring and equipment located in inside storage rooms used } \\
\text { for the storage of Class I liquids are suitable for Class } 1 \text {, Division } 1 \text { hazardous } \\
\text { (classified) locations. } \\
\text { Verify that electrical wiring and equipment in inside storage rooms used for the } \\
\text { storage of Class II and Class III liquids only is suitable for general purpose use } \\
\text { (see NFPA Standard } 70 \text { ). } \\
\text { Verify that dispensing of other than Class I flammable liquids is done by an ap- } \\
\text { proved pump or self-closing faucet. } \\
\text { Verify that storage in the rooms meets the requirements in Appendix } 3-3 \text {. } \\
\text { Verify that containers of over } 30 \text {-gal capacity are not stacked one upon the other. }\end{array}$ \\
\hline $\begin{array}{l}\text { HM.140.2.OCAF. Inside } \\
\text { rooms for the storage of }\end{array}$ & $\begin{array}{l}\text { Verify that at least one portable fire extinguisher having a rating of not less than } \\
40-\mathrm{B} \text { is located outside of but not more than } 10 \mathrm{ft} \text { from the door opening into an }\end{array}$ \\
\hline
\end{tabular}




\section{COMPLIANCE CATEGORY: \\ HAZARDOUS MATERIALS MANAGEMENT \\ Overseas ESOHCAMP}

\begin{tabular}{|c|c|}
\hline $\begin{array}{l}\text { REGULATORY } \\
\text { REQUIREMENTS: }\end{array}$ & $\begin{array}{l}\text { REVIEWER CHECKS: } \\
\text { September } 2009\end{array}$ \\
\hline $\begin{array}{l}\text { flammable/combustible liq- } \\
\text { uids must meet fire protection } \\
\text { standards (AFOSH STD 91- } \\
\text { 501, paras 22.4.8.1, 22.4.8.2, } \\
\text { 22.4.8.3, and 22.4.9.6) [Re- } \\
\text { vised December 2002; Cita- } \\
\text { tion Revised December } \\
\text { 2002]. }\end{array}$ & $\begin{array}{l}\text { inside liquid storage area. } \\
\text { Verify that at least one portable fire extinguisher rated not less than } 40 \text {-BC is lo- } \\
\text { cated within } 30 \mathrm{ft} \text { of any Class I or Class II liquid storage area outside of a storage } \\
\text { room, but inside a building. } \\
\text { Verify that at least one portable fire extinguisher having a rating of } 12-\mathrm{B} \text { units is } \\
\text { located outside of but not more than } 10 \mathrm{ft} \text { from the door opening into any room } \\
\text { used for storage of flammable/combustible liquids. } \\
\text { Verify that installed fire suppression systems are approved per requirements in } \\
\text { Military Handbook 1008, Fire Protection for Facilities, Engineering, Design, } \\
\text { Construction. } \\
\text { (NOTE: See AFOSH STD 91-501, Chapter 6, Fire Protection, for guidance. In } \\
\text { addition, consult the installation fire department.) }\end{array}$ \\
\hline $\begin{array}{l}\text { HM.140.3.OCAF. Class I } \\
\text { liquids must not be stored or } \\
\text { handled within a building that } \\
\text { has a basement or pit through } \\
\text { which flammable vapors can } \\
\text { travel (AFOSH STD 91-501, } \\
\text { para 22.4.5.2) [Citation Re- } \\
\text { vised December 2002]. }\end{array}$ & $\begin{array}{l}\text { Verify that no Class I liquid is stored or handled within a building that has a base- } \\
\text { ment or pit through which flammable vapors can travel. } \\
\text { (NOTE: This prohibition does not apply if the basement or pit is provided with } \\
\text { ventilation that will prevent the accumulation of flammable vapors.) }\end{array}$ \\
\hline $\begin{array}{l}\text { HM.140.4.OCAF. Transfer } \\
\text { of flammable liquids from one } \\
\text { container to another must be } \\
\text { carried out only when the } \\
\text { containers are electrically } \\
\text { interconnected (AFOSH STD } \\
\text { 91-501, para 22.4.6.2) [Cita- } \\
\text { tion Revised December } \\
\text { 2002]. }\end{array}$ & $\begin{array}{l}\text { Verify that transfer of flammable liquids from one container to another is carried } \\
\text { out only when the containers are electrically interconnected (bonded). } \\
\text { (NOTE: When flammables are not being transferred from one container to an- } \\
\text { other, there is no requirement to have the containers bonded.) }\end{array}$ \\
\hline
\end{tabular}




\begin{tabular}{|c|c|}
\hline & $\begin{array}{c}\text { COMPLIANCE CATEGORY: } \\
\text { HAZARDOUS MATERIALS MANAGEMENT } \\
\text { Overseas ESOHCAMP }\end{array}$ \\
\hline $\begin{array}{l}\text { REGULATORY } \\
\text { REQUIREMENTS: }\end{array}$ & $\begin{array}{l}\text { REVIEWER CHECKS: } \\
\text { September } 2009\end{array}$ \\
\hline $\begin{array}{l}\text { HM.150 } \\
\text { FLAMMABLE/ } \\
\text { COMBUSTIBLE } \\
\text { LIQUIDS: } \\
\text { Storage Buildings }\end{array}$ & \\
\hline $\begin{array}{l}\text { HM.150.1.OCAF. Flamma- } \\
\text { ble and combustible liquid } \\
\text { storage buildings must meet } \\
\text { specific structural require- } \\
\text { ments (AFOSH STD 91-501, } \\
\text { para 22.4.9.4) [Revised De- } \\
\text { cember 2002; Citation Re- } \\
\text { vised December 2002]. }\end{array}$ & $\begin{array}{l}\text { Verify that flammable/combustible storage buildings are one story and devoted } \\
\text { principally to the handling and storing of flammable or combustible liquids. } \\
\text { Verify that such buildings have 2-h fire-rated exterior walls with no openings } \\
\text { within } 10 \mathrm{ft} \text { of the stored material. }\end{array}$ \\
\hline $\begin{array}{l}\text { HM.150.2.OCAF. [Deleted } \\
\text { July 2008]. }\end{array}$ & Deleted at the request of the sponsor. \\
\hline $\begin{array}{l}\text { HM.150.3.OCAF. [Deleted } \\
\text { February 1999]. }\end{array}$ & $\begin{array}{l}\text { This checklist item was deleted at the request of the sponsor as not primarily envi- } \\
\text { ronmental in nature. }\end{array}$ \\
\hline $\begin{array}{l}\text { HM.150.4.OCAF. Facility } \\
\text { pre-fire plans must be devel- } \\
\text { oped for flammable and com- } \\
\text { bustible liquid warehouses } \\
\text { and storage buildings } \\
\text { (AFOSH STD 91-501, para } \\
\text { 22.4.2) [Revised December } \\
\text { 2002; Citation Revised De- } \\
\text { cember 2002]. }\end{array}$ & $\begin{array}{l}\text { Verify that facility pre-fire plans have been developed for flammable and combus- } \\
\text { tible liquid warehouses, laboratories, and storage buildings. } \\
\text { Verify that the plans include the hazardous materials contained in installation fa- } \\
\text { cilities, their location, and emergency procedures to be followed. } \\
\text { Verify that the plans are maintained in the fire department communications center } \\
\text { and on vehicles designated by the fire chief. }\end{array}$ \\
\hline
\end{tabular}




\section{COMPLIANCE CATEGORY: \\ HAZARDOUS MATERIALS MANAGEMENT \\ Overseas ESOHCAMP}

\begin{tabular}{|l|}
\multicolumn{1}{|c|}{ REGULATORY } \\
REQUIREMENTS: \\
\hline HM.160 \\
FLAMMABLE/ \\
COMBUSTIBLE \\
LIQUIDS: \\
Ventilation in Dispensing \\
Areas \\
HM.160.1.OCAF. Liquid \\
storage areas where dispens- \\
ing is conducted must be pro- \\
vided with either a gravity or \\
continuous mechanical ex- \\
haust ventilation system \\
(AFOSH STD 91-501, para \\
22.4.7) [Citation Revised De- \\
cember 2002]. \\
HM.160.2.OCAF. Specific \\
criteria must be met in areas \\
where flammable/combustible \\
liquids in quantities greater \\
than 5 gal are transferred si- \\
multaneously (AFOSH STD \\
91-501, para 22.4.7) [Revised \\
December 2002; Citation Re- \\
vised December 2002]. \\
\end{tabular}

(NOTE: The requirements of this section apply to dispensing areas in both storage buildings and storage rooms inside buildings.)

Determine whether dispensing is conducted in the liquid storage area.

Verify that the area has either a gravity or continuous mechanical exhaust ventilation system.

Determine whether flammable/combustible liquids are transferred simultaneously from one container to another container or tank in quantities greater than 5 gal.

Verify that such simultaneous transfer operations are separated one from the other by $25 \mathrm{ft}$ or by construction having a fire resistance of at least $1 \mathrm{~h}$.

Verify that drainage or other means is provided to control spills.

Verify that natural or mechanical ventilation is provided that is adequate to maintain the concentration of flammable vapors at or below 10 percent, or 2 percent of the Lower Explosive Limit, of the flammable liquid.

Verify that mechanical ventilation is used if Class I liquids are dispensed within a room.

HM.160.3.OCAF. Specific criteria must be met with regard to exhaust air (AFOSH STD 91-501, para 22.4.7.1) [Citation Revised December 2002].

HM.160.4.OCAF. Mechanical ventilation systems must meet specific requirements

Verify that exhaust air is taken from a point near the wall on one side of the room and within $1 \mathrm{ft}$ of the floor, with one or more make-up inlets located on the opposite side of the room within $1 \mathrm{ft}$ of the floor.

Verify that both the exhaust and inlet air openings are located to provide air movement across all portions of the floor to prevent accumulation of flammable vapors.

Verify that air is exhausted from the room directly to the exterior of the building without recirculation.

Verify that mechanical ventilation systems provide for a complete change of air within the room at least six times per hour. 


\section{COMPLIANCE CATEGORY: \\ HAZARDOUS MATERIALS MANAGEMENT \\ Overseas ESOHCAMP}

\begin{tabular}{|c|c|}
\hline $\begin{array}{l}\text { REGULATORY } \\
\text { REQUIREMENTS: }\end{array}$ & $\begin{array}{l}\text { REVIEWER CHECKS: } \\
\text { September } 2009\end{array}$ \\
\hline $\begin{array}{l}\text { (AFOSH STD 91-501, para } \\
\text { 22.4.7.2) [Citation Revised } \\
\text { December 2002]. }\end{array}$ & $\begin{array}{l}\text { Verify that, if a mechanical exhausting system is used, it is controlled by a switch } \\
\text { located outside the door. } \\
\text { Verify that the ventilating equipment and any lighting fixtures are operated by the } \\
\text { same switch. } \\
\text { Verify that an electric pilot light is adjacent to the switch if flammable liquids are } \\
\text { dispensed within the room. } \\
\text { Verify that the mechanical ventilation system for dispensing areas is equipped } \\
\text { with an air flow switch or equally reliable method that is interlocked to sound an } \\
\text { audible alarm upon failure of the ventilation system. }\end{array}$ \\
\hline $\begin{array}{l}\text { HM.160.5.OCAF. Exhaust } \\
\text { and lighting systems must } \\
\text { meet specific requirements } \\
\text { (AFOSH STD 91-501, para } \\
\text { 22.4.7.3) [Citation Revised } \\
\text { December 2002]. }\end{array}$ & $\begin{array}{l}\text { Verify that exhaust and lighting system controls are located outside the door. } \\
\text { Verify that a single switch controls both the lights and the ventilation system. } \\
\text { Verify that the switch is illuminated. }\end{array}$ \\
\hline $\begin{array}{l}\text { HM.160.6.OCAF. Ventila- } \\
\text { tion ducts and air flow re- } \\
\text { quirements are in compliance } \\
\text { with specific standards } \\
\text { (AFOSH STD 91-501, para } \\
\text { 22.4.7.4) [Revised December } \\
\text { 2002; Citation Revised De- } \\
\text { cember 2002]. }\end{array}$ & $\begin{array}{l}\text { Verify that ventilation ducts and air flow requirements comply with AFOSH STD } \\
\text { 48-2, Industrial Ventilation, and NFPA 91, Standard for Exhaust Systems for Air } \\
\text { Conveying of Materials. } \\
\text { [Author's Note: As of May 2003, AFOSH STD } 48-2 \text { had not been published.] }\end{array}$ \\
\hline
\end{tabular}




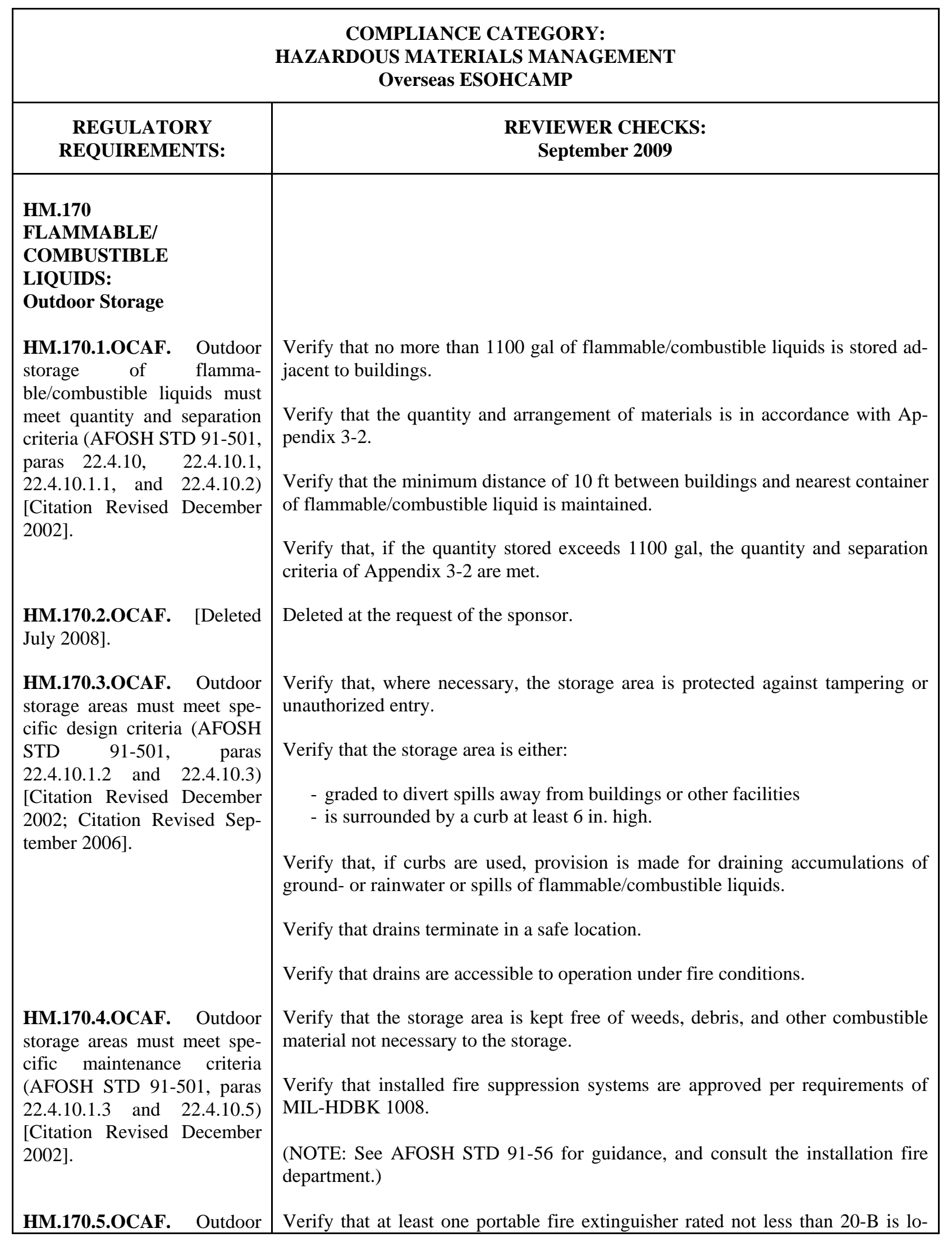




\section{COMPLIANCE CATEGORY: \\ HAZARDOUS MATERIALS MANAGEMENT \\ Overseas ESOHCAMP}

\begin{tabular}{|c|c|}
\hline $\begin{array}{l}\text { REGULATORY } \\
\text { REQUIREMENTS: }\end{array}$ & $\begin{array}{l}\text { REVIEWER CHECKS: } \\
\text { September } 2009\end{array}$ \\
\hline $\begin{array}{l}\text { storage areas must meet spe- } \\
\text { cific operational criteria } \\
\text { (AFOSH STD 91-501, paras } \\
\text { 22.4.10.4, 22.4.10.6, and } \\
\text { 22.4.10.7) [Citation Revised } \\
\text { December 2002]. }\end{array}$ & $\begin{array}{l}\text { cated not less than } 10 \mathrm{ft} \text { nor more than } 25 \mathrm{ft} \text { from any Class I or Class II liquid } \\
\text { storage area outside of a storage room. } \\
\text { Verify that containers and portable tanks used for Class I liquids are electrically } \\
\text { grounded and bonded during liquid transfer. } \\
\text { Verify that positive measures are taken to eliminate the following: } \\
\text { - any source of ignition } \\
\text { - open flames } \\
\text { - electrical ignition sources } \\
\text { - smoking } \\
\text { - cutting and welding } \\
\text { - hot surfaces } \\
\text { - static or mechanical sparks } \\
\text { - radiant heat } \\
\text { - spontaneous ignition sources. } \\
\text { Verify that all containers of flammable/combustible materials are protected from } \\
\text { heat sources. } \\
\text { Verify that no open flames or smoking is permitted within } 50 \mathrm{ft} \text { of flammable/ } \\
\text { combustible liquid storage areas. }\end{array}$ \\
\hline
\end{tabular}




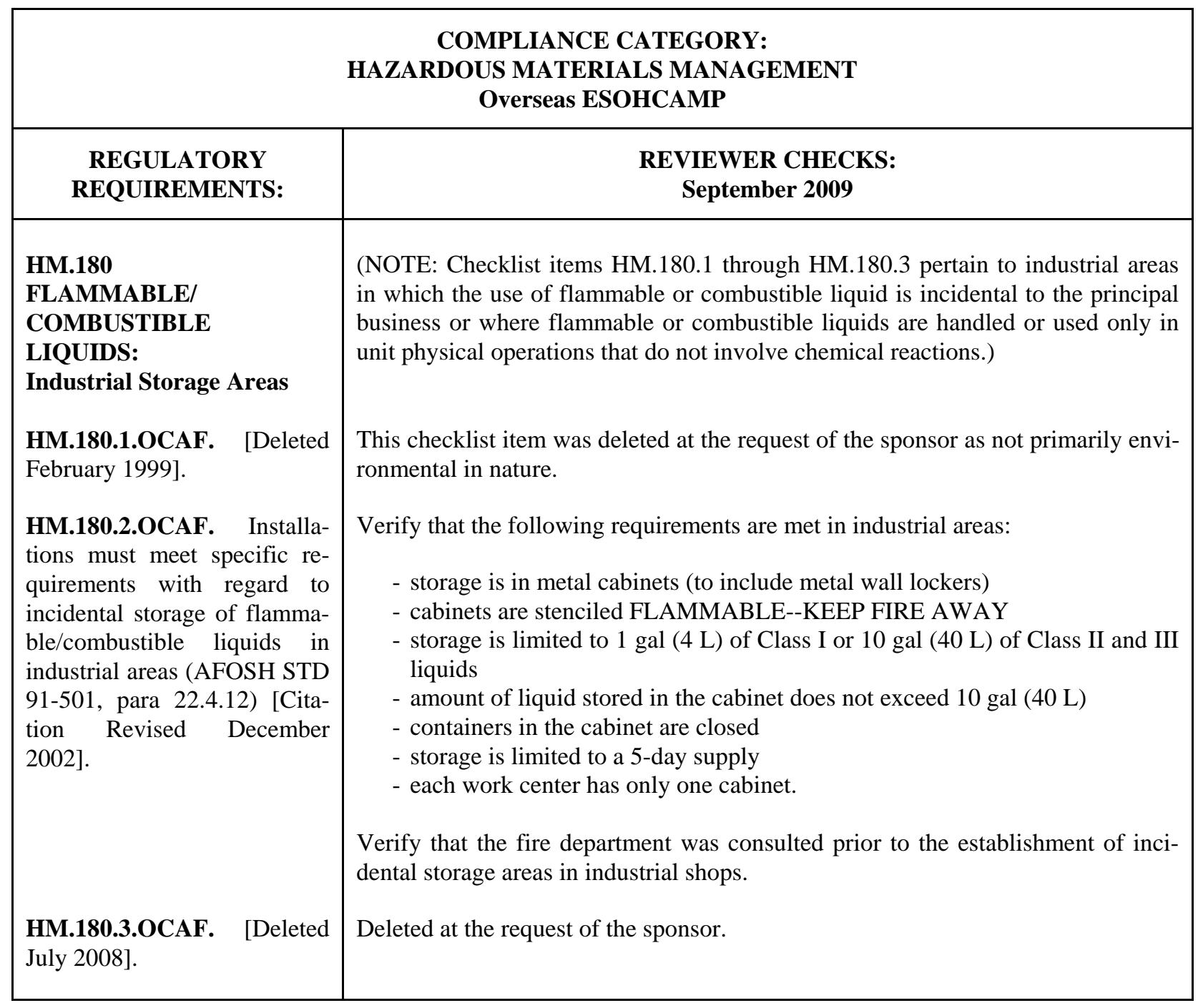




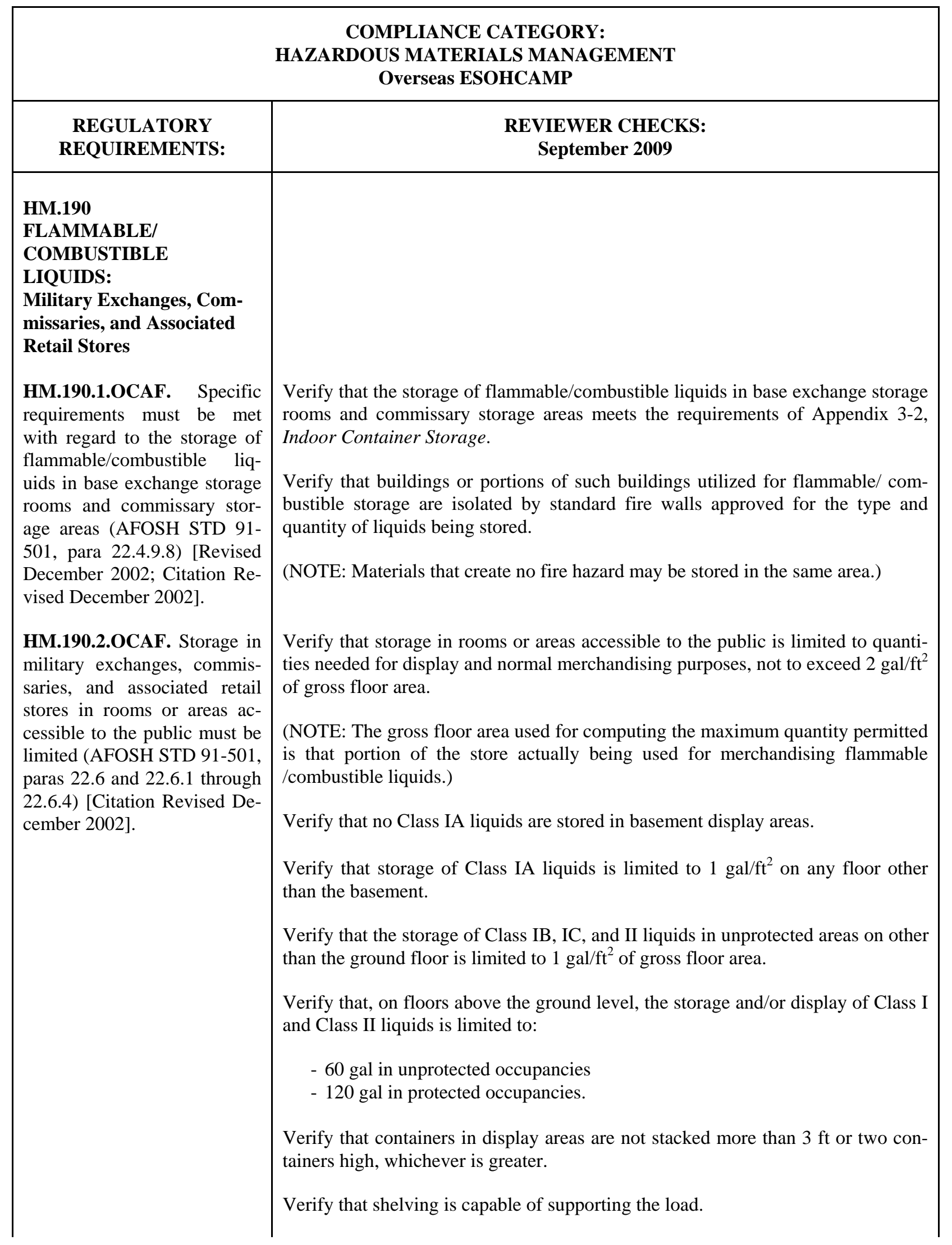




\section{COMPLIANCE CATEGORY: \\ HAZARDOUS MATERIALS MANAGEMENT \\ Overseas ESOHCAMP}

\begin{tabular}{c}
\hline REGULATORY \\
REQUIREMENTS:
\end{tabular}

HM.190.3.OCAF. Leaking containers in military exchanges, commissaries, and associated retail stores must be handled in accordance with specific requirements (AFOSH STD 91-501, para 22.6.5) [Citation Revised December 2002].

HM.190.4.OCAF. Storage of flammable/combustible liquids indoors in military exchanges, commissaries, and associated retail stores must meet specific requirements (AFOSH STD 91-501, paras 22.6.6 and 22.6.8 through 22.6.12) [Revised December 2002; Citation Revised December 2002].

HM.190.5.OCAF. [Deleted February 1999].

HM.190.6.OCAF. For military exchanges, commissaries, and associated retail stores, storage buildings located $50 \mathrm{ft}$

\section{REVIEWER CHECKS: September 2009}

Verify that containers on the shelves are arranged so that they are not easily knocked off the shelves to the floor.

Verify that leaking containers are removed to a safe location outside the building.

Verify that the contents of leaking containers are transferred to undamaged containers and appropriately labeled.

Verify that the leaking container is disposed of in a safe manner.

Verify that the indoor storage of containers meets the requirements of Appendix 3-2.

Verify that buildings or portions of such buildings utilized for flammable/ combustible storage are isolated by standard fire walls approved for the type and quantity of liquids being stored.

(NOTE: The total quantity of liquids within the building is not restricted.)

(NOTE: Materials that create no fire hazard to the liquids may be stored in the same area.)

Verify that stacked containers of flammable liquids are separated by pallets or dunnage, where necessary, to provide stability and prevent excessive stress on container walls.

Verify that no stack is closer than $3 \mathrm{ft}[0.9 \mathrm{~m}]$ to the nearest beam, chord, girder, or other construction object.

Verify that every stack is at least $3 \mathrm{ft}[0.9 \mathrm{~m}]$ below sprinkler deflectors or discharge orifices of water spray or other installed fire protection systems.

Verify that aisles at least $3 \mathrm{ft}[0.9 \mathrm{~m}]$ in width are provided for access to doors, windows, or fire department connections.

Verify that containers bear clearly legible labels that identify contents and indicate hazards.

This checklist item was deleted at the request of the sponsor as not primarily environmental in nature.

Determine whether the storage building is $50 \mathrm{ft}$ or less from another building or a property line that may be built upon.

Verify that the wall facing the building or property line is a blank wall with a fire- 


\begin{tabular}{|l|c|}
\hline \multicolumn{2}{|c|}{$\begin{array}{c}\text { COMPLIANCE CATEGORY: } \\
\text { HAZARDOUS MATERIALS MANAGEMENT } \\
\text { Overseas ESOHCAMP }\end{array}$} \\
\hline $\begin{array}{c}\text { REGULATORY } \\
\text { REQUIREMENTS: }\end{array}$ & $\begin{array}{c}\text { REVIEWER CHECKS: } \\
\text { September 2009 }\end{array}$ \\
\hline $\begin{array}{l}\text { or less from buildings or adja- } \\
\text { cent property lines that may } \\
\text { be built upon must meet fire } \\
\text { protection requirements } \\
\text { (AFOSH STD 91-501, para } \\
\text { 22.6.7) [Citation Revised De- } \\
\text { cember 2002]. }\end{array}$ & \\
\hline
\end{tabular}




\section{COMPLIANCE CATEGORY: \\ HAZARDOUS MATERIALS MANAGEMENT \\ Overseas ESOHCAMP}

\begin{tabular}{|c|c|}
\hline $\begin{array}{l}\text { REGULATORY } \\
\text { REQUIREMENTS: }\end{array}$ & $\begin{array}{l}\text { REVIEWER CHECKS: } \\
\text { September } 2009\end{array}$ \\
\hline $\begin{array}{l}\text { HM. } 200 \\
\text { FLAMMABLE/ } \\
\text { COMBUSTIBLE } \\
\text { LIQUIDS: } \\
\text { Laboratories }\end{array}$ & $\begin{array}{l}\text { (NOTE: The requirements of this section apply to general laboratories and health- } \\
\text { related laboratories [see definitions].) }\end{array}$ \\
\hline $\begin{array}{l}\text { HM.200.1.OCAF. Facility } \\
\text { pre-fire plans must be devel- } \\
\text { oped for laboratory buildings } \\
\text { (AFOSH STD 91-501, para } \\
\text { 22.4.2) [Citation Revised De- } \\
\text { cember 2002]. }\end{array}$ & $\begin{array}{l}\text { Verify that facility pre-fire plans have been developed for laboratory buildings. } \\
\text { Verify that the plans include the hazardous materials contained in installation fa- } \\
\text { cilities, their location, and emergency procedures to be followed. } \\
\text { Verify that the plans are maintained in the fire department communications center } \\
\text { and on vehicles designated by the fire chief. }\end{array}$ \\
\hline $\begin{array}{l}\text { HM.200.2.0CAF. [Deleted } \\
\text { February 1999]. }\end{array}$ & $\begin{array}{l}\text { This checklist item was deleted at the request of the sponsor as not primarily envi- } \\
\text { ronmental in nature. }\end{array}$ \\
\hline $\begin{array}{l}\text { HM.200.3.OCAF. A list of } \\
\text { working supplies and operat- } \\
\text { ing instructions on the han- } \\
\text { dling of flamma- } \\
\text { ble/combustible liquids must } \\
\text { be published (AFOSH STD } \\
\text { 91-501, para 22.5.1.2) [Cita- } \\
\text { tion Revised December } \\
\text { 2002]. }\end{array}$ & $\begin{array}{l}\text { Verify that the laboratory has a list of working supplies. } \\
\text { Verify that the laboratory has written operating instructions on the handling of } \\
\text { flammable/combustible liquids. }\end{array}$ \\
\hline $\begin{array}{l}\text { HM.200.4.OCAF. Laborato- } \\
\text { ries must store flammable } \\
\text { /combustible liquids in accor- } \\
\text { dance with specific require- } \\
\text { ments (AFOSH STD 91-501, } \\
\text { para 22.5.1.2 and 22.5.1.3) } \\
\text { [Revised December 2002; } \\
\text { Citation Revised December } \\
\text { 2002]. }\end{array}$ & $\begin{array}{l}\text { Verify that the aggregate total of flammable/combustible liquids outside of stor- } \\
\text { age cabinets does not exceed } 10 \text { gal in any laboratory. } \\
\text { Verify that all quantities of flammable/combustible liquids in excess of } 10 \text { gal in } \\
\text { any laboratory are stored in an approved storage cabinet or in an approved storage } \\
\text { room. } \\
\text { Verify that flammable/combustible liquids are not stored in any exit way, corri- } \\
\text { dor, or passageway leading to an exit. } \\
\text { Determine whether the laboratory regularly maintains a reserve storage capacity } \\
\text { in excess of } 300 \text { gal. } \\
\text { Verify that any building housing such a laboratory has a minimum of one ap- } \\
\text { proved storage room. } \\
\text { Verify that refrigerators or cooling equipment used to store or cool flammable } \\
\text { liquids are of a type approved for the material being stored or cooled. }\end{array}$ \\
\hline
\end{tabular}




\section{COMPLIANCE CATEGORY: \\ HAZARDOUS MATERIALS MANAGEMENT \\ Overseas ESOHCAMP}

\begin{tabular}{|l|}
\hline REGULATORY \\
REQUIREMENTS: \\
\hline \\
\\
\\
HM.200.5.OCAF. Laborato- \\
ries must handle flamma- \\
ble/combustible liquids in \\
accordance with specific re- \\
quirements (AFOSH STD 91- \\
501, paras 22.5.1.2 through \\
22.5.1.4) [Citation Revised \\
December 2002].
\end{tabular}

HM.200.6.OCAF. Laboratories must meet fire protection standards (AFOSH STD 91501, para 22.5.2) [Citation Revised December 2002].

HM.200.7.OCAF. Laboratories must dispose of flammable/combustible liquids in accordance with specific criteria (AFOSH STD 22.5.3) [Citation Revised December 2002].

\section{REVIEWER CHECKS: September 2009}

Verify that refrigerators or cooling equipment are labeled or stenciled:

\section{APPROVED FOR FLAMMABLE LIQUID STORAGE.}

(NOTE: See Appendix A to NFPA 45 for additional details.)

Verify that flammable/combustible liquids are not transferred from one vessel to another in any exit way, corridor, or passageway leading to an exit.

Verify that flammable/combustible liquids are not brought into a laboratory, receiving area, storage area, or storage facility unless adequately approved design, construction, and fire protection requirements are suitable for the hazard and quantity involved.

Verify that container types and maximum contents comply with the requirements of Appendix 3-4.

Verify that, if plastic containers are used, such containers are approved for the liquids they contain.

Verify that containers used to draw from an original container are marked to identify their contents.

Verify that neither flammable nor combustible liquids are positioned near Bunsen burners, hot surfaces, steam pipes, valves, or other sources of heat.

Verify that laboratories have fire protection appropriate for their fire hazard classification.

Verify that fire protection includes, as a minimum, the following:

- portable fire extinguishers

- an alarm system

- an evacuation and emergency plan.

(NOTE: NFPA 45 contains additional details on fire hazard classifications and fire protection requirements.)

Verify that the laboratory staff contact the installation environmental coordinator in Civil Engineering for assistance in disposal.

(NOTE: Hazardous materials are normally removed and disposed of by a commercial disposal specialist, who must comply with published environmental regulations.) 


\section{COMPLIANCE CATEGORY: \\ HAZARDOUS MATERIALS MANAGEMENT \\ Overseas ESOHCAMP}

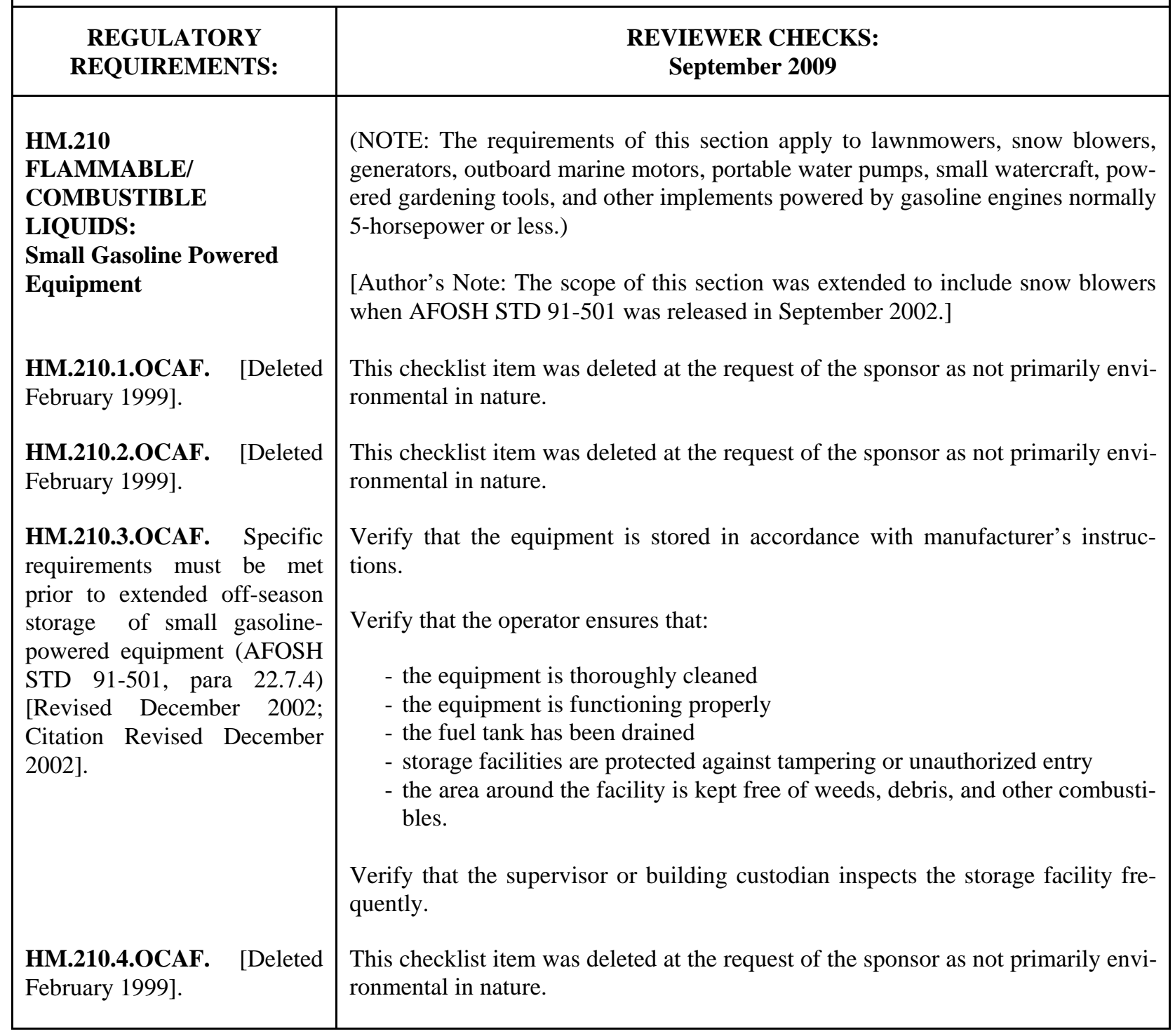




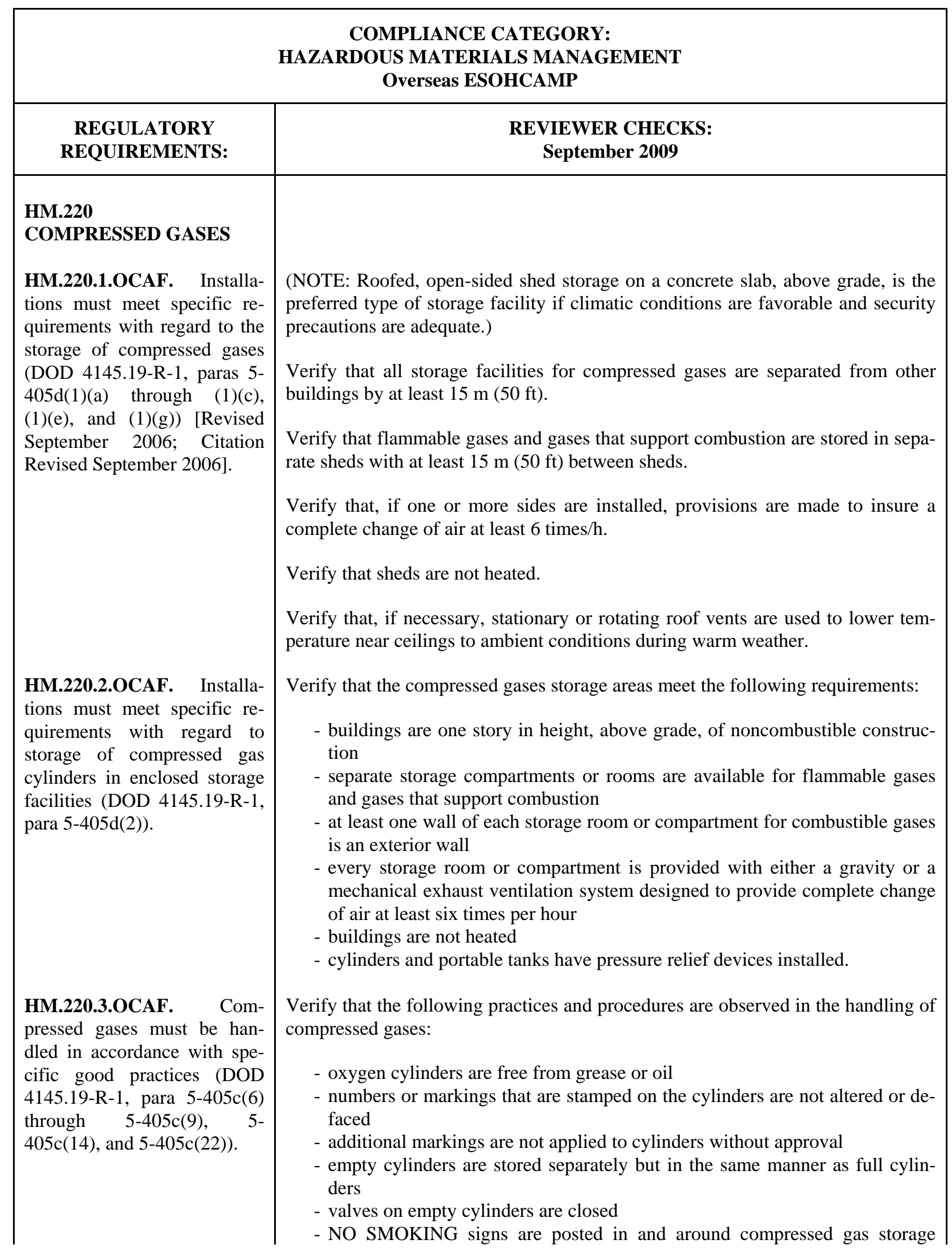




\begin{tabular}{|c|c|}
\hline \multicolumn{2}{|c|}{$\begin{array}{c}\text { COMPLIANCE CATEGORY: } \\
\text { HAZARDOUS MATERIALS MANAGEMENT } \\
\text { Overseas ESOHCAMP }\end{array}$} \\
\hline $\begin{array}{c}\text { REGULATORY } \\
\text { REQUIREMENTS: }\end{array}$ & $\begin{array}{c}\text { September 2009 } \\
\text { REVWER CHECKS: }\end{array}$ \\
\hline $\begin{array}{l}\text { HM.220.4.OCAF. Com- } \\
\text { pressed gas storage sheds } \\
\text { should be constructed of light, } \\
\text { noncombustible materials } \\
\text { (MP) [Added September } \\
\text { 2006]. }\end{array}$ & $\begin{array}{l}\text { Verify that compressed gas storage sheds are constructed of light, noncombustible } \\
\text { materials. } \\
\text { (NOTE: This MP is found at DOD 4145.19-R-1, para 5-405d(1)(d).) }\end{array}$ \\
\hline
\end{tabular}




\begin{tabular}{|c|c|}
\hline & $\begin{array}{c}\text { COMPLIANCE CATEGORY: } \\
\text { HAZARDOUS MATERIALS MANAGEMENT } \\
\text { Overseas ESOHCAMP }\end{array}$ \\
\hline $\begin{array}{l}\text { REGULATORY } \\
\text { REQUIREMENTS: }\end{array}$ & $\begin{array}{l}\text { REVIEWER CHECKS: } \\
\text { September } 2009\end{array}$ \\
\hline $\begin{array}{l}\text { HM.230 } \\
\text { ACID STORAGE } \\
\text { HM.230.1.OCAF. Installa- } \\
\text { tions must meet specific re- } \\
\text { quirements with regard to the } \\
\text { storage and handling of acids } \\
\text { in bulk (DOD 4145.19-R-1, } \\
\text { para 5-406). }\end{array}$ & $\begin{array}{l}\text { Verify that the bulk acid storage areas meet the following: } \\
\text { - buildings are one story in height, of noncombustible or fire-resistant con- } \\
\text { struction } \\
\text { - permanent louvered openings at floor and ceiling levels or other gravity ven- } \\
\text { tilation methods are provided } \\
\text { - safety equipment is available and operational (eye wash, deluge shower, } \\
\text { self-contained breathing apparatus, protective clothing) } \\
\text { - buildings are heated to prevent freezing (if applicable) } \\
\text { - different acids are stored separately in designated areas } \\
\text { - NO SMOKING signs are posted } \\
\text { - there are either floor drains or wall scuppers, if the building has automatic } \\
\text { - sprinkler protection. } \\
\text { (NOTE: Acid storage buildings should have automatic sprinkler protection.) } \\
\text { (NOTE: In lieu of aisle space, noncombustible barriers that are at least 3-ft high } \\
\text { and sealed at floor level may be used to obtain maximum storage space.) }\end{array}$ \\
\hline
\end{tabular}




\section{Appendix 3-1}

\section{Maximum Allowable Size of Containers and Portable Tanks}

(AFOSH STD 91-501, Table 22.1)

\begin{tabular}{|l|c|c|c|c|c|}
\hline \multicolumn{1}{|c|}{ Container Type } & \multicolumn{3}{c|}{ Flammable Liquids } & \multicolumn{2}{c|}{ Combustible Liquids } \\
\hline & $I A$ & $I B$ & $I C$ & $I I$ & $I I$ \\
\hline \hline Glass or approved plastic $^{1}$ & $1 \mathrm{pt}$ & $1 \mathrm{qt}$ & $1^{3}$ & 1 & 1 \\
\hline $\begin{array}{l}\text { Metal (other than Department of } \\
\text { Transportation [DOT] drums) }\end{array}$ & 1 & 5 & 5 & 5 & 5 \\
\hline Safety cans & 2 & 5 & 5 & 5 & 5 \\
\hline Metal drums (DOT specifications) & 60 & 60 & 60 & 60 & 60 \\
\hline Approved portable tanks & 660 & 660 & 660 & 660 & 660 \\
\hline $\begin{array}{l}\text { Polyethylene DOT specification 34 or } \\
\text { as authorized by DOT exception }\end{array}$ & 1 & 5 & 5 & 60 & 60 \\
\hline
\end{tabular}

${ }^{1}$ Nearest metric size is also acceptable for the glass and plastic containers listed.

${ }^{2}$ One gallon or nearest metric equivalent size may be used if metal containers must be avoided because of chemical reaction with their contents.

${ }^{3}$ Quantities are in gallons for the rest of this table. 
Appendix 3-2

Indoor/Outdoor Storage for Flammable/Combustible Materials

(AFOSH STD 91-501, Tables 22.3 through 22.6)

\begin{tabular}{|c|c|c|c|}
\hline \multicolumn{4}{|c|}{ Indoor Container Storage } \\
\hline $\begin{array}{c}\text { Class } \\
\text { Liquid }\end{array}$ & Storage Level & $\begin{array}{c}\text { *Protected Storage } \\
\text { Maximum per Pile In } \\
\text { Gallons }\end{array}$ & $\begin{array}{c}\text { Unprotected Storage } \\
\text { Maximum per Pile In } \\
\text { Gallons }\end{array}$ \\
\hline IA & $\begin{array}{l}\text { Ground and upper floors } \\
\text { Basement }\end{array}$ & $\begin{array}{l}2750 \\
(50) \\
\text { Not permitted }\end{array}$ & $\begin{array}{l}600 \\
(12) \\
\text { Not permitted }\end{array}$ \\
\hline IB & $\begin{array}{l}\text { Ground and upper floors } \\
\text { Basement }\end{array}$ & $\begin{array}{l}5500 \\
(100) \\
\text { Not permitted }\end{array}$ & $\begin{array}{l}1375 \\
(25) \\
\text { Not permitted }\end{array}$ \\
\hline IC & $\begin{array}{l}\text { Ground and upper floors } \\
\text { Basement }\end{array}$ & $\begin{array}{l}16,500 \\
(300) \\
\text { Not permitted }\end{array}$ & $\begin{array}{l}4125 \\
(25) \\
\text { Not permitted }\end{array}$ \\
\hline II & $\begin{array}{l}\text { Ground and upper floors } \\
\text { Basement }\end{array}$ & $\begin{array}{l}16,500 \\
(300) \\
5500 \\
(100)\end{array}$ & $\begin{array}{l}4125 \\
(75) \\
\text { Not permitted }\end{array}$ \\
\hline III & $\begin{array}{l}\text { Ground and upper floors } \\
\text { Basement }\end{array}$ & $\begin{array}{l}55,000 \\
(1000) \\
8250 \\
(450)\end{array}$ & $\begin{array}{l}13,750 \\
(250) \\
\text { Not permitted }\end{array}$ \\
\hline
\end{tabular}

* A sprinkler or equivalent fire protection system installed in accordance with NFPA Standard 30.

NOTES:

1. When two or more classes of materials are stored in a single pile, the maximum gallonage permitted in that pile must be the smallest of the two or more separate maximum gallonages.

2. Aisles must be provided so that no container is more than $4 \mathrm{~m}(12 \mathrm{ft}) \mathrm{from}$ an aisle. Main aisles must be at least 2-m (8-ft) wide and side aisles at least 1-m (4-ft) wide. (Numbers in parentheses indicate the number of 55-gal drums.)

3. Each pile must be separated from every other by at least $1 \mathrm{~m}(4 \mathrm{ft})$. 


\begin{tabular}{|l|l|l|l|l|}
\hline \multicolumn{5}{|c|}{ Outdoor Container Storage } \\
\hline $\begin{array}{c}\text { Class } \\
\text { Liquid }\end{array}$ & $\begin{array}{c}\text { Maximum per } \\
\text { pile } \\
\text { (gal) }\end{array}$ & $\begin{array}{c}\text { Distance between } \\
\text { piles }^{2} \\
(\mathrm{ft})\end{array}$ & $\begin{array}{c}\text { Distance to property line } \\
\text { that can be built upon } \\
(\mathrm{ft})\end{array}$ & $\begin{array}{c}\text { Distance to street, } \\
\text { alley, public way } \\
\text { (ft) }\end{array}$ \\
\hline \hline IA & 1100 & 5 & 20 & 10 \\
\hline IB & 2200 & 5 & 20 & 10 \\
\hline IC & 4400 & 5 & 20 & 5 \\
\hline II & 8800 & 5 & 10 & 5 \\
\hline III & 22,000 & 5 & 10 & 10 \\
\hline
\end{tabular}

${ }^{1}$ When two or more classes of materials are stored in a single pile, the maximum gallonage permitted in that pile must be the smallest of the two or more separate maximum gallonages.

${ }^{2}$ Within $200 \mathrm{ft}$ of each container, there must be a 12-ft wide accessway to permit access to fire control apparatus.

${ }^{3}$ The distances listed apply to properties that have protection for exposures as defined. If there are exposures, and such protection for exposures does not exist, the distances in column 4 must be doubled.

${ }^{4}$ When total quantity stored does not exceed 50 percent of maximum per pile, the distance in columns 4 and 5 may be reduced 50 percent, but not to less than $3 \mathrm{ft}$. 


\begin{tabular}{|c|c|c|c|}
\hline \multicolumn{4}{|c|}{ Indoor Portable Tank Storage } \\
\hline $\begin{array}{l}\text { Class } \\
\text { Liquid }\end{array}$ & Storage Level & $\begin{array}{c}\text { *Protected Storage } \\
\text { Maximum per Pile In } \\
\text { Gallons }\end{array}$ & $\begin{array}{c}\text { Unprotected Storage } \\
\text { Maximum per Pile In } \\
\text { Gallons }\end{array}$ \\
\hline IA & $\begin{array}{l}\text { Ground and upper floors } \\
\text { Basement }\end{array}$ & $\begin{array}{l}\text { Not permitted } \\
\text { Not permitted }\end{array}$ & $\begin{array}{l}\text { Not permitted } \\
\text { Not permitted }\end{array}$ \\
\hline IB & $\begin{array}{l}\text { Ground and upper floors } \\
\text { Basement }\end{array}$ & $\begin{array}{l}20,000 \\
\text { Not permitted }\end{array}$ & $\begin{array}{l}2000 \\
\text { Not permitted }\end{array}$ \\
\hline IC & $\begin{array}{l}\text { Ground and upper floors } \\
\text { Basement }\end{array}$ & $\begin{array}{l}40,000 \\
\text { Not permitted }\end{array}$ & $\begin{array}{l}5500 \\
\text { Not permitted }\end{array}$ \\
\hline II & $\begin{array}{l}\text { Ground and upper floors } \\
\text { Basement }\end{array}$ & $\begin{array}{l}40,000 \\
20,000\end{array}$ & $\begin{array}{l}5500 \\
\text { Not permitted }\end{array}$ \\
\hline III & $\begin{array}{l}\text { Ground and upper floors } \\
\text { Basement }\end{array}$ & $\begin{array}{l}60,000 \\
20,000\end{array}$ & $\begin{array}{l}22,000 \\
\text { Not permitted }\end{array}$ \\
\hline
\end{tabular}

* A sprinkler or equivalent fire protection system installed in accordance with NFPA Standard 30.

\section{NOTES:}

1. When two or more classes of materials are stored in a single pile, the maximum gallonage permitted in that pile must be the smallest of the two or more separate maximum gallonages.

2. Aisles must be provided so that no container is more than $4 \mathrm{~m}(12 \mathrm{ft})$ from an aisle. Main aisles must be at least 2-m (8-ft) wide and side aisles at least 1-m (4-ft) wide.

3. Each pile must be separated from every other by at least $1 \mathrm{~m}(4 \mathrm{ft})$. 


\begin{tabular}{|l|l|l|l|l|}
\hline \multicolumn{6}{|c|}{ Outdoor Portable Tank Storage } \\
\hline \hline $\begin{array}{c}\text { Class } \\
\text { Liquid }\end{array}$ & $\begin{array}{c}\text { Maximum per } \\
p^{1} e^{1} \\
(\mathrm{gal})\end{array}$ & $\begin{array}{c}\text { Distance between } \\
\text { piles }^{2} \\
(\mathrm{ft})\end{array}$ & $\begin{array}{c}\text { Distance to property line } \\
\text { that can be built upon } \\
(\mathrm{ft})\end{array}$ & $\begin{array}{c}\text { Distance to street, } \\
\text { alley, public way } \\
(\mathrm{ft})\end{array}$ \\
\hline \hline IA & 2200 & 5 & 20 & 10 \\
\hline IB & 4400 & 5 & 20 & 10 \\
\hline IC & 8800 & 5 & 20 & 5 \\
\hline II & 17,600 & 5 & 10 & 5 \\
\hline III & 44,000 & 5 & 10 & 10 \\
\hline
\end{tabular}

${ }^{1}$ When two or more classes of materials are stored in a single pile, the maximum gallonage permitted in that pile must be the smallest of the two or more separate maximum gallonages.

${ }^{2}$ Within $200 \mathrm{ft}$ of each container, there must be a 12-ft-wide accessway to permit access to fire control apparatus.

${ }^{3}$ The distances listed apply to properties that have protection for exposures as defined. If there are exposures, and such protection for exposures does not exist, the distances in column 4 must be doubled.

${ }^{4}$ When total quantity stored does not exceed 50 percent of maximum per pile, the distance in columns 4 and 5 may be reduced 50 percent, but not to less than $3 \mathrm{ft}$. 


\section{Appendix 3-3}

Storage Inside Rooms

(AFOSH STD 91-501, Table 22.2)

\begin{tabular}{|l|c|c|c|}
\hline $\begin{array}{c}\text { Fire Protection } \\
\text { Provided }^{\mathbf{1}}\end{array}$ & Fire Resistance & Maximum Size & $\begin{array}{c}\text { Total Allowable Quantities } \\
\text { (gal/ft' }\end{array}$ \\
\hline \hline Yloor area)
\end{tabular}

${ }^{1}$ Fire protection system will be sprinkler, water spray, or equivalent.

${ }^{2}$ If metric containers are being stored, use the nearest metric equivalent. 


\section{Appendix 3-4}

Maximum Allowable Size of Containers

(AFOSH STD 91-501, Tables 22.7 and 22.8)

\begin{tabular}{|l|c|c|c|c|c|}
\hline \multicolumn{1}{|c|}{ General Laboratories } \\
\hline \multicolumn{1}{|c|}{ Container Type } & \multicolumn{3}{c|}{ Flammable Liquids } & \multicolumn{2}{c|}{ Combustible Liquids } \\
\hline \hline & $I A$ & $I B$ & $I C$ & $I I$ & $I I$ \\
\hline \hline $\begin{array}{l}\text { Glass } \\
\begin{array}{l}\text { Transportat (other than Department of [DOT] drums) and } \\
\text { Approved Plastic Safety Cans }\end{array}\end{array}$ & $1 \mathrm{pt}^{1}$ & $1 \mathrm{gt}^{1}$ & $1 \mathrm{gal}^{2}$ & $1 \mathrm{gal}^{2}$ & $1 \mathrm{gal}^{2}$ \\
\hline Safety Cans (Metal) & $5 \mathrm{gal}^{3}$ & $5 \mathrm{gal}^{3}$ & $5 \mathrm{gal}^{3}$ & $5 \mathrm{gal}^{3}$ \\
\hline Metal drums (DOT specifications) & N/A & $5 \mathrm{gal}^{3}$ & $5 \mathrm{gal}^{3}$ & $60 \mathrm{gal}^{3}$ & $60 \mathrm{gal}^{3}$ \\
\hline
\end{tabular}

${ }^{1}$ Nearest metric equivalent is acceptable. Sizes as large as 1 gal or $4 \mathrm{~L}$ may be used if the liquid would be adversely affected by storage in metal or if the liquid would cause excessive corrosion of the metal container.

${ }^{2}$ Nearest metric equivalent.

${ }^{3}$ In instructional laboratories, containers of Class I or Class II liquids will not exceed 1 gal or 3 L, except for safety cans, where 2-gal capacity may be used.

\begin{tabular}{|l|c|c|c|c|c|}
\hline \multicolumn{7}{|c|}{ Health-Related Laboratories } \\
\hline \multicolumn{1}{|c|}{ Container Type } & \multicolumn{3}{c|}{ Flammable Liquids } & \multicolumn{2}{c|}{ Combustible Liquids } \\
\hline & $I A$ & $I B$ & $I C$ & $I I$ & $I I$ \\
\hline \hline Glass or Approved Plastic $^{1}$ & $1 \mathrm{pt}^{1}$ & $1 \mathrm{qt}^{2}$ & $1 \mathrm{gal}^{2}$ & $1 \mathrm{gal}^{2}$ & $1 \mathrm{gal}^{2}$ \\
\hline Safety Cans (Metal) & $1 \mathrm{gal}$ & $2 \mathrm{gal}$ & $2 \mathrm{gal}$ & 2 gal & 2 gal \\
\hline
\end{tabular}

${ }^{1}$ Gravity feed containers not permitted.

${ }^{2}$ Nearest metric equivalent is acceptable. 


\title{
SECTION 4
}

\section{HAZARDOUS WASTE MANAGEMENT}

\section{Overseas ESOHCAMP}

\author{
September 2009
}

\section{A. Service-specific Regulations and Policies}

- Air Force (AF) Policy Letter, 21 January 1994, Air Force Policy on the Application of the Resources Conservation and Recovery Act to Conventional Explosive Ordnance Operations, addresses the issue of when waste ordnance is to be handled as a hazardous waste; only that portion of the letter that specifies the procedures for identifying when conventional explosive ordnance becomes a waste is applicable to AF components located outside the United States and its territories.

- HQ USAF/ILEV Memorandum, Revised Environmental Quality Metrics, 14 February 2005, requires immediate implementation across the AF (including overseas installations and government-owned/contractor-operated (GOCO) facilities of Under Secretary of Defense Memorandum, Revised Pollution Prevention and Compliance Metrics, dated 12 October 2004.

- Air Force Instruction 32-7042, Waste Management, 21 April 2009, identifies compliance requirements for all solid waste (SW), including hazardous waste (HW), but excludes radioactive waste and medical waste.

\section{B. DOD Directives and Instructions}

- Under Secretary of Defense Memorandum, Revised Pollution Prevention and Compliance Metrics, dated 12 October 2004, publishes pollution prevention (P2) metrics and definitions. Implementation begins in 2005. The following goals for hazardous waste are established in the memorandum:

1. Efficiently manage hazardous waste in order to minimize life-cycle costs and future liabilities, protect environmental resources, and enhance operational flexibility

2. Promote efficient investments in pollution prevention to reduce the quantity of hazardous waste, protect strategic environmental resources, and ensure mission sustainability.

\section{Service-specific/DOD Definitions}

- Hazardous Waste (HW) - for overseas installations, HW is defined in the applicable FGS (Attachment 2, Under Secretary of Defense Memorandum, Revised Pollution Prevention and Compliance Metrics, 12 October 2004).

- Hazardous Waste Management Cost - for purposes of this metric, HW management is defined to include only the following activities: packaging for transportation; transportation; treatment/disposal of HW; and, other services that are paid through a HW disposal vehicle (either through the Defense Reutilization and Marketing Service (DRMS) or directly). HW management does not include the following activities: permitting; sampling/analysis/monitoring; inspections; and training. Further, it does not include the following in-house activities: manpower, supplies, and equipment purchase/maintenance. HW management has been defined in this way (for this metric) to make it consistent with definitions already used in existing DOD resource management systems and to ease reporting. More specifically, the definition is taken from the DOD POM Preparation Instructions, Tab E, Environmental Quality under the Waste Disposal line in Environmental Compliance, Recurring Costs (Attachment 2, Under Secretary of Defense Memorandum, Revised Pollution Prevention and Compliance Metrics, 12 October 2004). 
- Hazardous Waste Shipped Off-Site - for reporting purposes of this metric overseas, this includes all HW (as defined in applicable Final Governing Standards or international treaty) shipped from permanent DOD installations for treatment, recycling, or disposal (Attachment 2, Under Secretary of Defense Memorandum, Revised Pollution Prevention and Compliance Metrics, 12 October 2004).

- Overseas - outside any territory, possession, or commonwealth of the United States. This does not include contingency operations, training deployments, or the operations of military vessels and aircraft (Attachment 2, Under Secretary of Defense Memorandum, Revised Pollution Prevention and Compliance Metrics, 12 October 2004).

- Overseas Installations - permanent, base force structure facilities under the operational control of the Secretary of a military department or the Department of Defense that is located outside the United States and outside any territory, commonwealth or possession of the United States. Installations overseas do NOT include temporary, contingency operation or deployment support facilities. Tenants on overseas installations should report through their component headquarters reporting systems (Attachment 2, Under Secretary of Defense Memorandum, Revised Pollution Prevention and Compliance Metrics, 12 October 2004).

(NOTE: Include Government-owned, Contractor-operated [GOCO] installations.)

- PCB Wastes - waste derived from products containing PCBs (Attachment 2, Under Secretary of Defense Memorandum, Revised Pollution Prevention and Compliance Metrics, 12 October 2004).

- Quantity - for purposes of this metric, quantity should be measured in pounds (Attachment 2, Under Secretary of Defense Memorandum, Revised Pollution Prevention and Compliance Metrics, 12 October 2004).

- Recurring Compliance Investment (Hazardous Waste Disposal) - the metric to be used to track the costs of HW management is the total HW obligations as shown under PY-1 in the Waste Disposal line under "Recurring Compliance Investment" in the President's Budget. For this metric, the definition comes from the POM Preparation Instructions, Tab E, Environmental Quality, and includes prior year obligations for the following HW management activities: packaging of HW for transportation; transportation; treatment/disposal of HW; and other services that are paid through a HW disposal vehicle (either through DRMS or directly). It does not include costs for the following: permitting; sampling/analysis/monitoring; inspections; and training. It further, does not include costs for the following in-house activities: manpower, supplies, and equipment purchase/maintenance (Attachment 2, Under Secretary of Defense Memorandum, Revised Pollution Prevention and Compliance Metrics, 12 October 2004).

- Remediation Wastes Shipped Off-site - for overseas installations, remediation wastes are hazardous wastes, as defined in the applicable FGS, generated as a result of cleanup conducted in accordance with DOD Instruction 4715.8, "Environmental Restoration Overseas" (Attachment 2, Under Secretary of Defense Memorandum, Revised Pollution Prevention and Compliance Metrics, 12 October 2004).

\section{Additional Records To Review}

- Hazardous Waste Management Plan (if none is required in the manual based on the FGS)

- Inventory of hazardous waste streams

- Waste analysis plan(s)

\section{E. Additional Physical Features To Inspect}

- None 


\section{F. Guidance for Checklist Users}

\begin{tabular}{ll}
\hline & REFER TO CHECKLIST ITEMS: \\
Missing Checklist Items/Positive Findings & HW.2.1.OCAF and HW.2.2.OCAF \\
All Installations & \\
General & HW.10.1.OCAF through HW.10.13.OCAF \\
Plans/Surveys & HW.20.1.OCAF through HW.20.7.OCAF \\
Waste Identification & HW.30.1.OCAF and HW.30.2.OCAF \\
Training & HW.40.1.OCAF through HW.40.5.OCAF \\
Hazardous Waste Generators & \\
Operating Procedures & HW.50.1.OCAF through HW.50.3.OCAF \\
Specific Wastes & HW.60.1.OCAF through HW.60.3.OCAF \\
Hazardous Waste Storage Areas & \\
Operating Procedures & HW.120.1.OCAF \\
Transportation of Hazardous Waste & HW.160.1.OCAF \\
\hline
\end{tabular}




\begin{tabular}{|c|c|}
\hline \multicolumn{2}{|r|}{$\begin{array}{l}\text { COMPLIANCE CATEGORY: } \\
\text { HAZARDOUS WASTE MANAGEMENT } \\
\text { Overseas ESOHCAMP }\end{array}$} \\
\hline $\begin{array}{l}\text { REGULATORY } \\
\text { REQUIREMENTS: }\end{array}$ & $\begin{array}{l}\text { REVIEWER CHECKS: } \\
\text { September } 2009\end{array}$ \\
\hline $\begin{array}{l}\text { HW.2 } \\
\text { MISSING CHECKLIST } \\
\text { ITEMS/POSITIVE } \\
\text { FINDINGS }\end{array}$ & \\
\hline $\begin{array}{l}\text { HW.2.1.OCAF. Installations } \\
\text { must comply with all applica- } \\
\text { ble regulatory requirements } \\
\text { not contained in this checklist } \\
\text { (a finding under this checklist } \\
\text { item will have the citation of } \\
\text { the applied regulation as a } \\
\text { basis of finding) [Added } \\
\text { March 2002]. }\end{array}$ & $\begin{array}{l}\text { Determine whether any new regulations concerning hazardous waste management } \\
\text { have been issued since the finalization of the manual. } \\
\text { Determine whether the installation has activities or facilities that are regulated but } \\
\text { not addressed in this checklist. } \\
\text { Verify that the installation is in compliance with all applicable and newly issued } \\
\text { regulations. }\end{array}$ \\
\hline $\begin{array}{l}\text { HW.2.2.OCAF. Installations } \\
\text { should go above and beyond } \\
\text { environmental statutory and } \\
\text { regulatory compliance (MP) } \\
\text { [Added March 2002]. }\end{array}$ & $\begin{array}{l}\text { Determine whether the installation has gone above and beyond simply complying } \\
\text { with environmental requirements. } \\
\text { (NOTE: This checklist item is used only to write positive findings.) }\end{array}$ \\
\hline
\end{tabular}




\begin{tabular}{|c|c|}
\hline & $\begin{array}{c}\text { COMPLIANCE CATEGORY: } \\
\text { HAZARDOUS WASTE MANAGEMENT } \\
\text { Overseas ESOHCAMP }\end{array}$ \\
\hline $\begin{array}{l}\text { REGULATORY } \\
\text { REQUIREMENTS: }\end{array}$ & $\begin{array}{l}\text { REVIEWER CHECKS: } \\
\text { September } 2009\end{array}$ \\
\hline $\begin{array}{l}\text { HW.10 } \\
\text { ALL INSTALLATIONS: } \\
\text { General }\end{array}$ & \\
\hline $\begin{array}{l}\text { HW.10.1.OCAF. [Moved } \\
\text { March 2002]. }\end{array}$ & Moved to HW.2.1.OCAF. \\
\hline $\begin{array}{l}\text { HW.10.2.OCAF. Installa- } \\
\text { tions must meet requirements } \\
\text { contained in MAJCOM sup- } \\
\text { plements to AFIs and policy } \\
\text { documents (a finding under } \\
\text { this checklist item will have } \\
\text { the citation of the MAJCOM } \\
\text { document as a basis of find- } \\
\text { ing). }\end{array}$ & $\begin{array}{l}\text { Determine whether the requirements in MAJCOM supplements to AFIs and pol- } \\
\text { icy documents are within the scope of the environmental compliance assessment. } \\
\text { Verify that the installation is in compliance with MAJCOM requirements. }\end{array}$ \\
\hline $\begin{array}{l}\text { HW.10.3.OCAF. [Moved } \\
\text { March 2002]. }\end{array}$ & Moved to HW.2.2.OCAF. \\
\hline $\begin{array}{l}\text { HW.10.4.OCAF. [Deleted } \\
\text { July 2008]. }\end{array}$ & Deleted at the request of the sponsor. \\
\hline $\begin{array}{l}\text { HW.10.5.OCAF. [Deleted } \\
\text { July 2008]. }\end{array}$ & Deleted at the request of the sponsor. \\
\hline $\begin{array}{l}\text { HW.10.6.OCAF. All instal- } \\
\text { lations that ship hazardous } \\
\text { waste off-site for disposal } \\
\text { must report specific informa- } \\
\text { tion on a calendar year basis } \\
\text { (HQ USAF/ILEV Memoran- } \\
\text { dum, Revised Environmental } \\
\text { Quality Metrics, } 14 \text { February } \\
\text { 2005, para 1; Under Secretary } \\
\text { of Defense Memorandum, } \\
\text { Revised Pollution Prevention } \\
\text { and Compliance Metrics, } 12 \\
\text { October 2004; Attachment 1, } \\
\text { paras III.c.2, III.d.1.c, and } \\
\text { III.d.2) [Added March 2005]. }\end{array}$ & $\begin{array}{l}\text { Determine whether the installation ships hazardous waste off-site for disposal. } \\
\text { (NOTE: The relevant definition of 'hazardous waste' is that found in the applica- } \\
\text { ble FGS.) } \\
\text { Verify that the installation reports hazardous waste shipped off-site in the follow- } \\
\text { ing subcategories: } \\
\text { - PCB wastes } \\
\text { - remediation wastes } \\
\text { - hazardous waste shipped off-site but not in one of the above subcategories. } \\
\text { - cost of hazardous waste management as reported in President's Budget (Ex- } \\
\text { hibit PB-28) in thousands of Dollars (\$): } \\
\text { - recurring compliance investment, waste disposal } \\
\text { - nonrecurring compliance investment, RCRA Subtitle C, Hazardous } \\
\text { - Waste } \\
\text { - nonrecurring pollution prevention investment, RCRA Subtitle C, Haz- } \\
\text { ardous Waste. } \\
\text { (NOTE: Potential sources of data include the President's Budget [Exhibit PB-28], }\end{array}$ \\
\hline
\end{tabular}




\section{COMPLIANCE CATEGORY: \\ HAZARDOUS WASTE MANAGEMENT \\ Overseas ESOHCAMP}

\begin{tabular}{|c|c|}
\hline $\begin{array}{l}\text { REGULATORY } \\
\text { REQUIREMENTS: }\end{array}$ & $\begin{array}{l}\text { REVIEWER CHECKS: } \\
\text { September } 2009\end{array}$ \\
\hline $\begin{array}{l}\text { HW.10.7.OCAF. The instal- } \\
\text { lation must have a hazardous } \\
\text { waste management program } \\
\text { that includes specific ele- } \\
\text { ments (AFI 32-7042, para } \\
2.1 .7 \text { ) [Added September } \\
\text { 2009]. }\end{array}$ & $\begin{array}{l}\text { installation hazardous waste reports, and hazardous waste manifests.) } \\
\text { (NOTE: Begin collecting this data in Calendar Year 2005.) } \\
\text { Verify that the installation has a HW management program that includes the fol- } \\
\text { lowing elements: } \\
\text { - a hazardous waste management plan (HWMP) } \\
\text { - training } \\
\text { - characterization } \\
\text { - turn-in and disposal procedures } \\
\text { - disposal contracts } \\
\text { - inspections } \\
\text { - munitions } \\
\text { - mixed waste } \\
\text { - recordkeeping } \\
\text { - host-tenant support. }\end{array}$ \\
\hline $\begin{array}{l}\text { HW.10.8.OCAF. The instal- } \\
\text { lation commander (IC) must } \\
\text { sign, or delegate in writing } \\
\text { the authority to sign, HW } \\
\text { manifests (AFI 32-7042, para } \\
\text { 1.10.1.4) [Added September } \\
\text { 2009]. }\end{array}$ & $\begin{array}{l}\text { Verify that the IC signs, or delegates in writing the authority to sign, HW mani- } \\
\text { fests. } \\
\text { (NOTE: Signature delegation should remain with active duty and civilian em- } \\
\text { ployees only.) }\end{array}$ \\
\hline $\begin{array}{l}\text { HW.10.9.OCAF. Each gen- } \\
\text { erating activity unit organiza- } \\
\text { tion must designate an em- } \\
\text { ployee to serve as a focal } \\
\text { point for the organization's } \\
\text { waste management activities } \\
\text { (AFI 32-7042, para 1.10.8.5) } \\
\text { [Added September 2009]. }\end{array}$ & $\begin{array}{l}\text { Verify that each generating activity unit organization designates an employee to } \\
\text { serve as a focal point for the organization's waste management activities. }\end{array}$ \\
\hline $\begin{array}{l}\text { HW.10.10.OCAF. Tenant } \\
\text { organizations on AF installa- } \\
\text { tions must must meet specific } \\
\text { hazardous waste management } \\
\text { requirements (AFI 32-7042, } \\
\text { para 1.10.9) [Added Septem- } \\
\text { ber 2009]. }\end{array}$ & $\begin{array}{l}\text { Verify that AF installation tenants comply with the installation HW management } \\
\text { programs and applicable environmental laws, unless exempted by DoD/AF in- } \\
\text { struction. } \\
\text { (NOTE: When a tenant is in noncompliance with SW and HW laws, the installa- } \\
\text { tion commander has the authority to take whatever action is necessary to require } \\
\text { tenants to comply.) } \\
\text { Verify that AF installation tenants meet the appropriate tenant responsibilities as } \\
\text { spelled out in installation waste management plans. } \\
\text { Verify that AF installation tenants conduct their activities in accordance with the }\end{array}$ \\
\hline
\end{tabular}




\section{COMPLIANCE CATEGORY: \\ HAZARDOUS WASTE MANAGEMENT \\ Overseas ESOHCAMP}

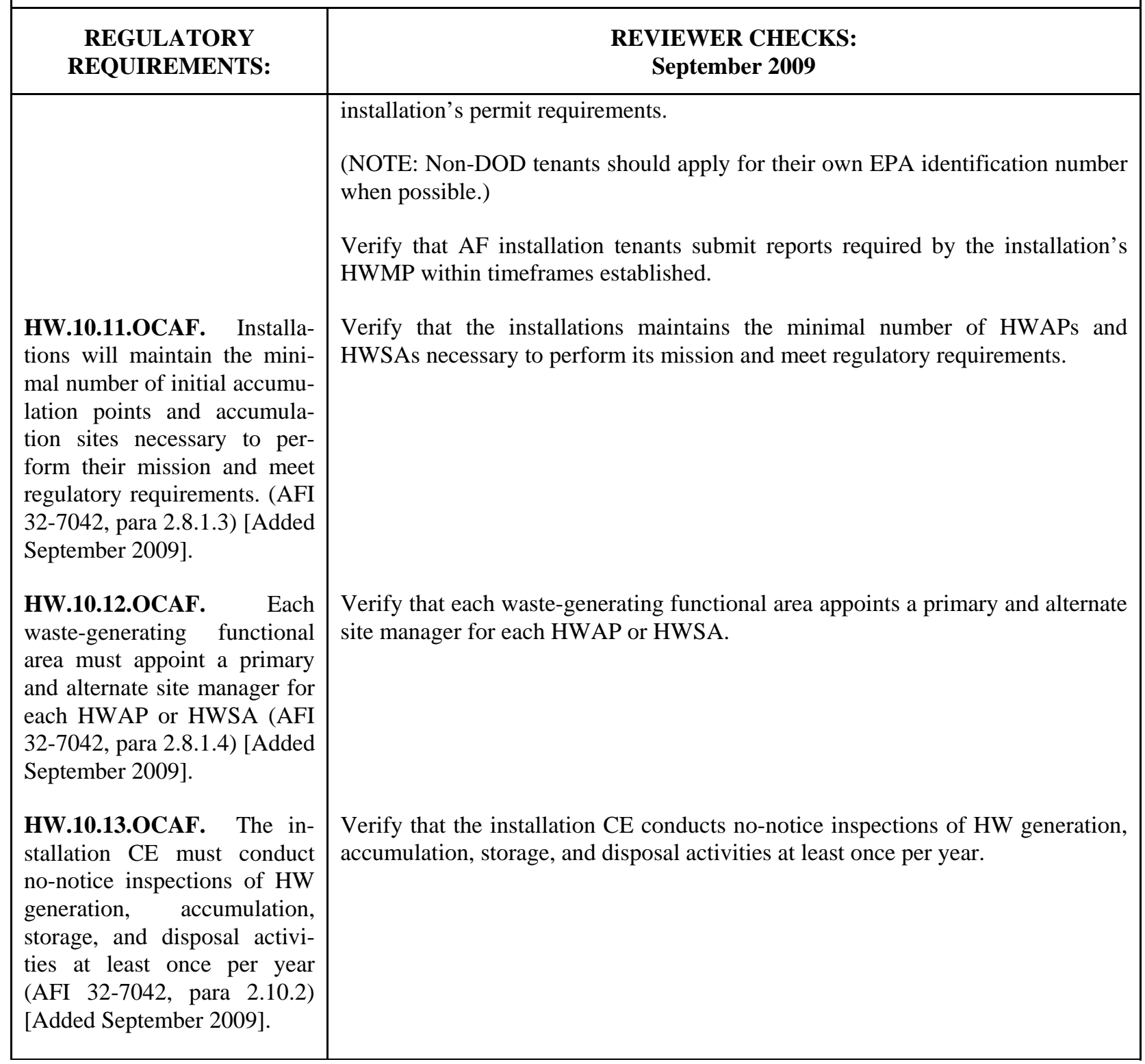




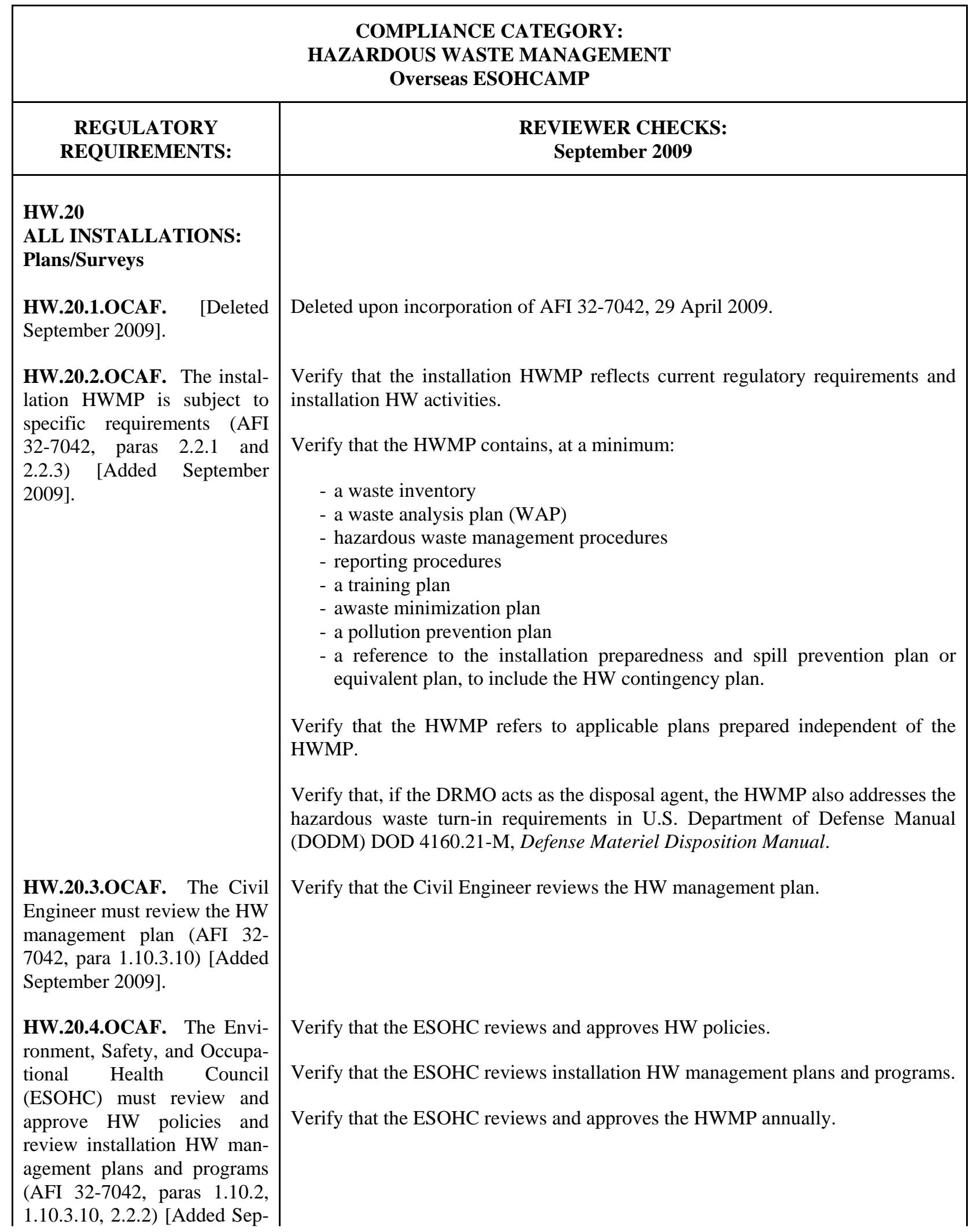




\section{COMPLIANCE CATEGORY: \\ HAZARDOUS WASTE MANAGEMENT \\ Overseas ESOHCAMP}

\begin{tabular}{|c|c|}
\hline $\begin{array}{c}\text { REGULATORY } \\
\text { REQUIREMENTS: }\end{array}$ & $\begin{array}{l}\text { REVIEWER CHECKS: } \\
\text { September } 2009\end{array}$ \\
\hline $\begin{array}{l}\text { tember 2009]. } \\
\text { HW.20.5.0CAF. Each in- } \\
\text { stallation must prepare a } \\
\text { WAP that meets specific re- } \\
\text { quirements (AFI 32-7042, } \\
\text { para 2.3.2) [Added September } \\
\text { 2009]. }\end{array}$ & $\begin{array}{l}\text { Verify that the WAP include a Hazardous Waste Stream Inventory (HWSI) and } \\
\text { descriptions on a HWPS. } \\
\text { Verify that the WAP identifies hazardous waste streams and sets forth procedures, } \\
\text { including specific sampling methods, necessary to ensure proper HW treatment, } \\
\text { storage, or disposal. } \\
\text { Verify that the WAP includes, at a minimum: } \\
\text { - the wastes that were evaluated and analyzed } \\
\text { - a description of the testing and analytical methods used } \\
\text { - the HW sampling methods used } \\
\text { - the location of samples taken for analysis } \\
\text { - frequency, sample documentation, sample quality assurance and quality con- } \\
\text { trol procedures } \\
\text { - sample request procedures. }\end{array}$ \\
\hline
\end{tabular}

Verify that the WAP documents chemical and physical analysis for each waste stream sampled.

Verify that WAP chemical and physical analyses are retained in accordance with AFMAN 33-363, Management of Records.

Verify that the WAP must be kept on-site.

HW.20.6.OCAF. The installation WAP should include specific elements (MP) [Added September 2009].

Verify that the WAP documents the reevaluation frequency for installation waste streams to ensure their characteristics have not substantially changed.

Verify that the WAP includes a description of the re-evaluation procedures.

Verify that the WAP requires re-characterization of waste streams when the generating process or operation is changed.

(NOTE: This MP is found at AFI 32-7042, para 2.3.2.1.)

HW.20.7.OCAF. The HWSI is subject to specific requirements (AFI 32-7042, para 2.3.3) [Added September

Verify that the HWSI describes all HW streams generated.

Verify that the HWSI lists at least the generating activity's identity and location, unique waste stream number, and the waste characteristics. 


\begin{tabular}{|c|c|}
\hline \multicolumn{2}{|r|}{$\begin{array}{l}\text { COMPLIANCE CATEGORY: } \\
\text { HAZARDOUS WASTE MANAGEMENT } \\
\text { Overseas ESOHCAMP }\end{array}$} \\
\hline $\begin{array}{l}\text { REGULATORY } \\
\text { REQUIREMENTS: }\end{array}$ & $\begin{array}{l}\text { REVIEWER CHECKS: } \\
\text { September } 2009\end{array}$ \\
\hline $\begin{array}{l}\text { HW.30 } \\
\text { ALL INSTALLATIONS: } \\
\text { Waste Identification }\end{array}$ & \\
\hline $\begin{array}{l}\text { HW.30.1.OCAF. [Deleted } \\
\text { July 2008]. }\end{array}$ & Deleted at the request of the sponsor. \\
\hline $\begin{array}{l}\text { HW.30.2.OCAF. Generating } \\
\text { activities must ensure that } \\
\text { waste streams are properly } \\
\text { characterized and must ensure } \\
\text { that appropriate documenta- } \\
\text { tion is maintained (AFI } 32- \\
\text { 7042, paras } 1.10 .8 .2 \text { and } \\
\text { 2.3.1) [Added September } \\
\text { 2009]. }\end{array}$ & $\begin{array}{l}\text { Verify that waste streams are properly characterized (i.e., to determine whether or } \\
\text { not they are hazardous wastes). } \\
\text { Verify that appropriate documentation is maintained. } \\
\text { Verify that all new and existing waste streams and/or process changes have been } \\
\text { coordinated with CE. } \\
\text { Verify that any waste streams generated are determined to be either hazardous or } \\
\text { non-hazardous at the point of generation of the waste. }\end{array}$ \\
\hline
\end{tabular}




\begin{tabular}{|c|c|}
\hline \multicolumn{2}{|r|}{$\begin{array}{c}\text { COMPLIANCE CATEGORY: } \\
\text { HAZARDOUS WASTE MANAGEMENT } \\
\text { Overseas ESOHCAMP }\end{array}$} \\
\hline $\begin{array}{l}\text { REGULATORY } \\
\text { REQUIREMENTS: }\end{array}$ & $\begin{array}{l}\text { REVIEWER CHECKS: } \\
\text { September } 2009\end{array}$ \\
\hline $\begin{array}{l}\text { HW.40 } \\
\text { TRAINING }\end{array}$ & \\
\hline $\begin{array}{l}\text { HW.40.1.OCAF. All per- } \\
\text { sonnel whose work involves } \\
\text { HW and their immediate su- } \\
\text { pervisors must receive and } \\
\text { successfully complete HW } \\
\text { training appropriate to their } \\
\text { job responsibilities (AFI 32- } \\
\text { 7042, para 2.6.1) [Added Sep- } \\
\text { tember 2009]. }\end{array}$ & $\begin{array}{l}\text { Verify that all personnel whose work involves HW and their immediate supervi- } \\
\text { sors receive and successfully complete HW training appropriate to their job re- } \\
\text { sponsibilities. } \\
\text { Verify that training occurs within three months of an employee's arrival or as- } \\
\text { signment to HW-related duties. } \\
\text { Verify that, until the employee has received the appropriate HW training, the em- } \\
\text { ployee handles HW only under the supervision of a HW trained individual. }\end{array}$ \\
\hline $\begin{array}{l}\text { HW.40.2.OCAF. Supervi- } \\
\text { sors and personnel must also } \\
\text { successfully complete annual } \\
\text { refresher training (AFI 32- } \\
\text { 7042, para 2.6.1) [Added Sep- } \\
\text { tember 2009]. }\end{array}$ & $\begin{array}{l}\text { Verify that both supervisors and personnel successfully complete annual refresher } \\
\text { training. }\end{array}$ \\
\hline $\begin{array}{l}\text { HW.40.3.OCAF. Supervi- } \\
\text { sors must examine employee } \\
\text { training to ensure that ade- } \\
\text { quate site- and task-specific } \\
\text { familiarization is accom- } \\
\text { plished, and supplemented } \\
\text { with on-the-job training, as } \\
\text { needed (AFI 32-7042, para } \\
2.6 .2 \text { ) [Added September } \\
\text { 2009]. }\end{array}$ & $\begin{array}{l}\text { Verify that supervisors examine employee training to ensure that adequate site- } \\
\text { and task-specific familiarization is accomplished. } \\
\text { Verify that employee training is supplemented with on-the-job training, as } \\
\text { needed. }\end{array}$ \\
\hline $\begin{array}{l}\text { HW.40.4.OCAF. Records of } \\
\text { hazardous waste training must } \\
\text { be managed in accordance } \\
\text { with specific requirements } \\
\text { (AFI 32-7042, para 2.6.3) } \\
\text { [Added September 2009]. }\end{array}$ & $\begin{array}{l}\text { Verify that HW generators retain personnel training records and those of former } \\
\text { employees in accordance with Air Force RDS (https://www.my.af.mil/gcss- } \\
\text { af61a/afrims/afrims/), Environmental and Natural Resources Data Training. } \\
\text { Verify that copies of certification of HW training are be on-site and available for } \\
\text { inspection. } \\
\text { (NOTE: Originals of these records may be kept by AF Form 1098, Special Task } \\
\text { Certification and Recurring Training; AF Form 55, Employee Safety and Health } \\
\text { Record; installation centralized training records; computer database; or letters of } \\
\text { completion.) }\end{array}$ \\
\hline $\begin{array}{l}\text { HW.40.5.OCAF. Hazardous } \\
\text { waste training records should } \\
\text { include specific information }\end{array}$ & $\begin{array}{l}\text { Verify that, at a minimum, training records include: } \\
\text { - the student's name }\end{array}$ \\
\hline
\end{tabular}




\begin{tabular}{|l|l|}
\hline \multicolumn{2}{|c|}{$\begin{array}{c}\text { COMPLIANCE CATEGORY: } \\
\text { HAZARDOUS WASTE MANAGEMENT } \\
\text { Overseas ESOHCAMP }\end{array}$} \\
\hline $\begin{array}{c}\text { REGULATORY } \\
\text { REQUIREMENTS: }\end{array}$ & $\begin{array}{c}\text { REVIEWER CHECKS: } \\
\text { September 2009 }\end{array}$ \\
\hline (AFI 32-7042, para 2.6.3.1) & $\begin{array}{l}\text { - the student's job title } \\
\text { - the student's job description } \\
\text { [Added September 2009]. }\end{array}$ \\
& $\begin{array}{l}\text { - dates of training } \\
\text { - instructor's name (or functional area) } \\
\text { - test score (if applicable), and } \\
\text { - date of annual refresher course. }\end{array}$ \\
\hline
\end{tabular}




\begin{tabular}{|c|c|}
\hline \multicolumn{2}{|r|}{$\begin{array}{c}\text { COMPLIANCE CATEGORY: } \\
\text { HAZARDOUS WASTE MANAGEMENT } \\
\text { Overseas ESOHCAMP }\end{array}$} \\
\hline $\begin{array}{l}\text { REGULATORY } \\
\text { REQUIREMENTS: }\end{array}$ & $\begin{array}{l}\text { REVIEWER CHECKS: } \\
\text { September } 2009\end{array}$ \\
\hline $\begin{array}{l}\text { HW.50 } \\
\text { HAZARDOUS WASTE } \\
\text { GENERATORS: } \\
\text { Operating Procedures }\end{array}$ & \\
\hline $\begin{array}{l}\text { HW.50.1.OCAF. Generating } \\
\text { activities must coordinate } \\
\text { process and waste changes } \\
\text { with BE to determine any } \\
\text { occupational or environ- } \\
\text { mental health risk (AFI 32- } \\
\text { 7042, paras 1.10.8.2 and } \\
\text { 2.3.1) [Added September } \\
\text { 2009]. }\end{array}$ & $\begin{array}{l}\text { Verify that the generating activity coordinates process and waste changes with } \mathrm{BE} \\
\text { to determine any occupational or environmental health risk. }\end{array}$ \\
\hline $\begin{array}{l}\text { HW.50.2.OCAF. Generating } \\
\text { activities must notify CE and } \\
\mathrm{BE} \text { of all administrative } \\
\text { changes in HW activities } \\
\text { (AFI 32-7042, para 1.10.8.3) } \\
\text { [Added September 2009]. }\end{array}$ & $\begin{array}{l}\text { Verify that generating activities notify CE and BE of all administrative changes in } \\
\text { HW activities. } \\
\text { (NOTE: Administrative changes include, but are not limited to, the location or } \\
\text { relocation of hazardous waste accumulation points (HWAPs) and hazardous } \\
\text { waste storage areas (HWSAs), and names of accumulation point/site managers } \\
\text { and alternates.) }\end{array}$ \\
\hline $\begin{array}{l}\text { HW.50.3.OCAF. All poten- } \\
\text { tially hazardous, yet unchar- } \\
\text { acterized wastes, must be han- } \\
\text { dled as HW, pending deter- } \\
\text { mination (AFI 32-7042, para } \\
\text { 2.3.5) [Added September } \\
\text { 2009]. }\end{array}$ & $\begin{array}{l}\text { Verify that all potentially hazardous, yet uncharacterized wastes, are handled as } \\
\text { HW, pending determination. }\end{array}$ \\
\hline
\end{tabular}




\begin{tabular}{|c|c|}
\hline \multicolumn{2}{|r|}{$\begin{array}{c}\text { COMPLIANCE CATEGORY: } \\
\text { HAZARDOUS WASTE MANAGEMENT } \\
\text { Overseas ESOHCAMP }\end{array}$} \\
\hline $\begin{array}{l}\text { REGULATORY } \\
\text { REQUIREMENTS: }\end{array}$ & $\begin{array}{l}\text { REVIEWER CHECKS: } \\
\text { September } 2009\end{array}$ \\
\hline $\begin{array}{l}\text { HW.60 } \\
\text { HAZARDOUS WASTE } \\
\text { GENERATORS: } \\
\text { Specific Wastes }\end{array}$ & \\
\hline $\begin{array}{l}\text { HW.60.1.OCAF. [Deleted } \\
\text { September 2009]. }\end{array}$ & Deleted upon incorporation of AFI 32-7042, 29 April 2009. \\
\hline $\begin{array}{l}\text { HW.60.2.OCAF. [Deleted } \\
\text { September 2009]. }\end{array}$ & Deleted upon incorporation of AFI 32-7042, 29 April 2009. \\
\hline $\begin{array}{l}\text { HW.60.3.OCAF. All conven- } \\
\text { tional explosive ordnance, } \\
\text { whether it remains use- } \\
\text { able/serviceable or has been } \\
\text { designated as unserviceable, } \\
\text { must be managed in accor- } \\
\text { dance with specific require- } \\
\text { ments (AFI 32-7042, para } \\
\text { 2.3.8) [Added September } \\
\text { 2009]. }\end{array}$ & $\begin{array}{l}\text { Verify that all conventional explosive ordnance, whether it remains use- } \\
\text { able/serviceable or has been designated as unserviceable, is managed in accor- } \\
\text { dance with: } \\
\text { - DOD 6055.9-STD, DOD Ammunition and Explosives Safety Standards, Oc- } \\
\text { tober 5, 2004 } \\
\text { - DOD Policy to Implement the EPA's Military Munitions Rule, } 1 \text { July 1998, } \\
\text { relayed per memorandum from HQ USAF/A4 (previously IL), dated No- } \\
\text { vember 2, 1998. }\end{array}$ \\
\hline
\end{tabular}




\begin{tabular}{|c|c|}
\hline \multicolumn{2}{|r|}{$\begin{array}{c}\text { COMPLIANCE CATEGORY: } \\
\text { HAZARDOUS WASTE MANAGEMENT } \\
\text { Overseas ESOHCAMP }\end{array}$} \\
\hline $\begin{array}{l}\text { REGULATORY } \\
\text { REQUIREMENTS: }\end{array}$ & $\begin{array}{c}\text { REVIEWER CHECKS: } \\
\text { September } 2009\end{array}$ \\
\hline $\begin{array}{l}\text { HW.120 } \\
\text { HAZARDOUS WASTE } \\
\text { STORAGE AREAS: } \\
\text { Operating Procedures }\end{array}$ & \multirow[b]{2}{*}{$\begin{array}{l}\text { Deleted at the request of the sponsor. } \\
\text { [Formerly checklist item number HW.50.1.OCAF.] }\end{array}$} \\
\hline $\begin{array}{l}\text { HW.120.1.OCAF. [Moved } \\
\text { June 2003; Deleted July } \\
\text { 2008]. }\end{array}$ & \\
\hline
\end{tabular}




\begin{tabular}{|l|c|}
\hline \multicolumn{2}{|c|}{$\begin{array}{c}\text { COMPLIANCE CATEGORY: } \\
\text { HAZARDOUS WASTE MANAGEMENT } \\
\text { Overseas ESOHCAMP }\end{array}$} \\
\hline \multicolumn{1}{|c|}{$\begin{array}{c}\text { REVIEWER CHECKS: } \\
\text { REQULATORY } \\
\text { REQREMENTS: }\end{array}$} & \\
\hline $\begin{array}{l}\text { HW.160 } \\
\text { TRANSPORTATION OF } \\
\text { HAZARDOUS WASTE } \\
\text { HW.160.1.OCAF. [Moved } \\
\begin{array}{l}\text { June 2003; Deleted July } \\
\text { 2008]. }\end{array}\end{array}$ & $\begin{array}{l}\text { Deleted at the request of the sponsor. } \\
\text { [Formerly checklist item number HW.60.1.OCAF.] }\end{array}$ \\
\hline
\end{tabular}




\section{SECTION 5}

\section{NATURAL RESOURCES MANAGEMENT}

\section{Overseas ESOHCAMP}

September 2009

\section{A. Service-specific Regulations and Policies}

- None

B. DOD Directives/Instructions

- None

C. Service-specific/DOD Definitions

- None

D. Additional Records to Review

- Mitigation and monitoring plan, if any

E. Additional Physical Features to Inspect

- None

F. Guidance for Checklist Users

\begin{tabular}{ll}
\hline & REFER TO CHECKLIST ITEMS: \\
Missing Checklist Items/Positive Findings & NR.2.1.OCAF and NR.2.2.OCAF \\
General & NR.3.1.OCAF through NR.3.3.OCAF \\
Training & NR.5.1.OCAF \\
Land Management & NR.10.1.OCAF \\
\hline
\end{tabular}




\begin{tabular}{|c|c|}
\hline & $\begin{array}{c}\text { COMPLIANCE CATEGORY: } \\
\text { NATURAL RESOURCES MANAGEMENT } \\
\text { Overseas ESOHCAMP }\end{array}$ \\
\hline $\begin{array}{l}\text { REGULATORY } \\
\text { REQUIREMENTS: }\end{array}$ & $\begin{array}{l}\text { REVIEWER CHECKS: } \\
\text { September } 2009\end{array}$ \\
\hline $\begin{array}{l}\text { NR.2 } \\
\text { MISSING CHECKLIST } \\
\text { ITEMS/POSITIVE } \\
\text { FINDINGS }\end{array}$ & \\
\hline $\begin{array}{l}\text { NR.2.1.OCAF. Installations } \\
\text { must comply with all applica- } \\
\text { ble regulatory requirements } \\
\text { not contained in this checklist } \\
\text { (a finding under this checklist } \\
\text { item will have the citation of } \\
\text { the applied regulation as a } \\
\text { basis of finding) [Added } \\
\text { March 2002]. }\end{array}$ & $\begin{array}{l}\text { Determine whether any new regulations concerning natural resources manage- } \\
\text { ment have been issued since the finalization of the manual. } \\
\text { Determine whether the installation has activities or facilities that are regulated but } \\
\text { not addressed in this checklist. } \\
\text { Verify that the installation is in compliance with all applicable and newly issued } \\
\text { regulations. }\end{array}$ \\
\hline $\begin{array}{l}\text { NR.2.2.OCAF. Installations } \\
\text { should go above and beyond } \\
\text { environmental statutory and } \\
\text { regulatory compliance (MP) } \\
\text { [Added March 2002]. }\end{array}$ & $\begin{array}{l}\text { Determine whether the installation has gone above and beyond simply complying } \\
\text { with environmental requirements. } \\
\text { (NOTE: This checklist item is used only to write positive findings.) }\end{array}$ \\
\hline
\end{tabular}




\begin{tabular}{|c|c|}
\hline & $\begin{array}{c}\text { COMPLIANCE CATEGORY: } \\
\text { NATURAL RESOURCES MANAGEMENT } \\
\text { Overseas ESOHCAMP }\end{array}$ \\
\hline $\begin{array}{l}\text { REGULATORY } \\
\text { REQUIREMENTS: }\end{array}$ & $\begin{array}{l}\text { REVIEWER CHECKS: } \\
\text { September } 2009\end{array}$ \\
\hline $\begin{array}{l}\text { NR.3 } \\
\text { GENERAL }\end{array}$ & \\
\hline $\begin{array}{l}\text { NR.3.1.OCAF. Installations } \\
\text { must meet requirements con- } \\
\text { tained in MAJCOM supple- } \\
\text { ments to AFIs and policy } \\
\text { documents (a finding under } \\
\text { this checklist item will have } \\
\text { the citation of the MAJCOM } \\
\text { document as a basis of find- } \\
\text { ing) [Moved June 2003]. }\end{array}$ & $\begin{array}{l}\text { Determine whether the requirements in MAJCOM supplements to AFIs and pol- } \\
\text { icy documents are within the scope of the environmental compliance assessment. } \\
\text { Verify that the installation is in compliance with MAJCOM requirements. } \\
\text { [Formerly checklist item number NR.10.2.OCAF.] }\end{array}$ \\
\hline $\begin{array}{l}\text { NR.3.2.OCAF. [Moved June } \\
\text { 2003; Deleted July 2008]. }\end{array}$ & $\begin{array}{l}\text { Deleted at the request of the sponsor. } \\
\text { [Formerly checklist item number NR.10.4.OCAF.] }\end{array}$ \\
\hline $\begin{array}{l}\text { NR.3.3.OCAF. [Moved June } \\
\text { 2003; Deleted July 2008]. }\end{array}$ & $\begin{array}{l}\text { Deleted at the request of the sponsor. } \\
\text { [Formerly checklist item number NR.40.2.OCAF.] }\end{array}$ \\
\hline
\end{tabular}




\begin{tabular}{|l|c|}
\hline \multicolumn{2}{|c|}{$\begin{array}{c}\text { COMPLIANCE CATEGORY: } \\
\text { NATURAL RESOURCES MANAGEMENT } \\
\text { Overseas ESOHCAMP }\end{array}$} \\
\hline \multicolumn{1}{|c|}{ REGULATORY } \\
REQUIREMENTS: & $\begin{array}{c}\text { REVIEWER CHECKS: } \\
\text { September 2009 }\end{array}$ \\
\hline $\begin{array}{l}\text { NR.5 } \\
\text { TRAINING } \\
\text { NR.5.1.OCAF. [Moved June } \\
\text { 2003; Deleted July 2008]. }\end{array}$ & Deleted at the request of the sponsor. \\
& [Formerly checklist item number NR.40.1.OCAF.] \\
\hline
\end{tabular}




\begin{tabular}{|l|c|}
\hline \multicolumn{2}{|c|}{$\begin{array}{c}\text { COMPLIANCE CATEGORY: } \\
\text { NATURAL RESOURCES MANAGEMENT } \\
\text { Overseas ESOHCAMP }\end{array}$} \\
\hline \multicolumn{1}{|c|}{$\begin{array}{c}\text { REVIEWER CHECKS: } \\
\text { September 2009 } \\
\text { REQUIREMENTS: }\end{array}$} \\
\hline $\begin{array}{l}\text { NR.10 } \\
\text { LAND MANAGEMENT } \\
\begin{array}{l}\text { NR.10.1.OCAF. [Moved } \\
\text { June 2003; Deleted July } \\
\text { 2008]. }\end{array}\end{array}$ & $\begin{array}{l}\text { Deleted at the request of the sponsor. } \\
\text { [Formerly checklist item number NR.20.1.OCAF.] }\end{array}$ \\
\hline
\end{tabular}




\title{
SECTION 6
}

\section{OTHER ENVIRONMENTAL ISSUES}

\section{Overseas ESOHCAMP}

\author{
September 2009
}

\section{A. Service-specific Regulations and Policies}

\section{Environmental Impacts}

- Air Force Instruction (AFI) 32-7061, Environmental Impact Analysis Process, 12 March 2003, adopts the current Title 32, Code of Federal Regulations, Part 989 (32 CFR 989), Environmental Impact Analysis Process (EIAP), as the controlling document on the AF EIAP. 32 CFR 989 is incorporated by reference into AFI 32-7061. In order to comply with AFI 32-7061, users must review and follow that version of 32 CFR 989 that is current at the time the EIAP is begun for the proposed action. For analysis of AF actions abroad, 32 CFR 187, Environmental Effects Abroad of Major Department of Defense (DOD) Actions, must be followed (per 32 CFR 989.37). Both regulations will be cited in this protocol, as appropriate.

- Headquarters (HQ) USAF/CEV Policy Letter, MAJCOM EPC Coordination of EIAP Documents, 26 August 1994, requires documentation indicating prior MAJCOM EPC coordination or approval to accompany EIAP documents sent to them for senior staff approval or signature.

Environmental Noise

- None

Cleanup (Restoration)

- AFI 32-7006, Environmental Program in Foreign Countries, 29 April 1994, contains requirements relevant to the cleanup of overseas sites that have been contaminated in the course of AF actions.

Pollution Prevention

- AFI 32-7042, Waste Management, 21 April 2009, includes provisions on the Qualified Recycling Program (QRP).

- AFI 32-7080, Pollution Prevention Program, 12 May 1994, outlines the requirements for the AF’s Pollution Prevention Program. It provides instruction in the areas of planning, use of ozone-depleting chemicals (ODCs), hazardous substance management and minimization, solid waste management, nonpoint source pollution, and air pollutant emissions.

- AFI 32-7086, Hazardous Materials Management, 1 November 2004, establishes procedures and standards that govern the management of hazardous materials (HAZMAT) throughout the Air Force (AF). It applies to all AF personnel (at classified and unclassified operations) who authorize, procure, issue, use, or dispose of HAZMAT in the course of their official duties; it also applies to those who manage, monitor, or track any of the preceding processes, whether the processes are performed by government or contractor personnel. AFI 32-7086 is applicable to all installations, except where international agreements require modified policy. Chapter 4 of the AFI addresses the Air Force ODS Management Program.

(NOTE: Throughout AFI 32-7086, the term “AF Form 3952” refers to either the hard copy of the AF Form 3952 or the standardized Air Force HAZMAT tracking system authorization data entry screens. The electronic data entry screens may or may not appear similar to the hard copy of the AF Form 3952. However, the standardized Air 
Force HAZMAT tracking system must be able to produce a hard copy of the AF Form 3952 in accordance with the AF Form 3952 authorization data requirements detailed in Attachment 2 to AFI 32-7086.)

- AF Pollution Prevention Strategy, 24 July 1995, details the goals and strategies promoted by the AF for pollution prevention.

- HQ USAF/ILEV Memorandum, Revised Environmental Quality Metrics, 14 February 2005, requires immediate implementation across the AF (including overseas installations and government-owned/contractor-operated (GOCO) facilities of Under Secretary of Defense Memorandum, Revised Pollution Prevention and Compliance Metrics, dated 12 October 2004.

- HQ USAF/A7C Memorandum, AF Solid Waste Diversion and Qualified Recycling Program (QRP) Policy, 11 April 2006, applies to Air Force operations, activities, and installations in the United States, Puerto Rico, and territories or possessions over which the United States has jurisdiction, including Government-owned, contractoroperated (GOCO) facilities, and facilities supported by appropriated and nonappropriated funds. Installations outside the United States, are directed to implement the elements of this policy to the maximum extent practicable consistent with DOD Instruction (DODI) 4715.4, international agreements, status of forces agreements, and Final Governing Standards (FGS) issued for host nations (or the Overseas Environmental Baseline Guidance Document where no FGS have been issued). This policy does not direct the management change at base level for the QRP. At some bases the environmental management flight oversees the QRP, and some the Operations Flight, this policy directs the improvements that need to be made in the QRP to meet the DOD, AFI, and audit requirements. Likewise, installations may change management to improve the oversight of the QRP. This memorandum is cited below as "AF QRP Policy."

\section{Program Management}

- AFI 13-212, Volume 1, Weapons Ranges, 07 August 2001, requires that the Range Operating Agency (ROA) prepare inputs on environmental factors for inclusion in the unit Comprehensive Range Plan.

- AFI 21-101, Maintenance, Aerospace Equipment Maintenance Management, 1 October 2002, requires aircraft and equipment maintenance units are required to appoint a Maintenance Group (MXG) Environmental Coordinator.

- AFI 32-7001, Environmental Budgeting, 9 May 1994, provides guidance on identifying, developing, and processing requirements to meet environmental standards at AF installations.

- AFI 32-7002, Environmental Information Management System, 31 May 1994, provides guidance and procedures to standardize the use of the Work Information Management System, Environmental Subsystem (WIMS-ES).

- AFI 32-7006, Environmental Program in Foreign Countries, 29 April 1994, requires installations to cooperate with host nation regulatory authorities. Further, it requires that copies of host nation regulatory authority inspection reports be forwarded to HQ USAF/CE and that receipt or notification of the imminent receipt of findings involving media attention or off-base impacts be reported to specific authorities. It also imposes on installations requirements for planning prior to receiving deployments.

- AFI 32-7047, Environmental Compliance Tracking and Reporting, 08 April 2004, identifies requirements for tracking, reporting, and managing enforcement actions (EAs), which include host nation enforcement actions (HNEAs), issued by federal, state, local, and overseas host nation regulatory agencies. Unless otherwise noted, the procedures outlined in AFI 32-7047 apply to all Air Force installations within the United States, its territories and possessions, and outside the U.S. and its territories. Tenant organizations also must comply with the provisions of AFI 32-7047. The Instruction is intended to provide MAJCOMs, MAJCOM-equivalent organizations, and installations a framework and schedule to track, report, and resolve noncompliance with environmental laws and standards. Only those provisions relevant to installations located outside the continental United States (OCONUS) are included here. 
- HQ USAF/A7CV, Policy Memorandum on Environmental Compliance Tracking and Reporting Requirements, 16 June 2006, clarifies the tracking and reporting of environmental noncompliance as directed by AFI 32-7047, Environmental Compliance Tracking and Reporting. The memorandum took effect on 01 July 2006 but is not retroactive to EAs received on or before 30 June 2006. It modifies the definition of an EA, and its definition is to be used until a change is made to the AFI. The memorandum does not change the AFI 32-7047 criteria for closing an HNEA, but it does extend the AFI 32-7047 criteria to closing other notices of noncompliance (ONONs).

- Air Force Instruction (AFI) 90-801, Environment, Safety, and Occupational Health Councils (ESOHC), 25 March 2005, establishes ESOHCs at Headquarters, United States Air Force (HQ USAF); at the headquarters of Major Commands (HQ MAJCOMs); and at installations to ensure a systematic, interdisciplinary approach to achieve ESOH goals throughout the Air Force. AFI 90-801 applies to all Air Force personnel, Air Force Reserve, the Air National Guard, and all Air Force installations with more than 300 assigned personnel. As the senior Air Force environment, safety, and occupational health steering group at each level of command, the ESOHC reviews policies and programs, establishes goals, monitors progress, and advises leadership. ESOHCs are an integral part of the Air Force ESOH Management System (ESOHMS).

- HQ USAF/ILEV Memorandum, Revised Environmental Quality Metrics, 14 February 2005, requires immediate implementation across the AF (including overseas installations and government-owned/contractor-operated (GOCO) facilities of Under Secretary of Defense Memorandum, Revised Pollution Prevention and Compliance Metrics, dated 12 October 2004.

Environmental Management System (EMS)

- CSAF/SECAF Memorandum, Air Force Environment, Safety, and Occupational Health Management System (ESOHMS), 5 January 2001, requires the implementation of an ESOHMS patterned after the ISO 14001 standard by 31 December 2005 in order to meet the requirements of Executive Order (EO) 13148, Greening the Government through Leadership in Environmental Management, 21 April 2000.

- HQ USAF/ILEV Memorandum, Environmental Management System (EMS) Implementation Criteria and Metrics, 29 May 2003, directs installations to develop an installation-specific Environmental Policy Statement and report on the achievement of specific EMS implementation milestones. The letter also requires that the leadership of the Environmental Protection Committee sign the policy statement, ensure its currency by reviewing it at least annually, and ensure that it is communicated to all installation personnel and made available to all interested parties.

- HQ USAF/CVA Policy Letter, Air Force Environment, Safety, and Occupational Health Management System (ESOHMS) Implementation, 9 September 2003, modified the requirements of the 5 January 2001 CSAF/SECAF memorandum by suspending implementation of the safety and occupational health portions of the ESOHMS until after the EMS is fully implemented. It also stressed that the EMS is not strictly a Civil Engineering program; instead, implementing and maintaining the EMS is the responsibility of all organizations.

- HQ USAF/ILEV Policy Letter, Enterprise Environmental, Safety, Occupational Health Management Information System (EESOH-MIS) Support of EMS, 11 December 2003, requires installations to use the EESOH-MIS, the environmental portion of the Automated Civil Engineer System (ACES), for identifying, scoring, and tracking environmental aspects.

- USAF Environmental Management System Implementation Plan, 22 April 2003, addresses the drivers for implementing an Air Force EMS, articulates the vision for the Air Force's ISO 14001-like EMS, identifies the gaps that exist between this vision and the current Air Force Environmental Program, and provides a roadmap for filling these gaps and implementing the Air Force EMS by the 31 December 2005 deadline imposed by EO 13148.

- The U.S. Air Force EMS Implementation Guidance Series, Module I, Planning Phase, 06 Feb 04, provides a step-by-step methodology for MAJCOMs and installations to implement the "Plan Phase" of the EMS. Specifically, the guide covers:

- identifying aspects and their impacts 
- scoring and ranking aspects based on their relative costs, environmental risk, regulatory implications, potential mission degradation, and level of community concern

- developing objectives and targets for mitigating/eliminating aspects

- developing Environmental Management Plans (EMPs) to achieve the objectives and targets

- the formation of Cross Functional Teams (CFTs) made up of individuals from across the installation, to assist the installation EMS Coordinator with ensuring the EMS is implemented and sustained.

- The U.S. Air Force EMS Implementation Guidance Series, Module II, Implementation \& Operation Phase, in coordination, provides MAJCOMs and installations with a step-by-step methodology for implementing the "Do Phase" of the Air Force EMS. Specifically, the guide covers:

- Structure and Responsibility: assigning roles and responsibilities and delegation of the necessary authority to ensure sound management of the EMS

- Training, Awareness, and Competence: identifying requirements and providing training to personnel whose work activities have the potential to impact the environment

- Communication and Reporting: developing and fielding of procedures to improve the flow of information between installation organizations, as well as between the installation and other functions, groups, and/or stakeholders

- Document Management and Control: ensuring that only current versions of EMS documents are available at all locations with environmental impacts

- Operational Control: ensuring operational controls are placed on all aspects to minimize their potential negative environmental impact(s)

- Emergency Response: establishing and maintaining procedures to identify potential emergency situations and prepare a response to each identified situation.

- The U.S. Air Force EMS Implementation Guidance Series, Module III, Checking/Corrective Action and Management Review Phases, under Development, provides MAJCOMs and installations with a step-by-step methodology for implementing the "Check and Act Phases" of the Air Force EMS. Specifically, the guide covers:

- Monitoring and Measuring: assessing the achievement of objectives and targets, the status of operational controls, the maintenance of regulatory compliance, and other parameters that must be watched to ensure the EMS remains effective

- Nonconformance and Checking and Corrective Actions: assessing the installation's compliance with regulatory requirements and conformance with the tenants of its EMS, and implementing corrective actions to address identified areas of noncompliance/nonconformance.

- Management Review: allowing the installation's senior leadership to determine if the EMS continues to be suitable, adequate, and effective for the organization, and to make corrections against noted deficiencies in policies and/or procedures.

- HQ USAF/ILEV Memorandum, Revised Environmental Quality Metrics, 14 February 2005, requires immediate implementation across the AF (including overseas installations and government-owned/contractor-operated (GOCO) facilities of Under Secretary of Defense Memorandum, Revised Pollution Prevention and Compliance Metrics, dated 12 October 2004.

\section{B. DOD Directives/Instructions}

\section{Environmental Impacts}

- None

\section{Environmental Noise}

- None 


\section{Cleanup (Restoration)}

- None

\section{Pollution Prevention}

- Department of Defense Instruction (DODI) 4715.4, Pollution Prevention, 18 June 1996, implements policy, assigns responsibility, and prescribes procedures for implementation of pollution prevention programs throughout the Department of Defense (DOD). Only those portions of the Instruction that are applicable outside the United States are included here.

- Memorandum from the Office of the Under Secretary of Defense, Qualified Recycling Program Guidance, 24 April 2003, supplements DODI 4715.4, para 6.2.3.3, with guidance on the management and distribution of recycling proceeds. DOD components are directed to incorporate that guidance into their respective componentspecific QRP guides. None of the memorandum's provisions are included in this manual.

- Under Secretary of Defense Memorandum, Establishment of the DOD Green Procurement Program (GPP). This memo, dated 27 August 2004, stipulates that the DOD goal is to achieve 100 percent compliance with mandatory Federal GPP programs in all acquisition transactions, from major systems programs to individual unit supply and service requisitions.

- Under Secretary of Defense Memorandum, Department of Defense (DOD) Integrated (Nonhazardous) Solid Waste Management Policy, dated 01 February 2008, implements the solid waste and recycling requirements of Executive Order 13423, Strengthening Federal Environmental, Energy, and Transportation Management, 24 January 2007 by requiring all facilities to maintain waste prevention and recycling programs in the most costeffective manner possible and setting solid waste diversion goals to be achieved by 2010 for the DOD. DOD Component installations are therefore required to implement integrated solid waste management (ISWM) to achieve these goals. The diversion goal for nonhazardous solid waste without construction and demolition (C\&D) waste is 40 percent by 2010. The goal for C\&D waste is 50 percent diversion by 2010 . The guidelines for implementing ISWM that make up the bulk of the document are "recommended procedures" only (DOD ISWM Policy, para B.1). The guidelines focus on reducing waste generation and maximizing diversion from disposal with emphasis on expanding and improving recycling programs.

\section{Program Management}

- Under Secretary of Defense Memorandum, Revised Pollution Prevention and Compliance Metrics, dated 12 October 2004, publishes pollution prevention (P2) metrics and definitions. Implementation begins in 2005. The following goals with respect to enforcement actions are established in the memorandum:

1. Full and sustained compliance with environmental obligations

2. Maintain robust self-audit and corrective action programs

3. Identify and correct noncompliance in a timely manner.

\section{Environmental Management System (EMS)}

- Assistant Deputy Undersecretary of Defense for Environment (ADUSD(E)) Memorandum, Environmental Management System (EMS) Implementation Criteria and Metrics, 30 January 2003, requires that the installation's EMS include an environmental policy statement, a self-assessment, a prioritized list of aspects, awareness-level EMS training, and a management review. It also calls for a written implementation plan and identifies specific metrics that must be reported during the implementation phase.

- Under Secretary of Defense Memorandum, Revised Pollution Prevention and Compliance Metrics, dated 12 October 2004, publishes pollution prevention (P2) metrics and definitions. Implementation begins in 2005. The following goals for environmental management systems are established in the memorandum:

1. Enhance mission performance by improving management of the environmental aspects of the mission 
2. Implement environmental management systems at all appropriate facilities by 31 December 2005 (as required by Executive Order 13148)

3. Pursue synergies with safety and occupational health management systems where appropriate.

- DOD Instruction 4715.17, Environmental Management Systems. This instruction, dated 15 April 2009, establishes policy, assigns responsibilities, and prescribes procedures for achieving conformance with Environmental Management Systems (EMS) pursuant to EO 13423 and the Council on Environmental Quality (CEQ) Instructions. This DODI applies to all DOD appropriate facilities and/or organizations worldwide, including installations; Government-owned, contractor-operated facilities; and DOD Components that are a host of or tenant on any DOD appropriate facility. The DODI does not apply to the operations of U.S. military vessels or aircraft, or to off-installation operational and training deployments. Off-installation operational deployments include cases of hostilities, contingency operations in hazardous areas, and when U.S. forces are operating as part of a multinational force not under full control of the United States. Such excepted operations and deployments shall be conducted in accordance with applicable international agreements, other DODDs and DOD Instructions (DODIs), and environmental annexes incorporated into operation plans or operation orders.

\section{Service-specific/DOD Definitions}

- Administrative/Operational Related Enforcement Action - any violation which results from incorrect administrative procedures; e.g. labeling problems, late reporting, improper storage of material/waste, and training (Attachment 2, Under Secretary of Defense Memorandum, Revised Pollution Prevention and Compliance Metrics, 12 October 2004).

- Affirmative Procurement - Federal agencies must establish programs to encourage purchase of products containing recycled materials, in particular, USEPA Guideline Items. Affirmative procurement programs must establish preference for products containing recycled material, must include a promotion plan to place emphasis on buying recycled, and must have procedures for obtaining and verifying estimates and certifications of recycled content (AFI 32-7080, Attachment 1, Section C).

- Alternatives - ways of reducing adverse effects of hazardous materials (HM). Alternatives, as applied to HM decision making, include, but are not limited to, such possibilities as substituting less hazardous or nonhazardous material; redesigning a component such that HM is not needed in its manufacture, use, or maintenance; modifying processes or procedures; restricting users; consumptive use; on-demand supply; direct ordering; extending shelf life; regenerating spent material; downgrading and reuse of spent material; use of waste as raw material in other manufacturing and combinations of those factors. Alternatives are to be analyzed in a could cost approach, considering what the lowest amount the decision could cost by overcoming barriers to getting the job done, while ensuring protection of human health and the environment (AFI 32-7080, Attachment 1, Section C).

- Appropriate Facility - defined in CEQs "Instructions for Implementing Executive Order 13423, Strengthening Federal Environmental, Energy, and Transportation Management” from March 2007. Additionally, for the purpose of this Instruction: A DOD EMS appropriate facility is typically a host command and its tenants within an installation fence line demarking contiguous property, as well as any satellite properties under direct control of the installation commanding officer (ICO). The appropriate facility may encompass multiple noncontiguous fence lines under direct control of the ICO or even the entire area of responsibility of the regional commander. An appropriate facility may also be defined as a major-mission tenant such as a naval shipyard or naval hospital when a major command elects to define its component command EMS separate from, but in coordination with, the respective host activity EMS (DODI 4715.17, Glossary, Part II).

- Appropriate Organization - defined in CEQs “Instructions for Implementing Executive Order 13423, Strengthening Federal Environmental, Energy, and Transportation Management” from March 2007. Additionally, for the purpose of this Instruction, an EMS appropriate organization is any DOD organization that conducts activities that can have a significant impact on the environment, either directly or indirectly, individually or cumulatively, due to the operations of that organization's mission, processes, or functions (DODI 4715.17, Glossary, Part II). 
- Appropriate Technical Representative (ATR) - the individual responsible for certifying that there are no Air Force preferred alternatives or commercially available, technically and economically feasible alternatives for an existing ozone depleting substance (ODS) requirement that do not increase the environment, safety, and occupational health risks and costs. It must be the person who has the authority to change the process or design that requires the use of the ODS, e.g., the Single Manager (SM) of a weapon system (AFI 32-7086, Attachment 1).

- Baseline - Quantified starting points from which progress is measured. For the purposes of this instruction, baselines are quantities of material purchased or generated over a specified period of time (AFI 32-7080, Attachment 1, Section C).

- Best Management Practices (BMP) - measures or practices to eliminate or reduce pollutants entering surface water, air, land, or groundwater. A Best Management Practice can be a process, activity, or physical structure. Structural BMPs include infiltration devices, ponds, filters and constructed wetlands. Non-structural BMPs include low impact development practices and management measures such as maintenance practices, street sweeping, public education and outreach programs (AFI 32-7041, Attachment 1).

- Biosolids - the byproduct of municipal wastewater treatment, also are known as sewage sludge (AFI 32-7041, Attachment 1).

- Categorical Effluent Limit - effluent contaminant limit using technology-based discharge standards developed by the Environmental Protection Agency for categories of industries (40 CFR 403 through 471) (AFI 32-7041, Attachment 1).

- Categorical Waste - an Environmental Protection Agency waste category under 40 CFR 403 through 471 (AFI 32-7041, Attachment 1).

- Characteristic Waste - a waste that exhibits any of the characteristics listed in 40 Code of Federal Regulations (CFR) 261, Subpart C (i.e., toxicity, corrosiveness, ignitability, reactivity) (AFI 32-7080, Attachment 1, Section $\mathrm{C})$.

- Closed Enforcement Action - an enforcement action that is resolved by (AFI 32-7047, Attachment 1 and para 2.4.4) [Added May 2004]:

1) revocation of the action by the issuing regulator

2) closure of the action following written notice by the regulator that the action is closed

3) closure of the action after 60 days following written notice to the regulator of an installation's intent to close an enforcement action if the regulator does not provide a written response

4) receipt of a signed compliance agreement or order; or

5) determination by the AFCEE REO that the EA is not open on regulatory agency records.

(NOTE: For overseas installations the MAJCOM CE and JA must agree the EA is closed, provided that:

1) the host-nation authority has indicated by letter that the planned action is a satisfactory resolution of the cited violations

2) funding for the project has been allocated in full, and

3) there is a clear indication that the project will be completed in a reasonable amount of time [as determined by MAJCOM CE]).

- Closed Enforcement Action - an enforcement action that is resolved by one of the following (Attachment 2, Under Secretary of Defense Memorandum, Revised Pollution Prevention and Compliance Metrics, 12 October 2004):

1. Revocation of the action by the imposing regulator/authority;

2. Closure of the action following written notice by the regulator/authority that the action is closed

3. Closure of the action because the installation has provided written notice to the regulator/authority that all required actions have been completed and no response has been received from the regulator/authority after a reasonable period of time (30-60 days) has elapsed (at least 30 days from the date written notice was provided to the regulatory authority); or 
4. Receipt of a signed compliance agreement or order.

- Combined Wasteload Formula - a formula based on categorical discharge limits that sets discharge limits for categorical wastes mixed with other wastewater (AFI 32-7041, Attachment 1).

- Combined Sewer - a wastewater collection system that collects stormwater and wastewater (AFI 32-7041, Attachment 1).

- Combined-Sewer Overflow - direct discharge of untreated wastewater from a combined sewer (AFI 32-7041, Attachment 1).

- Compliance Management Plan (CMP) - a requirement of EO 13423, in lieu of an EMS, that outlines how an organization will meet environmental compliance requirements within the framework of the President's Management Agenda (DODI 4715.17, Glossary, Part II).

- Composting - the controlled process for managing the degradation of organic materials which is biologically broken down into a useful product such as mulch or a soil (DOD ISWM Policy, para A.2.a).

- Conformance - the appropriate facility or organization meets the requirements of its EMS and ISO 14001:2004 or equivalent EMS in accordance with the DOD Component's EMS declaration of conformance protocol. An EMS with minor non-conformances can be considered conformant as long as corrective action is defined, planned, and endorsed (i.e., "recognized") by senior management. An EMS with non-reconciled major non-conformances cannot be considered in conformance (DODI 4715.17, Glossary, Part II).

- Core Mission Areas - For the purposes of AFI 90-801 and AF Environment, Safety, and Occupational Health (ESOH) programs, the term "Core Mission Areas" refers to the following organizations at every level of command (where they exist): Operations, Maintenance, Mission Support, Medical, and Acquisition (AFI 90-801, Attachment 1).

- Cost Factors - The expense and cost avoidance associated with hazardous materials that may be reduced to monetary terms, which includes future liability. Cost factors refer to direct and indirect costs attributable to hazardous materials that are encountered in operations such as acquisition, manufacture, supply use, supply, use, storage inventory control, treatment, recycling, emission control, training, work place safety, labeling, hazard assessments, engineering controls, personal protective equipment, medical monitoring, regulatory overhead, spill contingency, disposal, remedial action and liability (AFI 32-7080, Attachment 1, Section C).

- Crossconnection - interconnecting separate wastewater collection systems, such as (AFI 32-7041, Attachment 1):

(1) Industrial wastewater collection systems to domestic or storm sewers;

(2) Stormwater collection systems to domestic or industrial sewers;

(3) Domestic wastewater collection systems to storm or industrial sewers; and

(4) Unregulated non-stormwater discharges.

- Cross-Functional Team (CFT) - a group of people representing key organizations to include operations, maintenance, safety, environment, occupational health, transportation, ranges, and any others deemed critical for development and execution of ESOH initiatives. Typically, it also includes military, civilian and contractor personnel from all levels of the organizations. The ESOHMS coordinator usually chairs the team. He or she may wish to contact facility tenants, non-AF entities, and other units to serve on the CFT. The team is given broad objectives, but not specific directives. Decision-making within the team is usually based on consensus (AFI 90-801, Attachment 1).

- Decision Date - the date an installation or major command makes a decision to adopt a specific fix to correct an enforcement action violation (AFI 32-7047, Attachment 1). 
- Designated Employee Representative - an individual selected by civilian employees, either directly or through an exclusive representation bargaining agreement, to represent them as a member of the ESOHC (AFI 90-801, Attachment 1).

- Discharge Limit - the maximum pollutant concentration that a discharge permit allows (AFI 32-7041, Attachment 1).

- Discharge Permit - a permit that authorizes discharging wastewater or stormwater to the waters of the United States, or host nation, or to a POTW. There are two types of discharge permits, individual and general, and many permits include maximum contaminant levels allowed in the discharge (AFI 32-7041, Attachment 1).

- Disputed EA - a disputed EA occurs when the Air Force (Installation or MAJCOM CE) do not agree with the basis of the EA. Disputed EAs are reported in the same manner as all other OEAs. MAPs are required, however indicate in the "EA status classification" section that it is a disputed EA. Include in the MAP why the EA was issued and the rational for the dispute. Disputed EAs will not be reported outside the Air Force structure and will not be included in the OEA compliance metric until the dispute has been resolved (AFI 32-7047, Attachment 1 and para 2.4.1).

- Diversion (Solid Waste) - an activity to divert solid waste from landfill disposal or incineration, including reuse, donation, recycling, and composting/mulching. Diversion activities must be in accordance with all applicable DOD, DOD Component, federal, state and local requirements. Waste to energy recovery is not considered diversion for the solid waste diversion goal although it is applicable to the energy reduction goals of EO 13423 (DOD ISWM Policy, para A.2.b).

- DLA Class I ODS Defense Reserve - the only approved source of supply for Air Force Class I ODS usage requirements. Requires AF Form 3952 authorization and Senior Acquisition Official (SAO) approval from the HQ USAF HMMP team before DLA will process a requisition for a Class I ODS from the DLA Class I ODS Defense Reserve (AFI 32-7086, Attachment 1).

- DOD-Managed Treatment Works - for overseas installation, wastewater treatment works that are operated by Department of Defense (DOD) personnel, may or may not be owned by DOD, and are regulated under the FGS, the OEBGD, and/or host nation discharge permit (AFI 32-7041, Attachment 1).

- Domestic Sewer - a conveyance system for domestic or pretreated industrial wastewater collection (AFI 32-7041, Attachment 1).

- Domestic Wastewater - wastewater that contains human wastes and wastewater from food preparation, laundry, bathing, and similar activities. Domestic wastewater typically includes wastewater from housing units and wastewater from commercial or industrial facilities that is similar to that from housing units. Domestic wastewater does not include industrial process wastewater (AFI 32-7041, Attachment 1).

- Economic Analysis - An evaluation of the costs associated with the use of hazardous materials and potential alternatives. An economic analysis is not a specific, step-by-step procedure that can be applied by rote to all cases of analyzing whether to use a hazardous material. Rather, organizations shall be guided by basic principles of economics and informed judgment (AFI 32-7080, Attachment 1, Section C).

- Enforcement Action - a formal, written notification by the appropriate host-nation environmental regulatory authority of violation of any applicable environmental standard (as defined in the FGS). It should cite the relevant standard or criterion to be met and request the installation take corrective action. An enforcement action does not include warning letters that do not cite a violation of specific environmental law or regulation, informal notices of deficiencies, or notices of deficiencies to permit applications. (Note: Warning letters or similarly titled formal written notifications from authorized regulators that do cite violations with environmental laws and regulations, are considered enforcement actions.) One written notice, regardless of the number of individual violations, findings, or citation listed in it, counts as one enforcement action if all violations cited relate to a single environmental media. If the enforcement action cites violations of more than one environmental media area (e.g., air, 
hazardous waste, drinking water, etc.), then count it as multiple enforcement actions, one under each applicable media area. Items found to be out of compliance during an internal or other DOD Component review, compliance review or audit, are not to be counted as (included in this definition of) an enforcement action (Attachment 2, Under Secretary of Defense Memorandum, Revised Pollution Prevention and Compliance Metrics, 12 October 2004).

- Enforcement Action - for the purposes of reporting an EA, the document must meet all of the following three conditions (HQ USAF/A7CV, Policy Memorandum on Environmental Compliance Tracking and Reporting Requirements, 16 June 2006, pp. 1 and 2):

a. must be written (formal letter; e-mail; or field citation with fine/penalty)

b. state or indicate noncompliance with specific statute, regulation, or permit requirements

c. require corrective action on the part of the installation ("action" includes, but is not limited to, return to compliance, submit a report, meet with the agency, conduct additional sampling, update a plan, and also includes implied actions associated with the cause of noncompliance).

(NOTE: See also Other Notices of Noncompliance.)

- Environment - the natural and physical environment, and it excludes social, economic, and other environments. Social and economic effects do not give rise to any requirements under this 32 CFR 187 (32 CFR 187.3(a)).

- Environment, Safety, and Occupational Health (ESOH) - includes environmental programs (pollution prevention, conservation, clean-up, etc.), environmental health, fire protection, safety, and occupational health disciplines (AFI 90-801, Attachment 1).

- Environment, Safety, and Occupational Health Councils (ESOHC) - the ESOH steering group that reviews policies and programs, establishes goals, monitors progress, and advises leadership (AFI 90-801, Attachment 1).

- Environment, Safety, and Occupational Health Compliance Assessment and Management Program (ESOHCAMP) - an integrated environment, safety, and health process designed to help commanders assess their installation's environment, safety, and occupational health risk and cost reduction programs and to identify and track solutions to ESOH problems (AFI 90-801, Attachment 1).

- Environment, Safety, and Occupational Health Management System (ESOHMS) - the AF's management system designed to continually improve mission performance by systematically identifying and reducing ESOH risks and costs (AFI 90-801, Attachment 1).

- Environmental Aspect - an element of an organization's activities or products that can interact with the environment. The environmental aspect of an activity is that part of it that creates a possibility for an environmental impact. When considering safety in the scope of an EMS, the environmental aspect is equivalent to the concept of hazard, which is also defined as the possibility of a negative event (DODI 4715.17, Glossary, Part II).

- Environmental Health - the discipline and program concerned with identifying and preventing illness and injury due to exposure to hazardous chemical, physical, and biological agents that may be encountered in the ambient environment - air, water, or soil at in-garrison and deployed locations (AFI 90-801, Attachment 1).

- Environmental Manager - The Base environmental management function supervisor or designated representative. Synonymous with the term Environmental Coordinator (AFI 32-7080, Attachment 1, Section C).

- Environmental Objective - an overall environmental goal an organization sets that is based on its environmental policy and is quantified when practicable (DODI 4715.17, Glossary, Part II).

- Environmental Performance - the measurable results of an EMS related to an organization's control of its environmental aspects based on its environmental policy, objectives, and targets (DODI 4715.17, Glossary, Part II). 
- Environmental Policy - the overall intentions and direction of an organization related to its environmental performance as formally expressed by top management (DODI 4715.17, Glossary, Part II).

- Environmental Target - a detailed performance requirement, quantified when practicable and applicable to the organization or parts thereof, that arises from the organization's environmental objectives and that must be set and met to achieve those objectives (DODI 4715.17, Glossary, Part II).

- Environmentally Preferable - Products or services that are less harmful to human health and the environment to use, reuse, operate and maintain, and dispose of in comparison with competing products or services of equal value (AFI 32-7080, Attachment 1, Section C).

- Estimated Compliance Date - the date an installation or major command expects a regulator to acknowledge corrections for all findings of an EA (AFI 32-7047, Attachment 1).

- Excluded Materials - excluded items may not be sold through a qualified recycling program (QRP), and the proceeds from their sale shall not be returned to a QRP. Excluded items include, but are not limited to: (DODI 4715.4, Enclosure 3):

a. government-furnished material

b. precious metal bearing scrap

c. hazardous waste (including household hazardous waste)

d. ozone-depleting substances (ODS)

e. electrical components

f. unopened containers of solvents, paints, or oil

g. fuel

h. material that can be sold (as is) as a usable item

i. repairable items that may be used again for their original purposes or functions, e.g., used vehicles, vehicle or machine parts, etc.

j. ships, aircraft, weapons, and other material required to be demilitarized or mutilated, and scrap resulting from demilitarization

k. all Munitions List Items and Strategic List Items as defined in DOD 4160.21-M-1, except firing range expended brass and mixed metals gleaned from firing range cleanup

1. types of surplus personal property whose sales proceeds must be deposited to accounts other than a QRP per 32 CFR 172, Appendix B

1. scrap generated from Defense Business Operations Fund (DBOF) activities

2. usable personal property purchased by DBOF activities

3. property purchased with commissary surcharge funds

4. automatic data processing equipment owned by the General Services Administration (GSA)

5. property purchased for the Military Assistance Program or purchased with Foreign Military Sales Administrative funds

6. Coast Guard property

7. property owned by nonappropriated fund activities

8. lost, abandoned, or unclaimed privately owned personal property

9. property owned by a country or international organization

10. bones, fats, and meat trimmings generated by a commissary.

- Exfiltration - flow out of a sewer to the subsurface due to sewer pipe leakage from breaks or joints (AFI 32-7041, Attachment 1).

- External Audit - a second-party EMS audit performed by a qualified party from outside the control or scope of the EMS (DODI 4715.17, Glossary, Part II).

- Facility - all buildings, equipment, structures, and other stationary items which are located on a single site or on contiguous or adjacent sites and which are owned or operated by the same person (or by any person which controls, is controlled by, or under common control with, such person) (AFI 32-7041, Attachment 1). 
- Facility Response Plan - a plan that establishes a facility’s specific responses to an oil spill (AFI 32-7041, Attachment 1).

- Federal Action - an action that is implemented or funded directly by the United States government. It does not include actions in which the United States participates in an advisory, information- gathering, representational, or diplomatic capacity but does not implement or fund the action; actions taken by a foreign government or in a foreign country in which the United States is a beneficiary of the action, but does not implement or fund the action; or actions in which foreign governments use funds derived indirectly from United States funding (32 CFR 187.3(b)).

- Fix Date - the date an installation or major command expects to notify a regulator that corrections were made for all findings of an EA (AFI 32-7047, Attachment 1).

- Foreign Nation - any geographic area (land, water, and airspace) that is under the jurisdiction of one or more foreign governments; any area under military occupation by the United States alone or jointly with any other foreign government; and any area that is the responsibility of an international organization of governments. "Foreign nation" includes contiguous zones and fisheries zones of foreign nations. "Foreign government" in this context includes governments regardless of whether recognized by the United States, political factions, and organizations that exercise governmental power outside the United States (32 CFR 187.3(c)).

- Full Implementation - for the purpose of this Instruction and conformance to EO 13423, an EMS shall be considered fully implemented when (DODI 4715.17, Glossary, Part II):

1. it has been the subject of a formal audit by a qualified party outside the control or scope of the EMS;

2. audit findings have been recognized by the appropriate level of the agency implementing the EMS; and

3. the appropriate senior manager accountable for implementation of the EMS has declared conformance to EMS requirements.

- Global Commons - geographic areas that are outside the jurisdiction of any nation, and include the oceans outside territorial limits and Antarctica. Global commons do not include contiguous zones and fisheries zones of foreign nations (DODD 6050.7, para C(4) and 32 CFR 187.3(d)).

- Hazardous Materials - Any substances or materials that pose a threat to human health or the environment typically due to their toxic, corrosive, ignitable, explosive, or chemically reactive nature. More specific definitions may be found in various Federal regulations that implement statutes (i.e., Hazardous Material Transportation Act, Comprehensive Environmental Response, Compensation, and Liability Act (CERCLA)) (AFI 32-7080, Attachment 1, Section C).

- Hazardous Material Management Process (HMMP) - a standard methodology used to manage and track the procurement and use of HAZMAT to support Air Force missions, protect the safety and health of personnel on Air Force installations and communities surrounding Air Force installations from misuse of HAZMAT, minimize Air Force use of HAZMAT consistent with mission needs, and to maintain Air Force compliance with environmental requirements for HAZMAT usage. The HMMP is composed of three interdependent programs: the HAZMAT Pharmacy Program (IHMP), the Weapon System Hazardous Material (HAZMAT) Program (WSHP), and the ODS Program (ODSP) (AFI 32-7086, Attachment 1).

- Hazardous Material Pharmacy - Single point control of hazardous material (AFI 32-7080, Attachment 1, Section C).

- Hazardous Waste - Any waste by-products of society that can pose a substantial or potential hazard to human health or the environment when improperly managed; possess at least one of five characteristics (toxic, corrosive, ignitable, explosive, or chemically reactive) or are listed in 40 CFR 261.3 or applicable state or local waste management regulations (AFI 32-7080, Attachment 1, Section C).

- Hazardous Waste Characterization - the identification, description, and quantification of a hazardous waste stream (AFI 32-7080, Attachment 1, Section C). 
- HAZMART - a HAZMART is the "customer service desk" for the IHMP, and is the only entity on an installation authorized to issue government-owned HAZMAT. At a minimum, a HAZMART is a facility or location where customers can receive support for obtaining HAZMAT, and where HAZMAT are managed and tracked. A HAZMART is intended to be the primary location on an installation where LRS personnel stock, store, issue, and distribute HAZMAT. Each installation must have at least one primary HAZMART established by, and accountable to, the LRS commander. The HMMP team may designate additional unit-controlled supply activities as HAZMARTs, performing all the functions of the primary HAZMART. The HAZMART responsibilities include the receipt and entry of data on Government-wide Purchase Card purchases of HAZMAT and the receipt and entry of data on contractor usage of HAZMAT (AFI 32-7086, Attachment 1).

- Host Nation Enforcement Action (HNEA) - any written notice from a host-nation governmental authority indicating one or more violations of host nation environmental requirements validated by the MAJCOM environmental office and judge advocate, reflecting noncompliance with DOD FGS or OEBGD, obligations under applicable international agreements, or posing a known imminent and substantial endangerment to human health, safety or the environment (AFI 32-7047, Attachment 1 and para 2.3.1.1).

- Inadvertent Release - unintended and unplanned releases. Inadvertent releases do not include releases resulting from the intended use of the material (e.g., the release of halons in actual fire fighting or fuel tank inerting) (AFI 32-7086, Attachment 1).

- Industrial Sewer - a conveyance system for collecting industrial wastewater (AFI 32-7041, Attachment 1).

- Industrial Sludge - sludge from and wastewater treatment process or works that is not part of a domestic wastewater treatment system (AFI 32-7041, Attachment 1).

- Industrial Wastewater - wastewater from industrial activities such as electroplating, metal finishing, aircraft maintenance, corrosion control, vehicle maintenance, and other industrial processes at Air Force installations (AFI 32-7041, Attachment 1).

- Infiltration - groundwater that leaks into wastewater collection systems due to leakage through pipe breaks or joints (AFI 32-7041, Attachment 1).

- Inflow - stormwater flow into wastewater collection systems (AFI 32-7041, Attachment 1).

- Informal Notice - notification, possibly verbal, from a regulatory agency explaining a deficiency with respect to an environmental law or regulation not warranting issuance of a formal written EA in the judgment of the regulator (AFI 32-7047, Attachment 1).

- Installation - a piece of real property owned or controlled by the military (AFI 32-7041, Attachment 1).

- Integrated Solid Waste Management (ISWM) - a comprehensive approach to managing non-hazardous solid waste that encompasses waste prevention, recycling, composting, and disposal programs. Through ISWM, DOD Components seek to determine the most cost effective, energy-efficient, least-polluting ways to deal with the various segments of, and the items typically found in, an installation or facility solid waste stream (DOD ISWM Policy, para A.2.c).

- ISWM Hierarchy - ISWM employs a hierarchy of approaches and technologies for managing solid waste to maximize resource conservation and protect the environment. Generally, the higher in the hierarchy for the technology or process, the more benefits gained in efficiency and retained economic value. The ISWM hierarchy is listed below from highest to lowest (DOD ISWM Policy, para A.3):

1. Source Reduction

2. Reuse

3. Donation

4. Recycling 
5. Composting/Mulching

6. Incineration for Volume Reduction with Energy Recovery

7. Other Forms of Volume Reduction

8. Landfilling.

- Interference - disrupting a POTW operation or treatment by discharging an incompatible pollutant or waste stream to the POTW (AFI 32-7041, Attachment 1).

- Internal Audit - a first-party EMS audit led by a qualified party within the scope of the EMS under consideration (DODI 4715.17, Glossary, Part II).

- Level 1 Projects and Services - in the context of the A-106 Pollution Abatement Plan (AFI 32-7001, para 3.4.2.1.1):

1. correct conditions out of compliance with the FGS or the Overseas Environmental Baseline Guidance Document (OEBGD) if there are no FGS (see AFI 32-7006)

2. restore contaminated sites posing imminent and substantial endangerment to human health and safety

3. restore contaminated sites as needed to sustain current operations.

- Level 2 Projects and Services - in the context of the A-106 Pollution Abatement Plan, these address (AFI 327001, para 3.4.2.2.1):

1. conditions that will be out of compliance with future requirements of international agreements such as treaties, Status of Forces Agreements (SOFAs), or bilateral agreements

2. conditions that will be out of compliance with future FGS requirements.

- Level 3 Projects and Services - in the context of the A-106 Pollution Abatement Plan, these projects and services enhance the environment beyond current and future FGS requirements. (AFI 32-7001, para 3.4.2.2)

(NOTE: Do not use U.S. funds to restore contaminated sites beyond that needed to eliminate imminent and substantial endangerment to human health and safety or sustain current operations (unless required by international agreement).)

- Life Cycle Economic Analysis - An evaluation of the costs associated with the use of hazardous materials and potential alternatives over the life of the investment or hazardous material. The analysis is not a specific, step-bystep procedure that can be applied by rote to all cases. Analysis shall be guided by basic principles of economics and informed judgment (AFI 32-7080, Attachment 1, Section C).

- Life Cycle of Hazardous Material - The period starting when the use or potential use of hazardous material is first encountered and extending as long as the actual material or its after effects, such as a discarded residual in a landfill, have a bearing on cost. In the case of weapon system acquisition, the life cycle starts when the system is first envisioned. Effects of the use of hazardous material on later operations and maintenance are to be considered. This also holds true for a new use of a hazardous material. Where the hazardous material is already in general use, the life cycle starts when the material is first encountered by any organization that must deal with it (AFI 327080, Attachment 1, Section C).

- Lift Station - a wastewater collection system that pumps wastewater from a gravity sewer to a sewer or treatment plant at a higher elevation (AFI 32-7041, Attachment 1).

- Major Action - an action of considerable importance involving substantial expenditures of time, money, and resources, that affects the environment on a large geographic scale or has substantial environmental effects on a more limited geographical area, and that is substantially different or a significant departure from other actions, previously analyzed with respect to environmental considerations and approved, with which the action under consideration may be associated. Deployment of ships, aircraft, or other mobile military equipment is not a major action for purposes of this part (32 CFR 187.3(e)). 
- Management Practice (MP) - practices that, although not mandated by law, are encouraged to promote safe operating procedures.

- Media - The term referring to air, land, water, and groundwater (AFI 32-7080, Attachment 1, Section C).

- Municipal Separate Storm Sewer - a conveyance or system of conveyances designed or used for collecting and conveying stormwater (including roads with drainage systems, municipal streets, catch basins, curbs, gutters, ditches, man-made channels, or storm drains), that is owned or operated by a state, city, town, borough, county, parish, district, association, or other public body (AFI 32-7041, Attachment 1).

- Municipal Solid Waste (MSW) - trash wastes generated by administrative and domestic activities. MSW does not include hazardous wastes (AFI 32-7080, Attachment 1, Section C).

- New Enforcement Action - any enforcement action received during the reporting period, including those that were both received and closed out during the period. The date of an enforcement action is to be considered the date that the formal written notification has been received from the regulator/authority (Attachment 2, Under Secretary of Defense Memorandum, Revised Pollution Prevention and Compliance Metrics, 12 October 2004).

- Nonpoint or Nonstationary Source (NPS) Pollution - A diffuse source of pollution that does not discharge through a single point, such as (AFI 32-7080, Attachment 1, Section C):

1. for water - runoff from construction activities and agricultural, silvicultural, urban areas, and industrial areas including airfield operating areas

2. for air - aircraft test stands, vehicles, aerospace ground equipment (AGE), and aircraft operations.

- Nonpoint Source - a pollutant source that does not meet the definition of "point source." Nonpoint source pollution generally results from land runoff, atmospheric deposition, drainage, or seepage (AFI 32-7041, Attachment 1).

- Notice of Intent - an application to notify the permitting authority of a facility's intention to be covered by a general permit (AFI 32-7041, Attachment 1).

- Notice of Termination - an application used to notify the permitting authority of a facility's termination of coverage under a general permit (AFI 32-7041, Attachment 1).

- Occupational Health - the discipline and program concerned with identifying potential hazards in the workplace and preventing illness resulting from work-related factors. It includes the prevention of illness during deployments to reduce disease and nonbattle injury - (DNBI) rates (AFI 90-801, Attachment 1).

- Open Enforcement Action (OEA) - for overseas installations, a written notice from a host-nation regulatory authority indicating one or more violations of host-nation environmental requirements that has been validated by the MAJCOM Environmental Protection Committee (EPC) Compliance Subcommittee (AFI 32-7047, Attachment 1 and para 2.3.1.1).

- Open Enforcement Action - an enforcement action that has been issued, but is not yet closed by one of the resolutions described under the definition of closed enforcement action. An open enforcement action is further broken down into two subcategories: pending enforcement action and unresolved enforcement action (Attachment 2, Under Secretary of Defense Memorandum, Revised Pollution Prevention and Compliance Metrics, 12 October 2004).

- Operator - an owner or operator of any "facility or activity" subject to regulation under the NPDES program (AFI 32-7041, Attachment 1).

- Opportunity Assessment - A systematic procedure to identify and assess ways to prevent pollution by reducing or eliminating wastes (AFI 32-7080, Attachment 1, Section C). 
- Other Notices of Noncompliance (ONONs) - written notices indicating noncompliance that do not meet the definition of an EA (HQ USAF/A7CV, Policy Memorandum on Environmental Compliance Tracking and Reporting Requirements, 16 June 2006, p. 2).

- Other Qualified Recyclable Program Materials - materials that fit neither the definition of recyclable materials nor the definition of excluded materials (DODI 4715.4, Enclosure 3).

- Overseas Installation - permanent, base force structure facilities under the operational control of the Secretary of a military department or the Department of Defense that is located outside the United States and outside any territory, commonwealth or possession of the United States. Installations overseas do NOT include temporary, contingency operation or deployment support facilities. Tenants on overseas installations should report through their component headquarters reporting systems (Attachment 2, Under Secretary of Defense Memorandum, Revised Pollution Prevention and Compliance Metrics, 12 October 2004).

(NOTE: Include Government-owned, Contractor-operated [GOCO] installations.)

- Ozone-Depleting Chemicals (ODCs) - Chlorofluorocarbons, halons, and other substances that deplete the stratospheric ozone layer as classified by the Clean Air Act (CAA) Amendment of 1990 (AFI 32-7080, Attachment 1, Section C).

- Ozone Depleting Substance (ODS) - refers to Class I and Class II ODS, as defined by the Montreal Protocol on Substances that Deplete the Ozone Layer (AFI 32-7086, Attachment 1).

- Pending Enforcement Action - an enforcement action for which the deficiency(ies) has been corrected but remains open, pending agreement or order by the regulator that it is closed (AFI 32-7047, Attachment 1 and para 2.4.3).

- Permits - count the number of separate permits, not the number of permitted units or activities (Attachment 2, Under Secretary of Defense Memorandum, Revised Pollution Prevention and Compliance Metrics, 12 October 2004).

- Point Source - any discernible confined and discrete conveyance from which pollutants are or June be discharged, excluding agricultural stormwater discharges and return flows from irrigated agriculture. Point sources include (AFI 32-7041, Attachment 1):

(1) Pipes

(2) Ditches

(3) Channels

(4) Tunnels

(5) Conduits

(6) Wells

(7) Discrete fissures

(8) Containers

(9) Rolling stock

(10) Concentrated animal feeding operations

(11)Landfill leachate collection systems

(12) Vessel or other floating crafts.

- Pollution Prevention - All the actions necessary, to include use of processes, practices, products, or management actions that eliminate or reduce undesirable impacts on human health and the environment. These actions are a hierarchy of source reduction, recycling, treatment, and disposal or means source reduction and other practices that reduce or eliminate the creation of pollutants through increased efficiency in the use of raw materials, energy, water, or other natural resources, and the protection of natural resources (AFI 32-7080, Attachment 1, Section C). 
- Pretreatment - treatment of industrial wastewater required under federal, state or POTW pretreatment regulations to meet contaminant concentration limits (AFI 32-7041, Attachment 1).

- Pretreatment Permit - authorization to discharge untreated or pretreated industrial wastewater to a POTW. Permit prescribes maximum contaminant concentration limits in wastewater (AFI 32-7041, Attachment 1).

- Project-Related Enforcement Action - violation that requires a facility-related change to correct, regardless of funding level, minor or major construction, or repairs and is a Class I requirement (see DODI 4715.6). NOTE: If a single enforcement action contains both project and administrative/operational related violations, portray the action as "project related" (Attachment 2, Under Secretary of Defense Memorandum, Revised Pollution Prevention and Compliance Metrics, 12 October 2004).

- Proponent - any office, unit, or activity that proposes to initiate an action (32 CFR 989, Appendix A).

- Publicly-Owned Treatment Works (POTW) - a treatment plant belonging to a state, county, regional agency, or municipality that treats domestic wastewater or pretreated industrial wastewater (AFI 32-7041, Attachment 1).

- Pump Station - See Lift Station.

- Qualified Party - an EMS auditor who has successfully completed an accredited EMS lead auditor training course or equivalent DOD Component training. A qualified party may be staff, other DOD Components, other non-DOD Federal agencies, and/or private consultants. Personnel conducting external EMS audits must be outside the scope of the subject EMS (DODI 4715.17, Glossary, Part II).

- Qualified Recycling Program (QRP) - organized operations that require concerted efforts to divert or recover scrap or waste, as well as efforts to identify, segregate, and maintain the integrity of the recyclable materials in order to maintain or enhance their marketability. If the program is administered by a DOD component, a QRP includes adherence to a control process providing accountability for all materials processed through program operations (DODI 4715.4, Enclosure 3).

- Qualified Recycling Program (QRP) - a recycling program organized that requires diversion or recovery of recyclable materials from the non-hazardous solid waste stream. QRP proceeds are distributed in accordance with 10 U.S.C. 2577 (DOD ISWM Policy, para A.2.d).

- Range Operating Agency (ROA) - the agency designated to operate and maintain the range (AFI 13-212, Volume 1, Attachment 1).

(NOTE: The ROA may delegate the daily scheduling, management, and maintenance of the range to any appropriate subordinate unit.)

- Recyclable Materials - recyclable materials can include, but are not limited to: high-quality paper and paper products, mixed paper, newspaper, cardboard, plastic, metal cans, glass, used oil (except when hazardous waste), batteries, and tires. In addition, scrap (including ferrous and nonferrous scrap) and firing range expended brass and mixed metals gleaned from firing range cleanup that do not require demilitarization may be included in a QRP (DODI 4715.4, Enclosure 3).

- Recycling - The series of activities, including collection, separation, and processing, by which products or other materials are recovered from the solid waste stream for use in the form of raw materials in the manufacture of new products other than fuel for producing heat or power by combustion (DODI 4715.4, Enclosure 3).

- Recycling - The use, reclamation, and reuse of a material. Use/reuse includes return of the recovered waste to the original process or when the waste is substituted for a raw material in another process. Waste reclamation includes processing of residual waste to recover a useful product and generation of waste material (AFI 32-7080, Attachment 1, Section C). 
- Recycling - series of activities, including collection, separation, and. processing, by which products or other materials are recovered from the solid waste stream for use in the form of raw materials in the manufacture of new products other than fuel for producing heat or power by combustion (DOD ISWM Policy, para A.2.e).

- Regulated Construction - operations that result in the disturbance of greater than 1 acre of total land, including clearing, grading and excavation activities (AFI 32-7041, Attachment 1).

- Regulatory Inspections During Reporting Period - include all inspections by State, Federal, and Local regulators. Do not include self-audits or inspections by any DOD entity (Attachment 2, Under Secretary of Defense Memorandum, Revised Pollution Prevention and Compliance Metrics, 12 October 2004).

- Requiring Document - the document that requires the use of the requested HAZMAT in a work area. The requiring document will be a TO, owner/operator manual, work specification, or drawing (AFI 32-7086, Attachment $1)$.

- Retracted Enforcement Action - an enforcement action rescinded by the regulator (AFI 32-7047, Attachment 1 and para 2.3.1.1).

- Reuse - the subsequent uses of a product after the initial/first use without any change in its identity (DOD ISWM Policy, para A.2.f).

- Risk - a combination of the probability and severity of a loss or an adverse impact resulting from exposure to hazards. The greater the risk, the more likely it will cause a drain on resource capability and negatively affect the mission (AFI 90-801, Attachment 1).

- Safety - the discipline and program concerned with the prevention of any active or latent condition that can cause mission degradation, injury or death to personnel, or damage to, or loss of, systems, equipment, facilities, or property (AFI 90-801, Attachment 1).

- Sanitary Wastewater - See Domestic Wastewater.

- Senior Acquisition Official (SAO) - the SAF/AQR, HQ USAF/ILE, HQ USAF/ILM, and HQ USAF/ILG General Officer or civilian equivalents that provide centralized HQ USAF control of the ODSP. These SAO offices also have the authority and responsibility for approving an ODS requirement based on an ATR certification that there are no commercially available, technically and economically feasible alternatives that do not increase the environment, safety, and occupational health risks and costs (AFI 32-7086, Attachment 1).

- Source - any building, structure, facility, or installation from which there is or June be the discharge of pollutants (AFI 32-7041, Attachment 1).

- Source Reduction - Any practice that reduces or eliminates any hazardous material, pollutant, or contaminant entering any waste stream or otherwise residual waste generation at the source, usually within the generation process. The term includes equipment or technology modifications, process or procedure modifications, reformulation or redesign of products, feedstock substitutions, improvements in feedstock purity, shipping and packaging modifications, improvements in housekeeping, maintenance, training, and management practices, increases in machinery efficiency, and recycling within a process (AFI 32-7080, Attachment 1, Section C).

- Source Reduction - effecting changes in the design, manufacturing, purchase, or use of materials or products (including packaging) to reduce the amount or toxicity before they are discarded (DOD ISWM Policy, para A.2.g).

- Stabilization of Site - BMPs used to stabilize the soil, to reduce raindrop impact, to reduce the velocity of surface runoff, and to prevent erosion (AFI 32-7041, Attachment 1).

- Stormwater Discharge Associated with Industrial Activity - stormwater that has contacted manufacturing operations, or stored raw materials or supplies at an industrial activity, as defined. The Environmental Protection 
Agency defines 11 categories of industrial activities, some of which June apply to Air Force installations, including (AFI 32-7041, Attachment 1):

(1) Air and ground transportation facilities;

(2) Steam electric power generating facilities;

(3) Treatment works treating domestic sewage having a capacity over 1 million gallons per day (MGPD); and

(4) Construction sites.

- Stormwater Management Plan - a plan that documents functions and management practices to be employed at a small municipal separate stormsewer system (MS4) to improve the quality of stormwater runoff (AFI 32-7041, Attachment 1).

- Stormwater Pollution Prevention Plan - a series of steps and activities to identify sources of stormwater pollution at an industrial or construction site, including actions to be taken that will prevent or control stormwater contamination (AFI 32-7041, Attachment 1).

- Stormwater Pollution Prevention Team - a cross-functional committee established at an installation to develop, implement, and manage all stormwater management programs that will be effective in preventing and reducing the discharge of pollutants into receiving waters and will ensure compliance with construction, industrial, and MS4 stormwater permits (AFI 32-7041, Attachment 1).

- Supplemental Environmental Project (SEPs) - environmentally beneficial projects that an alleged violator agrees to undertake in full or partial settlement of an enforcement action, but which the alleged violator is not otherwise legally required to perform. DOD encourages SEPs because they can play a role in securing significant environmental benefits and protection of public health and the environment (Attachment 2, Under Secretary of Defense Memorandum, Revised Pollution Prevention and Compliance Metrics, 12 October 2004).

- Technology-Based Effluent Limit - a discharge standard based on an Environmental Protection Agency review of common treatment technologies for treating a type of wastewater. Technology-based effluent limits are the same for each type of wastewater, regardless of the location or quality of the receiving water (AFI 32-7041, Attachment 1).

- Third Party Audit - an audit conducted by an accredited, independent registrar (e.g., a registrar accredited by the American National Standards Institute and the American Society for Quality National Accreditation Board or equivalent or, for facilities outside the continental United States, a host nation-accredited auditor) (DODI 4715.17, Glossary, Part II).

- Total Fines and Penalties Assessed - those fines and penalties assessed for violation of environmental compliance obligations to which the Department of Defense is subject under applicable Federal and State environmental laws, excluding CERCLA, during the half of the Fiscal Year being reported - i.e. the initial amount assessed by the regulator. Report fines assessed against contractors operating on the installation and note that fine is against the contractor (Attachment 2, Under Secretary of Defense Memorandum, Revised Pollution Prevention and Compliance Metrics, 12 October 2004).

- Total Fines and Penalties Paid - those fines and penalties paid for violation of environmental compliance obligations under which the Department of Defense is subject under applicable Federal and State environmental laws during the half of the Fiscal Year being reported - i.e., the final amount agreed to between the regulator and the installation. Report the total payment costs, (i.e. fines paid, SEPs, and administration fees) of the fine/penalty in the period the penalty was paid; not in the period when it was assessed. Report fines paid by contractors and note that the contractor paid the fine (Attachment 2, Under Secretary of Defense Memorandum, Revised Pollution Prevention and Compliance Metrics, 12 October 2004).

- Toxic Chemicals - Those chemicals listed in Section 313 of the Emergency Planning and Community Right-toKnow Act (EPCRA) as of 1 December 1993 (AFI 32-7080, Attachment 1, Section C). 
- United States - all states, territories, and possessions of the United States; and all waters and airspace subject to the territorial jurisdiction of the United States. The territories and possessions of the United States include the Virgin Islands, American Samoa, Wake Island, Midway Island, Guam, Palmyra Island, Johnston Atoll, Navassa Island, and Kingman Reef (32 CFR 187.3(f)).

- Unresolved Enforcement Action - an enforcement action received in the current or a prior period and the action(s) to close it have not yet been completed or negotiating a compliance agreement or order is in process (AFI 327047, Attachment 1 and para 2.4.2).

- Urbanized Area - the Bureau of the Census determination of a central place (or places) and the adjacent densely settled surrounding territory that together have a minimum residential population of 50,000 people and a minimum average density of 1000 people per square mile (AFI 32-7041, Attachment 1).

- Volatile Organic Compound (VOCs) - Organic substances that react rapidly with $\mathrm{NO}_{\mathrm{x}}$ in the air and in the presence of sunlight to form oxidants or smog (AFI 32-7080, Attachment 1, Section C).

- Wastewater System - related units or devices and associate conveyances or appurtenances necessary to manage the generation, collection, storage, transportation, distribution, treatment, pollution prevention activities, recycling, reclamation, and disposal of domestic wastewater, industrial wastewater or stormwater runoff. The commonality of treatment characteristics and/or the commonality of classification of all wastewater systems are essential to good management and reporting requirements (AFI 32-7041, Attachment 1).

- Watershed - a geographical area that drains to a specified point on a water course, usually a confluence of streams or rivers. Also known as drainage area, catchment, or river basin (AFI 32-7041, Attachment 1).

- Water Quality-Based Effluent Limit - discharge limit to ensure that discharging the pollutant will not exceed the water quality standard for that pollutant. Water quality-based effluent limits are site-specific and pollutantspecific. As opposed to technology-based limits, water quality-based effluent limits June differ from those in other locations for the same type of wastewater (AFI 32-7041, Attachment 1).

- Water Quality Criteria - Environmental Protection Agency criteria for maximum in-stream concentrations of specific pollutants (AFI 32-7041, Attachment 1).

- Water Treatment Residuals - solids (sludge) and waste process water such as sludge dewatering decant water generated at water treatment plants (AFI 32-7041, Attachment 1).

- Wetlands - areas inundated by surface or groundwater that support plants and animals that need saturated or seasonally saturated soil to grow and reproduce. Wetlands include swamps, marshes, bogs, sloughs, mud flats, and natural ponds (AFI 32-7041, Attachment 1).

- Workforce - assigned personnel allotment needed to accomplish the mission (AFI 90-801, Attachment 1).

\section{Additional Records To Review}

\section{Environmental Impacts}

- None

Environmental Noise

- None

Cleanup (Restoration) 
- Documentation related to cleanup (restoration) 


\section{Pollution Prevention (P2)}

- Inventory records

- Supply/distribution procedures

- Opportunity assessments

- Baseline records

- Pollution Prevention Management Plan

- Records of any waste reduction/pollution prevention programs

- Records of resource recovery practices including the sale of materials for the purpose of recycling

- Equipment maintenance and inspection records

- Records of waste recovery equipment (i.e., solvent distillation equipment)

- Plans and procedures applicable to air pollution control

\section{Program Management}

- A-106 Pollution Abatement Plan

- Exercise- or contingency-specific environment plans, if any

Environmental Management System (EMS)

- Installation Environmental Policy

- Environmental Aspects Inventory

- Environmental Aspects Evaluation Method

- Significant Impact Inventory

- Environmental targets and objectives

- Environmental Performance Indicators

- Environmental Management Plans (EMPs)

- Work procedures, instructions and checklists

- EMS Manual and the EMS procedures applicable to the installation being assessed

- The findings of the last EMS assessment of the installation and any available EMS assessment checklists

- Performance Measures: results and trends

- Management Review meeting minutes

- Any EMS Corrective Action Plans and management’s review of those actions

\section{E. Additional Physical Features To Inspect}

\section{Environmental Impacts}

- None

Environmental Noise

- None

Cleanup (Restoration)

- None

\section{Pollution Prevention}

- Shop activities

- Hazardous materials and wastes storage areas

- Firefighting equipment

- Vehicle maintenance areas/motor pool 
- Supply area

- Waste recovery areas

- Reuse facility

- VOC sources

- Recycling area

Program Management

- None

Environmental Management System (EMS)

- EMS aspects /impacts

- Physical, engineering, and operational controls used to manage significant environmental impacts

- Other features identified in the EMS Manual 


\section{F. Guidance for Checklist Users}

\section{REFER TO CHECKLIST ITEMS:}

Environmental Impacts

Missing Checklist Items/Positive Findings

General

Environmental Analyses

Environmental Noise

Missing Checklist Items/Positive Findings

Environmental Noise Management

Cleanup (Restoration)

Missing Checklist Items/Positive Findings

General

Pollution Prevention (P2)

Missing Checklist Items/Positive Findings

General

Opportunity Assessments

ODCs/ODSs

Hazardous Substances (Waste and Material)

Solid Waste

Program Management

Missing Checklist Items/Positive Findings

General

Automated Management Systems

ESOH Leadership

Weapons Ranges

Deployments

EMS

Missing Checklist Items/Positive Findings

All Facilities

Policy

Planning

Implementation and Operations

Monitoring and Measuring

Management Review
O1.2.1.OCAF and O1.2.2.OCAF

O1.3.1.OCAF through O1.3.6.OCAF

O1.10.1.OCAF through O1.10.7.OCAF

O2.2.1.OCAF and O2.2.2.OCAF

O2.10.1.OCAF through O2.10.3.OCAF

O3.2.1.OCAF and O3.2.2.OCAF

O3.10.1.OCAF through O3.10.5.OCAF

O4.2.1.OCAF and O4.2.2.OCAF

O4.3.1.OCAF through O4.3.13.OCAF

O4.10.1.OCAF

O4.20.1.OCAF through O4.20.13.OCAF

O4.30.1.OCAF through O3.30.5.OCAF

O4.40.1.OCAF through O4.40.22.OCAF

O5.2.1.OCAF and O5.2.2.OCAF

O5.10.1.OCAF through O5.10.23.OCAF

O5.30.1.OCAF through O5.30.4.OCAF

O5.40.1.OCAF through O5.40.7.OCAF

O5.50.1.OCAF

O5.60.1.OCAF and O5.60.2.OCAF

O7.2.1.OCAF and O7.2.2.OCAF

O7.10.1.OCAF and O7.10.2.OCAF

O7.20.1.OCAF and O7.20.2.OCAF

O7.30.1.OCAF through O7.30.6.OCAF

O7.40.1.OCAF through O7.40.9.OCAF

O7.50.1.OCAF through O7.50.9.OCAF

O7.60.1.OCAF through O7.60.13.OCAF 


\begin{tabular}{|c|c|}
\hline \multicolumn{2}{|r|}{$\begin{array}{c}\text { COMPLIANCE CATEGORY: } \\
\text { OTHER ENVIRONMENTAL ISSUES } \\
\text { Overseas ESOHCAMP }\end{array}$} \\
\hline $\begin{array}{l}\text { REGULATORY } \\
\text { REQUIREMENTS: }\end{array}$ & $\begin{array}{l}\text { REVIEWER CHECKS: } \\
\text { September } 2009\end{array}$ \\
\hline $\begin{array}{l}\text { O1.2 } \\
\text { ENVIRONMENTAL } \\
\text { IMPACTS: } \\
\text { Missing Checklist } \\
\text { Items/Positive Findings }\end{array}$ & \\
\hline $\begin{array}{l}\text { O1.2.1.OCAF. Installations } \\
\text { must comply with all applica- } \\
\text { ble regulatory requirements } \\
\text { not contained in this checklist } \\
\text { (a finding under this checklist } \\
\text { item will have the citation of } \\
\text { the applied regulation as a } \\
\text { basis of finding) [Added } \\
\text { March 2002]. }\end{array}$ & $\begin{array}{l}\text { Determine whether any new regulations concerning management of environ- } \\
\text { mental impacts have been issued since the finalization of the manual. } \\
\text { Determine whether the installation has activities or facilities that are regulated but } \\
\text { not addressed in this checklist. } \\
\text { Verify that the installation is in compliance with all applicable and newly issued } \\
\text { regulations. }\end{array}$ \\
\hline $\begin{array}{l}\text { O1.2.2.OCAF. Installations } \\
\text { should go above and beyond } \\
\text { environmental statutory and } \\
\text { regulatory compliance (MP) } \\
\text { [Added March 2002]. }\end{array}$ & $\begin{array}{l}\text { Determine whether the installation has gone above and beyond simply complying } \\
\text { with environmental requirements. } \\
\text { (NOTE: This checklist item is used only to write positive findings.) }\end{array}$ \\
\hline
\end{tabular}




\section{COMPLIANCE CATEGORY: \\ OTHER ENVIRONMENTAL ISSUES \\ Overseas ESOHCAMP}

\begin{tabular}{l} 
REGULATORY \\
REQUIREMENTS: \\
\hline O1.3 \\
ENVIRONMENTAL \\
IMPACTS: \\
General \\
O1.3.1.OCAF. Installations \\
must meet requirements con- \\
tained in MAJCOM supple- \\
ments to AFIs and policy \\
documents (a finding under \\
this checklist item will have \\
the citation of the MAJCOM \\
document as a basis of find- \\
ing) [Moved June 2003]. \\
O1.3.2.OCAF. Installations \\
must have an Environmental \\
Planning Function (EPF) (32 \\
CFR 989.3(e) and 32 CFR \\
989.38) [Moved June 2003; \\
Revised September 2003; \\
Citation Revised September \\
2003].
\end{tabular}

Determine whether the requirements in MAJCOM supplements to AFIs and policy documents are within the scope of the environmental compliance assessment.

Verify that the installation is in compliance with MAJCOM requirements.

[Formerly checklist item number O1.10.2.OCAF.]

Verify that the installation has an EPF.

(NOTE: At every level of command, the EPF is one of the key Air Force participants responsible for the EIAP. The EPF can be the environmental flight within a civil engineer squadron, a separate environmental management office at an installation, the CEV at MAJCOMs, or an equivalent environmental function located with a program office.)

Verify that the EPF:

- brings key participants in at the beginning of a proposed action and involving them throughout the EIAP

- prepares (at the request of the proponent) environmental documents using an interdisciplinary approach (or obtains technical assistance through Air Force channels or contract support)

- assists the proponent in obtaining review of environmental documents

- assists the proponent in preparing a description of proposed action and alternatives (DOPAA) and actively supports the proponent during all phases of the EIAP

- evaluates proposed actions and completes Sections II and III of AF Form 813 (subsequent to submission by the proponent) and determines whether a Categorical Exclusion (CATEX) applies

- identifies and documents, with technical advice from the Bioenvironmental Engineer and other staff members, environmental quality standards that relate to the action under evaluation

- supports the proponent in preparing environmental documents (or obtains technical assistance through Air Force channels or contract support) and adopts the documents as official Air Force papers when completed and approved

- ensures the EIAP is conducted on base-level plans

- prepares Notices of Intent to prepare an EIS with assistance from the propo- 


\section{COMPLIANCE CATEGORY: \\ OTHER ENVIRONMENTAL ISSUES \\ Overseas ESOHCAMP}

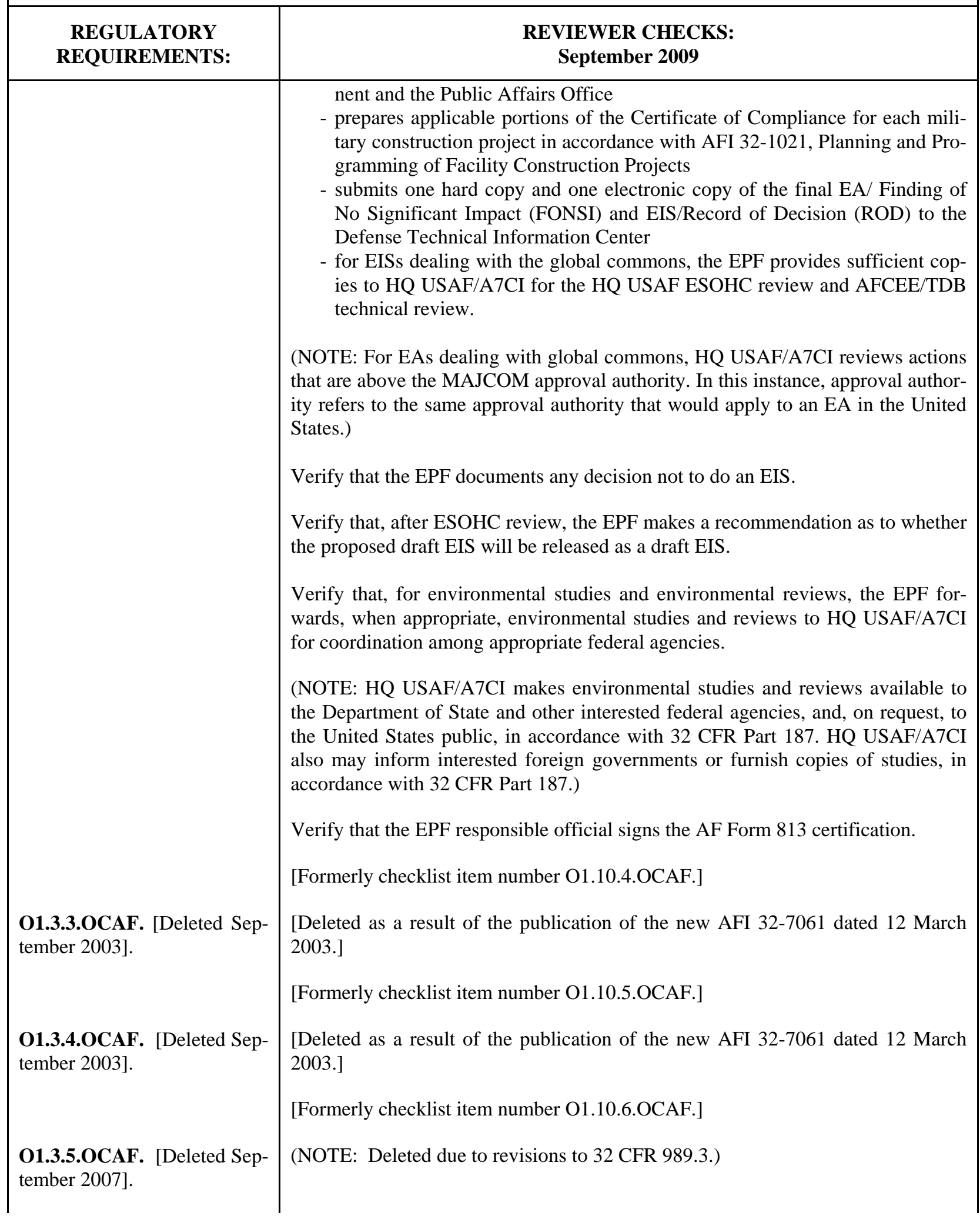




\section{COMPLIANCE CATEGORY: \\ OTHER ENVIRONMENTAL ISSUES \\ Overseas ESOHCAMP}

\begin{tabular}{c|c} 
REGULATORY & REVIEWER CHECKS: \\
REQUIREMENTS: & September 2009
\end{tabular}

O1.3.6.OCAF. Installations must provide documentation indicating prior MAJCOM EPC coordination or approval on documents sent to HQ USAF/CEV (HQ USAF/CEV policy letter of 26 August 1994) [Added September 2007].
Verify that documentation is provided indicating prior MAJCOM EPC coordination or approval on EIAP documents sent to HQ USAF/CEV for senior staff approval or signature.

(NOTE: The policy is directed at, but not limited to, Draft and Final EISs, EAs, Records of Decision, Findings of No Practicable Alternative, and FONSIs.)

(NOTE: See also 05.40.7.OCAF for ESOHC responsibilities.) 


\section{COMPLIANCE CATEGORY: \\ OTHER ENVIRONMENTAL ISSUES \\ Overseas ESOHCAMP}

\begin{tabular}{|l|}
\hline \multicolumn{1}{|c|}{ REGULATORY } \\
REQUIREMENTS: \\
\hline O1.10 \\
ENVIRONMENTAL \\
IMPACTS: \\
Environmental Analyses \\
O1.10.1.0CAF. Specific \\
analyses and documentation \\
procedures must be carried \\
out when an installation per- \\
forms certain types of major \\
DOD actions that do signifi- \\
cant harm to the environment \\
of a foreign nation or to a \\
protected global resource (32 \\
CFR 187 and DODD 6050.7, \\
Encl. 2, para B(1) and \\
C(3)(a)) [Moved June 2003; \\
Citation Revised September \\
2003].
\end{tabular}

\section{REVIEWER CHECKS: September 2009}

(NOTE: The decision whether a proposed action is one that would significantly affect the environments [potential for significant harm] covered by this section is taken by the EPF.)

Verify that the installation performs appropriate analyses and creates documentation for the following types of major Federal actions:

- those that significantly affect the environment of a foreign nation that is not involved in the action

- those that are determined to cause significant harm to the environment because they provide to that nation:

- a product or involve a physical project that produces a principal product, emission, or effluent that is prohibited or strictly regulated by Federal law in the United States because its toxic effects on the environment create a serious public health risk

- a physical project that is prohibited or strictly regulated in the United States by Federal law to protect the environment against radioactive substances

- those that significantly harm natural or ecological resources of global importance designated for protection by the President or, in case of such a resource protected by international agreement binding on the United States, designated for protection by the Secretary of State.

(NOTE: Included in the category of "prohibited or strictly regulated" are the following: asbestos, vinyl chloride, acrylonitrile, isocyanates, polychlorinated biphenyls, mercury, beryllium, arsenic, cadmium, and benzene.)

Determine whether any of the actions occurring at the installation have been granted a categorical exclusion by the DOD.

Verify that either an environmental study or an environmental review was prepared, as appropriate.

(NOTE: The following are exempt from these requirements:

- actions that the EPF determines do not significantly affect the environment of a foreign nation that is not participating in the action, or that do not cause significant harm to a designated resource of global importance

- actions taken by the President

- actions taken by or pursuant to the direction of the President or a cabinet officer in the course of armed conflict

- actions taken by or pursuant to the direction of the President or a cabinet officer when the national security or national interest is involved

- intelligence activities and arms transfers

- votes and other actions in international conferences and organizations 


\section{COMPLIANCE CATEGORY: \\ OTHER ENVIRONMENTAL ISSUES \\ Overseas ESOHCAMP}

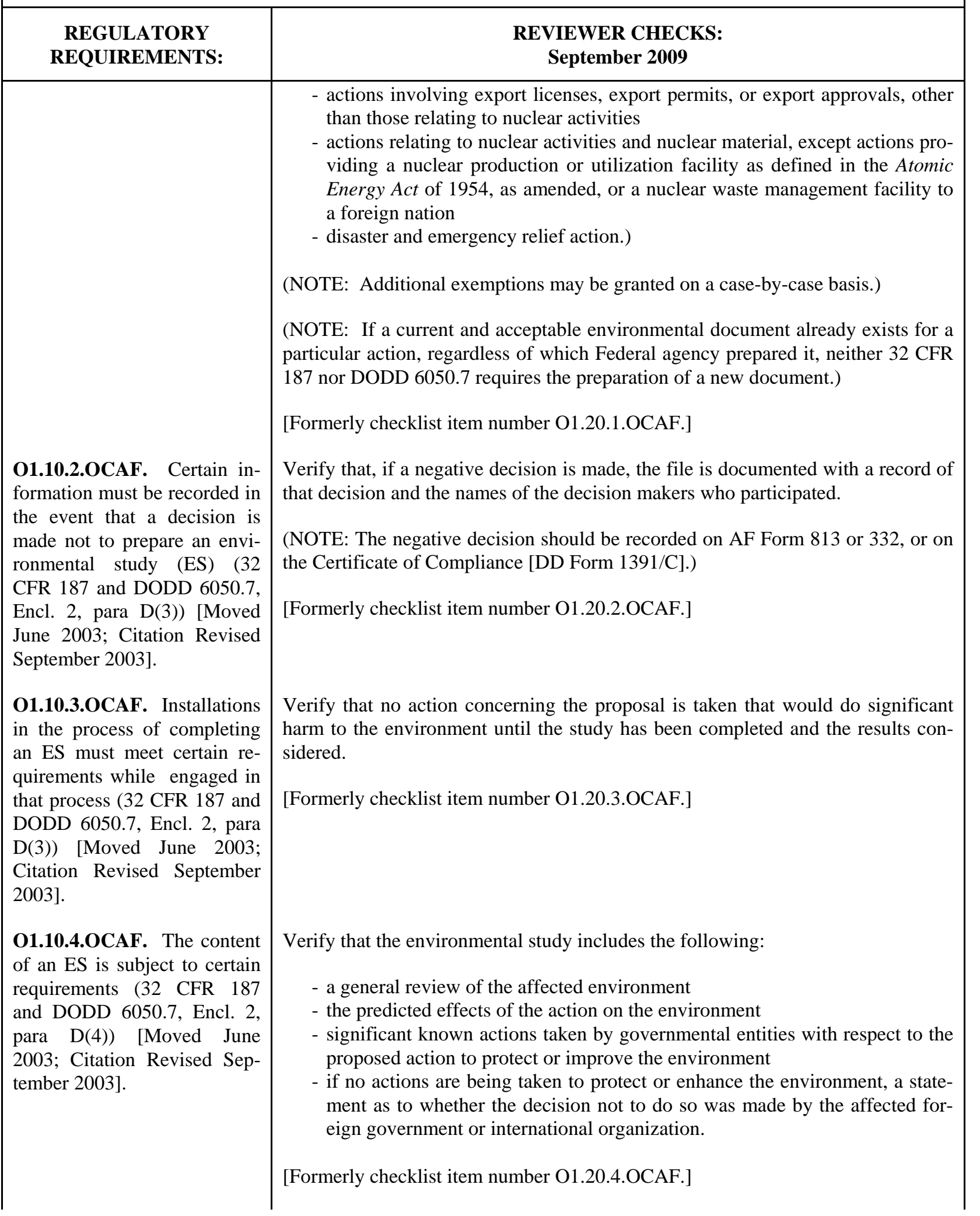




\section{COMPLIANCE CATEGORY: \\ OTHER ENVIRONMENTAL ISSUES \\ Overseas ESOHCAMP}

\begin{tabular}{|c|c|}
\hline $\begin{array}{l}\text { REGULATORY } \\
\text { REQUIREMENTS: }\end{array}$ & $\begin{array}{l}\text { REVIEWER CHECKS: } \\
\text { September } 2009\end{array}$ \\
\hline $\begin{array}{l}\text { O1.10.5.OCAF. Certain in- } \\
\text { formation must be recorded in } \\
\text { the event that a decision is } \\
\text { made not to prepare an envi- } \\
\text { ronmental review (ER) (32 } \\
\text { CFR 187 and DODD 6050.7, } \\
\text { Encl. 2, para E(3)) [Moved } \\
\text { June 2003; Revised Septem- } \\
\text { ber 2003; Citation Revised } \\
\text { September 2003]. }\end{array}$ & $\begin{array}{l}\text { Verify that, if a decision is made not to prepare an ER, a record is made of that } \\
\text { decision and its basis. } \\
\text { [Formerly checklist item number O1.20.5.OCAF.] }\end{array}$ \\
\hline $\begin{array}{l}\text { O1.10.6.0CAF. Installations } \\
\text { in the process of completing } \\
\text { an ER must meet certain re- } \\
\text { quirements while engaged in } \\
\text { that process ( } 32 \text { CFR } 187 \text { and } \\
\text { DODD 6050.7, Encl. 2, para } \\
\text { E(3)) [Moved June 2003; } \\
\text { Citation Revised September } \\
\text { 2003]. }\end{array}$ & $\begin{array}{l}\text { Verify that no action concerning the proposal is taken that would do significant } \\
\text { environmental harm until the review has been completed. } \\
\text { [Formerly checklist item number O1.20.6.OCAF.] }\end{array}$ \\
\hline $\begin{array}{l}\text { O1.10.7.OCAF. The content } \\
\text { of an ER is subject to certain } \\
\text { requirements (32 CFR } 187 \\
\text { and DODD 6050.7, Encl. 2, } \\
\text { para E(4)) [Moved June 2003; } \\
\text { Citation Revised September } \\
\text { 2003]. }\end{array}$ & $\begin{array}{l}\text { Verify that the ER includes the following, to the extent reasonably practical: } \\
\text { - a statement of the proposed action including its timetable, physical features, } \\
\text { general operating plan, and other similar broad-gauge descriptive factors } \\
\text { - identification of the important issues involved } \\
\text { - the aspects of the actions taken or to be taken by the AF that ameliorate or } \\
\text { minimize the impact on the environment } \\
\text { - the actions known to have been taken or to be planned by the government of } \\
\text { any participating and affected foreign nations that will affect environmental } \\
\text { considerations. } \\
\text { [Formerly checklist item number O1.20.7.OCAF.] }\end{array}$ \\
\hline
\end{tabular}




\begin{tabular}{|c|c|}
\hline \multicolumn{2}{|r|}{$\begin{array}{l}\text { COMPLIANCE CATEGORY: } \\
\text { OTHER ENVIRONMENTAL ISSUES } \\
\text { OverSeas ESOHCAMP }\end{array}$} \\
\hline $\begin{array}{l}\text { REGULATORY } \\
\text { REQUIREMENTS: }\end{array}$ & $\begin{array}{l}\text { REVIEWER CHECKS: } \\
\text { September } 2009\end{array}$ \\
\hline $\begin{array}{l}\text { O2.2 } \\
\text { ENVIRONMENTAL } \\
\text { NOISE: } \\
\text { Missing Checklist } \\
\text { Items/Positive Findings }\end{array}$ & \\
\hline $\begin{array}{l}\text { O2.2.1.OCAF. Installations } \\
\text { must comply with all applica- } \\
\text { ble regulatory requirements } \\
\text { not contained in this checklist } \\
\text { (a finding under this checklist } \\
\text { item will have the citation of } \\
\text { the applied regulation as a } \\
\text { basis of finding) [Added } \\
\text { March 2002]. }\end{array}$ & $\begin{array}{l}\text { Determine whether any new regulations concerning management of environ- } \\
\text { mental noise have been issued since the finalization of the manual. } \\
\text { Determine whether the installation has activities or facilities that are regulated but } \\
\text { not addressed in this checklist. } \\
\text { Verify that the installation is in compliance with all applicable and newly issued } \\
\text { regulations. }\end{array}$ \\
\hline $\begin{array}{l}\text { O2.2.2.OCAF. Installations } \\
\text { should go above and beyond } \\
\text { environmental statutory and } \\
\text { regulatory compliance (MP) } \\
\text { [Added March 2002]. }\end{array}$ & $\begin{array}{l}\text { Determine whether the installation has gone above and beyond simply complying } \\
\text { with environmental requirements. } \\
\text { (NOTE: This checklist item is used only to write positive findings.) }\end{array}$ \\
\hline
\end{tabular}




\begin{tabular}{|c|c|}
\hline \multicolumn{2}{|r|}{$\begin{array}{c}\text { COMPLIANCE CATEGORY: } \\
\text { OTHER ENVIRONMENTAL ISSUES } \\
\text { Overseas ESOHCAMP }\end{array}$} \\
\hline $\begin{array}{l}\text { REGULATORY } \\
\text { REQUIREMENTS: }\end{array}$ & $\begin{array}{l}\text { REVIEWER CHECKS: } \\
\text { September } 2009\end{array}$ \\
\hline $\begin{array}{l}\text { O2.10 } \\
\text { ENVIRONMENTAL } \\
\text { NOISE: } \\
\text { Environmental Noise Ma- } \\
\text { nagement }\end{array}$ & \\
\hline $\begin{array}{l}\text { O2.10.1.OCAF. } \\
\text { March 2002]. }\end{array}$ & Moved to O2.2.1.OCAF. \\
\hline $\begin{array}{l}\text { O2.10.2.OCAF. Installations } \\
\text { must meet requirements con- } \\
\text { tained in MAJCOM supple- } \\
\text { ments to AFIs and policy } \\
\text { documents (a finding under } \\
\text { this checklist item will have } \\
\text { the citation of the MAJCOM } \\
\text { document as a basis of find- } \\
\text { ing). }\end{array}$ & $\begin{array}{l}\text { Determine whether the requirements in MAJCOM supplements to AFIs and pol- } \\
\text { icy documents are within the scope of the environmental compliance assessment. } \\
\text { Verify that the installation is in compliance with MAJCOM requirements. }\end{array}$ \\
\hline $\begin{array}{l}\text { O2.10.3.0CAF. } \\
\text { March 2002]. }\end{array}$ & Moved to O2.2.2.OCAF. \\
\hline
\end{tabular}




\begin{tabular}{|c|c|}
\hline \multicolumn{2}{|r|}{$\begin{array}{c}\text { COMPLIANCE CATEGORY: } \\
\text { OTHER ENVIRONMENTAL ISSUES } \\
\text { Overseas ESOHCAMP }\end{array}$} \\
\hline $\begin{array}{l}\text { REGULATORY } \\
\text { REQUIREMENTS: }\end{array}$ & $\begin{array}{l}\text { REVIEWER CHECKS: } \\
\text { September } 2009\end{array}$ \\
\hline $\begin{array}{l}\text { O3.2 } \\
\text { CLEANUP } \\
\text { (RESTORATION): } \\
\text { Missing Checklist } \\
\text { Items/Positive Findings }\end{array}$ & \\
\hline $\begin{array}{l}\text { O3.2.1.OCAF. Installations } \\
\text { must comply with all applica- } \\
\text { ble regulatory requirements } \\
\text { not contained in this checklist } \\
\text { (a finding under this checklist } \\
\text { item will have the citation of } \\
\text { the applied regulation as a } \\
\text { basis of finding) [Added } \\
\text { March 2002]. }\end{array}$ & $\begin{array}{l}\text { Determine whether any new regulations concerning management of cleanup (res- } \\
\text { toration) have been issued since the finalization of the manual. } \\
\text { Determine whether the installation has activities or facilities that are regulated but } \\
\text { not addressed in this checklist. } \\
\text { Verify that the installation is in compliance with all applicable and newly issued } \\
\text { regulations. }\end{array}$ \\
\hline $\begin{array}{l}\text { O3.2.2.OCAF. Installations } \\
\text { should go above and beyond } \\
\text { environmental statutory and } \\
\text { regulatory compliance (MP) } \\
\text { [Added March 2002]. }\end{array}$ & $\begin{array}{l}\text { Determine whether the installation has gone above and beyond simply complying } \\
\text { with cleanup (restoration) requirements. } \\
\text { (NOTE: This checklist item is used only to write positive findings.) }\end{array}$ \\
\hline
\end{tabular}




\begin{tabular}{|c|c|}
\hline \multicolumn{2}{|r|}{$\begin{array}{c}\text { COMPLIANCE CATEGORY: } \\
\text { OTHER ENVIRONMENTAL ISSUES } \\
\text { Overseas ESOHCAMP }\end{array}$} \\
\hline $\begin{array}{l}\text { REGULATORY } \\
\text { REQUIREMENTS: }\end{array}$ & $\begin{array}{l}\text { REVIEWER CHECKS: } \\
\text { September } 2009\end{array}$ \\
\hline $\begin{array}{l}\text { O3.10 } \\
\text { CLEANUP } \\
\text { (RESTORATION): } \\
\text { General }\end{array}$ & \\
\hline $\begin{array}{l}\text { O3.10.1.OCAF. } \\
\text { March 2002]. }\end{array}$ & Moved to O3.2.1.OCAF. \\
\hline $\begin{array}{l}\text { O3.10.2.OCAF. Installations } \\
\text { must meet requirements con- } \\
\text { tained in MAJCOM supple- } \\
\text { ments to AFIs and policy } \\
\text { documents (a finding under } \\
\text { this checklist item will have } \\
\text { the citation of the MAJCOM } \\
\text { document as a basis of find- } \\
\text { ing). }\end{array}$ & $\begin{array}{l}\text { Determine whether the requirements in MAJCOM supplements to AFIs and pol- } \\
\text { icy documents are within the scope of the environmental compliance assessment. } \\
\text { Verify that the installation is in compliance with MAJCOM requirements. }\end{array}$ \\
\hline $\begin{array}{l}\text { O3.10.3.OCAF. Cleanup } \\
\text { projects at sites contaminated } \\
\text { by AF operations must be } \\
\text { executed to a point estab- } \\
\text { lished by AF policy (AFI 32- } \\
\text { 7006, para } 2.2 \text { and } 2.3 \text { ). }\end{array}$ & $\begin{array}{l}\text { Determine whether the installation has planned or conducted any cleanup pro- } \\
\text { jects. } \\
\text { Verify that cleanup projects are executed to the point that contamination no longer } \\
\text { poses an imminent and substantial danger to human health and safety. } \\
\text { Verify that cleanup projects are executed as needed to sustain current operations. } \\
\text { (NOTE: These requirements do not apply if the AF is bound by international } \\
\text { agreement to do more.) }\end{array}$ \\
\hline $\begin{array}{l}\text { O3.10.4.OCAF. Installations } \\
\text { or facilities identified for re- } \\
\text { turn to the host nation must } \\
\text { meet specific requirements } \\
\text { with regard to documentation } \\
\text { (AFI 32-7006, para 2.3.2). }\end{array}$ & $\begin{array}{l}\text { Determine whether the installation or facility has been identified for return to the } \\
\text { host nation. } \\
\text { Verify that the installation or facility documents all known environmental con- } \\
\text { tamination and provides the documentation to the host nation. } \\
\text { (NOTE: This requirement applies only after appropriate U.S.-host public an- } \\
\text { nouncement of the return, and only after the MAJCOM has granted clearance to } \\
\text { release the documentation.) }\end{array}$ \\
\hline $\begin{array}{l}\text { O3.10.5.0CAF. All written } \\
\text { notices of noncompliance } \\
\text { related to restoration activities } \\
\text { issued by a regulator must be } \\
\text { tracked and reported as } \\
\text { ONONs (HQ USAF/A7CV, } \\
\text { Policy Memorandum on Envi- }\end{array}$ & $\begin{array}{l}\text { Verify that all written notices of noncompliance related to restoration activities } \\
\text { issued by a regulator are tracked and reported as ONONs. } \\
\text { (NOTE: See checklist items O5.10.22.OCAF and O5.10.23.OCAF. }\end{array}$ \\
\hline
\end{tabular}




\begin{tabular}{|l|c|}
\hline \multicolumn{2}{|c|}{$\begin{array}{c}\text { COMPLIANCE CATEGORY: } \\
\text { OTHER ENVIRONMENTAL ISSUES } \\
\text { Overseas ESOHCAMP }\end{array}$} \\
\hline \multicolumn{1}{|c|}{$\begin{array}{c}\text { REGULATORY } \\
\text { REQUIREMENTS: }\end{array}$} & $\begin{array}{c}\text { REVIEWER CHECKS: } \\
\text { September 2009 }\end{array}$ \\
\hline $\begin{array}{l}\text { ronmental Compliance Track- } \\
\text { ing and Reporting Require- } \\
\text { ments, 16 June 2006, p. 2) } \\
\text { [Added September 2006]. }\end{array}$ & \\
\hline
\end{tabular}




\begin{tabular}{|c|c|}
\hline \multicolumn{2}{|r|}{$\begin{array}{c}\text { COMPLIANCE CATEGORY: } \\
\text { OTHER ENVIRONMENTAL ISSUES } \\
\text { Overseas ESOHCAMP }\end{array}$} \\
\hline $\begin{array}{l}\text { REGULATORY } \\
\text { REQUIREMENTS: }\end{array}$ & $\begin{array}{l}\text { REVIEWER CHECKS: } \\
\text { September } 2009\end{array}$ \\
\hline $\begin{array}{l}\text { O4.2 } \\
\text { POLLUTION } \\
\text { PREVENTION: } \\
\text { Missing Checklist } \\
\text { Items/Positive Findings }\end{array}$ & \\
\hline $\begin{array}{l}\text { O4.2.1.OCAF. Installations } \\
\text { must comply with all applica- } \\
\text { ble regulatory requirements } \\
\text { not contained in this checklist } \\
\text { (a finding under this checklist } \\
\text { item will have the citation of } \\
\text { the applied regulation as a } \\
\text { basis of finding) [Added } \\
\text { March 2002]. }\end{array}$ & $\begin{array}{l}\text { Determine whether any new regulations concerning pollution prevention have } \\
\text { been issued since the finalization of the manual. } \\
\text { Determine whether the installation has activities or facilities that are regulated but } \\
\text { not addressed in this checklist. } \\
\text { Verify that the installation is in compliance with all applicable and newly issued } \\
\text { regulations. }\end{array}$ \\
\hline $\begin{array}{l}\text { O4.2.2.OCAF. Installations } \\
\text { should go above and beyond } \\
\text { environmental statutory and } \\
\text { regulatory compliance (MP) } \\
\text { [Added March 2002]. }\end{array}$ & $\begin{array}{l}\text { Determine whether the installation has gone above and beyond simply complying } \\
\text { with environmental requirements. } \\
\text { (NOTE: This checklist item is used only to write positive findings.) }\end{array}$ \\
\hline
\end{tabular}




\section{COMPLIANCE CATEGORY: \\ OTHER ENVIRONMENTAL ISSUES \\ Overseas ESOHCAMP}

\begin{tabular}{|l}
\multicolumn{1}{|c|}{ REGULATORY } \\
REQUIREMENTS: \\
O4.3 \\
POLLUTION \\
PREVENTION: \\
General \\
O4.3.1.OCAF. Installations \\
must meet requirements con- \\
tained in MAJCOM supple- \\
ments to AFIs and policy \\
documents (a finding under \\
this checklist item will have \\
the citation of the MAJCOM \\
document as a basis of find- \\
ing) [Moved June 2003].
\end{tabular}

O4.3.2.OCAF. Installations must develop and execute a Pollution Prevention Management Plan (AFI 32-7080, para 2.2 and DODI 4715.4, para 6.2.3.2) [Moved June 2003].

O4.3.3.OCAF. Installations should include additional strategies for improving the
REVIEWER CHECKS: September 2009

Determine whether the requirements in MAJCOM supplements to AFIs and policy documents are within the scope of the environmental compliance assessment.

Verify that the installation is in compliance with MAJCOM requirements.

[Formerly checklist item number O4.10.2.OCAF.]

Verify that the installation has a Pollution Prevention Management Plan.

Verify that the plan addresses all of the following issues:

- the process required to run a pollution prevention program

- the program required to fund pollution prevention projects

- the road map to achieve AF pollution prevention goals

- the actions required to execute the program.

Verify that the plan contains management strategies for the following areas:

- ODCs

- USEPA 17 industrial toxics

- hazardous wastes

- municipal solid waste

- affirmative procurement of environmentally friendly products

- energy conservation

- air and water pollutant reduction.

Verify that the plan identifies and programs projects needed to achieve stated objectives.

Verify that the installation maintains and executes pollution prevention plans that identify goals and cost-effective management processes or technologies to eliminate or reduce the use and disposal of hazardous materials.

[Formerly checklist item number O4.30.1.OCAF.]

Verify that the plan includes the following information:

- plans to crossfeed information to the rest of the AF 


\section{COMPLIANCE CATEGORY: \\ OTHER ENVIRONMENTAL ISSUES \\ Overseas ESOHCAMP}

\section{REVIEWER CHECKS: September 2009}

\begin{tabular}{|l|}
\hline \multicolumn{1}{|c|}{$\begin{array}{l}\text { REGULATORY } \\
\text { REQUIREMENTS: }\end{array}$} \\
\hline $\begin{array}{l}\text { pollution prevention program } \\
\text { in the Pollution Prevention } \\
\text { Management Plan (MP) } \\
\text { [Moved June 2003]. }\end{array}$ \\
O4.3.4.OCAF. Installations \\
or installation activities initi- \\
ating contracting/procurement \\
actions or credit card pur- \\
chases have responsibilities \\
for complying with GPP pur- \\
chasing mandates and imple- \\
menting the GPP Strategy for \\
policy and planning (Memo- \\
randum, Establishment of the \\
DOD GPP, 27 August 2004) \\
[Added March 2005].
\end{tabular}

pollution prevention program in the Pollution Prevention Management Plan

MP)

plans to brief the base EPC

- plans to implement Opportunity Assessments

- oil/water separator management strategies

- usable measures of success

- programming and budgeting strategies.

[Formerly checklist item number O4.30.2.OCAF.]

Verify that the installation has established policy for a GPP that meets the requirements of the guidance document and is appropriate for the nature of the installation's procurement activities.

Verify that installation activities that define requirements, place orders, make purchases, or contract for products and services have established and documented a process to identify opportunities to procure green products and services in the normal course of business, maintain a list of such opportunities, and update the list regularly to reflect changes in the mission and availability of green products and services relevant to the mission.

(NOTE: The list of green procurement opportunities should be developed and maintained at a level of the organization where initial purchasing requirements are defined.)

Verify that each installation has established and documented a process for setting, maintaining, and annually reviewing and updating objectives and targets for GPP performance that are appropriate for the nature and quantity of purchases made by installation activities.

(NOTE: Objectives and targets relative to the installation's Environmental Management System [EMS] should be established for significant opportunities to purchase green products and services. Objectives and targets should be based on the installation's procurement activities and applied at a level of the organization where initial purchasing requirements are defined.)

Verify that the installation documents the objectives, targets, and actions necessary to achieve them in an installation-level plan for improving green procurement performance.

(NOTE: Existing AP Plans may meet many of the basic requirements; however, they should be expanded during future reviews to include the DOD GPP management system structure and appropriate reference to all Federal procurement preference programs.)

(NOTE: The GPP Strategy can be found at: https://www.denix.osd.mil/denix/Public/ESPrograms/Pollution/Procurement/GPP/ gpp-intro.html.)

O4.3.5.0CAF. Each organi- (NOTE: This checklist item applies to each organization in DOD that defines 


\section{COMPLIANCE CATEGORY: \\ OTHER ENVIRONMENTAL ISSUES \\ Overseas ESOHCAMP}

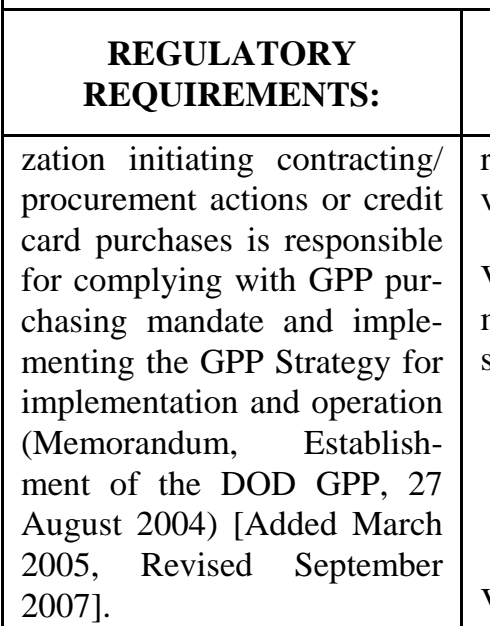

\section{REVIEWER CHECKS: September 2009}

requirements, places orders, makes purchases, or contracts for products and ser-
vices shall implement the following management elements in its GPP.)

Verify that each organization in DOD that defines requirements, places orders, makes purchases, or contracts for products and services defines roles and responsibilities for GPP implementation and operation, and:

- ensures each individual is aware of his/her responsibilities under the GPP

- ensures each individual has received training to fulfill such responsibilities competently.

Verify that each organization in DOD that defines requirements, places orders, makes purchases, or contracts for products and services tailors the GPP awareness training program to the nature and quantity of purchases made by the organization.

Verify that each organization in DOD that defines requirements, places orders, makes purchases, or contracts for products and services includes initial and refresher training for all personnel involved in the procurement process from requirements generation to contracting, credit card, or other purchase actions.

Verify that each organization in DOD that defines requirements, places orders, makes purchases, or contracts for products and services incorporates the GPP awareness training program into established training programs for installation management and staff, such as new employee orientation, environmental awareness training, Contracting Officer's Representative and other procurement training, and office staff training.

Verify that each organization in DOD that defines requirements, places orders, makes purchases, or contracts for products and services establishes a process to identify training requirements for each position, and document initial and followup training for each individual with responsibilities under the GPP.

Verify that each organization in DOD that defines requirements, places orders, makes purchases, or contracts for products and services implements internal and external communication programs, and:

- educates government personnel and contractors about complying with the requirements of Federal procurement preference programs.

- uses the following tools, and others, as appropriate: electronic broadcast messages; articles in agency/site newsletters; web sites to provide information and notices on waste prevention, recycling, and AP of recycled content and green products and services; publications, speeches, commitments, and presentations in association with DOD-sponsored and national events such as Earth Day, America Recycles Day, and DOD’s annual Pollution Prevention Conference; and DOD Solid Waste/Recycling Work Shop

- defines GPP documentation requirements such as documenting the following: initial and follow-up training for each individual with responsibilities 


\section{COMPLIANCE CATEGORY: \\ OTHER ENVIRONMENTAL ISSUES \\ Overseas ESOHCAMP}

\section{REGULATORY REQUIREMENTS: \\ O4.3.6.OCAF. Each organi- zation initiating contracting/ procurement actions or credit card purchases is responsible for complying with GPP pur- chasing mandate and imple- menting the GPP Strategy for reporting and corrective ac- tions (Memorandum, Estab- lishment of the DOD GPP, 27 August 2004) [Added March 2005].}

\section{REVIEWER CHECKS: September 2009}

under the GPP; justification for not purchasing green products and services; certifications, estimations, and verifications; performance data and metrics; required reports and records; other records needed for a successful program

- establishes procedures to ensure GPP requirements are addressed in all procurement actions and at each appropriate stage of the procurement process

- establishes procedures and approval authorities for justifications not to purchase green products

- establishes automatic substitution procedures where appropriate and feasible.

(NOTE: Overseas programs will comply to the maximum extent practicable.)

(NOTE: This checklist item applies to each organization in DOD that defines requirements, places orders, makes purchases, or contracts for products and services shall implement the following management elements in its GPP.)

Verify that each organization in DOD that defines requirements, places orders, makes purchases, or contracts for products and services establishes a process for evaluation and reporting of GPP performance.

Verify that each organization in DOD that defines requirements, places orders, makes purchases, or contracts for products and services measures performance based on:

- unit-level objectives and targets established at the organization level where initial purchasing requirements are defined

- installation-level objectives and targets.

- DOD Component-level objectives and targets.

Verify that each organization in DOD that defines requirements, places orders, makes purchases, or contracts for products and services uses established DOD data tracking systems to measure performance consistent with DOD and Federal metrics and reporting requirements:

- DD Form 350 (Federal Procurement Data System) data

- Defense Logistics Agency's web-based Green Procurement Report at www.dlis.dla.mil/erlsgpr

- GPP training data from Defense Acquisition University.

Verify that each organization in DOD that defines requirements, places orders, makes purchases, or contracts for products and services develops other measurement tools as necessary to meet local mission and management goals.

Verify that each organization in DOD that defines requirements, places orders, makes purchases, or contracts for products and services annually reports up the chain of command as necessary to meet the Federal, DOD, and Component reporting requirements: 


\section{COMPLIANCE CATEGORY: \\ OTHER ENVIRONMENTAL ISSUES \\ Overseas ESOHCAMP}

\begin{tabular}{|l|c|}
$\begin{array}{c}\text { REGULATORY } \\
\text { REQUIREMENTS: }\end{array}$ & $\begin{array}{c}\text { REVIEWER CHECKS: } \\
\text { September } 2009\end{array}$ \\
\hline & - DOD will collect data annually to comply with the statutory and Executive \\
order reporting requirements. Reporting guidance will be issued annually by \\
OUSD(AT\&L)/I\&E and DP\&AP \\
- all DOD organizations' respective evaluation and reporting processes shall \\
be conducted in a manner that supports the content and timing of DOD's re- \\
porting requirements \\
- currently, DOD's Federal agency-level reporting requirements are limited to \\
the RCRA 6002 and EO 13101 annual reports for the AP Program, and the \\
reporting requirements of Section 314 of the FY 2003 Defense Authoriza- \\
tion Act.
\end{tabular}

Verify that each organization in DOD that defines requirements, places orders, makes purchases, or contracts for products and services incorporates GPP requirements into self assessments, compliance inspection protocols, management system audit protocols, and contract audit protocols.

(NOTE: See DOD GPP Facility Questionnaire at the website.)

Verify that each organization in DOD that defines requirements, places orders, makes purchases, or contracts for products and services develops corrective action procedures to address deficiencies identified in assessments, inspections, and audits.

Verify that each organization in DOD that defines requirements, places orders, makes purchases, or contracts for products and services conducts routine self assessments of the effectiveness of GPP awareness training, the completeness and integrity of GPP performance data, and the overall GPP.

Verify that each organization in DOD that defines requirements, places orders, makes purchases, or contracts for products and services evaluates the effectiveness of audit procedures, including implementation of corrective actions.

O4.3.7.OCAF. Each organization initiating contracting/ procurement actions or credit card purchases is responsible for complying with GPP purchasing mandate and implementing the GPP Strategy for management review (Memorandum, Establishment of the DOD GPP, 27 August 2004) [Added March 2005].

(NOTE: This checklist item applies to each organization in DOD that defines requirements, places orders, makes purchases, or contracts for products and services and each organization shall implement the following management elements in its GPP.)

Verify that each organization in DOD that defines requirements, places orders, makes purchases, or contracts for products and services establishes procedures for routine (at least annual) senior management review of the effectiveness of the GPP in each relevant organization and at each level of the Department.

(NOTE: The organization's management should review the GPP comprehensively to ensure its continued suitability and effectiveness in meeting green procurement requirements, and to ensure continual improvement in green procurement performance.)

Verify that each organization in DOD that defines requirements, places orders, 


\section{COMPLIANCE CATEGORY: \\ OTHER ENVIRONMENTAL ISSUES \\ Overseas ESOHCAMP}

\section{REGULATORY REQUIREMENTS:}

O4.3.8.OCAF. Installations must execute a Green Procurement Program (GPP) plan and review it annually (USAF Memorandum, Policy to Establish the Air Force GPP, 29 September 2006) [Added September 2007].

O4.3.9.OCAF. Training on the GPP is mandatory for all Contracting, Civil Engineering, and other personnel involved in the procurement process including Government Purchasing Card (GPC) holders and their approving officials (USAF Memorandum, Policy to Establish the Air Force GPP, 29 September 2006; USAF Memorandum, Green Procurement Program (GPP) Training Suspense Update, 16 Nov 2006) [Added September 2007].

\section{REVIEWER CHECKS: September 2009}

makes purchases, or contracts for products and services includes, at a minimum: results from audits, progress on objectives and targets, DD Form 350, DLAprovided green procurement data, training data, and the effectiveness of the GPP in meeting local, Component, and DOD GPP requirements.

(NOTE: The management review process should result in documented conclusions and recommendations for which follow-on actions are required and tracked through the GPP.)

(NOTE: Each installation will annually reports up the chain of command as necessary to meet the Federal, DOD, and Component reporting requirements. DOD will collect data annually to comply with the statutory and Executive order reporting requirements. Reporting guidance will be issued annually by OUSD(AT\&L)/I\&E and DP\&AP. It is expected that the installations evaluation and reporting processes shall be conducted in a manner that supports the content and timing of DOD's reporting requirements. Currently, DOD's Federal agencylevel reporting requirements are limited to the RCRA 6002 and EO 13101 annual reports for the AP Program, and the reporting requirements of Section 314 of the FY 2003 Defense Authorization Act.)

Verify that each installation executes a GPP plan and review it annually in accordance with the base Environmental Management System (EMS) process.

Verify that all Contracting, Civil Engineering, and other personnel involved in the procurement process including Government Purchasing Card (GPC) holders and their approving officials received training on GPP.

Verify that the base GPP team evaluates base training needs and ensures appropriate personnel receive training.

(NOTE: Air Force personnel may obtain GPP training via the Office of Personnel Management [OPM] Go Learn website, at www.goleam.gov. This two-hour, web-based training course is designed for contracting personnel, GPC cardholders, project managers, and fleet managers, and provides a foundation in the fundamentals of GPP. The GoLearn website at has started charging a fee of $\$ 6.50$ per person for accessing the GoLearn course. The GPC may be used by training and education office personnel to pay for this training. Refer to AFI64-117, para 2.11, for specific guidance. As an alternative to the GoLearn course, AFCEE is developing a no-cost training module for GPP, which will be accessible through the Environmental Web University at https://webu.brooks.af.mil; look for "Air Force Green Procurement Program Training.” This computer-based training [CBT] module should be available in the week of 23 Oct 06.) 


\section{COMPLIANCE CATEGORY: \\ OTHER ENVIRONMENTAL ISSUES \\ Overseas ESOHCAMP}

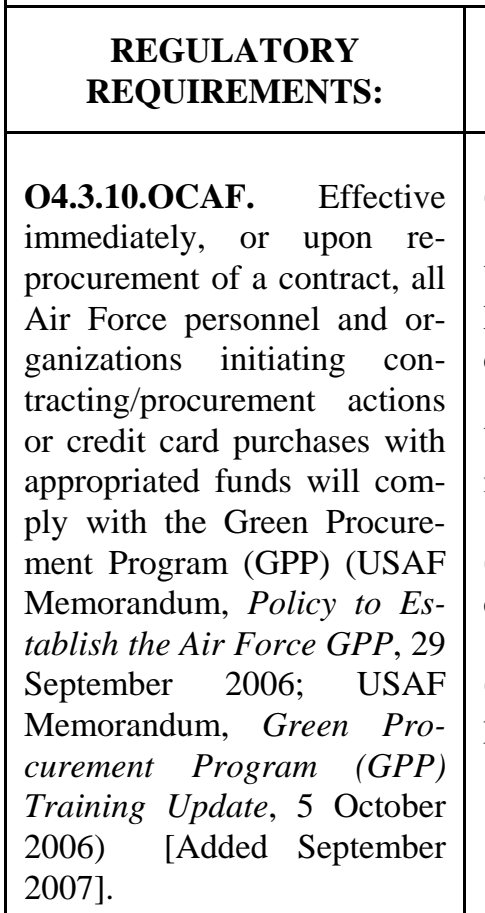

2007].

O4.3.11.OCAF. The Environmental, Safety, and Occupational Health Committee (ESOHC) at each installation must establish a GPP team to develop and implement a viable GPP (USAF Memorandum, Policy to Establish the Air Force GPP, 29 September 2006) [Added September 2007].

04.3.12.0CAF. Purchasing of deicing chemicals containing an ethylene glycol-based fluid for runway deicing is prohibited (AF Memorandum, Prohibition on Purchase of Environmentally

\section{REVIEWER CHECKS: September 2009}

(NOTE: See Appendix 6-8 for the current list of CPG products.)

Verify that, effective immediately, or upon re-procurement of a contract, all Air Force personnel and organizations initiating contracting/procurement actions or credit card purchases with appropriated funds comply with the GPP.

Verify that environmental and contracting offices across the USAF support units in meeting GPP mandates.

(NOTE: Each organization initiating contracting/procurement actions or credit card purchases is responsible for complying with GPP purchasing mandates.)

(NOTE: According to FAR 23.404(b), products meeting GPP guidelines will be purchased unless they are not available:

competitively within a reasonable period of time

at reasonable prices

to meet reasonable performance standards in specifications. A written determination by technical or requirements personnel of the performance standard's reasonableness must be included with the justification.)

(NOTE: The GPP does not authorize the violation of Technical Order [TO] requirements to use specified materials. Air Force personnel should refer to AFI 327086, Chapter 3, for proper procedures in requesting ESOH-related changes to TOs if modifications are necessary to support GPP goals.)

(NOTE: For additional contractual requirements on Green Procurement, see the Contracting Officer's Primer on Green Procurement.)

Verify that the Environmental, Safety, and Occupational Health Committee (ESOHC) at each installation establishes a GPP team to develop and implement a viable GPP.

(NOTE: For further details on compliance and implementation of GPP requirements, see The Air Force Guide to Green Purchasing, located at www.afcee.brooks.af.mil/eq/ap/gglguide.doc.)

Verify that there is no purchasing of deicing chemicals containing an ethylene glycol-based fluid for runway deicing.

(NOTE: Ethylene glycol is also known as Glycol, Type 2.)

(NOTE: The use of the relatively less toxic alternative runway anti-icers/deicers of Chevron Chemical E-36 [Potassium Acetate, NSN 6850-01-341-9856] or Urea 


\section{COMPLIANCE CATEGORY: \\ OTHER ENVIRONMENTAL ISSUES \\ Overseas ESOHCAMP}

\begin{tabular}{|c|c|}
\hline $\begin{array}{l}\text { REGULATORY } \\
\text { REQUIREMENTS: }\end{array}$ & $\begin{array}{l}\text { REVIEWER CHECKS: } \\
\text { September } 2009\end{array}$ \\
\hline $\begin{array}{l}\text { Hazardous Deicing Chemi- } \\
\text { cals, } 31 \text { March 1992) [Added } \\
\text { September 2007]. }\end{array}$ & [NSN 6810-00-782-6521] is recommended.) \\
\hline $\begin{array}{l}\text { O4.3.13.0CAF. The memo- } \\
\text { randum Air Force Solid } \\
\text { Waste Diversion and Quali- } \\
\text { fied Recycling Program } \\
\text { (QRP) Policy must be refer- } \\
\text { enced in certain contracts } \\
\text { (HQ USAF/A7C Memoran- } \\
\text { dum, Air Force Solid Waste } \\
\text { Diversion and Qualified Re- } \\
\text { cycling Program (QRP) Pol- } \\
\text { icy) [Added September 2007]. }\end{array}$ & $\begin{array}{l}\text { Verify that all contracts that provide for contractor operation of a government- } \\
\text { owned or -leased facility and /or contracts that provide for contractor or other } \\
\text { support services at Government-owned or operated facilities awarded by execu- } \\
\text { tive agencies awarded by the Air Force include provisions to requiring the con- } \\
\text { tractor to comply with USAF/A7C Memorandum, Air Force Solid Waste Diver- } \\
\text { sion and Qualified Recycling Program (QRP) Policy. } \\
\text { Verify that refuse and disposal contracts include provisions to collect and report } \\
\text { solid waste data appropriate for implementing Air Force solid waste diversion } \\
\text { policy. } \\
\text { (NOTE: Protocols and procedures to obtain data from third parties (e.g. landfill } \\
\text { operators) should be developed to augment service contract data.) }\end{array}$ \\
\hline
\end{tabular}




\begin{tabular}{|c|c|}
\hline & $\begin{array}{c}\text { COMPLIANCE CATEGORY: } \\
\text { OTHER ENVIRONMENTAL ISSUES } \\
\text { Overseas ESOHCAMP }\end{array}$ \\
\hline $\begin{array}{l}\text { REGULATORY } \\
\text { REQUIREMENTS: }\end{array}$ & $\begin{array}{l}\text { REVIEWER CHECKS: } \\
\text { September } 2009\end{array}$ \\
\hline $\begin{array}{l}\text { O4.10 } \\
\text { POLLUTION } \\
\text { PREVENTION: } \\
\text { Opportunity Assessments } \\
\text { O4.10.1.OCAF. Installations } \\
\text { must conduct Opportunity } \\
\text { Assessments to review waste } \\
\text { generating activities and in- } \\
\text { stallation waste streams (AFI } \\
\text { 32-7080, para 2.2.1). }\end{array}$ & $\begin{array}{l}\text { Verify that an Opportunity Assessment of each waste generating activity is con- } \\
\text { ducted on a recurring basis. } \\
\text { Verify that the Opportunity Assessment provides a systematic review of the waste } \\
\text { generating activities and installation waste streams. } \\
\text { Verify that the assessment examines the total waste generation by type and vol- } \\
\text { ume of content and determines the most economical and practical waste minimi- } \\
\text { zation option. } \\
\text { Verify that consideration is given to cost/benefit analysis when evaluating op- } \\
\text { tions. } \\
\text { (NOTE: An example of the composition of an assessment team includes the fol- } \\
\text { lowing persons: } \\
\text { - raw material supplier } \\
\text { - Quality Assurance/Quality Control [QA/QC] Officer } \\
\text { - consultant } \\
\text { - process engineer } \\
\text { - safety engineer } \\
\text { - purchasing specialist } \\
\text { - line laborer } \\
\text { - plant manager.) } \\
\text { [Formerly checklist item number O4.20.1.OCAF.] }\end{array}$ \\
\hline
\end{tabular}




\section{COMPLIANCE CATEGORY: \\ OTHER ENVIRONMENTAL ISSUES \\ Overseas ESOHCAMP}

\begin{tabular}{|c|c|}
\hline $\begin{array}{l}\text { REGULATORY } \\
\text { REQUIREMENTS: }\end{array}$ & $\begin{array}{l}\text { REVIEWER CHECKS: } \\
\text { September } 2009\end{array}$ \\
\hline $\begin{array}{l}\text { O4.20 } \\
\text { POLLUTION } \\
\text { PREVENTION: } \\
\text { ODCs/ODSs }\end{array}$ & \\
\hline $\begin{array}{l}\text { O4.20.1.OCAF. Users of } \\
\text { Class I ODS halons must re- } \\
\text { turn any excess amounts to } \\
\text { the DLA Class I ODS De- } \\
\text { fense Reserve for recovery, } \\
\text { reclamation, and redistribu- } \\
\text { tion (AFI 32-7086, para } \\
\text { 4.4.2.5) [Moved June 2003; } \\
\text { Revised January 2005; Cita- } \\
\text { tion Revised January 2005]. }\end{array}$ & $\begin{array}{l}\text { Verify that users of Class I ODS halons return any excess amounts to the DLA } \\
\text { Class I ODS Defense Reserve for recovery, reclamation, and redistribution. } \\
\text { (NOTE: Installation HMMP teams are permitted to shift stocks of Class I ODS } \\
\text { refrigerants from one authorized user to another, before declaring them excess, } \\
\text { and turning them in to the Defense Reserve.) } \\
\text { Verify that users responsibly dispose of used Class I ODS solvents in a manner } \\
\text { that minimizes release to the environment. } \\
\text { [Formerly checklist item number O4.40.1.OCAF.] }\end{array}$ \\
\hline $\begin{array}{l}\text { O4.20.2.OCAF. } \quad \text { [Deleted } \\
\text { January 2004]. }\end{array}$ & $\begin{array}{l}\text { Deleted as a result of the revision of AFI 32-7086 dated } 01 \text { November } 2004 . \\
\text { [Formerly checklist item number O4.40.2.OCAF.] }\end{array}$ \\
\hline $\begin{array}{l}\text { O4.20.3.0CAF. Each instal- } \\
\text { lation must have a facility } \\
\text { halon management plan and a } \\
\text { Class I ODS refrigeration } \\
\text { management plan (AFI 32- } \\
\text { 7086, paras 4.4.2.7 and } \\
\text { 4.11.3.2) [Moved June 2003; } \\
\text { Revised January 2005; Cita- } \\
\text { tion Revised January 2005]. }\end{array}$ & $\begin{array}{l}\text { Verify that the installation has a current Halon Management Plan and a current } \\
\text { Refrigerant Management Plan (addressing both Class I and Class II ODS) in ac- } \\
\text { cordance with AFCESA guidance. } \\
\text { [Formerly checklist item number O4.40.3.OCAF.] }\end{array}$ \\
\hline $\begin{array}{l}\text { O4.20.4.OCAF. CE has spe- } \\
\text { cific responsibilities with re- } \\
\text { gard to the ODS Program } \\
\text { (ODSP) (AFI 32-7086, paras } \\
\text { 4.12.2.1 through 4.12.2.7) } \\
\text { [Revised September 1999; } \\
\text { Moved June 2003; Revised } \\
\text { January 2005; Citation Re- } \\
\text { vised January 2005]. }\end{array}$ & $\begin{array}{l}\text { Verify that CE: } \\
\text { - manages facility air conditioning, refrigeration, and fire suppression equip- } \\
\text { ment using existing CE Class I ODS stocks } \\
\text { - identifies all excess facility halons and Class I ODS refrigerants to the } \\
\text { MAJCOM and ensures they are reallocated within the MAJCOM or the Air } \\
\text { Force or turned-in to the DLA Class I ODS Defense Reserve according to } \\
\text { established procedures } \\
\text { - advises SE of any inadvertent releases of Class I ODS from installation CE } \\
\text { facilities, equipment, or processes for possible reporting as a mishap } \\
\text { - ensures that procedures are in place for the proper reporting of inadvertent } \\
\text { installation releases of Class I ODS, in accordance with applicable reporting } \\
\text { requirements } \\
\text { - issues an environmental Notice to Airman (NOTAM) within } 30 \text { work days } \\
\text { of an inadvertent release of a Class I ODS that requires Class A or Class B }\end{array}$ \\
\hline
\end{tabular}




\begin{tabular}{|c|c|}
\hline & $\begin{array}{c}\text { COMPLIANCE CATEGORY: } \\
\text { OTHER ENVIRONMENTAL ISSUES } \\
\text { Overseas ESOHCAMP }\end{array}$ \\
\hline $\begin{array}{c}\text { REGULATORY } \\
\text { REQUIREMENTS: }\end{array}$ & $\begin{array}{l}\text { REVIEWER CHECKS: } \\
\text { September } 2009\end{array}$ \\
\hline $\begin{array}{l}\text { O4.20.6.OCAF. Work area } \\
\text { supervisors have specific re- } \\
\text { sponsibilities with regard to } \\
\text { the ODSP (AFI 32-7086, } \\
\text { paras 4.12.5.1 through } \\
\text { 4.12.5.5) [Moved June 2003; } \\
\text { Revised January 2005; Cita- } \\
\text { tion Revised January 2005]. }\end{array}$ & $\begin{array}{l}\text { mishap reporting } \\
\text { - ensures that the NOTAM includes information on the release (date of } \\
\text { occurrence, location and amounts of Class I ODS released), the identi- } \\
\text { fication of causes, and recommended corrective actions } \\
\text { - includes MAJCOM/CEV and SAF/AQRE as addressees on each Class } \\
\text { I ODS inadvertent release NOTAM, regardless of mishap category } \\
\text { - ensures the preparation and maintenance of current Halon and Refrigerant } \\
\text { Management Plans } \\
\text { - provides initial and revised Refrigerant Management Plans to the MAJCOM } \\
\text { Refrigerant Manager and AFCESA for review and comment to include BCE } \\
\text { exceptions to the Class II ODS policy for installation Real Property air con- } \\
\text { ditioning and refrigeration equipment. } \\
\text { (NOTE: Facility Class I ODS requirements may not be met by requisitions from } \\
\text { the DLA Class I ODS Defense Reserve or purchase of Class I ODS.) } \\
\text { [Formerly checklist item number O4.40.4.OCAF.] } \\
\text { Verify that LRS: } \\
\text { - ensures that the HAZMART obtains Class I ODS Requisition SAO approv- } \\
\text { als in accordance with the procedures described at AFI 32-7086, para 4.6, } \\
\text { prior to requisitioning Class I ODS from the DLA Class I ODS Defense Re- } \\
\text { serve } \\
\text { - ensures that the standardized Air Force HAZMAT tracking system tracks } \\
\text { Class I ODS requisitions } \\
\text { - ensures that the LRS HAZMART supervisor assigns appropriate USAF } \\
\text { REX code to all Class I ODS NSNs. } \\
\text { [Formerly checklist item number O4.40.5.OCAF.] } \\
\text { Verify that work area supervisors: } \\
\text { - participate in the HMMP team, as necessary } \\
\text { - ensure that Class I ODS supplies are obtained only from an installation } \\
\text { HAZMART, in accordance with the Class I ODS Requisition SAO approval } \\
\text { procedures described in AFI 32-7086, para 4.6 } \\
\text { - ensure that there is a requiring document for each Class I ODS use that } \\
\text { specifies the exclusive use of that Class I ODS } \\
\text { - advise SE of any inadvertent releases of Class I ODS in their work area for } \\
\text { possible reporting as a mishap } \\
\text { tiese CE of any inadvertent releases of Class I ODS from work area facili- } \\
\text { ment, or processes, and comply with applicable reporting require- } \\
\text { [atist item number O4.40.6.OCAF.] }\end{array}$ \\
\hline
\end{tabular}




\section{COMPLIANCE CATEGORY: \\ OTHER ENVIRONMENTAL ISSUES \\ Overseas ESOHCAMP}

\section{REGULATORY REQUIREMENTS:}

04.20.7.0CAF. Maintenance (Weapon Systems) has specific responsibilities with regard to the ODSP (AFI 327086, paras 4.12.3.1 through 4.12.3.5) [Added January 2005].

04.20.8.0CAF. SE has specific responsibilities with regard to the ODSP (AFI 327086, paras 4.12.6.1 and 4.12.6.2) [Added January 2005].

04.20.9.OCAF. The installation HMMP team has specific responsibilities with regard to the ODSP (AFI 32-7086, paras 4.12.1.1 through 4.12.1.5) [Added January 2005].

\section{REVIEWER CHECKS: September 2009}

Verify that Maintenance (Weapon Systems):

- participates in the HMMP team

- manages weapon system Class I ODS in accordance with SAO approvals

- ensures that there is a formal technical document (e.g., TO or commercial technical manual) requirement for each Class I ODS use

- identifies all excess weapon system halons and Class I ODS refrigerants to the MAJCOM and ensure they are reallocated within the MAJCOM, the Air Force, or turned-in to the DLA Class I ODS Defense Reserve in accordance with established procedures

- advises SE of any inadvertent releases of Class I ODS from installation LG facilities, equipment, or processes for possible reporting as a mishap

- advises CE of any inadvertent releases of Class I ODS from installation LG facilities, equipment, or processes, and complies with applicable reporting requirements.

Verify that SE:

- investigates all inadvertent releases of Class I ODS to determine reporting requirements in accordance with AFI 91-204, Safety Investigations and Reports

- reviews the mishap report with the other members of the HMMP team, to include, as a minimum, CE, LG, and BE, consistent with the restrictions on release of privileged information

- provides necessary support to CE for the issuance of an environmental NOTAM that summarizes the inadvertent release of a Class I ODS.

(NOTE: Class I ODS are valued at \$100 per pound. Inadvertent release does not include releases resulting from the intended use of the material [e.g., the release of halons in actual fire fighting or fuel tank inerting].)

(NOTE: Mishap reports related to Class I ODS inadvertent releases are non-rate producing for mishap rate calculations.)

Verify that the installation HMMP team:

- ensures that installation personnel using ODS are involved in a responsible use program to prevent losses and to conduct recovery, recycling, and reuse of ODS to the maximum extent practicable

- prohibits the use and discharges of Class I ODS halons during both facility and weapon system training

- prohibits the discharge of Class I and Class II ODS refrigerants during both facility and weapon system training.

- ensures that deploying units provide the Class I ODS deployment report in accordance with AFI 32-7086, para 4.7.2.3.4

- ensures the turn in of installation excess refrigerants and halons (including halon bottles with the contents intact) to the DLA Class I ODS Defense Reserve IAW paragraph 4.4.2.5 


\section{COMPLIANCE CATEGORY: \\ OTHER ENVIRONMENTAL ISSUES \\ Overseas ESOHCAMP}

\begin{tabular}{|l|}
\hline \multicolumn{2}{|c|}{ REGULATORY } \\
REQUIREMENTS: \\
\hline \\
O4.20.10.OCAF. Specific \\
requirements must be met \\
when it becomes necessary to \\
service or replace an aircraft \\
halon bottle (AFI 32-7086, \\
paras 4.12.5.1 through \\
4.12.5.5) [Added January \\
2005].
\end{tabular}

O4.20.11.OCAF. Units must obtain Class I ODS through the installation HAZMART only (AFI 32-7086, paras 4.4.1 and 4.6.2.1) [Added January 2005].

O4.20.12.0CAF. Contractors who requisition ODS must do so in accordance with specific requirements (AFI 32-7086, paras 4.4.3, 4.4.3.1, and 4.6.2.1) [Added January 2005].

O4.20.13.OCAF. The use of Class II ODS requires prior approval through the AF Form 3952 Authorization Process (AFI 32-7086, para 4.8) [Added January 2005].

\section{REVIEWER CHECKS: September 2009}

- prohibits the transfer of excess installation Class I ODS outside the Air Force, except to the DLA Class I ODS Defense Reserve.

Verify that, when it becomes necessary to service or replace an aircraft halon bottle, the unit sends the bottle, with its contents intact, to the Warner-Robins Air Logistics Center (WR-ALC) for recovery and reclamation of the halon and servicing or replacement of the bottle.

(NOTE: There are only two exceptions to the above requirement:

- the unit should send all 5-lb Halon 1211 fire bottles with their contents intact to the DLA Class I ODS Defense Reserve for recovery and reclamation of the halon and servicing or replacement of the bottle

- if a unit has a mission-driven need to contract for halon recovery, reclamation, or bottle servicing, the unit must first obtain a contract SAO approval.

Verify that no unit obtains Class I ODS other than through the installation HAZMART.

Verify that units obtain Class I ODS via an approved AF Form 3952.

(NOTE: An AF Form 3952 for a Class I ODS cannot be approved unless it identifies a requiring document that specifies the exclusive use of a Class I ODS.)

Verify that contractors who submit a requisition for a Class I ODS have completed the HAZMAT authorization process.

Verify that there is current SAO approval for the contract requirement to use the Class I ODS.

(NOTE: No requiring activity may include in solicitations or contracts any specification, standard, drawing, or other document that requires the use of, or establishes a requirement that can only be met by the use of, a Class I ODS in the manufacture, test, operation, or maintenance of any system, subsystem, item, component, or process. If a requiring activity does require a contractor to use a Class I ODS, or establishes a requirement that the contractor can meet only by using a Class I ODS, it must first obtain SAO approval of each Class I ODS usage requirement.)

(NOTE: A contract to operate a HAZMART does not require SAO approval for ordering, receiving, stocking, and storing of Class I ODS.)

Verify that any users of Class II ODS have obtained prior approval through the AF Form 3952 Authorization Process.

(NOTE: Class II ODS are HAZMAT.) 


\section{COMPLIANCE CATEGORY: \\ OTHER ENVIRONMENTAL ISSUES \\ Overseas ESOHCAMP}

\section{REGULATORY REQUIREMENTS: \\ O4.30 \\ POLLUTION \\ PREVENTION: \\ Hazardous Substances \\ (Waste and Material)}

O4.30.1.OCAF. Installations must develop centralized control procedures for the purchase and use of hazardous materials (AFI 32-7080, para 2.4.1) [Moved June 2003].

04.30.2.OCAF. Installations must reduce the use of USEPA ITP chemicals (AFI 32-7080, para 3.2) [June 2003].

O4.30.3.OCAF. Installations must work to minimize hazardous waste generation (AFI 32-7080, para 3.3 and para 2.4.3) [Moved June 2003].

O4.30.4.OCAF. Installations
REVIEWER CHECKS: September 2009

Verify that the purchase of hazardous materials is under centralized control.

(NOTE: This requirement also applies to ODCs.)

Verify that the issuance and distribution of hazardous materials is centrally controlled.

Verify that hazardous materials are issued in the smallest quantity necessary to meet the customer's need.

[Formerly checklist item number O4.50.1.OCAF.]

Verify that the installation is working to reduce the use of the chemicals listed in Appendix 6-1.

(NOTE: Due to the high levels of certain USEPA 17 toxics in jet fuel, and the direct link between fuels and flying hours, the AF's USEPA 17 reduction goals exempt jet fuels.)

[Formerly checklist item number O4.50.2.OCAF.]

Verify that hazardous waste from industrial, maintenance, and cleanup operations is minimized to the greatest extent practical and economical.

Verify that the installation strives to reduce hazardous waste generation at the source.

Verify that alternatives to hazardous materials and processes are used whenever possible.

Verify that, when TOs require the use of many hazardous substances or out-ofdate technology, the installation submits an Air Force Technical Order (AFTO) Form 22.

(NOTE: This requirement applies only if alternative substances/technology are known to exist.)

[Formerly checklist item number O4.50.3.OCAF.]

Verify that the installation maintains inventory management and control processes 


\section{COMPLIANCE CATEGORY: \\ OTHER ENVIRONMENTAL ISSUES \\ Overseas ESOHCAMP}

\begin{tabular}{|l|l|}
\hline \multicolumn{1}{|c|}{$\begin{array}{c}\text { REGULATORY } \\
\text { REQUIREMENTS: }\end{array}$} & \multicolumn{1}{c|}{$\begin{array}{c}\text { REVIEWER CHECKS: } \\
\text { September 2009 }\end{array}$} \\
\hline $\begin{array}{l}\text { must maintain inventory man- } \\
\text { agement and control proc- } \\
\text { esses that minimize the use of } \\
\text { hazardous materials (DODI } \\
\text { 4715.4, para 6.2.3.1) [Moved } \\
\text { June 2003]. }\end{array}$ & $\begin{array}{l}\text { that minimize the use of hazardous materials, as appropriate, in the most eco- } \\
\text { nomical manner. } \\
\text { [Formerly checklist item number O4.50.4.OCAF.] } \\
\begin{array}{l}\text { O4.30.5.OCAF. Installations } \\
\text { should encourage complete } \\
\text { use of hazardous materials } \\
\text { (MP) [Moved June 2003]. }\end{array}\end{array}$ [Formerly checklist item number O4.50.5.OCAF.] \\
\hline
\end{tabular}




\section{COMPLIANCE CATEGORY: \\ OTHER ENVIRONMENTAL ISSUES \\ Overseas ESOHCAMP}

\begin{tabular}{|l|}
\hline \multicolumn{1}{|c|}{ REGULATORY } \\
REQUIREMENTS: \\
\hline O4.40 \\
POLLUTION \\
PREVENTION: \\
Solid Waste \\
O4.40.1.OCAF. Installations \\
must institute pollution pre- \\
vention procedures as part of \\
their solid waste management \\
(AFI 32-7080, paras 3.4.1, \\
3.4.1.1, and 3.4.1.2; AF QRP \\
Policy, pp. 1 and 3; and AFI \\
32-7042, paras 3.6.3.2, \\
3.6.3.4.1, and 3.6.3.4.3) \\
[Moved June 2003; Revised \\
September 2006; Citation \\
Revised September 2006; \\
Revised September 2009; \\
Citation Revised September \\
2009].
\end{tabular}

Verify that cost-effective waste reduction and recycling programs have been integrated into the Municipal Solid Waste Management program.

Verify that the installation either operates a composting program for yard wastes or participates in a regional composting program.

(NOTE: This requirement does not apply if the program can be shown to be cost prohibitive.)

Verify that the installation establishes a single qualified recycling program (QRP) that serves all AF and tenant organizations occupying space on the installation, including leased space.

Verify that the installation has a QRP manager.

Verify that the Wing Commander (or, if designated, the ESOHC Chairperson) has designated the QRP manager by issuing a QRP designation/appointment letter.

(NOTE: Once appointed, the QRP manager is responsible for the day-to-day operation of the QRP. This position is not mandated to be an environmental flight position. The MAJCOM or installation commander has the authority and the responsibility to determine where this position should reside.)

(NOTE: The QRP manager is the single point of contact for all aspects of the QRP.)

Verify that all organizations actively participate in the QRP.

Verify that all recycling sections (appropriated funded activities, Services, Army AF Exchange Service [AAFES], and Defense Commissary Agency [DeCA]) forward appropriate recycling/diversion and proceeds data and information to the QRP manager as required.

Verify that each facility (other than AAFES and DeCA) collects and segregates recyclable materials for collection by the QRP.

Verify that the Services Squadron, AAFES, and the Commissary coordinate their recycling activities with the QRP manager.

Verify that recycling includes the following materials as a minimum: 


\section{COMPLIANCE CATEGORY: \\ OTHER ENVIRONMENTAL ISSUES \\ Overseas ESOHCAMP}

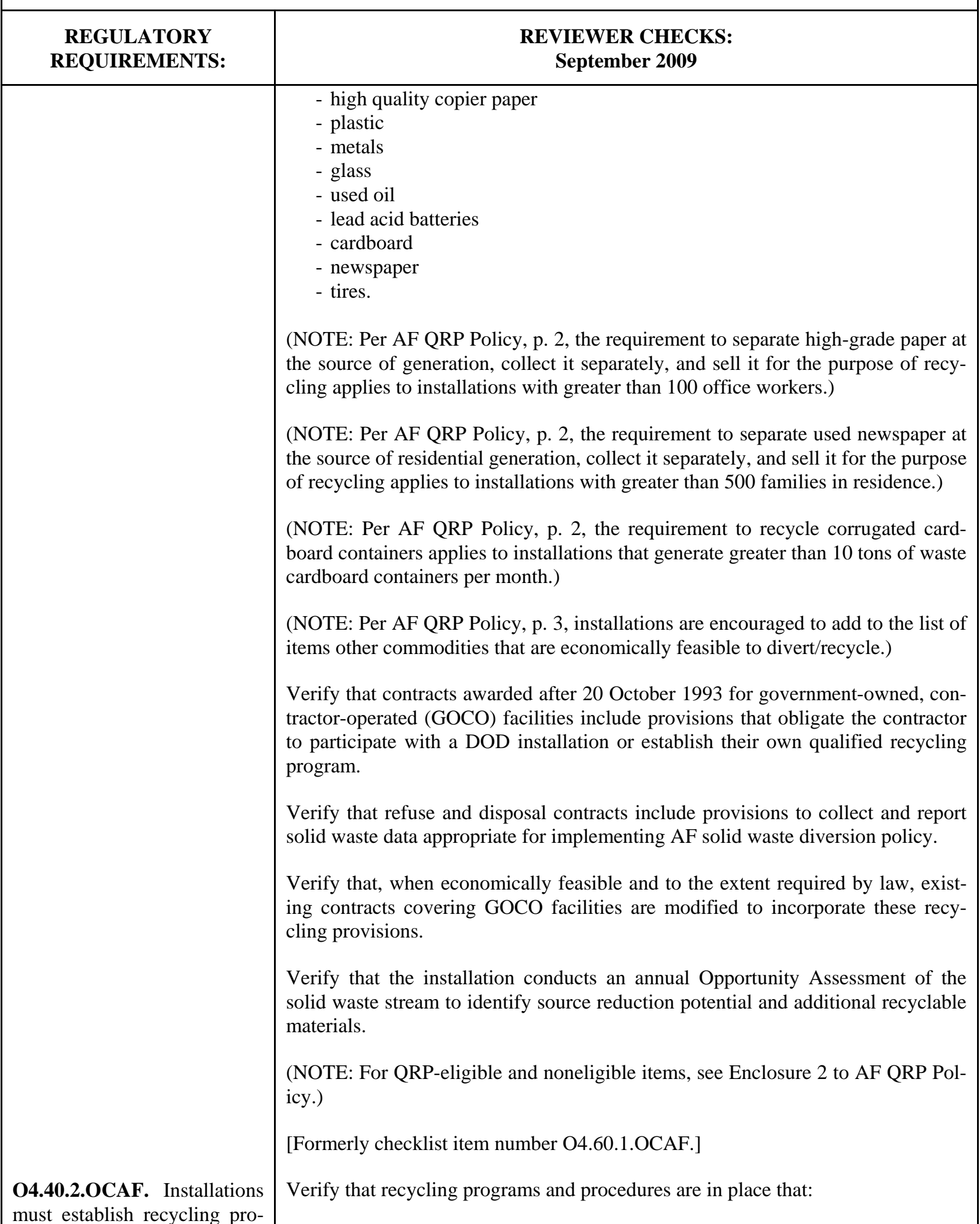




\section{COMPLIANCE CATEGORY: \\ OTHER ENVIRONMENTAL ISSUES \\ Overseas ESOHCAMP}

\section{REGULATORY REQUIREMENTS:}

grams that meet specific requirements (DODI 4715.4, para 6.2.3.3) [Moved June 2003].

O4.40.3.OCAF. Installations must issue a municipal solid waste and recycling report quarterly (AFI 32-7080, para 3.4.2, and AF QRP Policy, p. 3) [Moved June 2003; Revised September 2006].

04.40.4.OCAF. [Moved

\section{REVIEWER CHECKS: September 2009}

- ensure, where cost-effective, the installation has or participates in a QRP

- ensure installation recycling programs are available to serve all host and tenant organizations that occupy space on the installation, including leased space

- ensure QRP procedures address recyclable materials, excluded materials, and other qualified recycling program materials

- divert recyclable materials from the nonhazardous solid waste stream if economically feasible

- establish controls to ensure excluded materials are not sold through a QRP

- authorize ICs, as appropriate, to sell directly recyclable and other QRP materials or to consign them to DRMS for sale

- ensure expended brass is crushed, shredded, or otherwise destroyed prior to public sale

- ensure local reuse screening considers reutilization, transfer, and donation programs in accordance with DOD 4160.21-M

- ensure that disposition of recyclable and other QRP materials derived from goods that have been imported duty-free is accomplished (if at all) consistent with the provisions contained in status of forces, surplus or excess property agreements, or other international agreements with host nations

- ensure that distribution of recycling proceeds is consistent with 10 USC 2577.

(NOTE: Installations should require participation by contractors operating government-owned or leased facilities overseas where recycling programs are available.)

[Formerly checklist item number O4.60.2.OCAF.]

Verify that the municipal solid waste and recycling report (RCS, HAF$\mathrm{CEV}(\mathrm{Q}) 9424)$ is released quarterly to the Air Staff within 45 days after the end of each quarter.

(NOTE: This report can be discontinued during emergency conditions.)

Verify that all solid waste disposal, diversion, and recycling data are reported through, and validated by, the MAJCOM, prior to submission to HQ USAF/A7CV.

Verify that the installation utilizes standard volume-to-weight conversion factors to ensure accurate calculations.

(NOTE: For standard volume-to-weight conversion factors, see Enclosure 1 to AF QRP Policy.)

[Formerly checklist item number O4.60.3.OCAF.]

Moved to O4.40.13.OCAF 


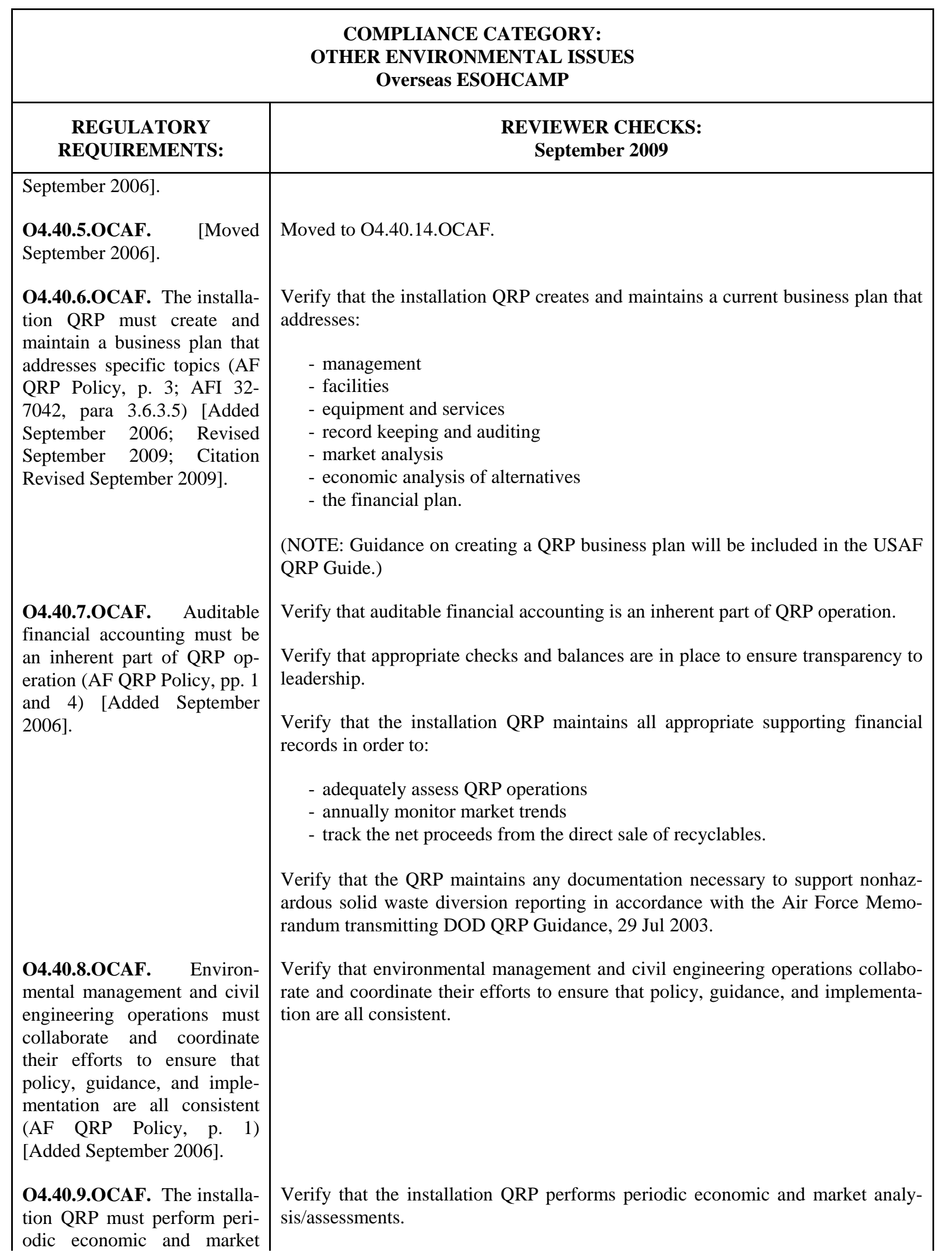




\section{COMPLIANCE CATEGORY: \\ OTHER ENVIRONMENTAL ISSUES \\ Overseas ESOHCAMP}

\section{REGULATORY REQUIREMENTS:}

analysis/assessments (AF QRP Policy, p. 4, and AFI 327042, para 3.6.3.5.1) [Added September 2006; Citation Revised September 2009].

04.40.10.0CAF. Installations must be able to adequately justify lack of recycling/diversion efforts for mandatory items, recommended items in accordance with AFI 32-7080, and any subsequently recommended commodities (AF QRP Policy, p. 4, and AFI 32-7042, para 3.6.3.5.2) [Added September 2006; Revised September 2009; Citation Revised September 2009].

04.40.11.0CAF. The installation QRP must consistently process and track any outstanding recouping actions for unreimbursed DRMO scrap sales (AF QRP Policy, p. 4) [Added September 2006].

O4.40.12.OCAF. The QRP Manager must ensure that DRMO scrap sale proceeds and QRP revenue are reported no less than once per quarter to the wing commander or the appropriate designee and the MAJCOM (AF QRP Policy, p. 4) [Added September 2006].

04.40.13.OCAF. Installations must implement affirmative procurement programs for materials with recycled content (AFI 32-7080, para 3.5) [Moved June 2003; Revised January 2005 Moved

\section{REVIEWER CHECKS: September 2009}

Verify that the installation QRP rechecks with vendors to determine whether mandatory and recommended items can be recycled, and whether they can be recycled more cost effectively either locally or elsewhere.

Verify that the installation is able to adequately justify (via documentation, economic and market analysis, etc.) lack of recycling /diversion efforts for mandatory items, recommended items in accordance with AFI 32-7080, and any subsequently recommended commodities.

(NOTE: Guidance on completing economic and market analysis/assessment, and documentation of the lack of recycling efforts will be included in the USAF QRP Guide.)

Verify that this justification is included in the QRP business plan.

Verify that the installation QRP consistently processes and tracks any outstanding recouping actions for unreimbursed DRMO scrap sales.

(NOTE: This occurs with the assistance of the appropriate CE/A7C Resource personnel.)

Verify that the QRP Manager ensures that DRMO scrap sale proceeds and QRP revenue are reported no less than once per quarter to the wing commander or the appropriate designee and to the MAJCOM.

Verify that each activity reviews and revises specifications for the following designated items to allow procurement of products containing recycled materials:

- paper

- retread tires

- building insulation

- cement/concrete containing fly ash

- re-refined oils. 


\begin{tabular}{|c|c|}
\hline \multicolumn{2}{|r|}{$\begin{array}{c}\text { COMPLIANCE CATEGORY: } \\
\text { OTHER ENVIRONMENTAL ISSUES } \\
\text { Overseas ESOHCAMP }\end{array}$} \\
\hline $\begin{array}{l}\text { REGULATORY } \\
\text { REQUIREMENTS: }\end{array}$ & $\begin{array}{l}\text { REVIEWER CHECKS: } \\
\text { September } 2009\end{array}$ \\
\hline September 2006]. & $\begin{array}{l}\text { Verify that all of the following elements are included in the installation's affirma- } \\
\text { tive procurement program: } \\
\text { - a preference program } \\
\text { - a promotion plan } \\
\text { - procedures requiring vendors and contractors to estimate and certify the con- } \\
\text { tent of recovered materials in the above designated items that they sell to the } \\
\text { installation or use in construction projects on the installation } \\
\text { - annual review of the effectiveness of the program. } \\
\text { [Formerly checklist item number O4.40.4.OCAF.] } \\
\text { (NOTE: The Strategic Plan for the Implementation of Executive Order [EO] } \\
\text { 13101 [Greening the Government Through Waste Prevention, Recycling, and } \\
\text { Federal Acquisition, } 12 \text { March 1999] of the Office of the Federal Environmental } \\
\text { Executive states [Part II, Background] that "Requirements of EO 13101 do not } \\
\text { apply to facilities and posts abroad except for purchases made in the United States } \\
\text { for shipments overseas.") }\end{array}$ \\
\hline $\begin{array}{l}\text { O4.40.14.OCAF. Installa- } \\
\text { tions must issue an affirma- } \\
\text { tive procurement purchases } \\
\text { report quarterly (AFI 32- } \\
\text { 7080, para 3.5.4) [Moved } \\
\text { June 2003; Moved September } \\
\text { 2006]. }\end{array}$ & $\begin{array}{l}\text { Verify that the affirmative procurement report (RCS, HAF-CEV(Q)9424) is re- } \\
\text { leased quarterly to the Air Staff within } 45 \text { days after the end of each quarter. } \\
\text { (NOTE: This report can be discontinued during emergency conditions.) } \\
\text { [Formerly checklist item number O4.40.5.OCAF.] }\end{array}$ \\
\hline $\begin{array}{l}\text { O4.40.15.OCAF. Installa- } \\
\text { tions should conduct an initial } \\
\text { solid waste characterization } \\
\text { study to define the basis for } \\
\text { the reduction/diversion goal } \\
\text { and evaluate the composition } \\
\text { and seasonal variability of } \\
\text { waste streams as well as the } \\
\text { weight and waste types pre- } \\
\text { sent (MP) [Added June 2008]. }\end{array}$ & $\begin{array}{l}\text { Verify that the installation has conducted an initial solid waste characterization } \\
\text { study to define the basis for the reduction/diversion goal and evaluate the compo- } \\
\text { sition and seasonal variability of waste streams as well as the weight and waste } \\
\text { types present. } \\
\text { (NOTE: This MP is found at DOD ISWM Policy, para B.2.a.) }\end{array}$ \\
\hline $\begin{array}{l}\text { O4.40.16.OCAF. Installa- } \\
\text { tions should review regula- } \\
\text { tions to determine applicable } \\
\text { DOD, DOD-Component, Fi- } \\
\text { nal Governing Standard, in- } \\
\text { ternational agreement, and } \\
\text { applicable host-nation recy- } \\
\text { cling requirements and/or }\end{array}$ & $\begin{array}{l}\text { Verify that the installation has reviewed regulations to determine applicable DOD, } \\
\text { DOD-Component, Final Governing Standard, international agreement, and appli- } \\
\text { cable host-nation recycling requirements and/or diversion requirements or goals. } \\
\text { (NOTE: This MP is found at DOD ISWM Policy, para B.2.b.) }\end{array}$ \\
\hline
\end{tabular}




\section{COMPLIANCE CATEGORY: \\ OTHER ENVIRONMENTAL ISSUES \\ Overseas ESOHCAMP}

\begin{tabular}{l}
\hline \multicolumn{2}{|c|}{ REGULATORY } \\
REQUIREMENTS: \\
\hline $\begin{array}{l}\text { diversion requirements or } \\
\text { goals (MP) [Added June } \\
\text { 2008]. }\end{array}$ \\
\hline
\end{tabular}

O4.40.17.OCAF. Installations should review the status of solid waste generation from all sources at least annually (MP) [Added June 2008].

O4.40.18.0CAF. Installations should evaluate waste streams with emphasis on reduced generation (MP) [Added June 2008].

O4.40.19.0CAF. Installations should employ specific procedures in the course of conducting economic analysis/market research (MP) [Added June 2008].

\section{REVIEWER CHECKS: September 2009}

Verify that the installation reviews the status of solid waste generation from all sources at least annually.

(NOTE: Examples of sources to consider include office trash, nonhazardous industrial waste, nonhazardous process waste, residential trash, C\&D wastes, yard wastes, and logistics waste such as packaging.)

(NOTE: This MP is found at DOD ISWM Policy, para B.2.c.)

Verify that the installation evaluates waste streams with emphasis on reduced generation.

Verify that the installation uses waste characterization or annual source inventory results to target and prioritize waste types and waste generation locations for implementing waste reduction.

(NOTE: The following are actions that affect source reduction:

- devising manufacturing processes that create fewer or less toxic waste byproducts;

- complying with GPP mandates for all acquisitions.)

(NOTE: Some GPP practices that target solid waste reduction include:

- reducing or eliminating packaging

- purchasing products with low or no toxic or hazardous waste constituents

- purchasing products from manufacturers that close the procurement loop through use of take back programs that accept return of used products for recycling.)

(NOTE: This MP is found at DOD ISWM Policy, para B.2.d.)

Verify that the installation performs an economic analysis of potential diversion opportunities to determine if the opportunity can create a positive economic benefit.

(NOTE: The opportunity may be to add a commodity to the QRP or divert the material through other recycling, composting, or donation.)

Verify that the installation performs market research for current and potential items for diversion through the QRP, non-QRP recycling, donation, composting or other diversion opportunity.

(NOTE: The following process is suggested:

- estimate installation-wide generated weight/volume of each commodity, including activities that handle their own wastes, such as the Commissary or 


\section{COMPLIANCE CATEGORY: \\ OTHER ENVIRONMENTAL ISSUES \\ Overseas ESOHCAMP}

\begin{tabular}{|c|c|}
\hline $\begin{array}{l}\text { REGULATORY } \\
\text { REQUIREMENTS: }\end{array}$ & $\begin{array}{l}\text { REVIEWER CHECKS: } \\
\text { September } 2009\end{array}$ \\
\hline $\begin{array}{l}\text { O4.40.20.OCAF. Installa- } \\
\text { tions should base approval on } \\
\text { specific decision criteria be- } \\
\text { fore beginning any collections } \\
\text { or entering into any contracts } \\
\text { with buyers/brokers (MP) } \\
\text { [Added June 2008]. }\end{array}$ & 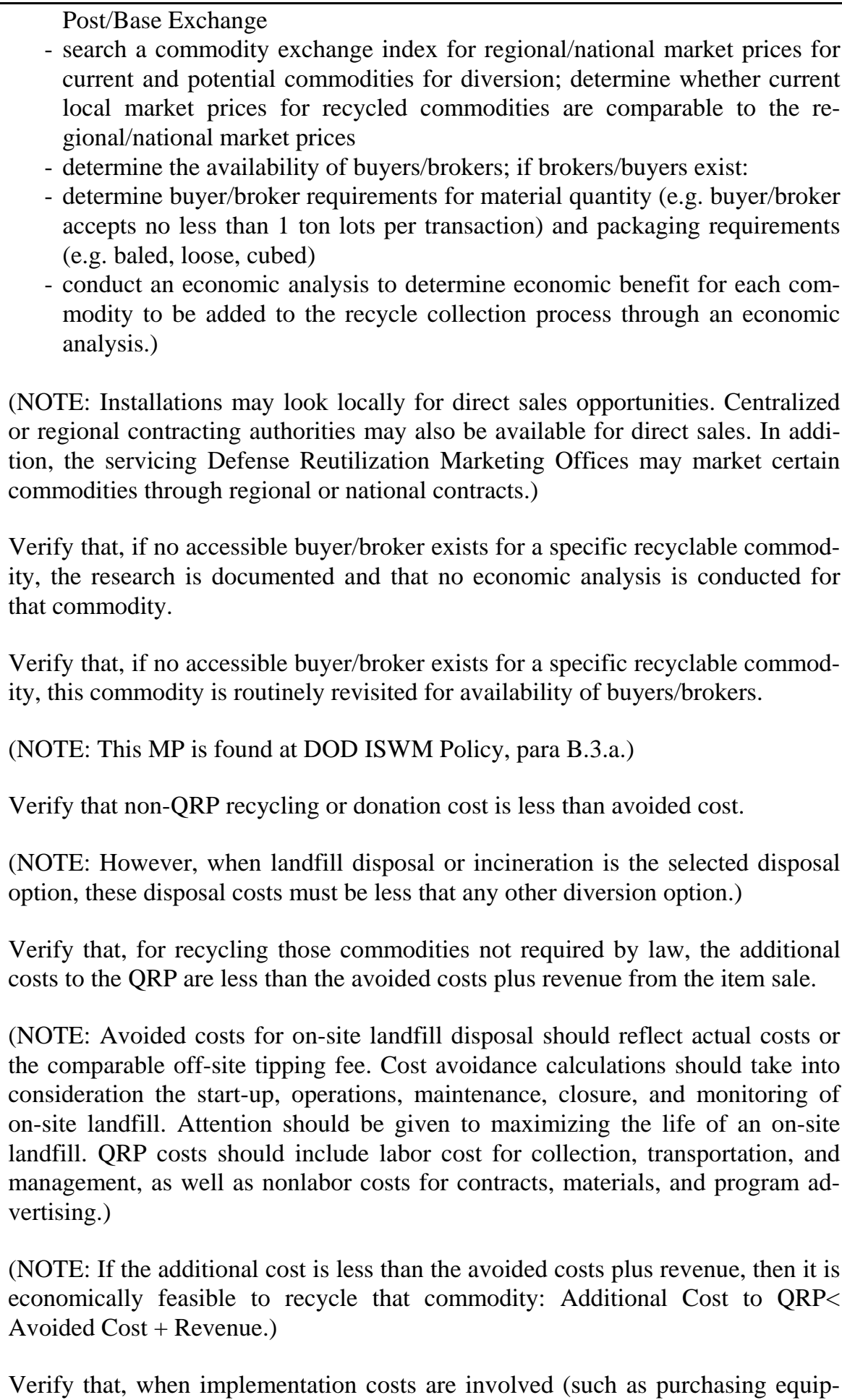 \\
\hline
\end{tabular}




\section{COMPLIANCE CATEGORY: \\ OTHER ENVIRONMENTAL ISSUES \\ Overseas ESOHCAMP}

\begin{tabular}{|c|c|}
\hline $\begin{array}{l}\text { REGULATORY } \\
\text { REQUIREMENTS: }\end{array}$ & $\begin{array}{l}\text { REVIEWER CHECKS: } \\
\text { September } 2009\end{array}$ \\
\hline $\begin{array}{l}\text { O4.40.21.OCAF. The QRP } \\
\text { Manager should present the } \\
\text { results of the program review } \\
\text { and economic analysis to the } \\
\text { installation QRP Committee } \\
\text { for approval before beginning } \\
\text { any collections or entering } \\
\text { into any contracts with buy- } \\
\text { ers/brokers (MP) [Added June } \\
\text { 2008]. }\end{array}$ & $\begin{array}{l}\text { ment, upfront labor, expanding facilities, and transportation/energy costs), the } \\
\text { payback period on the initial investment is determined. } \\
\text { (NOTE: The payback period is calculated by dividing the implementation cost by } \\
\text { the sum of the annual cost savings and annual revenue. The result will indicate the } \\
\text { payback period in years. Decision makers must make a determination of what is } \\
\text { an acceptable payback period.) } \\
\text { (NOTE: This MP is found at DOD ISWM Policy, paras B.3.b.1 through B.3.b.3.) } \\
\text { Verify that, before beginning any collections or entering into any contracts with } \\
\text { buyers/brokers, the QRP Manager presents the results of the program review and } \\
\text { economic analysis to the installation QRP Committee for approval. } \\
\text { (NOTE: This MP is found at DOD ISWM Policy, para B.3.b.4.) }\end{array}$ \\
\hline $\begin{array}{l}\text { O4.40.22.OCAF. Contracts } \\
\text { that generate waste must in- } \\
\text { clude provisions that obligate } \\
\text { the contractor to participate in } \\
\text { the QRP for recyclable wastes } \\
\text { generated on the installation, } \\
\text { where applicable (AFI 32- } \\
\text { 7042, para 3.6.3.6) [Added } \\
\text { June 2008]. }\end{array}$ & $\begin{array}{l}\text { Verify that contracts that generate waste include provisions that obligate the con- } \\
\text { tractor to participate in the QRP for recyclable wastes generated on the installa- } \\
\text { tion, where applicable. } \\
\text { Verify that contracts covering government-owned, contractor-operated (GOCO) } \\
\text { facilities include provisions that obligate the contractor to participate in the instal- } \\
\text { lation QRP or if one does not exist, establish their own QRP. } \\
\text { Verify that, to the extent required by law, existing contracts covering GOCO fa- } \\
\text { cilities are modified to incorporate these QRP provisions. }\end{array}$ \\
\hline
\end{tabular}




\begin{tabular}{|c|c|}
\hline \multicolumn{2}{|r|}{$\begin{array}{c}\text { COMPLIANCE CATEGORY: } \\
\text { OTHER ENVIRONMENTAL ISSUES } \\
\text { Overseas ESOHCAMP }\end{array}$} \\
\hline $\begin{array}{l}\text { REGULATORY } \\
\text { REQUIREMENTS: }\end{array}$ & $\begin{array}{l}\text { REVIEWER CHECKS: } \\
\text { September } 2009\end{array}$ \\
\hline $\begin{array}{l}\text { O5.2 } \\
\text { PROGRAM } \\
\text { MANAGEMENT: } \\
\text { Missing Checklist } \\
\text { Items/Positive Findings }\end{array}$ & \\
\hline $\begin{array}{l}\text { O5.2.1.OCAF. Installations } \\
\text { must comply with all applica- } \\
\text { ble regulatory requirements } \\
\text { not contained in this checklist } \\
\text { (a finding under this checklist } \\
\text { item will have the citation of } \\
\text { the applied regulation as a } \\
\text { basis of finding) [Added } \\
\text { March 2002]. }\end{array}$ & $\begin{array}{l}\text { Determine whether any new regulations concerning program management have } \\
\text { been issued since the finalization of the manual. } \\
\text { Determine whether the installation has activities or facilities that are regulated but } \\
\text { not addressed in this checklist. } \\
\text { Verify that the installation is in compliance with all applicable and newly issued } \\
\text { regulations. }\end{array}$ \\
\hline $\begin{array}{l}\text { O5.2.2.OCAF. Installations } \\
\text { should go above and beyond } \\
\text { environmental statutory and } \\
\text { regulatory compliance (MP) } \\
\text { [Added March 2002]. }\end{array}$ & $\begin{array}{l}\text { Determine whether the installation has gone above and beyond simply complying } \\
\text { with environmental requirements. } \\
\text { (NOTE: This checklist item is used only to write positive findings.) }\end{array}$ \\
\hline
\end{tabular}




\begin{tabular}{|c|c|}
\hline \multicolumn{2}{|r|}{$\begin{array}{c}\text { COMPLIANCE CATEGORY: } \\
\text { OTHER ENVIRONMENTAL ISSUES } \\
\text { Overseas ESOHCAMP }\end{array}$} \\
\hline $\begin{array}{l}\text { REGULATORY } \\
\text { REQUIREMENTS: }\end{array}$ & $\begin{array}{l}\text { REVIEWER CHECKS: } \\
\text { September } 2009\end{array}$ \\
\hline $\begin{array}{l}\text { O5.10 } \\
\text { PROGRAM } \\
\text { MANAGEMENT: } \\
\text { General }\end{array}$ & \\
\hline $\begin{array}{l}\text { O5.10.1.OCAF. } \\
\text { March 2002]. }\end{array}$ & Moved to O5.2.1.OCAF. \\
\hline $\begin{array}{l}\text { O5.10.2.OCAF. Installations } \\
\text { must meet requirements con- } \\
\text { tained in MAJCOM supple- } \\
\text { ments to AFIs and policy } \\
\text { documents (a finding under } \\
\text { this checklist item will have } \\
\text { the citation of the MAJCOM } \\
\text { document as a basis of find- } \\
\text { ing). }\end{array}$ & $\begin{array}{l}\text { Determine whether the requirements in MAJCOM supplements to AFIs and pol- } \\
\text { icy documents are within the scope of the environmental compliance assessment. } \\
\text { Verify that the installation is in compliance with MAJCOM requirements. }\end{array}$ \\
\hline $\begin{array}{l}\text { O5.10.3.OCAF. [Moved } \\
\text { March 2002]. }\end{array}$ & Moved to O5.2.2.OCAF. \\
\hline $\begin{array}{l}\text { O5.10.4.OCAF. The base } \\
\text { SJA should possess current } \\
\text { editions of specific documents } \\
\text { or be able to access them elec- } \\
\text { tronically (MP) [Revised } \\
\text { March 2001]. }\end{array}$ & $\begin{array}{l}\text { Verify that the base SJA possesses current editions of the following documents or } \\
\text { is able to access them electronically: } \\
\text { - Final Governing Standards for the host nation } \\
\text { - DODI 4715.8, Environmental Remediation for DoD Activities Overseas) } \\
\text { - AFPD 32-70, Environmental Quality } \\
\text { - AFI 32-7001, Environmental Budgeting } \\
\text { - AFI 32-7006, Environmental Program in Foreign Countries } \\
\text { - AFI 32-7045, Environmental Compliance Assessment and Management } \\
\text { Program } \\
\text { - AFI 32-7061, The Environmental Impact Analysis Process } \\
\text { - AFI 90-801, Environment, Safety, and Occupational Health Councils } \\
\text { - NATO Status of Forces Agreement and any relevant supplementing bi- } \\
\text { lateral or multi-lateral agreements } \\
\text { - Environmental Law for Department of Defense Installations Overseas, by Lt } \\
\text { Col Richard A. Phelps } \\
\text { - MAJCOM supplements to the listed AFIs. }\end{array}$ \\
\hline $\begin{array}{l}\text { O5.10.5.OCAF. Installations } \\
\text { must remove or destroy offi- } \\
\text { cial records only in accor- } \\
\text { dance with AFMAN 37-139, } \\
\text { Disposition of Records- } \\
\text { Standards, or other directive } \\
\text { authorized in AFI } 37-138\end{array}$ & $\begin{array}{l}\text { Verify that the installation removes or destroys official records only in accordance } \\
\text { with AFMAN 37-139, Disposition of Records-Standards, or other directive au- } \\
\text { thorized in AFI 37-138. } \\
\text { [Author's Note: AFMAN 37-139, Record Disposition Schedule has been replaced } \\
\text { by the Air Force Records Disposition Schedule, which is available online at }\end{array}$ \\
\hline
\end{tabular}




\section{COMPLIANCE CATEGORY: \\ OTHER ENVIRONMENTAL ISSUES \\ Overseas ESOHCAMP}

\begin{tabular}{c|c} 
REGULATORY & REVIEWER CHECKS: \\
REQUIREMENTS: & September 2009 \\
\hline
\end{tabular}

(AFI 37-138, para 2.1.1)

[Added February 2002; Re-

vised September 2006].

O5.10.6.OCAF. Aircraft and equipment maintenance units must appoint a MXG Environmental Coordinator (AFI 21-101, para 1.8.5.2) [Added December 2002].

O5.10.7.OCAF. All installations must track and report information such as, but not limited to, the number and type of inspections, regulatory agency conducting inspection, applicable law and date of inspection (AFI 32-7047, para 2.1) [Added June 2004].

O5.10.8.OCAF. All installations must execute all release notification and reporting requirements according to applicable host nation laws and regulations (AFI 32-7047, para 2.2) [Added June 2004].

O5.10.9.OCAF. Installations must notify the appropriate MAJCOM offices and HQ USAF/ILEV/ILEX of any release that meets specific criteria (AFI 32-7047, para 2.2.1) [Added June 2004].

O5.10.10.0CAF. All installations must submit environmental release notification within the Air Force using the Air Force Operations Report-

Verify that a focal point is identified as the MXG Environmental Coordinator for all Environmental, Safety, and Occupational Health requirements, compliance, and, as appropriate, worker protection issues for Most Efficient Organizations and contract organizations.

(NOTE: This MXG Environmental Coordinator focal point will lead the installation Candidate Process analysis program as identified in AFPD 90-8/AFI 327080/7086 and assist installation tenants and other organizations as required.)

Verify that the installation tracks information such as, but not limited to:

- the number and type of inspections

- regulatory agency conducting inspection

- applicable law

- date of inspection.

Verify that the installation reports this information as part of the Assistant Deputy Under Secretary of Defense (Environment) reporting requirements.

Verify that the installation executes all release notification and reporting requirements according to applicable host nation laws and regulations (see AFI 10-2501, Full Spectrum Threat Response Planning and Operations, Chapter 5).

(NOTE: In addition, AF activities in foreign countries must achieve and maintain compliance with the DOD Final Governing Standards [FGS] where applicable, or the Overseas Environmental Baseline Guidance Document [OEBGD].)

Verify that the installation notifies the appropriate MAJCOM offices and HQ USAF/ILEV/ILEX of any release that meets one or more of the following criteria:

- results in injury or loss of life

- results in loss of aircraft or facility

- causes interruption of flying operations

- causes environmental contamination extending beyond installation boundaries

- creates financial impact exceeding \$50,000

- may result in litigation, publicity, or media coverage, or

- other reasons, as specified by the local commander.

Verify that the installation submits environmental release notification within the Air Force using the Air Force Operations Reporting System, Operational Event/Incident Reports (OPREP-3).

(NOTE: Specific requirements for OPREP-3, HAZMAT Reporting requirements 


\section{COMPLIANCE CATEGORY: \\ OTHER ENVIRONMENTAL ISSUES \\ Overseas ESOHCAMP}

\begin{tabular}{|c|c|}
\hline $\begin{array}{c}\text { REGULATORY } \\
\text { REQUIREMENTS: }\end{array}$ & $\begin{array}{l}\text { REVIEWER CHECKS: } \\
\text { September } 2009\end{array}$ \\
\hline $\begin{array}{l}\text { ing System, Operational } \\
\text { Event/Incident } \\
\text { (OPREP-3) (AFI 32-7047, } \\
\text { para 2.2.1) [Added June } \\
\text { 2004]. }\end{array}$ & $\begin{array}{l}\text { are found in AFI 10-2501.) } \\
\text { (NOTE: Installations closed under Base Realignment and Closure [BRAC] must } \\
\text { also send the OPREP-3 to AFRPA.) }\end{array}$ \\
\hline $\begin{array}{l}\text { O5.10.11.OCAF. All installa- } \\
\text { tions must provide follow-up } \\
\text { reports on incidents meeting } \\
\text { any of the criteria listed in } \\
\text { AFI 32-7047, para 2.2.1, to } \\
\text { the MAJCOM by telephone, } \\
\text { email, or OPREP-3 (see AFI } \\
\text { 10-2501) as required by the } \\
\text { situation (AFI 32-7047, para } \\
\text { 2.2.2) [Added June 2004]. }\end{array}$ & $\begin{array}{l}\text { Verify that the installation provides follow-up reports on incidents meeting any of } \\
\text { the criteria listed in AFI 32-7047, para 2.2.1, to the MAJCOM by telephone, } \\
\text { email, or OPREP-3 (see AFI 10-2501) as required by the situation. } \\
\text { (NOTE: See checklist item number O5.10.9.OCAF.) } \\
\text { (NOTE: MAJCOMs submit follow-up information to AF/ILEV to fulfill HQ } \\
\text { USAF information requirements. BRAC installations also submit follow-up re- } \\
\text { ports to AFRPA.) }\end{array}$ \\
\hline $\begin{array}{l}\text { O5.10.12.0CAF. All installa- } \\
\text { tions must issue an Environ- } \\
\text { mental Notice to Airmen } \\
\text { (ENOTAM) on incidents } \\
\text { meeting any of the criteria } \\
\text { listed in AFI 32-7047, para } \\
2.2 .1 \text { (AFI 32-7047, para } \\
2.2 .3 \text { ) [Added June 2004]. }\end{array}$ & $\begin{array}{l}\text { Verify that the installation issues an ENOTAM on any incident that meets any of } \\
\text { the criteria listed in AFI 32-7047, para 2.2.1. } \\
\text { (NOTE: See checklist item number O5.10.9.OCAF.) } \\
\text { (NOTE: An ENOTAM is sent to the MAJCOM CE, SG, and JA and to the } \\
\text { AFCEE REO. An ENOTAM is also required if a public notice is issued.) }\end{array}$ \\
\hline $\begin{array}{l}\text { O5.10.13.0CAF. ENOTAMs } \\
\text { on incidents that meet the } \\
\text { criteria listed in AFI 32-7047, } \\
\text { para 2.2.1, should contain } \\
\text { certain information (MP) } \\
\text { [Added June 2004]. }\end{array}$ & $\begin{array}{l}\text { Verify that the installation's ENOTAMs describe the incident, specify the root } \\
\text { cause, and identify recommended corrective actions. } \\
\text { (NOTE: See checklist item number O5.10.9.OCAF.) } \\
\text { (NOTE: This MP is found at AFI 32-7047, para 2.2.3.) }\end{array}$ \\
\hline $\begin{array}{l}\text { O5.10.14.OCAF. Installa- } \\
\text { tions should inform the instal- } \\
\text { lation SJA, SG, and PA, the } \\
\text { MAJCOM CE, and appropri- } \\
\text { ate AFCEE REO of a regula- } \\
\text { tory agency's intent to issue } \\
\text { an EA (MP) [Added June } \\
2004 \text { ]. }\end{array}$ & $\begin{array}{l}\text { Verify that the installation informs the installation SJA, SG, and PA, the } \\
\text { MAJCOM CE, and appropriate AFCEE REO of a regulatory agency's intent to } \\
\text { issue an EA. } \\
\text { (NOTE: This MP is found at AFI 32-7047, para 2.3.3.) }\end{array}$ \\
\hline $\begin{array}{l}\text { O5.10.15.0CAF. Installa- } \\
\text { tions must submit a copy of } \\
\text { any issued HNEA to the in- } \\
\text { stallation SJA, SG, and PA, } \\
\text { and the MAJCOM CE within } \\
\text { one working day of receipt }\end{array}$ & $\begin{array}{l}\text { Verify that the installation submits a copy of any issued HNEA to the installation } \\
\text { SJA, SG, and PA, and the MAJCOM CE within one working day of receipt (ei- } \\
\text { ther by facsimile or scanned PDF email attachment). } \\
\text { [Author's Note: See the definition of Enforcement Action.] }\end{array}$ \\
\hline
\end{tabular}




\section{COMPLIANCE CATEGORY: \\ OTHER ENVIRONMENTAL ISSUES \\ Overseas ESOHCAMP}

\section{REGULATORY REQUIREMENTS:}

(AFI 32-7047, para 2.3.2, and HQ USAF/A7CV, Policy Memorandum on Environmental Compliance Tracking and Reporting Requirements, 16 June 2006, p. 2) [Added June 2004; Revised September 2006].

O5.10.16.0CAF. Following the initial immediate notification, installations must also prepare and submit to the MAJCOM CE a MAP for the EA within 10 working days of receipt (AFI 32-7047, para 2.3.2, and HQ USAF/A7CV, Policy Memorandum on Environmental Compliance Tracking and Reporting Requirements, 16 June 2006, p. 2) [Added June 2004; Revised September 2006].

O5.10.17.OCAF. The installation CEV must assign a root cause category code for the EA/HNEA in the MAP (AFI 32-7047, para 2.3.6) [Added June 2004].

O5.10.18.0CAF. MAPs should detail all action items required for closure (MP) [Added June 2004].

O5.10.19.0CAF. Installations must provide the appropriate MAJCOM monthly updates to their MAPs in accordance with specific requirements (AFI 32-7047,

\section{REVIEWER CHECKS: September 2009}

Verify that the installation also reports EAs to the Regional Environmental Office and the Regional Environmental Counsel (REC).

(NOTE: The MAJCOMs report the EAs to HQ USAF/A7CVQ and AFLOA/JACE and include them in monthly MAPs. Tracking EAs requires securing, at a minimum, the initial written notification, written response to the regulator address the corrective actions to be taken, any other correspondence to or from the regulator regarding the EA, and documentation that the EA is closed in accordance with AFI 32-7047. )

Verify that the installation also prepares and submits to the MAJCOM CE a MAP for the EA within 10 working days of receipt.

(NOTE: See Attachment 3 to AFI 32-7047.)

Verify that a MAP is produced for each reported EA.

Verify that the installation CEV assigns a root cause category code for the EA/HNEA in the MAP.

(NOTE: See Attachment 2 to AFI 32-7047.)

(NOTE: The purpose of the codes is to identify the underlying cause for deficiencies or incidents and make it easier to identify and analyze trends and create solutions to prevent recurrence. AFCEE REOs make use of root cause analysis and identify trends in media areas or policy areas in preparing Enforcement Vulnerability Assessments for MAJCOMs.)

Verify that the installations MAPs detail all action items required for closure.

(NOTE: See Attachment 2 to AFI 32-7047.)

(NOTE: This MP is found at AFI 32-7047, para 2.3.5.1.)

Verify that the installation provides the appropriate MAJCOM monthly updates to its MAPs on the last workday of each month after the initial MAP is submitted.

Verify that monthly reporting via MAPs is continued until the EA is closed.

(NOTE: If installations have questions regarding whether a notice constitutes an 


\title{
COMPLIANCE CATEGORY: \\ OTHER ENVIRONMENTAL ISSUES \\ Overseas ESOHCAMP
}

\begin{tabular}{l} 
REGULATORY \\
REQUIREMENTS: \\
\hline paras 2.3.5.1 and 3.2; and HQ \\
USAF/A7CV, Policy Memo- \\
randum on Environmental \\
Compliance Tracking and \\
Reporting Requirements, 16 \\
June 2006, pp. 2 and 3) \\
[Added June 2004; Revised \\
September 2006].
\end{tabular}

September 2006].

\begin{abstract}
EA or how to track an EA, they should contact the appropriate AFCEE REO and REC for guidance.)

(NOTE: MAJCOMs provide monthly updates in the form of MAPs for all OEAs to AF/ILEV and the appropriate AFCEE REO by the fifth working day of each month.)

(NOTE: One designated AFCEE REO will provide AF/ILEV with a service-wide [Environmental Compliance Program Summary] Enforcement Action Monthly Status Report by the 10th working day of each month. This consists of an overall status report with regional summaries attached.)

(NOTE: A HNOEA is closed when any one of the following criteria is met:

- receipt of written notification from the HNGA stating that it is satisfied with the actions taken to resolve the cited violation[s]

- the HNGA has rescinded the HNEA

- the HNGA does not respond within 60 days following written notice [sent via certified mail or other delivery confirmation receipt method]:

- informing the HNGA that the base is in full compliance concerning the matters cited in the HNEA

- requesting written confirmation from the HNGA that the EA is closed

- apprising the HNGA that in the absence of confirmation, the base will deem the EA closed within 60 days of the HNGA receipt of the letter.
\end{abstract}

(NOTE: Written notice [60-day closeout letter] is only sent after it is determined by the installation and their MAJCOM that the project has been fully developed to correct all violations associated with an OEA, and funding for the project[s] has been allocated in full).

Verify that the 60-day closeout letter contains the following information:

- identification of the issued document

- noncompliance or violations noted

- corrective actions taken

- statement of compliance

- request for written confirmation that the matter is closed within 60 days of receipt

- statement that we will consider the matter resolved if no response is received within 60 days of receipt.

(NOTE: The Attachment to the Policy Memorandum includes a sample 60-day closeout letter.)

(NOTE: If the HNGA responds within the 60-day window with additional requirements, the EA may need to stay open. If the HNGA responds after 60 days with additional requirements to close the EA, the original EA is reopened).

Verify that, upon return to compliance, the installation proactively requests a writ- 


\section{COMPLIANCE CATEGORY: \\ OTHER ENVIRONMENTAL ISSUES \\ Overseas ESOHCAMP}

\section{REGULATORY REQUIREMENTS:}

O5.10.20.OCAF. Installations must report all disputed EAs in accordance with specific criteria (AFI 32-7047, paras 2.3.4.1 through 2.3.4.4) [Added June 2004].

O5.10.21.OCAF. All installations that receive an enforcement action for alleged noncompliance with a host nation environmental requirement must report specific information on a calendar year basis (HQ USAF/ILEV Memorandum, Revised Environmental Quality Metrics, 14 February 2005, para 1; Under Secretary of Defense Memorandum, Revised Pollution Prevention and Compliance Metrics, 12 October 2004; Attachment 1, paras V.c.2, V.d.1 through V.d.3, V.g.2.b, V.g.3, and V.g.5) [Added March 2005].

\section{REVIEWER CHECKS: September 2009}

ten confirmation from the regulator that the HNEA is closed.

Verify that the installation reports all disputed EAs to the MAJCOM CE, JA, and AFCEE REO, within one working day of receipt/notification for appropriate determination.

(NOTE: Disputed EAs will not be reported outside the Air Force structure and will not be included in the OEA compliance metric until the dispute has been resolved.)

Verify that the installation prepares and submits MAPs for disputed EAs.

Verify that MAPs for disputed EAs indicate that the status of the EA is disputed.

Verify that MAPs for disputed EAs address why the EA was issued and the rationale for the dispute.

(NOTE: The MAJCOM CE, JA, SG and AFCEE REO, in consultation with the installation, will define the dispute and work to resolve the issue with the appropriate regulating authority. If consensus cannot be reached within 60 days contact ILEV for resolution.)

Determine whether the installation has received an enforcement action for alleged noncompliance with a host nation environmental requirement.

(NOTE: See FGS or international treaties, as applicable.)

Verify that the installation reports:

- number of enforcement actions received, each enforcement action received during the reporting period, including those that were both received and closed out during the period (NOTE: The date of an enforcement action is to be considered the date that the formal written notification has been received from the regulator)

- number of open enforcement actions, each enforcement action that has been issued, but is not yet closed by one of the resolutions described under the definition of closed enforcement action

- fines and penalties, in thousands of dollars (\$):

- fines assessed

- fines paid, including "cash" paid, Supplemental Environmental Projects (SEPs), and the amount originally assessed.

Verify that the installation also reports:

- number of permits and permit applications submitted on behalf of DOD as required by FGS or international treaty; permit categories are defined by FGS

- number of environmental regulatory inspections conducted by host nation 


\section{COMPLIANCE CATEGORY: \\ OTHER ENVIRONMENTAL ISSUES \\ Overseas ESOHCAMP}

\begin{tabular}{|l|}
\hline \multicolumn{1}{|c|}{ REGULATORY } \\
REQUIREMENTS:
\end{tabular}

\section{REVIEWER CHECKS: \\ September 2009}

governments

- number of open administrative/operational and project related enforcement actions.

(NOTE: Begin collecting this data in Calendar Year 2005.)

Verify that the installation reports ONONs to the MAJCOM, REO, and REC within 5 working days of receipt.

(NOTE: The MAJCOMs report the ONONs to HQ USAF/A7CVQ and AFLOA/JACE and track them [along with REO and REC] to ensure they are promptly closed. Tracking EAs requires securing, at a minimum, the initial written notification, written response to the regulator address or other documents addressing the corrective actions taken or to be taken, any other correspondence to or from the regulator regarding the ONON, and documentation that the ONON is closed in accordance with AFI 32-7047. MAJCOMs submit an initial MAP to the REO and HQ USAF/A7CVQ. Although monthly MAPs are not required, MAJCOMs must report the closure of ONONs to the REO and HQ USAF/A7CVQ.)

(NOTE: If installations have questions regarding whether a notice constitutes an ONON, they should contact the appropriate AFCEE REO and REC for guidance.)

O5.10.23.0CAF. Upon return to compliance, the installation proactively requests a written confirmation from the regulator that the ONON is closed (HQ USAF/A7CV, Policy Memorandum on Environmental Compliance Tracking and Reporting Requirements, 16 June 2006, pp. 2 and 3) [Added September 2006].

Verify that, upon return to compliance, the installation proactively requests a written confirmation from the regulator that the ONON is closed.

Verify that, if necessary, a 60-day closeout letter is sent via certified mail or return-receipt requested.

Verify that the 60-day closeout letter contains the following information:

- identification of the issued document

- noncompliance or violations noted

- corrective actions taken

- statement of compliance

- request for written confirmation that the matter is closed within 60 days of receipt

- statement that we will consider the matter resolved if no response is received within 60 days of receipt.

(NOTE: The Attachment to the Policy Memorandum includes a sample 60-day closeout letter.)

(NOTE: Installations may close ONONs when the issuing regulator provides documentation stating satisfactory resolution of the cited violation or noncompliance, or rescinds the matter, or fails to respond to the installation's 60-day letter.) 


\section{COMPLIANCE CATEGORY: \\ OTHER ENVIRONMENTAL ISSUES \\ Overseas ESOHCAMP}

\section{REGULATORY REQUIREMENTS: \\ O5.30 \\ PROGRAM \\ MANAGEMENT: \\ Automated Management Systems}

05.30.1.OCAF. Installations must submit a 5-yr pollution abatement plan (the A-106 report) that details the actions they plan to take to get into or maintain compliance (AFI 327001, para 3.8).

05.30.2.OCAF. The installation's A-106 Plan should meet specific requirements with regard to content (MP).

\section{REVIEWER CHECKS: September 2009}

(NOTE: See Appendix 6-7 for additional guidance on determining A-106 compliance.)

Verify that the installation submits a 5-yr pollution abatement plan (the A-106 report) that details the actions they plan to take to get into or maintain compliance.

Verify that the installation A-106 Pollution Abatement Plan reflects environmental requirements and properly prioritizes each as Operation and Services, Level 1, Level 2, or Level 3.

Verify that the A-106 Plan includes all projects involving costs that are necessary to comply with environmental standards.

Verify that projects resulting from previous Environmental Compliance Assessment and Management Program (ECAMP) evaluations or regulatory inspections are included in the A-106 Plan.

(NOTE: Management action plans from ECAMP will give projects required to get installation back in compliance.)

Verify that the A-106 Plan includes funds required for studies, management, and monitoring associated with the definition and development of corrective measures and necessary equipment to assure compliance with standards.

Verify that the installation budgets for the environmental requirements are recorded in the installation A-106 Plan.

(NOTE: Assessors compare listings in the A-106 with the Project by Contract Management System [PCMS] and PDC listings in Civil Engineering and compare official financial records with obligation/expenditure data reflected in the A-106 system.)

Verify that funds have been requested for Level 1 projects in the current fiscal year.

Verify that design funds have been requested for those projects that will be Level 1 projects in the subsequent fiscal year. 


\section{COMPLIANCE CATEGORY: \\ OTHER ENVIRONMENTAL ISSUES \\ Overseas ESOHCAMP}

\begin{tabular}{c|c} 
REGULATORY & REVIEWER CHECKS: \\
REQUIREMENTS: & September 2009
\end{tabular}

05.30.3.0CAF. Installations must meet specific requirements with regard to the tracking and reporting of certain data (AFI 32-7006, para 6.1) [Moved June 2003].

05.30.4.OCAF. Program management reporting should be done in WIMS-ES (AFI 32-7002, paras 3.1, 4.1, 5.1, 6.1, 7.1, 8.1, 9.1, 10.1, 11.1, 12.1, 13.1, 14.1, and 15.1) [Moved June 2003].
Verify that the installation tracks and reports data from the following areas using WIMS-ES, if the MAJCOM requires that the module be used:

- cleanup

- compliance with FGS

- ECAMP

- EIAP

- comprehensive planning

- pollution prevention

- data on host nation regulatory findings.

[Formerly checklist item number O5.50.1.OCAF.]

Verify that quarterly reports are being added and released.

Verify that programming records are being added for projects and Operations and Services expenses.

Verify that the following modules are in use:

- A-106 Module, for reporting planned environmental expenditures and budgeting for the following programs:

- restoration

- compliance

- conservation

- pollution prevention

- Release Reporting Module, for tracking and reporting releases

- ECAMP Module, for tracking and reporting ECAMP findings and action plans

- Underground storage tanks (USTs) Module, for tracking and monitoring USTs

- PCB Module, for inventorying all PCB-containing equipment (excluding sealed PCB items and capacitors containing less than $3 \mathrm{lb}[\approx 1 \mathrm{~kg}]$ of dielectric fluid)

- Inspection and Enforcement Module, for tracking host nation regulatory findings

- Hazardous Waste Module, for tracking and monitoring hazardous waste data

- Air Management Module, for tracking and monitoring air pollution sources and permits

- Water and Wastewater Module, for tracking water- and wastewater-related data

- Cleanup Module, for tracking and reporting information concerning cleanup of contaminated sites

- Pollution Prevention Module, for reporting data related to the pollution prevention program, including the following:

- solid waste disposal

- hazardous material purchases

- affirmative procurement of recycled products 


\begin{tabular}{|c|c|}
\hline \multicolumn{2}{|c|}{$\begin{array}{c}\text { COMPLIANCE CATEGORY: } \\
\text { OTHER ENVIRONMENTAL ISSUES } \\
\text { Overseas ESOHCAMP }\end{array}$} \\
\hline $\begin{array}{c}\text { REVIEWER CHECKS: } \\
\text { September 2009 }\end{array}$ \\
\hline REQUIREMENTS: & $\begin{array}{c}\text { REATORY } \\
\text { - Conservation Module, for tracking and reporting of the following: } \\
\text { - Base Comprehensive Plan status } \\
\text { - Installation compatible use zone (ICUZ) status } \\
\text { - EIAP actions } \\
\text { - Natural and Cultural Resource data. } \\
\text { (NOTE: The Training Tracking Module may be used to track environmental train- } \\
\text { ing received by personnel at all levels.) } \\
\text { [Formerly checklist item number O5.50.2.OCAF.] }\end{array}$ \\
\hline
\end{tabular}




\begin{tabular}{|c|c|}
\hline & $\begin{array}{c}\text { COMPLIANCE CATEGORY: } \\
\text { OTHER ENVIRONMENTAL ISSUES } \\
\text { Overseas ESOHCAMP }\end{array}$ \\
\hline $\begin{array}{l}\text { REGULATORY } \\
\text { REQUIREMENTS: }\end{array}$ & $\begin{array}{l}\text { REVIEWER CHECKS: } \\
\text { September } 2009\end{array}$ \\
\hline $\begin{array}{l}\text { O5.40 } \\
\text { PROGRAM } \\
\text { MANAGEMENT: } \\
\text { ESOH Leadership }\end{array}$ & \\
\hline $\begin{array}{l}\text { O5.40.1.OCAF. } \quad \text { [Deleted } \\
\text { June 2005]. }\end{array}$ & Deleted as a consequence of the release of AFI 90-801. \\
\hline $\begin{array}{l}\text { O5.40.2.OCAF. [Deleted } \\
\text { June 2005]. }\end{array}$ & Deleted as a consequence of the release of AFI 90-801. \\
\hline $\begin{array}{l}\text { O5.40.3.OCAF. [Deleted } \\
\text { June 2005]. }\end{array}$ & Deleted as a consequence of the release of AFI 90-801. \\
\hline $\begin{array}{l}\text { O5.40.4.OCAF. Installation } \\
\text { ESOHCs must meet member- } \\
\text { ship requirements (AFI 90- } \\
\text { 801, para 4.3) [Added June } \\
\text { 2005]. }\end{array}$ & $\begin{array}{l}\text { (NOTE: The wing commander serves as the chairperson but may delegate to the } \\
\text { vice wing commander.) } \\
\text { Verify that the ESOHC chairperson selects the executive secretary. } \\
\text { Verify that, in addition, the ESOHC membership includes group commanders, } \\
\text { representatives from each 2-letter office, and all tenant organizations as a mini- } \\
\text { mum. } \\
\text { Verify that the Designated Employee Representative is invited to participate } \\
\text { unless representation is otherwise covered under management-labor contracts. } \\
\text { (NOTE: The ESOHC monitors progress toward achieving higher headquarters } \\
\text { goals, and reports progress and issues to higher headquarters for assis- } \\
\text { tance/resolution.) }\end{array}$ \\
\hline $\begin{array}{l}\text { O5.40.5.OCAF. The } \\
\text { ESOHC's Executive Secre- } \\
\text { tary must carry out specific } \\
\text { tasks (AFI } 90-801 \text {, paras 5.1.1 } \\
\text { and 6) [Added June 2005]. }\end{array}$ & $\begin{array}{l}\text { Verify that the ESOHC Executive Secretary establishes the meeting schedule, } \\
\text { develops and distributes the agenda in advance, serves as the meeting facilitator, } \\
\text { records, and publishes committee minutes. } \\
\text { (NOTE: The ESOHC Executive Secretary is responsible for all committee ar- } \\
\text { rangements.) } \\
\text { Verify that, within } 30 \text { days following an ESOHC meeting, the executive secretary } \\
\text { prepares and coordinates minutes. } \\
\text { Verify that the minutes summarize the substance and outcome of all discussions. } \\
\text { (NOTE: If privileged information is discussed and included in the minutes, the } \\
\text { preparing organization must comply with instructions for handling and release of } \\
\text { privileged information in accordance with AFI 91-204, Safety Investigations and }\end{array}$ \\
\hline
\end{tabular}




\section{COMPLIANCE CATEGORY: \\ OTHER ENVIRONMENTAL ISSUES \\ Overseas ESOHCAMP}

\begin{tabular}{|c|c|}
\hline $\begin{array}{l}\text { REGULATORY } \\
\text { REQUIREMENTS: }\end{array}$ & $\begin{array}{l}\text { REVIEWER CHECKS: } \\
\text { September } 2009\end{array}$ \\
\hline $\begin{array}{l}\text { O5.40.6.0CAF. ESOHCs } \\
\text { must meet at least semiannu- } \\
\text { ally (AFI 90-801, para 5.1.1) } \\
\text { [Added June 2005]. } \\
\text { O5.40.7.OCAF. The installa- } \\
\text { tion ESOHC must carry out } \\
\text { specific tasks (AFI 90-801, } \\
\text { paras 5.1.2 through 5.1.6 and } \\
\text { 5.3) [Added June 2005]. }\end{array}$ & $\begin{array}{l}\text { Verify that the installation ESOHC: } \\
\text { - ensures a systematic, interdisciplinary approach to environment, safety, and } \\
\text { occupational health } \\
\text { - ensures Core Mission Areas integrate this approach into planning, budgeting } \\
\text { and decision-making } \\
\text { - establishes subgroups and working groups as necessary to support local ini- } \\
\text { tiatives and emphasis (i.e., cross-functional team) } \\
\text { - exercises their independent judgment in determining what action to take } \\
\text { upon the recommendations of subgroups and working groups } \\
\text { - acts as the primary executive steering group to ensure ESOH management } \\
\text { decisions enhance mission capability } \\
\text { - oversees ESOHMS implementation and ESOH performance to ensure con- } \\
\text { tinual improvement consistent with AF ESOH goals and objectives } \\
\text { - reports and tracks instances where a mission or operation has been, or is ex- } \\
\text { pected to be, negatively impacted because of ESOH restrictions; and actions } \\
\text { taken to affect, change, or eliminate the impact } \\
\text { - reviews policy, resource requirements, and ESOH performance, and makes } \\
\text { recommendations on changes required } \\
\text { - ensures appropriate training and manpower exist to meet responsibilities out- } \\
\text { lined in AFI 90-801 } \\
\text { - provides guidance and oversight for implementing, maintaining, and im- } \\
\text { proving the AF ESOHMS } \\
\text { - reports progress on ESOH goals as defined by next higher level ESOHC } \\
\text { - implements ESOHCAMPs as a tool to assess implementation and status of } \\
\text { the ESOHMS } \\
\text { - evaluates ESOHCAMP findings and tracks progress to correct validated de- } \\
\text { ficiencies } \\
\text { - develops, approves, and monitors ESOH risk-based performance goals, } \\
\text { measures, objectives, and targets }\end{array}$ \\
\hline
\end{tabular}




\begin{tabular}{|c|c|}
\hline & $\begin{array}{c}\text { COMPLIANCE CATEGORY: } \\
\text { OTHER ENVIRONMENTAL ISSUES } \\
\text { Overseas ESOHCAMP }\end{array}$ \\
\hline REGULATORY & $\begin{array}{c}\text { REVIEWER CHECKS: } \\
\text { September 2009 }\end{array}$ \\
\hline REQUIREMENTS: & \\
\hline & - uses risk assessment methodology to identify and prioritize requirements \\
that maximize mission performance and minimize ESOH risk and cost \\
- champions inclusion of ESOH in Program Action Directives, Operational \\
Plans, ICDs, CDDs, CPDs, Program Objective Memorandums (POM) and \\
Budget Execution Submissions (BES), where applicable \\
- addresses appropriate topics to meet the responsibilities listed above \\
- considers the additional topics listed in Attachment 2 to AFI 90-801. \\
(NOTE: The chairperson may also add additional topics as appropriate.)
\end{tabular}




\begin{tabular}{|c|c|}
\hline \multicolumn{2}{|r|}{$\begin{array}{c}\text { COMPLIANCE CATEGORY: } \\
\text { OTHER ENVIRONMENTAL ISSUES } \\
\text { Overseas ESOHCAMP }\end{array}$} \\
\hline $\begin{array}{l}\text { REGULATORY } \\
\text { REQUIREMENTS: }\end{array}$ & $\begin{array}{l}\text { REVIEWER CHECKS: } \\
\text { September } 2009\end{array}$ \\
\hline $\begin{array}{l}\text { O5.50 } \\
\text { PROGRAM } \\
\text { MANAGEMENT: } \\
\text { Weapons Ranges } \\
\text { O5.50.1.OCAF. ROAs must } \\
\text { prepare inputs on environ- } \\
\text { mental factors for inclusion in } \\
\text { the unit Comprehensive } \\
\text { Range Plan (AFI 13-212, } \\
\text { Volume 1, para 3.7.3) } \\
\text { [Moved June 2003]. }\end{array}$ & $\begin{array}{l}\text { Determine whether the unit has air-to-surface weapons ranges. } \\
\text { Verify that the unit has a Comprehensive Range Plan. } \\
\text { Verify that the plan includes a summary of all environmental factors on the range: } \\
\text { - range clearance } \\
\text { - endangered species } \\
\text { - emissions } \\
\text { - air quality } \\
\text { - noise } \\
\text { - wetlands } \\
\text { - water resources } \\
\text { - coastal zones } \\
\text { - mineral resources } \\
\text { - soil conservation } \\
\text { - dual-use programs } \\
\text { - hazardous wastes } \\
\text { - historical/archaeological sites } \\
\text { - wilderness areas } \\
\text { - flood plains. } \\
\text { (NOTE: The following are examples of dual-use programs: grazing, timber, farm- } \\
\text { ing, hunting, fishing, and camping.) } \\
\text { Verify that a list is included of all environmental analyses performed on the range } \\
\text { and associated airspace, with result, date signed, and location of full document. } \\
\text { Verify that any noise-sensitive areas, seasonal restrictions from environmental } \\
\text { actions, etc., are documented. } \\
\text { [Formerly checklist item number O5.20.2.OCAF.] }\end{array}$ \\
\hline
\end{tabular}




\begin{tabular}{|c|c|}
\hline & $\begin{array}{c}\text { COMPLIANCE CATEGORY: } \\
\text { OTHER ENVIRONMENTAL ISSUES } \\
\text { Overseas ESOHCAMP }\end{array}$ \\
\hline $\begin{array}{l}\text { REGULATORY } \\
\text { REQUIREMENTS: }\end{array}$ & $\begin{array}{l}\text { REVIEWER CHECKS: } \\
\text { September } 2009\end{array}$ \\
\hline $\begin{array}{l}\text { O5.60 } \\
\text { PROGRAM } \\
\text { MANAGEMENT: } \\
\text { Deployments } \\
\text { O5.60.1.OCAF. Installations } \\
\text { must comply with specific } \\
\text { instructions for deployments } \\
\text { (AFI 32-7006, para 7.1). } \\
\text { O5.60.2.0CAF. Installations } \\
\text { must develop and comply } \\
\text { with an exercise- or contin- } \\
\text { gency-specific environmental } \\
\text { plan (AFI 32-7006, para } 7.1 \\
\text { and 7.3.2). }\end{array}$ & $\begin{array}{l}\text { Verify that the installation complies with the provisions of AFI 32-7061 (EIAP) } \\
\text { for deployments. } \\
\text { (NOTE: See checklist items O1.10.3.OCAF and O1.10.4.OCAF.) } \\
\text { Verify that the installation develops and complies with an exercise- or contin- } \\
\text { gency-specific environmental plan. } \\
\text { Verify that the plan meets the requirements of Joint Chiefs of Staff (JCS) Publica- } \\
\text { tion 4-04. } \\
\text { Verify the plan specifies environmental responsibilities and policies. } \\
\text { Verify that the plan addresses at least the following concerns: } \\
\text { - certification of local water sources by medical field units } \\
\text { - solid and liquid waste management } \\
\text { - hazardous materials management } \\
\text { - protection of flora and fauna } \\
\text { - archaeological and historical preservation } \\
\text { - spill response. }\end{array}$ \\
\hline
\end{tabular}




\begin{tabular}{|c|c|}
\hline \multicolumn{2}{|r|}{$\begin{array}{l}\text { COMPLIANCE CATEGORY: } \\
\text { OTHER ENVIRONMENTAL ISSUES } \\
\text { OverSeas ESOHCAMP }\end{array}$} \\
\hline $\begin{array}{l}\text { REGULATORY } \\
\text { REQUIREMENTS: }\end{array}$ & $\begin{array}{l}\text { REVIEWER CHECKS: } \\
\text { September } 2009\end{array}$ \\
\hline $\begin{array}{l}\text { O7.2 } \\
\text { EMS: } \\
\text { Missing Checklist } \\
\text { Items/Positive Findings }\end{array}$ & \\
\hline $\begin{array}{l}\text { O7.2.1.OCAF. Installations } \\
\text { must comply with all applica- } \\
\text { ble regulatory requirements } \\
\text { not contained in this checklist } \\
\text { (a finding under this checklist } \\
\text { item will have the citation of } \\
\text { the applied regulation as a } \\
\text { basis of finding) [Added Sep- } \\
\text { tember 2004]. }\end{array}$ & $\begin{array}{l}\text { Determine whether any new regulations concerning EMS have been issued since } \\
\text { the finalization of the manual. } \\
\text { Determine whether the installation has activities or facilities that are regulated but } \\
\text { not addressed in this checklist. } \\
\text { Verify that the installation is in compliance with all applicable and newly issued } \\
\text { regulations. }\end{array}$ \\
\hline $\begin{array}{l}\text { O7.2.2.OCAF. Installations } \\
\text { should go above and beyond } \\
\text { environmental statutory and } \\
\text { regulatory compliance (MP) } \\
\text { [Added September 2004]. }\end{array}$ & $\begin{array}{l}\text { Determine whether the installation has gone above and beyond simply complying } \\
\text { with environmental requirements. } \\
\text { (NOTE: This checklist item is used only to write positive findings.) }\end{array}$ \\
\hline
\end{tabular}




\section{COMPLIANCE CATEGORY: \\ OTHER ENVIRONMENTAL ISSUES \\ Overseas ESOHCAMP}

\begin{tabular}{|c|c|}
\hline $\begin{array}{l}\text { REGULATORY } \\
\text { REQUIREMENTS: }\end{array}$ & $\begin{array}{l}\text { REVIEWER CHECKS: } \\
\text { September } 2009\end{array}$ \\
\hline $\begin{array}{l}\text { O7.10 } \\
\text { EMS: } \\
\text { All Facilities }\end{array}$ & \\
\hline $\begin{array}{l}\text { O7.10.1.OCAF. Installations } \\
\text { must determine the scope of } \\
\text { their EMS and convey it to } \\
\text { their MAJCOM (HQ } \\
\text { USAF/ILEV Policy Letter, } 29 \\
\text { May 2003) [Added September } \\
\text { 2004]. }\end{array}$ & $\begin{array}{l}\text { Verify that the installation has defined the scope of its EMS and has conveyed this } \\
\text { information to the installation's MAJCOM. } \\
\text { (NOTE: The checklist items in sections O7.20 through O7.60 apply only to those } \\
\text { portions of the installation's property and/or activities included in the EMS } \\
\text { scope.) }\end{array}$ \\
\hline $\begin{array}{l}\text { O7.10.2.OCAF. All AF ap- } \\
\text { propriate facilities must report } \\
\text { specific information related to } \\
\text { their environmental manage- } \\
\text { ment systems on a calendar } \\
\text { year basis (HQ USAF/ILEV } \\
\text { Memorandum, Revised Envi- } \\
\text { ronmental Quality Metrics, } 14 \\
\text { February 2005, para 1; Under } \\
\text { Secretary of Defense Memo- } \\
\text { randum, Revised Pollution } \\
\text { Prevention and Compliance } \\
\text { Metrics, 12 October 2004; } \\
\text { Attachment 1, paras VIII.c, } \\
\text { VIII.d, and VIII.g) [Added } \\
\text { March 2005]. }\end{array}$ & $\begin{array}{l}\text { Verify that each facility considered “appropriate” for EMS purposes reports: } \\
\text { - the number of DOD-Component appropriate facilities subject to DOD and } \\
\text { Component EMS policy } \\
\text { - for each of the following criteria, the number of appropriate facilities that } \\
\text { have: } \\
\text { - policy statement consistent with DOD and DOD Component EMS } \\
\text { policies } \\
\text { - self-assessment consistent with DOD and DOD Component EMS poli- } \\
\text { cies } \\
\text { - written plans with defined dates, identified resources, and organiza- } \\
\text { tional responsibilities for implementing EMS consistent with DOD and } \\
\text { DOD Component EMS policies } \\
\text { - prioritized list of aspects } \\
\text { - appropriate personnel having received awareness-level EMS training } \\
\text { - completed at least one management review in accordance with the in- } \\
\text { stallation's documented procedure for recurring internal EMS man- } \\
\text { agement review. }\end{array}$ \\
\hline & $\begin{array}{l}\text { Verify that the facility also reports the basis for determining "appropriate facili- } \\
\text { ties" and an explanation of any changes. } \\
\text { (NOTE: For definitions, refer to ISO 14001, appropriate DOD Component policy, } \\
\text { and Executive Order 13148.) } \\
\text { (NOTE: Begin collecting this data in Fiscal Year 2005.) }\end{array}$ \\
\hline
\end{tabular}




\begin{tabular}{|c|c|}
\hline \multicolumn{2}{|r|}{$\begin{array}{c}\text { COMPLIANCE CATEGORY: } \\
\text { OTHER ENVIRONMENTAL ISSUES } \\
\text { Overseas ESOHCAMP }\end{array}$} \\
\hline $\begin{array}{l}\text { REGULATORY } \\
\text { REQUIREMENTS: }\end{array}$ & $\begin{array}{l}\text { REVIEWER CHECKS: } \\
\text { September } 2009\end{array}$ \\
\hline $\begin{array}{l}\text { O7.20 } \\
\text { EMS: } \\
\text { Policy }\end{array}$ & \\
\hline $\begin{array}{l}\text { O7.20.1.OCAF. The installa- } \\
\text { tion must have an Environ- } \\
\text { mental Policy Statement en- } \\
\text { dorsed by the Wing Com- } \\
\text { mander, EPC/ESOHC Chair, } \\
\text { or equivalent, that articulates } \\
\text { the senior leadership's vision } \\
\text { of what they desire the EMS } \\
\text { to accomplish (HQ } \\
\text { USAF/ILEV Policy Letter, } 29 \\
\text { May 2003, Appendix A) } \\
\text { [Added September 2004]. }\end{array}$ & $\begin{array}{l}\text { Verify that the installation has prepared an Environmental Policy Statement that } \\
\text { includes a statement endorsing the development and execution of an installation- } \\
\text { wide EMS and a commitment to compliance with laws and applicable require- } \\
\text { ments, prevention of pollution, and continuous improvement. } \\
\text { Verify that the Environmental Policy Statement is specific to the execution of the } \\
\text { installation's mission and any unique local environmental concerns. } \\
\text { Verify the Wing Commander, EPC/ESOHC Chair, or equivalent has signed the } \\
\text { policy statement, and ensure it has been reviewed at least annually and modified } \\
\text { as necessary to reflect changes in the installations mission and/or its EMS scope. }\end{array}$ \\
\hline $\begin{array}{l}\text { O7.20.2.OCAF. The EMS } \\
\text { policy must be communicated } \\
\text { to all installation personnel } \\
\text { and made available to all in- } \\
\text { terested parties (HQ } \\
\text { USAF/ILEV Policy Letter, } 29 \\
\text { May 2003, Appendix A) } \\
\text { [Added September 2004]. }\end{array}$ & $\begin{array}{l}\text { Verify that the EPC/ESOHC has made efforts to communicate the installation's } \\
\text { Environmental Policy Statement effectively to all installation personnel (including } \\
\text { tenants and appropriate contractors). } \\
\text { Verify that the policy is recommunicated if it is updated or modified by the } \\
\text { EPC/ESOHC. }\end{array}$ \\
\hline
\end{tabular}




\section{COMPLIANCE CATEGORY: \\ OTHER ENVIRONMENTAL ISSUES \\ Overseas ESOHCAMP}

\begin{tabular}{l} 
REGULATORY \\
REQUIREMENTS: \\
\hline O7.30 \\
EMS: \\
Planning \\
O7.30.1.OCAF. Installations \\
must develop an Aspect In- \\
ventory List of their activities, \\
products, and services that \\
interact with the environment \\
and identify the impacts of \\
those aspects on the environ- \\
ment (USAF EMS Planning \\
Phase Guide, Section 3) \\
[Added September 2004]. \\
O7.30.2.OCAF. Installations \\
must score their environ- \\
mental aspects to determine \\
the significance of their im- \\
pacts (USAF EMS Planning \\
Phase Guide, Section 4) \\
[Added September 2004].
\end{tabular}

\section{REVIEWER CHECKS:}

September 2009

Verify the installation has developed, documented, and followed a written procedure for identifying its environmental aspects and impacts.

Verify that this process has been updated as necessary to reflect changes in the installation's mission and/or its EMS scope.

(NOTE: Once the EESOH-MIS has been fielded, installations will be required to use the software to develop their Aspect Inventory List in accordance with the HQ USAF/ILEV policy memorandum, 11 Dec 03.)

Verify that the installation has identified its significant environmental aspects.

(NOTE: Aspects identified during internal or external ECAMP/ESOHCAMP assessments that are not in compliance with applicable regulatory requirements, regardless of whether or not an enforcement action has been initiated, as well as those identified as likely lead to the loss of the ability to accomplish the installation's mission or place serious restrictions on the mission, must be included in the significant aspect list.)

Verify the installation has developed, documented, and followed a written procedure for scoring its aspects impacts and identifying which aspects represent a significantly negative or positive impact on the environment and the installation's mission.

Verify that the aspect scoring procedure:

- addresses, at a minimum, the relative costs, environmental risk, regulatory implications, potential mission degradation, and community concern associated with the aspect

- has higher headquarters approval for the use of additional scoring criteria and/or criteria weighting factors, if required by MAJCOM policy

- identifies how the installation will distinguish significant aspects from non-significant aspects.

Verify that the installation has scored all aspects on the Aspect Inventory List by Environmental Aspect Category.

(NOTE: Installations may also score aspects individually if doing so is included as part of their scoring procedure. 


\section{COMPLIANCE CATEGORY: \\ OTHER ENVIRONMENTAL ISSUES \\ Overseas ESOHCAMP}

\section{REGULATORY REQUIREMENTS: \\ REVIEWER CHECKS: September 2009}

07.30.3.0CAF. Installations must develop objectives and targets to address their significant environmental impacts (USAF EMS Planning Phase Guide, Section 5) [Added September 2004].

07.30.4.OCAF. Installations must develop Environmental Management Plans to achieve the stated objectives and targets (USAF EMS Planning Phase Guide, Section 6) [Added September 2004].

07.30.5.OCAF. The installation should develop a formal schedule for keeping the EMS updated (MP) [Added March 2009].
Verify the installation has developed, documented, and followed a written procedure for developing environmental objectives and targets to address significant impacts.

Verify that objectives describe the installation's goals for environmental performance and include performance indicators that can be measured and address:

- applicable regulatory requirements

- the views of all interested parties including installation personnel, neighbors, and environmental groups

- financial, operational, and technological options that are available and feasible

- the installation's mission and continued operations.

Verify that targets are specific, can be measured in terms of obtaining the objectives, and that the metrics used to measure target attainment are valid.

Verify that the installation has developed Environmental Management Plans (EMPs) to achieve the stated objectives and targets for each of its significant aspects.

Verify that each EMP:

- clearly identifies the personnel responsible for achieving the objective(s) and target(s), their roles and responsibilities, and ensures that personnel are aware of their roles and responsibilities

- clearly identifies the milestones and dates to achieve the objective(s) and target(s)

- clearly identifies the resources (money, equipment, personnel, etc.) needed to achieve the objective(s) and target(s).

Verify that the installation has developed, documented, and followed a written procedure for creating EMPs.

Verify that the installation has a a formal, detailed schedule for keeping the EMS updated.

Verify that the EMS update plan includes developing approaches to maintain and improve personnel interest, commitment, and enthusiasm for the EMS.

(NOTE: Some ideas that may be useful to accomplish this include recognition, announcing the EMS assessment schedule, displaying the progress in achieving the EMS's objectives and targets, and communicating the system's benefits to the installation's personnel.)

Verify that schedules have been developed for assessing and (when necessary) revising the elements of the EMS that require periodic revision. 


\section{COMPLIANCE CATEGORY: \\ OTHER ENVIRONMENTAL ISSUES \\ Overseas ESOHCAMP}

\begin{tabular}{|c|c|}
\hline $\begin{array}{l}\text { REGULATORY } \\
\text { REQUIREMENTS: }\end{array}$ & $\begin{array}{l}\text { REVIEWER CHECKS: } \\
\text { September } 2009\end{array}$ \\
\hline $\begin{array}{l}\text { O7.30.6.OCAF. When ap- } \\
\text { propriate facilities manage } \\
\text { DOD real property on which } \\
\text { private activities are permit- } \\
\text { ted, licensed, or otherwise } \\
\text { authorized or regulated, the } \\
\text { appropriate facilities and/or } \\
\text { organizations must consider } \\
\text { the environmental impacts of } \\
\text { these private activities in their } \\
\text { EMS (DODI 4715.17, Enclo- } \\
\text { sure 3, para 2(b)) [Added } \\
\text { September 2009]. }\end{array}$ & $\begin{array}{l}\text { Verify that procedures in the EMS are kept current. } \\
\text { Verify that the following elements of the EMS are updated on an on-going basis: } \\
\text { - awareness of applicable legal and other requirements; } \\
\text { - environmental aspects of installation's activities, products, and services; } \\
\text { - objectives and targets that have been set for the EMS; } \\
\text { - resources allocated to the EMS programs; } \\
\text { - implementation of EMPs to achieve the objectives and targets; } \\
\text { - operating instructions for specific processes or activities; } \\
\text { - any new records associated with new programs; and } \\
\text { - training to maintain personnel awareness and competence to meet EMS } \\
\text { needs. } \\
\text { (NOTE: This MP is found at USAF EMS Checking/Corrective Action and Man- } \\
\text { agement Review Guide, Section 3.) } \\
\text { Verify that, when appropriate facilities manage DOD real property on which pri- } \\
\text { vate activities are permitted, licensed, or otherwise authorized or regulated, the } \\
\text { environmental impacts of these private activities are considered in the appropriate } \\
\text { facility's and/or organization's EMS. }\end{array}$ \\
\hline
\end{tabular}




\section{COMPLIANCE CATEGORY: \\ OTHER ENVIRONMENTAL ISSUES \\ Overseas ESOHCAMP}

\begin{tabular}{|l|}
\hline \multicolumn{1}{|c|}{ REGULATORY } \\
REQUIREMENTS: \\
\hline O7.40 \\
EMS: \\
Implementation and Opera- \\
tions \\
O7.40.1.OCAF. Installations \\
must identify a structure to \\
develop, implement, and \\
maintain the EMS (USAF \\
EMS Implementation and \\
Operations Phase Guide, Sec- \\
tion 2) [Added September \\
2004].
\end{tabular}

07.40.2.OCAF. All personnel operating within the scope of the installation's EMS must be trained to perform their duties in a manner that minimizes negative impacts to the environment and must also receive training on their roles and responsibilities within the EMS (USAF EMS Implementation and Operations Phase Guide, Section 3) [Added September 2004].

Verify that the installation has identified (in writing) a structure for developing, implementing, and maintaining the EMS, including the identification of key individuals, units, and organizations.

Verify that an EMS Coordinator has been identified and appointed in writing by the EPC/ESOHC Chair or the Installation Commander.

Verify that the roles and responsibilities of the EMS Coordinator have been clearly defined in writing.

Verify that an EMS Cross-Functional Team (CFT) has been identified and appointed in writing by the EPC/ESOHC Chair or the Installation Commander.

Verify that the roles and responsibilities of the CFT members have been clearly defined in writing.

Verify that other key personnel, units, and organizations (e.g., Unit Environmental Coordinators [UECs], EPC/ESOHC members, Spill Response Team members) have been identified and appointed in writing by the appropriate authority within the EMS.

Verify that the roles and responsibilities for these key personnel, units, and organizations have been clearly defined in writing and communicated.

Verify that the installation has developed, implemented, and maintained a written process for identifying personnel environmental training requirements, including EMS training requirements.

Verify that all required training has been accomplished.

Verify that senior installation leaders have received EMS Senior Leadership Training.

Verify that members of the CFT and other key personnel identified in the EMS structure have received EMS Practitioner Level Training.

Verify that all personnel operating within the scope of the installation's EMS, but who do not receive Senior Leadership or Practitioner Level EMS Training, have received EMS General Awareness Level Training. 


\section{COMPLIANCE CATEGORY: \\ OTHER ENVIRONMENTAL ISSUES \\ Overseas ESOHCAMP}

\begin{tabular}{c}
\hline REGULATORY \\
REQUIREMENTS:
\end{tabular}

07.40.3.OCAF. Effective internal and external communications are required between all environmental stakeholders in a manner that facilitates two-way dialog between interested parties (USAF EMS Implementation and Operations Phase Guide, Section 4) [Added September 2004].

O7.40.4.OCAF. Documents related to the environment must be maintained and controlled in a manner that ensures that the most current and accurate versions are readily available (USAF EMS Implementation and Operations Phase Guide, Section 5) [Added September 2004].

\section{REVIEWER CHECKS: September 2009}

Verify that procedures or lesson plans been established and maintained to make personnel aware of the impacts of their work activities and the environmental benefits of improved performance related to those impacts.

Verify that procedures been established and maintained to make personnel aware of their roles and responsibilities in achieving conformance with the environmental policy and with the requirements of the EMS.

Verify that the installation has developed, implemented, and maintained a written installation-specific process for communicating environmental issues that is consistent with requirements contained in Air Force policy directives, memoranda, and instructions.

Verify that this communication is effective to all relevant levels and functions both internal and external to the installation.

Verify that the installation has developed, implemented, and maintains installation-specific procedures for communicating issues related to the EMS with external parties.

Verify that procedures are written, maintained, and followed for communicating information about significant environmental aspects.

Verify that procedures are established, maintained, and followed for receiving, documenting, and responding to relevant communications from external parties as it relates to the EMS.

Verify that procedures are established, maintained, and followed to communicate relevant information about the EMS to key suppliers and contractors.

Verify that the installation has developed, implemented, and maintained a written installation-specific process for identifying, managing, and controlling written (paper and/or electronic) environmentally related documents that is consistent with requirements contained in Air Force policy directives, memoranda, and instructions

Verify that procedures have been developed and followed for:

- identifying environmentally related documents

- ensuring that they are made available to personnel who require them

- reviewing them on a regular basis to ensure their currency

- removing/replacing them when they become obsolete.

(NOTE: Some obsolete documents may need to be retained for legal and/or knowledge-preservation purposes; if this is the case, they should be appropriately marked.) 


\section{COMPLIANCE CATEGORY: \\ OTHER ENVIRONMENTAL ISSUES \\ Overseas ESOHCAMP}

\section{REGULATORY REQUIREMENTS:}

07.40.5.OCAF. Operational controls must be identified, developed, implemented/installed, and maintained as necessary to control environmental aspects and documented in Environmental Management Plans when appropriate (USAF EMS Implementation and Operations Phase Guide, Section 6) [Added September 2004].

07.40.6.OCAF. Installations must develop, maintain, and periodically test procedures to identify potential and appropriate responses to accidents and emergency situations and to prevent or mitigate the environmental impacts that may be associated with such occurrences (USAF EMS Implementation and Operations Phase Guide, Section 7)

\section{REVIEWER CHECKS: September 2009}

Verify that procedures and responsibilities are established, implemented, and maintained for creating, modifying, and removing from service environmentally related documents in accordance with all appropriate Air Force, legal, and other requirements.

Verify through a review the EMS Manual that:

- all EMS documents have been identified;

- current versions of relevant documents are available and in their proper location;

- documents are periodically reviewed, revised (as necessary), and approved by the proper authority;

- current versions of relevant documents are available at all locations where operations essential to the functioning of the EMS are performed; and

Verify that all documents are legible, dated (with dates of revision as appropriate), readily identifiable, maintained in an orderly manner, and retained for the appropriate period of time.

Verify that the installation has developed, implemented, and maintained a written installation-specific process for identifying, evaluating, installing, and managing operational controls put in place to control environmental aspects.

Verify that procedures and responsibilities are established, implemented, and maintained, in accordance with all appropriate Air Force, legal, and other requirements, for:

- identifying operational controls

- developing, implementing, and maintaining administrative operational controls

- developing, installing, and maintaining physical and/or engineering operational controls.

Verify that operational controls included in the EMPs for significant aspects are in place.

Verify that the installation has developed, implemented, and maintained a written installation-specific process for identifying potential emergency response scenarios; developing appropriate plans, procedures, agreements, etc. to respond to these scenarios.

Verify that the installation periodically tests and/or evaluates its response to these scenarios in accordance with all appropriate Air Force, legal, and other requirements.

Verify that procedures and responsibilities are established, implemented, and maintained for identifying potential accident and emergency response scenarios and for developing, implementing, and maintaining plans, procedures, agree- 


\section{COMPLIANCE CATEGORY: \\ OTHER ENVIRONMENTAL ISSUES \\ Overseas ESOHCAMP}

\begin{tabular}{l} 
REGULATORY \\
REQUIREMENTS: \\
\hline [Added September 2004]. \\
\\
\\
\\
\\
O7.40.7.OCAF. Appropriate \\
facilities and organizations \\
must maximize the use of \\
cross-functional team to im- \\
plement and maintain the \\
EMS as appropriate (DODI \\
4715.17, Enclosure 3, para \\
1(a)) [Added September \\
2009]. \\
O7.40.8.OCAF. Specific ac- \\
tions must be taken when \\
energy and transportation \\
functions entail significant \\
environmental aspects (DODI \\
4715.17, Enclosure 3, para \\
1(c)) [Added September \\
2009].
\end{tabular}

Verify that the appropriate facility and/or organization establishes objectives, targets, and environmental management programs for energy and transportation functions within the framework of the EMS.

(NOTE: Where energy and transportation management systems already exist, they need not be replaced or overtaken by the EMS. Leadership, management, and operations from these energy and transportation systems can remain if the EMS recognizes those programs as contributing to the appropriate facility's or organization's EMS.)

Verify that each management system's goals, practices, and programs are mutually supporting and enhance each other.

(NOTE: The DOD Components and/or their appropriate facilities and organizations will develop procedures and mechanisms to strengthen coordination between their management systems and with EMS.)

07.40.9.0CAF. Specific actions must be taken when tenant, contractor, and concessionaire activities affect an appropriate facility's environmental issues certain actions are required (DODI 4715.17, Enclosure 3, para 2(a)) [Added September

Verify that compliance with DODI 4175.17 is ensured at all appropriate organizational levels and facilities as required by DODD 4715.1E and EO 13423.

Verify that, when tenant, contractor, and concessionaire activities affect an appropriate facility's environmental issues, these activities determine which of their functions constitute appropriate operational and support functions and they ensure management systems address a life-cycle approach. 


\begin{tabular}{|l|c|}
\hline \multicolumn{2}{|c|}{$\begin{array}{c}\text { COMPLIANCE CATEGORY: } \\
\text { OTHER ENVIRONMENTAL ISSUES } \\
\text { Overseas ESOHCAMP }\end{array}$} \\
\hline $\begin{array}{c}\text { REGULATORY } \\
\text { REQUIREMENTS: }\end{array}$ & $\begin{array}{c}\text { REVIEWER CHECKS: } \\
\text { September 2009 }\end{array}$ \\
\hline 2009$].$ & \\
\hline
\end{tabular}




\section{COMPLIANCE CATEGORY: \\ OTHER ENVIRONMENTAL ISSUES \\ Overseas ESOHCAMP}

\begin{tabular}{|l|}
\hline \multicolumn{1}{|c|}{ REGULATORY } \\
REQUIREMENTS: \\
\hline O7.50 \\
EMS: \\
Monitoring and Measuring \\
O7.50.1.OCAF. Installations \\
must develop a process for \\
monitoring key activities and \\
tracking the performance of \\
their EMS. (USAF EMS \\
Checking/Corrective Action \\
and Management Review \\
Guide, Section 2) [Added \\
September 2004].
\end{tabular}

O7.50.2.OCAF. Installations must conduct periodic regulatory and EMS compliance assessments. (USAF EMS Checking/Corrective Action and Management Review Guide, Section 3) [Added September 2004].

Verify that the installation has developed, implemented, and maintained a written installation-specific process for identifying, monitoring, and tracking the performance of key activities within its EMS.

(NOTE: Key activities [i.e., performance indicators] are those items that provide ongoing indications on the achievement of objectives and targets, the status of operational controls, the maintenance of regulatory compliance, and other parameters that must be watched to ensure the EMS remains effective.)

Verify that procedures and responsibilities are established, implemented, and maintained for identifying key activities within the EMS, monitoring them, and tracking their performance against specific milestones and other relevant indicators.

Verify that the anticipated rate of progress is in accordance with the installation's policy and commitment to continual improvement.

Verify that the installation has developed, implemented, and maintained a written installation-specific process for assessing its compliance with appropriate regulatory requirements and its EMS policies and procedures.

Verify that the installation has developed, implemented, and maintained a written process to assess its compliance with regulatory requirements (ECAMP or ESOHCAMP) and the tenants of its EMS.

Verify that installation assessors for both the ECAMP/ESOHCAMP and EMS assessments have been properly trained in accordance with the installation's written EMS assessment program.

Verify that the installation has conducted an environmental regulatory assessment (ECAMP or ESOHCAMP) in accordance with applicable Air Force directives.

Verify that the findings from the environmental regulatory assessments have been documented.

Verify that the results of environmental regulatory assessments have been reviewed by the installation's senior leadership (i.e., EPC/ESOHC).

Verify that the installation has conducted EMS compliance assessments on at least an annual basis.

Verify that the findings from the EMS compliance assessments have been docu- 


\section{COMPLIANCE CATEGORY: \\ OTHER ENVIRONMENTAL ISSUES \\ Overseas ESOHCAMP}

\begin{tabular}{|c|c|}
\hline $\begin{array}{l}\text { REGULATORY } \\
\text { REQUIREMENTS: }\end{array}$ & $\begin{array}{l}\text { REVIEWER CHECKS: } \\
\text { September } 2009\end{array}$ \\
\hline $\begin{array}{l}\text { O7.50.3.OCAF. Installations } \\
\text { must have a process for im- } \\
\text { plementing corrective actions } \\
\text { associated with failures to } \\
\text { comply with regulatory re- } \\
\text { quirements and/or EMS poli- } \\
\text { cies and procedures (USAF } \\
\text { EMS Checking/Corrective } \\
\text { Action and Management Re- } \\
\text { view Guide, Section 3) } \\
\text { [Added September 2004]. }\end{array}$ & $\begin{array}{l}\text { mented. } \\
\text { Verify that the results of EMS compliance assessments have been reviewed by the } \\
\text { installation's senior leadership (i.e., EPC/ESOHC). } \\
\text { Verify that the installation has developed, implemented, and maintained a written } \\
\text { installation-specific process for implementing corrective actions associated with } \\
\text { identified failures within key activities to comply with regulatory requirements } \\
\text { and/or its EMS policies and procedures. } \\
\text { Verify that the installation has developed, implemented, and maintained a written } \\
\text { process to develop, implement, and document actions taken to correct failures } \\
\text { and/or EMS policies and procedures. } \\
\text { Verify that the corrective action process: } \\
\text { - identifies and targets, when applicable, the root cause of the non-compliance } \\
\text { - ensures that corrective or preventive actions taken to eliminate the causes of } \\
\text { actual or potential non-conformances are appropriate to the magnitude of the } \\
\text { problems and commensurate with the environmental impact encountered } \\
\text { - is periodically reviewed to verify the effectiveness of the corrective ac- } \\
\text { tion(s). }\end{array}$ \\
\hline $\begin{array}{l}\text { O7.50.4.OCAF. Installations } \\
\text { must ensure that all equip- } \\
\text { ment that measures and moni- } \\
\text { tors environmental perform- } \\
\text { ance is properly calibrated } \\
\text { and maintained, and that re- } \\
\text { cords of this process are re- } \\
\text { tained following existing Air } \\
\text { Force and installation instruc- } \\
\text { tions and procedures (USAF } \\
\text { EMS Checking/Corrective } \\
\text { Action and Management Re- } \\
\text { view Guide, Section 3) } \\
\text { [Added March 2009]. }\end{array}$ & $\begin{array}{l}\text { Verify that the installation ensures that: } \\
\text { - all equipment that measures and monitors environmental performance is } \\
\text { properly calibrated and maintained, and } \\
\text { - that records of this process are retained following existing Air Force and in- } \\
\text { stallation instructions and procedures. } \\
\text { (NOTE: Examples of equipment requiring calibration include, but are not limited } \\
\text { to, meters and gauges.) }\end{array}$ \\
\hline $\begin{array}{l}\text { O7.50.5.OCAF. Installations } \\
\text { must develop a list of all } \\
\text { equipment that requires cali- } \\
\text { bration and identify the fre- } \\
\text { quency of the calibration } \\
\text { (USAF EMS Check- } \\
\text { ing/Corrective Action and } \\
\text { Management Review Guide, } \\
\text { Section 3) [Added March }\end{array}$ & $\begin{array}{l}\text { Verify that the installation has developed a list of all equipment that requires cali- } \\
\text { bration. } \\
\text { Verify that the installation's list identifies the frequency of the calibration. } \\
\text { Verify that the list includes specific responsibilities and, if appropriate, unique } \\
\text { guidance on the calibration of monitoring and measuring instruments used for } \\
\text { performance measurement. }\end{array}$ \\
\hline
\end{tabular}




\section{COMPLIANCE CATEGORY: \\ OTHER ENVIRONMENTAL ISSUES \\ Overseas ESOHCAMP}

\begin{tabular}{|l|}
\hline \multicolumn{1}{|c|}{$\begin{array}{c}\text { REGULATORY } \\
\text { REQUIREMENTS: }\end{array}$} \\
\hline 2009]. \\
O7.50.6.OCAF. In establish- \\
ing its EMS assessment pro- \\
gram, each installation should \\
give consideration to specific \\
elements (MP) [Added March \\
2009].
\end{tabular}

O7.50.7.OCAF. Team members conducting the EMS assessment should have relevant skills and experience (MP) [Added March 2009].

O7.50.8.OCAF. Installations should follow existing Air Force Instructions (AFIs) and MAJCOM instructions and, if necessary, develop installation-specific operating instructions for conducting

\section{REVIEWER CHECKS: September 2009}

(NOTE: A properly structured EMS includes the administration of EMS assessments that institutionalize the system and gives it structure, reliability, and predictability.)

Verify that, in establishing its EMS assessment program, the installation considers the following elements:

- communicating the assessment program to ESOHC members

- coordinating and scheduling assessments and other assessment program activities

- establishing and maintaining a process for the initial training of assessors and for the ongoing evaluation of their training needs

- ensuring the selection of assessment teams

- providing required resources to the assessment teams

- ensuring the conduct of assessments according to the assessment program

- ensuring the control of records of the assessment activities

- ensuring review/approval of assessment reports as well as their distribution to the installation and other specified parties

- ensuring assessment follow-ups are conducted according to the corrective action program.

(NOTE: This MP is found at USAF EMS Checking/Corrective Action and Management Review Guide, Section 3.)

Verify that team members conducting the EMS assessment have appropriate technical backgrounds.

Verify that team members conducting the EMS assessment properly trained to function effectively in accordance with existing ECAMP/ESOHCAMP guidance.

Verify that team members conducting the EMS assessment possess specific knowledge of the Air Force's EMS and how it was implemented on their installations.

(NOTE: Formal EMS auditing training is also desired, but not essential.)

(NOTE: This MP is found at USAF EMS Checking/Corrective Action and Management Review Guide, Section 3.)

Verify that the installation follow existing Air Force Instructions (AFIs) and MAJCOM instructions.

Verify that, if necessary, the installation develops installation-specific operating instructions for conducting EMS assessments.

Verify that any installation-specific operating instructions for conducting EMS 


\section{COMPLIANCE CATEGORY: \\ OTHER ENVIRONMENTAL ISSUES \\ Overseas ESOHCAMP}

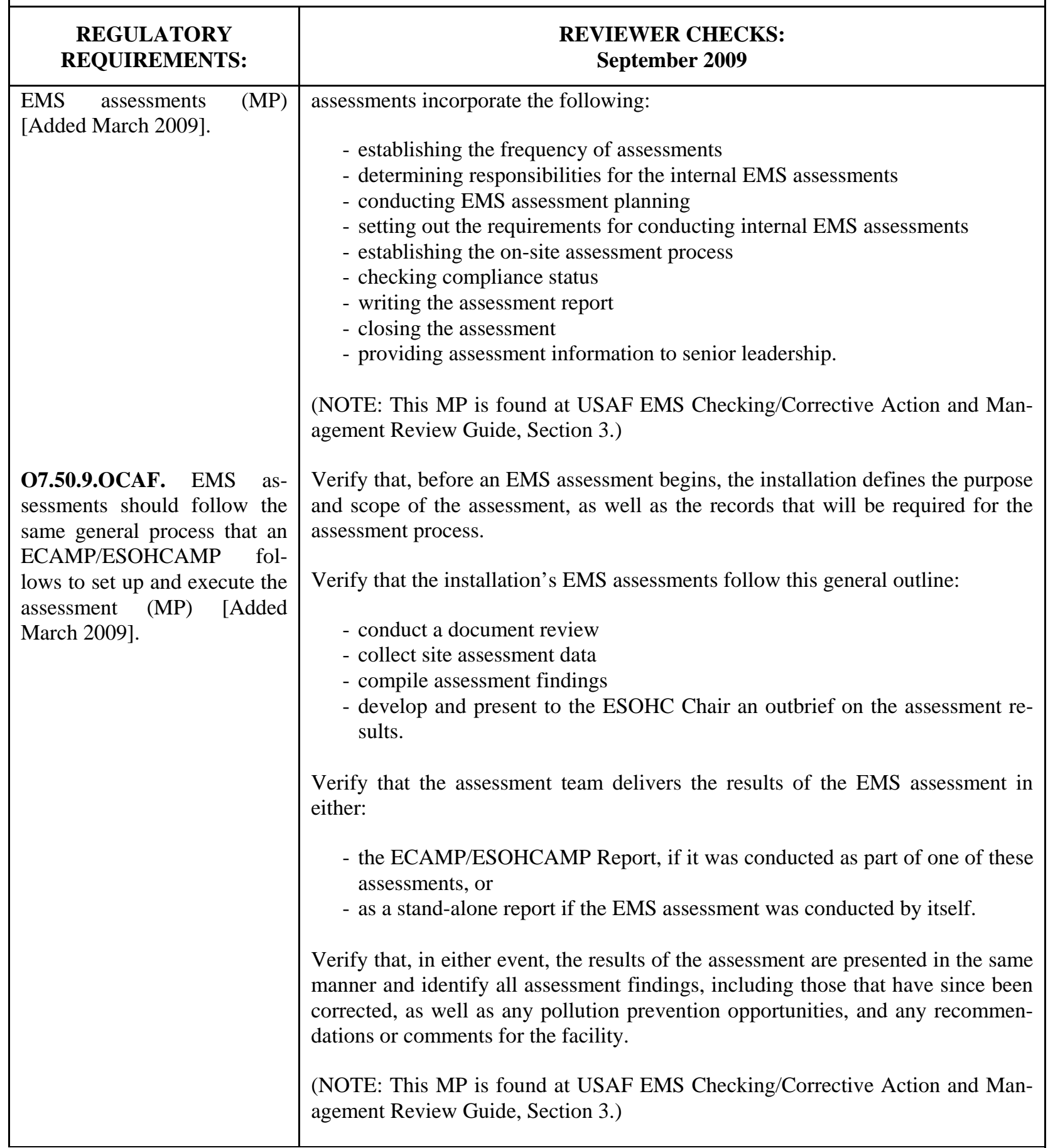




\section{COMPLIANCE CATEGORY: \\ OTHER ENVIRONMENTAL ISSUES \\ Overseas ESOHCAMP}

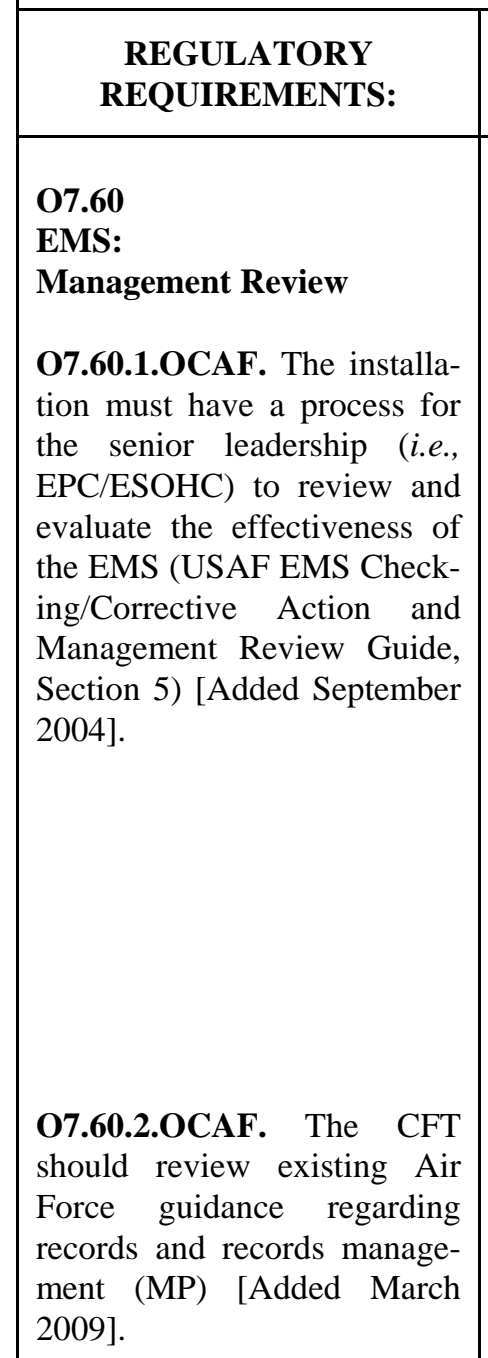

\section{REVIEWER CHECKS: September 2009}

Verify that the installation has developed, implemented, and maintained a written installation-specific process for the senior leadership (i.e., EPC/ESOHC) to review the EMS, evaluate its effectiveness, and update its policies and procedures.

Verify that the installation has developed, implemented, and maintained a written process for the senior leadership to review and evaluate the effectiveness of the EMS's policies and procedures.

Verify that the specifically addresses:

- the adequacy of the EMS policy, procedures, and practices;

- the continual improvement of the system;

- improvements in environmental performance; and

- the ability to support the installation's mission.

Verify that senior leadership has documented in writing the results of its Management Review and has initiated/directed modifications to the EMS based upon the findings of the review.

(NOTE: A solid records management program is imperative for the establishment of an effective EMS. Air Force directives contain sufficient guidance to meet EMS records management program requirements. Thus, in general, installations need only to follow existing AFIs and Air Force Manuals [AFMANs] to establish and maintain an effective environmental records management program. In some instances, however, installations may need to augment these directives with installation-specific procedures to govern the identification, maintenance, and disposition of EMS-specific environmental records.)

Verify that the CFT reviews existing Air Force guidance regarding records and records management.

Verify that at least one member of the CFT has a background in document and records management.

Verify that, at a minimum, the CFT reviews:

- AFI 32-7002, Environmental Information Management System;

- AFMAN 37-123, Management of Records;

- AFI 33-322, Records Management Program;

- AFI 37-138, Records Disposition - Procedures and Responsibilities; and

- any other Air Force, MAJCOM, or installation supplemental guidance related to records management. 


\section{COMPLIANCE CATEGORY: \\ OTHER ENVIRONMENTAL ISSUES \\ Overseas ESOHCAMP}

\begin{tabular}{|c|c|}
\hline $\begin{array}{l}\text { REGULATORY } \\
\text { REQUIREMENTS: }\end{array}$ & $\begin{array}{l}\text { REVIEWER CHECKS: } \\
\text { September } 2009\end{array}$ \\
\hline $\begin{array}{l}\text { O7.60.3.OCAF. After re- } \\
\text { viewing the existing Air } \\
\text { Force records management } \\
\text { guidance documents, the CFT } \\
\text { should identify any proce- } \\
\text { dures not being followed and } \\
\text { take actions to rectify defi- } \\
\text { ciencies (MP) [Added March } \\
\text { 2009]. }\end{array}$ & $\begin{array}{l}\text { Verify that, once the appropriate members of the CFT have reviewed the require- } \\
\text { ments discussed in the guidance documents listed above, they compare the re- } \\
\text { quirements to determine whether the installation is following the AFIs and } \\
\text { whether supplemental installation-specific procedures or instructions need to be } \\
\text { developed. } \\
\text { (NOTE: This MP is found at USAF EMS Checking/Corrective Action and Man- } \\
\text { agement Review Guide, Section 3.) } \\
\text { Verify that, after reviewing the existing Air Force records management guidance } \\
\text { documents, the CFT identifies any procedures not being followed and takes ac- } \\
\text { tions to rectify deficiencies. } \\
\text { (NOTE: This MP is found at USAF EMS Checking/Corrective Action and Man- } \\
\text { agement Review Guide, Section 3.) }\end{array}$ \\
\hline $\begin{array}{l}\text { O7.60.4.OCAF. The CFT } \\
\text { must identify what it consid- } \\
\text { ers environmental records in } \\
\text { general, and those that are } \\
\text { necessary to demonstrate con- } \\
\text { formance to the requirements } \\
\text { of the EMS (USAF EMS } \\
\text { Checking/Corrective Action } \\
\text { and Management Review } \\
\begin{array}{l}\text { Guide, Section 3) [Added } \\
\text { March 2009]. }\end{array}\end{array}$ & $\begin{array}{l}\text { Verify that the CFT identifies what it considers environmental records in general, } \\
\text { and those records that are necessary to demonstrate conformance to the require- } \\
\text { ments of the EMS. }\end{array}$ \\
\hline $\begin{array}{l}\text { O7.60.5.OCAF. The CFT } \\
\text { should identify which docu- } \\
\text { ments become records and } \\
\text { develop record retention } \\
\text { schedules specifically for } \\
\text { EMS-related records (MP) } \\
\text { [Added March 2009]. }\end{array}$ & $\begin{array}{l}\text { Verify that the CFT identifies which documents become records and develops } \\
\text { record retention schedules specifically for EMS-related records. } \\
\text { Verify that, as the CFT considers the application of existing records management } \\
\text { requirements to the EMS, they consider the following: } \\
\text { - environmental records must be legible, identifiable, and traceable to the ac- } \\
\text { tivity involved; } \\
\text { - environmental records must be stored and maintained in such a way that they } \\
\text { are readily retrievable and protected against damage, deterioration, or loss; } \\
\text { and } \\
\text { - if not otherwise documented, record retention times must be established and } \\
\text { recorded. } \\
\text { (NOTE: This MP is found at USAF EMS Checking/Corrective Action and Man- } \\
\text { agement Review Guide, Section 3.) }\end{array}$ \\
\hline
\end{tabular}




\section{COMPLIANCE CATEGORY: \\ OTHER ENVIRONMENTAL ISSUES \\ Overseas ESOHCAMP}

\section{REGULATORY REQUIREMENTS:}

07.60.6.0CAF. Annual management reviews of the EMS should be carefully planned (MP) [Added March 2009].

O7.60.7.OCAF. The installation's senior leadership must review the EMS at least annually (USAF EMS Checking/Corrective Action and Management Review Guide, Section 3) [Added March 2009].

O7.60.8.OCAF. The management review process should use the existing ESOHC platform to ensure that all necessary information is available to allow senior leadership to carry out this evaluation (MP) [Added

\section{REVIEWER CHECKS: September 2009}

(NOTE: The management review is an opportunity for management to step back and confirm that it is satisfied with the direction of the EMS. Management considers whether or not the EMS is achieving the policy statement as well as the objectives and targets that management had planned for, and also whether the EMS continues to align with the installation's mission and central policies. In effect, the focus is whether the EMS continues to be suitable, adequate, and effective for the installation. The goals for the management review include:

- highlighting management commitment;

- promoting senior leadership involvement in the EMS; and

- gaining management reemphasis and legitimatization of EMS objectives and commitment of resources.)

Verify that the ESOHC is used as the forum for conducting EMS management reviews.

(NOTE: At the installation's discretion, the review can be accomplished by the entire ESOHC or just a few members, but the entire council should decide who participates in the management review process in accordance with AFI 90-802.)

Verify that the CFT prepares EMS information to identify trends and to develop coherent diagnostics so that management is presented with a clear picture of the current status.

Verify that the CFT develops recommendations based on knowledge and understanding of areas where improvement should be made, resources reallocated, or new objectives set.

(NOTE: This MP is found at USAF EMS Checking/Corrective Action and Management Review Guide, Section 3.)

Verify that, at least annually, the installation's senior leadership review the EMS to ensure its continuing suitability, adequacy, and effectiveness towards achieving broader goals of mission enhancement and sustainment.

(NOTE: At the installation level, senior leaders include wing/vice wing/group commanders and any additional ESOHC members.)

(NOTE: This MP is found at USAF EMS Checking/Corrective Action and Management Review Guide, Section 3.)

Verify that senior leaders is given all relevant information that will allow them to make accurate and sound judgments regarding the EMS.

(NOTE: It is generally the responsibility of the EMS Coordinator and the CFT to provide this information to the Senior Leadership. Typically, this information will include the results of the EMS assessment as well as monitoring and measurement results.) 


\section{COMPLIANCE CATEGORY: \\ OTHER ENVIRONMENTAL ISSUES \\ Overseas ESOHCAMP}

\section{REGULATORY REQUIREMENTS:}

March 2009].

07.60.9.0CAF. The management review should address the possible need for changes to policy, objectives, and other elements of the EMS, in light of EMS assessment results, changing circumstances, and the commitment to continual improvement (MP) [Added March 2009].

O7.60.10.OCAF. The management review process, including the decisions made by the installation's senior leadership, must be recorded and maintained (USAF EMS Checking/Corrective Action and Management Review Guide, Section 3) [Added March 2009].

O7.60.11.OCAF. Installations must follow up on the outcomes of the management review (USAF EMS Check-

\section{REVIEWER CHECKS: September 2009}

(NOTE: This MP is found at USAF EMS Checking/Corrective Action and Management Review Guide, Section 3.)

Verify that the EMS Coordinator or other designated individual guide the installation's senior leadership toward considering the following questions:

- Is the EMS operating as planned?

- Is the EMS meeting the basic objectives of the environmental policy of the installation?

- Are objectives and targets being achieved?

- Do EMPs address aspects and achieve objectives and targets; how should they be improved?

- Is personnel training adequate to assure the goals of the EMS are being met and, if not, how should the program be improved?

- Are resources used effectively or should they be redirected or changed?

Verify that the following questions, primarily as they relate to achieving enhanced mission performance and sustainability, are answered as part of the review:

- Is the EMS still suitable for the installation?

- Is the EMS still adequate for the installation?

- Is the EMS still effective for its intended purposes?

- Based on the assessment of these three characteristics, does the EMS need changes?

- If it needs changes, what actions and what resources will management decree for those changes?

- Who is responsible to oversee the implementation of those changes?

- When does senior leadership want an update on the status and effect of the changes?

(NOTE: This MP is found at USAF EMS Checking/Corrective Action and Management Review Guide, Section 3.)

Verify that the management review process, including the decisions made by the installation's senior leadership, is recorded.

(NOTE: Typically the management review process and the decisions made by the installation's senior leadership are included in the ESOHC meeting minutes.)

Verify that these minutes are maintained as an EMS document in accordance with each installation's EMS document control procedures.

(NOTE: The EMS Coordinator and the CFT will most likely lead the implementation of the actions necessary to effect the changes that senior leadership has asked for in the EMS.) 


\section{COMPLIANCE CATEGORY: \\ OTHER ENVIRONMENTAL ISSUES \\ Overseas ESOHCAMP}

\begin{tabular}{|c|c|}
\hline $\begin{array}{l}\text { REGULATORY } \\
\text { REQUIREMENTS: }\end{array}$ & $\begin{array}{l}\text { REVIEWER CHECKS: } \\
\text { September } 2009\end{array}$ \\
\hline $\begin{array}{l}\text { ing/Corrective Action and } \\
\text { Management Review Guide, } \\
\text { Section 3) [Added March } \\
\text { 2009]. }\end{array}$ & $\begin{array}{l}\text { Verify that the coordinator ensures that changes occur through the appropriate } \\
\text { means at the disposal of the installation. } \\
\text { Verify that the execution of these actions and the achievement of the desired } \\
\text { changes is documented and maintained within the EMS. }\end{array}$ \\
\hline $\begin{array}{l}\text { O7.60.12.OCAF. After initial } \\
\text { full implementation and EMS } \\
\text { declaration of conformance, } \\
\text { EMS conformance at all ap- } \\
\text { propriate facilities and/or or- } \\
\text { ganizations must be formally } \\
\text { re-declared at least every } 3 \text { yr } \\
\text { (DODI 4715.17, Enclosure 2, } \\
\text { para g and Enclosure 3, para } \\
\text { 3) [Added September 2009]. }\end{array}$ & $\begin{array}{l}\text { Verify that, after initial full implementation and EMS declaration of conformance, } \\
\text { EMS conformance at all appropriate facilities and/or organizations is formally re- } \\
\text { declared at least every } 3 \text { yr. } \\
\text { Verify that all declarations of conformance are based upon an audit by a qualified } \\
\text { party outside the control or scope of the EMS. } \\
\text { (NOTE: Variations from the } 3 \text {-yr conformance audit shall be coordinated with } \\
\text { the ADUSD[ESOH] on an appropriate facility and/or organization basis.) }\end{array}$ \\
\hline $\begin{array}{l}\text { O7.60.13.OCAF. Internal } \\
\text { EMS audits must be con- } \\
\text { ducted annually (DODI } \\
\text { 4715.17, Enclosure 2, para g) } \\
\text { [Added September 2009]. }\end{array}$ & $\begin{array}{l}\text { Verify that internal EMS audits (first party audits) are conducted annually at ap- } \\
\text { propriate facilities and organizations. }\end{array}$ \\
\hline
\end{tabular}




\section{Appendix 6-1}

\section{USEPA 17 Industrial Toxic Chemicals}

(AFI 32-7080, A2.2)

\section{Benzene}

2. Cadmium and its compounds

3. Carbon Tetrachloride

4. Chloroform

5. Chromium and its compounds

6. Cyanide and its compounds

7. Lead and compounds

8. Mercury and compounds

9. Methylene Chloride

10. Methyl Ethyl Ketone

11. Methyl Isobutyl Ketone

12. Nickel and its compounds

13. Tetrachloroethylene

14. Toluene

15. 1,1,1 - Trichloroethane

16. Trichloroethylene

17. Xylenes 


\section{Appendix 6-2}

Ozone-Depleting Substances to which AFI 32-7080 and AFI 32-7086 Apply

(AFI 32-7080, A2.1 and AFI 32-7086, Tables 4.1 and 4.2)

\begin{tabular}{|c|c|c|}
\hline Halocarbon Number & Molecular Formula & Name \\
\hline \multicolumn{3}{|c|}{ Class I Ozone-Depleting Substances } \\
\hline CFC-11 & $\mathrm{CCl}_{3} \mathrm{~F}$ & Trichlorofluoromethane \\
\hline CFC-12 & $\mathrm{CCl}_{2} \mathrm{~F}_{2}$ & Dichlorodifluoromethane \\
\hline CFC-113 & $\mathrm{C}_{2} \mathrm{Cl}_{3} \mathrm{~F}_{3}$ & Trichlorotrifluoroethane \\
\hline CFC-114 & $\mathrm{C}_{2} \mathrm{Cl}_{2} \mathrm{~F}_{4}$ & Dichlorotetrafluoroethane \\
\hline CFC-115 & $\mathrm{C}_{2} \mathrm{ClF}_{5}$ & Chloropentafluoroethane \\
\hline Halon 1011 & $\mathrm{CH}_{2} \mathrm{BrCl}$ & Bromochloromethane \\
\hline Halon 1202 & $\mathrm{CBr}_{2} \mathrm{~F}_{2}$ & Dibromodifluoromethane \\
\hline Halon 1211 & $\mathrm{CF}_{2} \mathrm{ClBr}$ & Bromochlorodifluoromethane \\
\hline Halon 1301 & $\mathrm{CF}_{3} \mathrm{Br}$ & Bromotrifluoromethane \\
\hline Halon 2402 & $\mathrm{C}_{2} \mathrm{~F}_{4} \mathrm{Br}_{2}$ & Dibromotetrafluoroethane \\
\hline CFC-13 & $\mathrm{CClF}_{3}$ & Chlorotrifluoromethane \\
\hline CFC-111 & $\mathrm{C}_{2} \mathrm{Cl}_{5} \mathrm{~F}$ & Pentachlorofluoroethane \\
\hline CFC-112 & $\mathrm{C}_{2} \mathrm{Cl}_{4} \mathrm{~F}_{2}$ & Tetrachlorodifluoroethane \\
\hline CFC-211 & $\mathrm{C}_{3} \mathrm{Cl}_{7} \mathrm{~F}_{3}$ & Heptachlorofluoropropane \\
\hline CFC-212 & $\mathrm{C}_{3} \mathrm{Cl}_{6} \mathrm{~F}_{2}$ & Hexachlorodifluoropropane \\
\hline CFC-213 & $\mathrm{C}_{3} \mathrm{Cl}_{5} \mathrm{~F}_{3}$ & Pentachlorotrifluoropropane \\
\hline CFC-214 & $\mathrm{C}_{3} \mathrm{Cl}_{4} \mathrm{~F}_{4}$ & Tetrachlorotetrafluoropropane \\
\hline CFC-215 & $\mathrm{C}_{3} \mathrm{Cl}_{3} \mathrm{~F}_{5}$ & Trichloropentafluoropane \\
\hline CFC-216 & $\mathrm{C}_{3} \mathrm{Cl}_{2} \mathrm{~F}_{6}$ & Dichlorohexafluoropropane \\
\hline CFC-217 & $\mathrm{C}_{3} \mathrm{ClF}_{7}$ & Chloroheptafluoropropane \\
\hline Carbon Tetrachloride & $\mathrm{CCl}_{4}$ & Tetrachloromethane \\
\hline Methyl Chloroform & $\mathrm{C}_{2} \mathrm{H}_{3} \mathrm{Cl}_{3}$ & Trichloroethane (all isomers) \\
\hline Methyl Bromide & $\mathrm{CH}_{3} \mathrm{BR}$ & Bromomethane \\
\hline
\end{tabular}




\begin{tabular}{|c|c|c|}
\hline \multicolumn{3}{|c|}{ Class II Ozone-Depleting Substances } \\
\hline HCFC Number & Molecular Formula & \\
\hline HCFC-21 & $\mathrm{CHFCl}_{2}$ & \\
\hline HCFC-22 & $\mathrm{CHF}_{2} \mathrm{Cl}$ & \\
\hline HCFC-31 & $\mathrm{CH}_{2} \mathrm{FCl}$ & \\
\hline HCFC-121 & $\mathrm{C}_{2} \mathrm{HFCl}_{4}$ & \\
\hline HCFC-122 & $\mathrm{C}_{2} \mathrm{H} \mathrm{F}_{2} \mathrm{Cl}_{3}$ & \\
\hline HCFC-123 & $\mathrm{C}_{2} \mathrm{HF}_{3} \mathrm{Cl}_{2}$ & \\
\hline HCFC-123b & $\mathrm{CHCl}_{2} \mathrm{CF}_{3}$ & \\
\hline HCFC-124 & $\mathrm{C}_{2} \mathrm{HF}_{4} \mathrm{Cl}$ & \\
\hline HCFC-124b & $\mathrm{CHFClCF}_{3}$ & \\
\hline HCFC-131 & $\mathrm{C}_{2} \mathrm{H}_{2} \mathrm{FCl}_{3}$ & \\
\hline HCFC-132 & $\mathrm{C}_{2} \mathrm{H}_{2} \mathrm{~F}_{2} \mathrm{Cl}_{2}$ & \\
\hline HCFC-133 & $\mathrm{C}_{2} \mathrm{H}_{2} \mathrm{~F}_{3} \mathrm{Cl}$ & \\
\hline HCFC-141 & $\mathrm{C}_{2} \mathrm{H}_{3} \mathrm{FCl}_{2}$ & \\
\hline HCFC-141b & $\mathrm{CH}_{3} \mathrm{CFCl}_{2}$ & \\
\hline HCFC-142 & $\mathrm{C}_{2} \mathrm{H}_{3} \mathrm{~F}_{2} \mathrm{Cl}$ & \\
\hline HCFC-142b & $\mathrm{CH}_{3} \mathrm{CF}_{2} \mathrm{Cl}$ & \\
\hline HCFC-151 & $\mathrm{C}_{2} \mathrm{H}_{4} \mathrm{FCl}$ & \\
\hline HCFC-221 & $\mathrm{C}_{3} \mathrm{HFCl}_{6}$ & \\
\hline HCFC-222 & $\mathrm{C}_{3} \mathrm{HF}_{2} \mathrm{Cl}_{5}$ & \\
\hline HCFC-223 & $\mathrm{C}_{3} \mathrm{HF}_{3} \mathrm{CL}_{4}$ & \\
\hline HCFC-224 & $\mathrm{C}_{3} \mathrm{HF}_{4} \mathrm{Cl}_{3}$ & \\
\hline HCFC-225 & $\mathrm{C}_{3} \mathrm{HF}_{5} \mathrm{Cl}_{2}$ & \\
\hline HCFC-225ca & $\mathrm{CF}_{3} \mathrm{CF}_{2} \mathrm{CHCl}_{2}$ & \\
\hline HCFC-225cb & $\mathrm{CF}_{2} \mathrm{CICF}_{23} \mathrm{CHCIF}$ & \\
\hline HCFC-226 & $\mathrm{C}_{3} \mathrm{HF}_{6} \mathrm{Cl}$ & \\
\hline HCFC-231 & $\mathrm{C}_{3} \mathrm{H}_{2} \mathrm{Cl}_{5}$ & \\
\hline HCFC-232 & $\mathrm{C}_{3} \mathrm{H}_{2} \mathrm{~F}_{2} \mathrm{Cl}_{4}$ & \\
\hline HCFC-233 & $\mathrm{C}_{3} \mathrm{H}_{2} \mathrm{~F}_{3} \mathrm{Cl}_{3}$ & \\
\hline HCFC-234 & $\mathrm{C}_{3} \mathrm{H}_{2} \mathrm{~F}_{4} \mathrm{Cl}_{2}$ & \\
\hline HCFC-235 & $\mathrm{C}_{3} \mathrm{H}_{2} \mathrm{~F}_{35} \mathrm{Cl}$ & \\
\hline HCFC-241 & $\mathrm{C}_{3} \mathrm{H}_{3} \mathrm{FCl}_{4}$ & \\
\hline HCFC-242 & $\mathrm{C}_{3} \mathrm{H}_{3} \mathrm{~F}_{2} \mathrm{Cl}_{3}$ & \\
\hline
\end{tabular}




\begin{tabular}{|l|l|l|}
\hline \multicolumn{3}{|c|}{ Class II Ozone-Depleting Substances } \\
\hline \multicolumn{1}{|c|}{ HCFC Number } & \multicolumn{1}{|c|}{ Molecular Formula } & \\
\hline HCFC-243 & $\mathrm{C}_{3} \mathrm{H}_{3} \mathrm{~F}_{3} \mathrm{Cl}_{2}$ & \\
\hline HCFC-244 & $\mathrm{C}_{3} \mathrm{H}_{3} \mathrm{~F}_{4} \mathrm{Cl}$ & \\
\hline HCFC-251 & $\mathrm{C}_{3} \mathrm{H}_{4} \mathrm{FCl}_{3}$ & \\
\hline HCFC-252 & $\mathrm{C}_{3} \mathrm{H}_{4} \mathrm{~F}_{2} \mathrm{CI}_{2}$ & \\
\hline HCFC-253 & $\mathrm{C}_{3} \mathrm{H}_{4} \mathrm{~F}_{3} \mathrm{CI}$ & \\
\hline HCFC-261 & $\mathrm{C}_{3} \mathrm{H}_{5} \mathrm{FCI}_{2}$ & \\
\hline HCFC-262 & $\mathrm{C}_{3} \mathrm{H}_{5} \mathrm{~F}_{2} \mathrm{CI}$ & \\
\hline HCFC-271 & $\mathrm{C}_{3} \mathrm{H}_{6} \mathrm{FCI}$ & \\
\hline
\end{tabular}




\section{Appendix 6-3}

\section{Deleted}

AFMAN 37-139, Record Disposition Schedule has been replaced by the Air Force Records Disposition Schedule, which is available online at https://afrims.amc.af.mil/. 


\section{Appendix 6-4}

\section{Deleted}

AFMAN 37-139, Record Disposition Schedule has been replaced by the Air Force Records Disposition Schedule, which is available online at https://afrims.amc.af.mil/. 


\section{Appendix 6-5}

\section{Deleted}

AFMAN 37-139, Record Disposition Schedule has been replaced by the Air Force Records Disposition Schedule, which is available online at https://afrims.amc.af.mil/. 


\section{Appendix 6-6}

\section{Deleted}

AFMAN 37-139, Record Disposition Schedule has been replaced by the Air Force Records Disposition Schedule, which is available online at https://afrims.amc.af.mil/. 


\section{Appendix 6-7}

\section{Guidance for A-106 Compliance}

(NOTE: This was formerly Appendix 6-3; it was renumbered when checklist item O5.10.5.OCAF and its Appendixes were added in February 2002.)

Use the following list of questions to aid in determining whether the A-106 package has been completed correctly.

1. Is MAJCOM field correct?

2. Is the BASE field filled in?

3. Is the PROJECT number correct in accordance with CEV A-106 guidance letter?

4. Does the MODULE IND read PREV?

5. Is the TITLE one of the standard titles included in the call letter?

6. Is the Nature of the PROJECT I, E, or O? If it is E, is it fully justified? If it is $\mathrm{O}$, is it an O\&S project?

7. Is a BASE POC and a PHONE listed?

8. Is there an $\mathbf{N}$ on screen two?

9. Is the Pgm FY correct?

10. Does the PA amount match the PPPN?

11. Is the CWE entered in? For an initial entry, is it the same as the PA amount?

12. Is the fund type entered?

13. Is there an $\mathrm{N}$ in Multiple INST?

14. PGM Element for 3400, 3010, or 3020 money should be 78054. For 3600 money, it should be 65854 .

15. Is Assessment left blank?

16. Is the progress code only one of the following: (for an initial entry it should be either 1 or 9)

$1=$ project validated and funded

$2=$ funds have been obligated

$6=$ project canceled

$9=$ all $O \& S$

17. Is ownership type and statutory auth filled in?

18. Does design/plan have a year and month that the project will be RTA? Does it make sense (i.e., too late in the FY or already past)?

19. Is pollutant category entered only for O\&S projects? 
20. COMPL level is left blank for O\&S. For all other purposes, ensure the validated level is entered as follows: Level 1 - ESDP

Level $2=\mathrm{ESDF}$

Level 3 = ESDL

21. On Narrative Screen, does the narrative match the PPPN and is it complete? 


\section{Appendix 6-8}

\section{CPG Categories and Products and Recovered Materials Advisory Notice (RMAN)}

(40 CFR 247.2 through 40 CFR 247.17)

[Added September 2007]

The following is the current list of CPG categories and products:

- $\quad$ paper and paper products, excluding building and construction paper grades vehicular products:

o lubricating oils containing re-refined oil, including engine lubricating oils, hydraulic fluids, and gear oils, excluding marine and aviation oils

o tires, excluding airplane tires

o reclaimed engine coolants, excluding coolants used in non-vehicular applications

o rebuilt vehicular parts

- construction products:

0 building insulation products, including the following items:

- loose-fill insulation, including but not limited to cellulose fiber, mineral fibers (fiberglass and rock wool), vermiculite, and perlite

- blanket and batt insulation, including but not limited to mineral fibers (fiberglass and rock wool)

- board (sheathing, roof decking, wall panel) insulation, including but not limited to structural fiberboard and laminated paperboard products, perlite composite board, polyurethane, polyisocyanurate, polystyrene, phenolics, and composites

- $\quad$ spray-in-place insulation, including but not limited to foam-in-place polyurethane and polyisocyanurate, and spray-on cellulose

o structural fiberboard and laminated paperboard products for applications other than building insulation, including building board, sheathing, shingle backer, sound deadening board, roof insulating board, insulating wallboard, acoustical and non-acoustical ceiling tile, acoustical and non-acoustical lay-in panels, floor underlayments, and roof overlay (coverboard)

o cement and concrete, including concrete products such as pipe and block, containing coal fly ash or ground granulated blast furnace (GGBF) slag

o carpet made of polyester fiber for moderate end uses

o floor tiles and patio blocks containing recovered rubber or plastic

o shower and restroom dividers/partitions containing recovered plastic or steel

o consolidated latex paint used for covering graffiti

o reprocessed latex paint used for interior and exterior architectural applications such as wallboard, ceilings, and trim; gutter boards; and concrete, stucco, masonry, wood, and metal surfaces

o modular threshold ramps

o nonpressure pipe

o roofing materials

- transportation products:

o traffic barricades and traffic cones used in controlling or restricting vehicular traffic

o parking stops made from concrete or containing recovered plastic or rubber

o channelizers containing recovered plastic or rubber

o delineators containing recovered plastic, rubber, or steel

o flexible delineators containing recovered plastic

- $\quad$ park and recreation products: 
o playground surfaces and running tracks containing recovered rubber or plastic

o plastic fencing containing recovered plastic for use in controlling snow or sand drifting and as a warning/safety barrier in construction or other applications

o park benches and picnic tables containing recovered steel, aluminum, plastic, or concrete

o playground equipment containing recovered plastic, steel, or aluminum

o bike racks

- landscaping products:

o hydraulic mulch products containing recovered paper or recovered wood used for hydroseeding and as an over-spray for straw mulch in landscaping, erosion control, and soil reclamation

o compost made from yard trimmings, leaves, grass clippings, and/or food waste for use in landscaping, seeding of grass or other plants on roadsides and embankments, as a nutritious mulch under trees

o shrubs, and in erosion control and soil reclamation, garden and soaker hoses containing recovered plastic or rubber

o lawn and garden edging containing recovered plastic or rubber

o plastic lumber landscaping timbers and posts containing recovered materials

- non-paper office products:

o office recycling containers and office waste receptacles

o plastic desktop accessories

0 toner cartridges

o plastic-covered binders containing recovered plastic; chipboard and pressboard binders containing recovered paper; and solid plastic binders containing recovered plastic

o plastic trash bags

o printer ribbons

o plastic envelopes

o plastic clipboards containing recovered plastic

o plastic file folders containing recovered plastic

o plastic clip portfolios containing recovered plastic

o plastic presentation folders containing recovered plastic

o office furniture

- miscellaneous products:

o pallets containing recovered wood, plastic, or paperboard

o sorbents containing recovered materials for use in oil and solvent clean-ups and as animal bedding

o industrial drums containing recovered steel, plastic, or paper

o awards and plaques containing recovered glass, wood, paper, or plastic

o mats containing recovered rubber and/or plastic

o non-road signs containing recovered plastic or aluminum and road signs containing recovered aluminum

o sign supports and posts containing recovered plastic or steel

o manual-grade strapping containing recovered steel or plastic

o blasting grit.

(NOTE: The CPG guidelines do not apply to purchases of designated items that are unrelated to or incidental to Federal funding, i.e., not the direct result of a contract or agreement with, or a grant, loan, or funds disbursement to, a procuring agency. The guidelines also do not apply to purchases made by private party recipients [e.g., individuals, non-profit organizations] of Federal funds pursuant to grants, loans, cooperative agreements, and other funds disbursements.) 


\section{Recovered Materials Advisory Notice (RMAN)}

For each designated CPG, USEPA has issued an RMAN, which establishes the recommended recycle content level for a given product. See the following for examples of the RMANs for designated CPGs.

Recommended Recovered Materials Content Levels for CPG Products

(http://www.epa.gov/epaoswer/non-hw/procure/products.htm)

This is a selection of the recommended recovered materials content levels for CPG products. This Appendix does not contain the recommendations for all CPG products. See the above website for more information on product procurement.

Selected Non-Paper Office Products

USEPA's Recommended Recovered Materials Content Levels for Binders, Clipboards, File Folders, Clip Portfolios, and Presentation Folders ${ }^{1}$

\begin{tabular}{|c|c|c|c|}
\hline Item & Material & $\frac{\text { Postconsumer }}{\text { Content (\%) }}$ & Total $\underset{\text { Recovered Materials Content }}{(\%)}$ \\
\hline Binders & $\begin{array}{l}\text { Plastic-covered } \\
\text { Paper-covered } \\
\text { Pressboard } \\
\text { Solid plastic } \\
\underline{\text { HDPE }} \\
\underline{\text { PET }} \\
\underline{\text { Misc. plastics }}\end{array}$ & $\begin{array}{c}-- \\
75-100 \\
20 \\
90 \\
30-50 \\
100 \\
80\end{array}$ & $\begin{array}{c}25-50 \\
90-100 \\
50 \\
\\
90 \\
30-50 \\
100 \\
80\end{array}$ \\
\hline Plastic clipboards & $\begin{array}{l}\text { HDPE } \\
\frac{\text { PS }}{\text { Misc. plastics }}\end{array}$ & $\begin{array}{l}90 \\
50 \\
15\end{array}$ & $\begin{array}{c}90 \\
50 \\
15-80\end{array}$ \\
\hline Plastic file folders & HDPE & 90 & 90 \\
\hline Plastic clip portfolios & HDPE & 90 & 90 \\
\hline Plastic presentation folders & HDPE & 90 & 90 \\
\hline
\end{tabular}

1 USEPA's recommendations do not preclude a procuring agency from purchasing binders, clipboards, file folders, clip portfolios, or presentation folders made from another material. They simply require that procuring agencies, when purchasing these items made from the materials above, purchase them made from recovered materials when these items meet applicable specifications and performance requirements. 
USEPA's Recommended Recovered Materials Content Levels for Plastic Trash Bags ${ }^{1}$

\begin{tabular}{|c|c|c|}
\hline Product: & Material (\%): & Postconsumer Content (\%): \\
\hline Plastic Trash Bags & Plastic & $10-100$ \\
\hline
\end{tabular}

${ }^{1}$ USEPA's recommendation does not preclude procuring agencies from purchasing a trash bag manufactured using another material, such as paper. It merely recommends that procuring agencies, when purchasing plastic trash bags, purchase items made from recovered materials.

USEPA's Recommended Recovered Materials Content Levels for Office Recycling Containers and Office Waste Receptacles ${ }^{1}$

\begin{tabular}{|c|c|c|}
\hline Materials & Postconsumer Content (\%): & $\begin{array}{l}\text { Total Recovered Materials Content } \\
(\%):\end{array}$ \\
\hline Plastic & $20-100$ & -- \\
\hline Steel $^{2}$ & 16 & $25-30$ \\
\hline \multicolumn{3}{|l|}{ Paper } \\
\hline -Corrugated & $25-50$ & $25-50$ \\
\hline -Solid Fiber Boxes & 40 & -- \\
\hline -Industrial Paperboard & $40-80$ & 100 \\
\hline
\end{tabular}

${ }^{1}$ USEPA's recommendations do not preclude a procuring agency from purchasing containers or receptacles manufactured using another material such as wood. They simply require that procuring agencies, when purchasing office recycling containers or office waste receptacles manufactured from plastic, paper, or steel, purchase such containers made with recovered materials when they meet applicable specifications and performance requirements.

${ }^{2}$ The recommended recovered materials content levels for steel in this table reflect the fact that the designated items are made from steel manufactured in a Basic Oxygen Furnace (BOF). Steel from the BOF process contains 25-30\% total recovered materials, of which $16 \%$ is postconsumer steel.

\section{$\underline{\text { Selected Paper and Paper Products }}$}

EPA's Recommended Recovered Fiber Content Levels for Uncoated Printing and Writing Papers ${ }^{1}$

\begin{tabular}{|l|c||c||}
\hline \multicolumn{1}{|c|}{ Item } & $\frac{\text { Postconsumer Fiber }}{\mathbf{( \% ) :}}$ & Recovered Fiber (\%): \\
\hline $\begin{array}{l}\text { Reprographic Paper (e.g., mimeo and duplicator pa- } \\
\text { per, high-speed copier paper, and bond paper*) }\end{array}$ & 30 & 30 \\
\hline $\begin{array}{l}\text { Offset Paper (e.g., offset printing paper*, book pa- } \\
\text { per*, and bond paper*) }\end{array}$ & 30 & 30 \\
\hline $\begin{array}{l}\text { Tablet Paper (e.g., offset paper such as note pads, } \\
\text { stationery*, and other writing* papers) }\end{array}$ & 30 & 30 \\
\hline $\begin{array}{l}\text { Forms Bond (e.g., forms, computer printout paper, } \\
\text { and ledger*) }\end{array}$ & 30 & 30 \\
\hline Envelope Paper & 30 & 30 \\
\hline \hline
\end{tabular}




\begin{tabular}{|c|c|c|}
\hline Item & $\frac{\text { Postconsumer Fiber }}{(\%):}$ & Recovered Fiber (\%): \\
\hline $\begin{array}{l}\text { Wove } \\
\text { Kraft }\end{array}$ & $10-20$ & $10-20$ \\
\hline $\begin{array}{l}\text { - White and colored } \\
\text { (including manila) }\end{array}$ & 10 & 10 \\
\hline - Unbleached & & \\
\hline $\begin{array}{l}\text { Cotton Fiber Paper (e.g., cotton fiber papers, ledger*, } \\
\text { stationery* and matching envelopes, and other writ- } \\
\text { ing* papers) }\end{array}$ & 30 & 30 \\
\hline $\begin{array}{l}\text { Text \& Cover Paper (e.g., cover stock, book paper*, } \\
\text { stationery* and matching envelopes, and other writ- } \\
\text { ing* paper) }\end{array}$ & 30 & 30 \\
\hline Supercalendered & 10 & 10 \\
\hline Machine Finish Groundwood & 10 & 10 \\
\hline Papeteries & 30 & 30 \\
\hline Check Safety Paper & 10 & 10 \\
\hline
\end{tabular}

*These items can be made from a variety of printing and writing papers, depending on the performance characteristics of the item. Some of the papers are a commodity-type and some are specialty papers. USEPA recommends that procuring agencies determine the performance characteristics required of the paper prior to establishing minimum content standards. Bond, ledger, or stationery made from cotton fiber paper or a text \& cover paper, for example, have different characteristics than similar items made from commodity papers.

\section{EPA's Recommended Recovered Fiber Content Levels for Coated Printing and Writing Papers}

\begin{tabular}{|l||c||c||}
\hline \multicolumn{1}{|c|}{ Item } & $\frac{\text { Postconsumer Fiber }}{(\mathbf{\% ) :}}$ & $\frac{\text { Recovered Fiber (\%): }}{}$ \\
\hline Coated Printing Paper & 10 & 10 \\
\hline Carbonless & 30 & 30 \\
\hline
\end{tabular}

USEPA's Recommended Recovered Fiber Content Levels for Bristols

\begin{tabular}{||l||c||c|}
\hline \multicolumn{1}{|c||}{ Item } & $\frac{\text { Postconsumer Fiber }}{\mathbf{( \% ) :}}$ & Recovered Fiber (\%): \\
\hline File Folders (manila and colored) & 30 & 30 \\
\hline Dyed Filing Products & 20 & $20-50$ \\
\hline $\begin{array}{l}\text { Cards (index, postal, and other, including } \\
\text { index sheets) }\end{array}$ & 20 & 50 \\
\hline \hline
\end{tabular}




\begin{tabular}{|l||c||c|}
\hline & & \\
\hline Pressboard Report Covers and Binders & 20 & 50 \\
\hline Tags and Tickets & 20 & $20-50$ \\
\hline
\end{tabular}

NOTE: The content levels for all USEPA recommendations should be read as X\% recovered fiber, including $\mathrm{Y} \%$ postconsumer fiber and not as $\mathrm{X} \%$ recovered fiber plus Y\% postconsumer fiber.

\section{Selected Parks and Recreation Products}

EPA's Recommended Recovered Materials Content Levels for Playground Equipment ${ }^{1}$

\begin{tabular}{|c|c|c|}
\hline Material & $\frac{\text { Postconsumer Con- }}{\text { tent (\%) }}$ & $\begin{array}{l}\text { Total Recovered Materials Con- } \\
\text { tent (\%) }\end{array}$ \\
\hline Plastics² & $90-100$ & 100 \\
\hline Plastic composites & $50-75$ & $95-100$ \\
\hline Steel $^{3}$ & $\begin{array}{l}16 \\
67\end{array}$ & $\begin{array}{c}25-30 \\
100\end{array}$ \\
\hline Aluminum & 25 & 25 \\
\hline
\end{tabular}

${ }^{1}$ USEPA's recommendations do not preclude a procuring agency from purchasing playground equipment manufactured from other materials. They simply require that a procuring agency, when purchasing playground equipment made from plastic, steel, wood, or aluminum, purchase these items with recovered materials when those items meet applicable specifications and performance requirements.

2 "Plastics" includes both single and mixed plastic resins. Playground equipment made with recovered plastics may also contain other recovered materials such as wood or fiberglass. The percentage of these materials contained in the product would also count toward the recovered materials content level of the item.

${ }^{3}$ The recommended recovered materials content levels for steel in this table reflect the fact that the designated items can be made from steel manufactured in either a Basic Oxygen Furnace (BOF) or an Electric Arc Furnace (EAF). Steel from the BOF process contains $25-30 \%$ total recovered materials, of which $16 \%$ is postconsumer steel. Steel from the EAF process contains a total of $100 \%$ recovered steel, of which $67 \%$ is postconsumer.

\section{USEPA's Recommended Recovered Materials Content Levels for Fencing Containing Recovered Plastic ${ }^{1,2}$}

\begin{tabular}{||l||c||c|}
\hline \hline Material: & Postconsumer Content (\%): & Total Recovered Materials Con- \\
\hline tent (\%):
\end{tabular}

1 USEPA's recommendation does not preclude a procuring agency from purchasing fencing manufactured from another material, such as wood. It simply requires that a procuring agency, when purchasing plastic fencing, purchase this item made with recovered materials when this item meets applicable specifications and performance requirements.

${ }^{2}$ Designation includes fencing containing recovered plastic for use in controlling snow or sand drifting and as a warning/safety barrier in construction or other applications. 
Selected Landscaping Products

USEPA's Recommended Recovered Materials Content Levels for Plastic Lumber Landscaping Timbers and Posts ${ }^{1}$

\begin{tabular}{||l||c||c||}
\hline \multicolumn{1}{|c||}{ Material } & $\frac{\text { Postconsumer Content }}{\mathbf{( \% )}}$ & Total Recovered Materials Content (\%) \\
\hline \hline HDPE & $25-100$ & $75-100$ \\
\hline \hline Mixed plastics/Sawdust & 50 & 100 \\
\hline \hline HDPE/Fiberglass & 75 & 95 \\
\hline \hline Other mixed resins & $50-100$ & $95-100$ \\
\hline \hline
\end{tabular}

${ }^{1}$ USEPA's recommendations do not preclude a procuring agency from purchasing wooden landscaping timbers and posts. They simply require that procuring agencies, when purchasing plastic landscaping timbers and posts, purchase these items made with recovered materials when the items meet applicable specifications and performance requirements.

Selected Construction Products

USEPA's Recommended Recovered Materials Content Levels for Building Insulation ${ }^{1}$

\begin{tabular}{|c|c|c|c|}
\hline Product & Material & $\begin{array}{l}\text { Postconsumer } \\
\text { Content (\%) }\end{array}$ & Total Recovered Materials \\
\hline Rock Wool & Slag & -- & 75 \\
\hline Fiberglass & Glass Cullet & -- & $20-25$ \\
\hline Cellulose Loose-Fill and Spray-On & $\begin{array}{l}\text { Postconsumer } \\
\text { Paper }\end{array}$ & 75 & 75 \\
\hline Perlite Composite Board & $\begin{array}{l}\text { Postconsumer } \\
\text { Paper }\end{array}$ & 23 & 23 \\
\hline $\begin{array}{l}\text { Plastic Rigid Foam, Polyisocyanurate } \\
\text { Polyurethane: } \\
\text { Rigid Foam } \\
\text { Foam-in-Place } \\
\text { Glass Fiber Reinforced }\end{array}$ & $\begin{array}{l}-- \\
-- \\
--\end{array}$ & $\begin{array}{l}-- \\
-- \\
-\end{array}$ & $\begin{array}{l}9 \\
5 \\
6\end{array}$ \\
\hline Phenolic Rigid Foam & -- & -- & 5 \\
\hline Plastic, Non-Woven Batt & $\begin{array}{l}\text { Recovered and/or } \\
\text { Postconsumer }\end{array}$ & -- & 100 \\
\hline
\end{tabular}




\begin{tabular}{|l||l||l||}
\hline \hline & Plastics & \\
\hline \hline
\end{tabular}

${ }^{1}$ The recommended recovered materials content levels are based on the weight (not volume) of materials in the insulating core only.

USEPA's Recommended Recovered Materials Content Levels for Carpet ${ }^{1}$

\begin{tabular}{||l||c||c||c||}
\hline \multicolumn{1}{|c||}{ Product } & Material & $\frac{\text { Postconsumer }}{\text { Content }}$ & Total Recovered Materials \\
Content (\%)
\end{tabular}

${ }^{1}$ EPA recommends that, based on the recovered materials content levels shown in the table above, procuring agencies establish minimum content standards for use in purchasing polyester carpet for light- and moderate-wear applications. This recommendation does not include polyester carpet for use in heavy-wear or severe-wear applications; however, procuring agencies are encouraged to evaluate the suitability of polyester carpet in these applications. These recommendations do not preclude a procuring agency from purchasing carpet made of other materials such as nylon, wool, or polypropylene.

USEPA's Recommended Recovered Materials Content Levels for Carpet Cushion ${ }^{1}$

\begin{tabular}{|c|c|c|c|}
\hline Product & Material & $\frac{\text { Postconsumer }}{\text { Content (\%) }}$ & $\begin{array}{c}\text { Total } \frac{\text { Recovered Materials }}{\text { Content (\%) }} \\
\end{array}$ \\
\hline Bonded polyurethane & $\begin{array}{l}\text { Old carpet } \\
\text { cushion }\end{array}$ & $15-50$ & $15-50$ \\
\hline Jute & Burlap & 40 & 40 \\
\hline Synthetic fibers & \begin{tabular}{|c|} 
Carpet fabrica- \\
tion \\
scrap \\
\end{tabular} & -- & 100 \\
\hline Rubber & Tire rubber & $60-90$ & $60-90$ \\
\hline
\end{tabular}

${ }^{1}$ EPA's recommendations do not preclude a procuring agency from purchasing another type of carpet cushion. They simply require that procuring agencies, when purchasing bonded polyurethane, jute, synthetic fiber, or rubber carpet cushions, purchase these items made with recovered materials when these items meet applicable specifications and performance requirement. Refer to Section C-4 in RMAN I for USEPA's recommendations for purchasing polyester carpet containing recovered materials. 


\section{USEPA's Recommended Recovered Materials Content Levels for Reprocessed and Consolidated Latex Paints ${ }^{1}$}

\begin{tabular}{||c||c||c||}
\hline \multicolumn{1}{|c||}{ Product } & $\frac{\text { Postconsumer }}{\text { Content (\%) }}$ & Total Recovered Materials \\
\hline $\begin{array}{l}\text { Content (\%) } \\
\text { Reprocessed Latex Paint } \\
\text { - } \begin{array}{l}\text { White, Off-White, Pas- } \\
\text { tel Colors }\end{array}\end{array}$ & 20 \\
$\begin{array}{l}\text { Grey, Brown, Earth- } \\
\text { tones, and Other Dark } \\
\text { Colors }\end{array}$ & $50-99$ & 20 \\
\hline Consolidated Latex Paint & 100 & $50-99$ \\
\hline \hline
\end{tabular}

${ }^{1}$ USEPA's recommendations apply to reprocessed latex paints used for interior and exterior architectural applications such as wallboard, ceilings, and trim; gutter boards; and concrete, stucco, masonry, wood, and metal surfaces, and to consolidated latex paints used for covering graffiti, where color and consistency of performance are not primary concerns.

\section{EPA's Recommended Recovered Materials Content Levels for Shower and Restroom Dividers/Partitions Containing Recovered Plastic or Steel ${ }^{1}$}

\begin{tabular}{||l||c|c||}
\hline \multicolumn{1}{|c|}{ Material } & $\frac{\text { Postconsumer }}{\text { Content }}$ & Total Recovered Materials Content (\%) \\
\hline Steel $^{2}$ & 16 & $25-30$ \\
& 67 & 100 \\
\hline Plastic & $20-100$ & $20-100$ \\
\hline
\end{tabular}

${ }^{1}$ USEPA's recommendations do not preclude an agency from purchasing shower and restroom dividers/partitions manufactured from another material such as wood. they simply require that procuring agencies, when purchasing shower and restroom dividers/partitions made from plastic or steel, purchase these items made from recovered materials when they meet applicable specifications and performance requirements.

${ }^{2}$ The recommended recovered materials content levels for steel in this table reflect the fact that the designated items can be made from steel manufactured in either a Basic Oxygen Furnace (BOF) or an Electric Arc Furnace (EAF). Steel from the BOF process contains $25-30 \%$ total recovered materials, of which $16 \%$ is postconsumer steel. Steel from the EAF process contains a total of $100 \%$ recovered steel, of which $67 \%$ is postconsumer. 


\section{Selected Transportation Products}

\section{USEPA's Recommended Recovered Materials Content Levels for Parking Stops Made from Concrete or Containing Recovered Plastic or Rubber ${ }^{1}{ }^{2}$}

\begin{tabular}{|c|c|c|}
\hline Material & Postconsumer Content (\%) & \begin{tabular}{|c|} 
Total Recovered Materials Con- \\
tent $(\%)$
\end{tabular} \\
\hline Plastic and/or Rubber ${ }^{3}$ & 100 & \begin{tabular}{|l|l}
- \\
-
\end{tabular} \\
\hline $\begin{array}{l}\text { Concrete Containing Coal Fly } \\
\text { Ash }\end{array}$ & -- & $20-40^{4}$ \\
\hline $\begin{array}{l}\text { Concrete Containing Ground } \\
\text { Granulated Blast Furnace } \\
\underline{\text { Slag (GGBF) }}\end{array}$ & -- & $25-70$ \\
\hline
\end{tabular}

${ }^{1}$ USEPA's recommendation does not preclude a procuring agency from purchasing parking stops manufactured from another material. It simply requires that a procuring agency, when purchasing concrete parking stops or parking stops made with plastic or rubber, purchase these items made with recovered materials when these items meet applicable specifications and performance requirements.

2 Transportation products containing recovered materials must conform to the Manual on Uniform Highway Traffic Control Devices used by the Federal Highway Administration, as well as other applicable federal requirements and specifications.

${ }^{3}$ Parking stops made with recovered plastics may also include other recovered materials such as sawdust, wood, or fiberglass. The percentage of these materials contained in the product would also count toward the recovered materials content level of the parking stops.

${ }^{4}$ Generally, 20 to 30 percent, but could be up to 40 percent. Fifteen percent when used as a partial cement replacement as an admixture in concrete.

EPA's Recommended Recovered Materials Content Levels for Traffic Cones ${ }^{1}$

\begin{tabular}{||l||c|c|}
\hline \multicolumn{1}{||c||}{ Material } & Postconsumer Materials (\%): & Total Recovered Materials Con- \\
tent (\%)
\end{tabular}

${ }^{1}$ Transportation products containing recovered materials must conform to the Manual on Uniform Traffic Devices used by the Federal Highway Administration, as well as other applicable federal requirements and specifications.

${ }^{2}$ The recommended recovered materials content levels are based on the dry weight of the raw materials, exclusive of any additives such as adhesives, binders, or coloring agents. 


\section{Selected Vehicular Products}

\section{Recommended Recovered Materials Content Ranges For Engine Coolant:}

USEPA recommends that procuring agencies whose vehicles are serviced by a motor pool or vehicle maintenance facility establish a program for engine coolant reclamation and reuse that consists of either reclaiming the spent engine coolants onsite for use in the agencies' vehicles or establishing a service contract for reclamation of the agencies' spent engine coolant for use in the agencies' vehicles.

USEPA also recommends that procuring agencies request reclaimed engine coolant when having their vehicles serviced at commercial service centers. Additionally, USEPA recommends that agencies purchase reclaimed engine coolant when making direct purchases of this item, such as when necessary to make up for losses due to leakage or spillage.

- USEPA does not recommend one type of engine coolant over another. USEPA recommends, however, that procuring agencies purchase engine coolant containing only one base chemical, typically ethylene glycol or propylene glycol, to prevent the commingling of incompatible types of engine coolant

\section{Recommended Recovered Materials Content Ranges for Re-refined Lubricating Oils:}

USEPA recommends that procuring agencies set their minimum re-refined oil content standard at the highest level of re-refined oil that they determine meets the statutory requirements of RCRA section 6002(c)(1), but no lower than 25 percent re-refined oil.

USEPA recommends that procuring agencies review their procurement practices and eliminate those that would inhibit or preclude procurement of lubricating oils containing re-refined oil. For example, procuring agencies should review the practices of inviting bids and issuing contracts to do the following:

- Supply a broad range of lubricating oil products on an "all or none" basis.

- Supply lubricating oils for an excessively long period of time.

- Deliver lubricating oils to geographic locations throughout the United States or to an excessively broad geographic area.

- Supply excessively large contract quantities.

\section{Selected Miscellaneous Products}

EPA's Recommended Recovered Materials Content Levels for Awards and Plaques ${ }^{1}$

\begin{tabular}{||l||c||c||}
\hline \multicolumn{1}{|c||}{ Material } & Postconsumer Content (\%) & Total Recovered Materials Content (\%) \\
\hline Glass & $75-100$ & 100 \\
\hline Wood & -- & 100 \\
\hline Paper & $40-100$ & $40-100$ \\
\hline $\begin{array}{l}\text { Plastic and Plastic/ } \\
\text { Wood Composite }\end{array}$ & $50-100$ & $95-100$ \\
\hline \hline
\end{tabular}

${ }^{1}$ USEPA's recommendations do not preclude a procuring agency from purchasing awards and plaques manufactured from other materials. They simply require that a procuring agency, when purchasing glass, wood, paper, or plastic awards or plaques, purchase these items containing recovered materials when the item meets applicable specifications and performance requirements. 


\section{USEPA's Recommended Recovered Materials Content Levels for Sorbents Used in Oil and Solvents Cleanups and for Use as Animal Bedding ${ }^{1}$}

\begin{tabular}{||l||c||c||}
\hline \multicolumn{1}{|c||}{ Material } & $\frac{\text { Postconsumer Content }}{\mathbf{( \% )}}$ & $\begin{array}{c}\text { Total Recovered Materials Content } \\
\text { (\%) }\end{array}$ \\
\hline \hline Paper & $90-100$ & 100 \\
\hline \hline Textiles & $95-100$ & $95-100$ \\
\hline \hline Plastics & -- & $25-100$ \\
\hline Wood $^{2}$ & -- & 100 \\
\hline Other Organics/Multi-Materials & & 100 \\
\hline \hline
\end{tabular}

${ }^{1}$ USEPA's recommendations do not preclude a procuring agency from purchasing sorbents made from other materials. They simply require that a procuring agency, when purchasing sorbents made from paper, wood, textiles, plastic, or other organic materials, purchase them made with recovered materials when these items meet applicable specifications and performance requirements.

2 "Wood" includes materials such as sawdust and lumber mill trimmings.

${ }^{3}$ Examples of other organics include, but are not limited to, peanut hulls and corn stover. An example of multimaterial sorbents would include, but not be limited to, a polymer and cellulose fiber combination. 


\title{
SECTION 7
}

\section{PESTICIDE MANAGEMENT}

\section{Overseas ESOHCAMP}

\author{
September 2009
}

\section{A. Service-specific Regulations and Policies}

- Air Force Instruction (AFI) 32-1053, Pest Management Program, 23 June 2009, provides guidance for pest management at Air Force (AF) installations. For installations outside the United States and its territories, compliance requirements within the Overseas Environmental Baseline Guidance Document (OEBGD) or the Final Governing Standards (FGS) for the host country take precedence over AFI 32-1053.

- AFI 32-1074, Aerial Application of Pesticides, 27 August 2009, provides guidance for aerial application of pesticides on Department of Defense (DOD) installations or utilizing Air Force assets. For installations outside the United States and its territories, compliance requirements within the Overseas Environmental Baseline Guidance Document (OEBGD) or the final governing standard (FGS) for the host country take precedence over AFI 321074.

- Air Force Self-Help Pest Management Program for Military Housing (MH) Occupants and Building Managers, Headquarters (HQ) AFCESA/CES, 28 September 1998, provides guidance on self-help pest management programs. Its guidance expands the self-help program beyond occupants of $\mathrm{MH}$ to include other installation facilities that are under control of a building manager.

\section{B. DOD Directives and Instructions}

- Department of Defense Instruction (DODI) 4150.07, Department of Defense Pest Management Program, dated 29 May 2008, establishes the Department of Defense (DOD) policies of using integrated pest management (IPM) techniques in carrying out pest management activities and promoting IPM through procurement and regulatory policies, and other activities; using IPM to prevent or control pests and disease vectors that may adversely impact readiness or military operations by affecting the health of personnel, or by damaging structures, materiel, or property; and incorporating sustainable IPM philosophy, strategies, and techniques in all aspects of DOD vector control and pest management planning, training, and operations, including in installation pest management plans and other written guidance, to reduce pesticide risk and prevent pollution. Outside the continental United States, DODI 4150.07 applies where consistent with applicable international agreements, status of forces agreements, Final Governing Standards (FGS) issued for the host nations, or, where no such FGS have been issued, the criteria in the Overseas Environmental Baseline Guidance Document (see DODI 4150.07, para 2.6).

- DOD 4145.19-R-1, Storage and Materials Handling, September 1979. Chapter 5, Section 4 of this regulation provides overall guidance for storage and handling of various hazardous commodities.

- Armed Forces Pest Management Board Technical Guide No. 45, Storage and Display of Retail Pesticides, dated November 2006, is to provide basic information on storage and display of retail pesticides to ensure the safety of employees and customers, protect the environment, and conserve DOD funds.

- Technical Information Memoranda (TIM) supplement DODI 4150.07. They provide specific criteria and procedures for the operation of a pest management program, but they contain guidance only and are not regulatory in nature. It is appropriate to have the following TIM on hand:

TIM 13 - Ultra Low Volume Dispersal of Insecticides by Ground Equipment (March 1985)

TIM 14 - Personal Protective Equipment for Pest Management Personnel (March 1992)

TIM 15 - Pesticide Spill Prevention and Management (June 1992) 
TIM 16 - Pesticide Fires: Prevention, Control, and Cleanup (June 1981)

TIM 18 - Installation Pest Management Program Guide (February 1987)

TIM 20 - Pest Management Operations in Medical Treatment Facilities (October 1989)

TIM 21 - Pesticide Disposal Guide for Pest Control Shops (October 1986)

TIM 24 - Contingency Pest Management Pocket Guide (September 1991)

TIM 25 - Devices for Electrocution of Flying Insects (August 1988)

TIM 26 - Lyme Disease - Vector Surveillance and Control (March 1990)

TIM 27 - Stored Products Pest Monitoring Techniques (June 1992)

TIM 29 - Integrated Pest Management In and Around Buildings (July 1994).

\section{Service-specific/DOD Definitions}

- Aerial Application of Pesticides - any application of pesticides by military or civilian, fixed or rotary-wing aircraft (AFI 32-1074, Attachment 1).

- Aerial Application of Pesticide Mission - the actual aerial application of a pesticide over an approved area (AFI 32-1074, Attachment 1).

- Aerial Application of Pesticide Project Statement of Need - a document prepared by a Pest Management Professional (PMP) with certification in DOD Category 11, Aerial Application. If this document states that the proposed project is justified, preparation of an environmental assessment or environmental impact statement is initiated and prepared as required by the MAJCOM (AFI 32-1074, Attachment 1).

- Approved Aerial Application of Pesticides Projects - a proposed project that has received written approval from a DOD Category 11, Aerial Application, Certified PMP at the requester's MAJCOM or higher command in accordance with DODI 4150.07. This PMP approval is only provided after reviewing the Project's Aerial Application of Pesticides Statement of Need and appropriate environmental documentation (AFI 32-1074, Attachment 1).

- Certified DOD Pesticide Dispersal Equipment Trainer - a certified DOD pesticide applicator authorized by a Military Service training center to provide hands-on pesticide dispersal equipment training in partial fulfillment of DOD pesticide applicator recertification competency requirements (DODI 4150.07, para E2.1).

- Certified Pesticide Applicator - any individual who applies pesticides or, in the case of DOD employees, supervises the use of pesticides during apprenticeship training. A certified applicator has successfully completed an EPA-approved training program that includes written examinations in core and specific application categories. Certification may be by the DOD, a State, or for OCONUS by the provisions of DODI 4150.07, para 2.5 (DODI 4150.07, para E2.16.1).

- Contractor Applicator - a contract employee, certified by a State or host nation, who applies pesticides on DOD installations and property. The contractor shall be required to provide evidence of certification of applicators in all appropriate pest management categories for which the work is to be done at the time the contract is let (DODI 4150.07, para E2.16.3).

- Direct Supervision - supervision that includes being at the specific location where pesticide application is conducted; providing instruction and control; and maintaining a line-of-sight view of the work performed. Certain circumstances may temporarily remove the line-of-sight view. Under these temporary circumstances, the supervisor shall be responsible for the actions of the pesticide applicators. Direct supervision is permitted only for DOD applicators who are in training; it is not permitted for contractor applicators (DODI 4150.07, para E2.3).

For the purposes of AFI 32-1053, supervision that includes being at the specific location where pest management work is conducted; providing instruction and control; and maintaining a line-of-sight view of the work performed. Certain circumstances may temporarily remove the line-of-sight view of the application of pesticide from the supervisor, such as topographic constraints, vegetation constraints, or building structural constraints. Under 
these temporary circumstances, the supervisor shall be responsible for the actions of the pesticide applicator (AFI 32-1053, Attachment 1).

- Disease Vector - any animal capable of transmitting the causative agent of a human disease; serving as an intermediate or reservoir host of a pathogenic organism; or producing human discomfort or injury, including (but not limited to) mosquitoes, flies, ticks, mites, snails, and rodents (DODI 4150.07, para E2.4).

For the purposes of AFI 32-1053, any animal capable of transmitting the causative agent of a human disease; serving as an intermediate or reservoir host of a pathogenic organism; or producing human discomfort or injury, including (but not limited to) mosquitoes, flies, other insects, ticks, mites, snails, and rodents (AFI 32-1053, Attachment 1).

- Disinsection - the procedure of killing or removing insects from ships or aircraft to prevent their importation into another port or country (DODI 4150.07, para E2.5).

- DOD Employee - Federal employees of the DOD, to include title 5, U.S.C. civilians, Active Duty military members, Active Guard Reserve (AGR) military members, National Guard and Reserve military members while on unit training assemblies, and Federal technicians. This term does not include employees involved in civil work functions of the Army Corps of Engineers, National Guard military members who are not on AGR (i.e., do not perform 180 days of continuous active service), or state civilians for whom the Federal government pays salaries through cooperative agreements (DODI 4150.07, para E2.6).

- DOD Property - a DOD installation, site, or activity on property that is under control of the DOD by ownership, permit, lease, license, or other land or facility-use agreement (DODI 4150.07, para E2.8).

- DOD-Certified Pesticide Applicator - DOD military or civilian personnel certified in accordance with (IAW) the DOD Plan for the Certification of Pesticide Applicators of Restricted-Use Pesticides, 30 September 1996 or IAW DOD 4150.07-M, DOD Pest Management Training and Certification, 24 April 1997, who applies pesticides on DOD installations and property (DODI 4150.07, para E2.16.2).

- Installation IPM Coordinator - a DOD employee or contractor officially designated by the installation commander (IC) to coordinate and oversee the installation IPM program (DODI 4150.07, para E2.11).

(NOTE: This term is understood to be synonymous with 'installation pest control coordinator/supervisor (IPMC),' in AFI 32-1053, q.v.)

- Installation Pest Management Coordinator (IPMC) - installation pest management supervisor or natural resources manager for the installation that is designated by the installation civil engineer (in accordance with MAJCOM guidance) to serve as the IPMC with responsibility for developing and updating the installation pest management plan. The IPMC will also review installation pest management contracts and the monthly pesticide use (active ingredient) reports submitted to the MAJCOM PMC. Pesticide chemical requests will be provided to the IPMC for review to ensure compliance with hazardous materials management (AFI 32-1053, Attachment 1).

- Integrated Natural Resources Management Plan (INRMP) - a plan based on ecosystem management that describes and delineates the interrelationships of the individual natural resources elements in concert with the mission and land use activities affecting the basic land management plans; defines the natural resources elements and the activities required to implement stated goals and objectives for those resources (AFI 32-1053, Attachment 1).

- Integrated Pest Management (IPM) - for the purposes of DODI 4150.07, a sustainable approach to managing pests by combining biological, cultural, physical, and chemical tools in a way that minimizes economic, health, and environmental risks (DODI 4150.07, para E2.9)

For the purposes of AFI 32-1053, a planned program incorporating continuous monitoring, education, record keeping, and communication to prevent pests and disease vectors from causing unacceptable damage to operations, people, property, materiel, or the environment. IPM includes methods such as habitat modification, biological control, genetic control, cultural methods, mechanical control, physical control, regulatory control, and 
cal control, genetic control, cultural methods, mechanical control, physical control, regulatory control, and the judicious use of least-hazardous pesticides (AFI 32-1053, Attachment 1).

- IPM Plan - a long-range, well-defined planning and operational document that describes the IPM program. Written pest management plans are required as a means of establishing and implementing IPM (DODI 4150.07, para E2.10).

- Invasive Species - a nonnative species whose introduction does or is likely to cause economic harm or harm to human health (DODI 4150.07, para E2.12).

For the purposes of AFI 32-1053, an alien species whose introduction does or is likely to cause economic or environmental harm or harm to human health (Executive Order 13112) (AFI 32-1053, Attachment 1).

- Management Practice (MP) - practices that, although not mandated by law, are encouraged to promote safe operating procedures.

- Monitoring - thorough inspections or surveys conducted on a regular basis to determine the presence and abundance of pests or disease vectors (DODI 4150.07, para E2.13).

- Nuisance Pests - insects, other arthropods, and other organisms that do not cause economic damage or adversely affect human health but that cause annoyance (DODI 4150.07, para E2.14).

- Nuisance Wildlife - wildlife that damages property, impedes installation operations, or endangers public health and safety to the point where control measures are required. This category excludes wildlife species protected by the Endangered Species Act or Migratory Bird Treaty Act. All wildlife control efforts should be conducted in accordance with AFI 32-7064 and appropriate regulatory authorities (AFI 32-1053, Attachment 1).

- Personal Relief - pest control efforts made by DOD personnel or their family members at their own expense for control of pests consistent with DOD and Military Service pest management policy (DODI 4150.07, para E2.15).

- Pest Management - the prevention and control of disease vectors and pests that may adversely affect the DOD mission or military operations; the health and well-being of people; or structures, materiel, or property (DODI 4150.07, para E2.17).

- Pest Management Consultant - a DOD employee pest management professional who provides technical and management guidance on using IPM to prevent and control pests and disease vectors. The AFPMB Director approves some pest management consultants as certifying officials of pesticide applicators (DODI 4150.07, para E2.18).

For the purposes of AFI 32-1074, DOD PMPs located at Component headquarters, FOAs, MAJCOMs, facilities engineering field divisions, or activities, or area support activities, who provide technical and management guidance for the conduct of installation pest management operations. Some PMCs may be designated by their Component as certifying officials (AFI 32-1074, Attachment 1).

- Pest Management Materiel - equipment or pesticides used to monitor, prevent, or control pests and disease vectors. Equipment items include, but are not limited to, all pesticide dispersal equipment, traps, nets, and pestattracting or pest-repelling devices (DODI 4150.07, para E2.19).

- Pest Management Professional (PMP) - a DOD military officer commissioned in the Medical Service or Biomedical Sciences Corps or DOD civilian employee with a college degree in biological, physical, or agricultural sciences whose current job includes pest management responsibilities. A DOD civilian employee must also meet Office of Personnel Management qualification standards. Based on assignment, some pest management professionals are pest management consultants (DODI 4150.07, para E2.20). 
For the purposes of AFI 32-1074, DOD military officers commissioned in the Medical Service or Biomedical Sciences Corps or DOD civilian personnel with college degrees in biological or agricultural sciences who are in a current assignment that includes pest management responsibilities exercised regularly. DOD civilian employees also shall meet Office of Personnel Management (OPM) qualification standards. Based on assignment, some PMPs are PMCs (AFI 32-1074, Attachment 1).

- Pest Management Quality Assurance Evaluator (PMQAE) or Pest Management Performance Assessment Representative (PMPAR) - a DOD employee trained in pest management at DOD sponsored courses, who protects the government's interest through on-site performance evaluation of commercial pest management contracts or other contracts that involve the use of pesticides (DODI 4150.07, para E2.21).

- Pesticide - any substance or mixture of substances, including biological control agents, that may prevent, destroy, repel, or mitigate pests and is specifically labeled for use by the EPA. Also, any substance or mixture of substances used as a plant regulator, defoliant, desiccant, disinfectant, or biocide. The AFPMB does not review or approve disinfectants or biocides (DODI 4150.07, para E2.16).

- Pests - arthropods, birds, rodents, nematodes, fungi, bacteria, viruses, algae, snails, marine borers, snakes, weeds, or other organisms (except for human or animal disease-causing organisms) that adversely affect readiness, military operations, or the well-being of personnel and animals; attack or damage real property, supplies, equipment, or vegetation; or are otherwise undesirable (DODI 4150.07, para E2.22 and AFI 32-1053, Attachment 1).

- Quality Assurance Evaluator (QAE) - a quality assurance inspector who is an Air Force employee, trained in pest management, who protects the government's interest through on-site performance evaluation of commercial pest management contracts or other contracts that involve the use of pesticides (AFI 32-1053, Attachment 1).

- Surveillance - thorough inspections or surveys made before or after pest management treatments to determine the presence and abundance of pests or disease vectors (DODI 4150.07, para E2.25).

- Technical Guides - guides (formerly called Technical Information Memoranda) prepared by the AFPMB on specific pest management and disease vector control topics. Technical Guides are available on the AFPMB web site, http://www.afpmb.org (DODI 4150.07, para E2.26).

- Training - formal or informal instruction in one or more subject areas of IPM and disease vector control to increase the expertise and measurable competence of pest management personnel in performance of specific IPM and disease vector control skills. Training methods include workshops, seminars, conferences, symposia, training courses, apprenticeships, interactive models, distance learning including satellite and video tele-training, correspondence courses, training support packages including video-based products, and other distributive learning products or materials (DODI 4150.07, para E2.27).

- Uncertified DOD Applicator - a DOD employee who is not certified and can only apply pesticides under the direct supervision of a DOD-certified applicator during an apprenticeship period not exceeding $2 \mathrm{yr}$ (DODI 4150.07, para E2.16.4).

\section{Additional Records to Review}

- Self-help program records

- Pesticide ordering documents

- DD Forms 1532, Pest Management Report

\section{E. Additional Physical Features to Inspect}

- Pest management vehicles 


\section{F. Guidance for Checklist Users}

REFER TO CHECKLIST ITEMS:

Missing Checklist Items/Positive Findings

General

Pesticide Application

Documentation and Notification

Storing, Mixing, or Preparation of Pesticides

Storage and Display of Retail Pesticides

Disposal
PM.2.1.OCAF and PM.2.2.OCAF

PM.10.1.OCAF through PM.10.39.OCAF

PM.20.1.OCAF through PM.20.23.OCAF

PM.30.1.OCAF through PM.30.8.OCAF

PM.50.1.OCAF through PM.50.6.OCAF

PM.53.1.OCAF through PM.53.48.OCAF

PM.60.1.OCAF and PM.60.2.OCAF 


\begin{tabular}{|c|c|}
\hline \multicolumn{2}{|r|}{$\begin{array}{c}\text { COMPLIANCE CATEGORY: } \\
\text { PESTICIDE MANAGEMENT } \\
\text { Overseas ESOHCAMP }\end{array}$} \\
\hline $\begin{array}{l}\text { REGULATORY } \\
\text { REQUIREMENTS: }\end{array}$ & $\begin{array}{l}\text { REVIEWER CHECKS: } \\
\text { September } 2009\end{array}$ \\
\hline $\begin{array}{l}\text { PM.2 } \\
\text { MISSING CHECKLIST } \\
\text { ITEMS/POSITIVE } \\
\text { FINDINGS }\end{array}$ & \\
\hline $\begin{array}{l}\text { PM.2.1.OCAF. Installations } \\
\text { must comply with all applica- } \\
\text { ble regulatory requirements } \\
\text { not contained in this checklist } \\
\text { (a finding under this checklist } \\
\text { item will have the citation of } \\
\text { the applied regulation as a } \\
\text { basis of finding) [Added } \\
\text { March 2002]. }\end{array}$ & $\begin{array}{l}\text { Determine whether any new regulations concerning pesticide management have } \\
\text { been issued since the finalization of the manual. } \\
\text { Determine whether the installation has activities or facilities that are regulated but } \\
\text { not addressed in this checklist. } \\
\text { Verify that the installation is in compliance with all applicable and newly issued } \\
\text { regulations. }\end{array}$ \\
\hline $\begin{array}{l}\text { PM.2.2.OCAF. Installations } \\
\text { should go above and beyond } \\
\text { environmental statutory and } \\
\text { regulatory compliance (MP) } \\
\text { [Added March 2002]. }\end{array}$ & $\begin{array}{l}\text { Determine whether the installation has gone above and beyond simply complying } \\
\text { with environmental requirements. } \\
\text { (NOTE: This checklist item is used only to write positive findings.) }\end{array}$ \\
\hline
\end{tabular}




\begin{tabular}{|c|c|}
\hline & $\begin{array}{c}\text { COMPLIANCE CATEGORY: } \\
\text { PESTICIDE MANAGEMENT } \\
\text { Overseas ESOHCAMP }\end{array}$ \\
\hline $\begin{array}{l}\text { REGULATORY } \\
\text { REQUIREMENTS: }\end{array}$ & $\begin{array}{l}\text { REVIEWER CHECKS: } \\
\text { September } 2009\end{array}$ \\
\hline $\begin{array}{l}\text { PM.10 } \\
\text { GENERAL } \\
\text { PM.10.1.OCAF. Every pest } \\
\text { control management should } \\
\text { have AFI 32-1053, certain } \\
\text { other publications, and access } \\
\text { to specific websites (MP) } \\
\text { [Revised May 1999; Revised } \\
\text { September 2009]. }\end{array}$ & 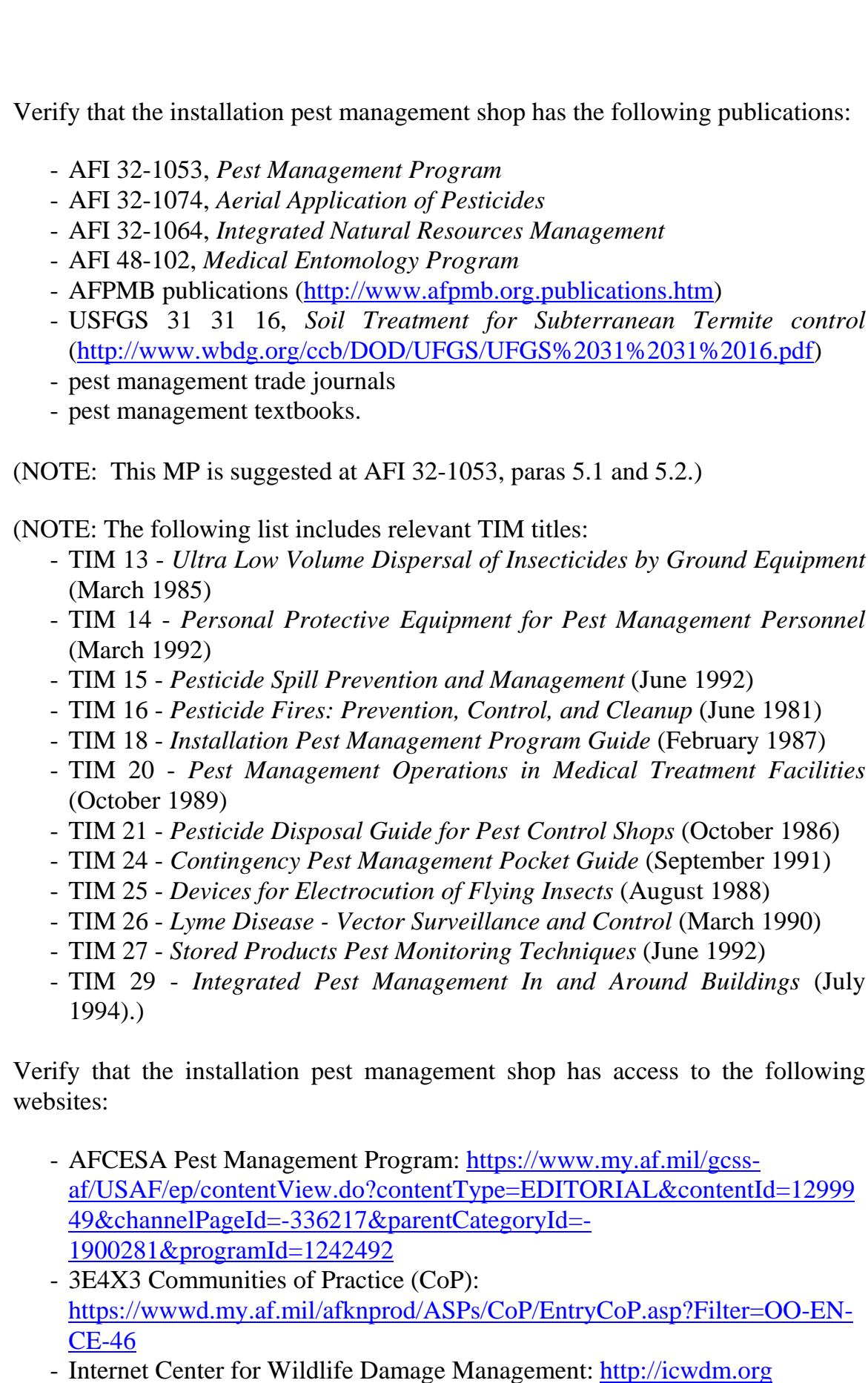 \\
\hline
\end{tabular}




\begin{tabular}{|c|c|}
\hline \multicolumn{2}{|r|}{$\begin{array}{l}\text { COMPLIANCE CATEGORY: } \\
\text { PESTICIDE MANAGEMENT } \\
\text { Overseas ESOHCAMP }\end{array}$} \\
\hline $\begin{array}{l}\text { REGULATORY } \\
\text { REQUIREMENTS: }\end{array}$ & $\begin{array}{l}\text { REVIEWER CHECKS: } \\
\text { September } 2009\end{array}$ \\
\hline $\begin{array}{l}\text { PM.10.2.OCAF. [Moved } \\
\text { March 2002]. }\end{array}$ & $\begin{array}{l}\text { - Integrated Pest Management Information System (IPMIS): } \\
\text { http://www.envirosoftinc.com/ipmis.html } \\
\text { - DOD Forms: } \\
\text { http://www.dtic.mil/whs/directives/infomgt/forms/formsprogram.htm. } \\
\text { Moved to PM.2.1.OCAF. }\end{array}$ \\
\hline $\begin{array}{l}\text { PM.10.3.OCAF. Installations } \\
\text { must meet requirements con- } \\
\text { tained in MAJCOM supple- } \\
\text { ments to AFIs and policy } \\
\text { documents (a finding under } \\
\text { this checklist item will have } \\
\text { the citation of the MAJCOM } \\
\text { document as a basis of find- } \\
\text { ing). }\end{array}$ & $\begin{array}{l}\text { Determine whether the requirements in MAJCOM supplements to AFIs and pol- } \\
\text { icy documents are within the scope of the environmental compliance assessment. } \\
\text { Verify that the installation is in compliance with MAJCOM requirements. }\end{array}$ \\
\hline $\begin{array}{l}\text { PM.10.4.OCAF. [Moved } \\
\text { March 2002]. }\end{array}$ & Moved to PM.2.2.OCAF. \\
\hline $\begin{array}{l}\text { PM.10.5.OCAF. [Moved } \\
\text { June 2003]. }\end{array}$ & [Moved to PM.30.6.OCAF] \\
\hline $\begin{array}{l}\text { PM.10.6.OCAF. [Moved } \\
\text { June 2003]. }\end{array}$ & [Moved to PM.30.7.OCAF] \\
\hline $\begin{array}{l}\text { PM.10.7.OCAF. The IPM } \\
\text { coordinator must have the } \\
\text { educational background and } \\
\text { the management skills neces- } \\
\text { sary to implement and oversee } \\
\text { the installation's pest man- } \\
\text { agement program (DODI } \\
\text { 4150.07, para E4.4.1) [Re- } \\
\text { vised July 2008; Citation Re- } \\
\text { vised July 2008]. }\end{array}$ & $\begin{array}{l}\text { Verify that the IPM coordinator has the educational background and the manage- } \\
\text { ment skills necessary to implement and oversee the installation's pest manage- } \\
\text { ment program. }\end{array}$ \\
\hline $\begin{array}{l}\text { PM.10.8.OCAF. Installations } \\
\text { must meet specified measures } \\
\text { of merit in the pest manage- } \\
\text { ment program (DODI } \\
4150.07 \text {, paras E3.1 through } \\
\text { E3.3) [Revised July 2008; } \\
\text { Citation Revised July 2008]. }\end{array}$ & $\begin{array}{l}\text { Verify that the installation meets the following measures of merit: } \\
\text { - Measure of Merit 1: through the end of FY 2010, the installation has and } \\
\text { maintains an IPM plan that has been reviewed and approved by a DOD- } \\
\text { certified pest management consultant and annually updated by the installa- } \\
\text { tion pest management coordinator } \\
\text { - Measure of Merit 2: through the end of FY 2010, maintains the reduction } \\
\text { goal in annual pesticide use by both government and contractor pesticide ap- } \\
\text { plicators } \\
\text { (NOTE: This reduction goal is set at an average of the FY } 2002 \text { and } 2003\end{array}$ \\
\hline
\end{tabular}




\section{COMPLIANCE CATEGORY: PESTICIDE MANAGEMENT Overseas ESOHCAMP}

\begin{tabular}{|c|c|}
\hline $\begin{array}{l}\text { REGULATORY } \\
\text { REQUIREMENTS: }\end{array}$ & $\begin{array}{l}\text { REVIEWER CHECKS: } \\
\text { September } 2009\end{array}$ \\
\hline $\begin{array}{l}\text { PM.10.9.OCAF. [Deleted } \\
\text { July 2008] }\end{array}$ & $\begin{array}{l}\text { usage, which is 389,000 lb of active ingredient (45 percent of the original } \\
1993 \text { baseline - a } 55 \text { percent reduction.) } \\
\text { - Measure of Merit 3: through the end of FY 2010, } 100 \text { percent of installation } \\
\text { pesticide applicators are certified. } \\
\text { (NOTE: Direct hire employees have a maximum of } 2 \text { yr to become certified after } \\
\text { initial employment; contracted employees shall have appropriate State or host- } \\
\text { nation certification in the appropriate categories at the time the contract is let.) } \\
\text { (DODI } 4150.07 \text {, para E4.3.2, applies to observation of pest management opera- } \\
\text { tions by Federal, State, or local regulators only.) }\end{array}$ \\
\hline $\begin{array}{l}\text { PM.10.10.0CAF. Installa- } \\
\text { tions must not construct } \\
\text { buildings that have heating, } \\
\text { ventilation, or a air- } \\
\text { conditioning (HVAC) ducts } \\
\text { located in or below the floor } \\
\text { (DODI 4150.07, para E4.5.3) } \\
\text { [Revised July 2008; Citation } \\
\text { Revised July 2008]. }\end{array}$ & $\begin{array}{l}\text { Verify that buildings are not constructed with HVAC ducts located in and below } \\
\text { the floor. } \\
\text { (NOTE: This prohibition is intended to prevent accidental contamination of the } \\
\text { ducts with termiticides.) } \\
\text { (NOTE: Postconstruction treatment of structures with HVAC ducts is prohibited } \\
\text { without a waiver from the appropriate pest management consultant.) }\end{array}$ \\
\hline $\begin{array}{l}\text { PM.10.11.OCAF. Self-help } \\
\text { programs must be managed in } \\
\text { accordance with specific stan- } \\
\text { dards (DODI 4150.07, para } \\
\text { E4.7.7.3; “Air Force Self- } \\
\text { Help Pest Management Pro- } \\
\text { gram,” 28 September 1998, } \\
\text { para 4.a.3; and AFI 32-1053, } \\
\text { para 3.5.8.1) [Revised May } \\
\text { 1999; Revised July 2008; } \\
\text { Citation Revised July 2008; } \\
\text { Revised September 2009; } \\
\text { Citation Revised September } \\
\text { 2009]. }\end{array}$ & $\begin{array}{l}\text { Verify that self-help programs are established for military housing only when all } \\
\text { three of the following conditions are met: } \\
\text { - the program is cost effective } \\
\text { - IPM monitoring indicates the need for a self-help program } \\
\text { - these facilities are not part of the housing privatization program. } \\
\text { (NOTE: Self-help pest management materials issued to occupants may include } \\
\text { cockroach and ant baits and/or traps, mouse traps, glue boards, and ready-to-use } \\
\text { pesticide aerosols.) } \\
\text { Verify that the office designated to manage the installation's self-help program } \\
\text { coordinates procurement and storage of pest management materials with the in- } \\
\text { stallation pest management shop, hazardous material manager, and the DLA Sup- } \\
\text { ply Center. } \\
\text { Verify that self-help personnel provide written instructions and appropriate pre- } \\
\text { cautions, beyond those on pesticide labels, to qualified military quarters, housing } \\
\text { occupants, and building managers to ensure proper pesticide application and } \\
\text { safety. } \\
\text { Verify that, if a pesticide is issued to an occupant, records are maintained. } \\
\text { (NOTE: These records should enable installation self-help personnel to validate } \\
\text { the occupants' attempts to control target pests before providing installation pest } \\
\text { management services. Pest management consultants should review these records }\end{array}$ \\
\hline
\end{tabular}




\section{COMPLIANCE CATEGORY: \\ PESTICIDE MANAGEMENT \\ Overseas ESOHCAMP}

\begin{tabular}{|c|c|}
\hline $\begin{array}{l}\text { REGULATORY } \\
\text { REQUIREMENTS: }\end{array}$ & $\begin{array}{l}\text { REVIEWER CHECKS: } \\
\text { September } 2009\end{array}$ \\
\hline $\begin{array}{l}\text { PM.10.12.OCAF. Pest man- } \\
\text { agement and disease vector } \\
\text { control during military con- } \\
\text { tingency operations, readiness } \\
\text { training exercises, and de- } \\
\text { ployments must meet specific } \\
\text { standards (DODI 4150.07, } \\
\text { para E4.9 and AFI 32-1053, } \\
\text { para 3.5.6) [Revised July } \\
\text { 2008; Citation Revised July } \\
\text { 2008; Revised September } \\
\text { 2009; Citation Revised Sep- } \\
\text { tember 2009]. }\end{array}$ & 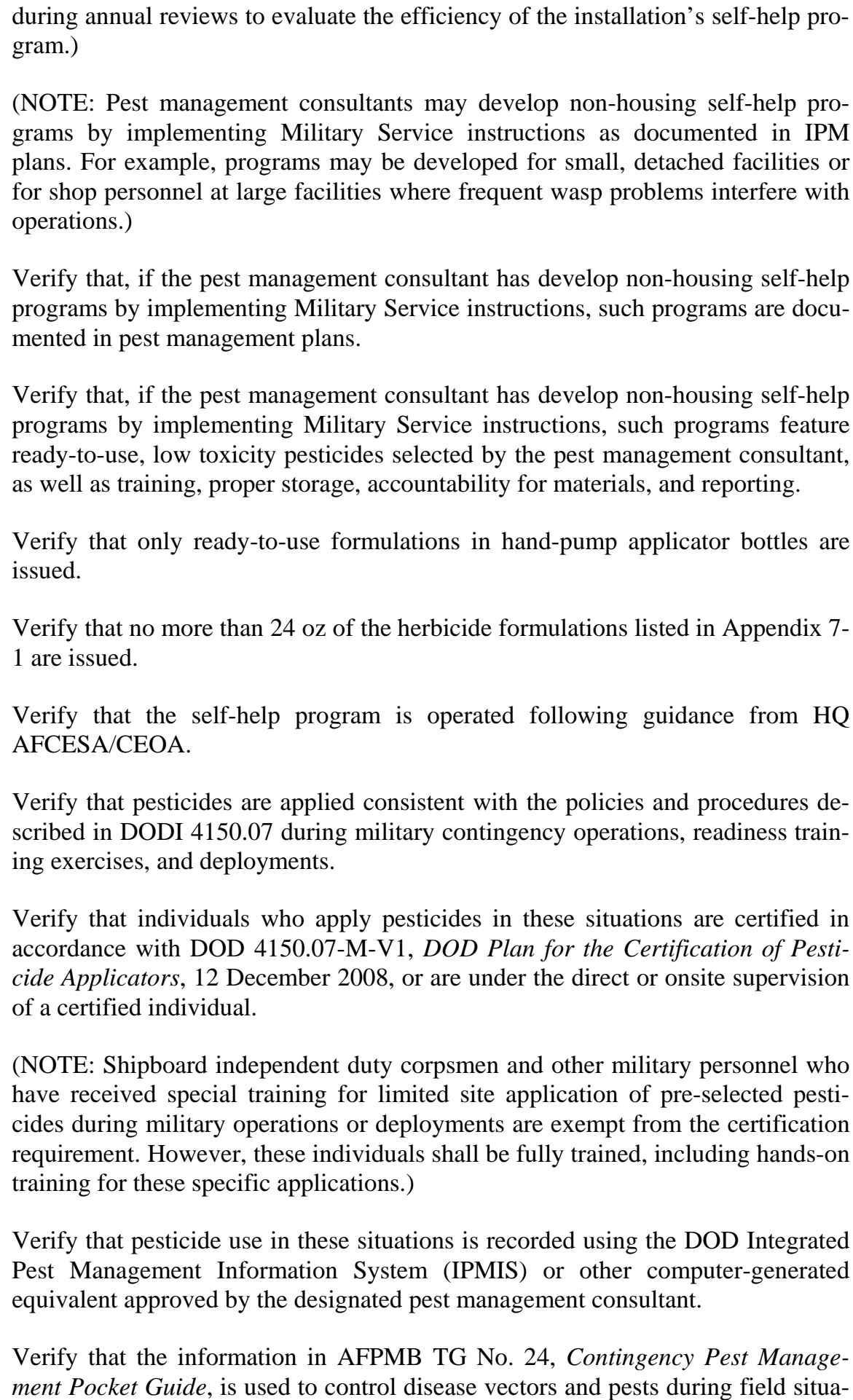 \\
\hline
\end{tabular}




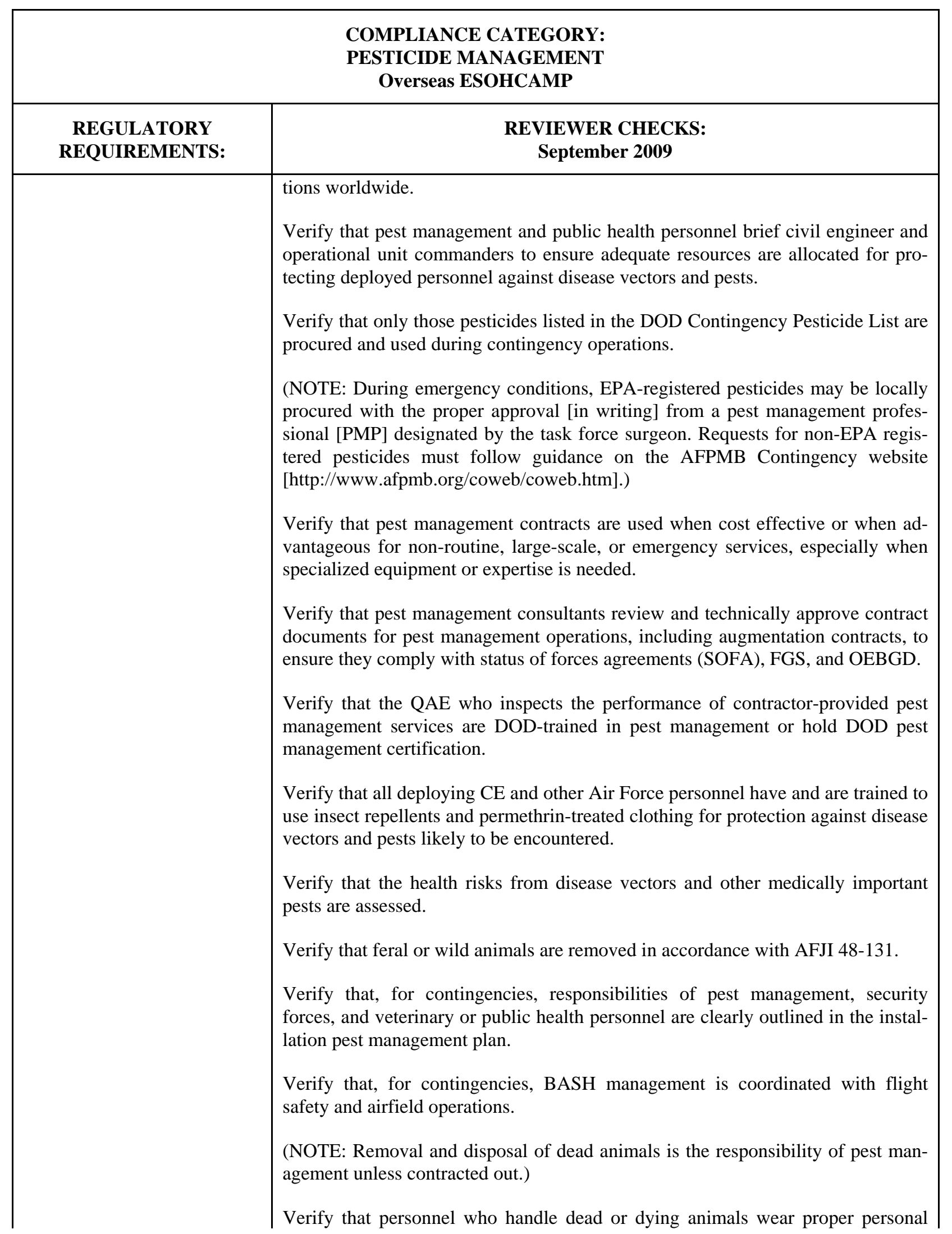




\begin{tabular}{|c|c|}
\hline \multicolumn{2}{|r|}{$\begin{array}{l}\text { COMPLIANCE CATEGORY: } \\
\text { PESTICIDE MANAGEMENT } \\
\text { Overseas ESOHCAMP }\end{array}$} \\
\hline $\begin{array}{l}\text { REGULATORY } \\
\text { REQUIREMENTS: }\end{array}$ & $\begin{array}{l}\text { REVIEWER CHECKS: } \\
\text { September } 2009\end{array}$ \\
\hline $\begin{array}{l}\text { PM.10.13.OCAF. Pest man- } \\
\text { agement consultants must } \\
\text { provide the guidance needed } \\
\text { to protect all closing or closed } \\
\text { facilities from pests from the } \\
\text { beginning of deactivation } \\
\text { until property disposal (DODI } \\
\text { 4150.07, para E4.7.8) [Cita- } \\
\text { tion Revised July 2008]. }\end{array}$ & $\begin{array}{l}\text { protective equipment for handling and disposing of the carcasses. } \\
\text { Verify that contingency pesticide use and pest surveillance are reported through } \\
\text { appropriate command channels or AOR PMC to HQ AFCESA/CEOA. } \\
\text { Verify that records are forwarded to USACHPPM for archiving in DOEHRS. } \\
\text { Verify that pest management consultants provide the guidance needed to protect } \\
\text { all closing or closed facilities from pests from the beginning of deactivation until } \\
\text { property disposal. }\end{array}$ \\
\hline $\begin{array}{l}\text { PM.10.14.OCAF. [Deleted } \\
\text { September 2009]. }\end{array}$ & $\begin{array}{l}\text { Deleted as a result of the June } 2009 \text { revision of AFI 32-1053. } \\
\text { See checklist item PM.10.1.OCAF for analogous provisions that are currently } \\
\text { applicable. }\end{array}$ \\
\hline $\begin{array}{l}\text { PM.10.15.0CAF. Pest man- } \\
\text { agement supervisors must } \\
\text { keep a current copy of } \\
\text { AFOSH STD 48-137, Respi- } \\
\text { ratory Protection, in the shop } \\
\text { and should be familiar with its } \\
\text { contents (AFI 32-1053, para } \\
\text { 4.4.3) [Revised June 2000]. }\end{array}$ & $\begin{array}{l}\text { Verify that the pest management supervisor keeps a current copy of AFOSH STD } \\
\text { 48-137, Respiratory Protection, in the shop. } \\
\text { Verify that the pest management supervisor is familiar with its contents. }\end{array}$ \\
\hline $\begin{array}{l}\text { PM.10.16.OCAF. The IPMC } \\
\text { must follow the guidance in in } \\
\text { AFPMB TG No. 17, Design } \\
\text { of Pest Management Facili- } \\
\text { ties, for designing new facili- } \\
\text { ties and renovating existing } \\
\text { facilities (AFI 32-1053, para } \\
\text { 3.5.2.1) [Added May 1999; } \\
\text { Revised September 2009; } \\
\text { Citation Revised September } \\
\text { 2009]. }\end{array}$ & $\begin{array}{l}\text { Verify that the IPMC follows the guidance in in AFPMB TG No. 17, Design of } \\
\text { Pest Management Facilities, for designing new facilities and renovating existing } \\
\text { facilities. } \\
\text { Verify that the installation pest control supervisor consults with BES regarding } \\
\text { the adequacy of the pest management facility to ensure it provides a safe work } \\
\text { environment for pest management personnel. }\end{array}$ \\
\hline $\begin{array}{l}\text { PM.10.17.OCAF. The IPMC } \\
\text { must protect the health and } \\
\text { safety of pest management } \\
\text { personnel through training }\end{array}$ & $\begin{array}{l}\text { Verify that the IPMC protects the health and safety of pest management personnel } \\
\text { through training. } \\
\text { (NOTE: Training includes initial and periodic occupational health and hazard }\end{array}$ \\
\hline
\end{tabular}




\section{COMPLIANCE CATEGORY: \\ PESTICIDE MANAGEMENT \\ Overseas ESOHCAMP}

\begin{tabular}{|c|c|}
\hline $\begin{array}{l}\text { REGULATORY } \\
\text { REQUIREMENTS: }\end{array}$ & $\begin{array}{l}\text { REVIEWER CHECKS: } \\
\text { September } 2009\end{array}$ \\
\hline $\begin{array}{l}\text { (AFI 32-1053, paras 3.5.2.4, } \\
\text { 3.7.5, and 3.5.9.2) } \text { [Added } \\
\text { May 1999]. }\end{array}$ & $\begin{array}{l}\text { communication [HAZCOM] training.) } \\
\text { Verify that the Public Health Officer provides consultation on training and techni- } \\
\text { cal matters to pest management supervisors on the HAZCOM program. } \\
\text { Verify that supervisors provide HAZCOM training to other pest management per- } \\
\text { sonnel. } \\
\text { Verify that host nation personnel receive non-FIFRA training in accordance with } \\
\text { DODI } 4150.07 \text { and the FGS. }\end{array}$ \\
\hline $\begin{array}{l}\text { PM.10.18.OCAF. [Deleted } \\
\text { September 2009]. }\end{array}$ & Duplicated at PM.20.11.OCAF. \\
\hline $\begin{array}{l}\text { PM.10.19.0CAF. The Bio- } \\
\text { environmental Engineer must } \\
\text { evaluate potential occupa- } \\
\text { tional exposures and the ade- } \\
\text { quacy of exposure control } \\
\text { through periodic shop visits } \\
\text { (AFI 32-1053, paras 3.8.1 and } \\
\text { 3.8.2) [Added May 1999; } \\
\text { Citation Revised September } \\
\text { 2009]. }\end{array}$ & $\begin{array}{l}\text { Verify that the Bioenvironmental Engineer evaluates potential occupational expo- } \\
\text { sures and the adequacy of exposure control through periodic shop visits. } \\
\text { Verify that Bioenvironmental Engineer sets local standards for obtaining and us- } \\
\text { ing PPE for pest management personnel. }\end{array}$ \\
\hline $\begin{array}{l}\text { PM.10.20.0CAF. The Bio- } \\
\text { environmental Engineer must } \\
\text { conduct respirator training } \\
\text { and respirator fit testing of } \\
\text { pest management personnel } \\
\text { (AFI 32-1053, para 3.8.3) } \\
\text { [Added May 1999; Citation } \\
\text { Revised September 2009]. }\end{array}$ & $\begin{array}{l}\text { Verify that the Bioenvironmental Engineer conducts respirator training and respi- } \\
\text { rator fit testing of pest management personnel. }\end{array}$ \\
\hline $\begin{array}{l}\text { PM.10.21.OCAF. The Base } \\
\text { Exchange Manager has spe- } \\
\text { cific responsibilities with re- } \\
\text { gard to pest management } \\
\text { (AFI 32-1053, para 3.11) } \\
\text { [Added May 1999; Revised } \\
\text { September 2009; Citation } \\
\text { Revised September 2009]. }\end{array}$ & $\begin{array}{l}\text { Verify that the Base Exchange Manager: } \\
\text { - maintains a current pesticide inventory } \\
\text { - follows the guidance in AFPMB TG No. 15, Pesticide Spill Prevention and } \\
\text { Management, and AFPMB TG No. 45, Storage and Display of Retail Pesti- } \\
\text { cides } \\
\text { - market only pesticides with current EPA, state, and/or host nation registra- } \\
\text { tion } \\
\text { - coordinates all pesticide disposal with the IMPC and follows that individ- } \\
\text { ual's guidance } \\
\text { - makes hardcopy MSDSs available for review by employees, BES, and the } \\
\text { Fire Department. }\end{array}$ \\
\hline & not defined in AFI 32-1053. For the purposes of it \\
\hline
\end{tabular}




\begin{tabular}{|c|c|}
\hline \multicolumn{2}{|r|}{$\begin{array}{c}\text { COMPLIANCE CATEGORY: } \\
\text { PESTICIDE MANAGEMENT } \\
\text { Overseas ESOHCAMP }\end{array}$} \\
\hline $\begin{array}{l}\text { REGULATORY } \\
\text { REQUIREMENTS: }\end{array}$ & $\begin{array}{l}\text { REVIEWER CHECKS: } \\
\text { September } 2009\end{array}$ \\
\hline $\begin{array}{l}\text { PM.10.22.OCAF. PMQAEs } \\
\text { or PMPARs must monitor and } \\
\text { evaluate contractor perform- } \\
\text { ance of pest management ser- } \\
\text { vices (DODI 4150.07, para } \\
\text { E4.4.2.3) [Added July 2008]. } \\
\text { PM.10.23.OCAF. The IC } \\
\text { must implement measures to } \\
\text { prevent unacceptable damage } \\
\text { to shade trees, ornamental } \\
\text { plantings, and turf by insects, } \\
\text { diseases, and weeds (DODI } \\
\text { 4150.07, para E4.7.11) } \\
\text { [Added July 2008]. }\end{array}$ & $\begin{array}{l}\text { compliance assessments, HQ USAFE/A7AV defines current as monthly.) } \\
\text { (NOTE: For retail display, see PM.53.) } \\
\text { Verify that a PMQAE or PMPAR monitors and evaluates contractor performance } \\
\text { of pest management services. } \\
\text { (NOTE: If an installation's pest management contract efforts are less than } 0.25 \\
\text { work-years, the presence of a trained PMQAE at the installation is recommended, } \\
\text { but is not mandatory.) } \\
\text { Verify that measures are taken to prevent unacceptable damage to shade trees, } \\
\text { ornamental plantings, and turf by insects, diseases, and weeds. }\end{array}$ \\
\hline $\begin{array}{l}\text { PM.10.24.OCAF. Electro- } \\
\text { magnetic exclusion or control } \\
\text { devices, ultrasonic repellent } \\
\text { or control devices, and out- } \\
\text { door devices for electrocuting } \\
\text { flying insects are not ap- } \\
\text { proved for use (DODI } \\
4150.07 \text {, para E4.10.1) } \\
\text { [Added July 2008]. }\end{array}$ & $\begin{array}{l}\text { Verify that none of the following are in use on the installation: } \\
\text { - electromagnetic exclusion or control devices } \\
\text { - ultrasonic repellent or control devices } \\
\text { - outdoor devices for electrocuting flying insects. } \\
\text { (NOTE: Indoor devices for electrocuting flying insects are permitted, when se- } \\
\text { lected, purchased, located, and used in accordance with AFPMB Technical Guide } \\
\text { 36, "Personal Protective Measures Against Insects and Other Arthropods of Mili- } \\
\text { tary Significance," current edition.) }\end{array}$ \\
\hline $\begin{array}{l}\text { PM.10.25.OCAF. The DeCA } \\
\text { Manager has specific respon- } \\
\text { sibilities with regard to pest } \\
\text { management (AFI 32-1053, } \\
\text { para 3.11) [Added September } \\
\text { 2009]. }\end{array}$ & $\begin{array}{l}\text { Verify that the DeCA Manager: } \\
\text { - maintains a current pesticide inventory } \\
\text { - follows the guidance in AFPMB TG No. 15, Pesticide Spill Prevention and } \\
\text { Management, and AFPMB TG No. 45, Storage and Display of Retail Pesti- } \\
\text { cides } \\
\text { - market only pesticides with current EPA, state, and/or host nation registra- } \\
\text { tion } \\
\text { - coordinates all pesticide disposal with the IMPC and follows that individ- } \\
\text { ual's guidance } \\
\text { - makes hardcopy MSDSs available for review by employees, BES, and the } \\
\text { Fire Department. } \\
\text { (NOTE: The term current is not defined in AFI 32-1053. For the purposes of its } \\
\text { compliance assessments, HQ USAFE/A7AV defines current as monthly.) }\end{array}$ \\
\hline
\end{tabular}




\section{COMPLIANCE CATEGORY: \\ PESTICIDE MANAGEMENT \\ Overseas ESOHCAMP}

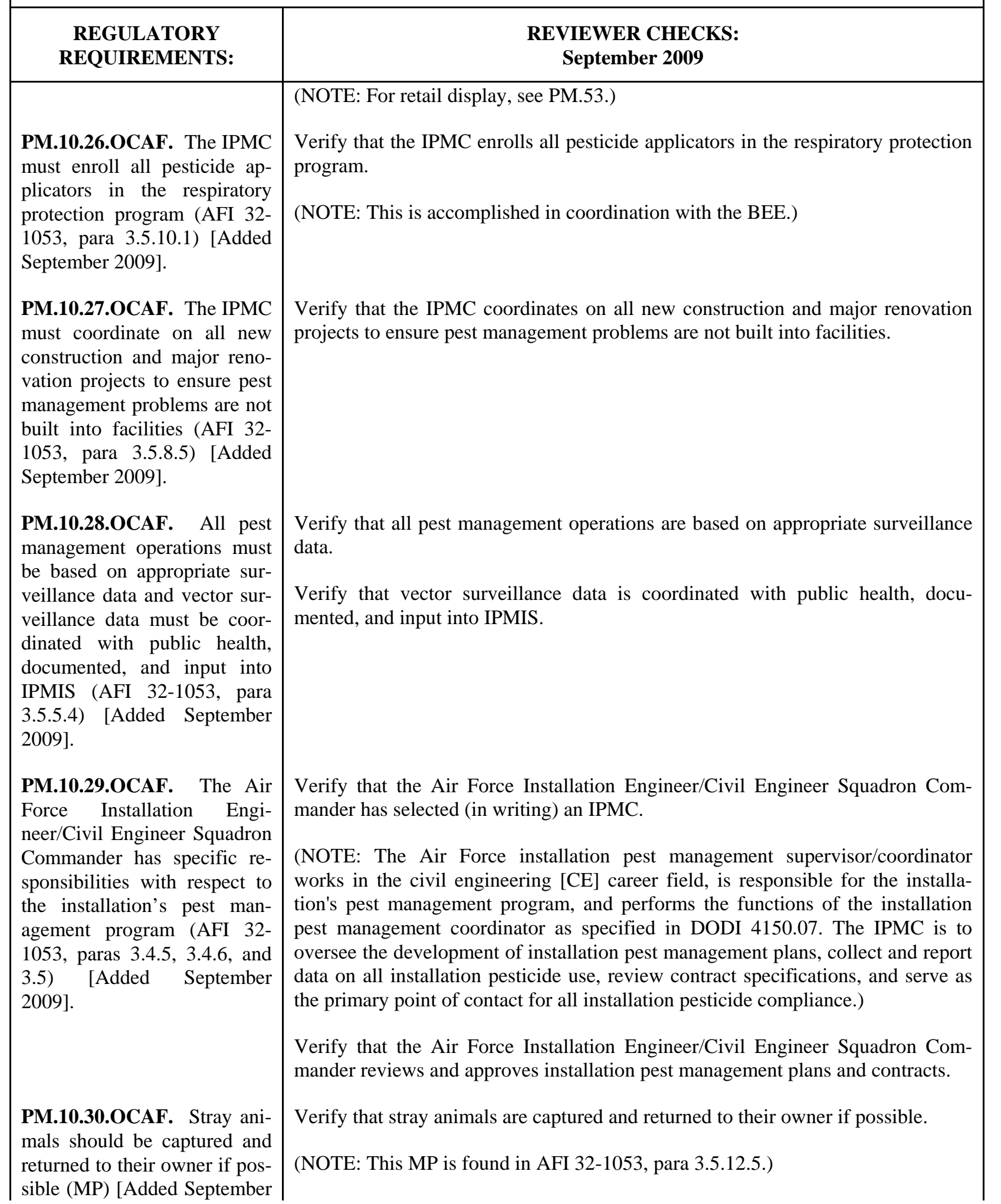




\section{COMPLIANCE CATEGORY: \\ PESTICIDE MANAGEMENT \\ Overseas ESOHCAMP}

\begin{tabular}{|c|c|}
\hline $\begin{array}{l}\text { REGULATORY } \\
\text { REQUIREMENTS: }\end{array}$ & $\begin{array}{l}\text { REVIEWER CHECKS: } \\
\text { September } 2009\end{array}$ \\
\hline 2009]. & \\
\hline $\begin{array}{l}\text { PM.10.31. OCAF. The man- } \\
\text { agement of stray and feral } \\
\text { animals is subject to specific } \\
\text { requirements (AFI 32-1053, } \\
\text { paras 3.5.12.4 and 3.5.12.5) } \\
\text { [Added September 2009]. }\end{array}$ & $\begin{array}{l}\text { Verify that stray and feral animals are removed in accordance with AFJI 48-131, } \\
\text { Veterinary Health Services, and AFI 32-7064, Integrated Natural Resources } \\
\text { Management. } \\
\text { Verify that feral animals are transported to an approved humane shelter facility as } \\
\text { specified by the base veterinarian. }\end{array}$ \\
\hline & Verify that pest management facilities are not used as holding areas for animals. \\
\hline $\begin{array}{l}\text { PM.10.32.OCAF. Personnel } \\
\text { who handle dead or dying } \\
\text { animals must wear proper } \\
\text { personal protective equipment } \\
\text { for handling and disposing of } \\
\text { the carcasses (AFI 32-1053, } \\
\text { para 3.5.12.6) [Added Sep- } \\
\text { tember 2009]. }\end{array}$ & $\begin{array}{l}\text { (NOTE: Removal and disposal of dead animals is the responsibility of pest man- } \\
\text { agement unless contracted out.) } \\
\text { Verify that personnel who handle dead or dying animals wear proper personal } \\
\text { protective equipment for handling and disposing of the carcasses. }\end{array}$ \\
\hline $\begin{array}{l}\text { PM.10.33.OCAF. Collection } \\
\text { and disposal of dead animals } \\
\text { must be tracked and reported } \\
\text { to pest management, natural } \\
\text { resources, and veterinary and } \\
\text { public health personnel if } \\
\text { dead animals harbor disease } \\
\text { or parasites of medical impor- } \\
\text { tance to human or animal } \\
\text { health (AFI 32-1053, para } \\
\text { 3.5.12.7) [Added September } \\
\text { 2009]. }\end{array}$ & $\begin{array}{l}\text { Verify that collection and disposal of dead animals is tracked and reported to pest } \\
\text { management, natural resources, and veterinary and public health personnel if dead } \\
\text { animals harbor disease or parasites of medical importance to human or animal } \\
\text { health. }\end{array}$ \\
\hline $\begin{array}{l}\text { PM.10.34.OCAF. Public } \\
\text { awareness of local disease } \\
\text { presence must be coordinated } \\
\text { with the installation public } \\
\text { affairs office (AFI 32-1053, } \\
\text { para 3.5.12.7) [Added Sep- } \\
\text { tember 2009]. }\end{array}$ & $\begin{array}{l}\text { Verify that public awareness of local disease presence must be coordinated with } \\
\text { the installation public affairs office. }\end{array}$ \\
\hline $\begin{array}{l}\text { PM.10.35.0CAF. Installa- } \\
\text { tion personnel must receive } \\
\text { MAJCOM PMC approval } \\
\text { before a request is made for } \\
\text { procuring commercial pest } \\
\text { management service (AFI 32- } \\
\text { 1053, paras } 4.7 .1 \text { and } 4.7 .2 \text { ) }\end{array}$ & $\begin{array}{l}\text { (NOTE: Pest management contracts are used when more cost effective than in- } \\
\text { house services.) } \\
\text { Verify that installation personnel receive MAJCOM PMC approval before a re- } \\
\text { quest is made for procuring commercial pest management service. } \\
\text { (NOTE: This requirement also applies to use of GPCs and AF IMT 9, Request for }\end{array}$ \\
\hline
\end{tabular}




\begin{tabular}{|c|c|}
\hline \multicolumn{2}{|r|}{$\begin{array}{l}\text { COMPLIANCE CATEGORY: } \\
\text { PESTICIDE MANAGEMENT } \\
\text { Overseas ESOHCAMP }\end{array}$} \\
\hline $\begin{array}{l}\text { REGULATORY } \\
\text { REQUIREMENTS: }\end{array}$ & $\begin{array}{l}\text { REVIEWER CHECKS: } \\
\text { September } 2009\end{array}$ \\
\hline $\begin{array}{l}\text { PM.10.36.OCAF. The } \\
\text { MAJCOM PMC must review } \\
\text { and approve all performance } \\
\text { work statements for con- } \\
\text { tracted pest management ser- } \\
\text { vices (AFI 32-1053, para } \\
\text { 4.7.2) [Added September } \\
\text { 2009]. }\end{array}$ & $\begin{array}{l}\text { Purchase, and also to base operations support [BOS], General Services Admini- } \\
\text { stration [GSA], subcontracts, or other support service contracts that utilize pesti- } \\
\text { cides.) } \\
\text { Verify that the MAJCOM PMC reviews and approves all performance work state- } \\
\text { ments for contracted pest management services. }\end{array}$ \\
\hline 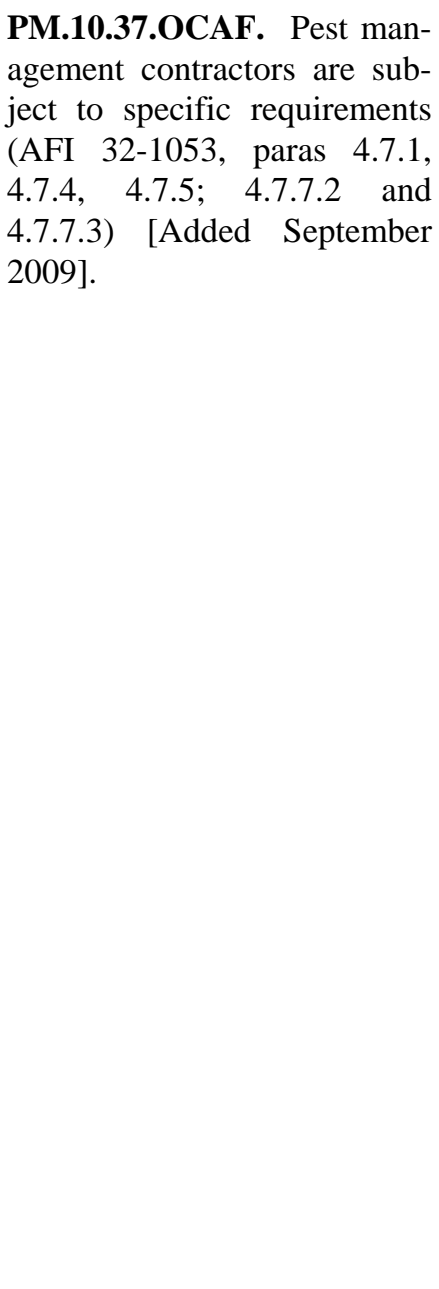 & $\begin{array}{l}\text { Verify that all pest management contractors use integrated pest management [as] } \\
\text { identified in the installation pest management plan. } \\
\text { Verify that all pest management contractors comply with the pesticide applicator } \\
\text { certification, licensing, and registration requirements of the country where the } \\
\text { work is performed. } \\
\text { Verify that all pest management contractors also comply with sections of DODI } \\
4150.07 \text { and AFI } 32-1053 \text { that apply to contract pest management operations. } \\
\text { (NOTE: On overseas installations outside U.S., see the country-specific FGS } \\
\text { and/or MAJCOM policy for pest management contract requirements.) } \\
\text { Verify that the contracting officer and IPMC have approved the location where } \\
\text { pesticides are mixed and/or stored prior to starting work. } \\
\text { Verify that this site has secondary containment and backflow prevention as identi- } \\
\text { fied in AFPMB TG No. } 17 \text {. } \\
\text { Verify that the contractor ensures that this area is properly managed to prevent } \\
\text { spills. } \\
\text { Verify that the contractor furnishes the quality assurance evaluator (QAE) with } \\
\text { labels and MSDSs for all contract pesticide materials } 25 \text { days prior to the start of } \\
\text { the contract. } \\
\text { Verify that the contractor provides data on daily pesticide use for input into the } \\
\text { IPMIS pesticide management database. } \\
\text { (NOTE: The contractor, QAE, or other CE representative will input data into } \\
\text { IPMIS and forward it monthly [by } 10 \text { days after the close of the month] to the } \\
\text { MAJCOM PMC, as specified in the contract.) }\end{array}$ \\
\hline $\begin{array}{l}\text { PM.10.38.OCAF. QAEs for } \\
\text { pest management service con- }\end{array}$ & Verify that QAEs receive training in pest management according to guidance in \\
\hline
\end{tabular}




\section{COMPLIANCE CATEGORY: \\ PESTICIDE MANAGEMENT \\ Overseas ESOHCAMP}

\begin{tabular}{|c|c|}
\hline $\begin{array}{l}\text { REGULATORY } \\
\text { REQUIREMENTS: }\end{array}$ & $\begin{array}{l}\text { REVIEWER CHECKS: } \\
\text { September } 2009\end{array}$ \\
\hline $\begin{array}{l}\text { tracts must meet specific re- } \\
\text { quirements (AFI 32-1053, } \\
\text { paras 4.7.7, 4.7.7.1 and } \\
\begin{array}{l}\text { 4.7.7.2) [Added September } \\
\text { 2009]. }\end{array}\end{array}$ & $\begin{array}{l}\text { DODI } 4150.07 . \\
\text { (NOTE: If an installation's total pest management contract efforts are less than } \\
0.25 \text { work year annually, the presence of a trained QAE at the installation is not } \\
\text { mandatory.) } \\
\text { Verify that the QAE submits labels and MSDSs to the MAJCOM PMC for ap- } \\
\text { proval at least } 15 \text { days prior to the start of the contract. } \\
\text { Verify that, during the contract period, the QAE forwards to the MAJCOM PMC } \\
\text { any request to use unapproved pesticides. } \\
\text { Verify that MAJCOM PMC approval for use of unapproved pesticides is obtained } \\
\text { prior to their use. } \\
\text { (NOTE: Certified pest management shop personnel will help the QAE evaluate } \\
\text { pest management contracts.) }\end{array}$ \\
\hline $\begin{array}{l}\text { PM.10.39.OCAF. The QAE } \\
\text { or other CE representative } \\
\text { must maintain historical pes- } \\
\text { ticide data according to the } \\
\text { RDS (AFI 32-1053, paras } \\
\text { 4.7.7.4) [Added September } \\
\text { 2009]. }\end{array}$ & $\begin{array}{l}\text { Verify that the QAE or other CE representative maintains historical pesticide data } \\
\text { according to the RDS. }\end{array}$ \\
\hline
\end{tabular}




\begin{tabular}{|c|c|}
\hline & $\begin{array}{c}\text { COMPLIANCE CATEGORY: } \\
\text { PESTICIDE MANAGEMENT } \\
\text { Overseas ESOHCAMP }\end{array}$ \\
\hline $\begin{array}{l}\text { REGULATORY } \\
\text { REQUIREMENTS: }\end{array}$ & $\begin{array}{l}\text { REVIEWER CHECKS: } \\
\text { September } 2009\end{array}$ \\
\hline $\begin{array}{l}\text { PM.20 } \\
\text { PESTICIDE } \\
\text { APPLICATION } \\
\text { PM.20.1.OCAF. Certain } \\
\text { information must be included } \\
\text { on ordering documents in } \\
\text { order to make sure that no one } \\
\text { buys or issues nonapproved } \\
\text { pesticides (AFI 32-1053, para } \\
\text { 4.5.2) [Citation Revised May } \\
\text { 1999; Citation Revised Sep- } \\
\text { tember 2009]. }\end{array}$ & $\begin{array}{l}\text { Verify that pest management personnel use advice code } 2 \mathrm{~B} \text { on ordering docu- } \\
\text { ments to tell Supply that it may not substitute another product for the requested } \\
\text { item. }\end{array}$ \\
\hline 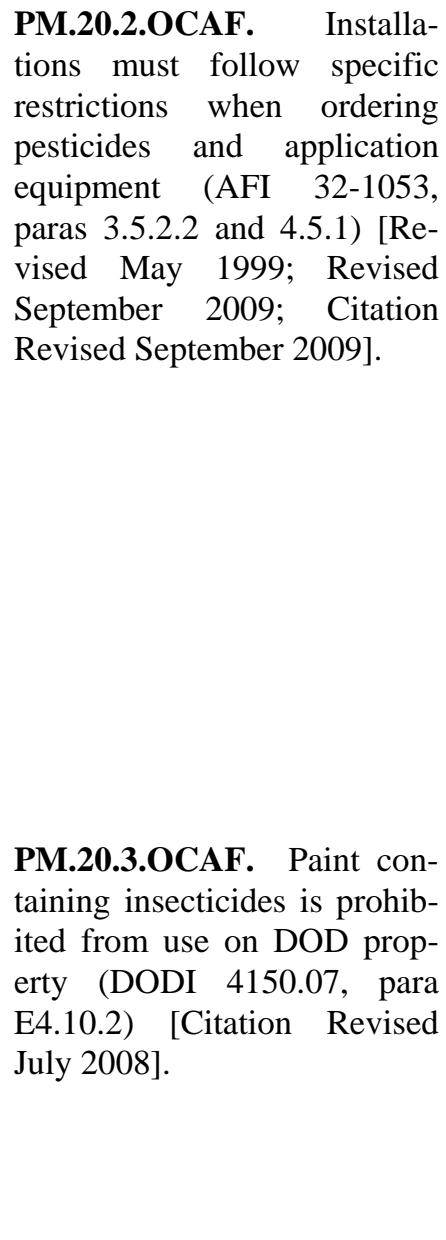 & $\begin{array}{l}\text { Verify that only pesticides approved in writing by the MAJCOM PMC are used. } \\
\text { Verify that all installation pest management personnel obtain pesticides and } \\
\text { equipment through Air Force supply channels, except as provided by service con- } \\
\text { tracts. } \\
\text { Verify that standard pesticide application equipment is ordered from Federal sup- } \\
\text { ply catalogues. } \\
\text { Verify that pesticides are procured from AFPMB Standard Pesticides List or non- } \\
\text { stock listed products that are approved by the MAJCOM PMC. } \\
\text { Verify that pesticides are used in accordance with the pest management plan. } \\
\text { Verify that approval from the MAJCOM PMC is requested and received before } \\
\text { ordering or using nonstandard, locally purchased pesticides or application equip- } \\
\text { ment. } \\
\text { (NOTE: This approval requirement applies to use of GPCs and all other forms of } \\
\text { procurement.) } \\
\text { Verify that neither interior nor exterior paint that contains pesticides is used on } \\
\text { the installation. } \\
\text { (NOTE: This prohibition also applies to insecticides formulated and labeled for } \\
\text { use as paint additives.) } \\
\text { (NOTE: Paints containing fungicides as mildew inhibitors may be used when the } \\
\text { application directions specify no special restrictions due to the fungicide. Ap- } \\
\text { proved marine anti-fouling compounds or coatings may be applied to protect the } \\
\text { surfaces of watercraft.) }\end{array}$ \\
\hline
\end{tabular}




\section{COMPLIANCE CATEGORY: \\ PESTICIDE MANAGEMENT \\ Overseas ESOHCAMP}

\section{REGULATORY REQUIREMENTS:}

PM.20.4.OCAF. The use of regularly scheduled, periodic pesticide applications and of preventative pesticide treatments is prohibited (DODI 4150.07, para E4.10.3) [Revised July 2008; Citation Revised July 2008; Citation Revised March 2009].

PM.20.5.OCAF. Installations must use recyclable and refillable pesticide containers and closed pesticide mixing and transfer systems as much as possible (AFI 32-1053, para 3.5.11.1) [Citation Revised May 1999; Citation Revised September 2009].

PM.20.6.OCAF. Pesticide applicators must use all pesticides in accordance with label directions and pest managment personnel must use equipment in accordance with the manufacturer's instructions (AFI 32-1053, paras 4.5.3 and 4.6.1) [Citation Revised May 1999; Revised September 2009; Citation Revised September 2009].

PM.20.7.0CAF. Pesticide applicators must meet certification requirements (DODI 4150.07, paras E.4.4.2 and E.4.4.2.2; and AFI 32-1053, paras 3.5.3.1, 3.5.3.5, 3.5.3.6, and 3.4.3.8) [Citation Revised May 1999; Revised July 2008; Citation Revised July 2008; Citation Revised March 2009; Revised September 2009; Citation Revised Sep-

\section{REVIEWER CHECKS: September 2009}

Verify that the installation does not perform regularly scheduled, periodic pesticide applications.

(NOTE: This prohibition does not apply in situations where the IPM plan clearly documents that no other technology or approach is available to protect personnel or property of high value.)

Verify that preventative pesticide treatments are not used unless the appropriate pest management consultant has given approval based on current surveillance information or records documenting past disease vectors or pest problems that require this approach.

Verify that the installation uses recyclable and refillable pesticide containers and closed pesticide mixing and transfer systems as much as possible.

Verify that pesticide applicators use all pesticides in accordance with label directions.

Verify that pest management personnel use equipment in accordance with the manufacturer's instructions.

Verify that only pest management personnel use pest management vehicles.

Verify that all DOD personnel who apply or supervise the application of pesticides are trained and certified within 2 yr of employment in accordance with DOD 4150.07-M-V1, DOD Plan for the Certification of Pesticide Applicators, 12 December 2008.

Verify that personnel who are undergoing apprenticeship training, but are not yet certified, apply pesticides only under the direct supervision of a certified pesticide applicator.

(NOTE: Uncertified but trained pest management personnel may apply pesticides under the direct supervision of a certified applicator.)

(NOTE: Under the terms of Japan Environmental Governing Standards, para 


\section{COMPLIANCE CATEGORY: \\ PESTICIDE MANAGEMENT \\ Overseas ESOHCAMP}

\begin{tabular}{|c|c|}
\hline $\begin{array}{c}\text { REGULATORY } \\
\text { REQUIREMENTS: }\end{array}$ & $\begin{array}{l}\text { REVIEWER CHECKS: } \\
\text { September } 2009\end{array}$ \\
\hline tember 2009]. & $\begin{array}{l}\text { 11.3.4.c, pesticides may be applied only by or under the direct supervision of a } \\
\text { certified applicator; there is no provision for line-of-sight supervision.) } \\
\text { (NOTE: See Appendix 7-2 for a list of restricted-use pesticides.) } \\
\text { (NOTE: After receiving training from pest management personnel, nonpest- } \\
\text { management personnel may apply pesticides in the following situations: } \\
\text { - adult military housing occupants [nonprivatized], facility building managers, } \\
\text { and others with an approved installation IPM plan may apply approved self- } \\
\text { help pesticides } \\
\text { - military personnel may apply approved arthropod repellents [including indi- } \\
\text { vidual dynamic absorption kits] for personnel protection and for use on uni- } \\
\text { forms, tents, and mosquito netting } \\
\text { - civilian personnel working outdoors may apply only repellents labeled for } \\
\text { civilian use by the EPA to skin or clothing } \\
\text { - military personnel may apply approved aerosol insecticide for quarantine in- } \\
\text { sect extermination on aircraft.) } \\
\text { Verify that military personnel who apply approved aerosol insecticide for quaran- } \\
\text { tine insect extermination on aircraft do so only after receiving training from the } \\
\text { CE Pest Management Section. } \\
\text { Verify that neither prisoners nor volunteer workers are assigned to apply pesti- } \\
\text { cides. } \\
\text { Verify that contractor personnel are certified prior to beginning the job. }\end{array}$ \\
\hline $\begin{array}{l}\text { PM.20.8.OCAF. DOD- } \\
\text { certified pesticide applicators } \\
\text { must be recertified every } 3 \text { yr } \\
\text { (DODI 4150.07, para } \\
\text { E4.4.2.1 and AFI 32-1053, } \\
\text { para 3.5.3.3) [Citation Re- } \\
\text { vised July 2008; Revised Sep- } \\
\text { tember 2009; Citation Re- } \\
\text { vised September 2009]. }\end{array}$ & $\begin{array}{l}\text { Verify that DOD-certified pesticide applicators are recertified every } 3 \text { yr. } \\
\text { (NOTE: Pesticide applicator recertification should be scheduled not later than six } \\
\text { months prior to expiration.) }\end{array}$ \\
\hline $\begin{array}{l}\text { PM.20.9.OCAF. [Deleted } \\
\text { June 2000]. }\end{array}$ & Duplicated at PM.20.7.OCAF. \\
\hline $\begin{array}{l}\text { PM.20.10.0CAF. At the } \\
\text { direction of the Medical } \\
\text { Treatment Facility Com- } \\
\text { mander, BEE must make sure } \\
\text { that medical treatment facili- } \\
\text { ties personnel neither store } \\
\text { nor use EPA-classified pesti- }\end{array}$ & $\begin{array}{l}\text { Verify that, if directed to do so by the Medical Treatment Facility Commander, } \\
\text { BEE makes sure that medical treatment facilities personnel neither store nor use } \\
\text { EPA-classified pesticides. } \\
\text { (NOTE: This prohibition does not apply to disinfectants or germicides or to in- } \\
\text { sect repellents and permethrin-treated clothing for protection of deploying per- }\end{array}$ \\
\hline
\end{tabular}




\begin{tabular}{|c|c|}
\hline \multicolumn{2}{|r|}{$\begin{array}{l}\text { COMPLIANCE CATEGORY: } \\
\text { PESTICIDE MANAGEMENT } \\
\text { Overseas ESOHCAMP }\end{array}$} \\
\hline $\begin{array}{l}\text { REGULATORY } \\
\text { REQUIREMENTS: }\end{array}$ & $\begin{array}{l}\text { REVIEWER CHECKS: } \\
\text { September } 2009\end{array}$ \\
\hline $\begin{array}{l}\text { cides (AFI 32-1053, para } \\
\text { 3.8.4) [Revised May 1999; } \\
\text { Citation Revised September } \\
\text { 2009]. }\end{array}$ & sonnel against insect vectors.) \\
\hline $\begin{array}{l}\text { PM.20.11.OCAF. The instal- } \\
\text { lation pest control supervisor } \\
\text { has specific responsibilities } \\
\text { for protecting the health of } \\
\text { personnel (AFI 32-1053, } \\
\text { paras 3.5.9 and 3.5.2.4) [Re- } \\
\text { vised May 1999; Revised } \\
\text { September 2009; Citation } \\
\text { Revised September 2009]. }\end{array}$ & $\begin{array}{l}\text { Verify that all personnel new to the carrier field receive a baseline physical exam } \\
\text { prior to potential occupational exposure to pesticides. } \\
\text { Verify that, after the baseline physical exam, pest management personnel receive } \\
\text { periodic occupational physical exams as directed by the occupational and envi- } \\
\text { ronmental working group. } \\
\text { Verify that the installation pest control supervisor protects the health and safety of } \\
\text { pest management personnel through emphasis on good work habits (such as using } \\
\text { protective clothing and equipment). } \\
\text { Verify that the installation pest control supervisor provides protective clothing } \\
\text { and equipment to all BCE pest management persons who mix and apply pesti- } \\
\text { cides. } \\
\text { Verify that the installation pest control supervisor protects the health and safety of } \\
\text { pest management personnel by emphasizing construction that reduces or elimi- } \\
\text { nates hazards. } \\
\text { Verify that the installation pest control supervisor ensures that pregnant and } \\
\text { breastfeeding pest management personnel have been referred to Public Health. }\end{array}$ \\
\hline $\begin{array}{l}\text { PM.20.12.OCAF. Individu- } \\
\text { als who handle pesticides } \\
\text { must wear an approved respi- } \\
\text { ratory device (DOD 4145.19- } \\
\text { R-1, para 3-415a(6) and 3- } \\
415 \mathrm{a}(7)) \text {. }\end{array}$ & $\begin{array}{l}\text { Verify that all personnel who handle pesticides wear an approved respiratory de- } \\
\text { vice that is appropriate for protection against the pesticides they use. } \\
\text { Verify that all respirators, gas masks, cartridges, and canisters are Occupational } \\
\text { Safety and Health Administration/Mine Safety and Health Administration } \\
\text { (OSHA/MSHA) approved for the specific pesticide being handled. } \\
\text { (NOTE: Paint respirators do not provide protection from pesticide vapors.) }\end{array}$ \\
\hline $\begin{array}{l}\text { PM.20.13.0CAF. [Deleted - } \\
\text { March 2000] }\end{array}$ & Deleted at the request of sponsor. \\
\hline $\begin{array}{l}\text { PM.20.14.0CAF. Pest man- } \\
\text { agement personnel who mix } \\
\text { and apply pesticides must } \\
\text { meet specific requirements } \\
\text { with regard to PPE and cloth- } \\
\text { ing (AFI 32-1053, paras } 4.4 \\
\text { and 4.4.1) [Revised May } \\
\text { 1999; Revised September }\end{array}$ & $\begin{array}{l}\text { Verify that use of protective equipment and level of protection complies with at } \\
\text { least the minimum stated on the pesticide label. } \\
\text { (NOTE: Protective clothing and equipment for personnel who mix and apply } \\
\text { pesticide may include coveralls, respirators, goggles, nitrile or chemical and oil- } \\
\text { resistant rubber gloves, rubber boots, safety shoes, and special fumigation safety } \\
\text { equipment.) }\end{array}$ \\
\hline
\end{tabular}




\begin{tabular}{|c|c|}
\hline \multicolumn{2}{|r|}{$\begin{array}{l}\text { COMPLIANCE CATEGORY: } \\
\text { PESTICIDE MANAGEMENT } \\
\text { Overseas ESOHCAMP }\end{array}$} \\
\hline $\begin{array}{l}\text { REGULATORY } \\
\text { REQUIREMENTS: }\end{array}$ & $\begin{array}{l}\text { REVIEWER CHECKS: } \\
\text { September } 2009\end{array}$ \\
\hline 2009]. & $\begin{array}{l}\text { Verify that overalls are kept clean at all times. } \\
\text { Verify that shop washing machines and dryers are used or that any clothing sent } \\
\text { to base laundry services is clearly identified as being contaminated with pesti- } \\
\text { cides. } \\
\text { Verify that contaminated work clothing is never taken home or cleaned in wash- } \\
\text { ing machines with other clothing. }\end{array}$ \\
\hline $\begin{array}{l}\text { PM.20.15.0CAF. Installa- } \\
\text { tions must meet specific re- } \\
\text { quirements with regard to } \\
\text { their pest control vehicles } \\
\text { (AFI 32-1053, para 4.6) [Re- } \\
\text { vised May 1999; Revised } \\
\text { September 2009; Citation } \\
\text { Revised September 2009]. }\end{array}$ & $\begin{array}{l}\text { Verify that only pest management personnel use pest control vehicles. } \\
\text { Verify that vehicles are equipped with locking compartments for safe handling, } \\
\text { storage, and transport of pesticides. } \\
\text { (NOTE: A telephone maintenance truck will suit the purpose.) } \\
\text { Verify that the truck carries emergency phone numbers and a spill cleanup kit that } \\
\text { is capable of containing } 110 \% \text { of the largest pesticide volume on the vehicle. } \\
\text { Verify that pest control workers carry radios or portable phones in vehicles. } \\
\text { Verify that placards are attached to vehicle- or trailer-mounted sprayers that iden- } \\
\text { tify: } \\
\quad \text { - the product name (i.e., the brand name from the product label), preceded by } \\
\text { the word "Diluted" or "End-Use Concentrate" } \\
\text { - name of active ingredient(s) and percentage(s) of end-use dilution } \\
\text { - appropriate signal word, i.e., Poison, Danger, Warning, Caution (from prod- } \\
\text { uct label). } \\
\text { Verify that all pesticide dispersal equipment is kept in the BCE pest management } \\
\text { section. } \\
\text { (NOTE: Equipment at base golf courses that have certified pesticide applicators is } \\
\text { exempt from this requirement.) } \\
\text { Verify that all prime movers used for fogging, misting, dusting, or ultra-low vol- } \\
\text { ume (ULV) application are equipped with enclosed cabs and internal recycling air } \\
\text { conditioners. } \\
\text { Verify that the appropriate level of respiratory protection and other PPE is pro- } \\
\text { vided to the driver in addition to rolling up the windows. }\end{array}$ \\
\hline $\begin{array}{l}\text { PM.20.16.OCAF. [Deleted } \\
\text { March 2000]. }\end{array}$ & Deleted at the request of sponsor. \\
\hline $\begin{array}{l}\text { PM.20.17.OCAF. Insecti- } \\
\text { cides and termiticides must }\end{array}$ & $\begin{array}{l}\text { Verify that no insecticides or termiticides are injected into the soil to control sub- } \\
\text { terranean termites in any military buildings with subslab or in-slab heating, venti- }\end{array}$ \\
\hline
\end{tabular}




\section{COMPLIANCE CATEGORY: \\ PESTICIDE MANAGEMENT \\ Overseas ESOHCAMP}

\begin{tabular}{|c|}
\hline $\begin{array}{l}\text { REGULATORY } \\
\text { REQUIREMENTS: }\end{array}$ \\
\hline $\begin{array}{l}\text { not be injected into the soil to } \\
\text { control subterranean termites } \\
\text { in any military buildings with } \\
\text { subslab or in-slab heating, } \\
\text { ventilation, or air condition- } \\
\text { ing ducts (AFI 32-1053, para } \\
\text { 3.5.11.2) [Revised May 1999; } \\
\text { Citation Revised September } \\
\text { 2009]. }\end{array}$ \\
\hline $\begin{array}{l}\text { PM.20.18.OCAF. Installa- } \\
\text { tions must ensure the preven- } \\
\text { tion of damage to wildlife } \\
\text { from pesticide applications } \\
\text { (DOD 4145.19-R-1, para 3- } \\
417 \text { ). }\end{array}$ \\
\hline $\begin{array}{l}\text { PM.20.19.OCAF. [Deleted } \\
\text { July 2008] }\end{array}$ \\
\hline $\begin{array}{l}\text { PM.20.20.OCAF. The Golf } \\
\text { Course Manager and/or Su- } \\
\text { perintendent has specific re- } \\
\text { sponsibilities with regard to } \\
\text { pest management (AFI 32- } \\
\text { 1053, paras 3.9.1 through } \\
\text { 3.9.4) [Added May 1999; } \\
\text { Revised September 2009; } \\
\text { Citation Revised September } \\
\text { 2009]. }\end{array}$ \\
\hline
\end{tabular}

\section{REVIEWER CHECKS: \\ September 2009}

lation, or air-conditioning ducts.

(NOTE: This prohibition does not apply if permanent blocks are made to the ducts.)

Verify that basic precautions are observed that prevent drift of pesticides to the following:

- wooded areas occupied by wildlife

- land areas not intended for treatment

- fish-bearing waters.

Verify that the installation guards against runoff or washoff by rain from treated areas to fish-bearing waters.

Deleted at the request of the sponsor.

Verify that the Golf Course Manager and/or Superintendent:

- follows the guidance in AFI 32-1053, Pesticide Management and DODI 4150.07

- develops a golf course IPM plan for inclusion in the installation pest management plan

- consults with the installation pest management supervisor and the MAJCOM PMC on pest management issues.

- requests nonstandard pesticides for golf courses through the installation pest management coordinator and receives approval from the MAJCOM PMC before ordering or using nonstandard, locally purchased pesticides.

(NOTE: The requirements addressing nonstandard pesticides apply to use of government purchase cards [GPC] and all other forms of procurement.)

PM.20.21.0CAF. The IC must appoint a project coordinator for aerial pesticide spray projects (AFI 32-1074, para 3.8) [Added May 1999; Citation Revised September 2009].

PM.20.22.0CAF. The project coordinator for aerial spray projects.

Verify that the project coordinator meets these environmental requirements: 


\section{COMPLIANCE CATEGORY: PESTICIDE MANAGEMENT Overseas ESOHCAMP}

\begin{tabular}{|c|c|}
\hline $\begin{array}{l}\text { REGULATORY } \\
\text { REQUIREMENTS: }\end{array}$ & $\begin{array}{l}\text { REVIEWER CHECKS: } \\
\text { September } 2009\end{array}$ \\
\hline $\begin{array}{l}\text { pesticide spray projects must } \\
\text { meet specific environmental } \\
\text { requirements (AFI 32-1074, } \\
\text { para 3.8.1) [Added May 1999; } \\
\text { Revised September 2009; } \\
\text { Citation Revised September } \\
\text { 2009]. }\end{array}$ & $\begin{array}{l}\text { - ensures a spray map with well-delineated spray and no-spray area is in- } \\
\text { cluded in the Statement of Need } \\
\text { - ensures pre- and post-treatment surveys are all accomplished to evaluate } \\
\text { mission effectiveness (NOTE: Surveys are normally done by SG personnel } \\
\text { for medical-related pests and Base Civil Engineer (BCE) personnel for other } \\
\text { pests.) } \\
\text { - accomplishes environmental documentation, as required by the MAJCOM, } \\
\text { which includes an Aerial Application Statement of Need (NOTE: An Aerial } \\
\text { Application Statement of Need is required for all routine AF aerial spray } \\
\text { projects, including contracts. All routine projects by other Service Agencies } \\
\text { requiring use of AF aerial spray assets to control pests must also have an Ae- } \\
\text { rial Application Statement of Need.) } \\
\text { - coordinates with Aerospace Medicine to ensure medical, toxicological, and } \\
\text { occupational health concerns are fully addressed } \\
\text { - coordinates with MAJCOM, and, as needed, EEA for the host nation, and/or } \\
\text { local host nation authorities to ensure compliance with applicable host na- } \\
\text { tion environmental laws and standards (NOTE: This requirement is based } \\
\text { on AFI 32-1074, para 3.8.1.3.5.) } \\
\text { - requests legal review of project } \\
\text { - sends the Aerial Spray Statement of Need and environmental documentation } \\
\text { to the MAJCOM Pest Management Consultant, who has certification in } \\
\text { DOD Category } 11 \text {, Aerial Application, for approval } \\
\text { - ensures unused pesticides and empty pesticide containers receive proper } \\
\text { storage and disposal } \\
\text { - oversees amendments to the environmental documentation and Aerial Spray } \\
\text { Statement of Need when scope of project changes } \\
\text { - applies relevant FGS to the project. }\end{array}$ \\
\hline
\end{tabular}

(NOTE: AFI 32-1074, para 3.7.1.1.6 erroneously identifies application of the FGS as an administrative requirement.)

Verify that, in order to accomplish the above administrative and environmental tasks, the Project Coordinator forms a working group consisting of representatives from the following organizations:

- Aerospace Medicine (or Service Component equivalent)

- Public Health

- Bioenvironmental Engineering

- Civil Engineer Pest Management

- Installation Environmental Coordinator

- Public Affairs

- Legal

- Others deemed necessary.

PM.20.23.OCAF. Installation pest management personnel must not apply pesticides or perform other control proce-

Verify that no installation pest management personnel apply pesticides or perform other control procedures for nuisance pests unless such measures have been approved by the appropriate pest management consultant. 


\section{COMPLIANCE CATEGORY:}

PESTICIDE MANAGEMENT

Overseas ESOHCAMP

\begin{tabular}{|c|c|}
\hline $\begin{array}{l}\text { REGULATORY } \\
\text { REQUIREMENTS: }\end{array}$ & $\begin{array}{l}\text { REVIEWER CHECKS: } \\
\text { September } 2009\end{array}$ \\
\hline $\begin{array}{l}\text { dures for nuisance pests } \\
\text { unless such measures have } \\
\text { been approved by the appro- } \\
\text { priate pest management con- } \\
\text { sultant (DODI 4150.07, para } \\
\text { E4.7.5) [Added July 2008]. }\end{array}$ & \\
\hline
\end{tabular}




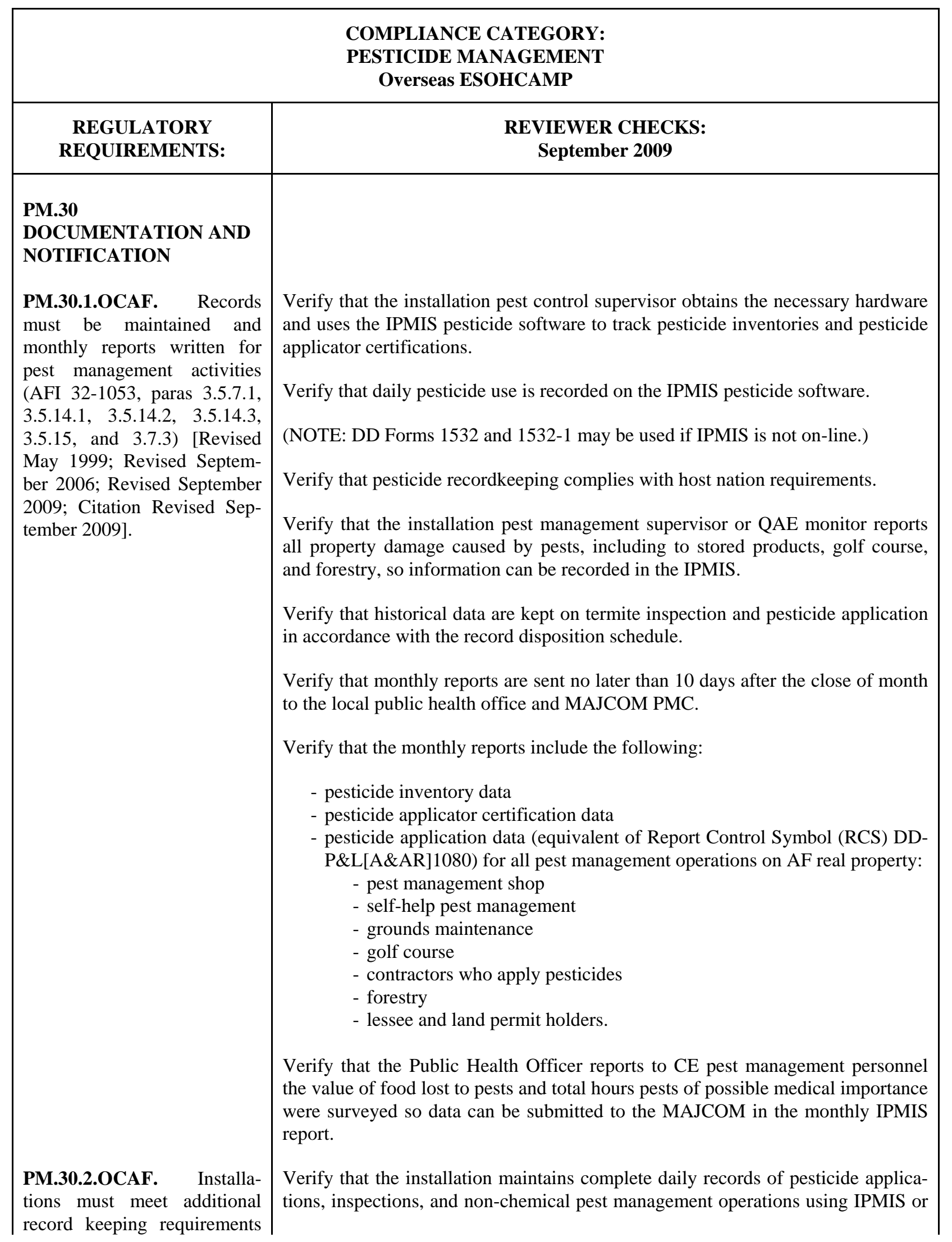




\section{COMPLIANCE CATEGORY: \\ PESTICIDE MANAGEMENT \\ Overseas ESOHCAMP}

\begin{tabular}{|c|c|}
\hline $\begin{array}{c}\text { REGULATORY } \\
\text { REQUIREMENTS: }\end{array}$ & $\begin{array}{l}\text { REVIEWER CHECKS: } \\
\text { September } 2009\end{array}$ \\
\hline $\begin{array}{l}\text { (DODI } 4150.07, \quad \text { paras } \\
\text { E4.11.1, E4.11.2, E4.11.4, } \\
\text { and E4.2.1.8) [Revised July } \\
\text { 2008; Citation Revised July } \\
\text { 2008]. }\end{array}$ & $\begin{array}{l}\text { a computer-generated equivalent. } \\
\text { Verify that that all pest management operations performed on the installation, } \\
\text { except those for personal relief, are recorded. } \\
\text { Verify that all records are properly maintained and reported as defined by the des- } \\
\text { ignated pest management consultant. } \\
\text { Verify that the records: } \\
\text { - account for all pest control operations and provide a historical record of pest } \\
\text { management operations and pesticide applications for each building, struc- } \\
\text { tures, or outdoor site } \\
\text { - include information on kinds, amounts, uses, dates, places of application, } \\
\text { and applicators' names and certification numbers } \\
\text { - include all in-house, housing, formally contracted, and Government pur- } \\
\text { chase card-procured pesticide application performed on the installation, in- } \\
\text { cluding work done on golf courses by nonappropriated fund activities, by } \\
\text { contract services, and as a part of outleases and land management and for- } \\
\text { estry programs, as well as the work performed by the installation pest man- } \\
\text { agement shop. }\end{array}$ \\
\hline
\end{tabular}

Verify that applications performed during military operations, excluding arthropod skin and clothing repellant, are recorded.

Verify that DD Form 1532, Pest Management Report, or an equivalent computer product, is produced monthly using the DD Form 1532-1 information.

Verify that these records are archived at the installation.

(NOTE: Pesticides applied by installation personnel for their own relief are excluded from the recordkeeping requirements.)

PM.30.3.OCAF. Notification must be made and/or approval received for certain application activities (AFI 321053, paras 3.5.9.4, 3.5.12.2, and 3.5.12.3) [Revised May 1999; Revised September 2009; Citation Revised September 2009].

PM.30.4.OCAF. The installation pest control supervisor must provide BES with specific documents (AFI 32-

Verify that PH and BES are notified prior to any pesticide applications in food preparation or consumption facilities, medical facilities, or child development centers.

Verify that the installation pest control supervisor coordinates all fumigations with installation medical, fire, security forces, and safety personnel.

Verify that no internal combustion or electrical power-driven spraying machines for aerosol or mist sprays are used inside buildings without approval from BES and the installation fire chief.

Verify that the installation pest control supervisor provides BES with:

- a hard copy of installation pesticide inventories

- pertinent MSDSs. 


\begin{tabular}{|c|c|}
\hline \multicolumn{2}{|r|}{$\begin{array}{c}\text { COMPLIANCE CATEGORY: } \\
\text { PESTICIDE MANAGEMENT } \\
\text { Overseas ESOHCAMP }\end{array}$} \\
\hline $\begin{array}{l}\text { REGULATORY } \\
\text { REQUIREMENTS: }\end{array}$ & $\begin{array}{l}\text { REVIEWER CHECKS: } \\
\text { September } 2009\end{array}$ \\
\hline $\begin{array}{l}\text { 1053, para 3.5.10.2) [Added } \\
\text { May 1999; Revised Septem- } \\
\text { ber 2009]. } \\
\text { PM.30.5.OCAF. The IPMC } \\
\text { must provide the fire depart- } \\
\text { ment with specific documents } \\
\text { (AFI 32-1053, para 3.5.12.1) } \\
\text { [Added May 1999; Revised } \\
\text { September 2009; Citation } \\
\text { Revised September 2009]. } \\
\text { PM.30.6.OCAF. Installa- } \\
\text { tions must have an integrated } \\
\text { pest management (IPM) plan } \\
\text { that meets content require- } \\
\text { ments (DODI 4150.07, paras } \\
\text { E4.2, E4.2.2, E4.7.11, and } \\
\text { E4.8.4) [Moved June 2003; } \\
\text { Revised July 2008; Citation } \\
\text { Revised July 2008]. }\end{array}$ & $\begin{array}{l}\text { Verify that the installation pest control supervisor provides the fire department } \\
\text { with a hard copy of pest management, self-help, and golf course building loca- } \\
\text { tion(s) and layout(s) indicating pesticide storage areas. } \\
\text { Verify that the installation pest control supervisor provides the fire department } \\
\text { annually with a hard copy of installation pesticide inventories and a hard copy of } \\
\text { MSDSs. } \\
\text { Verify that the installation has an IPM. } \\
\text { Verify that the IPM lists all program objectives according to potential or actual } \\
\text { impact on mission and readiness. } \\
\text { Verify that the IPM coordinator ensures compliance with the plan. } \\
\text { (NOTE: A suggested format for the plan appears in Enclosure } 5 \text { of DODI } \\
4150.07 \text {.) } \\
\text { Verify that the IPM plan is a well-defined, long-range, narrative document, as } \\
\text { outlined in Enclosure } 5 \text {. } \\
\text { Verify that, as part of the annual IPM plan update, pesticides are listed for ap- } \\
\text { proval, including EPA registration numbers, target pests, and sites that were ap- } \\
\text { proved by a certified pest management consultant for use in the IPM program. } \\
\text { Verify that the plan describes all health and safety measures, including posting } \\
\text { and notification, that will be taken prior to conducting operations to protect both } \\
\text { pest management personnel and others from pesticide exposure. } \\
\text { Verify that the plan describes any pest management operations with special envi- } \\
\text { ronmental considerations, such as those that may adversely affect water, endan- } \\
\text { gered or other protected species or their habitats, or involve the aerial application } \\
\text { of pesticides. } \\
\text { Verify that the plan identifies vector-borne disease threats and describes medical } \\
\text { department collaboration with the host nation for vector surveillance and control. } \\
\text { Verify that the plan includes golf course pest management operations where ap- } \\
\text { plicable. } \\
\text { Verify thantings and turf. } \\
\text { Verify that the plan describes the use of IPM for turf and ornamental pests as well }\end{array}$ \\
\hline
\end{tabular}




\section{COMPLIANCE CATEGORY: \\ PESTICIDE MANAGEMENT \\ Overseas ESOHCAMP}

\begin{tabular}{|c|c|}
\hline $\begin{array}{l}\text { REGULATORY } \\
\text { REQUIREMENTS: }\end{array}$ & $\begin{array}{l}\text { REVIEWER CHECKS: } \\
\text { September } 2009\end{array}$ \\
\hline $\begin{array}{l}\text { PM.30.7.OCAF. Installa- } \\
\text { tions must meet additional } \\
\text { requirements with regard to } \\
\text { pest management plans } \\
\text { (DODI 4150.07, paras } \\
\text { E4.2.1.1 through E4.2.1.7; } \\
\text { and AFI 32-1053, paras } \\
\text { 3.5.5.1 through 3.5.5.3, } \\
\text { 3.5.5.6 through 3.5.5.8, and } \\
\text { 3.5.7.2) [Revised May 1999; } \\
\text { Moved June 2003; Revised } \\
\text { July 2008; Citation Revised } \\
\text { July 2008; Revised September } \\
\text { 2009; Citation Revised Sep- } \\
\text { tember 2009]. }\end{array}$ & $\begin{array}{l}\text { as environmentally and economically beneficial land management practices, such } \\
\text { as the use of native plants, to reduce pesticide use. } \\
\text { Verify that the plan identifies areas within the installations that are considered } \\
\text { historic properties or cultural sites. } \\
\text { (NOTE: Personnel using pesticides on the installation need to understand the po- } \\
\text { tential impact that pesticide applications could have on historic properties and } \\
\text { cultural sites.) } \\
\text { Verify that the plan and budgets for the development and maintenance of the plan. } \\
\text { Verify that qualified personnel update the plan annually. } \\
\text { Verify that the IC has designated an IPM coordinator in writing to oversee the } \\
\text { plan. } \\
\text { Verify that the plan has been reviewed and technically approved by the designated } \\
\text { pest management consultant. } \\
\text { Verify that the plan has been approved, signed, and implemented by the IC. } \\
\text { Verify that the IPM coordinator formally coordinates, as appropriate, portions of } \\
\text { the plan as listed in Enclosure } 5 \text { and signs the cover sheet of the plan. } \\
\text { Verify that the plan has been coordinated with the ICRMP on the limitation of } \\
\text { pesticide usage. } \\
\text { Verify that the natural resource program manager reviews and cross-references } \\
\text { appropriate portions of the IPM plan for consistency with the goals and objectives } \\
\text { of current and planned installation programs, plans, and projects, including those } \\
\text { for: } \\
\text { Verify that the plan addresses annual requirements, such as labor and integrated- } \\
\text { pest management measures to be used against each pest. } \\
\text { - training and test ranges } \\
\text { applicators, bird airstrike hazard management } \\
\text { - golf course management } \\
\text { - grounds maintenance } \\
\text { - facilities construction site approvals } \\
\text { ather plans, programs, and projects. }\end{array}$ \\
\hline
\end{tabular}




\section{COMPLIANCE CATEGORY: \\ PESTICIDE MANAGEMENT \\ Overseas ESOHCAMP}

\begin{tabular}{c|c} 
REGULATORY & REVIEWER CHECKS: \\
REQUIREMENTS: & September 2009
\end{tabular}

Verify that the plan includes necessary attachments such as pesticide labels, MSDSs, golf course integrated pest management plans, and agreements between appropriate pesticide organizations and DOD.

Verify that any other unique pest management programs are included in this plan (e.g., BASH, invasive species management plans).

Verify that termite inspection frequency is included in the installation pest management plan.

Verify that, in preparing this plan, the IPMC follows the format guidance in DODI 4150.07, Enclosure 5, or alternate direction from MAJCOMs.

Verify that all activities such as ranges, radar sites, missile sites, recreation areas, and any other activities that employ pesticides are included in the plan.

Verify that the plan is updated annually.

Verify that the plan is completely revised and formally staffed every five years with the following individuals:

- installation natural resources manager and/or pest management coordinator.

- installation environmental coordinator.

- public health officer.

- bioenvironmental engineer officer.

- installation civil engineer.

- mission support group commander.

- wing commander.

Verify that an electronic copy of the plan is provided to the MAJCOM for approval by the PMC.

[Formerly checklist item number PM.10.6.OCAF.]

PM.30.8.OCAF. The responsibilities of pest management, natural resources, security forces, and veterinary or public health personnel with respect to stray and feral animals should be clearly outlined in the installation pest management plan (MP) [Added September 2009].
Verify that the responsibilities of pest management, natural resources, security forces, and veterinary or public health personnel with respect to stray and feral animals are clearly outlined in the installation pest management plan.

(NOTE: This MP is found in AFI 32-1053, para 3.5.12.4.) 


\begin{tabular}{|c|c|}
\hline \multicolumn{2}{|r|}{$\begin{array}{l}\text { COMPLIANCE CATEGORY: } \\
\text { PESTICIDE MANAGEMENT } \\
\text { Overseas ESOHCAMP }\end{array}$} \\
\hline $\begin{array}{l}\text { REGULATORY } \\
\text { REQUIREMENTS: }\end{array}$ & $\begin{array}{l}\text { REVIEWER CHECKS: } \\
\text { September } 2009\end{array}$ \\
\hline $\begin{array}{l}\text { PM.50 } \\
\text { STORAGE, MIXING, OR } \\
\text { PREPARATION OF } \\
\text { PESTICIDES }\end{array}$ & \\
\hline $\begin{array}{l}\text { PM.50.1.OCAF. [Deleted } \\
\text { March 2000] }\end{array}$ & $\begin{array}{l}\text { Deleted at the request of sponsor. } \\
\text { [Formerly checklist item number PM.40.2.OCAF.] }\end{array}$ \\
\hline $\begin{array}{l}\text { PM.50.2.OCAF. The instal- } \\
\text { lation pest management su- } \\
\text { pervisor must store contin- } \\
\text { gency pesticides under the } \\
\text { same controlled temperature, } \\
\text { security, and other conditions } \\
\text { as daily use pesticides (AFI } \\
\text { 32-1023, para 3.5.6.4) [Cita- } \\
\text { tion Revised May 1999; } \\
\text { Moved June 2003; Citation } \\
\text { Revised September 2009]. }\end{array}$ & $\begin{array}{l}\text { Verify that the installation pest management supervisor stores contingency pesti- } \\
\text { cides under the same controlled temperature, security, and other conditions as } \\
\text { daily use pesticides. } \\
\text { [Formerly checklist item number PM.40.2.OCAF.] }\end{array}$ \\
\hline $\begin{array}{l}\text { PM.50.3.OCAF. The instal- } \\
\text { lation pest management su- } \\
\text { pervisor must rotate contin- } \\
\text { gency pesticide stocks back to } \\
\text { pest management shop inven- } \\
\text { tories and replace them with } \\
\text { fresh chemicals as needed } \\
\text { (AFI 32-1023, para 3.5.6.5) } \\
\text { [Revised May 1999; Citation } \\
\text { Revised September 2009]. }\end{array}$ & $\begin{array}{l}\text { Verify that the installation pest management supervisor rotates contingency pesti- } \\
\text { cide stocks back to pest management shop inventories and replaces them with } \\
\text { fresh chemicals as needed. } \\
\text { [Formerly checklist item number PM.40.3.OCAF.] }\end{array}$ \\
\hline $\begin{array}{l}\text { PM.50.4.OCAF. [Revised } \\
\text { June 2000; Deleted July } \\
\text { 2008]. }\end{array}$ & Deleted at the request of the sponsor. \\
\hline $\begin{array}{l}\text { PM.50.5.OCAF. [Revised } \\
\text { June 2000; Deleted July } \\
\text { 2008]. }\end{array}$ & Deleted at the request of the sponsor. \\
\hline $\begin{array}{l}\text { PM.50.6.OCAF. } \quad \text { [Deleted } \\
\text { March 2000] }\end{array}$ & Deleted at the request of sponsor. \\
\hline
\end{tabular}




\begin{tabular}{|c|c|}
\hline \multicolumn{2}{|r|}{$\begin{array}{c}\text { COMPLIANCE CATEGORY: } \\
\text { PESTICIDE MANAGEMENT } \\
\text { Overseas ESOHCAMP }\end{array}$} \\
\hline $\begin{array}{l}\text { REGULATORY } \\
\text { REQUIREMENTS: }\end{array}$ & $\begin{array}{l}\text { REVIEWER CHECKS: } \\
\text { September } 2009\end{array}$ \\
\hline $\begin{array}{l}\text { PM.53 } \\
\text { STORAGE AND DISPLAY } \\
\text { OF RETAIL PESTICIDES }\end{array}$ & \\
\hline $\begin{array}{l}\text { PM.53.1.OCAF. Pesticides } \\
\text { must always be stored in strict } \\
\text { accordance with the label } \\
\text { instructions (AFPMB TG, } \\
\text { para 1, 1.3, and 1.9) [Added } \\
\text { September 2009]. }\end{array}$ & $\begin{array}{l}\text { Verify that pesticides are stored in strict accordance with the label instructions. } \\
\text { (NOTE: Pesticides packaged as personal or pet products may be handled like } \\
\text { other household supplies of similar hazard if they are kept in the manufacturer's } \\
\text { original consumer-safe packaging.) } \\
\text { (NOTE: Examples of these pesticides include: insect repellents; head lice treat- } \\
\text { ments; pet shampoos; dusts or tick/flea collars; and moth flakes, crystals or } \\
\text { cakes.) } \\
\text { Verify that any specific storage separation requirements on the product label are } \\
\text { followed. }\end{array}$ \\
\hline $\begin{array}{l}\text { PM.53.2.OCAF. Retailers are } \\
\text { permitted to sell only general- } \\
\text { use pesticides, appropriate for } \\
\text { use by uncertified, untrained } \\
\text { personnel (AFPMB TG, para } \\
\text { 1.1) [Added September } \\
\text { 2009]. }\end{array}$ & $\begin{array}{l}\text { Verify that only general-use pesticides, appropriate for use by uncertified, un- } \\
\text { trained personnel, are sold. } \\
\text { Verify that no pesticides that carry the label "Restricted Use" are sold. }\end{array}$ \\
\hline $\begin{array}{l}\text { PM.53.3.OCAF. Pesticides } \\
\text { must be protected from ex- } \\
\text { treme low and extreme high } \\
\text { temperatures (AFPMB TG, } \\
\text { para 1.2) [Added September } \\
\text { 2009]. }\end{array}$ & $\begin{array}{l}\text { Verify that pesticides are protected from extreme low and extreme high tempera- } \\
\text { tures. } \\
\text { Verify that the product labels are read to ensure that the appropriate requirements } \\
\text { are met. }\end{array}$ \\
\hline $\begin{array}{l}\text { PM.53.4.OCAF. Retailers } \\
\text { must determine and comply } \\
\text { with any and all applicable } \\
\text { local codes for pesticide han- } \\
\text { dling TG, para 1.4) [Added } \\
\text { September 2009]. }\end{array}$ & $\begin{array}{l}\text { Verify that retailers determine and comply with any and all applicable local codes } \\
\text { for pesticide handling. }\end{array}$ \\
\hline $\begin{array}{l}\text { PM.53.5.OCAF. Copies of } \\
\text { the pesticide storage location } \\
\text { floor plan must be kept in a } \\
\text { secure place, away from the } \\
\text { storage area, for emergency } \\
\text { responders (AFPMB TG, para } \\
\text { 1.5) [Added September }\end{array}$ & $\begin{array}{l}\text { Verify that copies of the pesticide storage location floor plan are kept in a secure } \\
\text { place, away from the storage area, for emergency responders. }\end{array}$ \\
\hline
\end{tabular}




\begin{tabular}{|c|c|}
\hline \multicolumn{2}{|r|}{$\begin{array}{l}\text { COMPLIANCE CATEGORY: } \\
\text { PESTICIDE MANAGEMENT } \\
\text { Overseas ESOHCAMP }\end{array}$} \\
\hline $\begin{array}{l}\text { REGULATORY } \\
\text { REQUIREMENTS: }\end{array}$ & $\begin{array}{l}\text { REVIEWER CHECKS: } \\
\text { September } 2009\end{array}$ \\
\hline 2009]. & \\
\hline $\begin{array}{l}\text { PM.53.6.OCAF. Workers } \\
\text { must be especially careful } \\
\text { when loading, unloading, and } \\
\text { moving pallets containing } \\
\text { pesticide products (TG para } \\
\text { 1.6) [Added September } \\
\text { 2009]. }\end{array}$ & $\begin{array}{l}\text { Verify that workers are especially careful when loading, unloading, and moving } \\
\text { pallets containing pesticide products. } \\
\text { (NOTE: Forklifts and other moving devices can severely damage packing materi- } \\
\text { als and cause leaks or spills.) }\end{array}$ \\
\hline $\begin{array}{l}\text { PM.53.7.OCAF. Any pesti- } \\
\text { cide item that is leaking or } \\
\text { otherwise damaged must be } \\
\text { immediately moved to an area } \\
\text { where its contents will be } \\
\text { fully contained (TG para 1.7) } \\
\text { [Added September 2009]. }\end{array}$ & $\begin{array}{l}\text { Verify that any pesticide item that is leaking or otherwise damaged is immediately } \\
\text { moved to an area where its contents will be fully contained. }\end{array}$ \\
\hline $\begin{array}{l}\text { PM.53.8.OCAF. Food, } \\
\text { drinks, medications, first aid } \\
\text { supplies, veterinary supplies, } \\
\text { clothing, and protective } \\
\text { equipment must be kept sepa- } \\
\text { rated from pesticide products } \\
\text { (TG para 1.8) [Added Sep- } \\
\text { tember 2009]. }\end{array}$ & $\begin{array}{l}\text { Verify that food, drinks, medications, first aid supplies, veterinary supplies, cloth- } \\
\text { ing, and protective equipment are kept separated from pesticide products. } \\
\text { (NOTE: It is particularly important to keep respiratory protection free from con- } \\
\text { tamination.) } \\
\text { Verify that, in the event of cross-contamination, the affected area and items are } \\
\text { promptly decontaminated. }\end{array}$ \\
\hline $\begin{array}{l}\text { PM.53.9.0CAF. Herbicides } \\
\text { must not be stored above } \\
\text { other types of pesti-cides (TG } \\
\text { para 1.10) [Added September } \\
\text { 2009]. }\end{array}$ & Verify that herbicides are not stored above other types of pesticides. \\
\hline $\begin{array}{l}\text { PM.53.10.OCAF. A current } \\
\text { pesticide inventory must be } \\
\text { kept for use in case of spills, } \\
\text { fire, weather-related damage, } \\
\text { or theft (TG para } 1.5 \text { and } \\
\text { 1.11) [Added September } \\
\text { 2009]. }\end{array}$ & $\begin{array}{l}\text { Verify that a current pesticide inventory is kept for use in case of spills, fire, } \\
\text { weather-related damage, or theft. } \\
\text { Verify that copies are kept at the storage site and are filed at the office for use by } \\
\text { local emergency responders. }\end{array}$ \\
\hline $\begin{array}{l}\text { PM.53.11.OCAF. Any pesti- } \\
\text { cide material that has been } \\
\text { spilled must be immediately } \\
\text { cleaned up by the appropriate } \\
\text { decontamination method (TG } \\
\text { para } 1.12 \text { and 4.1) [Added }\end{array}$ & $\begin{array}{l}\text { Verify that any pesticide material that has been spilled is immediately cleaned up } \\
\text { by the appropriate decontamination method. }\end{array}$ \\
\hline
\end{tabular}




\begin{tabular}{|c|c|}
\hline \multicolumn{2}{|r|}{$\begin{array}{l}\text { COMPLIANCE CATEGORY: } \\
\text { PESTICIDE MANAGEMENT } \\
\text { Overseas ESOHCAMP }\end{array}$} \\
\hline $\begin{array}{l}\text { REGULATORY } \\
\text { REQUIREMENTS: }\end{array}$ & $\begin{array}{l}\text { REVIEWER CHECKS: } \\
\text { September } 2009\end{array}$ \\
\hline $\begin{array}{l}\text { September 2009]. } \\
\text { PM.53.12.0CAF. Material } \\
\text { Safety Data Sheets (MSDSs) } \\
\text { must be kept in an accessible } \\
\text { location in accordance with } \\
29 \text { Code of Federal Regula- } \\
\text { tions (CFR) 1910.1200 (TG } \\
\text { para 1.14) [Added September } \\
\text { 2009]. }\end{array}$ & $\begin{array}{l}\text { Verify that MSDSs are kept in an accessible location in accordance with } 29 \text { CFR } \\
1910.1200 .\end{array}$ \\
\hline $\begin{array}{l}\text { PM.53.13.OCAF. Pesticides } \\
\text { must be purchased in quanti- } \\
\text { ties for one season of sale } \\
\text { only (TG para 1.15) [Added } \\
\text { September 2009]. }\end{array}$ & $\begin{array}{l}\text { Verify that, to minimize off-season storage and associated hazards, only quantities } \\
\text { of pesticides required for one season of sale are purchased. }\end{array}$ \\
\hline $\begin{array}{l}\text { PM.53.14.OCAF. Inventory } \\
\text { must be rotated to ensure that } \\
\text { the oldest products are sold } \\
\text { first, before their shelf-life } \\
\text { expires (TG para 1.16) } \\
\text { [Added September 2009]. }\end{array}$ & $\begin{array}{l}\text { Verify that inventory is rotated to ensure that the oldest products are sold first } \\
\text { before their shelf-life expires. } \\
\text { (NOTE: This also minimizes chances of leaks from wear and tear on containers.) }\end{array}$ \\
\hline $\begin{array}{l}\text { PM.53.15.OCAF. Retail fa- } \\
\text { cilities with bulk quantities of } \\
\text { pesticides that are not placed } \\
\text { on shelves for retail sale must } \\
\text { be stored in a dedicated stor- } \\
\text { age area (AFPMB TG, para 2, } \\
2.1 \text {, and 2.2) [Added Septem- } \\
\text { ber 2009]. }\end{array}$ & $\begin{array}{l}\text { Verify that, in retail facilities with bulk quantities of pesticides that are not placed } \\
\text { on shelves for retail sale, such pesticides are stored in a dedicated storage area. } \\
\text { (NOTE: Where a distribution system such as DeCA's Frequent Delivery System } \\
\text { is used, in which the retail facility orders only what they need for quick turnover } \\
\text { and pesticides are limited to smaller quantities of general-use products in con- } \\
\text { sumer-safe packaging, separate bulk storage at the retail facility is not required.) } \\
\text { (NOTE: National Fire Protection Association Code } 434 \text { for the storage of pesti- } \\
\text { cides does not apply where storage is } 1,000 \text { gal [3,790 L] or } 10,000 \text { pounds ( } 4,540 \\
\text { kg) or less, or where pesticide storage time in a calendar year is } 14 \text { days or less, } \\
\text { with the exception of hazard identification - hazardous materials must always be } \\
\text { clearly identified.) }\end{array}$ \\
\hline
\end{tabular}




\section{COMPLIANCE CATEGORY: \\ PESTICIDE MANAGEMENT \\ Overseas ESOHCAMP}

\section{REGULATORY REQUIREMENTS:}

PM.53.16.0CAF. Pesticide storage must be sited in accordance with specific requirements (AFPMB TG, para 2.3, and 2.4.1 through 2.4.4) [Added September 2009].

PM.53.17.OCAF. If required by regulations, such as NFPA Code 434, National Fire Protection Association Code for the Storage of Pesticides, pesticides must be stored in an approved lockable storage unit (AFPMB TG, para 2.4) [Added September 2009].

PM.53.18.0CAF. If the storage unit is separate from other structures, it must be fenced in and the gate kept locked between accesses (AFPMB TG, para 2.4.5) [Added September 2009].

PM.53.19.0CAF. Pesticide storage must be located so that it is accessible to delivery

\section{REVIEWER CHECKS: September 2009}

Verify that pesticide storage is sited so as to prevent physical damage to the products from weather, puncturing, rupturing, or other causes

(NOTE: Even small amounts of moisture can rust metal containers and disintegrate paper or cardboard packaging, making labels unreadable or causing them to detach. Water and moisture may cause dry formulations to become unusable hazardous waste that can be expensive to discard.)

(NOTE: Pesticides released from compromised containers can contaminate the storage area and other parts of the structure or vicinity, necessitating expensive cleanup.)

Verify that all pesticide storage units are sited in locations that are not subject to flooding by overflow, runoff or tides, and with as little runoff area as possible to prevent contamination of surface waters in case of a leak or spill.

Verify that storage units are positioned as far as practical from other structures that could threaten the storage if they should catch fire, and vice versa.

Verify that storage units are positioned at least 100 feet away and downslope from surface waters and wells, animal feeding stations or shelters, food or feed storage, and dwellings.

Verify that storage units are positioned with regard to the direction of prevailing winds to minimize potential for contamination downwind in the event of a pesticide spill or fire.

Verify that, if required by regulations such as NFPA Code 434, National Fire Protection Association Code for the Storage of Pesticides, pesticides are stored in an approved lockable storage unit.

Verify that, if the storage unit is separate from other structures, it is fenced in and the gate kept locked between accesses.

Verify that pesticide storage is located so that it is accessible to delivery and pickup vehicles, and to emergency vehicles, but not in the way of unrelated ve- 


\begin{tabular}{|c|c|}
\hline \multicolumn{2}{|r|}{$\begin{array}{l}\text { COMPLIANCE CATEGORY: } \\
\text { PESTICIDE MANAGEMENT } \\
\text { Overseas ESOHCAMP }\end{array}$} \\
\hline $\begin{array}{l}\text { REGULATORY } \\
\text { REQUIREMENTS: }\end{array}$ & $\begin{array}{l}\text { REVIEWER CHECKS: } \\
\text { September } 2009\end{array}$ \\
\hline $\begin{array}{l}\text { and pickup vehicles, and to } \\
\text { emergency vehicles, but not } \\
\text { in the way of unrelated ve- } \\
\text { hicular traffic (AFPMB TG, } \\
\text { para 2.4.6) [Added September } \\
\text { 2009]. }\end{array}$ & hicular traffic. \\
\hline $\begin{array}{l}\text { PM.53.20.OCAF. If pesticide } \\
\text { storage must be in an area } \\
\text { with vehicular traffic, barriers } \\
\text { must be used to prevent dam- } \\
\text { age by vehicles (AFPMB TG, } \\
\text { para 2.4.6) [Added September } \\
\text { 2009]. }\end{array}$ & $\begin{array}{l}\text { Verify that, where pesticide storage must be in an area with vehicular traffic, bar- } \\
\text { riers such as posts are used to prevent damage by vehicles. }\end{array}$ \\
\hline $\begin{array}{l}\text { PM.53.21.OCAF. Pesticide } \\
\text { storage space must be kept to } \\
\text { a minimum (AFPMB TG, } \\
\text { para 2.4.7) [Added September } \\
\text { 2009]. }\end{array}$ & $\begin{array}{l}\text { Verify that the amount of storage space is kept to a minimum, but large enough to } \\
\text { handle what one might reasonably sell, as well as excess held for turn-in, and } \\
\text { damaged containers and cleanup material for proper disposal. } \\
\text { (NOTE: Review installation-specific requirements with respect to materials held } \\
\text { for disposal.) }\end{array}$ \\
\hline $\begin{array}{l}\text { PM.53.22.0CAF. Access to } \\
\text { pesticide storage must be lim- } \\
\text { ited to authorized persons } \\
\text { (AFPM TG, para 2.4.8) } \\
\text { [Added September 2009]. }\end{array}$ & $\begin{array}{l}\text { Verify that access to pesticide storage is limited to authorized persons. } \\
\text { (NOTE: Unauthorized individuals include: workers who do not handle pesticides, } \\
\text { visitors, children, etc.) }\end{array}$ \\
\hline $\begin{array}{l}\text { PM.53.23.OCAF. Pesticide } \\
\text { storage units, structures, or } \\
\text { fences are subject to specific } \\
\text { signager requirements } \\
\text { (AFPMB TG, para 2.4.9, 2.5, } \\
\text { and 2.6) [Added September } \\
\text { 2009]. }\end{array}$ & $\begin{array}{l}\text { Verify that signs are posted on the storage unit, structure, or fence to mark pesti- } \\
\text { cide storage and warn people to stay out: "Danger - Pesticides / Unauthorized } \\
\text { Persons KEEP OUT." } \\
\text { Verify that emergency telephone numbers are posted for reporting pesticide spills } \\
\text { or accidental release. } \\
\text { Verify that at least one telephone number is posted for emergency response (fire, } \\
\text { rescue, etc.). } \\
\text { (NOTE: Poison Control Center telephone numbers are a good additional choice.) } \\
\text { Verify that there are multiple contacts for reporting pesticide-related accidents, in } \\
\text { case the contact is a victim of exposure or too involved with other issues to ad- } \\
\text { dress pesticide concerns. } \\
\text { Verify that there are signs clearly indicating the location of the nearest accessible }\end{array}$ \\
\hline
\end{tabular}




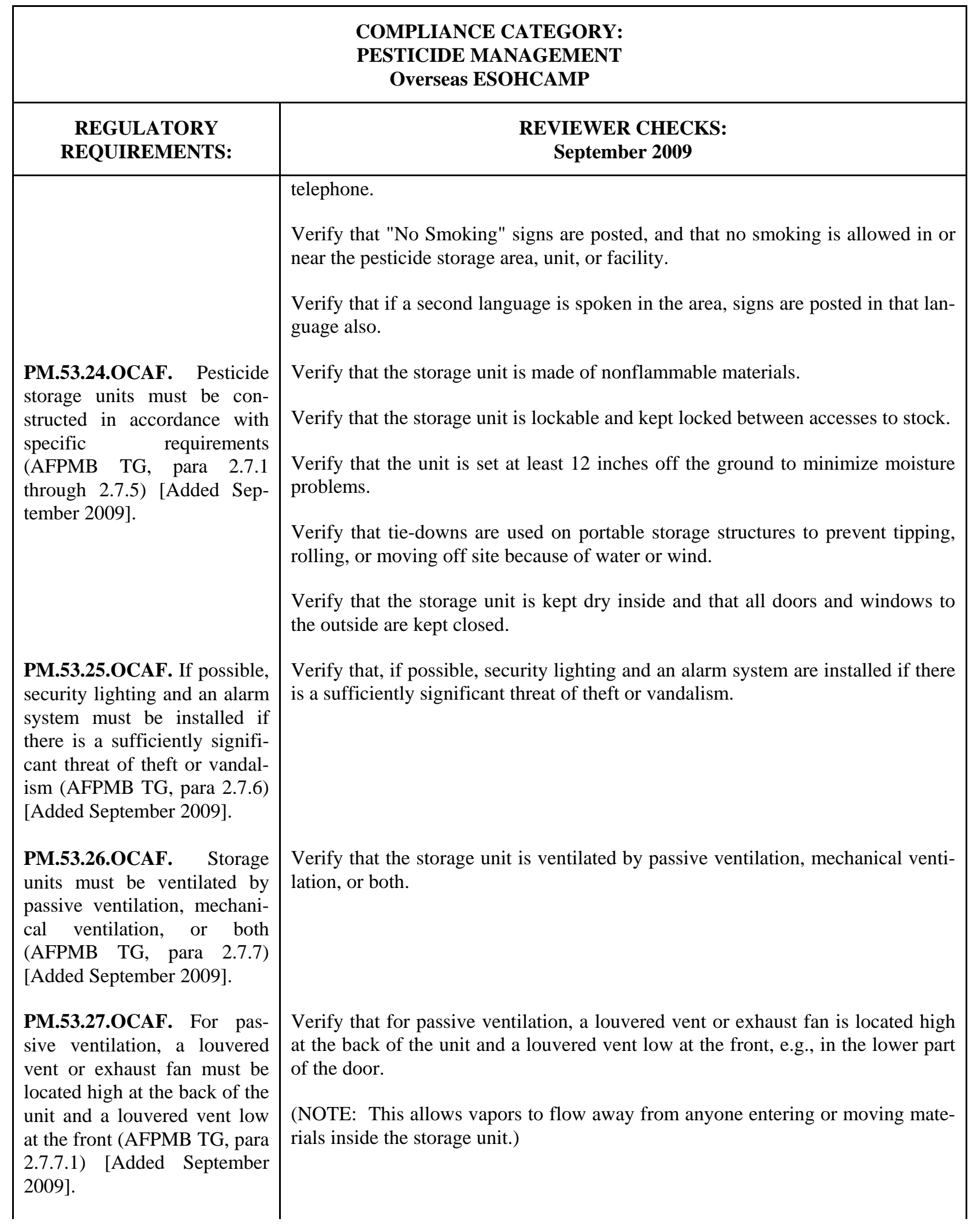




\section{COMPLIANCE CATEGORY: \\ PESTICIDE MANAGEMENT \\ Overseas ESOHCAMP}

\section{REGULATORY REQUIREMENTS:}

PM.53.28.0CAF. For mechanical ventilation, an exhaust fan that meets specific standards must be used (AFPMB TG, para 2.7.7.2) [Added September 2009].

PM.53.29.OCAF. Lighting must enable workers to read labeling, see leaks and damaged containers, clean up spills, and note inventory changes (AFPMB TG, para 2.7.10) [Added September 2009].

PM.53.30.0CAF. Flooring must meet specific requirements (AFPMB TG, para 2.7.11) [Added September 2009].

PM.53.31.OCAF. Materials used for shelving must meet specific requirements (AFPMB TG, para 2.7.12 and 2.7.13) [Added September 2009].

PM.53.32.0CAF. Facilities that have a built-in sump or that drain to a sump must meet specific requirements (AFPMB TG, para 2.7.14) [Added September 2009].

PM.53.33.0CAF. Pesticides destined for retail sale must be displayed in a manner that protects health and safety

\section{REVIEWER CHECKS: September 2009}

Verify that, for mechanical ventilation, an exhaust fan is used that is capable of changing the air in the unit at least once every six minutes, increasing to once every three minutes when pesticide handlers are in the unit.

(NOTE: Explosion-proof wiring and switches are recommended.)

Verify that the fan is wired to the light switch so that the fan is always on or increases speed whenever pesticide handlers are in the unit.

Verify that the fan is wired to a thermostat set to turn it on when the temperature reaches between $75^{\circ}$ and $85^{\circ} \mathrm{F}$, if possible.

Verify that fan switches are weatherproof and are located on the outside of the storage unit so the unit can be ventilated before entry.

Verify that adequate lighting is installed to enable workers to read labeling, see leaks and damaged containers, clean up spills, and note inventory changes.

(NOTE: Explosion-proof wiring and switches are recommended.)

Verify that floors are non-absorbing metal, sealed concrete, epoxy-coated metal, wood or concrete, no-wax sheet flooring, or some other easily cleaned, nonabsorbent material.

Verify that non-absorbing materials are used for shelving, such as metal with a lip to contain spills, or leak-proof plastic trays.

Verify that a continuous internal structural lip or curb of sufficient height is installed to prevent spills from overflowing and getting outside the building.

Determine whether the facility has a built-in sump pump or a drain to a sump.

Verify that any external sump is located next to the building instead of under it.

Verify that sumps are protected from filling with water from rain or runoff.

Verify that pesticides destined for retail sale are displayed in a manner that protects health and safety. 


\section{COMPLIANCE CATEGORY: \\ PESTICIDE MANAGEMENT \\ Overseas ESOHCAMP}

\section{REGULATORY REQUIREMENTS:}

(AFPMB TG, para 3.0) [Added September 2009].

PM.53.34.0CAF. All pesticide products offered for sale must be in the registrant's approved container with the registrant's labeling permanently attached, and in good, serviceable condition (AFPMB TG, para 3.1) [Added September 2009].

PM.53.35.OCAF. Workers must be especially careful when loading, unloading, and moving pesticide products (AFPMB TG, para 3.2) [Added September 2009].

PM.53.36.OCAF. Display areas must be regularly checked for damaged packaging or displays (AFPMB TG, para 3.3) [Added September 2009].

PM.53.37.OCAF. Poisonous or toxic materials must be stored and displayed for retail sale in such a way that they cannot contaminate food, equipment, utensils, linens, and single-service and singleuse articles (AFPMB TG, para 3.4) [Added September 2009].

\section{REVIEWER CHECKS: September 2009}

(NOTE: Marketing priorities shall be secondary considerations.)

Verify that all pesticide products offered for sale are in the registrant's approved container with the registrant's labeling permanently attached, and in good, serviceable condition.

Verify that punctured, rusted, or leaking pesticide containers and pesticide products with unreadable labels are immediately removed from the sales area.

Verify that, if the label states "Keep Out of Reach of Children," the pesticide is not be readily accessible to children in the sales or storage area.

(NOTE: EPA guidance on the safe storage of pesticides states "Child resistant does not mean child proof, so you still must be extra careful to store properly out of children's reach - those products that are sold in child-resistant packaging.")

Verify that workers are especially careful when loading, unloading, and moving pesticide products.

(NOTE: A separate safety reminder for pesticide handling actions can help increase awareness and reduce accidents.)

(NOTE: Contract stocking personnel are held to the same standards that apply to federal employees.)

Verify that display areas are regularly checked for damaged packaging or displays.

Verify that poisonous or toxic materials are stored and displayed for retail sale in such a way that they cannot contaminate food, equipment, utensils, linens, and single-service and single-use articles.

(NOTE: This can be accomplished by separating the poisonous or toxic materials through spacing or partitioning, and by locating the poisonous or toxic materials in an area that does not overlie the above items.)

Verify that pesticide products are not displayed adjacent to, beside or above, fresh, soft, and non-prepackaged or loosely packaged food items, such as bread, pastries, vegetables, fresh meats, pasta, and candy.

(NOTE: General-use pesticides may be displayed back-to-back with items on ad- 


\section{COMPLIANCE CATEGORY: \\ PESTICIDE MANAGEMENT \\ Overseas ESOHCAMP}

\begin{tabular}{|c|c|}
\hline $\begin{array}{l}\text { REGULATORY } \\
\text { REQUIREMENTS: }\end{array}$ & $\begin{array}{l}\text { REVIEWER CHECKS: } \\
\text { September } 2009\end{array}$ \\
\hline $\begin{array}{l}\text { PM.53.38. OCAF. Pesticides } \\
\text { must be grouped by type (in- } \\
\text { secticide, herbicide, fungi- } \\
\text { cide, etc.) to prevent cross } \\
\text { contamination (AFPMB TG, } \\
\text { para 3.5) [Added September } \\
2009 \text { ]. }\end{array}$ & $\begin{array}{l}\text { jacent aisles, if there is a solid nonporous barrier between aisle displays.) } \\
\text { (NOTE: Pesticide products in their original consumer-safe packaging may be } \\
\text { displayed adjacent to non-food personal/animal-use items [such as toiletries, sun- } \\
\text { screen, clothing, toys, kitty litter, etc.] if separated by non-continuous shelving or } \\
\text { a solid, nonporous barrier [plastic, Plexiglas, metal, etc.] that prevents the hori- } \\
\text { zontal flow of material. Items displayed on a pegboard or clip-strips next to a } \\
\text { shelf also meet this criterion.) } \\
\text { Verify that pesticide products are not displayed above food or animal feed prod- } \\
\text { ucts where an undetected leak could result in contamination of those products. } \\
\text { Verify that liquid formulations are placed below dry formulations. } \\
\text { Verify that pesticides are grouped by type (insecticide, herbicide, fungicide, etc.) } \\
\text { to prevent cross contamination. }\end{array}$ \\
\hline $\begin{array}{l}\text { PM.53.39.OCAF. Herbicides } \\
\text { must not be displayed above } \\
\text { other types of pesticides } \\
\text { (AFPMB TG, para 3.6) } \\
\text { [Added September 2009]. }\end{array}$ & Verify that herbicides are not displayed above other types of pesticides. \\
\hline $\begin{array}{l}\text { PM.53.40.0CAF. Pesticides } \\
\text { must be separately displayed } \\
\text { from flammables, such as } \\
\text { starter fluid, lighter fluid, lan- } \\
\text { tern fuel, and similar products } \\
\text { (AFPMB TG, para 3.7) } \\
\text { [Added September 2009]. }\end{array}$ & $\begin{array}{l}\text { Verify that pesticides are displayed separately from flammables, such as starter } \\
\text { fluid, lighter fluid, lantern fuel, and similar products. }\end{array}$ \\
\hline $\begin{array}{l}\text { PM.53.41.OCAF. All pesti- } \\
\text { cide containers must be off } \\
\text { the floor, preferably on exist- } \\
\text { ing shelves (AFPMB TG, } \\
\text { para 3.8) [Added September } \\
\text { 2009]. }\end{array}$ & $\begin{array}{l}\text { Verify that all pesticide containers are placed off the floor, preferably on existing } \\
\text { shelves. } \\
\text { Verify that, if pallets are used for temporary display, they are protected from traf- } \\
\text { fic by kick plates or other barrier devices around the display. }\end{array}$ \\
\hline $\begin{array}{l}\text { PM.53.42.0CAF. Pesticide } \\
\text { containers must be secured to } \\
\text { prevent rolling and sliding } \\
\text { and to reduce breaking and } \\
\text { leaking (AFPMB TG, para }\end{array}$ & $\begin{array}{l}\text { Verify that pesticide containers are secured to prevent rolling and sliding and re- } \\
\text { duce breaking and leaking. }\end{array}$ \\
\hline
\end{tabular}




\section{COMPLIANCE CATEGORY: \\ PESTICIDE MANAGEMENT \\ Overseas ESOHCAMP}

\begin{tabular}{|l|}
\hline \multicolumn{2}{|c|}{ REGULATORY } \\
REQUIREMENTS: \\
\hline 3.9) [Added September \\
2009]. \\
PM.53.43.OCAF. Pesticide \\
containers, especially glass \\
and bags, must be protected \\
from breakage, puncture, \\
tears, and degradation due to \\
climatic factors (AFPMB TG, \\
para 3.10) [Added September \\
2009].
\end{tabular}

PM.53.44.OCAF. Purchasing and stocking pesticide products that come in glass or other frangible containers must be avoided (AFPMB TG, para 3.11) [Added September 2009].

PM.53.45.OCAF. Spill control supplies and personnel protective equipment must be kept in or immediately accessible to the pesticide display area (AFPMB TG, para 4.2) [Added September 2009].

PM.53.46.OCAF. OSHA guidelines for number and placement of fire extinguishers, must be followed in coordination with the local fire protection authority (AFPMB TG, para 1.13 and 4.3) [Added September 2009].

PM.53.47.OCAF. Each DOD retail establishment's Hazard Communication (HAZCOM) program must include a statement on how workers will be informed of hazards connected with non-routine jobs (AFPMB TG, para 4.4)

\section{REVIEWER CHECKS: September 2009}

Verify that, if pesticide packages must be kept outside for display, a roof is provided over the storage area and plastic covers used for pallets to minimize weather and sunlight damage of the packaging materials.

Verify that pesticide product labels are consulted to determine specific storage requirements.

(NOTE: The label is the law.)

Verify that pesticide containers are kept out of direct sunlight, and glass or aerosol containers kept out of windows, even temporarily.

Verify that pesticide products that come in glass or other frangible containers are not purchased or stocked.

Verify that failure-resistant packaging is used to the greatest extent possible.

Verify that, if glass containers are purchased, they are placed on the lowest level to minimize damage from falls or drops.

Verify that spill control supplies and personnel protective equipment are kept in or immediately accessible to the pesticide display area for emergency spill containment.

(NOTE: Cleanup materials become hazardous waste for disposal purposes.)

Verify that OSHA guidelines are followed for the number and placement of fire extinguishers, in coordination with the local fire protection authority.

Verify that each DOD retail establishment's Hazard Communication (HAZCOM) program includes a statement on how workers will be informed of hazards connected with non-routine jobs.

(NOTE: Dealing with accidental spills of pesticide products is an example of a non-routine job.) 


\begin{tabular}{|l|c|}
\hline \multicolumn{2}{|c|}{$\begin{array}{c}\text { COMPLIANCE CATEGORY: } \\
\text { PESTICIDE MANAGEMENT } \\
\text { Overseas ESOHCAMP }\end{array}$} \\
\hline \multicolumn{1}{|c|}{ REGULATORY } \\
REQUIREMENTS: & $\begin{array}{c}\text { REVIEWER CHECKS: } \\
\text { September 2009 }\end{array}$ \\
\hline $\begin{array}{l}\text { [Added September 2009]. } \\
\text { PM.53.48.OCAF. Retailers } \\
\text { must coordinate in advance } \\
\text { with local firefighting re- } \\
\text { sponders to ensure that they } \\
\text { are prepared to respond ap- } \\
\text { propriately to a fire at the } \\
\text { facility (AFPMB TG, para } \\
\text { 4.6) [Added September } \\
\text { 2009]. }\end{array}$ & $\begin{array}{l}\text { Verify that advance coordination takes place with local firefighting responders to } \\
\text { ensure that they are prepared to respond appropriately to a fire at the facility. }\end{array}$ \\
\hline
\end{tabular}




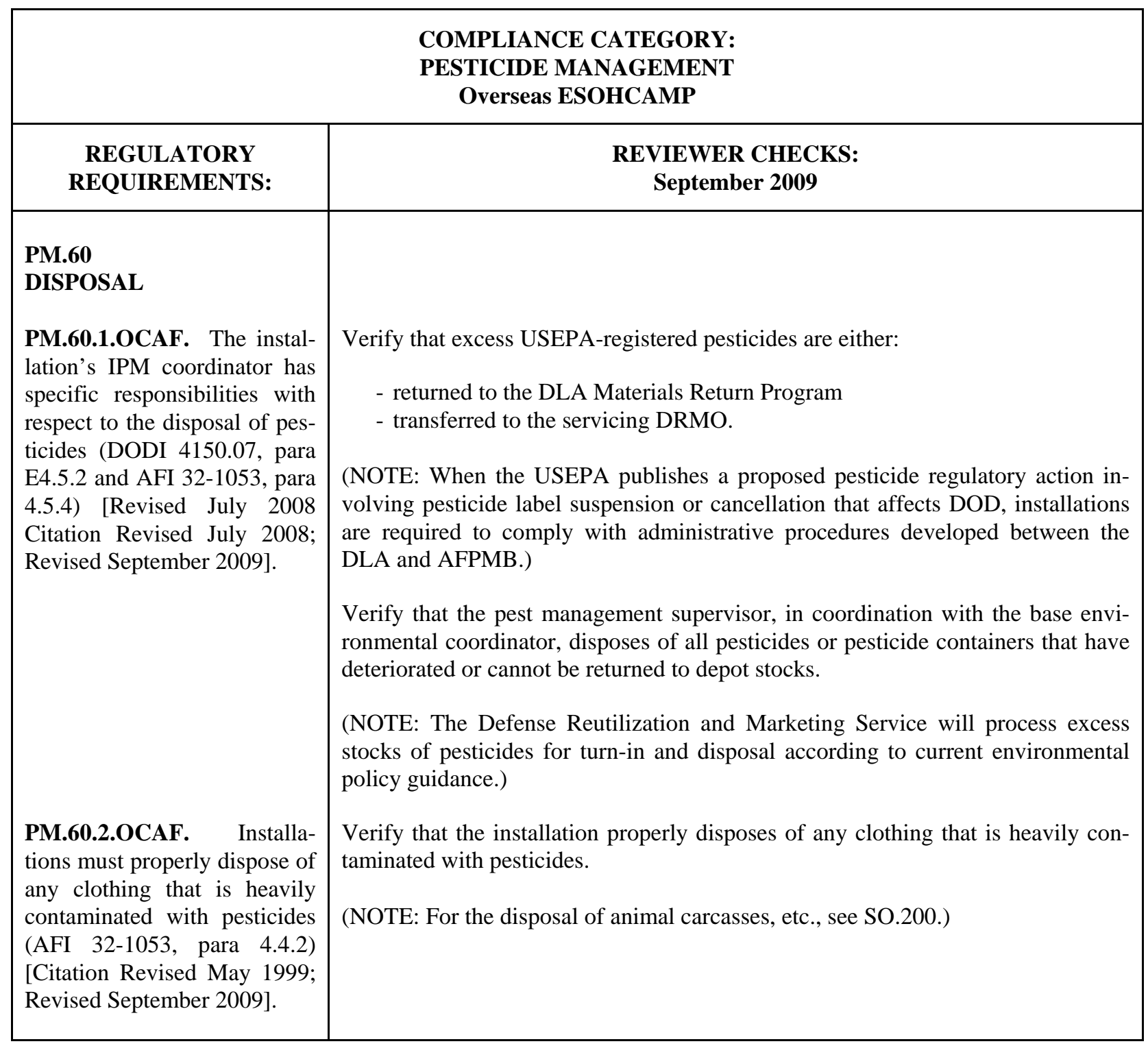




\section{Appendix 7-1}

\section{Pesticides and Pest Control Items Available to Adult MH Occupants and Building Managers Under the Self-Help Program}

(Air Force Self-Help Pest Management Program for Military Housing (MH) Occupants and Building Managers, HQ AFCESA/CES, 28 September 1998, para 6)

a.The following items are approved for use in the Air Force (AF) self-help pest control program, and some or all of the items will be available on all AF installations with $\mathrm{MH}$ and other facilities.

(1) 6840-01-224-1269 Insecticide, fipronil, cockroach, large size (Combat Quick Kill) 8 bait stations/box/12 boxes, D 85.03 PG.

(2) 6840-01-180-0167 Insecticide, fipronil, cockroach, regular size (Combat Quick Kill) 12 bait stations/box/12 boxes, D $80.28 \mathrm{PG}$.

(3) 6840-01-298-1122 Insecticide, fipronil (MaxForce Ant Bait) 96 stations, D 91.68 PG.

(4) 6840-01-287-3913 Insecticide, Hydramethylnon (Amdro Fire Ant Bait) (24) 6-oz bottle, L ----- PG.

(5) 6840-01-377-7113 Herbicide, Isopropylamine salt of gylphosate, 0.96 percent, water-soluble liquid (Roundup Ready-to-Use) 24-oz pump spray bottle, D 5.83 BT.

(6) 6840-01-377-7110 Herbicide, 2,4-Dichlorophenoxy-acetic acid (2,4-D), 0.4 percent, water-soluble liquid (amine salt form) (Weed-B-Gone) 24-oz pump spray bottle, D 6.21 BT.

(7) 6840-00-459-2443 Insecticide, Pyrethrins, allethrin, d-phenothrin, or resmethrin, aerosol (PT 515 Wasp Freeze \& Hornet Killer/Wasp Stopper II Plus/Wasp \& Hornet Killer II) (12) 12-oz cans, D 43.56 BX.

(8) 6840-01-067-2137 Insecticide, D-trans Allethrin and Resmethrin, 0.15 percent and 0.2 percent minimum, respectively, aerosol 11-oz can, D $1.81 \mathrm{CN}$.

(9) 3740-00-252-3384 Mouse Trap, Spring, Model CANTMISS or GGG-M-550, WD base, with 4-way release, 4” X 2” X 0.5”, 98878 G 5.36 DZ.

(10) 3740-01-096-1632 Trap, Insect, Sticky Trap, Roach, box of 24 traps, 5” X 3.5” X 2”, D 65.90 BX.

(11) 3740-01-240-6170 Trap, Rodent, Glue, Woodstream Model M-319 (Holdfast), 9” X 9” X 4”, wt 1 lb, 24 traps per box, $84155 \mathrm{D} 23.78 \mathrm{BX}$.

(12) 3740-00-252-3383 Swatter, Fly, Model Plasti-Swat 51, 18”lg X 4”w X 0.5”, wt 5 oz, 12 per package, 54749 G 2.89 PG.

b. The pesticides above are among the safest on the market. If used according to label directions, the potential human hazard from these pesticides is slight. 


\section{Appendix 7-2}

\section{Restricted-Use Pesticides}

(40 Code of Federal Regulation (CFR) 152.175)

The following uses of pesticide products containing the active ingredients specified below have been classified for restricted use and are limited to use by or under the direct supervision of a certified applicator.

\begin{tabular}{|c|c|c|c|c|}
\hline $\begin{array}{c}\text { Active } \\
\text { Ingredient }\end{array}$ & Formulation & Use Pattern & Classification $^{1}$ & $\begin{array}{c}\text { Criteria } \\
\text { Influencing } \\
\text { Restriction } \\
\end{array}$ \\
\hline Acrolein & $\begin{array}{l}\text { As sole active ingredient. } \\
\text { No mixtures registered. }\end{array}$ & All uses & Restricted & $\begin{array}{l}\text { Inhalation hazard to } \\
\text { humans. Residue ef- } \\
\text { fects on avian species } \\
\text { and aquatic organisms. }\end{array}$ \\
\hline Aldicarb & $\begin{array}{l}\text { As sole active ingredient. } \\
\text { No mixtures registered. }\end{array}$ & $\begin{array}{l}\text { Ornamental uses } \\
\text { (indoor and out- } \\
\text { door). } \\
\text { Agricultural crop } \\
\text { uses. } \\
\end{array}$ & $\begin{array}{l}\text { do } \\
\text { Under further } \\
\text { evaluation. }\end{array}$ & $\begin{array}{l}\text { Other hazards- } \\
\text { accident history. }\end{array}$ \\
\hline $\begin{array}{l}\text { Aluminum } \\
\text { phosphide }\end{array}$ & $\begin{array}{l}\text { As sole active ingredient. } \\
\text { No mixtures registered. }\end{array}$ & do & do & $\begin{array}{l}\text { Inhalation hazard to } \\
\text { humans. }\end{array}$ \\
\hline $\begin{array}{l}\text { Azinphos } \\
\text { methyl }\end{array}$ & $\begin{array}{l}\text { All liquids with a concen- } \\
\text { tration greater than } 13.5 \\
\text { percent. } \\
\text { All other formulations. }\end{array}$ & do & $\begin{array}{l}\text { do } \\
\text { Under further } \\
\text { evaluation. }\end{array}$ & do \\
\hline Carbofuran & $\begin{array}{l}\text { All concrete suspensions } \\
\text { and wettable powders } 40 \\
\text { percent and greater. } \\
\text { All granular formulations. } \\
\text { All granular and fertilizer } \\
\text { formulations. }\end{array}$ & $\begin{array}{l}\text { do } \\
\text { Rice } \\
\text { All uses except } \\
\text { rice. }\end{array}$ & $\begin{array}{l}\text { do } \\
\text { Under evaluation. } \\
\text { do }\end{array}$ & $\begin{array}{l}\text { Acute inhalation } \\
\text { toxicity. }\end{array}$ \\
\hline Chloropicrin & $\begin{array}{l}\text { All formulations greater } \\
\text { than } 2 \text { percent. } \\
\text { All formulations. } \\
\text { All formulations } 2 \text { per } \\
\text { cent and less. }\end{array}$ & $\begin{array}{l}\text { All uses. } \\
\text { Rodent control. } \\
\text { Outdoor uses } \\
\text { (other than } \\
\text { rodent control). }\end{array}$ & $\begin{array}{l}\text { do } \\
\text { do } \\
\text { Unclassified }\end{array}$ & $\begin{array}{l}\text { Acute inhalation } \\
\text { toxicity. } \\
\text { Hazard to nontarget } \\
\text { organisms. }\end{array}$ \\
\hline Clonitralid & $\begin{array}{l}\text { All wettable powders } 70 \\
\text { percent and greater. } \\
\text { All granulars and wet- } \\
\text { table powders. } \\
\text { Pressurized sprays } 0.55 \\
\text { percent and less. }\end{array}$ & $\begin{array}{l}\text { All uses. } \\
\text { Molluscide uses. } \\
\text { Hospital } \\
\text { antiseptics. }\end{array}$ & $\begin{array}{l}\text { Restricted } \\
\text { do } \\
\text { Unclassified }\end{array}$ & $\begin{array}{l}\text { Acute inhalation } \\
\text { toxicity. } \\
\text { Effects on aquatic or- } \\
\text { ganisms. }\end{array}$ \\
\hline
\end{tabular}




\begin{tabular}{|c|c|c|c|c|}
\hline $\begin{array}{c}\text { Active } \\
\text { Ingredient }\end{array}$ & Formulation & Use Pattern & Classification $^{1}$ & $\begin{array}{c}\text { Criteria } \\
\text { Influencing } \\
\text { Restriction } \\
\end{array}$ \\
\hline Dicrotophos & $\begin{array}{l}\text { All liquid formulations } 8 \\
\text { percent and greater. }\end{array}$ & All uses. & Restricted & $\begin{array}{l}\text { Acute dermal toxicity; } \\
\text { residue effects on } \\
\text { avian species (except } \\
\text { for tree injections). }\end{array}$ \\
\hline \multirow[t]{3}{*}{ Disulfoton } & $\begin{array}{l}\text { All emulsifiable concen- } \\
\text { trates } 65 \text { percent and } \\
\text { greater, } \\
\text { all emulsifiable concen- } \\
\text { trates and concentrate } \\
\text { solutions } 21 \text { percent } \\
\text { and greater with } \\
\text { fensulfothion } 43 \text { percent } \\
\text { and greater, } \\
\text { all emulsifiable concen- } \\
\text { trates } 32 \text { percent and } \\
\text { greater in combination } \\
\text { with } 32 \text { percent fensul- } \\
\text { fothion and greater. }\end{array}$ & do & Restricted & $\begin{array}{l}\text { do } \\
\text { Acute inhalation toxic- } \\
\text { ity. }\end{array}$ \\
\hline & $\begin{array}{l}\text { Nonaqueous solution } 95 \\
\text { percent and greater. }\end{array}$ & $\begin{array}{l}\text { Commercial } \\
\text { seed treatment. }\end{array}$ & Restricted & $\begin{array}{l}\text { Acute dermal } \\
\text { toxicity. }\end{array}$ \\
\hline & $\begin{array}{l}\text { Granular formulations } 10 \\
\text { percent and greater. }\end{array}$ & $\begin{array}{l}\text { Indoor uses } \\
\text { (greenhouse). }\end{array}$ & do & $\begin{array}{l}\text { Acute inhalation } \\
\text { toxicity. }\end{array}$ \\
\hline Ethoprop & $\begin{array}{l}\text { Emulsifiable concentrates } \\
40 \text { percent and greater. } \\
\text { All granular and fertilizer } \\
\text { formulations. }\end{array}$ & $\begin{array}{l}\text { Aquatic uses } \\
\text { All uses }\end{array}$ & $\begin{array}{l}\text { do } \\
\text { Under evaluation. }\end{array}$ & Acute dermal toxicity. \\
\hline \multirow[t]{3}{*}{$\begin{array}{l}\text { Ethyl para- } \\
\text { thion }\end{array}$} & $\begin{array}{l}\text { All granular and dust } \\
\text { formulations greater than } \\
2 \text { percent fertilizer formu- } \\
\text { lations, wettable powders, } \\
\text { emulsifiable concentrates, } \\
\text { concentrated suspensions, } \\
\text { concentrated solutions. }\end{array}$ & do & Restricted & $\begin{array}{l}\text { Inhalation hazard to } \\
\text { humans. Acute dermal } \\
\text { toxicity. Residue ef- } \\
\text { fects on mammalian, } \\
\text { aquatic, avian species. }\end{array}$ \\
\hline & Smoke fumigants. & do & do & $\begin{array}{l}\text { Inhalation hazard to } \\
\text { humans. }\end{array}$ \\
\hline & $\begin{array}{l}\text { Dust and granular formu- } \\
\text { lations } 2 \text { percent and be- } \\
\text { low. }\end{array}$ & do & do & $\begin{array}{l}\text { Other hazards- } \\
\text { accident history. }\end{array}$ \\
\hline Fenamiphos & $\begin{array}{l}\text { Emulsifiable concentrates } \\
35 \text { percent and greater. }\end{array}$ & do & do & Acute dermal toxicity. \\
\hline Fonofos & $\begin{array}{l}\text { Emulsifiable concentrates } \\
44 \text { percent and greater. }\end{array}$ & do & do & Acute dermal toxicity. \\
\hline
\end{tabular}




\begin{tabular}{|c|c|c|c|c|}
\hline $\begin{array}{c}\text { Active } \\
\text { Ingredient }\end{array}$ & Formulation & Use Pattern & Classification $^{1}$ & $\begin{array}{c}\text { Criteria } \\
\text { Influencing } \\
\text { Restriction } \\
\end{array}$ \\
\hline & $\begin{array}{l}\text { Emulsifiable concentrates } \\
12.6 \text { percent and less with } \\
\text { pebulate } 50.3 \text { percent and } \\
\text { less. }\end{array}$ & Tobacco & Unclassified & \\
\hline $\begin{array}{l}\text { Methamido- } \\
\text { phos }\end{array}$ & $\begin{array}{l}\text { Liquid formulations } 40 \\
\text { percent and greater. } \\
\text { Dust formulations } 2.5 \\
\text { percent and greater. }\end{array}$ & $\begin{array}{l}\text { Tobacco } \\
\text { do }\end{array}$ & $\begin{array}{l}\text { Restricted } \\
\text { do }\end{array}$ & $\begin{array}{l}\text { Acute dermal toxicity; } \\
\text { residue effects on } \\
\text { avian species. } \\
\text { Residue effects on } \\
\text { avian species. }\end{array}$ \\
\hline Methidathion & $\begin{array}{l}\text { All formulations. } \\
\text { All formulations. }\end{array}$ & $\begin{array}{l}\text { All uses except } \\
\text { nursery stock, } \\
\text { safflower and } \\
\text { sunflower. } \\
\text { Nursery stock, } \\
\text { safflower, and } \\
\text { sunflower. }\end{array}$ & $\begin{array}{l}\text { do } \\
\text { Unclassified }\end{array}$ & do \\
\hline Methomyl & $\begin{array}{l}\text { As sole active ingredient } \\
\text { in } 1 \text { percent to } 2.5 \text { baits } \\
\text { (except } 1 \text { percent fly } \\
\text { bait). } \\
\text { All concentrated solution } \\
\text { formulations. } \\
90 \text { percent wettable pow- } \\
\text { der formulations (not in } \\
\text { water soluble bags). } \\
90 \text { percent wettable pow- } \\
\text { der formulation in water } \\
\text { soluble bags. } \\
\text { All granular formulations. } \\
25 \text { percent wettable } \\
\text { powder formulations. }\end{array}$ & $\begin{array}{l}\text { Nondomestic out- } \\
\text { doors-agricultural } \\
\text { crops, ornamental } \\
\text { and turf. All other } \\
\text { registered uses. } \\
\text { do } \\
\text { do } \\
\text { do } \\
\text { do } \\
\text { do }\end{array}$ & $\begin{array}{l}\text { Restricted } \\
\text { do } \\
\text { do } \\
\text { Unclassified } \\
\text { do } \\
\text { do }\end{array}$ & $\begin{array}{l}\text { Residue effects on } \\
\text { mammalian species. } \\
\text { Other hazards-accident } \\
\text { history. } \\
\text { do }\end{array}$ \\
\hline $\begin{array}{l}\text { Methomyl } \\
\text { (continued) }\end{array}$ & $\begin{array}{l}\text { In } 1.24 \text { percent to } 2.5 \\
\text { percent dusts as sole ac- } \\
\text { tive ingredient and in }\end{array}$ & do & do & \\
\hline
\end{tabular}




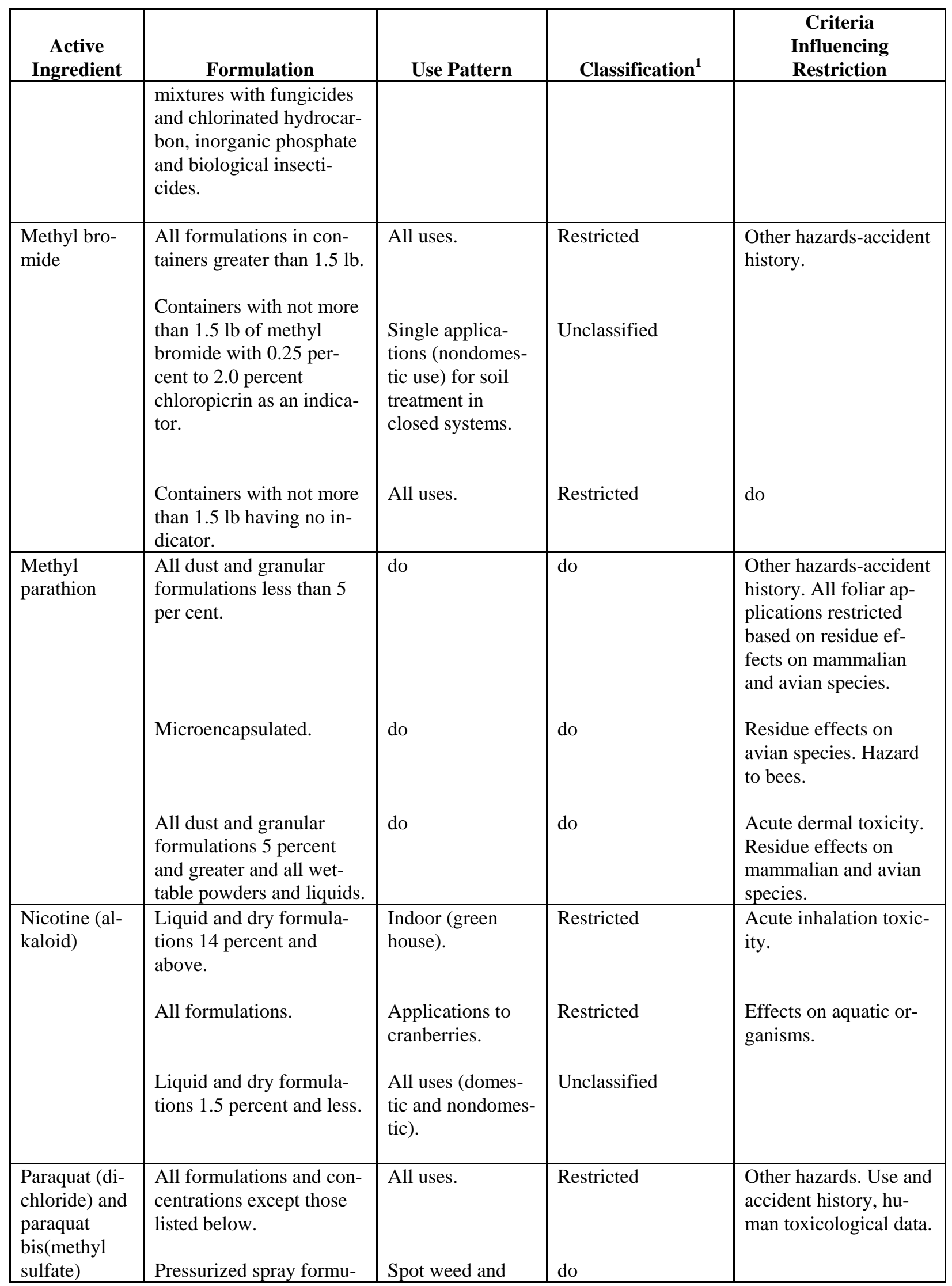




\begin{tabular}{|c|c|c|c|c|}
\hline $\begin{array}{c}\text { Active } \\
\text { Ingredient }\end{array}$ & Formulation & Use Pattern & Classification $^{1}$ & $\begin{array}{c}\text { Criteria } \\
\text { Influencing } \\
\text { Restriction }\end{array}$ \\
\hline & $\begin{array}{l}\text { lations containing } 0.44 \\
\text { percent Paraquat } \\
\text { bis(methylsulfate) and } 15 \\
\text { percent petroleum distil- } \\
\text { lates as active ingredients. } \\
\text { Liquid fertilizers contain- } \\
\text { ing concentrations of } \\
0.025 \text { percent paraquat } \\
\text { dichloride and } 0.03 \text { per- } \\
\text { cent atrazine; } 0.03 \text { per- } \\
\text { cent paraquat dichloride } \\
\text { and } 0.37 \text { percent atrazine, } \\
0.04 \text { percent paraquat } \\
\text { dichloride and } 0.49 \text { per- } \\
\text { cent atrazine. }\end{array}$ & grass control. & Unclassified & \\
\hline Phorate & $\begin{array}{l}\text { Liquid formulations } 65 \\
\text { percent and greater. } \\
\text { All granular formulations. }\end{array}$ & Rice & $\begin{array}{l}\text { Restricted } \\
\text { do }\end{array}$ & $\begin{array}{l}\text { Acute dermal toxicity. } \\
\text { Residue effects on } \\
\text { avian species (applies } \\
\text { to foliar applications } \\
\text { only). Residue effects } \\
\text { on mammalian species } \\
\text { (applies to foliar appli- } \\
\text { cation only). } \\
\text { Effects on aquatic or- } \\
\text { ganisms. }\end{array}$ \\
\hline $\begin{array}{l}\text { Phosphami- } \\
\text { don }\end{array}$ & $\begin{array}{l}\text { Liquid formulations } 75 \\
\text { percent and greater. } \\
\text { Dust formulations } 1.5 \\
\text { percent and greater. }\end{array}$ & do & 更 & $\begin{array}{l}\text { Acute dermal toxicity. } \\
\text { Residue effects on } \\
\text { mammalian species. } \\
\text { Residue effects on } \\
\text { avian species. } \\
\text { do } \\
\text { Residue effects on } \\
\text { mammalian species. }\end{array}$ \\
\hline Picloram & $\begin{array}{l}\text { All formulations and con- } \\
\text { centrations except tordon } \\
\text { 101R. } \\
\text { Tordon } 101 \mathrm{R} \text { forestry } \\
\text { herbicide containing } 5.4 \\
\text { percent picloram and } 20.9 \\
\text { percent } 2 \text {, 4-D. }\end{array}$ & $\begin{array}{l}\text { Control of un- } \\
\text { wanted trees by } \\
\text { cut surface treat- } \\
\text { ment. }\end{array}$ & $\begin{array}{l}\text { do } \\
\text { Unclassified }\end{array}$ & $\begin{array}{l}\text { Hazard to nontarget } \\
\text { organisms (specifically } \\
\text { nontarget plants both } \\
\text { crop and noncrop). }\end{array}$ \\
\hline $\begin{array}{l}\text { Sodium cya- } \\
\text { nide }^{3}\end{array}$ & $\begin{array}{l}\text { All capsules and ball for- } \\
\text { mulations. }\end{array}$ & All uses. & Restricted & $\begin{array}{l}\text { Inhalation hazard to } \\
\text { humans. }\end{array}$ \\
\hline
\end{tabular}




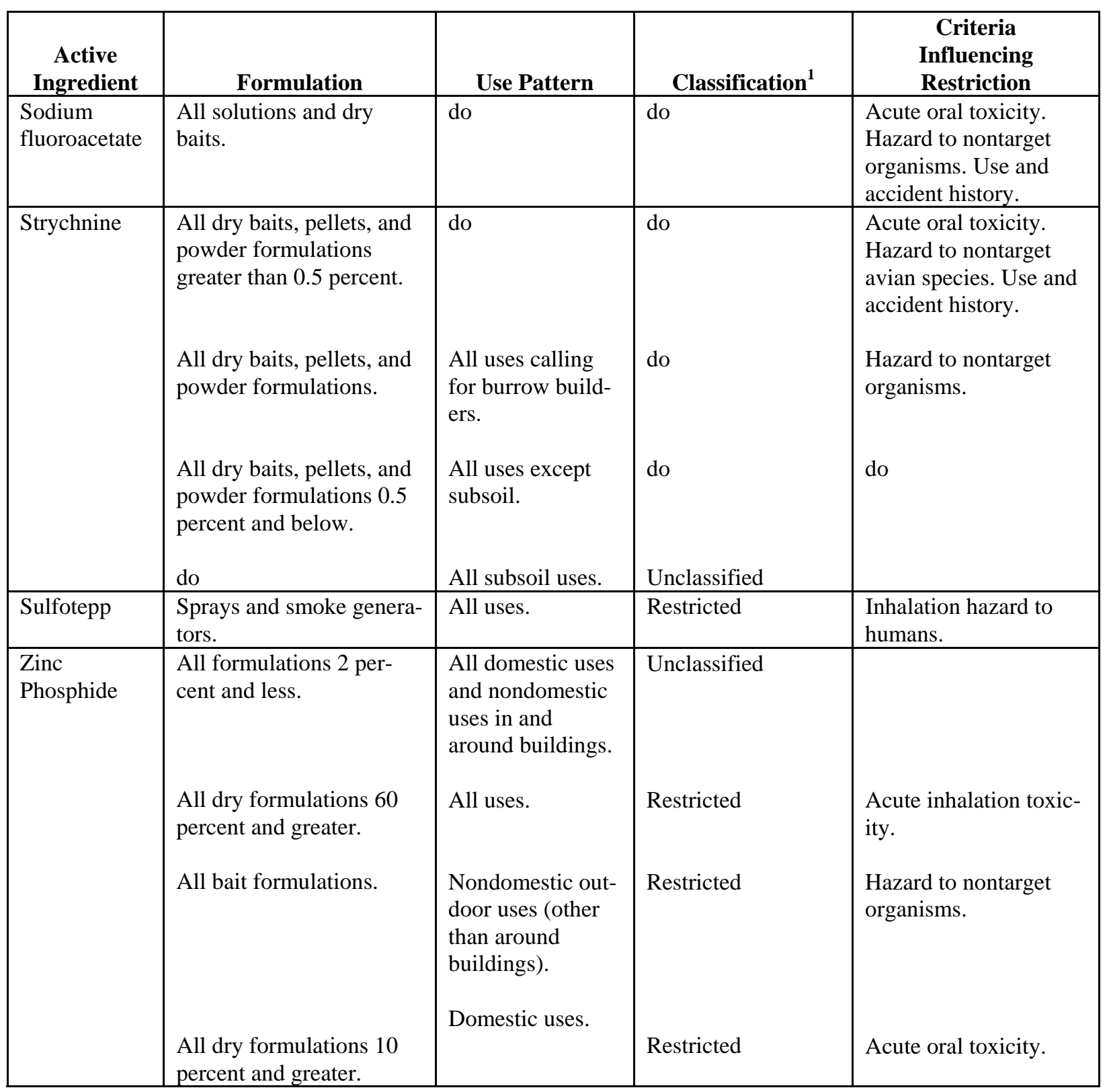

*do means same as above (previous row). 
NOTES:

${ }^{1}$ Under evaluation means no classification decision has been made and the use/formulation in question is still under active review within the USEPA.

${ }^{2}$ Percentages given are the total of dioxathion plus related compounds.

${ }^{3}$ NOTE: M-44 sodium cyanide capsules may only be used by certified applicators who have also taken the required additional training.

(NOTE: This table is up-to-date through the July 2008 edition of the CFR.) 


\title{
SECTION 8
}

\section{PETROLEUM, OILS, AND LUBRICANTS (POL) MANAGEMENT}

\section{Overseas ESOHCAMP}

\author{
September 2009
}

\section{A. Service-specific Regulations and Policies}

- Air Force Instruction (AFI) 13-212, Volume 1, Weapons Ranges, 28 July 1994, includes a number of provisions relevant to the handling of used POL generated at air-to-surface weapons ranges.

- AFI 23-201, Fuels Management, 24 April 2009, provides managers at all Air Force (AF) activities with policy and procedures for fuels operations.

- AFI 23-502, Recoverable and Unusable Liquid Petroleum Products, 15 August 2008, sets goals, assigns responsibilities, and provides guidance for recovering usable and disposing of unusable liquid petroleum products.

- AFI 32-7044, Storage Tank Compliance, 13 November 2003, identifies compliance requirements for storage tanks and associated piping that store petroleum and hazardous substances except hazardous waste. This AFI includes requirements for hydrant fueling systems (see PO.100).

- Unified Facilities Criteria (UFC) 3-460-03, Operations and Maintenance: Maintenance of Petroleum Systems, 21 January 2003, includes inspection criteria for on-base pipelines and off-base piping systems.

- Air Force Technical Order (AFTO) 42B-1-23, Management of Recoverable and Waste Liquid Petroleum Products, provides guidelines for collecting, segregating, and processing reclaimed, recoverable, and waste petroleum products.

\section{B. DOD Directives and Instructions}

- None

\section{Service-specific/DOD Definitions}

- Generating Activity - a base agency (host, tenant, or contractor) that generates recoverable or unusable petroleum products (AFI 23-502, Attachment 1).

- Management Practice (MP) - practices that, although not mandated by law, are encouraged to promote safe operating procedures.

- Off-Specification Product - a product that has more than one specification. Off-specification products can be blended as regraded products. Off-specification products are not identified as hazardous waste fuel (AFI 23-502, Attachment 1).

- On-Specification Product - a product that has a suitable quality to be returned to the base inventory. TO 42B-123, Table 3-1, Management of Recoverable and Waste Liquid Petroleum Products, sets the criteria for suitable quality (AFI 23-502, Attachment 1).

- Reclaimable Product - a product of known or determinable quality that can be used for the original grade without reprocessing (AFI 23-502, Attachment 1). 
- Recyclable Products - a product that does not meet its original specification, but which through processing can be recovered for the original grade or a lower grade without reprocessing except settling time, filtration, and/or blending (AFI 23-502, Attachment 1).

- Reprocessing - refining, clay filtering, or naphtha injection to bring off-specification product up to specification (AFI 23-502, Attachment 1).

- Waste Product - product that is no longer suitable for any use on an installation because of excessive contamination or quality degradation (AFI 23-502, Attachment 1).

\section{Additional Records To Review}

- None

\section{E. Additional Physical Features To Inspect}

- None

\section{F. Guidance for Checklist Users}

REFER TO CHECKLIST ITEMS:

Missing Checklist Items/Positive Findings

General

Pipelines

Discharges/Spills

Used POL/Waste POL

Hydrant Fueling Systems
PO.2.1.OCAF and PO.2.2.OCAF

PO.3.1.OCAF through PO.3.11.OCAF

PO.20.1.OCAF through PO.20.5.OCAF

PO.30.1.OCAF

PO.40.1.OCAF through PO.40.13.OCAF

PO.100.1.OCAF 


\begin{tabular}{|l|l|}
\hline \multicolumn{2}{|c|}{ PETROLEUM, OILS, AND LUBRICANTS (POL) MANAGEMENT } \\
Overseas ESOHCAMP
\end{tabular}




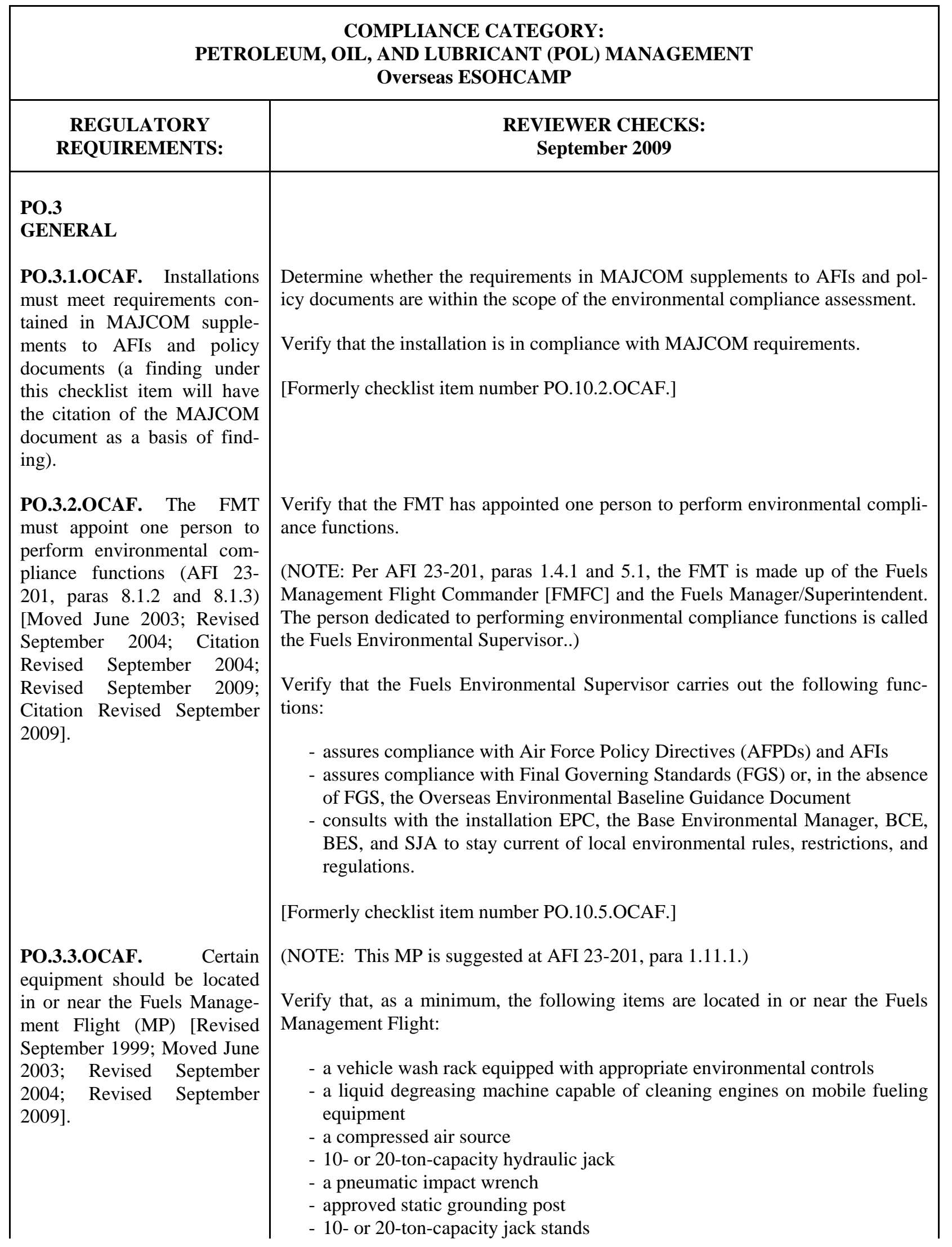




\begin{tabular}{|c|c|}
\hline \multicolumn{2}{|c|}{$\begin{array}{l}\text { COMPLIANCE CATEGORY: } \\
\text { PETROLEUM, OIL, AND LUBRICANT (POL) MANAGEMENT } \\
\text { Overseas ESOHCAMP }\end{array}$} \\
\hline $\begin{array}{l}\text { REGULATORY } \\
\text { REQUIREMENTS: }\end{array}$ & $\begin{array}{l}\text { REVIEWER CHECKS: } \\
\text { September } 2009\end{array}$ \\
\hline $\begin{array}{l}\text { PO.3.4.OCAF. The FMT } \\
\text { must take specific actions to } \\
\text { ensure appropriate environ- } \\
\text { mental management of fuel } \\
\text { (AFI 23-201, paras 8.7.8 and } \\
\text { 8.7.11) [Revised September } \\
\text { 1999; Moved June 2003; Re- } \\
\text { vised September 2004; Cita- } \\
\text { tion Revised September } \\
\text { 2009]. }\end{array}$ & $\begin{array}{l}\text { - a multimeter } \\
\text { - a tire dolly. } \\
\text { Verify that the discharge from the degreaser drains into appropriate environmental } \\
\text { controls. } \\
\text { [Formerly checklist item number PO.10.6.OCAF.] } \\
\text { Verify that the FMT develops local operating procedures for collection, segrega- } \\
\text { tion, storage, and disposition of waste and reusable bulk petroleum products in } \\
\text { accordance with AFI 23-502, Recoverable and Unusable Liquid Petroleum Prod- } \\
\text { ucts. } \\
\text { Verify that the FMT ensures that adequate spill prevention and cleanup materials } \\
\text { are readily available. } \\
\text { [Formerly checklist item number PO.10.7.OCAF.] }\end{array}$ \\
\hline $\begin{array}{l}\text { PO.3.5.OCAF. All fuels } \\
\text { elements must be evaluated at } \\
\text { least once every } 6 \text { mo (AFI } \\
\text { 23-201, paras } 8.3 \text { and } 8.4 .1 \\
\text { through 8.4.3) [Revised Sep- } \\
\text { tember 1999; Moved June } \\
\text { 2003; Revised September } \\
\text { 2004; Citation Revised Sep- } \\
\text { tember 2004; Revised Sep- } \\
\text { tember 2009]. }\end{array}$ & $\begin{array}{l}\text { Verify that the Compliance Section Chief evaluates each fuels element at least } \\
\text { once every } 6 \text { mo. } \\
\text { (NOTE: The Compliance and Environmental element does not evaluate itself. The } \\
\text { FMT designates an evaluator to perform a semiannual assessment of the Compli- } \\
\text { ance and Environmental element.) } \\
\text { Verify that a fuels element is revisited after } 30 \text { days (but within } 45 \text { days) to check } \\
\text { each discrepancy found during the semiannual assessment. } \\
\text { Verify that at least } 10 \text { no-notice spot checks are performed each week. } \\
\text { Verify that all shifts are spot checked. } \\
\text { (NOTE: If spot check is rated unsatisfactory, it is not consolidated with others. } \\
\text { Instead it will be routed separately, identifying the failure and circumstances in- } \\
\text { volved. Immediately route through the responsible supervisor and chain of com- } \\
\text { mand to the FMT.) } \\
\text { Verify that spot checks are conducted during exercises and contingencies. } \\
\text { (NOTE: At bases with fewer than } 20 \text { full-time fuels personnel, at least two no- } \\
\text { notice spot checks are performed per week.) } \\
\text { [Formerly checklist item number PO.20.1.OCAF.] }\end{array}$ \\
\hline $\begin{array}{l}\text { PO.3.6.OCAF. [Moved June } \\
\text { 2003; Deleted June 2003]. }\end{array}$ & Deleted at the request of the sponsor. \\
\hline
\end{tabular}




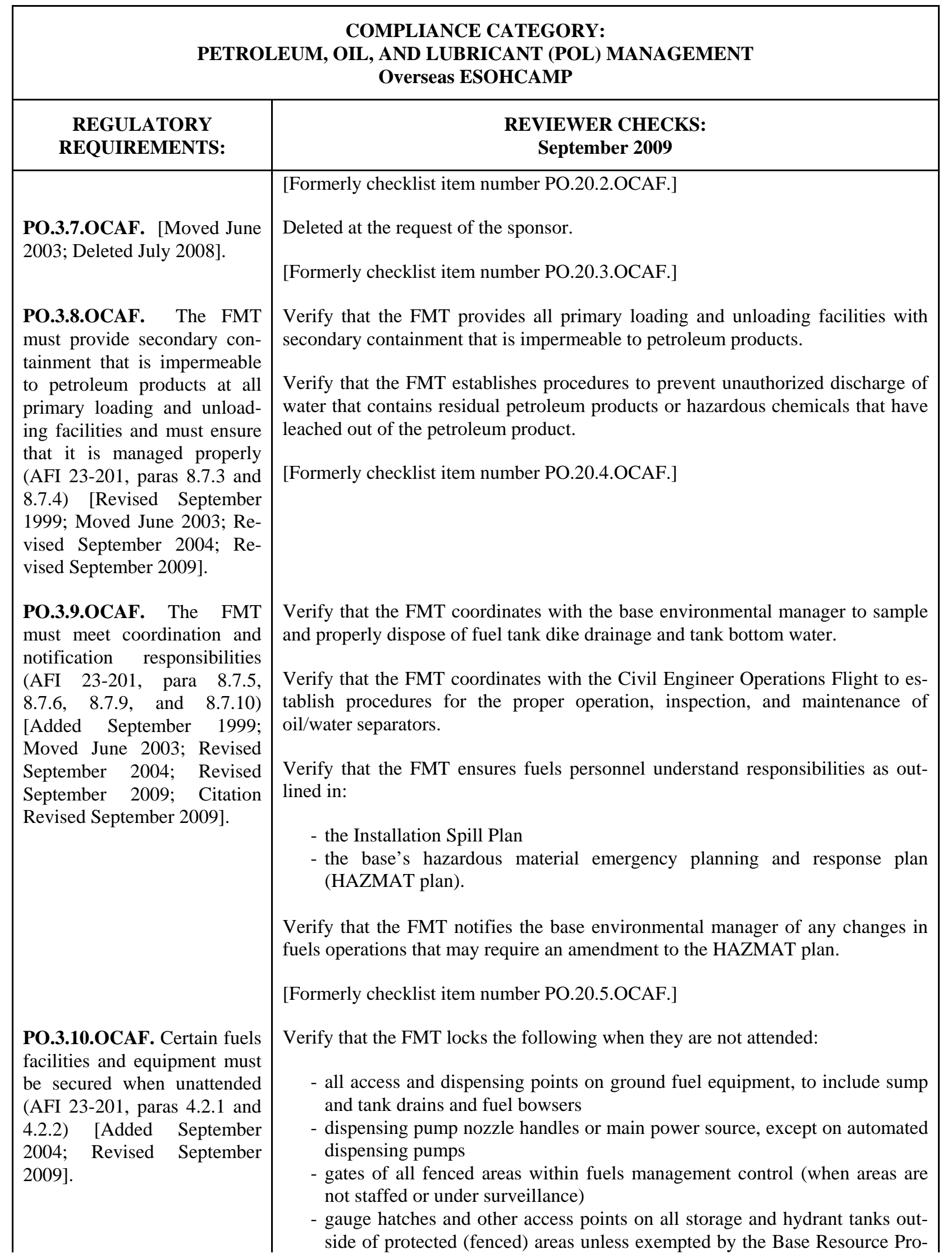




\begin{tabular}{|c|c|}
\hline \multicolumn{2}{|c|}{$\begin{array}{l}\text { COMPLIANCE CATEGORY: } \\
\text { PETROLEUM, OIL, AND LUBRICANT (POL) MANAGEMENT } \\
\text { Overseas ESOHCAMP }\end{array}$} \\
\hline $\begin{array}{l}\text { REGULATORY } \\
\text { REQUIREMENTS: }\end{array}$ & $\begin{array}{l}\text { REVIEWER CHECKS: } \\
\text { September } 2009\end{array}$ \\
\hline $\begin{array}{l}\text { PO.3.11.OCAF. Fuels expe- } \\
\text { diters must maintain spill re- } \\
\text { sponse kits for contain- } \\
\text { ment/clean-up of small leaks } \\
\text { or spills and must notify the } \\
\text { Fuels Environmental Coordi- } \\
\text { nator each time the kit is used } \\
\text { (AFI 23-201, paras 6.3.4) } \\
\text { [Added September 2004]. }\end{array}$ & $\begin{array}{l}\text { tection Committee } \\
\text { - electrical control panels and bulk fuel off-loading systems outside protected } \\
\text { areas. } \\
\text { Verify that sump and tank drains are secured in a manner that prevents access to } \\
\text { cargo tank contents. } \\
\text { Verify that proper key control is established. } \\
\text { Verify that prior approval is obtained from the local Resource Protection Commit- } \\
\text { tee for the use of combination locks. } \\
\text { (NOTE: AFI 23-201, para } 4.2 .2 \text {, recommends the use of magnetic locks for areas } \\
\text { where climatic conditions are severe.) } \\
\text { Verify that each fuels expediter maintains a spill response kit for contain- } \\
\text { ment/clean-up of small leaks or spills. } \\
\text { Verify that the fuels expediter notifies the Fuels Environmental Coordinator each } \\
\text { time the kit is used. }\end{array}$ \\
\hline
\end{tabular}




\begin{tabular}{|c|c|}
\hline \multicolumn{2}{|c|}{$\begin{array}{l}\text { COMPLIANCE CATEGORY: } \\
\text { PETROLEUM, OIL, AND LUBRICANT (POL) MANAGEMENT } \\
\text { Overseas ESOHCAMP }\end{array}$} \\
\hline $\begin{array}{l}\text { REGULATORY } \\
\text { REQUIREMENTS: }\end{array}$ & $\begin{array}{l}\text { REVIEWER CHECKS: } \\
\text { September } 2009\end{array}$ \\
\hline $\begin{array}{l}\text { PO.20 } \\
\text { PIPELINES } \\
\text { PO.20.1.OCAF. Off-base } \\
\text { piping systems are subject to } \\
\text { inspection requirements (UFC } \\
\text { 3-460-03, paras 2.4.4.1, } \\
\text { 2.4.4.2, and 2.4.4.1) [Moved } \\
\text { June 2003; Revised January } \\
\text { 2005; Citation Revised Janu- } \\
\text { ary 2005]. }\end{array}$ & 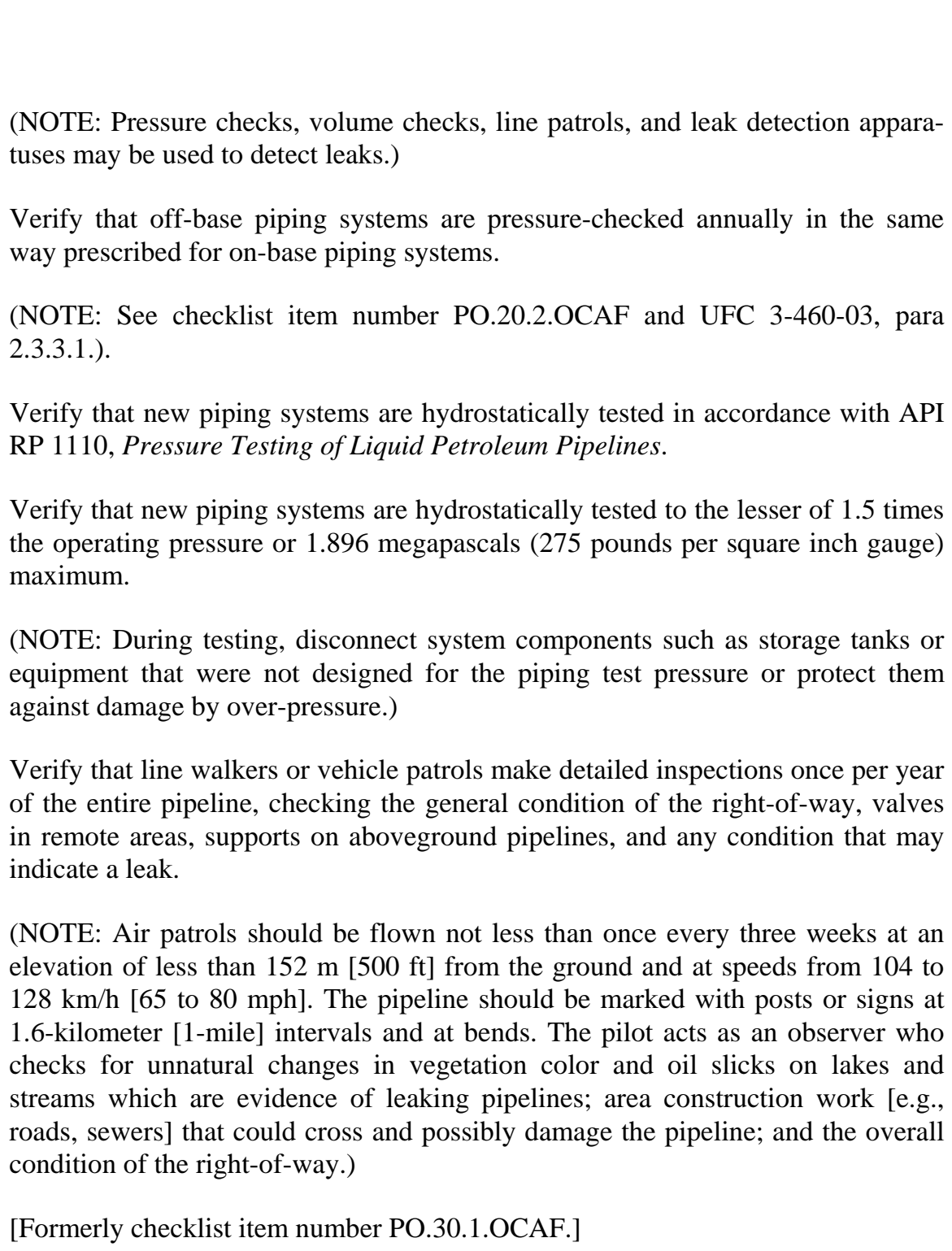 \\
\hline $\begin{array}{l}\text { PO.20.2.OCAF. On-base } \\
\text { pipelines must be tested an- } \\
\text { nually for leaks (UFC 3-460- } \\
\text { 03, paras 2.3.3 and 2.3.3.1) } \\
\text { [Moved June 2003; Revised } \\
\text { January 2005; Citation Re- }\end{array}$ & $\begin{array}{l}\text { Verify that on-base pipelines are tested annually for leaks. } \\
\text { Verify that all on-base fuel piping systems are pressure-tested annually using ex- } \\
\text { isting system pumps. } \\
\text { (NOTE: Additional guidance for conducting these tests is found in UFC 3-460- }\end{array}$ \\
\hline
\end{tabular}




\begin{tabular}{|l|l|}
\hline \multicolumn{2}{|c|}{ PETROLEUM, OIL, AND LUBRICANT (POL) MANAGEMENT } \\
Overseas ESOHCAMP
\end{tabular}




\begin{tabular}{|c|c|}
\hline \multicolumn{2}{|c|}{$\begin{array}{l}\text { COMPLIANCE CATEGORY: } \\
\text { PETROLEUM, OIL, AND LUBRICANT (POL) MANAGEMENT } \\
\text { Overseas ESOHCAMP }\end{array}$} \\
\hline $\begin{array}{l}\text { REGULATORY } \\
\text { REQUIREMENTS: }\end{array}$ & $\begin{array}{l}\text { REVIEWER CHECKS: } \\
\text { September } 2009\end{array}$ \\
\hline $\begin{array}{l}\text { PO.30 } \\
\text { DISCHARGES / SPILLS } \\
\text { PO.30.1.OCAF. The FMT } \\
\text { must report fuels-related mis- } \\
\text { haps in accordance with spe- } \\
\text { cific requirements (AFI 23- } \\
\text { 201, paras 1.5.1.1 through } \\
\text { 1.5.1.3) [Revised September } \\
\text { 1998; Moved June 2003; Re- } \\
\text { vised September 2004; Cita- } \\
\text { tion Revised September 2004; } \\
\text { Revised September 2009; } \\
\text { Citation Revised September } \\
\text { 2009]. }\end{array}$ & $\begin{array}{l}\text { Verify that the FMT reports mishaps as required by HQ AF/A4LE; the Air Force } \\
\text { Petroleum Agency (AFPET); and AFI 91-204, Safety Investigations and Reports, } \\
\text { and AFI 10-206, Operational Reporting. } \\
\text { (NOTE: A reportable fuel-related spill/mishap is defined as any fuel spill as a } \\
\text { result of a mishap, or any event resulting in suspected/confirmed fuel contamina- } \\
\text { tion, fuel spill, fire, product loss, fuel handling/equipment damage and/or failure, } \\
\text { fuel vehicle accident, and fuel related personnel injury.) } \\
\text { Verify that the FMT reports all mishaps using the AFPET Automated Mishap } \\
\text { Reporter. } \\
\text { (NOTE: If Automated Mishap Reporter is unavailable at the location, send mis- } \\
\text { hap reports to parent MAJCOM via fax using the format provided in AFI 23-201, } \\
\text { Attachment 11.) } \\
\text { (NOTE: The web-based Mishap Report program automatically forwards notifica- } \\
\text { tion to AF/A4LE, AFPET, and applicable MAJCOM Fuels Management Staff.) } \\
\text { (NOTE: Submission of the Mishap Report through the website does not preclude } \\
\text { the requirement to report fuel spills to the base Environmental Manager and local } \\
\text { command channels.) } \\
\text { Verify that FMT provides a report update within } 30 \text { days through the AFPET } \\
\text { Automated Mishap Reporter regarding final outcome of the investigation and les- } \\
\text { sons learned. }\end{array}$ \\
\hline
\end{tabular}




\begin{tabular}{|c|c|}
\hline \multicolumn{2}{|c|}{$\begin{array}{l}\text { COMPLIANCE CATEGORY: } \\
\text { PETROLEUM, OIL, AND LUBRICANT (POL) MANAGEMENT } \\
\text { Overseas ESOHCAMP }\end{array}$} \\
\hline $\begin{array}{l}\text { REGULATORY } \\
\text { REQUIREMENTS: }\end{array}$ & $\begin{array}{l}\text { REVIEWER CHECKS: } \\
\text { September } 2009\end{array}$ \\
\hline $\begin{array}{l}\text { PO.40 } \\
\text { USED POL / WASTE POL } \\
\text { PO.40.1.OCAF. } \quad \text { [Deleted } \\
\text { September 2009]. }\end{array}$ & \\
\hline $\begin{array}{l}\text { PO.40.2.OCAF. The FMT } \\
\text { has specific responsibilities } \\
\text { with regard to the manage- } \\
\text { ment of waste fuel (AFI 23- } \\
\text { 201, para 8.8.2) [Revised } \\
\text { September 1999; Moved June } \\
\text { 2003; Revised September } \\
\text { 2004; Revised September } \\
\text { 2009; Citation Revised Sep- } \\
\text { tember 2009]. }\end{array}$ & $\begin{array}{l}\text { Verify that the FMT ensures: } \\
\text { - MAJCOM and/or AFPET are contacted to get disposal instructions for off- } \\
\text { specification product or fuel/water mixtures } \\
\text { - installed hydrants, storage sumps, and slop tanks are NOT used to collect or } \\
\text { store waste fuels } \\
\text { - written MAJCOM approval is obtained if stock listed vehicles and trailers } \\
\text { are requested for the collection and transport of waste fuels or oils. } \\
\text { Verify that, before returning vehicles to normal service, FMT ensures they meet } \\
\text { the compliance requirements outlined in TO 42B-1-1. } \\
\text { [Formerly checklist item number PO.50.1.OCAF.] }\end{array}$ \\
\hline $\begin{array}{l}\text { PO.40.3.OCAF. Accumula- } \\
\text { tion points must be set up for } \\
\text { used petroleum products gen- } \\
\text { erated as part of the operation } \\
\text { and maintenance of air-to- } \\
\text { surface weapons ranges (AFI } \\
\text { 13-212, para 1.10.2.1) } \\
\text { [Moved June 2003]. }\end{array}$ & $\begin{array}{l}\text { Determine whether the installation operates air-to-surface weapons ranges that } \\
\text { generate used petroleum products. } \\
\text { Verify that accumulation points have been set up for such weapons ranges. } \\
\text { Verify that arrangements have been made for periodic transport of such products } \\
\text { to a storage facility. } \\
\text { [Formerly checklist item number PO.50.2.OCAF.] }\end{array}$ \\
\hline $\begin{array}{l}\text { PO.40.4.OCAF. [Deleted } \\
\text { September 2009]. }\end{array}$ & \\
\hline $\begin{array}{l}\text { PO.40.5.OCAF. Bases } \\
\text { should make maximum use of } \\
\text { all petroleum products an } \\
\text { energy priority (MP) [Added } \\
\text { September 2009]. }\end{array}$ & $\begin{array}{l}\text { Verify that the base makes maximum use of all petroleum products an energy } \\
\text { priority. } \\
\text { (NOTE: This MP is found at AFI 23-502, para 10.3.) }\end{array}$ \\
\hline $\begin{array}{l}\text { PO.40.6.OCAF. Installations } \\
\text { must make every effort to } \\
\text { collect, segregate, and reclaim } \\
\text { on-specification petroleum } \\
\text { products to inventory or recy- } \\
\text { cle petroleum products in } \\
\text { accordance with TO 42B-1- }\end{array}$ & $\begin{array}{l}\text { Verify that every effort is made to collect, segregate, and reclaim on-specification } \\
\text { petroleum products to inventory or recycle petroleum products in accordance with } \\
\text { TO 42B-1-23. }\end{array}$ \\
\hline
\end{tabular}




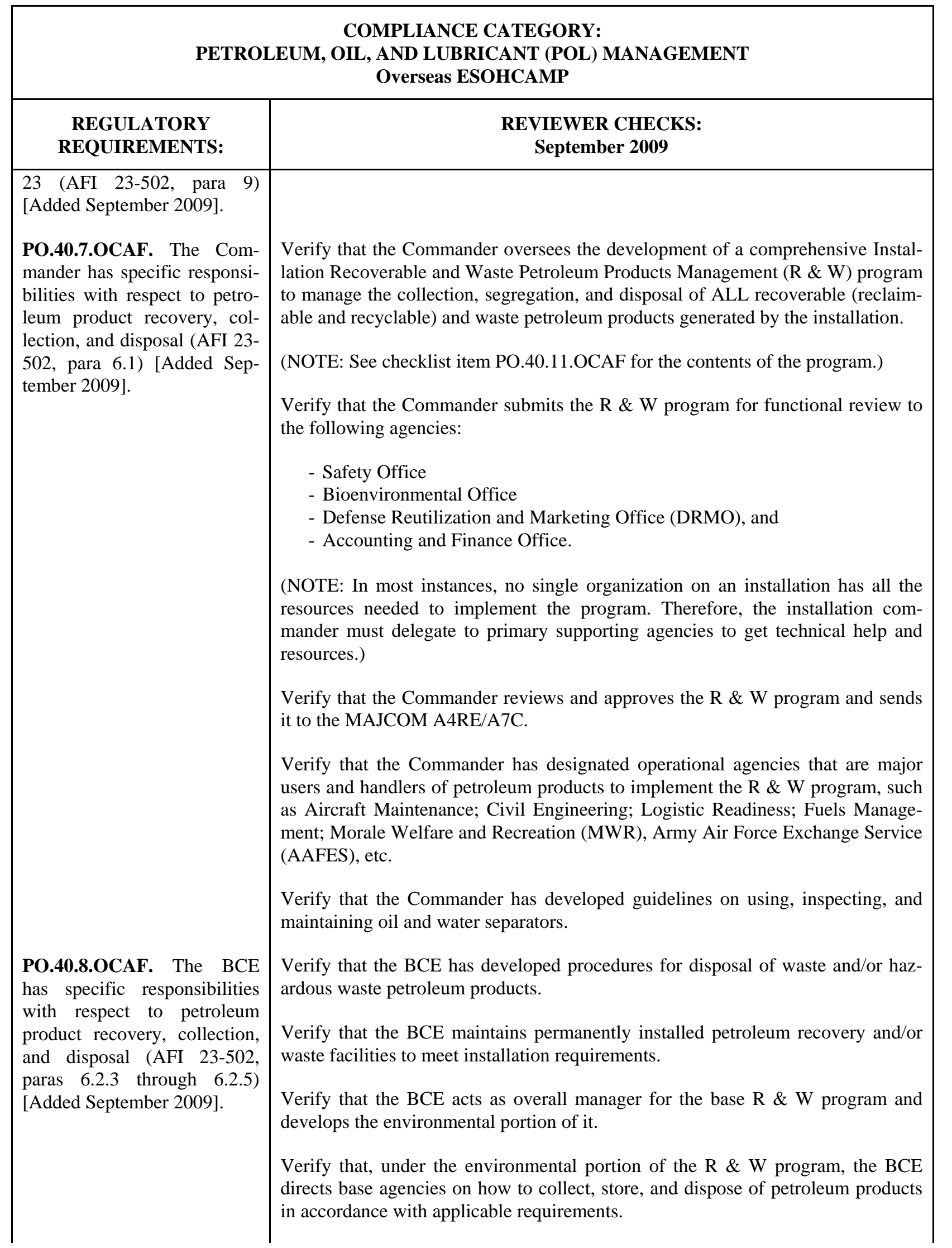




\begin{tabular}{|c|c|}
\hline \multicolumn{2}{|c|}{$\begin{array}{l}\text { COMPLIANCE CATEGORY: } \\
\text { PETROLEUM, OIL, AND LUBRICANT (POL) MANAGEMENT } \\
\text { Overseas ESOHCAMP }\end{array}$} \\
\hline $\begin{array}{l}\text { REGULATORY } \\
\text { REQUIREMENTS: }\end{array}$ & $\begin{array}{l}\text { REVIEWER CHECKS: } \\
\text { September } 2009\end{array}$ \\
\hline $\begin{array}{l}\text { PO.40.9.0CAF. The FMT } \\
\text { has specific responsibilities } \\
\text { with respect to petroleum } \\
\text { product recovery, collection, } \\
\text { and disposal (AFI 23-502, } \\
\text { paras 6.3) [Added September } \\
\text { 2009]. }\end{array}$ & $\begin{array}{l}\text { Verify that, under the environmental portion of the R \& W program, the BCE } \\
\text { evaluates the environmental program on compliance with established standards of } \\
\text { pollution prevention and controls. } \\
\text { Verify that the FMT assists base organizations in determining how to handle re- } \\
\text { covered (reclaimable and recyclable) and waste petroleum products. } \\
\text { Verify that, for economical quantities in excess of } 1000 \text { gal, the FMT sends a } \\
\text { composite sample to HQ AFPET/AFPT, Aerospace Fuels laboratory for specifica- } \\
\text { tion identification and quality analysis. } \\
\text { Verify that the FMT accepts and accounts for recoverable petroleum products that } \\
\text { are returned to fuels inventories. } \\
\text { Verify that the FMT analyzes all recovered product to determine fuel classifica- } \\
\text { tion as Reclaimable, Recoverable, or Waste. } \\
\text { (NOTE: This analysis is conducted in order to prevent product commingling.) } \\
\text { Verify that the FMT develops procedures for returning “on-specification" fuel to } \\
\text { inventory as part of the base program. } \\
\text { Verify that, if applicable, the FMT manages the base centralized petroleum recla- } \\
\text { mation facility. }\end{array}$ \\
\hline $\begin{array}{l}\text { PO.40.10.OCAF. Generating } \\
\text { activities have specific re- } \\
\text { sponsibilities with respect to } \\
\text { petroleum product recovery, } \\
\text { collection, and disposal (AFI } \\
\text { 23-502, para 6.4) [Added } \\
\text { September 2009]. }\end{array}$ & $\begin{array}{l}\text { Verify that each generating activity supervises proper collection, segregation, } \\
\text { handling and disposition of recoverable and waste petroleum products and/or haz- } \\
\text { ardous waste fuels in accordance with: } \\
\text { - TO 42B-1-23, Management of Recoverable and Waste Liquid Petroleum } \\
\text { Products } \\
\text { - the Installation R \& W Program } \\
\text { - applicable regulations. } \\
\text { Verify that, once the generating activity (based on FMT lab analysis) classifies the } \\
\text { suspect product as waste fuel rather than recoverable fuel, the fuel is managed in } \\
\text { accordance with applicable guidance. } \\
\text { Verify that each generating activity obtains enough suitable containers to properly } \\
\text { segregate and store recoverable and waste petroleum products, by product type. } \\
\text { Verify that aircraft ground support procures fuel bowsers to meet the standard } \\
\text { specifications in TO 42B-1-23, Appendix A. } \\
\text { Verify that each generating activity paints or marks containers and bowsers in } \\
\text { accordance with: } \\
\text { - TO 42B-1-23, Management of Recoverable and Waste Liquid Petroleum }\end{array}$ \\
\hline
\end{tabular}




\begin{tabular}{|c|c|}
\hline \multicolumn{2}{|c|}{$\begin{array}{l}\text { COMPLIANCE CATEGORY: } \\
\text { PETROLEUM, OIL, AND LUBRICANT (POL) MANAGEMENT } \\
\text { Overseas ESOHCAMP }\end{array}$} \\
\hline $\begin{array}{l}\text { REGULATORY } \\
\text { REQUIREMENTS: }\end{array}$ & $\begin{array}{l}\text { REVIEWER CHECKS: } \\
\text { September } 2009\end{array}$ \\
\hline $\begin{array}{l}\text { PO.40.11.OCAF. The instal- } \\
\text { lation R \& W program must } \\
\text { meet specific requirements } \\
\text { (AFI 23-502, para 8) [Added } \\
\text { September 2009]. }\end{array}$ & $\begin{array}{l}\text { Products, } \\
\text { - TO 35-1-3, Corrosion Prevention, Painting, and Marking of US Air Force } \\
\text { - TO 36-1-191, Technical and Managerial Reference for Motor Vehicle Main- } \\
\text { tenance, as appropriate. } \\
\text { Verify that each generating activity provides or arranges transportation of prod- } \\
\text { ucts to collection or disposal points in accordance with the installation R \& W } \\
\text { program. } \\
\text { Verify that each generating activity manages the R \& W program at the opera- } \\
\text { tional level. } \\
\text { Verify that each generating activity submits data on quantity and identity of re- } \\
\text { coverable and waste petroleum products, as required, to the designated installation } \\
\text { environmental component of the program. } \\
\text { Verify that the program states specific responsibilities and criteria for collecting, } \\
\text { storing, returning to inventory, reclaiming, recycling, and disposing of all recov- } \\
\text { erable and/or waste petroleum products generated on the base. } \\
\text { Verify that the program is environmentally consistent with effective energy con- } \\
\text { servation, property management, quality control principles, and sound economics. } \\
\text { Verify that, at a minimum, the program includes: } \\
\text { - identification of all generating agencies } \\
\text { - a list of all recoverable and waste fuels generated by an organization, includ- } \\
\text { ing source, approximate quantities } \\
\text { - specific responsibilities assigned to base organizations } \\
\text { - facilities and methods used to recover, store, and/or dispose of products in } \\
\text { accordance with applicable directives } \\
\text { - accounting procedures to credit using organizations for recoverable petro- } \\
\text { leum } \\
\text { - specific procedures for the entry, exit, and control of petroleum vehicles } \\
\text { needed to remove recyclable and waste petroleum products from the installa- } \\
\text { tion. } \\
\text { (NOTE: Accounting procedures to credit using organizations for recoverable pe- } \\
\text { troleum can be found in DOD } 4140.25 M \text {, Vol II, Chap 10, Management of Bulk } \\
\text { Petroleum Products, Natural Gas, and Coal, DESC Interim Policy and Section D } \\
\text { of AFI } 23-502 .) \\
\text { Verify that, if escort control is necessary, procedures are developed in accordance } \\
\text { with AFI 23-204, Organizational Fuel Tanks. } \\
\text { (NOTE: For organizational fuel tank requirements, see the checklist items under }\end{array}$ \\
\hline
\end{tabular}




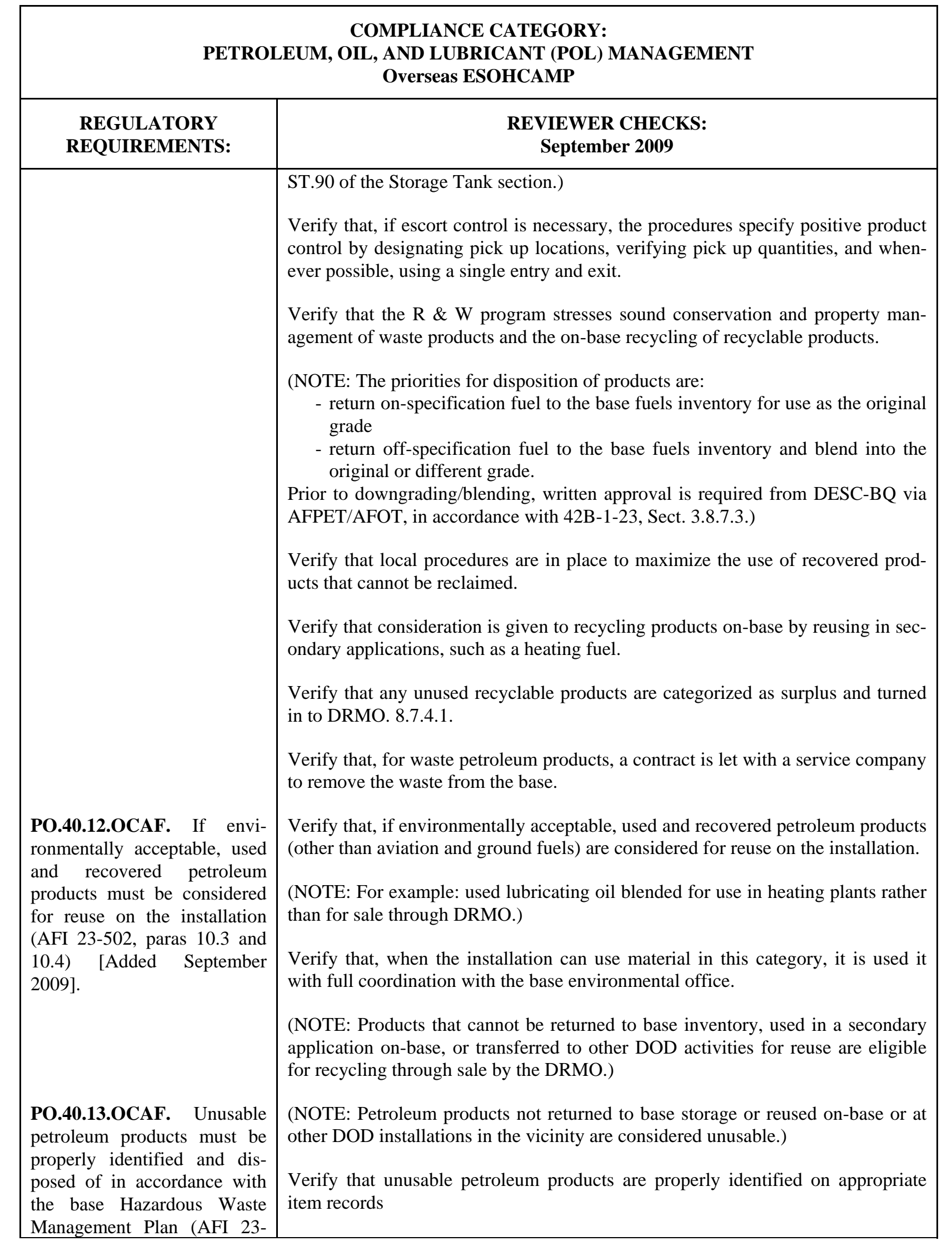




\begin{tabular}{|l|c|}
\hline \multicolumn{2}{|c|}{ PETROLEUM, OIL, AND LUBRICANT (POL) MANAGEMENT } \\
Overseas ESOHCAMP
\end{tabular}




\begin{tabular}{|l|l|}
\hline \multicolumn{2}{|c|}{ PETROLEUM, OIL, AND LUBRICANT (POL) MANAGEMENT } \\
Overseas ESOHCAMP
\end{tabular}




\title{
SECTION 9
}

\section{SOLID WASTE MANAGEMENT}

\section{Overseas ESOHCAMP}

\author{
September 2009
}

\section{A. Service-specific Regulations and Policies}

- Air Force Instruction (AFI) 41-201, Managing Clinical Engineering Programs, dated 25 March 2003, details how to establish a clinical engineering program for Air Force medical treatment facilities. The clinical engineering program addresses medical equipment maintenance, medical equipment management, and facility management, including managing regulated medical waste.

- HQ USAF/ILEV Memorandum, Revised Environmental Quality Metrics, 14 February 2005, requires immediate implementation across the AF (including overseas installations and government-owned/contractor-operated (GOCO) facilities of Under Secretary of Defense Memorandum, Revised Pollution Prevention and Compliance Metrics, dated 12 October 2004.

- Air Force Instruction 32-7042, Waste Management, 21 April 2009, identifies compliance requirements for all solid waste (SW), including hazardous waste (HW), but excludes radioactive waste and medical waste.

\section{B. DOD Directives and Instructions}

- Under Secretary of Defense Memorandum, Revised Pollution Prevention and Compliance Metrics, dated 12 October 2004, publishes pollution prevention (P2) metrics and definitions. Implementation begins in 2005. The following goals for solid waste are established in the memorandum:

1. Establish a cost-effective solid waste management program that includes reduction of waste generation and increased diversion

2. Optimize cost avoidance.

\section{Service-specific/DOD Definitions}

- Actual Disposal Cost $(A D C)$ - the cost to operate an integrated solid waste management program. AC $=$ collection and transportation costs + disposal cost + diversion cost - diversion proceeds. The collection and transportation costs are the actual cost to collect and transport the wastes for disposal and the diverted materials for diversion (Attachment 2, Under Secretary of Defense Memorandum, Revised Pollution Prevention and Compliance Metrics, 12 October 2004).

- Collection and Transportation Costs - the cost to collect and transport wastes and materials that are destined for either disposal or diversion. The collection and transportation costs include labor, maintenance, and other operational expenses associated with collection and transportation of all waste/material (Attachment 2, Under Secretary of Defense Memorandum, Revised Pollution Prevention and Compliance Metrics, 12 October 2004).

- Composting - a controlled biological decomposition process for managing the degradation of plant and other organic wastes to produce a useful product that can be used as mulch or soil conditioner (Attachment 2, Under Secretary of Defense Memorandum, Revised Pollution Prevention and Compliance Metrics, 12 October 2004).

- Construction and Demolition (C\&D) Debris - material produced during the construction, renovation, demolition or deconstruction of residential and commercial buildings and their infrastructure. C\&D waste typically includes 
concrete, wood, metals, gypsum wallboard, asphalt, and roofing material (Attachment 2, Under Secretary of Defense Memorandum, Revised Pollution Prevention and Compliance Metrics, 12 October 2004).

- Disposal Cost - the cost to dispose of wastes at disposal facilities (e.g., landfill, incinerator). Disposal cost is solely attributable to the management of the wastes destined for disposal and excludes collection and transportation costs to manage wastes destined for disposal. Disposal cost includes labor, maintenance, and other operational expenses for disposal (Attachment 2, Under Secretary of Defense Memorandum, Revised Pollution Prevention and Compliance Metrics, 12 October 2004).

- Diversion - nonhazardous solid waste is diverted from entering a disposal facility. Composting, mulching, recycling, reuse, and donation are generally accepted waste diversion methods (Attachment 2, Under Secretary of Defense Memorandum, Revised Pollution Prevention and Compliance Metrics, 12 October 2004).

- Diversion Cost - the cost to divert materials from disposal facilities. Diversion cost is solely attributable to the processing and marketing of material destined for diversion and excludes collection and transportation costs to manage materials destined for diversion. Diversion cost includes labor, maintenance, and other operational expenses for diversion (Attachment 2, Under Secretary of Defense Memorandum, Revised Pollution Prevention and Compliance Metrics, 12 October 2004).

- Diversion Proceeds - the income/earnings from the sale of diverted material (Attachment 2, Under Secretary of Defense Memorandum, Revised Pollution Prevention and Compliance Metrics, 12 October 2004).

- Economic Benefit of Integrated Solid Waste Management Programs - the cost avoided by diverting materials rather than disposing of them. Economic benefit equals Potential Cost minus Actual Disposal Cost. When the collection and transportation costs for the diverted material are about the same whether or not you divert, the Economic Benefit equals (diverted quantity $\mathrm{x}$ disposal tipping fee) - diversion cost + diversion proceeds. A positive economic benefit means that the cost to dispose of the diverted material is greater than the cost to divert the material (Attachment 2, Under Secretary of Defense Memorandum, Revised Pollution Prevention and Compliance Metrics, 12 October 2004).

- Incinerator - a device that burns solid waste as a fuel under controlled conditions, ideally converting organics to carbon dioxide and water (Attachment 2, Under Secretary of Defense Memorandum, Revised Pollution Prevention and Compliance Metrics, 12 October 2004).

- Installation Population - the number of military and civilian personnel, including their families, living or working at an installation as defined by the installation public affairs office. It should include contractors (Attachment 2, Under Secretary of Defense Memorandum, Revised Pollution Prevention and Compliance Metrics, 12 October 2004).

- Landfill - a discrete area of land or an excavation, on or off an installation, that receives household waste and that is not a land application unit, surface impoundment, injection well, or waste pile. A solid waste landfill also may receive other types of waste, such as commercial solid waste or industrial waste (Attachment 2, Under Secretary of Defense Memorandum, Revised Pollution Prevention and Compliance Metrics, 12 October 2004).

- Nonhazardous Solid Waste - refuse, garbage, scrap, sludge, and discarded waste that is routinely landfilled or incinerated. The waste is generally nonhazardous but may contain household hazardous waste, both hazardous and nonhazardous construction and demolition waste, lead acid batteries, ethylene glycol based antifreeze, and used motor oil (Attachment 2, Under Secretary of Defense Memorandum, Revised Pollution Prevention and Compliance Metrics, 12 October 2004).

- Nonhazardous Solid Waste Management Program - the systematic administrative activities which provide for the collection, source separation, storage, transportation, transfer, processing, treatment, or disposal of solid waste (Attachment 2, Under Secretary of Defense Memorandum, Revised Pollution Prevention and Compliance Metrics, 12 October 2004). 
- Nonrecurring Pollution Prevention Investment - the cost of equipment or facility that uses and produces nonhazardous components (Attachment 2, Under Secretary of Defense Memorandum, Revised Pollution Prevention and Compliance Metrics, 12 October 2004).

- Overseas - outside any territory, possession or commonwealth of the United States. This does not include contingency operations, training deployments, or the operations of military vessels and aircraft (Attachment 2, Under Secretary of Defense Memorandum, Revised Pollution Prevention and Compliance Metrics, 12 October 2004).

- Overseas Installation - permanent, base force structure facilities under the operational control of the Secretary of a military department or the Department of Defense that is located outside the United States and outside any territory, commonwealth or possession of the United States. Installations overseas do NOT include temporary, contingency operation or deployment support facilities. Tenants on overseas installations should report through their component headquarters reporting systems (Attachment 2, Under Secretary of Defense Memorandum, Revised Pollution Prevention and Compliance Metrics, 12 October 2004).

(NOTE: Include Government-owned, Contractor-operated [GOCO] installations.)

- Potential Cost (PC) - the estimated cost for disposal of all wastes/materials in the absence of diversion. PC = collection and transportation costs + disposal cost + diverted material disposal cost. The collection and transportation costs are the actual costs to collect and transport the wastes for disposal and the potential costs to collect and transport the diverted materials for disposal. The diverted material disposal cost equals the diverted quantity times the disposal tipping fee (Attachment 2, Under Secretary of Defense Memorandum, Revised Pollution Prevention and Compliance Metrics, 12 October 2004).

- Recycling - series of activities, including collection, separation, and processing, by which products or other materials are recovered from the solid waste stream for use in the form of raw materials in the manufacture of new products sold or distributed in commerce, or the reuse of such materials as substitutes for goods made of virgin materials, other than fuel, for producing heat or power by combustion (Attachment 2, Under Secretary of Defense Memorandum, Revised Pollution Prevention and Compliance Metrics, 12 October 2004).

- Reuse - return of a material or product to the economy for use without any change in its identity by finding different purposes for the materials. For example, a soft-drink bottle is reused when it is returned to the bottling company for refilling. Special processing is not required (Attachment 2, Under Secretary of Defense Memorandum, Revised Pollution Prevention and Compliance Metrics, 12 October 2004).

\section{Additional Records to Review}

- None

\section{E. Additional Physical Features to Inspect}

- None 


\section{F. Guidance for Checklist Users}

REFER TO CHECKLIST ITEMS:

Missing Checklist Items/Positive Findings

General

Solid Waste Storage and Collection

Land Disposal Sites

Closure and Postclosure

Construction and Demolition Debris

Medical Waste

General
SO.2.1.OCAF and SO.2.2.OCAF

SO.10.1.OCAF through SO.10.16.OCAF

SO.20.1.OCAF through SO.20.3.OCAF

SO.50.1.OCAF and SO.50.2.OCAF

SO.74.1.OCAF through SO.74.5.OCAF

SO.80.1.OCAF through SO.80.3.OCAF 


\begin{tabular}{|c|c|}
\hline \multicolumn{2}{|r|}{$\begin{array}{l}\text { COMPLIANCE CATEGORY: } \\
\text { SOLID WASTE MANAGEMENT } \\
\text { OverSeas ESOHCAMP }\end{array}$} \\
\hline $\begin{array}{l}\text { REGULATORY } \\
\text { REQUIREMENTS: }\end{array}$ & $\begin{array}{l}\text { REVIEWER CHECKS: } \\
\text { September } 2009\end{array}$ \\
\hline $\begin{array}{l}\text { SO.2 } \\
\text { MISSING CHECKLIST } \\
\text { ITEMS/POSITIVE } \\
\text { FINDINGS }\end{array}$ & \\
\hline $\begin{array}{l}\text { SO.2.1.OCAF. Installations } \\
\text { must comply with all applica- } \\
\text { ble regulatory requirements } \\
\text { not contained in this checklist } \\
\text { (a finding under this checklist } \\
\text { item will have the citation of } \\
\text { the applied regulation as a } \\
\text { basis of finding) [Added } \\
\text { March 2002]. }\end{array}$ & $\begin{array}{l}\text { Determine whether any new regulations concerning solid waste management have } \\
\text { been issued since the finalization of the manual. } \\
\text { Determine whether the installation has activities or facilities that are regulated but } \\
\text { not addressed in this checklist. } \\
\text { Verify that the installation is in compliance with all applicable and newly issued } \\
\text { regulations. }\end{array}$ \\
\hline $\begin{array}{l}\text { SO.2.2.OCAF. Installations } \\
\text { should go above and beyond } \\
\text { environmental statutory and } \\
\text { regulatory compliance (MP) } \\
\text { [Added March 2002]. }\end{array}$ & $\begin{array}{l}\text { Determine whether the installation has gone above and beyond simply complying } \\
\text { with environmental requirements. } \\
\text { (NOTE: This checklist item is used only to write positive findings.) }\end{array}$ \\
\hline
\end{tabular}




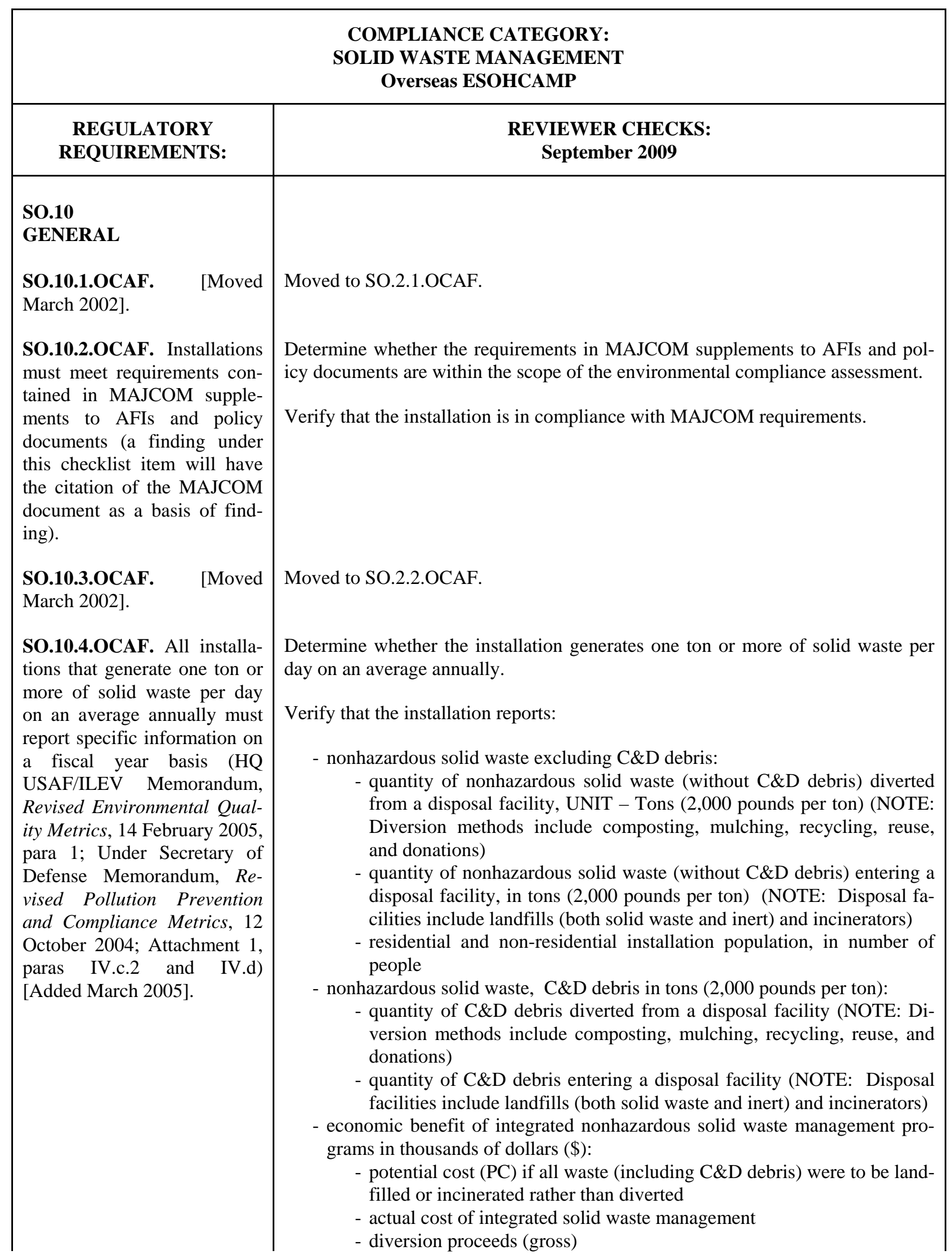




\begin{tabular}{|c|c|}
\hline \multicolumn{2}{|r|}{$\begin{array}{l}\text { COMPLIANCE CATEGORY: } \\
\text { SOLID WASTE MANAGEMENT } \\
\text { Overseas ESOHCAMP }\end{array}$} \\
\hline $\begin{array}{l}\text { REGULATORY } \\
\text { REQUIREMENTS: }\end{array}$ & $\begin{array}{l}\text { REVIEWER CHECKS: } \\
\text { September } 2009\end{array}$ \\
\hline $\begin{array}{l}\text { SO.10.5.OCAF. Installations } \\
\text { must have a complete ISWM } \\
\text { Plan that meets specific re- } \\
\text { quirements (AFI 32-7042, } \\
\text { paras 3.2.1, 3.2.2, 3.2.2.1, } \\
\text { 3.6.4.1, and 3.8.1.3) [Added } \\
\text { September 2009]. }\end{array}$ & $\begin{array}{l}\text { - cost of solid waste management reported in President's Budget (Exhibit PB- } \\
\text { 28) in thousands of dollars (\$): } \\
\text { - nonrecurring compliance investment, RCRA Subtitle D, Solid Waste } \\
\text { - nonrecurring pollution prevention investment, RCRA Subtitle D, Solid } \\
\quad \text { Waste. } \\
\text { (NOTE: A potential sources of data is the President's Budget [Exhibit PB-28].) } \\
\text { (NOTE: Begin collecting this data in Fiscal Year 2005.) } \\
\text { Verify that the ISWM plan has been reviewed annually, updated as appropriate, } \\
\text { and approved by the installation ESOHC. } \\
\text { Verify that the ISWM plan contains sections that address the following: } \\
\text { - Purpose } \\
\text { - Authority } \\
\text { - Responsibility } \\
\text { - Introduction or Executive Summary } \\
\text { - Program Elements } \\
\text { - Disposal and Diversion Options } \\
\text { - Waste Streams--Management Methods and Opportunities } \\
\text { - Plan Implementation } \\
\text { - Solid Waste Diversion Goals } \\
\text { - Materials Prohibited from Waste Streams } \\
\text { - Public Awareness, Education and Outreach } \\
\text { - On-Site MSW Landfills } \\
\text { - Management of C\&D debris } \\
\text { - Management of Overseas Refuse } \\
\text { - Recordkeeping and Reporting } \\
\text { - Programming and Budgeting } \\
\text { - the QRP Business Plan as an appendix, if the installation operates a QRP. }\end{array}$ \\
\hline $\begin{array}{l}\text { SO.10.6.OCAF. All solid } \\
\text { waste diversion and disposal } \\
\text { data must be collected and } \\
\text { maintained and reported upon } \\
\text { request to AFCEE (AFI 32- } \\
\text { 7042, para 3.3.2) [Added Sep- } \\
\text { tember 2009]. }\end{array}$ & $\begin{array}{l}\text { Verify that all solid waste diversion and disposal data is collected and maintained. } \\
\text { Verify that all solid waste diversion and disposal data is reported upon request to } \\
\text { AFCEE. }\end{array}$ \\
\hline $\begin{array}{l}\text { SO.10.7.OCAF. Installation } \\
\text { MSW management must in- } \\
\text { clude a recycling program } \\
\text { (AFI 32-7042, para 3.5.1) } \\
\text { [Added September 2009]. }\end{array}$ & $\begin{array}{l}\text { Verify that installation MSW management includes a recycling program that will } \\
\text { strive to divert as much MSW as economically and technically practical, and at a } \\
\text { minimum, in accordance with FGS requirements or OEBGD in the absence of } \\
\text { approved FGS. } \\
\text { (NOTE: An installation-recycling program consists of handling, storage, collec- }\end{array}$ \\
\hline
\end{tabular}




\begin{tabular}{|c|c|}
\hline \multicolumn{2}{|r|}{$\begin{array}{l}\text { COMPLIANCE CATEGORY: } \\
\text { SOLID WASTE MANAGEMENT } \\
\text { Overseas ESOHCAMP }\end{array}$} \\
\hline $\begin{array}{l}\text { REGULATORY } \\
\text { REQUIREMENTS: }\end{array}$ & $\begin{array}{l}\text { REVIEWER CHECKS: } \\
\text { September } 2009\end{array}$ \\
\hline $\begin{array}{l}\text { SO.10.8.OCAF. Installations } \\
\text { must integrate waste reduc- } \\
\text { tion solutions into ISWM, to } \\
\text { include MSW, in the most } \\
\text { cost effective manner possible } \\
\text { (AFI 32-7042, para 3.5.2) } \\
\text { [Added September 2009]. }\end{array}$ & $\begin{array}{l}\text { tion, sales, record keeping, and reporting.) } \\
\text { Verify that the installation integrates waste reduction solutions into ISWM, to } \\
\text { include MSW, in the most cost effective manner possible. }\end{array}$ \\
\hline $\begin{array}{l}\text { SO.10.9.OCAF. Installations } \\
\text { must strive to divert as much } \\
\text { of their SW stream in the } \\
\text { most cost-effective manner } \\
\text { possible (AFI 32-7042, para } \\
\text { 3.6.1) [Added September } \\
\text { 2009]. }\end{array}$ & $\begin{array}{l}\text { Verify that the installation strives to divert as much of their SW stream in the } \\
\text { most cost-effective manner possible. }\end{array}$ \\
\hline $\begin{array}{l}\text { SO.10.10.0CAF. Installa- } \\
\text { tions must conduct annual } \\
\text { opportunity assessments of } \\
\text { their SW stream to identify } \\
\text { source reduction potential and } \\
\text { additional recyclable materi- } \\
\text { als (AFI 32-7042, para } \\
\text { 3.6.2.5) [Added September } \\
\text { 2009]. }\end{array}$ & $\begin{array}{l}\text { Verify that the installation conducts annual opportunity assessments of their SW } \\
\text { stream to identify source reduction potential and additional recyclable materials. }\end{array}$ \\
\hline $\begin{array}{l}\text { SO.10.11.OCAF. Installa- } \\
\text { tions must, as appropriate, } \\
\text { operate a composting program } \\
\text { or participate in a regional } \\
\text { composting program (AFI 32- } \\
\text { 7042, para 3.6.4) [Added Sep- } \\
\text { tember 2009]. }\end{array}$ & $\begin{array}{l}\text { Verify that, if appropriate, the installation operates a composting program or par- } \\
\text { ticipates in a regional composting program. } \\
\text { (NOTE: Installations may consider participating in existing municipal and com- } \\
\text { munity composting programs before implementing an installation-operated com- } \\
\text { posting program.) } \\
\text { (NOTE: Installation programs should include yard trimmings, tree trimmings, } \\
\text { food wastes, and biosolids.) } \\
\text { Verify that the installations develops a composting operations plan prior to begin- } \\
\text { ning a composting operation. } \\
\text { Verify that the installations develops a composting operations plan is part of the } \\
\text { ISWM Plan. } \\
\text { Verify that the nstallation maintains facility-monitoring logs to record operational } \\
\text { parameters such as turning frequency, temperature readings, watering frequency, } \\
\text { and windrow/pile composition. }\end{array}$ \\
\hline
\end{tabular}




\section{COMPLIANCE CATEGORY: \\ SOLID WASTE MANAGEMENT \\ Overseas ESOHCAMP}

\begin{tabular}{|c|c|}
\hline $\begin{array}{l}\text { REGULATORY } \\
\text { REQUIREMENTS: }\end{array}$ & $\begin{array}{l}\text { REVIEWER CHECKS: } \\
\text { September } 2009\end{array}$ \\
\hline $\begin{array}{l}\text { SO.10.12.OCAF. The instal- } \\
\text { lation's composting opera- } \\
\text { tions plan should include spe- } \\
\text { cific elements (MP) [Added } \\
\text { September 2009]. }\end{array}$ & $\begin{array}{l}\text { Verify that the installation's composting operations plan includes: } \\
\text { - operating procedures } \\
\text { - safety and emergency procedures } \\
\text { - operational checklists } \\
\text { - process troubleshooting. } \\
\text { (NOTE: This MP is found at AFI 32-7042, para 3.6.4.1.) }\end{array}$ \\
\hline $\begin{array}{l}\text { SO.10.13.OCAF. Installa- } \\
\text { tions must inspect trash recep- } \\
\text { tacles used to collect indus- } \\
\text { trial shop waste to make sure } \\
\text { they do not contain HW (AFI } \\
\text { 32-7042, para 3.9.3 and } \\
\text { 3.9.3.2) [Added September } \\
\text { 2009]. }\end{array}$ & $\begin{array}{l}\text { Verify that trash receptacles used to collect industrial shop waste are inspected to } \\
\text { make sure they do not contain HW. } \\
\text { Verify that inspection records are retained in accordance with the Air Force Re- } \\
\text { cords Disposition Schedule. }\end{array}$ \\
\hline $\begin{array}{l}\text { SO.10.14.OCAF. Squadron } \\
\text { facility managers must ensure } \\
\text { that hazardous materials, haz- } \\
\text { ardous waste and recyclables } \\
\text { are not disposed of in trash } \\
\text { receptacles and must conduct } \\
\text { periodic squadron spot in- } \\
\text { spections (AFI 32-7042, para } \\
\text { 3.9.3.1) [Added September } \\
\text { 2009]. }\end{array}$ & $\begin{array}{l}\text { Verify that that hazardous materials, hazardous waste, and recyclables are not } \\
\text { disposed of in trash receptacles. } \\
\text { Verify that squadron facility managers conduct periodic squadron spot inspec- } \\
\text { tions. }\end{array}$ \\
\hline $\begin{array}{l}\text { SO.10.15.OCAF. Installa- } \\
\text { tions must establish an ongo- } \\
\text { ing program to inform all in- } \\
\text { stallation personnel of prohib- } \\
\text { ited materials in the MSW } \\
\text { stream (AFI 32-7042, para } \\
\text { 3.9.3.3) [Added September } \\
\text { 2009]. }\end{array}$ & $\begin{array}{l}\text { Verify that the installation has established an ongoing program to inform all in- } \\
\text { stallation personnel of prohibited materials in the MSW stream. }\end{array}$ \\
\hline $\begin{array}{l}\text { SO.10.16.OCAF. Tenant } \\
\text { organizations on AF installa- } \\
\text { tions must must meet specific } \\
\text { solid waste management re- } \\
\text { quirements (AFI 32-7042, } \\
\text { para 1.10.9) [Added Septem- } \\
\text { ber 2009]. }\end{array}$ & $\begin{array}{l}\text { Verify that AF installation tenants comply with the installation solid waste man- } \\
\text { agement programs and applicable environmental laws, unless exempted by } \\
\text { DoD/AF instruction. } \\
\text { (NOTE: When a tenant is in noncompliance with } \mathrm{SW} \text { and HW laws, the installa- } \\
\text { tion commander has the authority to take whatever action is necessary to require } \\
\text { tenants to comply.) } \\
\text { Verify that AF installation tenants meet the appropriate tenant responsibilities as }\end{array}$ \\
\hline
\end{tabular}




\begin{tabular}{|c|c|}
\hline \multicolumn{2}{|c|}{$\begin{array}{c}\text { COMPLIANCE CATEGORY: } \\
\text { SOLID WASTE MANAGEMENT } \\
\text { Overseas ESOHCAMP }\end{array}$} \\
\hline $\begin{array}{c}\text { REGULATORY } \\
\text { REQUIREMENTS: }\end{array}$ & \multicolumn{1}{c|}{$\begin{array}{c}\text { REVIEWER CHECKS: } \\
\text { September 2009 }\end{array}$} \\
\hline & $\begin{array}{l}\text { spelled out in installation waste management plans. } \\
\text { Verify that AF installation tenants conduct their activities in accordance with the } \\
\text { installation's permit requirements. }\end{array}$ \\
\hline
\end{tabular}




\begin{tabular}{|c|c|}
\hline \multicolumn{2}{|r|}{$\begin{array}{l}\text { COMPLIANCE CATEGORY: } \\
\text { SOLID WASTE MANAGEMENT } \\
\text { Overseas ESOHCAMP }\end{array}$} \\
\hline $\begin{array}{l}\text { REGULATORY } \\
\text { REQUIREMENTS: }\end{array}$ & $\begin{array}{l}\text { REVIEWER CHECKS: } \\
\text { September } 2009\end{array}$ \\
\hline $\begin{array}{l}\text { SO.20 } \\
\text { SOLID WASTE STORAGE } \\
\text { AND COLLECTION }\end{array}$ & \\
\hline $\begin{array}{l}\text { SO.20.1.OCAF. [Deleted } \\
\text { July 2008]. }\end{array}$ & Deleted at the request of the sponsor. \\
\hline $\begin{array}{l}\text { SO.20.2.OCAF. [Deleted } \\
\text { July 2008]. }\end{array}$ & Deleted at the request of the sponsor. \\
\hline $\begin{array}{l}\text { SO.20.3.OCAF. [Deleted } \\
\text { July 2008]. }\end{array}$ & Deleted at the request of the sponsor. \\
\hline
\end{tabular}




\begin{tabular}{|c|c|}
\hline \multicolumn{2}{|r|}{$\begin{array}{l}\text { COMPLIANCE CATEGORY: } \\
\text { SOLID WASTE MANAGEMENT } \\
\text { Overseas ESOHCAMP }\end{array}$} \\
\hline $\begin{array}{l}\text { REGULATORY } \\
\text { REQUIREMENTS: }\end{array}$ & $\begin{array}{l}\text { REVIEWER CHECKS: } \\
\text { September } 2009\end{array}$ \\
\hline $\begin{array}{l}\text { SO.50 } \\
\text { LAND DISPOSAL SITES: } \\
\text { Closure and Postclosure }\end{array}$ & $\begin{array}{l}\text { (NOTE: The requirements of this section of the manual apply only to those instal- } \\
\text { lations that operate a municipal solid waste landfill [MSWLF].) }\end{array}$ \\
\hline $\begin{array}{l}\text { SO.50.1.OCAF. [Moved June } \\
\text { 2003; Deleted July 2008]. }\end{array}$ & $\begin{array}{l}\text { Deleted at the request of the sponsor. } \\
\text { [Formerly checklist item number SO.30.1.OCAF.] }\end{array}$ \\
\hline $\begin{array}{l}\text { SO.50.2.OCAF. [Moved June } \\
\text { 2003; Deleted July 2008]. }\end{array}$ & $\begin{array}{l}\text { Deleted at the request of the sponsor. } \\
\text { [Formerly checklist item number SO.30.2.OCAF.] }\end{array}$ \\
\hline
\end{tabular}




\section{COMPLIANCE CATEGORY: SOLID WASTE MANAGEMENT Overseas ESOHCAMP}

\section{REGULATORY REQUIREMENTS: \\ SO.74 \\ CONSTRUCTION AND DEMOLITION DEBRIS}

SO.74.1.OCAF. Installations should pursue cost-effective management approaches that decrease the landfill space required for $C \& D$ debris, decrease the amount of HW contami-nating $C \& D$ debris, and help the Air Force further its commitment to pollution prevention (MP) [Added September 2009].

SO.74.2.OCAF. Installations must document and report data on the weight of C\&D debris diverted and the weight of C\&D debris disposed (AFI 32-7042, para 3.8.1.4) [Added September 2009].

SO.74.3.OCAF. C\&D debris must be characterized to determine whether to dispose of it as non-hazardous SW or HW (AFI 32-7042, paras 3.8.2.1 and 3.8.2.2) [Added September 2009].

SO.74.4.OCAF. C\&D debris that is determined to be hazardous waste must be managed in accordance with specific requirements (AFI 327042, para 3.8.2.1.3) [Added September 2009].

SO.74.5.OCAF. The asbes-

\section{REVIEWER CHECKS:} September 2009

Verify that the installation pursues cost-effective management approaches that:

- decrease the landfill space required for $C \& D$ debris

- decrease the amount of HW contaminating C\&D debris, and

- help the Air Force further its commitment to pollution prevention.

(NOTE: This MP is found at AFI 32-7042, para 3.8.1.2.)

Verify that the installation documents and reports data on the weight of C\&D debris diverted and the weight of C\&D debris disposed.

Verify that all C\&D debris disposal contracts are reviewed to ensure this requirement is being met.

Verify that this information is reported as requested to AFCEE.

Verify that C\&D debris is characterized to determine whether to dispose of it as nonhazardous SW or HW.

Verify that $C \& D$ debris samples reflect all components of the $C \& D$ debris.

(NOTE: Nonhazardous C\&D debris may be disposed of in a MSWLF or in a landfill that only accepts $C \& D$ debris, depending upon local regulations.)

(NOTE: C\&D debris may be contaminated with lead-based paint; see the checklist items under T4 in Toxic Substances Management, both in this manual and in the FGS-based manual.)

Verify that C\&D debris determined to be hazardous is separated from non-HW, appropriately containerized, labeled, and properly manifested prior to transportation for final disposal.

Verify that C\&D debris classified as HW is disposed of in a permitted HW facility.

Verify that the asbestos-contaminated C\&D debris generated from construction, 


\begin{tabular}{|c|c|}
\hline \multicolumn{2}{|c|}{$\begin{array}{c}\text { COMPLIANCE CATEGORY: } \\
\text { SOLID WASTE MANAGEMENT } \\
\text { Overseas ESOHCAMP }\end{array}$} \\
\hline $\begin{array}{c}\text { REGULATORY } \\
\text { REQUIREMENTS: }\end{array}$ & $\begin{array}{c}\text { REVIEWER CHECKS: } \\
\text { September 2009 }\end{array}$ \\
\hline $\begin{array}{l}\text { tos-contaminated C\&D debris } \\
\text { generated from construction, } \\
\text { renovation, or demolition } \\
\text { activities must be treated as } \\
\text { asbestos-containing waste } \\
\text { (AFI 32-7042, para 3.8.3.3) } \\
\text { [Added September 2009]. }\end{array}$ & $\begin{array}{l}\text { (NOTE: See the checklist items under T2 in Toxic Substances Management, both } \\
\text { in this manual and in the FGS-based manual.) }\end{array}$ \\
\hline
\end{tabular}




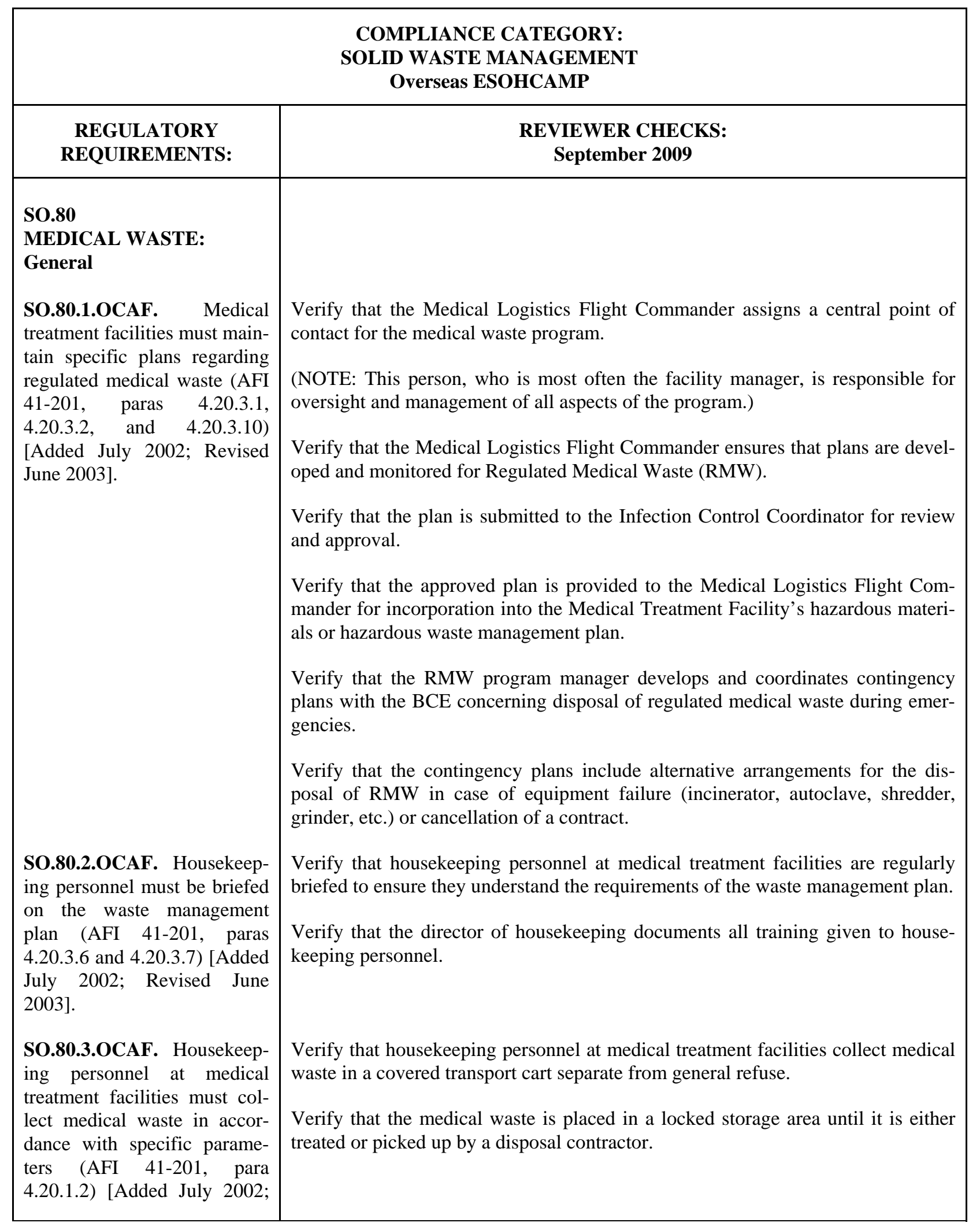




\begin{tabular}{|c|c|}
\hline \multicolumn{1}{|c|}{} & $\begin{array}{c}\text { COMPLIANCE CATEGORY: } \\
\text { SOLID WASTE MANAGEMENT } \\
\text { Overseas ESOHCAMP }\end{array}$ \\
\hline REGULATORY & REVIEWER CHECKS: \\
REQUIREMENTS: & \\
\hline Revised June 2003]. & \\
\hline
\end{tabular}




\title{
SECTION 10
}

\section{STORAGE TANK MANAGEMENT}

\section{Overseas ESOHCAMP}

\author{
September 2009
}

\section{A. Service-specific Regulations and Policies}

- Air Force Instruction (AFI) 23-201, Fuels Management, 24 April 2009, provides managers at all AF activities with policy and procedures for fuels operations.

- AFI 23-204, Organizational Fuel Tanks, 24 June 2009, contains guidelines and procedures for establishing and operating organizational fuel tanks. The policies and procedures in this instruction apply primarily to AF operations, both military and civilian. They may also apply to contractor-operated locations when practical and economically justifiable. Contracting personnel must specify these policies in legal agreements with contractors to make them binding.

- AFI 32-7044, Storage Tank Compliance, 13 November 2003, identifies compliance requirements for storage tanks and associated piping that store petroleum and hazardous substances except hazardous waste. It explains how to assess, attain, and sustain compliance with Federal, state and local environmental regulations, Final Governing Standards (FGS), or the Overseas Environmental Baseline Guidance Document (OEBGD), applicable international agreements, and related Department of Defense (DOD) and Air Force (AF) directives. For DOD components at installations outside the United States, its territories, and possessions, i.e. overseas, implement the applicable portions of this AFI in accordance with international agreements and the applicable FGS or Environmental Governing Standards or, in their absence, the OEBGD. See AFI 32-7006, Environmental Program in Foreign Countries for additional environmental guidance for overseas installations. Unless otherwise noted, the guidance and procedures outlined in this instruction apply to all Air Force installations within the United States, its territories, and in foreign countries. This AFI describes the environmental and engineering requirements for underground and aboveground storage tanks (ASTs and USTs) and associated piping that store petroleum and hazardous substances; it does not address the storage of hazardous waste in tanks.

- Unified Facilities Criteria (UFC) 3-460-03, Operations and Maintenance: Maintenance of Petroleum Systems, 21 January 2003, requires the Fuels Management Flight (FMF), having been trained in proper procedures by the Liquid Fuels Maintenance (LFM) shop foreman, to drain floating roofs and interior dike basins as required.

\section{B. DOD Directives and Instructions}

- None

\section{Service-specific/DOD Definitions}

- Aboveground Storage Tank - an unburied storage tank, such as a bulk storage tank, and includes any aboveground container containing oil, as provided in Title 40, Code of Federal Regulations (40 CFR) 112.1(b)(1); or bunkered tank, partially buried tank or completely buried tank containing oil, as defined in 40 CFR 112.2 (AFI 32-7044, Attachment 1).

- Automated Line Leak Detectors - devices attached to the pressurized piping from a service-station-type dispenser for detection of $3 \mathrm{gal} / \mathrm{h}$ product loss. These detectors briefly restrict flow after pump start up by sensing vapor space resultant from lost product in piping during off periods (AFI 32-7044, Attachment 1). 
- Bulk Petroleum Products - petroleum product delivered in volumes greater than 208 L (55 U.S. gal), such as tank trucks/cars, pipelines, coastal barges, and ocean tankers. This term can apply to several Defense Energy Support Center (DESC) purchase programs including the Bulk Fuels Program for military specification jet and marine fuels, the Posts, Camps, and Stations commercial gasoline and diesels, and the Bunkers Fuel Program. Product is stored in tankage having a fill capacity greater than 208 liters (55 U.S. gal) (AFI 23-201, Attachment 1).

- Bulk Storage Tank - has the same meaning here as "bulk storage container" in 40 CFR 112.2. An AST, of 55 gal or greater capacity, used to store oil, including the storage of oil prior to use, while being used, or prior to further distribution in commerce. Oil-filled electrical, operating, or manufacturing equipment is not a bulk storage container (AFI 32-7044, Attachment 1).

- Bunkered Tank - a container constructed or placed in the ground by cutting the earth and re-covering the container in a manner that breaks the surrounding natural grade, or that lies above grade, and is covered with earth, sand, gravel, asphalt, or other material (See Aboveground Storage Tank) (40 CFR 112.2).

- Cathodic Protection - a technique for preventing corrosion of a metal surface by making the surface the cathode of an electrochemical cell. A tank system can be cathodically protected by applying either galvanic anodes or impressed current (AFI 32-7044, Attachment 1).

- Change-In-Service - continued use of an underground storage tank system to store an unregulated substance (AFI 32-7044, Attachment 1).

- Completely Buried Tank - any container completely below grade and covered with earth, sand, gravel, asphalt, or other material (See Aboveground Storage Tank) (40 CFR 112.2).

- Existing UST - a tank system containing a regulated substance that was installed on or before 22 December 1988 (AFI 32-7044, Attachment 1).

- Facility Response Plan - a plan required to be prepared in accordance with 40 CFR 112.20 by an owner or operator of a nontransportation related facility that, because of its location, reasonably can be expected to cause substantial harm to the environment through the discharge of oil into or on navigable waters or adjoining shorelines (AFI 32-7044, Attachment 1).

- Field-Constructed ASTs - large volume vertical cylindrical tanks constructed onsite. The bottom surface of these tanks is in contact with ground and cannot be visually inspected (AFI 32-7044, Attachment 1).

- Final Governing Standards (FGS) - country specific substantive provisions concerning the environment, typically technical limitations on effluent, discharges, etc., or a specific management practice for DOD installations in specific countries (AFI 32-7044, Attachment 1).

- Free Product - a regulated substance that exists as a non-aqueous phase liquid (a liquid that does not dissolve in water) (AFI 32-7044, Attachment 1).

- Hazardous Substance UST - a UST system containing a Comprehensive Environmental Response, Compensation, and Liability Act (CERCLA) hazardous substance that is not also a Resource Conservation and Recovery Act (RCRA) hazardous waste (see Appendix 10-1) (AFI 32-7044, Attachment 1).

- Issue Tank - a type of organizational fuel tank, namely one that is not physically connected to any equipment or facility and that is used to dispense fuel to mobile trailers, ground-support equipment, or portable containers (AFI 23-204, para 2.3).

- Management Practice (MP) - practices that, although not mandated by law, are encouraged to promote safe operating procedures. 
- New UST - a tank system containing a regulated substance that was installed after 22 December 1988 (AFI 327044, Attachment 1).

- Oil - has the meaning provided for "petroleum oil' in 40 CFR 112.2. It generally includes crude oil, fuel oil, gasoline, jet fuel, mineral oil, sludge, oil refuse, greases, oil mixed with wastes other than dredged spoil, or any other kind or form of oil. However, "oil" as used in AFI 32-7044 does not include "animal oils" such animal, fish, or marine mammal fats, oils, or greases; or "vegetable oils" such as oils from seeds, nuts, fruits, or kernels since the latter oils are not stored in tanks on AF installations (AFI 32-7044, Attachment 1).

- Organizational Fuel Tank - any tank, other than integral vehicle tanks or hand-carried safety cans, not under exclusive fuels management control. There are three types of organizational fuel tanks: support, issue, and portable (q.v.) (AFI 23-201, Attachment 1 and AFI 23-204, para 2.1).

- Overfill Release - a release occurring when someone attempts to fill a tank beyond its capacity, resulting in discharging the regulated substance to the environment (AFI 32-7044, Attachment 1).

- Overseas - a nation, territory or geographic area that is outside the United States and its territories (AFI 32-7044, Attachment 1).

- Overseas Environmental Baseline Guidance Document (OEBGD) - developed by the DOD, a set of procedures and minimum criteria for environmental compliance at DOD installations in overseas locations. It is used by the Environmental Executive Agent to establish the FGS, and in the case where no FGS exists, provides the compliance criteria (AFI 32-7044, Attachment 1).

- Partially Buried Tank - a storage container that is partially inserted or constructed in the ground, but not entirely below grade, and not completely covered with earth, sand, gravel, asphalt, or other material (See Aboveground Storage Tank) (40 CFR 112.2).

- Petroleum AST - an AST containing petroleum or a petroleum mixture, including: motor fuels, jet fuels, distillate fuel oils, residential fuel oils, lubricants, petroleum solvents, and used oils (AFI 32-7044, Attachment 1).

- Petroleum UST - a UST system containing petroleum or a petroleum mixture, including: motor fuels, jet fuels, distillate fuel oils, residential fuel oils, lubricants, petroleum solvents, and used oils (AFI 32-7044, Attachment 1).

- Portable Tank - a type of organizational fuel tank, namely any mobile tank (A1B fuel trailer, vehicle-mounted tank, Mobile Engine Test Stand Tank, etc.) used for mobility maintenance, research and development, or similar purposes. NOTE: Portable tanks may be used for either issue or support purposes (AFI 23-204, para 2.4).

- Regulated Substance - has the meaning provided in 40 CFR 280.12 and any more protective state regulation. It generally includes (AFI 32-7044, Attachment 1):

(1) Petroleum, including crude oil or any crude oil mixture that remains a liquid at standard temperatures and pressures. "Regulated substances" include petroleum and petroleum based substances composed of a complex blend of hydrocarbons derived from crude oil through separation, conversion, upgrading, and finishing, such as: motor fuels, jet fuels, distillate fuel oils, residual fuel oils, lubricants, petroleum solvents, and used oils.

(2) Any hazardous substance defined in Section 101(14) of the Comprehensive Environmental Response, Compensation, and Liability Act (CERCLA) of 1980, but not including any substance regulated as a hazardous waste under Subtitle C of the Resource Conservation and Recovery Act (RCRA) of 1976 (see Appendix 10-1).

- Release - spilling, leaking, emitting, discharging, escaping, leaching, or disposing of a substance from an underground storage tank into groundwater, surface water, or soil (AFI 32-7044, Attachment 1). 
- Release Detection - determining whether a UST system has released a regulated substance into the environment or into the interstitial space between a UST system and its secondary barrier or secondary containment area. Common release detection methods include (AFI 32-7044, Attachment 1):

(1) Inventory Control - a physical accounting system in which records are kept of input, output, and daily tank inventories, including:

(2) Manual Tank Gauging - measuring a tank's liquid level at the beginning and end of a 36-h time period and calculating the change in volume. Limited to 550-gal or smaller USTs when manual tank gauging is used alone.

(3) Tank-Tightness Testing - one of several technologies that can measure very small changes in product volume to find a leak. Civil Engineering (CE) must adjust the results for temperature, structural deformation, trapped air, and so on.

(4) Automatic Tank Gauging - collecting release detection and inventory information by continuously monitoring the product level.

(5) Nonvolumetric Tank-Tightness Testing - includes a variety of methodologies that apply to piping and tanks of any size. Some involve injecting a tracer gas for monitoring the presence of a release outside the tank. Others track the sound of product or bubbles leaving the tank. In about 50 percent of the cases, piping leaks are the cause.

(6) Secondary Containment with Interstitial Monitoring - detects product in the space between the wall of the tank and the secondary containment liner or wall. Applies to piping and tanks of any size.

(7) Groundwater Monitoring - detects regulated substances in groundwater. The substance must be immiscible in water and have a specific gravity less than 1.0. Applies to piping and tanks of any size.

(8) Vapor Monitoring - detects fuel vapors in soil above the groundwater table. This test is not always reliable. Applies to tanks of any size and piping.

(9) Release Detection for Piping - note that automatic line leak detectors are manufactured only for small diameter piping on systems with low flow rates normally associated with submersible pumps and service station dispensers to issue ground fuels. Automatic line leak detectors are not intended for high volume pressurized piping for aviation hydrant systems or truck loading facilities. These systems are excluded from this requirement if the flow rates exceed $10 \mathrm{gal} / \mathrm{min}$. Periodic line testing or monitoring may still be required per AFI 32-7044, para 2.2.3.

- Self-Diking Tanks (or Aboveground Secondary Containment [Vaulted] Tanks) - small rectangular or horizontal cylindrical ASTs delivered to the site fully constructed. These tanks have integral secondary containment which is sometimes filled with lightweight concrete for fire protection (AFI 32-7044, Attachment 1).

- Spill Prevention, Control, and Countermeasures - the Clean Water Act oil pollution prevention procedures provided in 40 CFR 112 (AFI 32-7044, Attachment 1).

- Storage Tank - a stationary device that contains an accumulation of regulated substances (AFI 32-7044, Attachment 1).

- Support Tank - a type of organizational fuel tank, namely one that is physically connected, by fixed piping, to a consuming facility or installed piece of equipment. NOTE: Do not issue fuel from support tanks to vehicles or other equipment (AFI 23-204, para 2.2).

- Suspected Releases - the following consitute suspected releases [from USTs] (AFI 32-7044, paras 2.4.1.1.1 through 2.4.1.1.4):

1. The discovery of regulated substances at the UST site or in the surrounding area (such as free product or vapors in soils, basements, sewer and utility lines and near surface water)

2. Unusual operating conditions, such as the erratic behavior of dispensing equipment, the sudden loss of product from the system, or an unexplained loss of product from the system. (Note that mechanical automatic line leak detectors and some electronic line leak detectors signal a suspected line leak by greatly slowing down the flow of product in the distribution line. This can appear as erratic operation of dispensing equipment.) Any of these conditions are considered a suspected release unless system equipment is found to be defective but not leaking within the 24-h period allowed for reporting suspected releases and is immediately repaired or replaced. 
3. Monitoring results from a required tank or line release detection method that indicate a release may have occurred, unless the following conditions are within the allowed 24-h period:

a. The monitoring device is found to be defective and is immediately repaired, recalibrated, or replaced and additional monitoring does not confirm the initial result

b. If inventory control shows excessive variance (i.e., if monthly reconciliations [using the EPA leak check comparison of book inventories versus tank measurements] exceed 1 percent of tank throughput plus 130 gal), a suspected release must be reported and followed up if there are two consecutive months of excessive variances.

- Tank in a Vault - a tank located above the floor of a subterranean vault (AFI 32-7044, Attachment 1).

- Underground Storage Tank (UST) - any tank or combination of tanks (including underground pipes connected to the tank), with a volume of at least 110 gal, that contains an accumulation of regulated substances, where 10 percent or more of the volume (including underground pipes connected to the tank) lies beneath the ground surface (AFI 32-7044, Attachment 1).

- UST System or Tank System - generally means an underground storage tank, connected underground piping, underground ancillary equipment, and any containment system (AFI 32-7044, Attachment 1).

\section{Additional Records to Review}

- Listing of organizational fuel tanks

- Documentation related to the tank custodian program

\section{E. Additional Physical Features to Inspect}

- None 


\section{F. Guidance for Checklist Users}

REFER TO CHECKLIST ITEMS:

Missing Checklist Items/Positive Findings

General

ASTs and USTs

ASTs

Design

Operations

USTs

General

New USTs

Existing USTs

Leaking USTs

Hazardous Waste Tank Systems

Organizational Fuel Tanks
ST.2.1.OCAF and ST.2.2.OCAF

ST.3.1.OCAF through ST.3.11.OCAF

ST.7.1.OCAF through ST.7.20.OCAF

ST.11.1.OCAF through ST.11.8.OCAF

ST.12.1.OCAF through ST.12.9.OCAF

ST.20.1.OCAF through ST.20.14.OCAF

ST.30.1.OCAF and ST.30.2.OCAF

ST.40.1.OCAF through ST.40.3.OCAF

ST.50.1.OCAF and ST.50.2.OCAF

ST.70.1.OCAF and ST.70.2.OCAF

ST.90.1.OCAF through ST.90.26.OCAF 


\begin{tabular}{|c|c|}
\hline \multicolumn{2}{|r|}{$\begin{array}{l}\text { COMPLIANCE CATEGORY: } \\
\text { STORAGE TANK MANAGEMENT } \\
\text { Overseas ESOHCAMP }\end{array}$} \\
\hline $\begin{array}{l}\text { REGULATORY } \\
\text { REQUIREMENTS: }\end{array}$ & $\begin{array}{l}\text { REVIEWER CHECKS: } \\
\text { March } 2009\end{array}$ \\
\hline $\begin{array}{l}\text { ST.2 } \\
\text { MISSING CHECKLIST } \\
\text { ITEMS/POSITIVE } \\
\text { FINDINGS }\end{array}$ & \\
\hline $\begin{array}{l}\text { ST.2.1.OCAF. Installations } \\
\text { must comply with all applica- } \\
\text { ble regulatory requirements } \\
\text { not contained in this checklist } \\
\text { (a finding under this checklist } \\
\text { item will have the citation of } \\
\text { the applied regulation as a } \\
\text { basis of finding) [Added } \\
\text { March 2002]. }\end{array}$ & $\begin{array}{l}\text { Determine whether any new regulations concerning storage tank management } \\
\text { have been issued since the finalization of the manual. } \\
\text { Determine whether the installation has activities or facilities that are regulated but } \\
\text { not addressed in this checklist. } \\
\text { Verify that the installation is in compliance with all applicable and newly issued } \\
\text { regulations. }\end{array}$ \\
\hline $\begin{array}{l}\text { ST.2.2.OCAF. Installations } \\
\text { should go above and beyond } \\
\text { environmental statutory and } \\
\text { regulatory compliance (MP) } \\
\text { [Added March 2002]. }\end{array}$ & $\begin{array}{l}\text { Determine whether the installation has gone above and beyond simply complying } \\
\text { with environmental requirements. } \\
\text { (NOTE: This checklist item is used only to write positive findings.) }\end{array}$ \\
\hline
\end{tabular}




\begin{tabular}{|c|c|}
\hline \multicolumn{2}{|r|}{$\begin{array}{c}\text { COMPLIANCE CATEGORY: } \\
\text { STORAGE TANK MANAGEMENT } \\
\text { Overseas ESOHCAMP }\end{array}$} \\
\hline $\begin{array}{l}\text { REGULATORY } \\
\text { REQUIREMENTS: }\end{array}$ & $\begin{array}{l}\text { REVIEWER CHECKS: } \\
\text { September } 2009\end{array}$ \\
\hline $\begin{array}{l}\text { ST.3 } \\
\text { GENERAL }\end{array}$ & \\
\hline $\begin{array}{l}\text { ST.3.1.OCAF. } \quad \text { [Moved } \\
\text { March 2002; Moved June } \\
\text { 2003]. }\end{array}$ & $\begin{array}{l}\text { Moved to ST.2.1.OCAF. } \\
\text { [Formerly checklist item number ST.10.1.OCAF.] }\end{array}$ \\
\hline $\begin{array}{l}\text { ST.3.2.OCAF. Installations } \\
\text { must meet requirements con- } \\
\text { tained in MAJCOM supple- } \\
\text { ments to AFIs and policy } \\
\text { documents (a finding under } \\
\text { this checklist item will have } \\
\text { the citation of the MAJCOM } \\
\text { document as a basis of find- } \\
\text { ing). }\end{array}$ & $\begin{array}{l}\text { Determine whether the requirements in Major Command (MAJCOM) supple- } \\
\text { ments to AFIs and policy documents are within the scope of the environmental } \\
\text { compliance assessment. } \\
\text { Verify that the installation is in compliance with MAJCOM requirements. } \\
\text { [Formerly checklist item number ST.10.2.OCAF.] }\end{array}$ \\
\hline $\begin{array}{l}\text { ST.3.3.OCAF. } \quad \text { [Moved } \\
\text { March 2002; Moved June } \\
\text { 2003]. }\end{array}$ & $\begin{array}{l}\text { Moved to ST.2.2.OCAF. } \\
\text { [Formerly checklist item number ST.10.3.OCAF.] }\end{array}$ \\
\hline $\begin{array}{l}\text { ST.3.4.OCAF. [Moved De- } \\
\text { cember 2003]. }\end{array}$ & Moved to ST.7.7.OCAF, December 2003. \\
\hline $\begin{array}{l}\text { ST.3.5.OCAF. Neither USTs } \\
\text { nor vaulted tanks may be in- } \\
\text { stalled at a site located in a } \\
\text { 25-year flood plain (AFI 32- } \\
\text { 7044, para 2.1.3) [Added De- } \\
\text { cember 2003] }\end{array}$ & $\begin{array}{l}\text { Verify that no USTs orvaulted tanks are installed at a site located in a } 25 \text {-yr flood } \\
\text { plain. }\end{array}$ \\
\hline $\begin{array}{l}\text { ST.3.6.OCAF. The installa- } \\
\text { tion must notify the appropri- } \\
\text { ate regulatory agency of all } \\
\text { new ASTs/USTs within } 30 \\
\text { calendar days after use of a } \\
\text { newly installed AST/UST } \\
\text { commences (AFI 32-7044, } \\
\text { para 2.1.2.7.3) [Added De- } \\
\text { cember 2003]. }\end{array}$ & $\begin{array}{l}\text { Verify that the installation notifies the appropriate regulatory agency of all new } \\
\text { ASTs/USTs within } 30 \text { calendar days after use of a newly installed AST/UST com- } \\
\text { mences. } \\
\text { [Author's Note: Consultation with HQ USAFE/JAME has established that, for the } \\
\text { purposes of compliance assessment, the regulatory agency is the host nation au- } \\
\text { thority who would inspect the tanks.] }\end{array}$ \\
\hline $\begin{array}{l}\text { ST.3.7.OCAF. Facility tank } \\
\text { car and tank truck load- } \\
\text { ing/unloading areas without a } \\
\text { catchment basin or treatment } \\
\text { facility must have a contain- }\end{array}$ & $\begin{array}{l}\text { Verify that facility tank car and tank truck loading/unloading areas without a } \\
\text { catchment basin or treatment facility have a containment system. } \\
\text { Verify that, in the opinion of the certifying professional engineer, the containment } \\
\text { system is sufficiently large to hold the entire capacity of the largest single con- }\end{array}$ \\
\hline
\end{tabular}




\section{COMPLIANCE CATEGORY: \\ STORAGE TANK MANAGEMENT \\ Overseas ESOHCAMP}

\section{REGULATORY REQUIREMENTS:}

ment system that meets specific standards (AFI 32-7044, paras 2.1.1.3 and 2.1.1.4) [Added December 2003].

ST.3.8.OCAF. Installations must develop and maintain a comprehensive list of all tank systems locations and characteristics (AFI 32-7044, para 2.5.1.1) [Added December 2003].

ST.3.9.OCAF. CE must maintain documentation related to certain tank issues (AFI 32-7044, para 2.5.1.2) [Added December 2003].

\section{REVIEWER CHECKS: September 2009}

tainer at that area and, if there is no continuously present on-site operator, sufficient freeboard to contain normal annual precipitation events.

(NOTE: Facility tank car and tank truck loading/unloading storage/parking areas for vehicles operated primarily off-installation and where loading/unloading does not occur do not require a catchment basin or treatment facility.)

Verify that the installation develops and maintains a comprehensive list of all tank systems locations and characteristics.

Verify that the installation uses an existing information management system until an applicable AF-wide information management system is available.

Verify that data are updated when tank systems are removed, replaced, or upgraded or when abandoned tanks are found or removed.

Verify that the Civil Engineer environmental flight (CEV) or Environmental Management Office maintains tank system inventory control records for environmental purposes and makes them available for inspection.

Verify that tank system inventory information is included in or accessible to the real property records for the installation.

Verify that CE keeps records showing performance of required inspections and tests of installation corrosion protection systems.

Verify that CE keeps records showing that a repaired or upgraded UST system was properly repaired or upgraded.

Verify that CE maintains similar information for other tank types.

Verify that CE keeps records of leak detection performance and maintenance including:

- prior year monitoring results and the most recent tightness test

- copies of performance claims, including third party certifications, provided by leak detection equipment manufacturers

- records of the most recent maintenance, repairs, and calibration of onsite leak detection equipment

- monthly monitoring of release detection systems (in log entry or annotation on site records such as automatic tank gauging-print-out)

Verify that CE keeps records of the results of the site investigations conducted during permanent closure.

Verify that CE keeps records of the site assessment results required for permanent closure for at least 3 yr after closing a UST. 


\section{COMPLIANCE CATEGORY: \\ STORAGE TANK MANAGEMENT \\ Overseas ESOHCAMP}

\begin{tabular}{|c|c|}
\hline $\begin{array}{l}\text { REGULATORY } \\
\text { REQUIREMENTS: }\end{array}$ & $\begin{array}{l}\text { REVIEWER CHECKS: } \\
\text { September } 2009\end{array}$ \\
\hline $\begin{array}{l}\text { ST.3.10.OCAF. Where tank } \\
\text { leak detection is performed } \\
\text { with an automatic tank gauge, } \\
\text { records of monthly inventory } \\
\text { reconciliation should be kept } \\
\text { for at least the previous year } \\
\text { (MP) [Added December } \\
\text { 2003]. } \\
\text { ST.3.11.OCAF. All tank } \\
\text { records should be maintained } \\
\text { for } 25 \text { yr or for the opera- } \\
\text { tional life of the tank, which- } \\
\text { ever is longer (MP) [Added } \\
\text { December 2003]. }\end{array}$ & $\begin{array}{l}\text { Verify that CE records responses to all alarms in site records. } \\
\text { Verify that CE keeps records of reports of releases or suspected releases. } \\
\text { Verify that, where tank leak detection is performed with an automatic tank gauge, } \\
\text { records of monthly inventory reconciliation are kept for at least the previous year. } \\
\text { (NOTE: This MP is found at AFI 32-7044, para 2.5.1.2.3.6.) }\end{array}$ \\
\hline
\end{tabular}


10-12 


\section{COMPLIANCE CATEGORY: \\ STORAGE TANK MANAGEMENT \\ Overseas ESOHCAMP}

\begin{tabular}{|c|c|}
\hline $\begin{array}{l}\text { REGULATORY } \\
\text { REQUIREMENTS: }\end{array}$ & $\begin{array}{l}\text { REVIEWER CHECKS: } \\
\text { September } 2009\end{array}$ \\
\hline $\begin{array}{l}\text { ST.7 } \\
\text { ASTs and USTs } \\
\text { ST.7.1.OCAF. The installa- } \\
\text { tion of new storage tanks } \\
\text { must be approved by the IC } \\
\text { (AFI 32-7044, para 2.1) } \\
\text { [Added December 2003]. }\end{array}$ & $\begin{array}{l}\text { Verify that the IC approves the installation of new storage tanks. } \\
\text { (NOTE: This requirement applies to ASTs and to USTs. It also applies to both } \\
\text { ASTs and USTs at AAFES stations.) }\end{array}$ \\
\hline $\begin{array}{l}\text { ST.7.2.OCAF. Tank systems } \\
\text { and piping must be installed } \\
\text { in accordance with applicable } \\
\text { requirements and the appro- } \\
\text { priate national codes and } \\
\text { standards for new tanks sys- } \\
\text { tems (AFI 32-7044, para } \\
2.1 .2 \text { ) [Added December } \\
\text { 2003]. }\end{array}$ & $\begin{array}{l}\text { Verify that tank systems and piping are installed in accordance with applicable } \\
\text { requirements and the appropriate national codes and standards for new tanks sys- } \\
\text { tems as detailed in Appendix 10-2. }\end{array}$ \\
\hline $\begin{array}{l}\text { ST.7.3.OCAF. All parts to } \\
\text { USTs, vaulted tanks, and cy- } \\
\text { lindrical ASTs must be an- } \\
\text { chored to prevent floating in } \\
\text { floods or dislocation in earth- } \\
\text { quakes or other conditions } \\
\text { (AFI 32-7044, para 2.1.3) } \\
\text { [Added December 2003]. }\end{array}$ & $\begin{array}{l}\text { Verify that all parts to USTs, vaulted tanks, and cylindrical ASTs are anchored to } \\
\text { prevent floating in floods or dislocation in earthquakes or other conditions. }\end{array}$ \\
\hline $\begin{array}{l}\text { ST.7.4.OCAF. Tanks must } \\
\text { be made of certain materials } \\
\text { only (AFI 32-7044, paras } \\
\text { 2.1.2.1.1 through 2.1.2.1.4) } \\
\text { [Added December 2003]. }\end{array}$ & $\begin{array}{l}\text { Verify that only tanks made of one of the following are installed: } \\
\text { - fiberglass-reinforced plastic (for USTs and certain ASTs) } \\
\text { - coated cathodically protected steel (for USTs and vaulted tanks) } \\
\text { - steel-fiberglass-reinforced plastic composite (for all types of storage tanks) } \\
\text { - coated steel (for ASTs). } \\
\text { (NOTE: These materials are specified because of their usefulness in preventing } \\
\text { corrosion.) }\end{array}$ \\
\hline $\begin{array}{l}\text { ST.7.5.OCAF. Piping for } \\
\text { tanks systems must be made } \\
\text { of certain materials only (AFI } \\
\text { 32-7044, para 2.1.2.2) [Added } \\
\text { December 2003]. }\end{array}$ & $\begin{array}{l}\text { Verify that fiberglass-reinforced plastic or cathodically protected, coated steel is } \\
\text { used for piping. } \\
\text { (NOTE: These materials are specified because of their usefulness in preventing } \\
\text { corrosion.) }\end{array}$ \\
\hline
\end{tabular}




\section{COMPLIANCE CATEGORY: \\ STORAGE TANK MANAGEMENT \\ Overseas ESOHCAMP}

\section{REGULATORY REQUIREMENTS:}

ST.7.6.OCAF. Overfilling of tanks must be controlled (AFI 32-7044, para 2.1.2.6.1) [Added December 2003].

ST.7.7.OCAF. The Fuels Management Team (FMT) must ensure that all FMT fuel tanks are equipped with highlevel alarms and/or automatic high-level shut-off valves (AFI 23-201, paras 8.7.1 and 8.7.2) [Added September 1999; Revised September 2002; Moved June 2003; Moved December 2003; Revised September 2004].

ST.7.8.OCAF. Tanks should be equipped with overflow equipment (AFI 32-7044, para 2.3.1.3) [Added December 2003].

ST.7.9.OCAF. Tank equipment must prevent spills when the transfer hose detaches (AFI 32-7044, para 2.1.2.6.1) [Added December 2003].

ST.7.10.OCAF. New and existing pressurized piping must be tightness tested or monitored (AFI 32-7044, para 2.2.3) [Added December 2003].

ST.7.11.OCAF. Automatic line-leak detection must be installed with all new pressurized piping (AFI 32-7044,

\section{REVIEWER CHECKS: September 2009}

(NOTE: Specialty products [i.e., double wall systems using a flexible carrier pipe for service stations] may be used. Bases that are unfamiliar with such products should consult with the MAJCOM or AFCESA before using them.).

Verify that overfilling of tanks is controlled by using an automatic shutoff, overfill containment, containment bucket, and other options such as alarms and regular observation of tank fillings.

Verify that all FMT fuel tanks are equipped with high-level alarms and/or automatic high-level shut-off valves.

(NOTE: These alarms are in addition to the Fuels Manager alarms.)

Verify that the FMT, in coordination with the BCE, establishes safe fill levels for all storage tanks.

[Formerly checklist item number ST.3.4.OCAF.]

Verify that overflow equipment in the tank includes:

- a minimum 15-gal spill bucket

- a fill pipe that will:

- alert the operator by restricting flow into the tank or triggering a high level alarm before tank is 90 percent full

- automatically shut off flow into the tank before the tank is filled to 95 percent of its capacity.

Verify that tank equipment is designed to prevent spills when the transfer hose detaches.

Verify that new and existing pressurized piping is tightness tested annually or monitored monthly using a release detection monitoring method that detects piping leaks.

Verify that automatic line-leak detection is installed with all new pressurized piping.

(NOTE: This requirement does not apply to pipelines carrying aircraft petroleum 


\section{COMPLIANCE CATEGORY: \\ STORAGE TANK MANAGEMENT \\ Overseas ESOHCAMP}

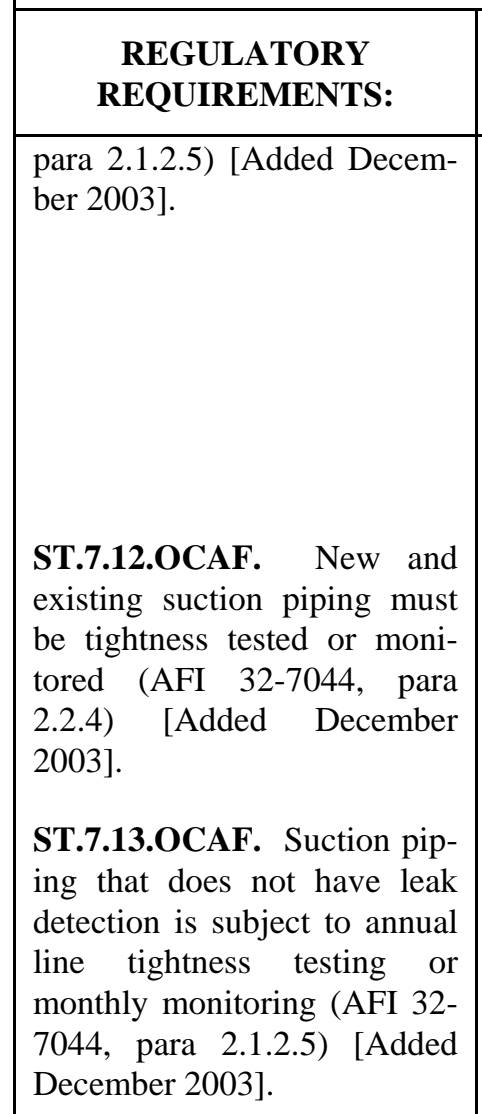

ST.7.14.OCAF. Underground piping for hazardous substances must be equipped with secondary containment (AFI 32-7044, para 2.1.2.5) [Added December 2003].

ST.7.15.OCAF. Service stations with reasonably short runs of piping should always use double wall piping or other secondary containment for piping (MP) [Added December 2003].

ST.7.16.OCAF. Integrity testing of a tank system must be performed on a repaired cathodic protection system before the tank system is returned to service (AFI 32-

\section{REVIEWER CHECKS: September 2009}

products [see MIL HDBK 1022].)

(NOTE: Suction piping operating at less than atmospheric pressure that drains the contents back into the tank, with a single check valve below the suction pump, does not require release detection.)

(NOTE: Automatic line leak detection for pressurized lines may not be available from all manufacturers. At some locations, only interstitial monitoring may be available for line leak detection for ASTs.)

Verify that new and existing suction piping is tightness tested at least every $3 \mathrm{yr}$ or monitored monthly method that detects piping leaks in single-walled suction piping.

Verify that suction piping without leak detection is either tightness tested annually or monitored monthly using a release detection monitoring method that detects piping leaks.

(NOTE: This requirement does not apply to pipelines carrying aircraft petroleum products [see MIL HDBK 1022].)

(NOTE: Follow applicable state and local requirements, and the appropriate national codes and standards listed in Attachment 2 to AFI 32-7044.)

Verify that underground piping for hazardous substances is equipped with secondary containment (e.g., trench liners, jacketing, or double-walled pipe.)

(NOTE: This requirement does not apply to pipelines carrying aircraft petroleum products [see MIL HDBK 1022].)

Verify that service stations with reasonably short runs of piping use double wall piping or other secondary containment for piping.

(NOTE: This MP is found at AFI 32-7044, para 2.1.2.4.)

Verify that any tank system whose cathodic protection system has been repaired is integrity tested before the tank system is returned to service. 


\section{COMPLIANCE CATEGORY: \\ STORAGE TANK MANAGEMENT \\ Overseas ESOHCAMP}

\begin{tabular}{|c|c|}
\hline $\begin{array}{l}\text { REGULATORY } \\
\text { REQUIREMENTS: }\end{array}$ & $\begin{array}{l}\text { REVIEWER CHECKS: } \\
\text { September } 2009\end{array}$ \\
\hline $\begin{array}{l}\text { 7044, para 2.3.3.3) [Added } \\
\text { December 2003]. }\end{array}$ & \\
\hline $\begin{array}{l}\text { ST.7.17.OCAF. Product } \\
\text { transfer operations must be } \\
\text { conducted in accordance with } \\
\text { specific requirements (AFI } \\
\text { 32-7044, para 2.3.1.1 and } \\
2.3 .1 .2 \text { ) [Added December } \\
\text { 2003]. }\end{array}$ & $\begin{array}{l}\text { Verify that available tank capacity exceeds the volume of the product being trans- } \\
\text { ferred into the tank. } \\
\text { Verify that the transfer operation is monitored constantly. }\end{array}$ \\
\hline $\begin{array}{l}\text { ST.7.18.OCAF. Specific } \\
\text { actions must be taken in the } \\
\text { event of a suspected release of } \\
\text { regulated substance from a } \\
\text { tank system (AFI 32-7044, } \\
\text { para 2.4.2.1) [Added Decem- } \\
\text { ber 2003]. }\end{array}$ & $\begin{array}{l}\text { Verify that, if a release of a regulated substance stored in a tank system is sus- } \\
\text { pected, immediate action to investigate and confirm the release using the follow- } \\
\text { ing steps: } \\
\text { - perform a tightness test of the system } \\
\text { - if a release is suspected because of the discovery of environmental contami- } \\
\text { nation in the vicinity of the tank but a leak is not detected in the tank system, } \\
\text { perform a site check by sampling and measuring for contamination at the } \\
\text { tank site. }\end{array}$ \\
\hline $\begin{array}{l}\text { ST.7.19.OCAF. Installations } \\
\text { must take specific actions in } \\
\text { the event that a release from } \\
\text { a tank system is confirmed } \\
\text { (AFI 32-7044, paras 2.4.2.2 } \\
\text { and 2.4.3.2, 2.4.3.3, and } \\
2.4 .3 .4 .2 \text { ) [Added December } \\
\text { 2003]. }\end{array}$ & $\begin{array}{l}\text { Verify that, if a release from a tank system is confirmed, as much of the regulated } \\
\text { substance is removed from the tank as necessary to prevent any further release. } \\
\text { Verify that, if a release from a tank system is confirmed, a visual inspection is } \\
\text { conducted for evidence of any aboveground or below-ground releases. } \\
\text { Verify that, if a release from a tank system is confirmed, further migration of the } \\
\text { regulated substance release to the surrounding soils and groundwater is prevented. } \\
\text { Verify that, if a release from a tank system is confirmed, fire, explosion, and va- } \\
\text { por hazards are identified and mitigated. } \\
\text { Verify that, if a release from a tank system is confirmed, the release is reported } \\
\text { per AFI 32-7044, para } 2.4 .4 \text {. } \\
\text { (NOTE: See checklist item ST.7.20.OCAF.) } \\
\text { Verify that the following corrective actions are taken and coordinated with regula- } \\
\text { tory authorities: } \\
\quad \text { - if the presence of free product outside the tank system is confirmed, as soon } \\
\text { as possible remove this regulated substance to the maximum extent practica- } \\
\text { ble } \\
\text { - determine the extent and location of contaminated soil and groundwater. } \\
\text { Verify that the installation complies with requests from the regulatory agency for } \\
\text { additional information or a corrective action plan to clean up contaminated soil, }\end{array}$ \\
\hline
\end{tabular}




\begin{tabular}{|c|c|}
\hline \multicolumn{2}{|r|}{$\begin{array}{c}\text { COMPLIANCE CATEGORY: } \\
\text { STORAGE TANK MANAGEMENT } \\
\text { Overseas ESOHCAMP }\end{array}$} \\
\hline $\begin{array}{l}\text { REGULATORY } \\
\text { REQUIREMENTS: }\end{array}$ & $\begin{array}{l}\text { REVIEWER CHECKS: } \\
\text { September } 2009\end{array}$ \\
\hline $\begin{array}{l}\text { ST.7.20.OCAF. Notification } \\
\text { of a confirmed release must } \\
\text { be provided to the MAJCOM } \\
\text { and to HQ USAF/ILEV in } \\
\text { accordance with specific re- } \\
\text { quirements (AFI 32-7044, } \\
\text { paras 2.4.4.2 and 2.4.4.3) } \\
\text { [Added December 2003]. }\end{array}$ & $\begin{array}{l}\text { surface water, or groundwater. } \\
\text { (NOTE: Site remediation abroad is governed by DODI 4715.8, Environmental } \\
\text { Remediation for DOD Activities Overseas.) } \\
\text { Verify that notification of a confirmed release is provided to the MAJCOM and } \\
\text { HQ USAF/ILEV in accordance with AFI 10-2501 and AFI 32-7002, Environ- } \\
\text { mental Information Management System. } \\
\text { Verify that the installation submits a detailed follow-up report that includes: } \\
\text { - name of the installation point of contact } \\
\text { - nature and estimated quantity of release } \\
\text { - information on surrounding population, water quality, use, and locations of } \\
\text { potentially affected wells, subsurface soil conditions, locations of sewers, } \\
\text { climatic conditions, and land use } \\
\text { - results of initial site check } \\
\text { - cause of release } \\
\text { - results of free-product investigation } \\
\text { - estimated quantity, type, and depth of any free product } \\
\text { - type of recovery system } \\
\text { - location of onsite or offsite discharges } \\
\text { - type of treatment and effluent quality } \\
\text { - steps taken to obtain the necessary permits } \\
\text { - personnel methods or plan to dispose of any recovered free product, con- } \\
\text { taminated soil, or groundwater. }\end{array}$ \\
\hline
\end{tabular}


10-18 


\begin{tabular}{|c|c|}
\hline \multicolumn{2}{|r|}{$\begin{array}{c}\text { COMPLIANCE CATEGORY: } \\
\text { STORAGE TANK MANAGEMENT } \\
\text { Overseas ESOHCAMP }\end{array}$} \\
\hline $\begin{array}{l}\text { REGULATORY } \\
\text { REQUIREMENTS: }\end{array}$ & $\begin{array}{l}\text { REVIEWER CHECKS: } \\
\text { September } 2009\end{array}$ \\
\hline $\begin{array}{l}\text { ST.10 } \\
\text { ASTs: } \\
\text { General }\end{array}$ & \\
\hline $\begin{array}{l}\text { ST.10.1.OCAF. [Moved } \\
\text { June 2003; Moved September } \\
\text { 2003]. }\end{array}$ & Moved to ST.12.1.OCAF. \\
\hline $\begin{array}{l}\text { ST.10.2.OCAF. [Moved } \\
\text { June 2003; Moved September } \\
\text { 2003]. }\end{array}$ & Moved to ST.12.2.OCAF. \\
\hline $\begin{array}{l}\text { ST.10.3.OCAF. [Moved } \\
\text { June 2003; Moved September } \\
\text { 2003]. }\end{array}$ & Moved to ST.13.1.OCAF. \\
\hline $\begin{array}{l}\text { ST.10.4.OCAF. [Moved } \\
\text { June 2003; Moved September } \\
\text { 2003]. }\end{array}$ & Moved to ST.12.3.OCAF. \\
\hline $\begin{array}{l}\text { ST.10.5.OCAF. [Moved } \\
\text { June 2003; Moved September } \\
\text { 2003]. }\end{array}$ & Moved to ST.12.4.OCAF. \\
\hline $\begin{array}{l}\text { ST.10.6.OCAF. } \\
\text { December 2003]. }\end{array}$ & Moved to ST.11.1.OCAF \\
\hline
\end{tabular}




\begin{tabular}{|c|c|}
\hline \multicolumn{2}{|r|}{$\begin{array}{c}\text { COMPLIANCE CATEGORY: } \\
\text { STORAGE TANK MANAGEMENT } \\
\text { Overseas ESOHCAMP }\end{array}$} \\
\hline $\begin{array}{l}\text { REGULATORY } \\
\text { REQUIREMENTS: }\end{array}$ & $\begin{array}{l}\text { REVIEWER CHECKS: } \\
\text { September } 2009\end{array}$ \\
\hline $\begin{array}{l}\text { ST.11 } \\
\text { ASTs: } \\
\text { Design }\end{array}$ & \\
\hline $\begin{array}{l}\text { ST.11.1.OCAF. The FMT } \\
\text { must provide secondary con- } \\
\text { tainment that is impermeable } \\
\text { to petroleum products for all } \\
\text { aboveground tanks larger than } \\
660 \text { gal (AFI 23-201, para } \\
\text { 8.7.3) [Added September } \\
\text { 1999; Moved June 2003; Re- } \\
\text { vised September 2009]. }\end{array}$ & $\begin{array}{l}\text { Verify that the FMT provides secondary containment that is impermeable to pe- } \\
\text { troleum products for all aboveground tanks larger than } 660 \text { gal. } \\
\text { [Formerly checklist item number ST.10.6.OCAF.] }\end{array}$ \\
\hline $\begin{array}{l}\text { ST.11.2.OCAF. ASTs con- } \\
\text { taining oil must have internal } \\
\text { (self-diking) or external sec- } \\
\text { ondary containment and/or } \\
\text { diversionary structures or } \\
\text { equipment wherever required } \\
\text { (AFI 32-7044, para 2.1.1.2) } \\
\text { [Added December 2003]. }\end{array}$ & $\begin{array}{l}\text { Verify that ASTs containing oil have internal (self-diking) or external secondary } \\
\text { containment and/or diversionary structures or equipment wherever required. } \\
\text { (NOTE: See generally MIL-HDBK-1022 for further details. See also API Stan- } \\
\text { dard 650, Welded Steel Tanks for Oil Storage-Includes Addendum } 1 \text { and 2; API } \\
\text { Standard 653, Tank Inspection, Repair, Alteration, and Reconstruction-Includes } \\
\text { Addenda 1-4.) }\end{array}$ \\
\hline $\begin{array}{l}\text { ST.11.3.OCAF. Self-diking } \\
\text { tanks that contain oil must } \\
\text { meet capacity standards (AFI } \\
\text { 32-7044, para 2.1.1.2.1) } \\
\text { [Added December 2003]. }\end{array}$ & $\begin{array}{l}\text { Verify that self-diking tanks that contain oil are capable of containing the entire } \\
\text { capacity of the inner tank if it fails within (a) the interstitial space; (b) a secondary } \\
\text { containment system; or (c) both. } \\
\text { (NOTE: Tanks with concrete outer shells are not satisfactory for this purpose.) }\end{array}$ \\
\hline $\begin{array}{l}\text { ST.11.4.OCAF. External } \\
\text { secondary containment for } \\
\text { tanks that contain oil must } \\
\text { meet capacity standards (AFI } \\
\text { 32-7044, para 2.1.1.2.2) } \\
\text { [Added December 2003]. }\end{array}$ & $\begin{array}{l}\text { Verify that, in the opinion of the certifying professional engineer, the external } \\
\text { secondary containment for tanks that contain oil is sufficient to hold the entire } \\
\text { capacity of the largest single container and sufficient freeboard to contain normal } \\
\text { annual precipitation events. } \\
\text { (NOTE: External secondary containment includes dikes, containment curbs, pits, } \\
\text { or drainage trenches.) }\end{array}$ \\
\hline $\begin{array}{l}\text { ST.11.5.OCAF. AST capac- } \\
\text { ity should be adequate to en- } \\
\text { sure that a container will not } \\
\text { overfill if pumper/gauger is } \\
\text { delayed in making regularly } \\
\text { scheduled rounds (MP) } \\
\text { [Added December 2003]. }\end{array}$ & $\begin{array}{l}\text { Verify that AST capacity is adequate to ensure that a container will not overfill if } \\
\text { pumper/gauger is delayed in making regularly scheduled rounds. } \\
\text { (NOTE: This MP is found at AFI 32-7044, para 2.1.2.6.2.) }\end{array}$ \\
\hline ST.11.6.OCAF. Each AST & Verify that each AST is engineered or updated in accordance with good engineer- \\
\hline
\end{tabular}




\begin{tabular}{|c|c|}
\hline \multicolumn{2}{|r|}{$\begin{array}{c}\text { COMPLIANCE CATEGORY: } \\
\text { STORAGE TANK MANAGEMENT } \\
\text { Overseas ESOHCAMP }\end{array}$} \\
\hline $\begin{array}{l}\text { REGULATORY } \\
\text { REQUIREMENTS: }\end{array}$ & $\begin{array}{l}\text { REVIEWER CHECKS: } \\
\text { September } 2009\end{array}$ \\
\hline $\begin{array}{l}\text { should be engineered or up- } \\
\text { dated in accordance with } \\
\text { good engineering practice to } \\
\text { avoid discharges (MP) } \\
\text { [Added December 2003]. }\end{array}$ & $\begin{array}{l}\text { ing practice to avoid discharges. } \\
\text { (NOTE: This MP is found at AFI 32-7044, para 2.1.2.6.2.) }\end{array}$ \\
\hline 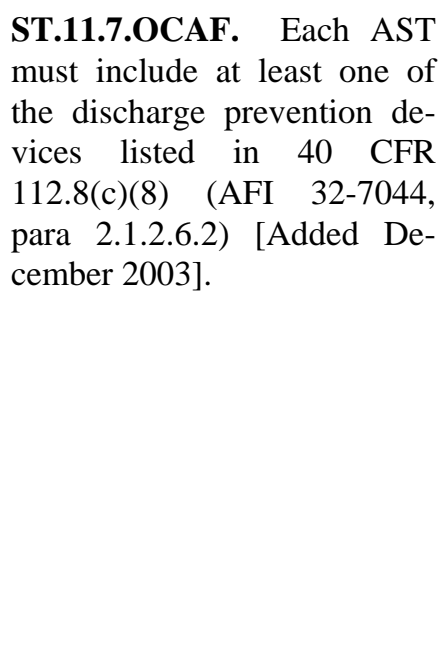 & $\begin{array}{l}\text { Verify that each AST includes at least one of the following devices: } \\
\text { - high liquid level alarms with an audible or visual signal at a constantly at- } \\
\text { tended operation or surveillance station (NOTE: In smaller facilities an au- } \\
\text { dible air vent may suffice.) } \\
\text { - high liquid level pump cutoff devices set to stop flow at a predetermined } \\
\text { container content level } \\
\text { - direct audible or code signal communication between the container gauger } \\
\text { and the pumping station } \\
\text { - a fast response system for determining the liquid level of each bulk storage } \\
\text { container such as digital computers, telepulse, or direct vision gauges } \\
\text { (NOTE: If this alternative is chosen, a person must be present to monitor } \\
\text { gauges and the overall filling of bulk storage containers.) } \\
\text { Verify that, if a liquid level sensing device is used, it is tested regularly to ensure } \\
\text { proper operation. }\end{array}$ \\
\hline $\begin{array}{l}\text { ST.11.8.OCAF. Line leak } \\
\text { detection for ASTs must be } \\
\text { installed as recommended to } \\
\text { avoid interference with opera- } \\
\text { tion of AST antisiphon device } \\
\text { (AFI 32-7044, para 2.1.2.5) } \\
\text { [Added December 2003]. }\end{array}$ & $\begin{array}{l}\text { Verify that line leak detection for ASTs is installed as recommended to avoid in- } \\
\text { terference with operation of AST antisiphon device. } \\
\text { (NOTE: This requirement does not apply to pipelines carrying aircraft petroleum } \\
\text { products [see MIL HDBK 1022].) }\end{array}$ \\
\hline
\end{tabular}




\begin{tabular}{|c|c|}
\hline \multicolumn{2}{|r|}{$\begin{array}{c}\text { COMPLIANCE CATEGORY: } \\
\text { STORAGE TANK MANAGEMENT } \\
\text { Overseas ESOHCAMP }\end{array}$} \\
\hline $\begin{array}{l}\text { REGULATORY } \\
\text { REQUIREMENTS: }\end{array}$ & $\begin{array}{l}\text { REVIEWER CHECKS: } \\
\text { September } 2009\end{array}$ \\
\hline $\begin{array}{l}\text { ST.12 } \\
\text { ASTs: } \\
\text { Operations }\end{array}$ & \\
\hline $\begin{array}{l}\text { ST.12.1.OCAF. [Moved June } \\
\text { 2003; Deleted July 2008]. }\end{array}$ & Deleted at the request of the sponsor. \\
\hline $\begin{array}{l}\text { ST.12.2.OCAF. [Moved June } \\
\text { 2003; Deleted July 2008]. }\end{array}$ & $\begin{array}{l}\text { Deleted at the request of the sponsor. } \\
\text { [Formerly checklist item number ST.10.2.OCAF.] }\end{array}$ \\
\hline $\begin{array}{l}\text { ST.12.3.OCAF. [Moved } \\
\text { June 2003; Deleted July } \\
\text { 2008]. }\end{array}$ & $\begin{array}{l}\text { Deleted at the request of the sponsor. } \\
\text { [Formerly checklist item number ST.10.4.OCAF.] }\end{array}$ \\
\hline $\begin{array}{l}\text { ST.12.4.OCAF. [Moved } \\
\text { June 2003; Deleted July } \\
\text { 2008]. }\end{array}$ & $\begin{array}{l}\text { Deleted at the request of the sponsor. } \\
\text { [Formerly checklist item number ST.10.5.OCAF.] }\end{array}$ \\
\hline $\begin{array}{l}\text { ST.12.5.OCAF. The FMF } \\
\text { must drain floating roofs and } \\
\text { interior dike basins as re- } \\
\text { quired (UFC 3-460-03, para } \\
\text { 10.3.3.2.3) [Added December } \\
\text { 2003]. }\end{array}$ & $\begin{array}{l}\text { Verify that the FMF drains floating roofs and interior dike basins as required. } \\
\text { (NOTE: The LFM shop foreman is responsible for training FMF personnel on } \\
\text { appropriate procedures.) }\end{array}$ \\
\hline $\begin{array}{l}\text { ST.12.6.OCAF. ASTs that } \\
\text { contain petroleum oil, includ- } \\
\text { ing valves or piping that are } \\
\text { entirely within buildings, are } \\
\text { subject to integrity and leak } \\
\text { testing regularly and when } \\
\text { material repairs are made } \\
\text { (AFI 32-7044, para 2.2.2) } \\
\text { [Added December 2003]. }\end{array}$ & $\begin{array}{l}\text { Verify that ASTs that contain petroleum oil, including valves or piping that are } \\
\text { entirely within buildings, are subject to integrity and leak testing regularly and } \\
\text { when material repairs are made. } \\
\text { Verify that the frequency of regular AST integrity testing takes into account con- } \\
\text { tainer (tank) size and design and is consistent with industry standards. } \\
\text { Verify that, for self-diking ASTs, the interstitial space is checked for leaks at least } \\
\text { quarterly. } \\
\text { (NOTE: Small, shop-built ASTs that are not in contact with the ground, all sides } \\
\text { of which are visible and which are inspected at least monthly may use visual in- } \\
\text { spection for integrity testing, consistent with good engineering practice.) } \\
\text { Verify that ASTs on the ground are subject to visual integrity testing and another } \\
\text { testing technique (such as hydrostatic testing, radiographic testing, ultrasonic test- } \\
\text { ing, acoustic emissions testing, or another system of nondestructive testing). } \\
\text { (NOTE: Material repairs include: } \\
\text { - removing the annular plate ring }\end{array}$ \\
\hline
\end{tabular}




\begin{tabular}{|c|c|}
\hline \multicolumn{2}{|r|}{$\begin{array}{c}\text { COMPLIANCE CATEGORY: } \\
\text { STORAGE TANK MANAGEMENT } \\
\text { Overseas ESOHCAMP }\end{array}$} \\
\hline $\begin{array}{l}\text { REGULATORY } \\
\text { REQUIREMENTS: }\end{array}$ & $\begin{array}{l}\text { REVIEWER CHECKS: } \\
\text { September } 2009\end{array}$ \\
\hline $\begin{array}{l}\text { ST.12.7.OCAF. The corro- } \\
\text { sion protection systems for } \\
\text { steel ASTs in direct contact } \\
\text { with soil must be maintained } \\
\text { in accordance with specific } \\
\text { standards (AFI 32-7044, paras } \\
\text { 2.3.2.1, 2.3.2.2, and 2.3.3.3) } \\
\text { [Added December 2003]. }\end{array}$ & $\begin{array}{l}\text { - replacement of the container bottom } \\
\text { - jacking of a container shell } \\
\text { - installation of a 12-in or larger nozzle in the shell } \\
\text { - a door sheet, tombstone replacement in the shell, or other shell repair } \\
\text { - any repairs that might potentially change the potential for oil to be dis- } \\
\text { charged from the container.) } \\
\text { Verify that a qualified cathodic protection specialist inspects new cathodic protec- } \\
\text { tion systems on steel ASTs in direct contact with soil in accordance with AF pro- } \\
\text { cedures for the maintenance and operation of cathodic protection systems or in } \\
\text { accordance with another reasonable time frame established by the implementing } \\
\text { agency. } \\
\text { (NOTE: A qualified cathodic protection specialist is a person certified by the Na- } \\
\text { tional Association of Corrosion Engineers [NACE].) } \\
\text { Verify that, at a minimum, cathodic protection systems on steel ASTs in direct } \\
\text { contact with soil are inspected within } 6 \text { mo of installation and at least every } 3 \text { yr } \\
\text { thereafter. } \\
\text { Verify that impressed current cathodic protection systems are inspected every } 60 \\
\text { calendar days. } \\
\text { Verify that galvanic systems are inspected annually. } \\
\text { (NOTE: These requirements also apply to tanks whose cathodic protection sys- } \\
\text { tems have been repaired.) }\end{array}$ \\
\hline $\begin{array}{l}\text { ST.12.8.OCAF. ASTs must } \\
\text { be checked for corrosion in } \\
\text { accordance with specific re- } \\
\text { quirements (AFI 32-7044, } \\
\text { para para 2.3.2.1) [Added } \\
\text { December 2003]. }\end{array}$ & $\begin{array}{l}\text { Verify that ASTs are checked for corrosion in accordance with the schedule de- } \\
\text { veloped to comply with AFI 32-7044, para 2.2.2.1. } \\
\text { (NOTE: See checklist item ST.12.16.OCAF.) }\end{array}$ \\
\hline $\begin{array}{l}\text { ST.12.9.0CAF. Authorized } \\
\text { inspectors must certify that } \\
\text { repairs were performed on } \\
\text { ASTs (AFI 32-7044, para } \\
\text { para 2.3.3.1) [Added Decem- } \\
\text { ber 2003]. }\end{array}$ & $\begin{array}{l}\text { Verify that authorized inspectors must certify that repairs were performed on } \\
\text { ASTs. } \\
\text { [Author's Note: The AFI does not address the question of who authorizes inspec- } \\
\text { tors.] }\end{array}$ \\
\hline
\end{tabular}




\begin{tabular}{|l|c|}
\hline \multicolumn{2}{|c|}{$\begin{array}{c}\text { COMPLIANCE CATEGORY: } \\
\text { STORAGE TANK MANAGEMENT } \\
\text { Overseas ESOHCAMP }\end{array}$} \\
\hline \multicolumn{1}{|c|}{$\begin{array}{c}\text { REGULATORY } \\
\text { REQUIREMENTS: }\end{array}$} & $\begin{array}{c}\text { REVIEWER CHECKS: } \\
\text { September 2009 }\end{array}$ \\
\hline $\begin{array}{l}\text { ST.13 } \\
\text { ASTs: } \\
\text { Documentation } \\
\text { ST.13.1.OCAF. [Deleted } \\
\text { December 2003]. }\end{array}$ & Deleted when UFC 3-460-03 replaced Air Force Manual 85-16. \\
& [Formerly checklist item number ST.10.3.OCAF.] \\
\hline
\end{tabular}


10-26 


\begin{tabular}{|c|c|}
\hline \multicolumn{2}{|r|}{$\begin{array}{l}\text { COMPLIANCE CATEGORY: } \\
\text { STORAGE TANK MANAGEMENT } \\
\text { Overseas ESOHCAMP }\end{array}$} \\
\hline $\begin{array}{l}\text { REGULATORY } \\
\text { REQUIREMENTS: }\end{array}$ & $\begin{array}{l}\text { REVIEWER CHECKS: } \\
\text { September } 2009\end{array}$ \\
\hline $\begin{array}{l}\text { ST.20 } \\
\text { USTs: } \\
\text { General }\end{array}$ & \\
\hline $\begin{array}{l}\text { ST.20.1.OCAF. [Moved June } \\
\text { 2003; Deleted July 2008]. }\end{array}$ & $\begin{array}{l}\text { Verify that the substances stored in UST systems are compatible with the system. } \\
\text { [Formerly checklist item number ST.30.1.OCAF.] }\end{array}$ \\
\hline $\begin{array}{l}\text { ST.20.2.OCAF. [Deleted } \\
\text { December 2003]. }\end{array}$ & Deleted December 2003 in consequence of the revision of AFI 32-7044. \\
\hline $\begin{array}{l}\text { ST.20.3.OCAF. [Moved June } \\
\text { 2003; Deleted July 2008]. }\end{array}$ & $\begin{array}{l}\text { Deleted at the request of the sponsor. } \\
\text { [Formerly checklist item number ST.30.3.OCAF.] }\end{array}$ \\
\hline $\begin{array}{l}\text { ST.20.4.OCAF. [Moved June } \\
\text { 2003; Deleted July 2008]. }\end{array}$ & $\begin{array}{l}\text { Deleted at the request of the sponsor. } \\
\text { [Formerly checklist item number ST.30.4.OCAF.] }\end{array}$ \\
\hline $\begin{array}{l}\text { ST.20.5.OCAF. Any UST } \\
\text { that contains a regulated sub- } \\
\text { stance must have double wall } \\
\text { construction with interstitial } \\
\text { monitoring (AFI 32-7044, } \\
\text { paras 2.1 and 2.1.1.1) [Added } \\
\text { December 2003]. }\end{array}$ & $\begin{array}{l}\text { Verify that any UST that contains a regulated substance has double wall construc- } \\
\text { tion with interstitial monitoring. } \\
\text { (NOTE: See MIL-HDBK 1022, Petroleum Fuel Facilities (30 Jun 1997) § 2.13.6.) } \\
\text { (NOTE: This requirement applies to new and existing USTs.) }\end{array}$ \\
\hline $\begin{array}{l}\text { ST.20.6.OCAF. USTs must } \\
\text { have release detection moni- } \\
\text { toring systems (AFI 32-7044, } \\
\text { para 2.1.2.3) [Added Decem- } \\
\text { ber 2003]. }\end{array}$ & $\begin{array}{l}\text { Verify that every UST has at least one of the following release detection monitor- } \\
\text { ing systems: } \\
\text { - automatic tank gauging } \\
\text { - vapor monitoring } \\
\text { - new groundwater monitoring systems in areas with no known prior contami- } \\
\text { nation } \\
\text { - continuous monitoring of the interstitial space between the tank system and a } \\
\text { secondary barrier } \\
\text { - other effective methods that comply with environmental regulations. } \\
\text { (NOTE: This requirement also applies to other type tanks, where required by state } \\
\text { or local requirements.) }\end{array}$ \\
\hline $\begin{array}{l}\text { ST.20.7.OCAF. The corro- } \\
\text { sion protection systems for } \\
\text { steel USTs must be main- } \\
\text { tained in accordance with } \\
\text { specific standards (AFI 32- }\end{array}$ & $\begin{array}{l}\text { Verify that a qualified cathodic protection specialist inspects new cathodic protec- } \\
\text { tion systems on steel USTs in accordance with AF procedures for the maintenance } \\
\text { and operation of cathodic protection systems or in accordance with another rea- } \\
\text { sonable time frame established by the implementing agency. }\end{array}$ \\
\hline
\end{tabular}




\section{COMPLIANCE CATEGORY: \\ STORAGE TANK MANAGEMENT \\ Overseas ESOHCAMP}

\section{REGULATORY REQUIREMENTS:}

7044, para 2.3.2.1, 2.3.2.2, and 2.3.3.3) [Added December 2003].

ST.20.8.OCAF. USTs must be checked quarterly for corrosion (AFI 32-7044, para 2.3.2.3) [Added December 2003].

ST.20.9.OCAF. USTs, including piping, must be tightness tested within 30 calendar days or earlier of completing repairs to any UST or underground piping (AFI 32-7044, para 2.3.3.2) [Added December 2003].

ST.20.10.OCAF. Suspected releases from USTs must be reported to the regulators within $24 \mathrm{~h}$ and appropriate investigation and confirmation steps must be taken (AFI 32-7044, para 2.4.1.1) [Added December 2003].

ST.20.11.OCAF. Specific requirements must be met if a UST system is closed temporarily (AFI 32-7044, para 2.10.1) [Added December 2003].

\section{REVIEWER CHECKS: September 2009}

(NOTE: A qualified cathodic protection specialist is a person certified by the National Association of Corrosion Engineers [NACE].)

Verify that, at a minimum, cathodic protection systems on USTs are inspected within 6 mo of installation and at least every $3 \mathrm{yr}$ thereafter.

Verify that impressed current cathodic protection systems are inspected every 60 calendar days.

Verify that galvanic systems are inspected annually.

(NOTE: These requirements also apply to tanks whose cathodic protection systems have been repaired.)

Verify that USTs are checked quarterly for corrosion.

Verify that USTs, including piping, are tightness tested within 30 calendar days or earlier of completing repairs to any UST or underground piping.

Verify that suspected releases from USTs are reported to the regulators within 24 h.

Verify that, when a UST system is temporarily closed, the installation continues to operate and maintain corrosion protection systems.

Verify that, when a UST system is temporarily closed and the UST is not empty, the installation continues to operate and maintain the release detection systems.

Verify that, if the UST system is temporarily closed for 3 mo or more, the vent lines are left open and other lines, pumps, manways, and equipment are capped and secured. 


\section{COMPLIANCE CATEGORY: \\ STORAGE TANK MANAGEMENT \\ Overseas ESOHCAMP}

\begin{tabular}{|c|c|}
\hline $\begin{array}{l}\text { REGULATORY } \\
\text { REQUIREMENTS: }\end{array}$ & $\begin{array}{l}\text { REVIEWER CHECKS: } \\
\text { September } 2009\end{array}$ \\
\hline $\begin{array}{l}\text { ST.20.12.OCAF. Any UST } \\
\text { system that is closed tempo- } \\
\text { rarily for more than } 12 \text { mo } \\
\text { must be permanently closed } \\
\text { unless specific conditions are } \\
\text { met (AFI 32-7044, para } \\
2.10 .1 \text { [Added December } \\
\text { 2003]. }\end{array}$ & $\begin{array}{l}\text { Verify that any UST system that is closed temporarily for more than } 12 \text { mo is per- } \\
\text { manently closed. } \\
\text { (NOTE: This requirement does not apply if the UST meets the requirements of } \\
\text { AFI 32-7044, paras } 2.1 .2 \text { and 2.2, except that spill and overflow prevention are } \\
\text { not required.) }\end{array}$ \\
\hline $\begin{array}{l}\text { ST.20.13.OCAF. A UST } \\
\text { system that is subject to clo- } \\
\text { sure must be properly re- } \\
\text { moved and disposed of con- } \\
\text { sistent with applicable re- } \\
\text { quirements and American } \\
\text { Petroleum Institute (API) } \\
\text { Recommended Practice 1604 } \\
\text { (AFI 32-7044, para 2.10.2.3) } \\
\text { [Added December 2003]. }\end{array}$ & $\begin{array}{l}\text { Verify that any UST system that is subject to closure is properly removed and } \\
\text { disposed of consistent with applicable requirements and API Recommended Prac- } \\
\text { tice 1604, Closure of Underground Petroleum Storage Tanks. }\end{array}$ \\
\hline $\begin{array}{l}\text { ST.20.14.OCAF. UST sys- } \\
\text { tems must not be closed in } \\
\text { place (AFI 32-7044, para } \\
\text { 2.10.2.3 and 2.10.2.4) [Added } \\
\text { December 2003]. }\end{array}$ & $\begin{array}{l}\text { Verify that no UST system is closed in place. } \\
\text { (NOTE: USTs may be abandoned in place only under extenuating circumstances, } \\
\text { if regulator approval is obtained. A UST is located under a building is an exam- } \\
\text { ple of an extenuating circumstance.) }\end{array}$ \\
\hline
\end{tabular}




\begin{tabular}{|c|c|}
\hline \multicolumn{2}{|r|}{$\begin{array}{c}\text { COMPLIANCE CATEGORY: } \\
\text { STORAGE TANK MANAGEMENT } \\
\text { Overseas ESOHCAMP }\end{array}$} \\
\hline $\begin{array}{l}\text { REGULATORY } \\
\text { REQUIREMENTS: }\end{array}$ & $\begin{array}{l}\text { REVIEWER CHECKS: } \\
\text { September } 2009\end{array}$ \\
\hline $\begin{array}{l}\text { ST.30 } \\
\text { USTs: } \\
\text { New USTs }\end{array}$ & \\
\hline $\begin{array}{l}\text { ST.30.2.OCAF. During the } \\
\text { first year following installa- } \\
\text { tion, the leak detection sys- } \\
\text { tems of new USTs must be } \\
\text { checked every } 30 \text { days to ver- } \\
\text { ify proper functioning (AFI } \\
\text { 32-7044, paras 2.2.1) [Added } \\
\text { December 2003]. }\end{array}$ & $\begin{array}{l}\text { Verify that, for new USTs, the installation obtains proper notification and certifi- } \\
\text { cation forms including necessary permits from the appropriate regulatory agency. } \\
\text { Verify that, where required, the installation sends state or local agencies a notice } \\
\text { of intent to install a tank before starting construction. } \\
\text { Verify that the installation obtains recent certification that tank was installed ac- } \\
\text { cording to national codes and standards, and maintains as built drawings in ap- } \\
\text { propriate files. } \\
\text { Verify that the installation notifies the regulator in advance if it cannot meet a } \\
\text { regulatory deadline. } \\
\text { Verify that, during the first year following installation, the leak detection systems } \\
\text { of new USTs are checked every } 30 \text { days to verify proper functioning. }\end{array}$ \\
\hline
\end{tabular}




\begin{tabular}{|c|c|}
\hline \multicolumn{2}{|r|}{$\begin{array}{c}\text { COMPLIANCE CATEGORY: } \\
\text { STORAGE TANK MANAGEMENT } \\
\text { Overseas ESOHCAMP }\end{array}$} \\
\hline $\begin{array}{l}\text { REGULATORY } \\
\text { REQUIREMENTS: }\end{array}$ & $\begin{array}{l}\text { REVIEWER CHECKS: } \\
\text { September } 2009\end{array}$ \\
\hline $\begin{array}{l}\text { ST.40 } \\
\text { USTs: } \\
\text { Existing USTs }\end{array}$ & $\begin{array}{l}\text { (NOTE: These requirements apply to USTs for POL and to those for hazardous } \\
\text { substances.) }\end{array}$ \\
\hline $\begin{array}{l}\text { ST.40.1.OCAF. } \quad \text { [Deleted } \\
\text { December 2003]. }\end{array}$ & Deleted in consequence of the incorporation of AFI 32-7044. \\
\hline $\begin{array}{l}\text { ST.40.2.OCAF. Upgraded } \\
\text { USTs that lack a release de- } \\
\text { tection monitoring system } \\
\text { must be inventoried monthly } \\
\text { and tightness tested at least } \\
\text { every } 5 \text { yr (AFI 32-7044, para } \\
\text { 2.2.1.1.1). }\end{array}$ & $\begin{array}{l}\text { Verify that upgraded USTs that lack a release detection monitoring system are } \\
\text { inventoried monthly. } \\
\text { Verify that upgraded USTs that lack a release detection monitoring system are } \\
\text { tightness tested at least every } 5 \mathrm{yr} \text { until } 10 \mathrm{yr} \text { after the tank was upgraded. } \\
\text { (NOTE: Upgraded USTs are those that meet the standards of AFI 32-7044, para } \\
\text { 2.1.) }\end{array}$ \\
\hline $\begin{array}{l}\text { ST.40.3.OCAF. During the } \\
\text { first year following upgrade, } \\
\text { the leak detection systems of } \\
\text { upgraded USTs with release } \\
\text { detection monitoring systems } \\
\text { must be checked every } 30 \\
\text { days to verify proper func- } \\
\text { tioning (AFI 32-7044, para } \\
\text { 2.2.1.1.2). }\end{array}$ & $\begin{array}{l}\text { Verify that, during the first year following upgrade, the leak detection systems of } \\
\text { upgraded USTs with release detection monitoring systems are checked every } 30 \\
\text { days to verify proper functioning. } \\
\text { (NOTE: Upgraded USTs are those that meet the standards of AFI 32-7044, para } \\
\text { 2.1.) }\end{array}$ \\
\hline
\end{tabular}


10-34

Storage Tanks 


\begin{tabular}{|c|c|}
\hline \multicolumn{2}{|r|}{$\begin{array}{l}\text { COMPLIANCE CATEGORY: } \\
\text { STORAGE TANK MANAGEMENT } \\
\text { Overseas ESOHCAMP }\end{array}$} \\
\hline $\begin{array}{l}\text { REGULATORY } \\
\text { REQUIREMENTS: }\end{array}$ & $\begin{array}{l}\text { REVIEWER CHECKS: } \\
\text { September } 2009\end{array}$ \\
\hline $\begin{array}{l}\text { ST.50 } \\
\text { USTs: } \\
\text { Leaking USTs }\end{array}$ & $\begin{array}{l}\text { (NOTE: These requirements apply to USTs for POL and to those for hazardous } \\
\text { substances.) }\end{array}$ \\
\hline $\begin{array}{l}\text { ST.50.1.OCAF. [Deleted } \\
\text { July 2008]. }\end{array}$ & Deleted at the request of the sponsor. \\
\hline $\begin{array}{l}\text { ST.50.2.OCAF. } \\
\text { December 2003]. }\end{array}$ & Deleted as a result of the incorporation of AFI 32-7044. \\
\hline
\end{tabular}


10-36 


\begin{tabular}{|c|c|}
\hline & $\begin{array}{l}\text { COMPLIANCE CATEGORY: } \\
\text { STORAGE TANK MANAGEMENT } \\
\text { Overseas ESOHCAMP }\end{array}$ \\
\hline $\begin{array}{l}\text { REGULATORY } \\
\text { REQUIREMENTS: }\end{array}$ & $\begin{array}{l}\text { REVIEWER CHECKS: } \\
\text { September } 2009\end{array}$ \\
\hline $\begin{array}{l}\text { ST.70 } \\
\text { HAZARDOUS WASTE } \\
\text { TANK SYSTEMS }\end{array}$ & \\
\hline $\begin{array}{l}\text { ST.70.1.OCAF. [Moved June } \\
\text { 2003; Deleted July 2008]. }\end{array}$ & $\begin{array}{l}\text { Deleted at the request of the sponsor. } \\
\text { [Formerly checklist item number ST.60.1.OCAF.] }\end{array}$ \\
\hline $\begin{array}{l}\text { ST.70.2.OCAF. [Moved June } \\
\text { 2003; Deleted July 2008]. }\end{array}$ & $\begin{array}{l}\text { Deleted at the request of the sponsor. } \\
\text { [Formerly checklist item number ST.60.2.OCAF.] }\end{array}$ \\
\hline
\end{tabular}


10-38 


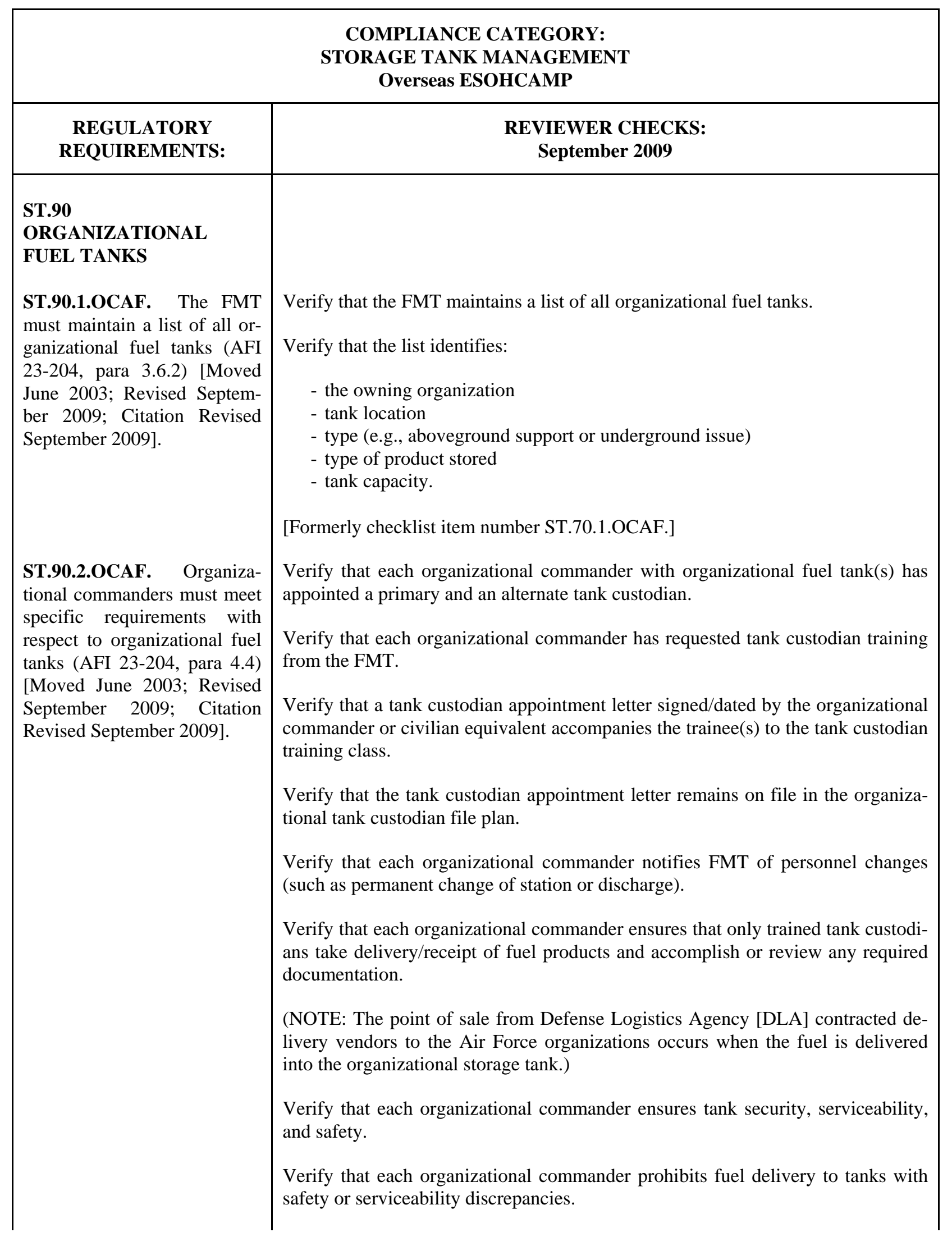




\section{COMPLIANCE CATEGORY: \\ STORAGE TANK MANAGEMENT \\ Overseas ESOHCAMP}

\begin{tabular}{|c|c|}
\hline $\begin{array}{l}\text { REGULATORY } \\
\text { REQUIREMENTS: }\end{array}$ & $\begin{array}{l}\text { REVIEWER CHECKS: } \\
\text { September } 2009\end{array}$ \\
\hline $\begin{array}{l}\text { ST.90.3.OCAF. The BCE } \\
\text { must provide a list of all or- } \\
\text { ganizational tanks to FMT } \\
\text { annually or when changes } \\
\text { occur (AFI 23-204, para } \\
\text { 4.5.2) [Moved June 2003; } \\
\text { Revised September 2009; } \\
\text { Citation Revised September } \\
\text { 2009]. }\end{array}$ & $\begin{array}{l}\text { Verify that each organizational commander continually evaluates requirements for } \\
\text { organizational tanks and maintains only the minimum number essential for mis- } \\
\text { sion requirements. } \\
\text { Verify that each organizational commander ensures fuel accountability in accor- } \\
\text { dance with the provisions of AFI 23-204, Chapter } 9 \\
\text { [Formerly checklist item number ST.70.2.OCAF.] } \\
\text { Verify that BCE provides a list of all organizational tanks to FMT annually or } \\
\text { when changes occur. } \\
\text { [Formerly checklist item number ST.70.3.OCAF.] }\end{array}$ \\
\hline $\begin{array}{l}\text { ST.90.4.OCAF. The FMT } \\
\text { must develop and maintain a } \\
\text { training guide or program to } \\
\text { train tank custodians and es- } \\
\text { corts when required (AFI 23- } \\
\text { 204, paras 4.7.1, 4.9.1, 11.1, } \\
\text { 11.3, and 11.4) [Revised Sep- } \\
\text { tember 1999; Moved June } \\
\text { 2003; Revised September } \\
\text { 2004; Revised September } \\
\text { 2009; Citation Revised Sep- } \\
\text { tember 2009]. }\end{array}$ & $\begin{array}{l}\text { Verify that the FMT has developed and maintains a training guide/program to } \\
\text { train tank custodians and escorts when required. } \\
\text { Verify that the FMT provides refresher training when requested by the using or- } \\
\text { ganization commander. } \\
\text { Verify that the FMT documents custodian training and keeps a record on file (sig- } \\
\text { nature cards, logs, letters, etc.). } \\
\text { Verify that the FMT ensures that fuel delivery escorts are briefed on responsibili- } \\
\text { ties. } \\
\text { Verify that the trainer briefs the following items: } \\
\text { - the hazards of petroleum products being handled such as sources of static } \\
\text { electricity, grounding and bonding, vapors, free falling fuel, etc. } \\
\text { - the importance of using personal protective equipment (PPE) } \\
\text { - daily facility inspection and maintenance requirements } \\
\text { - facility identification markings, leak detection techniques, condition of hoses } \\
\text { and nozzles, and proper procedures for documenting and reporting noted } \\
\text { discrepancies, using TO } 37-1-1 \text { as a reference } \\
\text { - safety precautions, proper storage of equipment, and management of re- } \\
\text { claimed or recoverable product referenced in AFI } 23-502 \text { and TO } 42 B-1-23 \\
\text { - guidance on requirements and methods for removing water } \\
\text { - the methods to secure tanks to prevent pilfering, sabotage, and contamina- } \\
\text { tion } \\
\text { - gauging procedures by either hands-on or media presentations, including } \\
\text { procedures for both fuel and water } \\
\text { - instructions on inventory accountability }\end{array}$ \\
\hline
\end{tabular}




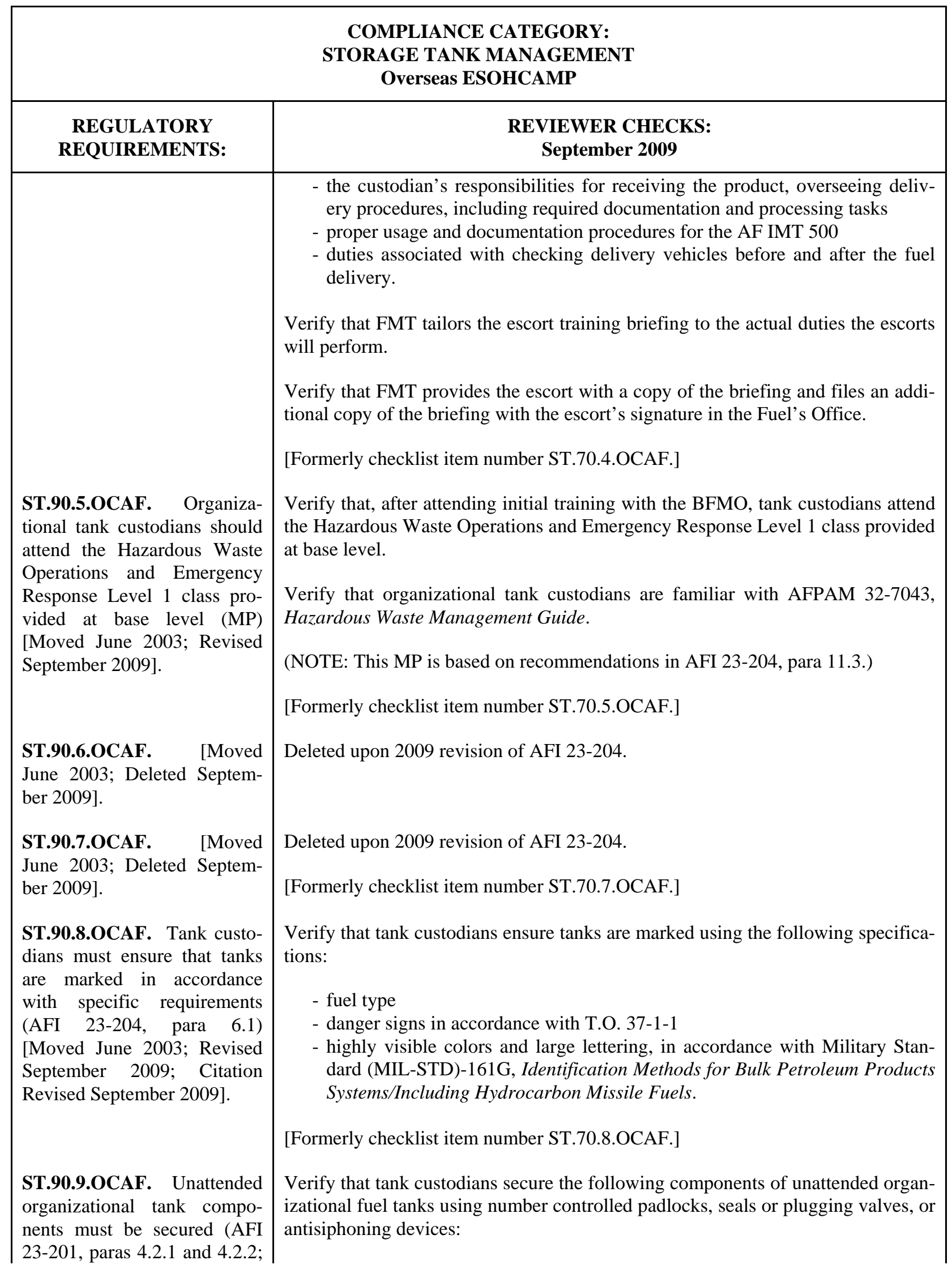




\section{COMPLIANCE CATEGORY: \\ STORAGE TANK MANAGEMENT \\ Overseas ESOHCAMP}

\section{REGULATORY REQUIREMENTS:}

AFI 23-204, para 5) [Moved June 2003; Revised September 2004; Citation Revised September 2004; Revised September 2009; Citation Revised September 2009].
ST.90.10.0CAF. All issue tanks must be equipped with calibrated dispensing meters (AFI 23-204, para 7.1) [Revised September 2009; Citation Revised September 2009].

\section{REVIEWER CHECKS: September 2009}

- pump dispensing nozzles and electrical power source for all issue tanks

- gauge hatches and other access points on all storage tanks

- bulk fuel off-loading systems

- low-point drains.

Verify that, if padlocks are used, the hasp, chain, handle, or any other attachment provides protective strength equivalent to more complicated devices.

Verify that tank custodians have established proper key control.

(NOTE: Combination and magnetic locks may be used.)

[Formerly checklist item number ST.70.9.OCAF.]

Verify that the FMT locks the following when they are not attended:

- all access and dispensing points on ground fuel equipment, to include fuel bowsers

- dispensing pump nozzles or main power source, except on automated dispensing pumps

- gates of fenced areas within fuels management control (when areas are not staffed or under surveillance)

- gauge hatches and other access points on all storage and hydrant tanks outside of protected (fenced) areas, unless exempted by the Base Resource Protection Committee

- electrical control panels and bulk fuel off-loading systems outside protected areas.

Verify that sump and tank drains are secured in a manner that prevents access to cargo tank contents.

Verify that locks are attached to a hasp, chain, handle, or other device of equivalent protective strength.

Verify that the use of combination locks has been approved by the local Resource Protection Committee and/or the local Installation Security Council.

[Author's Note: For the requirement to secure certain fuel facilities and equipment other than organizational tanks, see checklist item PO.3.10.OCAF.]

Verify that all issue tanks are equipped with a calibrated dispensing meter.

Verify that all issue tanks have certified calibration charts.

[Formerly checklist item number ST.70.10.OCAF.] 


\section{COMPLIANCE CATEGORY: \\ STORAGE TANK MANAGEMENT \\ Overseas ESOHCAMP}

\section{REGULATORY REQUIREMENTS:}

ST.90.11.OCAF. All support tanks must have certified calibration charts (AFI 23-204, para 7.2) [Moved June 2003; Revised September 2009; Citation Revised September 2009].

ST.90.12.OCAF. [Moved June 2003; Deleted July 2008].

ST.90.13.OCAF. [Moved June 2003; Deleted September 2009].

ST.90.14.OCAF. [Moved June 2003; Deleted September 2009].

ST.90.15.OCAF. [Moved June 2003; Deleted September 2009].

ST.90.16.OCAF. Fuel must not be issued from support tanks to vehicles or other equipment (AFI 23-204, paras 2.2 and 9.2) [Moved June 2003; Citation Revised September 2009].

ST.90.17.OCAF. Organizations that need to establish temporary or permanent organizational fuel tanks must meet specific requirements (AFI 23-204, para 3) [Added September 2009].

\section{REVIEWER CHECKS: September 2009}

Verify that certified tank calibration charts are present on all support tanks, regardless of size.

(NOTE: Computer-generated calibration charts are acceptable.)

(NOTE: This requirement may be waived by the MAJCOM Civil Engineer.)

(NOTE: HQ USAFE has currently waived this requirement.)

[Formerly checklist item number ST.70.11.OCAF.]

Deleted at the request of the sponsor.

[Formerly checklist item number ST.70.12.OCAF.]

Deleted upon 2009 revision of AFI 23-204.

[Formerly checklist item number ST.70.13.OCAF.]

Deleted upon 2009 revision of AFI 23-204.

[Formerly checklist item number ST.70.14.OCAF.]

Deleted upon 2009 revision of AFI 23-204.

Verify that fuel is not issued from support tanks to vehicles or other equipment.

[Formerly checklist item number ST.70.16.OCAF.]

Verify that organizations that need to establish temporary or permanent organizational fuel tanks coordinate requests for organizational tanks through the local Fuels Management Team (FMT) to ensure fuel cannot be efficiently provided from existing infrastructure.

Verify that organizations that need to establish temporary or permanent organizational fuel tanks include:

- the capacity and location of the tank

- the type of fuel required

- the type of equipment or vehicle(s) that the tank supports, and

- the reason why the organization cannot use the vehicle or ground support equipment service stations. 


\section{COMPLIANCE CATEGORY: \\ STORAGE TANK MANAGEMENT \\ Overseas ESOHCAMP}

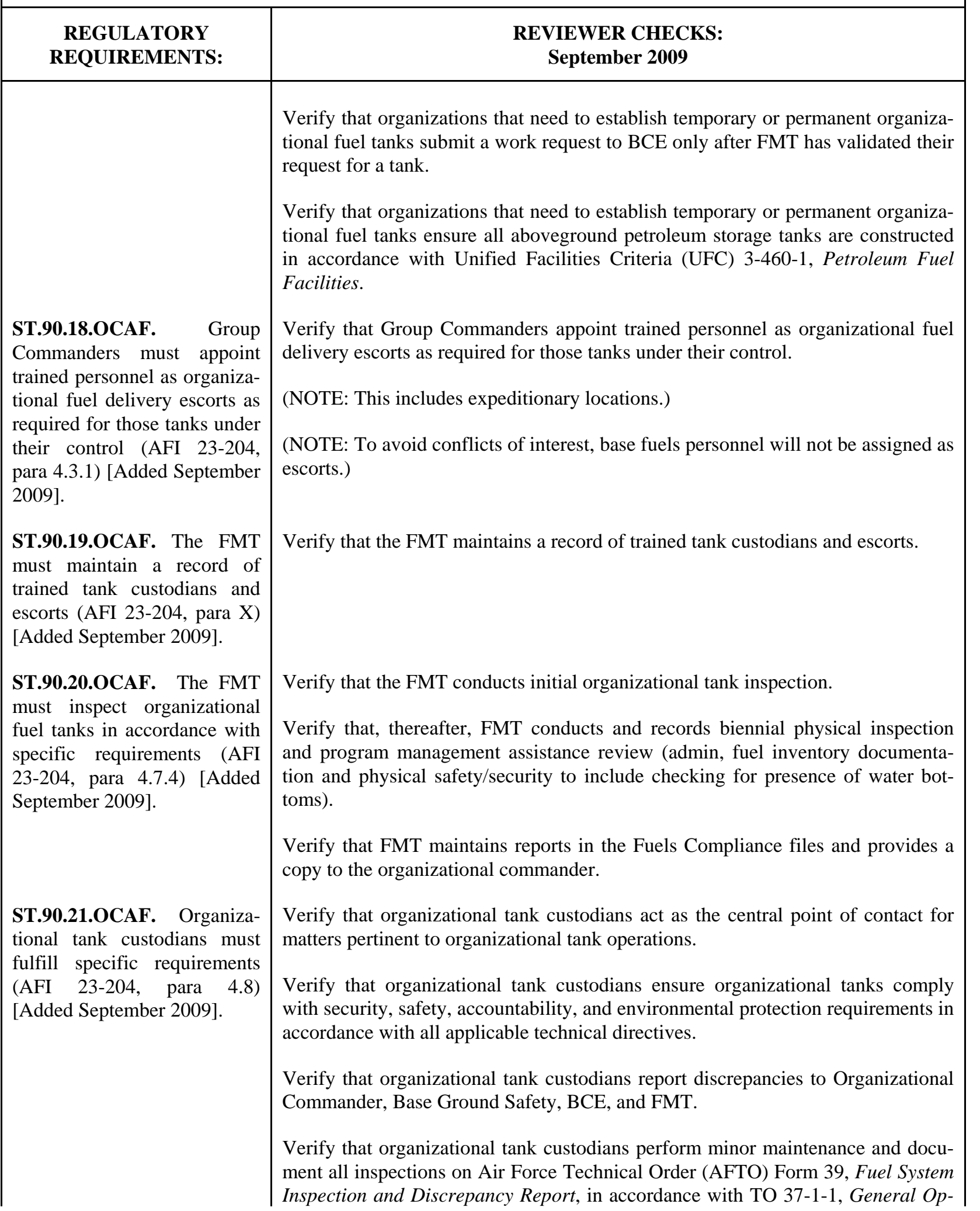




\section{COMPLIANCE CATEGORY: \\ STORAGE TANK MANAGEMENT \\ Overseas ESOHCAMP}

\section{REGULATORY REQUIREMENTS:}

ST.90.22.0CAF. Tank custodians/escorts must fulfill specific requirements when receiving fuel (AFI 23-204, para 8) [Added September 2009].

\section{REVIEWER CHECKS: September 2009}

eration and Inspection of Installed Fuel Storage System and Dispensing Systems (mark out or place N/A in the blocks that will not be utilized, e.g. FMT signatures).

Verify that organizational tank custodians monitor and record organizational tank inventory levels using AF IMT 500, Daily and Weekly Fuel Report (automated/locally developed substitutes for this form are NOT authorized).

Verify that organizational tank custodians gauge support tanks for inventory and water condensation monthly if not used.

Verify that organizational tank custodians receive bulk fuel deliveries and provide assistance during FMT deliveries of government-owned products.

Verify that organizational tank custodians operate the dispensing nozzle when receiving product via open port nozzle.

Verify that organizational tank custodians remove free water from tank bottoms in accordance with TO 42B-1-1, Quality Control of Fuels and Lubricants.

Verify that, on aboveground tanks, water removal systems are operated prior to any product movement (into or out of the tank).

(NOTE: In cases where all water cannot be removed, contact the BCE for tank modification.)

Verify that, for below-ground tanks without sump drains, all water is removed, when possible.

Verify that, in cases where all water cannot be removed, water accumulation does not exceed $0.25 \mathrm{in}$.

Verify that organizational tank custodians ensure that all wastewater removed from tanks is collected and disposed of in accordance with local policies, installation policies, and FGS requirements.

(NOTE: Escorts may perform receiving operations without a tank custodian if approved by the parent MAJCOM FMT and trained by the local FMT on all aspects of the operation they will perform.)

Verify that tank custodians/escorts gauge all tanks for water and fuel prior to receiving fuel to determine usable storage space.

Verify that tank custodians/escorts remove water prior to product receipt in accordance with TO 42B-1-1.

(NOTE: The safe fill level may differ with each tank design and should be established with initial tank installation. If not, contact FMT for assistance.) 


\section{COMPLIANCE CATEGORY: \\ STORAGE TANK MANAGEMENT \\ Overseas ESOHCAMP}

\begin{tabular}{|c|c|}
\hline $\begin{array}{l}\text { REGULATORY } \\
\text { REQUIREMENTS: }\end{array}$ & $\begin{array}{l}\text { REVIEWER CHECKS: } \\
\text { September } 2009\end{array}$ \\
\hline & $\begin{array}{l}\text { Verify that tank custodians/escorts assist in positioning the refueling unit. } \\
\text { Verify that tank custodians/escorts verify receipt documentation (i.e., product, } \\
\text { delivery, location, seals). } \\
\text { Verify that tank custodians/escorts contact FMT for sampling requirements and } \\
\text { collection by Fuels Laboratory Technicians. } \\
\text { Verify that, during metered fuel truck deliveries, tank custodians/escorts confirm } \\
\text { that the quantity on the truck meter matches the quantity on the delivery ticket. } \\
\text { Verify that, for single-drop deliveries, the contractor delivers the entire load into a } \\
\text { single organizational tank. } \\
\text { Verify that tank custodians/escorts ensure the carrier completely empties the } \\
\text { tank(s) and delivers all the fuel. } \\
\text { Verify that, upon completion of delivery, tank custodians/escorts sign all required } \\
\text { documentation and turn the documentation in to the FMT for processing (within } \\
\text { one duty day of fuel receipt). } \\
\text { Verify that, for multiple-drop deliveries, the contractor delivers products to more } \\
\text { than one fuel storage tank. } \\
\text { Verify that, upon completion of all drops, tank custodians/escorts ensure the } \\
\text { quantity the contractor shipped is the actual quantity received into all organiza- } \\
\text { tional tanks. } \\
\text { Verify that tank custodians/escorts immediately notify the FMT and organiza- } \\
\text { tional commander of irregularities or problems noted during fuel receipt. } \\
\text { Verify that tank custodians/escorts gauge tanks after receipt (calibrated charts } \\
\text { required). } \\
\text { Verify that tank custodians/escorts wait a minimum of } 30 \text { min after receipt before } \\
\text { gauging the tank to allow for dissipation of static electricity. } \\
\text { (NOTE: Fuel delivered to support tanks used for heating purposes requires sam- } \\
\text { pling and testing in accordance with AFI 32-1068, Heating Systems and Unfired } \\
\text { Pressure Vessels.) } \\
\text { local FMT. }\end{array}$ \\
\hline $\begin{array}{l}\text { ST.90.23.OCAF. The AF } \\
\text { IMT 500, Daily and Weekly } \\
\text { Fuels Report, must be used to } \\
\text { summarize fuel transactions }\end{array}$ & $\begin{array}{l}\text { Verify that the AF IMT 500, Daily and Weekly Fuels Report, is used to summa- } \\
\text { rize fuel transactions and compute gains and losses for organizational fuel tanks. } \\
\text { (NOTE: AFI 23-204, Attachment 2, contains detailed instructions on completing }\end{array}$ \\
\hline
\end{tabular}




\section{COMPLIANCE CATEGORY: \\ STORAGE TANK MANAGEMENT \\ Overseas ESOHCAMP}

\begin{tabular}{|l|}
\hline REGULATORY \\
REQUIREMENTS: \\
\hline and compute gains and losses \\
for organizational fuel tanks \\
(AFI 23-204, para 9.1) \\
[Added September 2009]. \\
ST.90.24.0CAF. Tank cus- \\
todians must meet specific \\
requirements with respect to \\
issues out of organizational \\
fuel tanks (AFI 23-204, paras \\
9.2.2 through 9.2.6) [Added \\
September 2009].
\end{tabular}

September 2009].

ST.90.25.OCAF. Tank custodians must meet specific requirements with respect to organizational fuel tank re-

\section{REVIEWER CHECKS: September 2009}

the AF IMT 500).

(NOTE: Gains and losses are commonly caused by temperature variations, equipment malfunctions, tank leaks, and/or pilfering. Consult the local FMT for guidelines on establishing acceptable gain and loss tolerances.)

Verify that the tank custodian gauges the issue tank(s) daily (prior to use) with fuel and water finding paste to determine the actual physical inventory.

Verify that the tank custodian removes any detected water in accordance with TO 42B-1-1.

Verify that, when gauging aboveground tanks, controls are in place to prevent people from falling.

Verify that the tank custodian prepares an AF IMT 500 for the issue tanks.

Verify that the tank custodian records on the back of the AF IMT 500 all fuel issued to "unit owned” vehicles and/or equipment.

Verify that the tank custodian records on the back of the AF IMT 500 all fuel issued to "non-unit owned" vehicles and/or equipment and documents each sale on a DD Form 1898, Fuel Sale Slip, in accordance with DESC I-21.

Verify that no non-DOD vehicles and equipment are refueled from organizational tanks.

Verify that the tank custodian delivers all applicable documentation to the local FMT accounting office weekly for review and submission into Business Systems Modernization-Energy (BSM-E) for processing to DESC's Fuels Automated System (FAS) Enterprise Server (FES).

(NOTE: The FMT accounting office returns the AF IMT 500 marked as "processed” to the tank custodian.)

Verify that the tank custodian delivers the AF IMT 500 marked as "processed" to their organization's Resource Advisor.

(NOTE: The Resource Advisor verifies transactions in the FES buyer's information section and returns the AF IMT 500 to the tank custodian.)

Verify that the tank custodian files the AF IMT 500 in accordance with AFMAN 33-363.

Verify that the tank custodian gauges the receipt tank(s) prior to receipt, with fuel and water finding paste to determine the actual physical inventory.

Verify that the tank custodian removes any detected water in accordance with TO 


\begin{tabular}{|c|c|}
\hline \multicolumn{2}{|r|}{$\begin{array}{c}\text { COMPLIANCE CATEGORY: } \\
\text { STORAGE TANK MANAGEMENT } \\
\text { Overseas ESOHCAMP }\end{array}$} \\
\hline $\begin{array}{l}\text { REGULATORY } \\
\text { REQUIREMENTS: }\end{array}$ & $\begin{array}{l}\text { REVIEWER CHECKS: } \\
\text { September } 2009\end{array}$ \\
\hline $\begin{array}{l}\text { ST.90.26.OCAF. Tank cus- } \\
\text { todians must monitor all un- } \\
\text { derground storage tanks and } \\
\text { associated piping for leaks } \\
\text { regardless of calibration and } \\
\text { report suspected leaks to the } \\
\text { base environmental manager } \\
\text { immediately (AFI 23-204, } \\
\text { para 10.1.2) [Added Septem- } \\
\text { ber 2009]. }\end{array}$ & $\begin{array}{l}\text { 42B-1-1. } \\
\text { Verify that the tank custodian prepares an AF IMT } 500 \text { for the receipt tank(s). } \\
\text { Verify that the tank custodian documents beginning and ending receipt tank quan- } \\
\text { tities on the AF IMT } 500 . \\
\text { Verify that the tank custodian signs and obtains applicable shipping documenta- } \\
\text { tion. } \\
\text { Verify that the tank custodian delivers all applicable documentation to the local } \\
\text { FMT accounting office within } 24 \text { h of receipt for review and submission into } \\
\text { Business Systems Modernization-Energy (BSM-E) for processing to DESC's Fu- } \\
\text { els Automated System (FAS) Enterprise Server (FES). } \\
\text { (NOTE: The FMT accounting office returns the AF IMT } 500 \text { marked as "proc- } \\
\text { essed" to the tank custodian.) } \\
\text { Verify that tank custodians monitor all underground storage tanks and associated } \\
\text { piping for leaks regardless of calibration. } \\
\text { Verify that tank custodians report suspected leaks to the base environmental man- } \\
\text { ager immediately. } \\
\text { (NOTE: Since leak detection methods for underground tanks may vary with the } \\
\text { type and age of the tank or pipeline, consult with the base environmental manager } \\
\text { for the correct monitoring technique.) }\end{array}$ \\
\hline
\end{tabular}




\section{Appendix 10-1}

\section{Hazardous Substances}

(NOTE: This list is derived from the Federal Consolidated List of Chemicals. That List is composed of SARA Section 302 Extremely Hazardous Substances, CERCLA Hazardous Substances [RQ] Chemicals, SARA Section 313 Toxic Chemicals, and RCRA Hazardous Wastes. For the purposes of Storage Tank Management, all RCRA hazardous wastes have been removed, because they are specifically excluded in the AFI definitions of Hazardous Substance UST and Regulated Substance. The listing is alphabetical, with numbered chemicals listed first.)

\begin{tabular}{|c|c|}
\hline Chemical Name & CAS No. \\
\hline Abamectin (Avermectin B1) & $71751-41-2$ \\
\hline Acenaphthene & $83-32-9$ \\
\hline Acenaphthylene & $208-96-8$ \\
\hline $\begin{array}{l}\text { Acephate (Acetylphos phoramidothioic acid O,S- } \\
\text { dimethyl ester }\end{array}$ & $30560-19-1$ \\
\hline Acetamide & $60-35-5$ \\
\hline Acetic acid & $64-19-7$ \\
\hline Acetic anhydride & $108-24-7$ \\
\hline Acetone thiosemicarba zide & $1752-30-3$ \\
\hline Acetyl bromide & $506-96-7$ \\
\hline Acifluorfen, sodium salt & $62476-59-9$ \\
\hline Acrylyl chloride & 814-68-6 \\
\hline Adiponitrile & $111-69-3$ \\
\hline Alachlor & $15972-60-8$ \\
\hline $\begin{array}{l}\text { d-trans-Allethrin [d- trans-Chrysan themic aacid of } \\
\text { d- allethrone0] }\end{array}$ & $28057-48-9$ \\
\hline Allylamine & $107-11-9$ \\
\hline Allyl chloride & $107-05-1$ \\
\hline alpha-Hexachlorocy clohexane & $319-84-6$ \\
\hline Aluminum (fume or dust) & $7429-90-5$ \\
\hline Aluminum oxide (fibrous forms) & $1344-28-1$ \\
\hline Aluminum sulfate & $10043-01-3$ \\
\hline Ametryn & $834-12-8$ \\
\hline 2-Aminoanthraquinone & $117-79-3$ \\
\hline 4-Aminoazobenzene & $60-09-3$ \\
\hline 4-Aminobiphenyl & $92-67-1$ \\
\hline Aminopterin & $54-62-6$ \\
\hline Amiton & $78-53-5$ \\
\hline Amiton oxalate & $3734-97-2$ \\
\hline
\end{tabular}




\begin{tabular}{|c|c|}
\hline Chemical Name & CAS No. \\
\hline Amitraz & 33689-61-1 \\
\hline Ammonia & $7664-41-7$ \\
\hline Ammonium acetate & 631-61-8 \\
\hline Ammonium benzoate & $1863-63-4$ \\
\hline Ammonium bicarbon ate & $1066-33-7$ \\
\hline Ammonium bichromate & 7789-09-5 \\
\hline Ammonium bifluoride & $1341-49-7$ \\
\hline Ammonium bisulfite & $10192-30-0$ \\
\hline Ammonium carbamate & $1111-78-0$ \\
\hline Ammonium carbonate & $506-87-6$ \\
\hline Ammonium chloride & $12125-02-9$ \\
\hline Ammonium chromate & 7788-98-9 \\
\hline Ammonium citrate,dibasic & $3012-65-5$ \\
\hline Ammonium fluoborate & $13826-83-0$ \\
\hline Ammonium fluoride & $12125-01-8$ \\
\hline Ammonium hydroxide & $336-21-6$ \\
\hline Ammonium oxalate & $5972-73-6$ \\
\hline Ammonium oxalate & $6009-70-7$ \\
\hline Ammonium oxalate & $14258-49-2$ \\
\hline Ammonium silicofluoride & $16919-19-0$ \\
\hline Ammonium sulfamate & $7773-06-0$ \\
\hline Ammonium sulfide & $12135-76-1$ \\
\hline Ammonium sulfite & 10196-04-0 \\
\hline Ammonium tartrate & $14307-43-8$ \\
\hline Ammonium tartrate & $3164-29-2$ \\
\hline Ammonium thiocyanate & $1762-95-4$ \\
\hline Amphetamine & $300-62-9$ \\
\hline Amyl acetate & $628-63-7$ \\
\hline iso-Amyl acetate & $123-92-2$ \\
\hline sec-Amyl acetate & $626-38-0$ \\
\hline tert-Amyl acetate & $625-16-1$ \\
\hline Analine,2,4,6-trime thyl- & $88-05-1$ \\
\hline Anilazine & $101-05-3$ \\
\hline o-Anisidine & $90-04-0$ \\
\hline p-Anisidine & $104-94-9$ \\
\hline o-Anisidine hydrochloride & $134-29-2$ \\
\hline Anthracene & $120-12-7$ \\
\hline
\end{tabular}




\begin{tabular}{|c|c|}
\hline Chemical Name & CAS No. \\
\hline 1,Amino-2-methyl- anthraquinone & $82-28-0$ \\
\hline Antimony & $7440-36-0$ \\
\hline Antimony pentachloride & 7647-18-9 \\
\hline Antimony pentafluoride & $7783-70-2$ \\
\hline Antimony potassium tartrate & $28300-74-5$ \\
\hline Antimony tribromide & 7789-61-9 \\
\hline Antimony trichloride & 10025-91-9 \\
\hline Antimony trifluoride & $7783-56-4$ \\
\hline Antimony trioxide & $1309-64-4$ \\
\hline Antimycin A & $1397-94-0$ \\
\hline ANTU & $86-88-4$ \\
\hline Aroclor 1016 & $12674-11-2$ \\
\hline Aroclor 1221 & $11104-28-2$ \\
\hline Aroclor 1232 & $11141-16-5$ \\
\hline Aroclor 1242 & $53469-21-9$ \\
\hline Aroclor 1248 & $12672-29-6$ \\
\hline Aroclor 1254 & 11097-69-1 \\
\hline Aroclor 1260 & $11096-82-5$ \\
\hline Arsenic & $7440-38-2$ \\
\hline Arsenic disulfide & $1303-32-8$ \\
\hline Arsenous oxide & $1327-53-3$ \\
\hline Arsenic trisulfide & 1303-33-9 \\
\hline Arsenous trichloride & 7784-34-1 \\
\hline Arsine & $7784-42-1$ \\
\hline Asbestos & $1332-21-4$ \\
\hline Atrazine & $1912-24-9$ \\
\hline Azinophos-ethyl & $2642-71-9$ \\
\hline Azinophos-methyl & $86-50-0$ \\
\hline Aziridine & $151-56-4$ \\
\hline Aziridine, 2-methyl & $75-55-8$ \\
\hline Barium and compounds & $7440-39-3$ \\
\hline Benfluralin & $1861-40-1$ \\
\hline Benzamide & $55-21-0$ \\
\hline Benzenamine,2-methyl & $95-53-4$ \\
\hline Benzenamine,3-(triflu oro-methyl)- & $98-16-8$ \\
\hline $\begin{array}{l}\text { Benzeneacetic acid, 4- chloro-a-(4-chlo rophenyl)- } \\
\text { a- hydroxy-, ethyl ester }\end{array}$ & $510-15-6$ \\
\hline Benzeneamine & $63-53-3$ \\
\hline
\end{tabular}




\begin{tabular}{|c|c|}
\hline Chemical Name & CAS No. \\
\hline Benzene, chloromethyl- & $100-44-7$ \\
\hline Benzenediamine, ar- methyl & $95-80-7$ \\
\hline 1,2-Benzenedicarboxy lic acid, dibutyl ester & $54-74-2$ \\
\hline Benzene, nitro & $98-95-3$ \\
\hline $\begin{array}{l}\text { Benzene, 1,1-(2,2,2- trichloroethylidene) bis(4- } \\
\text { methoxy }\end{array}$ & $72-43-5$ \\
\hline Benzo[b]fluoranthene & 205-99-2 \\
\hline Benzo[k]fluoranthene & 207-08-9 \\
\hline Benzoic acid & $65-85-0$ \\
\hline Benzonitrile & $100-47-0$ \\
\hline Benzoyl peroxide & $94-36-0$ \\
\hline Benzo[ghi]perylene & $191-24-2$ \\
\hline p-Benzoquinone & $106-51-4$ \\
\hline Benzoyl chloride & $98-88-4$ \\
\hline Benzyl cyanide & $140-29-4$ \\
\hline Beryllium chloride & $7787-47-5$ \\
\hline Beryllium fluoride & $7787-49-7$ \\
\hline Beryllium nitrate & $13597-99-4$ \\
\hline Beryllium nitrate & $7787-55-5$ \\
\hline alpha-BHC & $319-84-6$ \\
\hline beta-BHC & $319-85-7$ \\
\hline Delta-BHC & $319-86-8$ \\
\hline Biphenyl & $92-52-4$ \\
\hline Bis(chloromethyl )ether & $542-88-1$ \\
\hline Bis(chloromethyl)ketone & $534-07-6$ \\
\hline Bis(2-ethylhexyl)adi pate & $103-23-1$ \\
\hline Bis(tributylin) oxide & $56-35-9$ \\
\hline Boron trichloride & 10294-34-5 \\
\hline $\begin{array}{l}\text { Boron trifluoride compound with methyl ether } \\
\quad(1: 1)\end{array}$ & $353-42-4$ \\
\hline Boron trifluoride & $7637-07-2$ \\
\hline Bromadiolone & $18772-56-7$ \\
\hline Bromacil & $314-40-9$ \\
\hline Bromacil, lithium salt & $53404-19-6$ \\
\hline Bromine & $7726-95-6$ \\
\hline 2-Bromo-2-nitropropane -1,3-diol (Bronopol) & $52-51-7$ \\
\hline Bromochlorodifluo romethan (Halon 1211) & $353-59-3$ \\
\hline Bromotrifluorometh- ane (Halon 1301) & $75-63-8$ \\
\hline
\end{tabular}




\begin{tabular}{|lr|}
\hline Chemical Name & \multicolumn{1}{c|}{ CAS No. } \\
\hline \hline Bromoxynil & $1689-84-5$ \\
Bromoxynil octanoate & $1689-88-2$ \\
1,3-Butadiene & $106-99-0$ \\
2-Butene, 1,4-dichloro & $764-41-0$ \\
Butyl acetate & $123-86-4$ \\
iso-Butyl acetate & $110-19-0$ \\
sec-Butyl acetate & $105-46-4$ \\
tert-Butyl acetate & $540-88-5$ \\
Butyl acrylate & $141-32-2$ \\
sec-Butyl alcohol & $78-92-2$ \\
tert-Butyl alcohol & $75-65-0$ \\
Butyl benzyl Phthalate & $85-68-7$ \\
sec-Butylamine & $13952-84-6$ \\
sec-Butylamine & $513-49-5$ \\
tert-Butylamine & $75-64-9$ \\
Butylamine & $109-73-9$ \\
iso-Butylamine & $78-81-9$ \\
1,2-Butylene oxide & $106-88-7$ \\
Butyraldehyde & $7440-43-96-5$ \\
Butyric acid & $123-72-8$ \\
iso-Butyric acid & $107-92-6$ \\
CI Acid Green 3 & $79-31-2$ \\
CI Acid Red 114 & $3761-53-3$ \\
CI Basic Green 4 & $3118-97-6$ \\
CI Basic Red 1 & $4680-78-8$ \\
CI Direct Black 38 & $6459-94-5$ \\
CI Direct Blue 6 & $569-64-2$ \\
CI Direct Blue 218 & $989-38-8$ \\
CI Direct Brown 95 & $1937-37-7$ \\
CI Disperse Yellow 3 & $2602-46-2$ \\
CI Food Red 15 & $28407-37-6$ \\
CI Food Red 5 & $16071-86-6$ \\
CI Solvent Orange 7 & $2832-40-8$ \\
CI Solvent Yellow 14 & 81 Solvent Yellow 3 \\
CI Vat Yellow 4 & \\
\hline
\end{tabular}




\begin{tabular}{|c|c|}
\hline Chemical Name & CAS No. \\
\hline Cadmium acetate & $543-90-8$ \\
\hline Cadmium bromide & $7789-42-6$ \\
\hline Cadmium chloride & $10108-64-2$ \\
\hline Cadmium oxide & $1306-19-0$ \\
\hline Cadmium stearate & 2223-93-0 \\
\hline Calcium arsenate & $7778-44-1$ \\
\hline Calcium arsenite & $52740-16-6$ \\
\hline Calcium carbide & $75-20-7$ \\
\hline Calcium cyanamide & $156-62-7$ \\
\hline Calcium dodecylben zene sulfonate & 26264-06-2 \\
\hline Calcium hypochlorite & $7778-54-3$ \\
\hline Camphechlor & $8001-35-2$ \\
\hline Cantharidin & $56-25-7$ \\
\hline Caprolactam & $105-60-2$ \\
\hline Captan & $133-06-2$ \\
\hline Carbachol chloride & $51-83-2$ \\
\hline Carbaryl & $63-25-2$ \\
\hline Carbofuran & $1563-66-2$ \\
\hline Carbonic dichoride & $75-44-5$ \\
\hline Carbonyl sulfide & $463-58-1$ \\
\hline Carbophenothion & $786-19-6$ \\
\hline Carboxin & $5234-68-4$ \\
\hline Catechol & $120-80-9$ \\
\hline Chinomethionat & 2349-01-2 \\
\hline Chloramben & $133-90-4$ \\
\hline Chlorendic acid & $115-28-6$ \\
\hline Chlorfenvinfos & $470-90-6$ \\
\hline Chlorinated camphene & $8001-35-2$ \\
\hline Chlorinated fluorocar bon(Freon 113) & 76-13-1 \\
\hline Chlorine & $7782-50-5$ \\
\hline Chlorine dioxide & $10049-04-4$ \\
\hline Chlorinuron ethyl & $90982-32-4$ \\
\hline Chlormephos & 24934-91-6 \\
\hline Chlormequat chloride & $999-81-5$ \\
\hline 1-Chloro-1,1- difluoroethane (HCFC 142(b)) & $75-68-3$ \\
\hline 1-Chloro-2,3- epoxypropane & $106-89-8$ \\
\hline 2-Chloro-1,1,1-trifluoro-ethane (HCFC 133a) & $75-88-7$ \\
\hline
\end{tabular}




\begin{tabular}{|c|c|}
\hline Chemical Name & CAS No. \\
\hline Chloroacetaldehyde & $107-20-0$ \\
\hline Chloroacetic acid & $79-11-8$ \\
\hline 2-Chloroacetophenone & $532-27-4$ \\
\hline 3-chloroacetophenone & $532-27-4$ \\
\hline p-Chloroaniline & $106-47-8$ \\
\hline Chlorobenzene & $108-90-7$ \\
\hline Chlorodibromomethane & $124-48-1$ \\
\hline Chlorodifluoromethane (HCFC-22) & $75-45-6$ \\
\hline Chloroethane & $75-00-3$ \\
\hline Chloroethanol & $107-07-3$ \\
\hline Chloroethyl chlorofor mate & $627-11-2$ \\
\hline Chloromethane & $74-87-3$ \\
\hline Chloromethyl ether & $542-88-1$ \\
\hline p-Chloro-o-toluidine & $95-69-2$ \\
\hline (Mono)chloropenta- fluoroethane (CFC 115) & $76-15-3$ \\
\hline Chlorophacinone & $3691-35-8$ \\
\hline 4-Chlorophenyl phenyl ether & $7005-72-3$ \\
\hline p-Chlorophenyl isocy anate & $104-12-1$ \\
\hline Chloropicrin & $76-06-2$ \\
\hline Chloroprene & $126-99-8$ \\
\hline 3-Chloropropionitrile & $542-76-7$ \\
\hline Chlorotetrafluoroethane & $63938-10-3$ \\
\hline Chlorothalonil & $1897-45-6$ \\
\hline Chlorortrifluo romethane (CFC 13) & $75-72-9$ \\
\hline Chloroxuron & $1982-47-4$ \\
\hline Chlorpyrifos & 2921-88-2 \\
\hline Chlorpyrifos methyl & $5598-72-3$ \\
\hline Chlorsulfonic acid & $7790-94-5$ \\
\hline Chlorsulfuron & $64902-72-3$ \\
\hline Chlorthiophos & 21923-23-9 \\
\hline Chromic acetate & $1066-30-4$ \\
\hline Chromic acid & $11115-74-5$ \\
\hline Chromic acid & $7738-94-5$ \\
\hline Chromic chloride & $10025-73-7$ \\
\hline Chromic sulfate & $10101-53-8$ \\
\hline Chromium & $7440-47-3$ \\
\hline Chromous chloride & $10049-05-5$ \\
\hline
\end{tabular}




\begin{tabular}{|c|c|}
\hline Chemical Name & CAS No. \\
\hline Cobalt & $7440-50-8$ \\
\hline $\begin{array}{l}\text { Cobalt,((2,2’'-1,2- ethanediylbis (ni-trilomethyli } \\
\text { dyne))bis(6) }\end{array}$ & $62207-76-5$ \\
\hline Cobalt carbonyl & $10210-68-1$ \\
\hline Cobaltous bromide & $7789-43-7$ \\
\hline Cobaltous formate & $544-18-3$ \\
\hline Cobaltous sulfamate & $14017-41-5$ \\
\hline Colchicine & $64-86-8$ \\
\hline Copper & $7440-50-8$ \\
\hline Coumaphos & $56-72-4$ \\
\hline Coumatetralyl & $5836-29-3$ \\
\hline p-Cresidine & $120-71-8$ \\
\hline Cresylic acid (isomers and mixtures) & $1319-77-3$ \\
\hline m-Cresylic acid & $108-39-4$ \\
\hline o-Cresylic acid & $95-48-7$ \\
\hline p-Cresylic acid & $106-44-5$ \\
\hline Crimidine & $535-89-7$ \\
\hline Cumene & $98-82-8$ \\
\hline Cumene hyroperoxide & $80-15-9$ \\
\hline Cupferron & $135-20-6$ \\
\hline Cupric acetate & $142-71-2$ \\
\hline Cupric chloride & $7447-39-4$ \\
\hline Cupric nitrate & $3251-23-8$ \\
\hline Cupric oxalate & $5893-66-3$ \\
\hline Cupric sulfate & 7758-98-7 \\
\hline Cupric sulfate ammoniated & $10380-29-7$ \\
\hline Cupric tartrate & $815-82-7$ \\
\hline Cyanazine & $21725-46-2$ \\
\hline Cyanogen iodide & $506-78-5$ \\
\hline Cyanophos & $2636-26-2$ \\
\hline Cyanuric fluoride & $675-14-9$ \\
\hline 2,5-Cyclohexadiene- 1,4-dione & $106-51-4$ \\
\hline Cyclohexane, 1,2,3,4,5,6- hexachloro-, & $58-89-9$ \\
\hline Cyclohexanol & 108-93-0 \\
\hline Cycloheximide & $66-81-9$ \\
\hline Cyclohexylamine & 108-91-8 \\
\hline 1,3-Cyclopentadiene, 1,2,3,4,5,6- hexachloro & $77-47-4$ \\
\hline Cyfluthrin & $68359-37-5$ \\
\hline
\end{tabular}




\begin{tabular}{|c|c|}
\hline Chemical Name & CAS No. \\
\hline Cyhalothrin & $68085-85-8$ \\
\hline 2,4,-D8 & $94-82-6$ \\
\hline 2,4-D 2-ethyhexyl ester & $1928-43-4$ \\
\hline 2,4-D 2-ethyl-4-meth ylpentyl ester & $53404-37-8$ \\
\hline 2,4,-D Butoxyethyl ester & 1929-73-3 \\
\hline 2,4-D Butyl ester & $94-80-4$ \\
\hline 2,4-D chlorocrotyl ester & $2971-38-2$ \\
\hline 2,4-D esters & $94-11-1$ \\
\hline 2,4-D esters & $94-79-1$ \\
\hline 2,4-D esters & $94-80-4$ \\
\hline 2,4-D esters & $1320-18-9$ \\
\hline 2,4-D esters & $1928-38-7$ \\
\hline 2,4-D esters & $2971-38-2$ \\
\hline 2,4-D esters & $53467-11-1$ \\
\hline 2,4-D esters & $1928-61-6$ \\
\hline 2,4-D esters & $1929-73-3$ \\
\hline 2,4-D esters & $25168-26-7$ \\
\hline Dazomet, sodium salt & $53404-60-7$ \\
\hline DDE & $72-55-9$ \\
\hline 4,4,-DDE & $72-55-9$ \\
\hline Decaborane(14) & $17702-41-9$ \\
\hline Decabromodiphenyl oxide & $1163-19-5$ \\
\hline DEHP & $117-81-7$ \\
\hline Demeton & $8065-48-3$ \\
\hline Demeton-S-methyl & $919-86-8$ \\
\hline Desmmedipham & $13684-56-5$ \\
\hline Dialifor & $10311-84-9$ \\
\hline 2,4-Diaminoanisole sulfate & $39156-41-7$ \\
\hline 4,4'-Diaminodiphenyl ether & $101-80-4$ \\
\hline 2,4-Diaminosole & $615-41-7$ \\
\hline Diaminotoluene(mixed isomers) & $496-72-0$ \\
\hline Diazinon & $333-41-5$ \\
\hline Diazomethane & $334-88-3$ \\
\hline Dibenzofuran & $132-64-9$ \\
\hline Diborane & $19287-45-7$ \\
\hline Dibromotetrafluor- ethane (Halon 2402 & $124-73-2$ \\
\hline Dicamba & $1918-00-9$ \\
\hline
\end{tabular}




\begin{tabular}{|c|c|}
\hline Chemical Name & CAS No. \\
\hline Dichlone & $117-80-6$ \\
\hline \multicolumn{2}{|l|}{ 1,2-Dichloro-1,1-diflu oroethane (HCFC- 132b) } \\
\hline 1,2-Dichloro-1,1-difluoroethane (HCFC-132b) & $1649-08-7$ \\
\hline 2,2-Dichloro-1,1,1-tri-fluoroethane (HCFC 123) & $306-83-2$ \\
\hline Dichloran & $99-30-9$ \\
\hline p-Dichlorobenzene & $106-46-7$ \\
\hline 1,4,-Dichlorobenzene & $106-46-7$ \\
\hline Dichlorobenzene (mixed isomers) & 25321-22-6 \\
\hline 3,3-Dichlorobenzidine & $91-94-1$ \\
\hline 3,3-Dichlorobenzidine dihydrochloride & $612-83-9$ \\
\hline 3,3-Dichlorobenzidine sulfate & 64969-34-2 \\
\hline Dichlorobromomethane & $75-27-4$ \\
\hline Dichlorofluoromethane (HCFC-21) & $75-43-4$ \\
\hline Dichloromethane & $75-02-2$ \\
\hline Dichloromethyl ether & $542-88-1$ \\
\hline Dichloromethyl- phe nylsilane & $149-74-6$ \\
\hline Dichloropentafluoro propane & 127564-92- 5 \\
\hline Dichlorophene & $97-23-4$ \\
\hline 2,4-Dichlorophenol & $120-83-2$ \\
\hline Dichloropropane & 26638-19-7 \\
\hline Dichloropropane- & $8003-19-8$ \\
\hline Dichloropropene & 26952-23-8 \\
\hline 1,3,-Dichloropropene & $542-75-6$ \\
\hline 2,3-Dichloropropene & $78-88-6$ \\
\hline 2,2-Dichloropropionic acid & $75-99-0$ \\
\hline Dichlorotetrafluoro- ethane (CFC-114) & $76-14-2$ \\
\hline Dichlorotrifluoroethane & $34077-87-7$ \\
\hline Dichloro-1,1,2-trifluo roethane & $90454-18-5$ \\
\hline Dichlorvos & $62-73-7$ \\
\hline Dicholobenil & $1194-65-6$ \\
\hline Dicofol & $115-32-2$ \\
\hline Dicrotophos & $141-66-2$ \\
\hline Dicyclofop methyl & $51338-27-3$ \\
\hline \multicolumn{2}{|l|}{ Dicyclopenbtadiene } \\
\hline Diethanolamine & $111-42-2$ \\
\hline Diethatyl ethyl & $38727-55-8$ \\
\hline Diethylamine & 109-89-7 \\
\hline
\end{tabular}




\begin{tabular}{|c|c|}
\hline Chemical Name & CAS No. \\
\hline N,N-Diethylaniline & $91-66-7$ \\
\hline Diethyl chlorophos phate & $814-49-3$ \\
\hline Diethyl sulfate & $64-67-5$ \\
\hline 3.3.-Dimethylbenzidine & $119-93-7$ \\
\hline Diethylcarbamazine citrate & $1642-54-2$ \\
\hline \multicolumn{2}{|l|}{ Diethylhexylphthalate } \\
\hline 1,4-Diethyleneoxide & $123-91-1$ \\
\hline Diflubenzuron & $35367-38-5$ \\
\hline Digitoxin & $71-63-6$ \\
\hline Diglycidyl ether & $2238-07-5$ \\
\hline Diglycidyl resorcinol ether & $101-90-6$ \\
\hline Digoxin & $20830-75-5$ \\
\hline Dihydrosafrole & $94-58-6$ \\
\hline Dimefox & $115-26-4$ \\
\hline Dimethipin & $55290-64-7$ \\
\hline 3.3-Dimethoxybenzidine & $119-90-4$ \\
\hline 3,3-Dimethoxybenzidine dihydrochloride & $612-82-8$ \\
\hline 3,3-Dimethoxybenzidine dihydrochloride & $20325-40-0$ \\
\hline 3,3-Dimethoxybenzidine dihydrofluoride & $41756-75-0$ \\
\hline 3.3-Dimethoxybenzidine hydrochloride & 111984-09- 9 \\
\hline Dimethylamine dicamba & $2330-66-5$ \\
\hline Dimethyl aminoa zobenzene & $60-11-7$ \\
\hline N,N-Dimethylaniline & $121-69-7$ \\
\hline Dimethylcarbamoyl chloride & $79-44-7$ \\
\hline Dimethyl chlorothio phosphate & 2524-03-0 \\
\hline Dimethyldichlorosilane & $75-78-5$ \\
\hline Dimethylformamide & $68-12-2$ \\
\hline N-N'-Dimethylformamide & $68-12-2$ \\
\hline 1,1,-Dimethylhydrazine & $57-14-7$ \\
\hline 2,6-Dimethylphenol & $576-26-1$ \\
\hline Dimethyl phosphoro- chloridothioate & 2524-03-0 \\
\hline Dimethyl-p-phenyl- enediamine & $99-98-9$ \\
\hline Di-n-butyl phthalate & 84-74-2 \\
\hline Dinitrobenzene (mixed) & $25154-54-5$ \\
\hline o-Dinitrobenzene & $528-29-0$ \\
\hline p-Dinitrobenzene & $100-25-4$ \\
\hline Dinitrocresol & $534-52-1$ \\
\hline
\end{tabular}




\begin{tabular}{|c|c|}
\hline Chemical Name & CAS No. \\
\hline 4,6-Dinitro-o-cresol and salts & $534-52-1$ \\
\hline Dinitrophenol & $25550-58-7$ \\
\hline 3,4-Dinitrotoluene & $610-39-9$ \\
\hline Dinitrotoluene (mixed isomers) & 25321-14-6 \\
\hline 2,4-Dinitrotoluene & $121-14-2$ \\
\hline Di-(2-ethylhexyl)phthlate (DEHP) & $177-81-7$ \\
\hline Dinocap & $39300-45-3$ \\
\hline Dinoterb & $1420-07-1$ \\
\hline 1,4,-Dioxane & $123-91-1$ \\
\hline Dioxathion & $78-34-2$ \\
\hline Diphacinone & $82-66-6$ \\
\hline Diphenamid & $957-51-7$ \\
\hline Diphenylamine & $122-39-4$ \\
\hline Dipotassium enfothal & 2164-07-0 \\
\hline Dipropyl isocinchomer onate & $136-45-8$ \\
\hline Diquat & $85-00-7$ \\
\hline Diquat & $2764-72-9$ \\
\hline Disodium cyanodithio imidocarbonate & $138-93-2$ \\
\hline Dithiazinine iodide & $514-73-8$ \\
\hline 2,4-Dithiobiuret & $541-53-7$ \\
\hline Diuron & $330-54-1$ \\
\hline Dodecylbenzene sulfonic acid & $27176-87-0$ \\
\hline Dodine & $2439-10-3$ \\
\hline 2,4-DP & $120-36-5$ \\
\hline Emetine,dihyrochloride & $316-42-7$ \\
\hline alpha-Endosulfan & $959-98-8$ \\
\hline Endosulfan sulfate & $1031-07-8$ \\
\hline Endothion & $2778-04-3$ \\
\hline Endrin aldehyde & $7421-93-4$ \\
\hline EPN & 2104-64-5 \\
\hline 1,2-Epoxybutane & $106-88-7$ \\
\hline Ergocalciferol & $50-14-6$ \\
\hline Ergotamine tartrate & $379-79-3$ \\
\hline Ethanal & $75-07-0$ \\
\hline Ethane, 1,1-dichloro & $75-34-3$ \\
\hline Ethane, 11,2-dichloro & $107-06-2$ \\
\hline Ethane,1,1'-oxybis(2- chloro- & $111-44-4$ \\
\hline
\end{tabular}




\begin{tabular}{|c|c|}
\hline Chemical Name & CAS No. \\
\hline Ethanesulfonyl chlo ride, 2-chloro- & $1622-32-8$ \\
\hline Ethane, 1,1,1-trichloro & $71-55-6$ \\
\hline Ethanol,1,2-dichloro- acetate & $10140-87-1$ \\
\hline Ethanone, 1-phenyl & $98-86-2$ \\
\hline Ethene, 1,1-dichloro & $75-35-4$ \\
\hline Ethene, trichloro & 79-01-6 \\
\hline Ethion & $563-12-2$ \\
\hline Ethoprophos & 13194-48-4 \\
\hline 2-Ethoxyethanol & $110-80-5$ \\
\hline Ethyl carbamate & $51-79-6$ \\
\hline Ethylbenzene & $100-41-4$ \\
\hline Ethylbis(2-chloroet hyl)amine & $538-07-8$ \\
\hline Ethyl chloride & $75-00-3$ \\
\hline Ethyl chloroformate & $541-41-3$ \\
\hline Ethylene & $74-85-1$ \\
\hline Ethylenediamine & $107-15-3$ \\
\hline Ethylenediamine tetra- acetic acid (EDTA) & $60-00-4$ \\
\hline Ethylene dibromide & $106-93-4$ \\
\hline Ethylene dichloride & $107-06-2$ \\
\hline Ethylene Fluorohydrin & $371-62-0$ \\
\hline Ethylene glycol & $107-21-1$ \\
\hline Ethylenethiocyanate & $542-90-5$ \\
\hline Ethylidene dichloride & $75-34-3$ \\
\hline Fenamiphos & 22224-92-6 \\
\hline Fenarimol & $60100-88-9$ \\
\hline Fenbutatin oxide & $13356-08-6$ \\
\hline Fenitrothion & $122-14-5$ \\
\hline Fenoxaprop ethyl & 66441-23-4 \\
\hline Fenoxycarb & 72490-01-8 \\
\hline Fenpropathrin & 39515-41-8 \\
\hline Fensulfothion & $115-90-2$ \\
\hline Fenthion & $55-38-9$ \\
\hline Fenvalerate & 51630-58-1 \\
\hline Ferric ammonium citrate & $1185-57-5$ \\
\hline Ferric ammonium oxalate & $2944-67-4$ \\
\hline Ferric ammonium oxalate & $55488-87-4$ \\
\hline Ferric chloride & $7705-08-0$ \\
\hline
\end{tabular}




\begin{tabular}{|c|c|}
\hline Chemical Name & CAS No. \\
\hline Ferric fluoride & $7783-50-8$ \\
\hline Ferric nitrate & $10421-48-4$ \\
\hline Ferric sulfate & $10028-22-5$ \\
\hline Ferrous ammonium sulfate & $10045-89-3$ \\
\hline Ferrous chloride & $7758-94-3$ \\
\hline Ferrous sulfate & $7720-78-7$ \\
\hline Ferrous sulfate & $7782-63-0$ \\
\hline Florouracil & $51-21-8$ \\
\hline Fluenetil & $4301-50-2$ \\
\hline Fluometuron & $2164-17-2$ \\
\hline Fluorene & $86-73-7$ \\
\hline Fluoroacetic acid & $144-49-0$ \\
\hline Fluoroacetyl chloride & $359-06-8$ \\
\hline 1,1-Dichloro-1-fluoro ethane (HCFC-141b) & $1717-80-6$ \\
\hline 1,1,1,2-Tetrachloro-2- fluoroethane (HCFC- 121a) & $354-11-0$ \\
\hline 1,1,2,2-Tetrachloro-1- fluoroethane (HCFC 121) & $354-14-3$ \\
\hline Fluorouracil & $51-21-8$ \\
\hline Fluvalinate & $69409-94-5$ \\
\hline Folpet & $133-07-3$ \\
\hline Fomesafen & $72178-02-0$ \\
\hline Fonofos & $944-22-9$ \\
\hline Formaldehyde cyano hydrin & $107-16-4$ \\
\hline Formothion & $2540-82-1$ \\
\hline Fosthietan & 21548-32-3 \\
\hline Fuazifop-butyl & $69806-50-4$ \\
\hline Fuberidazole & $3878-19-1$ \\
\hline Fumaric acid & $110-17-8$ \\
\hline Gallium trichloride & $13450-90-3$ \\
\hline Heptachlor epoxide & $1024-57-3$ \\
\hline Hexachlorobenzene & $118-74-1$ \\
\hline Hexachlorobutadiene & $87-68-3$ \\
\hline Hexachlorocyclohex ane & $58-89-9$ \\
\hline Hexachloroethane & $67-72-1$ \\
\hline Hexachloronaphthalene & $1335-87-1$ \\
\hline Hexamethyleme-1,6- diisocyante & $822-06-0$ \\
\hline Hexamethylenedi amine, N,N'-dibutyl- & $4835-11-4$ \\
\hline Hexamethylphosphora mide & $680-31-9$ \\
\hline
\end{tabular}




\begin{tabular}{|c|c|}
\hline Chemical Name & CAS No. \\
\hline Hexane & $110-54-3$ \\
\hline Hexazinone & $51235-04-2$ \\
\hline Hexone & $108-10-1$ \\
\hline Hydramethylnon & $67485-29-4$ \\
\hline Hydrazine, 11,1-dime thyl- & $57-14-7$ \\
\hline Hydrazine, 1,2-diphe nyl- & $122-66-7$ \\
\hline Hydrazine. methy; & $60-34-4$ \\
\hline Hydrazine sulfate & 10034-93-2 \\
\hline Hydrochloric acid & $7647-01-0$ \\
\hline Hydrofluoric acid & $7664-39-3$ \\
\hline Hydrogen chloride (gas only) & $7647-01-0$ \\
\hline Hydrogen perioxide (conc > 52\%) & $7722-84-1$ \\
\hline Hydrogen phosphide & $7803-51-2$ \\
\hline Hydrogen selenide & $7783-07-5$ \\
\hline Hydroquinone & $123-31-9$ \\
\hline Imazalil & $35554-44-0$ \\
\hline 2-imidazolidinethione & $96-45-7$ \\
\hline Iron, pentacarbonyl- & 13463-40- 06 \\
\hline Isobenzan & $297-78-9$ \\
\hline Isobutyraldehyde & $78-84-2$ \\
\hline Isobutyronitrile & $78-82-0$ \\
\hline Isocyanic acid,3,4- dichlorophenyl ester & $102-36-3$ \\
\hline Isofenphos & 25311-71-1 \\
\hline Isoflurophate & $56-91-4$ \\
\hline Isomethane & $74-88-4$ \\
\hline Isophorone & $78-59-1$ \\
\hline Isophorone diisocyan ate & $4098-71-9$ \\
\hline Isoprene & $78-79-5$ \\
\hline Isopropanolamine dode-cyclbenzene sulfonate & $42504-46-1$ \\
\hline Isopropyl alcohol (mfg- strong acid processes) & $67-63-0$ \\
\hline Isopropyl chlorofor mate & $108-23-6$ \\
\hline 4,4'-Isopropylidene diphenol & $80-05-7$ \\
\hline Lactofen & 77501-63-4 \\
\hline Lactonitrile & $78-97-7$ \\
\hline Lead & $7439-92-1$ \\
\hline Lead arsenate & $10102-48-4$ \\
\hline Lead arsenate & $7645-25-2$ \\
\hline
\end{tabular}




\begin{tabular}{|c|c|}
\hline Chemical Name & CAS No. \\
\hline Lead arsenate & $7784-40-9$ \\
\hline Lead chloride & $7758-95-4$ \\
\hline Lead fluoborate & $13814-96-5$ \\
\hline Lead fluoride & $7783-46-2$ \\
\hline Lead iodide & 10101-63-0 \\
\hline Lead nitrate & 10099-74-8 \\
\hline Lead stearate & $1072-35-1$ \\
\hline Lead stearate & $52652-59-2$ \\
\hline Lead stearate & $7428-48-0$ \\
\hline Lead stearate & 56189-09-4 \\
\hline Lead sulfate & $15739-80-7$ \\
\hline Lead sulfate & $7446-14-2$ \\
\hline Lead sulfide & $1314-87-0$ \\
\hline Lead thiocyanate & $592-87-0$ \\
\hline Leptophos & $21609-90-5$ \\
\hline Lewisite & $541-25-3$ \\
\hline Linuron & $330-55-2$ \\
\hline Lithium carbonate & $554-13-2$ \\
\hline Lithium chromate & $14307-35-8$ \\
\hline Lithium hydride & $7580-67-8$ \\
\hline m-Nitrotoluene & $99-08-1$ \\
\hline Malathion & $121-75-5$ \\
\hline Maleic acid & $110-16-7$ \\
\hline Maleic anhydride & $108-31-6$ \\
\hline Maneb & $12427-38-2$ \\
\hline Manganese & $7439-96-5$ \\
\hline Manganese, tricarbo nyl methylcyclopen tadienyl & $12108-13-3$ \\
\hline $\begin{array}{l}\text { 1-(3-Chloroallyl)-3,5,7- triaza-1-azoniaada man- } \\
\quad \text { tane chloride }\end{array}$ & $4080-31-3$ \\
\hline MDI & $101-68-8$ \\
\hline Mechlorethamine & $51-75-2$ \\
\hline Mecoprop & $93-65-2$ \\
\hline MEK & $78-93-3$ \\
\hline Mephosfolan & $950-10-7$ \\
\hline 2-Mercaptobenzothiazole & $149-30-4$ \\
\hline Mercuric acetate & $1600-27-7$ \\
\hline Mercuric chloride & 7487-94-7 \\
\hline
\end{tabular}




\begin{tabular}{|c|c|}
\hline Chemical Name & CAS No. \\
\hline Mercuric cyanide & 592-04-1 \\
\hline Mercuric nitrate & $10045-94-0$ \\
\hline Mercuric oxide & 21908-53-2 \\
\hline Mercuric sulfate & $7783-35-9$ \\
\hline Mercuric thiocyanate & $592-85-8$ \\
\hline Mercurous nitrate & $7782-86-7$ \\
\hline Mercurous nitrate & $10415-75-5$ \\
\hline Merphos & $150-50-5$ \\
\hline Methacrolein diacetate & $10476-95-6$ \\
\hline Methacrylic anhydride & $760-93-0$ \\
\hline Methacryloyl chloride & $920-46-7$ \\
\hline Methacryloyloxyethyl isocyanate & $30674-80-7$ \\
\hline Methamidophos & $10265-92-6$ \\
\hline Methanamine, N- methyl-N-nitro & $62-75-9$ \\
\hline Methane, bromo & $74-83-9$ \\
\hline Methane, chloromethoxy & $107-30-2$ \\
\hline Methane, oxybis(chloro & $542-88-1$ \\
\hline Methanesulfonyl fluoride & $558-25-8$ \\
\hline Methane, tetrachloro & 58-23-5 \\
\hline Methane, tribromo & $75-25-2$ \\
\hline Methane, trichloro & $67-66-3$ \\
\hline $\begin{array}{l}\text { 4,7-Methano-1H- Indene, 1,4,5,6,7,8,8- hep ta- } \\
\text { chloro-3a,4,7,7a- tetrahydro }\end{array}$ & $57-75-9$ \\
\hline $\begin{array}{l}\text { 4,7-Methano-1H- Indene, 1,2,4,5,6,7,8,8- octa- } \\
\text { chloro- 2,3,3a,4,7,7a- hexahydro }\end{array}$ & $57-74-9$ \\
\hline Methazole & 20354-26-1 \\
\hline Methidathion & $950-37-8$ \\
\hline Methiocarb & $2032-65-7$ \\
\hline Methoxone & $94-74-6$ \\
\hline Methoxone sodium salt & $3653-48-3$ \\
\hline Methoxychlor & $72-43-5$ \\
\hline 2-Methoxyethanol & $109-86-4$ \\
\hline Methoxyethylmercuri cacetate & $151-38-2$ \\
\hline Methyl acrylate & $96-33-3$ \\
\hline Methyl alcohol & $67-56-1$ \\
\hline 2-Methyl azidine & $75-55-8$ \\
\hline Methyl Chloride & $74-87-3$ \\
\hline Methyl 2-chloroacry late & $80-63-7$ \\
\hline
\end{tabular}




\begin{tabular}{|c|c|}
\hline Chemical Name & CAS No. \\
\hline Methyl chlorocarbonate & $79-22-1$ \\
\hline 4,4'-Methylenebis(2- chloroaniline) & $101-14-4$ \\
\hline 4,4'-Methylenedi aniline & $101-77-9$ \\
\hline $\begin{array}{l}\text { 4,4'-Methylene bis(N,N-di- } \\
\text { methyl) benzenamine }\end{array}$ & $101-61-1$ \\
\hline Methylene-bis-(phenyl iso-cyanate)(MBI) & $101-68-8$ \\
\hline Methylene chloride & $75-09-2$ \\
\hline Methylene diphenyl diisocyanate & $101-68-8$ \\
\hline Methyl ethyl ketone & $78-93-3$ \\
\hline Methyl iodide & 74-88-4 \\
\hline Methyl isothiocyanate & $556-61-1$ \\
\hline 2-Methyllactonitrile & $75-86-5$ \\
\hline Methylmercuric dicy- anamide & $502-39-6$ \\
\hline N-Methylolacrylamide & $924-42-5$ \\
\hline Methyl parathion & $298-00-0$ \\
\hline 4-Methyl-2-pentanone & $108-10-1$ \\
\hline Methyl phenkapton & $3735-23-7$ \\
\hline Methyl phosphonic dichloride & $676-97-1$ \\
\hline 2-Methylpyridine & $109-06-8$ \\
\hline N-Methyl-2-pyrroli done & $873-50-4$ \\
\hline Methyl tert-butyl ether & $1634-04-4$ \\
\hline Methyl thiocyanate & $556-64-9$ \\
\hline Methyltrichlorosilane & $75-79-6$ \\
\hline Methyl vinyl ketone & $78-94-4$ \\
\hline Metiram & $9006-42-2$ \\
\hline Metribuzin & 21087-64-9 \\
\hline Mevinphos & $7786-34-7$ \\
\hline Mexacarbate & $315-18-4$ \\
\hline Michler’s ketone & $90-94-8$ \\
\hline Molybdenum trioxide & $1313-27-5$ \\
\hline Moncrotophos & $6923-22-4$ \\
\hline Monoethylamine & $75-04-7$ \\
\hline Monomethylamine & $74-89-5$ \\
\hline Monuron & $150-68-5$ \\
\hline Mustard gas & $505-60-2$ \\
\hline Myclobutanil & 88671-89-0 \\
\hline Nabam & $142-59-6$ \\
\hline
\end{tabular}




\begin{tabular}{|c|c|}
\hline Chemical Name & CAS No. \\
\hline Naled & $300-76-5$ \\
\hline Naphthenic acid & $1338-24-5$ \\
\hline Nickel & $7440-02-0$ \\
\hline Nickel ammonium sul fate & $15699-18-0$ \\
\hline Nickel chloride & $37211-05-5$ \\
\hline Nickel chloride & $7718-54-9$ \\
\hline Nickel hydroxide & $12054-48-7$ \\
\hline Nickel nitrate & $14216-75-2$ \\
\hline Nickel sulfate & $7786-81-4$ \\
\hline Nicotine sulfate & $65-30-5$ \\
\hline Nitrapyrin & $1929-82-4$ \\
\hline Nitric acid & $7697-37-2$ \\
\hline Nitrilotriacetic acid & $139-13-9$ \\
\hline p-Nitroaaniline & $100-01-6$ \\
\hline 4-Nitrobiphenyl & $92-93-3$ \\
\hline Nitrocyclohexane & $1122-60-7$ \\
\hline Nitrogen & $1836-75-5$ \\
\hline 5-Nitro-o-anisidine & $99-59-2$ \\
\hline 5-Nitro-o-toluidine & $99-55-6$ \\
\hline Nitrophenol (mixed) & $25154-55-6$ \\
\hline m-Nitrophenol & $554-84-7$ \\
\hline o-Nitrophenol & $88-75-5$ \\
\hline 4-Nitrophenol & $100-02-7$ \\
\hline N-Nitroso-N-ethylurea & 759-73-9 \\
\hline N-Nitroso-N-methy lurea & $684-93-5$ \\
\hline N-Nitrosodimethy lamine & $62-75-9$ \\
\hline N-Nitrosodipheny lamine & $86-30-6$ \\
\hline p-Nitrosodipheny lamine & $156-10-5$ \\
\hline N-Nitrosomethylviny lamine & $4549-40-0$ \\
\hline N-Nitrosomorpholine & $59-89-2$ \\
\hline N-Nitrosonornicotine & $16543-55-8$ \\
\hline Nitrotoluene & $1321-12-6$ \\
\hline o-Nitrotoluene & $88-72-2$ \\
\hline p-Nitrotoluene & $99-99-0$ \\
\hline Norbormide & $991-42-4$ \\
\hline Norflurazon & 27314--13- 2 \\
\hline Octachloronaphthalene & 2234-13-1 \\
\hline
\end{tabular}




\begin{tabular}{|c|c|}
\hline Chemical Name & CAS No. \\
\hline Octachlorostyrene & 29082-74-4 \\
\hline Oryzalin & $19044-88-3$ \\
\hline Ouabain & $630-60-4$ \\
\hline Oxetane,3,3- bis(chlo romethyl)- & $78-71-7$ \\
\hline Oxirane & $75-21-8$ \\
\hline Oxirane, (chlorome thyl) & $106-89-8$ \\
\hline Oxydemeton methyl & $301-12-2$ \\
\hline Oxydiazon & 19666-30-9 \\
\hline Oxydisulfoton & $2497-07-6$ \\
\hline Oxyfluorfen & $42874-03-3$ \\
\hline Ozone & $10028-15-6$ \\
\hline Paraformaldehyde & $30525-89-4$ \\
\hline Paraldehyde & $123-63-7$ \\
\hline Paraquat dichloride & $1910-42-5$ \\
\hline Paraquat methosulfate & $2074-50-2$ \\
\hline Paris green (Cuprie acetoarsenite) & $12002-03-8$ \\
\hline PCNB & $82-68-8$ \\
\hline Pendimethalin & $40487-42-1$ \\
\hline Pentaborane & $19624-22-7$ \\
\hline Pentachlorobenzene & $608-93-5$ \\
\hline Pentachloronitroben zene & $82-68-8$ \\
\hline Pentadecyclamine & $2570-26-5$ \\
\hline $\begin{array}{l}\text { 1,1-Dichloro-1,2,2,3,3- pentafluoropropane } \\
\text { (HCFC-225cC) }\end{array}$ & $13474-88-9$ \\
\hline $\begin{array}{l}\text { 1,1-Dichloro-1,2,3,3,3- pentafluoropropane } \\
\text { (HCFC-225ab) }\end{array}$ & 111512-56- 2 \\
\hline $\begin{array}{l}\text { 1,2-dichloro-1,1,2,3,3- pentafluoropropane } \\
\text { (HCFC-225bb) }\end{array}$ & $422-44-6$ \\
\hline $\begin{array}{l}\text { 1,2-Dichloro1,1,3,3,3- pentafluoropropane (HCFC- } \\
\text { 225da) }\end{array}$ & $431-86-7$ \\
\hline $\begin{array}{l}\text { 1,3-Dichloro-1,1,2,2,3- pentafluoropropane } \\
\text { (HCFC-225cb }\end{array}$ & $507-55-1$ \\
\hline $\begin{array}{l}\text { 1,3-Dichloro-1,1,2,3,3- pentafluoropropane } \\
\text { (HCFC-225ea) }\end{array}$ & 136013-79- 1 \\
\hline $\begin{array}{l}\text { 2,2-Dichloro-1,1,1,3,3- pentafluoropropane } \\
\text { (HCFC-225aa) }\end{array}$ & 128903-21- 9 \\
\hline $\begin{array}{l}\text { 2,3-Dichloro-1,1,1,2,3- pentafluoropropane } \\
\text { (HCFC-225ba) }\end{array}$ & 128903-21- 9 \\
\hline $\begin{array}{l}\text { 3,3-dichloro-1,1,1,2,2- pentafluoropropane } \\
\text { (HCFC-25ca) }\end{array}$ & $422-56-0$ \\
\hline
\end{tabular}




\begin{tabular}{|c|c|}
\hline Chemical Name & CAS No. \\
\hline Pentobarbital sodium & $57-33-0$ \\
\hline Peracetic acid & $79-121-0$ \\
\hline Perchloroethylene & $127-18-4$ \\
\hline Perchloromethyl mrcaptan & $594-42-3$ \\
\hline Permethrin & $52645-53-1$ \\
\hline Phenanthrene & $85-01-8$ \\
\hline Phenol,2,2'-thio bis (4- chloro-6-methyl & $4418-66-0$ \\
\hline Phenol, methyl & $1319-77-3$ \\
\hline Phenothrin & $26002-80-2$ \\
\hline Phenoxarsine,10,10'- oxydi- & $58-36-6$ \\
\hline p-Phenylenediamine & $106-50-3$ \\
\hline 1,2-Phenylenediamine & $95-54-5$ \\
\hline 1,2-Phenylenediamine dihydrochloride & $615-28-1$ \\
\hline 1,3-Phenylenediamine & $108-45-2$ \\
\hline 1,4-Phenylenediamine dihydrochloride & $624-18-0$ \\
\hline Phenylhydrazine hydrochloride & 59-88-1 \\
\hline 2-Phenylphenol & $90-43-7$ \\
\hline Phenylsilatrane & 2097-19-0 \\
\hline Phenytoin & $57-41-0$ \\
\hline Phosacetim & $4104-14-7$ \\
\hline Phosfolan & $947-02-4$ \\
\hline Phosmet & 732-11-6 \\
\hline Phosphamidon & $13171-21-6$ \\
\hline $\begin{array}{l}\text { Phosphonothioic acid methyl-O-(4-nitro phenyl)O- } \\
\text { phenyl ester }\end{array}$ & $2665-30-7$ \\
\hline $\begin{array}{l}\text { Phosphonothioic acid, methyl-O-ethyl-O- (4-(meth } \\
\text { ylthio)phenyk Ester }\end{array}$ & 2703-13-1 \\
\hline $\begin{array}{l}\text { Phosphonothioic acid, methyl-,s-(2-(bis(1- me- } \\
\text { thylethyl)amino Ethyl o-Ethyl Ester }\end{array}$ & $50782-69-9$ \\
\hline Phosphoric acid & $7664-38-2$ \\
\hline $\begin{array}{l}\text { Phosphoric acid, dimethyl 4-(meth ylthio)phenyl } \\
\text { ester }\end{array}$ & $3254-63-5$ \\
\hline $\begin{array}{l}\text { Phosphorothioc acid, O,O-diethyl, O- pyrazinyl } \\
\text { ester }\end{array}$ & $56-38-2$ \\
\hline $\begin{array}{l}\text { Phosphorothioic acid, O,O-dimethyl-S-(2- } \\
\text { methylthio)ethyl est }\end{array}$ & $2587-90-8$ \\
\hline Phosphorus & $7723-14-0$ \\
\hline Phosphorus oxychlo ride & $10025-87-3$ \\
\hline Phosphorus pentachlo ride & $10026-13-8$ \\
\hline
\end{tabular}




\begin{tabular}{|c|c|}
\hline Chemical Name & CAS No. \\
\hline Phosphorus pentoxide & $1314-56-3$ \\
\hline Phosphorus trichloride & $7719-12-2$ \\
\hline Phthalic anhydride & $85-44-9$ \\
\hline Picloram & $1918-02-1$ \\
\hline Picric acid & 88-89-1 \\
\hline Picrotoxin & $124-87-8$ \\
\hline Piperidine & $110-89-4$ \\
\hline Piperonyl butoxide & $51-03-6$ \\
\hline Pirimifos-ethyl & $23505-41-1$ \\
\hline Piriimiphos methyl & 29232-93-7 \\
\hline Polychlorinated biphe nyls & $1336-36-3$ \\
\hline Potassium arsenate & $7784-41-0$ \\
\hline Potassium arsenite & $10124-50-2$ \\
\hline Potassium bichromate & $7778-50-9$ \\
\hline Potassium bromate & $7758-01-2$ \\
\hline Potassium chromate & $7789-00-6$ \\
\hline Potassium hydroxide & $1310-58-3$ \\
\hline Potassium permangan ate & $7722-64-7$ \\
\hline Profenofos & $41198-08-7$ \\
\hline Prometryn & $7287-19-6$ \\
\hline Pronamide & $23950-58-5$ \\
\hline Propachlor & $1918-16-7$ \\
\hline \multicolumn{2}{|c|}{ 3-Chloro-1,1,1-trifluoro-propane (HCFC- 253fb) } \\
\hline & $460-35-5$ \\
\hline \multicolumn{2}{|c|}{$\begin{array}{l}\text { 1-Bromo-1-(bromomethyl)-1,3- propanedicarboni- } \\
\text { tril }\end{array}$} \\
\hline Propanil & 709-98-8 \\
\hline Propargite & $2312-35-8$ \\
\hline Propargyl bromide & $106-96-7$ \\
\hline 1-Propene, 1,3-dichloro & $542-76-6$ \\
\hline 3-Chloro-2-methyl-1- propene & $563-47-3$ \\
\hline 2-propenal & $106-02-8$ \\
\hline 2-Propenamide & $79-06-1$ \\
\hline 2-Propenenitrile & $107-13-1$ \\
\hline 2-Propenoic acid & 79-10-7 \\
\hline 2-Propenoic acid, ethyl ester & $140-88-5$ \\
\hline 2-Propenoic acid, 2- methyl-, methyl ester & $80-62-6$ \\
\hline
\end{tabular}




\begin{tabular}{|c|c|}
\hline Chemical Name & CAS No. \\
\hline Propfamphos & 31218-83-4 \\
\hline Propiconazole & $60207-90-1$ \\
\hline Propiolactone,beta- & $57-57-8$ \\
\hline Propionaldehyde & $123-38-6$ \\
\hline Propionic acid & $79-09-4$ \\
\hline Propionic anhydride & $123-62-6$ \\
\hline 2,2-Dibromo-3-nitrilo propionamide & $10222-01-2$ \\
\hline Propiophenone,4'- amino- & $70-69-9$ \\
\hline Propoxur & $114-26-1$ \\
\hline Propyl chloroformate & $109-61-5$ \\
\hline Propylene Dichloride & $78-87-5$ \\
\hline 1,2-Propylenimie & $75-55-8$ \\
\hline 2,4-D propylene glycol butyl ether ester & $1320-18-9$ \\
\hline Propylene oxide & $75-56-9$ \\
\hline Propylene (Propene) & $115-07-1$ \\
\hline Prothoate & $2275-18-5$ \\
\hline Pyrene & $129-00-0$ \\
\hline Pyrethrins & $121-21-1$ \\
\hline Pyrethrins & $121-29-9$ \\
\hline Pyrethrins & $8003-34-7$ \\
\hline Pyridine,2-methyl-5- vinyl- & $140-76-1$ \\
\hline Pyridine,4-nitro-1- oxide & $1124-33-0$ \\
\hline Pyriminil & $53558-25-1$ \\
\hline Quinoline & $91-22-5$ \\
\hline Quinone & $106-51-4$ \\
\hline Quintobenzene & $82-68-86$ \\
\hline Quizalofop-ethyl & 76578-14-8 \\
\hline Resmethrin & $10453-86-8$ \\
\hline Salcomine & $14167-18-1$ \\
\hline Sarin & $107-44-8$ \\
\hline Selenium & $7782-49-2$ \\
\hline Selenium oxychloride & $7791-23-3$ \\
\hline Semicarbazide hydro chloride & $563-41-7$ \\
\hline Sethoxydim & $74051-80-2$ \\
\hline Silane,(4-aminobutyl) diethoxymethyl- & $3037-72-7$ \\
\hline Silver & $7440-22-4$ \\
\hline Silver nitrate & $7761-88-8$ \\
\hline
\end{tabular}




\begin{tabular}{|c|c|}
\hline Chemical Name & CAS No. \\
\hline Simazine & $122-34-9$ \\
\hline Sodium & $7440-23-5$ \\
\hline Sodium arsenate & $7631-89-2$ \\
\hline Sodium arsenite & $7784-46-5$ \\
\hline Sodium bichromate & $10588-01-9$ \\
\hline Sodium bifluoride & $1333-83-1$ \\
\hline Sodium bisulfite & $7631-90-5$ \\
\hline Sodium cacodylate & $124-65-2$ \\
\hline Sodium chromate & $7775-11-3$ \\
\hline Sodium dicamba & $1982-69-0$ \\
\hline Sodium dodecylben zene sulfonate & $25155-30-0$ \\
\hline Sodium fluoride & $7681-49-4$ \\
\hline Sodium hydrosulfide & $16721-80-5$ \\
\hline Sodium hydroxide & $1310-73-2$ \\
\hline Sodium hypochlorite & $10022-70-5$ \\
\hline Sodium hypochlorite & $7681-52-9$ \\
\hline Sodium methylate & $124-41-4$ \\
\hline Sodium nitrite & $7632-00-0$ \\
\hline Sodium pentachlo rophenate & $131-52-2$ \\
\hline Sodium o-phenylphe noxide & $132-27-4$ \\
\hline Sodium phos- phate, dibasic & $10039-32-4$ \\
\hline Sodium phos- phate,dibasic & $10140-65-5$ \\
\hline Sodium phos- phate,dibasic & $7558-79-4$ \\
\hline Sodium phosphate, tribasic & $10101-89-0$ \\
\hline Sodium phosphate, tribasic & $10124-56-8$ \\
\hline Sodium phosphate, tribasic & $10361-89-4$ \\
\hline Sodium phosphate, tribasic & $7601-54-9$ \\
\hline Sodium phosphate, tribasic & $7758-29-4$ \\
\hline Sodium phosphate, tribasic & $7785-84-4$ \\
\hline 2,4-D sodium salt & $2702-72-9$ \\
\hline Sodium selenate & $13410-01-0$ \\
\hline Sodium selenite & $10102-18-8$ \\
\hline Sodium selenite & $7782-82-3$ \\
\hline Sodium tellurite & $10102-20-2$ \\
\hline Strannane,acetoxy- triphenyl- & $900-95-8$ \\
\hline Strontium chromate & $7789-06-2$ \\
\hline Strychnine, sulfate & $60-41-3$ \\
\hline
\end{tabular}




\begin{tabular}{|c|c|}
\hline Chemical Name & CAS No. \\
\hline Styrene & $100-42-5$ \\
\hline Styrene oxide & $96-09-3$ \\
\hline Sulfoxide,3-chloropro pyl octyl & $3569-57-1$ \\
\hline Sulfur dioxide & $7446-09-5$ \\
\hline Sulfur monochloride & $12771-08-3$ \\
\hline Sulfur tetrafluoride & $7783-60-0$ \\
\hline Sulfur trioxide & $7446-11-9$ \\
\hline $\begin{array}{l}\text { Sulfuric acid (acid aerosols including mists, va- } \\
\text { pors,gas, fog, and airborne forms of any particle } \\
\text { size }\end{array}$ & 7664-93-9 \\
\hline Sulfuric acid & 8014-95-7 \\
\hline Sulfuric acid, dimethyl ester & 77-78-1 \\
\hline Sulfurayl fluoride & 2699-79-8 \\
\hline Sulprrofos & $35400-43-2$ \\
\hline 2,4,5- $\mathrm{T}$ amines & $2008-46-0$ \\
\hline 2,4,5- $\mathrm{T}$ amines & $1319-72-8$ \\
\hline 2,4,5-T amines & 3813-14-7 \\
\hline 2,4,5-T amines & $6369-96-6$ \\
\hline 2,4,5- $\mathrm{T}$ amines & 6369-97-7 \\
\hline 2,4,5-T esters & $93-79-8$ \\
\hline 2,4,5-T esters & $1928-47-8$ \\
\hline 2,4,5-T esters & $2545-59-7$ \\
\hline 2,4,5-T esters & $61792-07-2$ \\
\hline 2,4,5-T esters & $25168-15-4$ \\
\hline 2,4,5-T salts & 13560-99-1 \\
\hline Tabun & $77-81-6$ \\
\hline TCDD & $1746-01-6$ \\
\hline Tebuthiuron & $34014-18-1$ \\
\hline Tellurium & $13494-80-9$ \\
\hline Tellurium hexafluoride & $7783-80-4$ \\
\hline Temephos & $3383-96-8$ \\
\hline Terbacil & $5902-51-2$ \\
\hline Terbufos & $13071-79-9$ \\
\hline Tetrabromobisphenol A & 79-94-7 \\
\hline 1,1,1,2-Tetrachloroethane & $630-20-6$ \\
\hline 1,1,2,2-Tetrachloroethane & $79-34-5$ \\
\hline Tetrachloroethene & $127-18-4$ \\
\hline Tetrahloroethylene & $127-18-9$ \\
\hline
\end{tabular}




\begin{tabular}{|c|c|}
\hline Chemical Name & CAS No. \\
\hline 2,3,7,8-Tetrachlorod ibenzo p-dioxin (TCDD) & $1746-01-6$ \\
\hline Tetrachlorvinphos & $961-11-5$ \\
\hline Tetracycline hydrochloride & $64-75-5$ \\
\hline Tetraethyltin & $597-64-8$ \\
\hline 1-Chloro-1,1,2,2-tetrafluoroethane (HCFC-124a) & $354-256$ \\
\hline 2-Chloro-1,1,2,2-tet rafluoroethane (HCFC 124) & 2837-89-0 \\
\hline Tetramethrin & $7696-12-0$ \\
\hline Tetramethyl Lead & $75-74-1$ \\
\hline Thallium & $7440-28-0$ \\
\hline Thallous malonate & $2757-18-8$ \\
\hline Thiabendazole & $140-79-8$ \\
\hline Thiobencarb & $28249-77-6$ \\
\hline Thiocarbazide & $2231-57-4$ \\
\hline 4,4’-Thiodianiline 6- dinitrophenoll & 139-65-1 \\
\hline Thionazin & $297-97-2$ \\
\hline Thiophanate ethyl & 23564-06-9 \\
\hline Thiourea & $62-56-6$ \\
\hline Thiourea, (2- methylphenyl)- & $614-78-8$ \\
\hline Thorium dioxide & $1314-20-1$ \\
\hline Titanium dioxide & $13463-67-7$ \\
\hline Titanium tetrachloride & $7550-45-0$ \\
\hline Toluene & $108-88-3$ \\
\hline Toluenediamine & $95-80-7$ \\
\hline 2,4-Toluene diamine & $95-80-7$ \\
\hline 2,4-Toluene diisocyan ate & $91-08-7$ \\
\hline Toluene2,4-diisocyan ate & $584-84-9$ \\
\hline Toluene2,6-diisocyan ate & $91-08-7$ \\
\hline Toluenediisocyanate & $584-84-9$ \\
\hline o-Toluidine & $95-53-4$ \\
\hline 2,4,5-TP acid esters & $32534-95-5$ \\
\hline trans 1,1-dichloro butene & $110-57-6$ \\
\hline trans-1,4-Dichloro-2- butene & $110-57-6$ \\
\hline trans-1,3-Dichloropro pene & $10061-02-6$ \\
\hline Triadimefon & $43121-43-3$ \\
\hline Triamiphos & $1031-47-6$ \\
\hline Triaziquone & 68-76-8 \\
\hline Triazofos & $24017-47-8$ \\
\hline
\end{tabular}




\begin{tabular}{|c|c|}
\hline Chemical Name & CAS No. \\
\hline Tribenuron methyl & $101200-48-0$ \\
\hline Tributyltin fluoride & $1982-10-4$ \\
\hline Tributultin methacry late & $2155-70-6$ \\
\hline S,S,S-Tributyltrithio phosphate & $78-48-8$ \\
\hline 1,2,4-Trichlorobenzene & $120-82-1$ \\
\hline Trichloroacetyl chloride & $76-02-8$ \\
\hline Trichloro(chlorome thyl) silane & $1558-25-4$ \\
\hline Trichloro(dichloro- phenyl) silane & $27137-85-5$ \\
\hline 1,1,1-Trichloroethane & $71-55-6$ \\
\hline 1,1,2-Trichloroethane & $79-00-5$ \\
\hline Trichloroethene & $79-01-6$ \\
\hline Trichloroethylsilane & $115-21-9$ \\
\hline Trichlorofon & $52-68-6$ \\
\hline Trichloronate & $327-98-0$ \\
\hline Trichlorophenol & $25167-82-2$ \\
\hline 2,3,4-Trichlorophenol & $15950-66-0$ \\
\hline 2,3,5-Trichlorophenol & $933-78-8$ \\
\hline 2,3,6-Trichlorophenol & $933-75-5$ \\
\hline 2,4,5-Trichlorophenol & $95-95-4$ \\
\hline 2,4,6-Trichlorophenol & $88-06-2$ \\
\hline 3,4,5-Trichlorophenol & $609-19-8$ \\
\hline Trichlorophenylsilane & $98-13-5$ \\
\hline 1,2,3-Trichloropropane & $96-18-4$ \\
\hline Triclopyr, triethylam monium salt & 57213-69-1 \\
\hline Triethanolamine dode-cylbenzene sulfonate & 27323-41-7 \\
\hline Triethoxysilane & $998-30-1$ \\
\hline Triethylamine & $121-44-8$ \\
\hline 1,1-Dichloro-1,2,2-trif luoroethane (HCFC- 123b) & $812-04-4$ \\
\hline 1,2-Dichloro-1,1,2-trif luoroethane (HCFC-123a) & $354-23-4$ \\
\hline Trifluralin & $1582-09-8$ \\
\hline Triforine & $26644-46-2$ \\
\hline Trimethylamine & $75-50-3$ \\
\hline Trimethylchlorosilane & $75-77-4$ \\
\hline Trimethylolpropane phosphite & $824-11-3$ \\
\hline 2,3,4-Trimethylpentane & $540-64-1$ \\
\hline 2,3,5-Trimethylphenyl methylcarbamate & $2655-15-4$ \\
\hline Trimethyltin chloride & $1066-45-1$ \\
\hline
\end{tabular}




\begin{tabular}{|c|c|}
\hline Chemical Name & CAS No. \\
\hline Triphenyltin chloride & $639-58-7$ \\
\hline Triphenyltin hydroxide & $76-87-9$ \\
\hline Tris(2-chloroethyl) amine & $555-77-1$ \\
\hline Uranyl acetate & $541-09-3$ \\
\hline Uranyl nitrate & 10102-06-4 \\
\hline Uranyl nitrate & $36478-76-9$ \\
\hline \multicolumn{2}{|l|}{ Urea, N-methyl -N- nitroso } \\
\hline Urethane & $51-79-6$ \\
\hline Valinomycin & 2001-95-8 \\
\hline Vanadium(fume or dust) & $7440-62-2$ \\
\hline Vanadyl sulfate & $27774-13-6$ \\
\hline Vinclozolin & $50471-44-8$ \\
\hline Vinyl acetate, monomer & $108-05-4$ \\
\hline Vinyl bromide & $593-60-2$ \\
\hline Vinylidienechloride & $75-35-4$ \\
\hline Warfarin sodium & $129-06-6$ \\
\hline Xylene & $1330-20-7$ \\
\hline m-Xylene & $108-38-3$ \\
\hline o-Xylene & $95-47-6$ \\
\hline p-Xylene & $106-42-3$ \\
\hline Xylene dichloride & $28347-13-9$ \\
\hline Xylene, isomers and mixture & $1330-20-7$ \\
\hline Xylene, mixed & $1330-20-7$ \\
\hline Xylenol & $1300-71-6$ \\
\hline 2,6-Xylidine & $87-62-7$ \\
\hline Zinc & $7440-66-6$ \\
\hline Zinc acetate & $557-34-6$ \\
\hline Zinc ammonium chloride & $52628-25-8$ \\
\hline Zinc ammonium chloride & $14639-97-5$ \\
\hline Zinc ammonium chloride & $14639-98-6$ \\
\hline Zinc borate & $1332-07-6$ \\
\hline Zinc bromide & $7699-45-8$ \\
\hline Zinc carbonate & $3486-35-9$ \\
\hline Zinc chloride & $7646-85-7$ \\
\hline Zinc, dichloro(4,4- & $58270-08-9$ \\
\hline dimethyl-5(( & \\
\hline
\end{tabular}




\begin{tabular}{|lr|}
\hline Chemical Name & CAS No. \\
\hline \hline (methylamino) & \\
carbnyl)oxy)imino) & \\
Pentane-nitrile)-,(T-4) & $7783-49-5$ \\
Zinc fluoride & $557-41-5$ \\
Zinc formate & $7779-86-4$ \\
Zinc hydrosulfite & $7779-88-6$ \\
Zinc nitrate & $127-82-2$ \\
Zinc phenolsulfonate & $16871-71-9$ \\
Zinc silicofluoride & $7733-02-0$ \\
Zinc sulfate & $12122-67-7$ \\
Zineb & $13746-89-9$ \\
Zirconium nitrate & $16923-95-8$ \\
Zirconium potassium & \\
fluoride & $14644-61-2$ \\
Zirconium sulfate & $10026-11-6$ \\
Zirconium tetrachloride & \\
\hline
\end{tabular}




\section{Appendix 10-2}

\section{National Codes and Standards}

(AFI 32-7044, Attachment 2)

A2.1. Fiberglass-Reinforced Plastic Tanks:

A2.1.1. Underwriters Laboratories: Standard 1316, Standard for Glass Fiber Reinforced Plastic Underground

Storage Tanks for Petroleum Products, Alcohols, and Alcohol-Gasoline Mixtures.

A2.2. Corrosion Protection Systems and Interior Linings:

A2.2.1. Steel Tank Institute: Specification for STI-P3-99, STI-P3 Specification and Manual for External Corrosion Protection of Underground Steel Storage Tanks.

A2.2.2. Underwriters Laboratories:

A2.2.2.1. Standard 1746, External Corrosion Protection Systems for Steel Underground Storage Tanks.

A2.2.2.2. Standard 58, Standards for Steel Underground Tanks for Flammable and Combustible Liquids.

A2.2.3. National Association of Corrosion Engineers:

A2.2.3.1. Standard RP-02-85, Corrosion Control of Underground Storage Tank Systems by Cathodic Protection.

A2.2.3.2. Standard RP-01-69, Control of External Corrosion on Underground or Submerged Metallic Pipe Systems.

A2.2.4. American Petroleum Institute:

A2.2.4.1. Publication 1631, Recommended Practice for the Interior Lining of Underground Storage Tanks.

A2.2.4.2. Publication 1632, Cathodic Protection of Underground Petroleum Storage Tanks and Piping Systems.

A2.2.5. National Leak Prevention Association: Standard 631, Spill Prevention, Minimum Ten Year Life Extension of Existing Steel Underground Tanks by Lining Without the Addition of Cathodic Protection.

A2.3. Steel-Fiberglass-Reinforced-Plastic Composite:

A2.3.1. Underwriters Laboratories: Standard 1746, External Corrosion Protection Systems for Steel Underground Storage Tanks.

A2.3.2. Association for Composite Tanks: ACT-100, Specification for the Fabrication of FRP Clad Underground Storage Tanks.

A2.4. Fiberglass-Reinforced-Plastic Piping:

A2.4.1. Underwriters Laboratories:

A2.4.1.1. Standard 971, Nonmetallic Underground Piping for Flammable Liquids.

A2.4.1.2. Standard 567, Emergency Breakaway Fittings, Swivel Connectors and Pipe-Connection Fittings for Petroleum Products and LP Gas.

A2.5. Tank and Piping System Installation:

A2.5.1. American Petroleum Institute: Publication 1615, Installation of Underground Petroleum Storage System.

A2.5.2. Petroleum Equipment Institute:

A2.5.2.1. Publication RP100, Recommended Practices for Installation of Underground Liquid Storage Systems.

A2.5.2.2. Publication RP 200, Recommended Practices for Installation of Aboveground Storage Systems for Motor Vehicle Fueling.

A2.5.2.3. Publication RP 300, Recommended Practices for Installation and Testing of Vapor Recovery Systems at Vehicle Fueling Sites.

A2.5.3. American Society of Mechanical Engineers:

A2.5.3.1. B31.3, Process Piping.

A2.5.3.2. B31.4, Pipeline Transportation Systems for Liquid Hydrocarbons and Other Liquids.

A2.5.4. National Fire Protection Association:

A2.5.4.1. Standard 30, Flammable and Combustible Liquids Code.

A2.5.4.2. Standard 30A, Motor Fuel Dispensing Facilities and Repair Garages.

A2.6. Spill and Overfill Control:

A2.6.1. American Petroleum Institute: Publication 1621, Recommended Practice for Bulk Liquid Stock Control at Retail Outlets.

A2.6.2. National Fire Protection Association: Standard 30, Flammable and Combustible Liquids Code. 
A2.7. Compatibility:

A2.7.1. American Petroleum Institute:

A2.7.1.1. Publication 1626, Storing and Handling Ethanol and Gasoline Ethanol Blends at Distribution Terminals and Service Stations.

A2.7.1.2. Publication 1627, Storage and Handling of Gasoline- Methanol/Cosolvent Blends at Distribution Terminals and Service Stations.

A2.8. Allowed Repairs:

A2.8.1. National Fire Protection Association: Standard 30, Flammable and Combustible Liquids Code.

A2.8.2. American Petroleum Institute:

A2.8.2.1. Publication 2200, Repairing Crude Oil, Liquified Petroleum Gas, and Product Pipelines.

A2.8.2.2. Publication 1631, Recommended Practice for the Interior Lining of Underground Storage Tanks.

A2.8.3. National Leak Prevention Association: Standard 631, Spill Prevention, Minimum 10 Year Life Extension of Existing Steel Underground Tanks by Lining Without the Addition of Cathodic Protection.

A2.9. Water Level Measurement:

A2.9.1. American Petroleum Institute: Publication 1621, Recommended Practice for Bulk Liquid Stock Control at Retail Outlets.

A2.10. Double-Walled Tanks:

A2.10.1. Steel Tank Institute: Standard for Dual Wall Underground Storage Tanks Cleaning and Closure Procedures.

A2.10.2. American Petroleum Institute:

A2.10.2.1. Recommended Practice 1604, Closure of Underground Petroleum Storage Tanks.

A2.10.2.2. Standard 1631, Interior Lining and Periodic Inspection of Underground Storage Tanks.

A2.10.2.3. Publication 2015, Cleaning Petroleum Storage Tanks.

A2.11. Confined Space Entry:

A2.11.1. National Institute for Occupational Safety and Health (NIOSH 80-106): Criteria for a Recommended Standard, Working in Confined Space.

A2.11.2. AFOSH Standard 91-25, Confined Spaces.

A2.12. Aboveground Tank Integrity Testing

A2.12.1. American Petroleum Recommended Practice 575, Inspection of Atmospheric and Low Pressure Storage Tanks.

A2.12.2. Steel Tank Institute SP001-03, Standard for Inspection of In-Service Shop Fabricated Aboveground Tanks for Storage of Combustible and Flammable Liquids. 


\section{SECTION 11}

\section{TOXIC SUBSTANCES MANAGEMENT}

\section{Overseas ESOHCAMP}

September 2009

\section{A. Service-specific Regulations and Policies}

\section{Polychlorinated Biphenyls (PCBs)}

- Although Air Force Instruction (AFI) 32-7042, Waste Management, 21 April 2009, contains a chapter on the management of PCB wastes, it explicitly (at para 4.1.4) directs the reader to chapter 14 of the Overseas Environmental Baseline Guidance Document or to the country-specific FGS, as appropriate, for PCB guidance. For this reason, none of the provisions in the chapter 4 of the AFI are included here.

- Headquarters (HQ) USAF/CE Letter, Air Force Policy on Measuring Air Force PCB-Free Status - Action Memorandum, 21 March 1994, revises how the Air Force's (AF's) PCB-free status is measured. Instead of measuring the number of PCB items rendered PCB-free, the new metric is the number of installations that are PCB-free based on data in the PCB Module of the Work Information Management System - Environmental Subsystem (WIMS-ES).

\section{Asbestos}

- Air Force Occupational Safety and Health (AFOSH) Standard 161-4, Exposure to Asbestos, January 1980, contains information on asbestos requirements and control.

\section{Radon}

- There are no AFIs on radon.

\section{Lead-Based Paint (LBP)}

- HQ USAF Policy Letter, Air Force Policy and Guidance on Lead-Based Paint (LBP) in Facilities, 24 May 1993, specifies actions necessary to protect facility occupants and workers and the environment from hazardous exposure to lead in LBPs. Appendix 11-1 summarizes the likelihood of LBP being present and the regulations/guidelines that normally must be followed.

- HQ USAF/CEV Policy Letter, Air Force Policy and Guidance on Lead-Based Paint Final Disclosure Rule, 19 August 1996, requires the disclosure of known LBP and/or LBP hazards in housing constructed before the phaseout of residential LBP use in 1978. The disclosure policy applies to the acceptance (leasing) of Air Force Military Family Housing (MFH) by qualified occupants and the sale (transfer) of Air Force MFH under Base Realignment and Closure (BRAC) and non-BRAC property disposals.

\section{B. Department of Defense (DOD) Directives/Instructions}

- None 


\section{Service-specific/DOD Definitions}

- High-Priority Facilities - with respect to LBP, facilities or portions of facilities that are or may be frequented/used by children under age seven, which are further prioritized as follows (USAF/CC Policy Letter, 24 May 1993, AF Guidance on LBP in Facilities, Section 5a):

1. child development centers (CDCs), annexes, and playground equipment

2. onbase AF-licensed family day care homes

3. youth centers, recreational facilities, and playgrounds

4. waiting areas in medical and dental treatment centers

5. AF-maintained DOD schools

6. MFH currently occupied by families with children under age 7

7. remaining MFH.

\section{Additional Records to Review}

- None

\section{E. Additional Physical Features to Inspect}

- None

\section{F. Guidance for Checklist Users}

\section{REFER TO CHECKLIST ITEMS:}

PCB Management

Missing Checklist Items/Positive Findings

General

PCB Records

PCB Transformers

PCB Spills

Asbestos Management

Missing Checklist Items/Positive Findings

General

Asbestos Disposal

Radon Management

Missing Checklist Items/Positive Findings

General

Lead-Based Paint

Missing Checklist Items/Positive Findings

General
T1.2.1.OCAF and T1.2.2.OCAF

T1.10.1.OCAF through T1.10.3.OCAF

T1.20.1.OCAF

T1.30.1.OCAF and T1.30.2.OCAF

T1.50.1.OCAF

T2.2.1.OCAF and T2.2.2.OCAF

T2.10.1.OCAF through T2.10.5.OCAF

$\mathrm{T} 2$.30.1.OCAF and $\mathrm{T} 2$.30.2.OCAF

T3.2.1.OCAF and T3.2.2.OCAF

T3.10.1.OCAF through T3.10.4.OCAF

T4.2.1.OCAF and T4.2.2.OCAF

T4.10.1.OCAF through T4.10.16.OCAF 


\begin{tabular}{|c|c|}
\hline \multicolumn{2}{|r|}{$\begin{array}{c}\text { COMPLIANCE CATEGORY: } \\
\text { TOXIC SUBSTANCES MANAGEMENT } \\
\text { Overseas ESOHCAMP }\end{array}$} \\
\hline $\begin{array}{l}\text { REGULATORY } \\
\text { REQUIREMENTS: }\end{array}$ & $\begin{array}{l}\text { REVIEWER CHECKS: } \\
\text { September } 2009\end{array}$ \\
\hline $\begin{array}{l}\text { T1.2 } \\
\text { PCB MANAGEMENT: } \\
\text { Missing Checklist } \\
\text { Items/Positive Findings }\end{array}$ & \\
\hline $\begin{array}{l}\text { T1.2.1.OCAF. Installations } \\
\text { must comply with all applica- } \\
\text { ble regulatory requirements } \\
\text { not contained in this checklist } \\
\text { (a finding under this checklist } \\
\text { item will have the citation of } \\
\text { the applied regulation as a } \\
\text { basis of finding) [Added } \\
\text { March 2002]. }\end{array}$ & $\begin{array}{l}\text { Determine whether any new regulations concerning PCB management have been } \\
\text { issued since the finalization of the manual. } \\
\text { Determine whether the installation has activities or facilities that are regulated but } \\
\text { not addressed in this checklist. } \\
\text { Verify that the installation is in compliance with all applicable and newly issued } \\
\text { regulations. }\end{array}$ \\
\hline $\begin{array}{l}\text { T1.2.2.OCAF. Installations } \\
\text { should go above and beyond } \\
\text { environmental statutory and } \\
\text { regulatory compliance (MP) } \\
\text { [Added March 2002]. }\end{array}$ & $\begin{array}{l}\text { Determine whether the installation has gone above and beyond simply complying } \\
\text { with environmental requirements. } \\
\text { (NOTE: This checklist item is used only to write positive findings.) }\end{array}$ \\
\hline
\end{tabular}




\begin{tabular}{|l|l|}
\hline \multicolumn{2}{|c|}{$\begin{array}{c}\text { COMPLIANCE CATEGORY: } \\
\text { TOXIC SUBSTANCES MANAGEMENT } \\
\text { Overseas ESOHCAMP }\end{array}$} \\
\hline \multicolumn{1}{|c|}{ REGULATORY } \\
REQUIREMENTS: \\
T1.10 \\
$\begin{array}{l}\text { PCB MANAGEMENT: } \\
\text { General }\end{array}$ \\
$\begin{array}{l}\text { T1.10.1.OCAF. } \\
\text { March 2002]. } \\
\text { T1.10.2.0CAF. Installations } \\
\text { must meet requirements con- } \\
\text { tained in MAJCOM supple- } \\
\text { ments to AFIs and policy } \\
\text { documents (a finding under } \\
\text { this checklist item will have } \\
\text { the citation of the MAJCOM } \\
\text { document as a basis of find- } \\
\text { ing). }\end{array}$ & $\begin{array}{l}\text { Determine whether the requirements in MAJCOM supplements to AFIs and pol- } \\
\text { icy documents are within the scope of the environmental compliance assessment. }\end{array}$ \\
T1.10.3.OCAF. \\
March 2002].
\end{tabular}




\begin{tabular}{|c|c|}
\hline \multicolumn{2}{|r|}{$\begin{array}{c}\text { COMPLIANCE CATEGORY: } \\
\text { TOXIC SUBSTANCES MANAGEMENT } \\
\text { Overseas ESOHCAMP }\end{array}$} \\
\hline $\begin{array}{l}\text { REGULATORY } \\
\text { REQUIREMENTS: }\end{array}$ & $\begin{array}{l}\text { REVIEWER CHECKS: } \\
\text { September } 2009\end{array}$ \\
\hline $\begin{array}{l}\text { T1.20 } \\
\text { PCB MANAGEMENT: } \\
\text { PCB Records }\end{array}$ & \\
\hline $\begin{array}{l}\text { T1.20.1.0CAF. [Deleted } \\
\text { July 2008]. }\end{array}$ & Deleted at the request of the sponsor. \\
\hline
\end{tabular}




\begin{tabular}{|c|c|}
\hline \multicolumn{2}{|r|}{$\begin{array}{c}\text { COMPLIANCE CATEGORY: } \\
\text { TOXIC SUBSTANCES MANAGEMENT } \\
\text { Overseas ESOHCAMP }\end{array}$} \\
\hline $\begin{array}{l}\text { REGULATORY } \\
\text { REQUIREMENTS: }\end{array}$ & $\begin{array}{l}\text { REVIEWER CHECKS: } \\
\text { September } 2009\end{array}$ \\
\hline $\begin{array}{l}\text { T1.30 } \\
\text { PCB MANAGEMENT: } \\
\text { PCB Transformers } \\
\text { ( } 500 \text { ppm or greater) }\end{array}$ & \multirow[b]{2}{*}{ Deleted at the request of the sponsor. } \\
\hline $\begin{array}{l}\text { T1.30.1.OCAF. } \quad \text { [Deleted } \\
\text { July 2008]. }\end{array}$ & \\
\hline $\begin{array}{l}\text { T1.30.2.0CAF. } \quad \text { [Deleted } \\
\text { July 2008] }\end{array}$ & Deleted at the request of the sponsor. \\
\hline
\end{tabular}




\begin{tabular}{|c|c|}
\hline \multicolumn{2}{|r|}{$\begin{array}{c}\text { COMPLIANCE CATEGORY: } \\
\text { TOXIC SUBSTANCES MANAGEMENT } \\
\text { Overseas ESOHCAMP }\end{array}$} \\
\hline $\begin{array}{l}\text { REGULATORY } \\
\text { REQUIREMENTS: }\end{array}$ & $\begin{array}{l}\text { REVIEWER CHECKS: } \\
\text { September } 2009\end{array}$ \\
\hline $\begin{array}{l}\text { T1.50 } \\
\text { PCB MANAGEMENT: } \\
\text { PCB Spills }\end{array}$ & \multirow[b]{2}{*}{$\begin{array}{l}\text { Deleted at the request of the sponsor. } \\
\text { [Formerly checklist item number T1.40.1.OCAF.] }\end{array}$} \\
\hline $\begin{array}{l}\text { T1.50.1.OCAF. [Moved } \\
\text { June 2003; Deleted July } \\
\text { 2008]. }\end{array}$ & \\
\hline
\end{tabular}




\begin{tabular}{|c|c|}
\hline \multicolumn{2}{|r|}{$\begin{array}{c}\text { COMPLIANCE CATEGORY: } \\
\text { TOXIC SUBSTANCES MANAGEMENT } \\
\text { Overseas ESOHCAMP }\end{array}$} \\
\hline $\begin{array}{l}\text { REGULATORY } \\
\text { REQUIREMENTS: }\end{array}$ & $\begin{array}{l}\text { REVIEWER CHECKS: } \\
\text { September } 2009\end{array}$ \\
\hline $\begin{array}{l}\text { T2.2 } \\
\text { ASBESTOS } \\
\text { MANAGEMENT: } \\
\text { Missing Checklist } \\
\text { Items/Positive Findings }\end{array}$ & \\
\hline $\begin{array}{l}\text { T2.2.1.OCAF. Installations } \\
\text { must comply with all applica- } \\
\text { ble regulatory requirements } \\
\text { not contained in this checklist } \\
\text { (a finding under this checklist } \\
\text { item will have the citation of } \\
\text { the applied regulation as a } \\
\text { basis of finding) [Added } \\
\text { March 2002]. }\end{array}$ & $\begin{array}{l}\text { Determine whether any new regulations concerning asbestos management have } \\
\text { been issued since the finalization of the manual. } \\
\text { Determine whether the installation has activities or facilities that are regulated but } \\
\text { not addressed in this checklist. } \\
\text { Verify that the installation is in compliance with all applicable and newly issued } \\
\text { regulations. }\end{array}$ \\
\hline $\begin{array}{l}\text { T2.2.2.OCAF. Installations } \\
\text { should go above and beyond } \\
\text { environmental statutory and } \\
\text { regulatory compliance (MP) } \\
\text { [Added March 2002]. }\end{array}$ & $\begin{array}{l}\text { Determine whether the installation has gone above and beyond simply complying } \\
\text { with environmental requirements. } \\
\text { (NOTE: This checklist item is used only to write positive findings.) }\end{array}$ \\
\hline
\end{tabular}


11-14

Toxic Substances 


\begin{tabular}{|c|c|}
\hline \multicolumn{2}{|r|}{$\begin{array}{c}\text { COMPLIANCE CATEGORY: } \\
\text { TOXIC SUBSTANCES MANAGEMENT } \\
\text { Overseas ESOHCAMP }\end{array}$} \\
\hline $\begin{array}{l}\text { REGULATORY } \\
\text { REQUIREMENTS: }\end{array}$ & $\begin{array}{l}\text { REVIEWER CHECKS: } \\
\text { September } 2009\end{array}$ \\
\hline $\begin{array}{l}\text { T2.10 } \\
\text { ASBESTOS } \\
\text { MANAGEMENT: } \\
\text { General }\end{array}$ & \\
\hline $\begin{array}{l}\text { T2.10.1.OCAF. [Moved } \\
\text { March 2002]. }\end{array}$ & Moved to T2.2.1.OCAF. \\
\hline $\begin{array}{l}\text { T2.10.2.OCAF. Installations } \\
\text { must meet requirements con- } \\
\text { tained in MAJCOM supple- } \\
\text { ments to AFIs and policy } \\
\text { documents (a finding under } \\
\text { this checklist item will have } \\
\text { the citation of the MAJCOM } \\
\text { document as a basis of find- } \\
\text { ing). }\end{array}$ & $\begin{array}{l}\text { Determine whether the requirements in MAJCOM supplements to AFIs and pol- } \\
\text { icy documents are within the scope of the environmental compliance assessment. } \\
\text { Verify that the installation is in compliance with MAJCOM requirements. }\end{array}$ \\
\hline $\begin{array}{l}\text { T2.10.3.OCAF. } \quad \text { [Moved } \\
\text { March 2002]. }\end{array}$ & Moved to T2.2.2.OCAF. \\
\hline $\begin{array}{l}\text { T2.10.4.OCAF. [Moved June } \\
\text { 2003; Deleted July 2008]. }\end{array}$ & $\begin{array}{l}\text { Deleted at the request of the sponsor. } \\
\text { [Formerly checklist item T2.20.1.OCAF.] }\end{array}$ \\
\hline $\begin{array}{l}\text { T2.10.5.OCAF. [Moved June } \\
\text { 2003; Deleted July 2008]. }\end{array}$ & $\begin{array}{l}\text { Deleted at the request of the sponsor. } \\
\text { [Formerly checklist item T2.30.1.OCAF.] }\end{array}$ \\
\hline
\end{tabular}


11-16

Toxic Substances 


\begin{tabular}{|l|c|}
\multicolumn{2}{|c|}{$\begin{array}{c}\text { COMPLIANCE CATEGORY: } \\
\text { TOXIC SUBSTANCES MANAGEMENT } \\
\text { Overseas ESOHCAMP }\end{array}$} \\
\hline \multicolumn{1}{|c|}{ REGULATORY } \\
REQUIREMENTS: & $\begin{array}{c}\text { REVIEWER CHECKS: } \\
\text { September 2009 }\end{array}$ \\
\hline $\begin{array}{l}\text { T2.30 } \\
\text { ASBESTOS } \\
\text { MANAGEMENT: } \\
\text { Asbestos Disposal } \\
\text { T2.30.1.OCAF. [Moved June } \\
\text { 2003; Deleted July 2008]. } \\
\text { T2.30.2.OCAF. [Moved June } \\
\text { 2003; Deleted July 2008]. }\end{array}$ & Deleted at the request of the sponsor. \\
\hline
\end{tabular}


11-18

Toxic Substances 


\begin{tabular}{|c|c|}
\hline \multicolumn{2}{|r|}{$\begin{array}{l}\text { COMPLIANCE CATEGORY: } \\
\text { TOXIC SUBSTANCES MANAGEMENT } \\
\text { Overseas ESOHCAMP }\end{array}$} \\
\hline $\begin{array}{l}\text { REGULATORY } \\
\text { REQUIREMENTS: }\end{array}$ & $\begin{array}{l}\text { REVIEWER CHECKS: } \\
\text { September } 2009\end{array}$ \\
\hline $\begin{array}{l}\text { T1.3 } \\
\text { RADON MANAGEMENT: } \\
\text { Missing Checklist } \\
\text { Items/Positive Findings }\end{array}$ & \\
\hline $\begin{array}{l}\text { T3.2.1.OCAF. Installations } \\
\text { must comply with all applica- } \\
\text { ble regulatory requirements } \\
\text { not contained in this checklist } \\
\text { (a finding under this checklist } \\
\text { item will have the citation of } \\
\text { the applied regulation as a } \\
\text { basis of finding) [Added } \\
\text { March 2002]. }\end{array}$ & $\begin{array}{l}\text { Determine whether any new regulations concerning radon management have been } \\
\text { issued since the finalization of the manual. } \\
\text { Determine whether the installation has activities or facilities that are regulated but } \\
\text { not addressed in this checklist. } \\
\text { Verify that the installation is in compliance with all applicable and newly issued } \\
\text { regulations. }\end{array}$ \\
\hline $\begin{array}{l}\text { T3.2.2.OCAF. Installations } \\
\text { should go above and beyond } \\
\text { environmental statutory and } \\
\text { regulatory compliance (MP) } \\
\text { [Added March 2002]. }\end{array}$ & $\begin{array}{l}\text { Determine whether the installation has gone above and beyond simply complying } \\
\text { with environmental requirements. } \\
\text { (NOTE: This checklist item is used only to write positive findings.) }\end{array}$ \\
\hline
\end{tabular}




\begin{tabular}{|c|c|}
\hline \multicolumn{2}{|r|}{$\begin{array}{c}\text { COMPLIANCE CATEGORY: } \\
\text { TOXIC SUBSTANCES MANAGEMENT } \\
\text { Overseas ESOHCAMP }\end{array}$} \\
\hline $\begin{array}{l}\text { REGULATORY } \\
\text { REQUIREMENTS: }\end{array}$ & $\begin{array}{l}\text { REVIEWER CHECKS: } \\
\text { September } 2009\end{array}$ \\
\hline $\begin{array}{l}\text { T3.10 } \\
\text { RADON MANAGEMENT: } \\
\text { General }\end{array}$ & \\
\hline $\begin{array}{l}\text { T3.10.1.OCAF. [Moved } \\
\text { March 2002]. }\end{array}$ & Moved to T3.2.1.OCAF. \\
\hline $\begin{array}{l}\text { T3.10.2.OCAF. Installations } \\
\text { must meet requirements con- } \\
\text { tained in MAJCOM supple- } \\
\text { ments to AFIs and policy } \\
\text { documents (a finding under } \\
\text { this checklist item will have } \\
\text { the citation of the MAJCOM } \\
\text { document as a basis of find- } \\
\text { ing). }\end{array}$ & $\begin{array}{l}\text { Determine whether the requirements in MAJCOM supplements to AFIs and pol- } \\
\text { icy documents are within the scope of the environmental compliance assessment. } \\
\text { Verify that the installation is in compliance with MAJCOM requirements. }\end{array}$ \\
\hline $\begin{array}{l}\text { T3.10.3.OCAF. } \\
\text { March 2002]. }\end{array}$ & Moved to T3.2.2.OCAF. \\
\hline $\begin{array}{l}\text { T3.10.4.OCAF. [Deleted July } \\
\text { 2008]. }\end{array}$ & Deleted at the request of the sponsor. \\
\hline
\end{tabular}


11-22

Toxic Substances 


\begin{tabular}{|c|c|}
\hline \multicolumn{2}{|r|}{$\begin{array}{c}\text { COMPLIANCE CATEGORY: } \\
\text { TOXIC SUBSTANCES MANAGEMENT } \\
\text { Overseas ESOHCAMP }\end{array}$} \\
\hline $\begin{array}{l}\text { REGULATORY } \\
\text { REQUIREMENTS: }\end{array}$ & $\begin{array}{l}\text { REVIEWER CHECKS: } \\
\text { September } 2009\end{array}$ \\
\hline $\begin{array}{l}\text { T4.2 } \\
\text { LEAD-BASED PAINT } \\
\text { MANAGEMENT: } \\
\text { Missing Checklist } \\
\text { Items/Positive Findings }\end{array}$ & \\
\hline $\begin{array}{l}\text { T4.2.1.OCAF. Installations } \\
\text { must comply with all applica- } \\
\text { ble regulatory requirements } \\
\text { not contained in this checklist } \\
\text { (a finding under this checklist } \\
\text { item will have the citation of } \\
\text { the applied regulation as a } \\
\text { basis of finding) [Added } \\
\text { March 2002]. }\end{array}$ & $\begin{array}{l}\text { Determine whether any new regulations concerning LBP management have been } \\
\text { issued since the finalization of the manual. } \\
\text { Determine whether the installation has activities or facilities that are regulated but } \\
\text { not addressed in this checklist. } \\
\text { Verify that the installation is in compliance with all applicable and newly issued } \\
\text { regulations. }\end{array}$ \\
\hline $\begin{array}{l}\text { T4.2.2.0CAF. Installations } \\
\text { should go above and beyond } \\
\text { environmental statutory and } \\
\text { regulatory compliance (MP) } \\
\text { [Added March 2002]. }\end{array}$ & $\begin{array}{l}\text { Determine whether the installation has gone above and beyond simply complying } \\
\text { with environmental requirements. } \\
\text { (NOTE: This checklist item is used only to write positive findings.) }\end{array}$ \\
\hline
\end{tabular}


11-24

Toxic Substances 


\begin{tabular}{|c|c|}
\hline & $\begin{array}{c}\text { COMPLIANCE CATEGORY: } \\
\text { TOXIC SUBSTANCES MANAGEMENT } \\
\text { Overseas ESOHCAMP }\end{array}$ \\
\hline $\begin{array}{l}\text { REGULATORY } \\
\text { REQUIREMENTS: }\end{array}$ & $\begin{array}{l}\text { REVIEWER CHECKS: } \\
\text { September } 2009\end{array}$ \\
\hline $\begin{array}{l}\text { T4.10 } \\
\text { LEAD-BASED PAINT } \\
\text { MANAGEMENT: } \\
\text { General }\end{array}$ & \\
\hline $\begin{array}{l}\text { T4.10.1.OCAF. } \\
\text { March 2002]. }\end{array}$ & Moved to T4.2.1.OCAF. \\
\hline $\begin{array}{l}\text { T4.10.2.OCAF. Installations } \\
\text { must meet requirements con- } \\
\text { tained in MAJCOM supple- } \\
\text { ments to AFIs and policy } \\
\text { documents (a finding under } \\
\text { this checklist item will have } \\
\text { the citation of the MAJCOM } \\
\text { document as a basis of find- } \\
\text { ing). }\end{array}$ & $\begin{array}{l}\text { Determine whether the requirements in MAJCOM supplements to AFIs and pol- } \\
\text { icy documents are within the scope of the environmental compliance assessment. } \\
\text { Verify that the installation is in compliance with MAJCOM requirements. }\end{array}$ \\
\hline $\begin{array}{l}\text { T4.10.3.OCAF. [Moved } \\
\text { March 2002]. }\end{array}$ & Moved to T4.2.2.OCAF. \\
\hline $\begin{array}{l}\text { T4.10.4.OCAF. Installations } \\
\text { must develop and implement } \\
\text { a plan for identifying, evaluat- } \\
\text { ing, managing, and abating } \\
\text { LBP hazards (HQ USAF/CC } \\
\text { Policy Letter } 24 \text { May 1993, } \\
\text { para 6). }\end{array}$ & $\begin{array}{l}\text { Verify that the installation has a management plan that includes a strategy for: } \\
\text { - identifying, evaluating, controlling, and eliminating existing LBP hazards } \\
\text { and preventing new hazards from developing } \\
\text { - protecting facility occupants, especially children, and workers from LBP } \\
\text { hazards } \\
\text { - ensuring compliance with all applicable environmental protection require- } \\
\text { ments and all laws and regulations pertaining to LBP activities. } \\
\text { Verify that the plan: } \\
\text { - is an integral part of the installation's overall plan for inspecting, construct- } \\
\text { ing, upgrading, repairing, maintaining, and demolishing the facility inven- } \\
\text { tory } \\
\text { - is based on local conditions and an evaluation of the health risk from LBP } \\
\text { onbase that considers available information on the conditions of the facili- } \\
\text { ties, the results of facility inspections and evaluations, and incidents of lead } \\
\text { toxicity resulting from LBP } \\
\text { - gives priority to finding and reducing or eliminating the risk of existing haz- } \\
\text { ardous conditions in high-priority facilities } \\
\text { - emphasizes in-place management to control existing hazards and reduce the } \\
\text { risk of hazardous exposure to acceptable levels } \\
\text { - considers abatement of LBP as part of the normal facility renovation and } \\
\text { upgrade programs when it is cost-effective } \\
\text { - ensures precautions and procedures are incorporated into all maintenance, }\end{array}$ \\
\hline
\end{tabular}




\section{COMPLIANCE CATEGORY: \\ TOXIC SUBSTANCES MANAGEMENT \\ Overseas ESOHCAMP}

\section{REGULATORY REQUIREMENTS:}

T4.10.5.OCAF. Installations must identify existing and potential LBP hazards in accordance with specific procedures (USAF/CC Policy Letter 24 May 1993, para 7).

T4.10.6.OCAF. Installations must determine whether LBP is present prior to the start of facility maintenance, repair, modification, and renovation activities (HQ USAF/CC Policy Letter 24 May 1993, para 11).

\section{REVIEWER CHECKS: September 2009}

repair, renovation, and upgrade activities that are performed in-house, by contract, or self-help and that disturb painted surfaces known or likely to contain lead.

Verify that the installation implements its plan.

Verify that, depending on local circumstances, one of the following is used to identify and evaluate existing and potential LBP hazards:

- evaluations of observations from routine facility inspections and activities such as walk-throughs by Public Health (PH), fire and safety inspections, inspections for family day care home licensing, and occupant reports of deteriorated paint

- inspections and evaluations specifically designed to locate existing and potential LBP hazards so that appropriate measures can be taken to avoid hazardous lead exposures

- facility investigations to determine the source of documented lead exposure.

Verify that facility personnel who conduct routine inspections have been instructed to report signs of paint deterioration or children chewing on painted surfaces in high-priority facilities.

Verify that procedures are in place to document and respond to information reported from inspections and occupants concerning potential LBP problems and the resulting evaluations and actions.

Verify that facility inspections that are done specifically to identify LBP problems meet the following requirements:

- they are focused on high-priority facilities and areas within those facilities with painted surfaces in deteriorated condition

- the evaluations are performed by a team consisting of PH and BES representatives or by a qualified contractor

- reports of the data results and resulting actions are collected, consolidated, and analyzed by the Chief, Aerospace Medicine for reporting through AF medical channels

- permanent records of facility evaluations are maintained by the BCE and/or BES.

Verify that the installation determines whether LBP is present prior to the start of maintenance, modification, or renovation activities.

(NOTE: This requirement applies to high priority facilities and other facilities likely to contain lead.) 


\section{COMPLIANCE CATEGORY: \\ TOXIC SUBSTANCES MANAGEMENT \\ Overseas ESOHCAMP}

\section{REGULATORY REQUIREMENTS:}

T4.10.7.OCAF. Installations must restrict the use of LBP (USAF/CC Policy Letter 24 May 1993, para 12).

T4.10.8.OCAF. [Deleted September 1999].

T4.10.9.0CAF. Certain personnel must receive training beyond the minimum level (USAF/CC Policy Letter 24 May 1993, para 13).

T4.10.10.OCAF. All training related to LBP must be documented (USAF/CC Policy Letter 24 May 1993, para 13).

T4.10.11.OCAF. Installations must perform a Lead Toxicity Investigation (LTI) when children with elevated blood lead levels have been identified at the installation (USAF/CC Policy Letter, 24 May 1993, para 14).

T4.10.12.OCAF. Sellers and lessors of most residential housing built before 1978 must disclose known LBP and/or LBP hazards in housing (USAF Disclosure Policy, 19 August 1996, para a).

T4.10.13.OCAF. Sellers and lessors must provide purchasers and lessees with any avail-

\section{REVIEWER CHECKS: September 2009}

Verify that the installation does not use paint with more than 0.06 percent lead by weight of the nonvolatile solids.

(NOTE: This restriction applies to all facilities, both industrial and nonindustrial.)

This checklist item has been deleted at the request of Air Staff.

Verify that the following personnel receive additional training in the requirements of the Occupational Safety and Health Act and those of the Department of Housing and Urban Development (HUD):

- personnel who perform larger jobs in which simple work practices will not reliably reduce or control dust

- personnel who assist in LBP evaluations.

Verify that all training is documented in official personnel folders.

Determine whether the installation has ever had a case of elevated levels of lead in the blood.

Verify that the LTI team consists of representatives from BCE, BES, PH, PAO, and the Staff Judge Advocate (SJA) as needed.

Verify that the installation conducted an LTI.

Determine whether the installation sells or leases residential housing built before 1978.

Verify that the installation discloses known LBP and/or LBP hazards in housing.

(NOTE: This requirement also applies to common areas in both residential housing and multifamily housing.)

(NOTE: This requirement does not apply to:

- housing built after 1977

- 0-bedroom dwellings [dormitory housing and military barracks]

- commercial lodging [e.g., Visiting Officer Quarters, Visiting Airmen Quarters, Transient Lodging Facilities].)

Verify that the installation provides purchasers and lessees with any available records or reports pertaining to the presence of LBP and/or LBP hazards. 


\section{COMPLIANCE CATEGORY: \\ TOXIC SUBSTANCES MANAGEMENT \\ Overseas ESOHCAMP}

\section{REGULATORY REQUIREMENTS:}

able records or reports pertaining to the presence of LBP and/or LBP hazards (USAF Disclosure Policy, 19 August 1996, para b).

T4.10.14.OCAF. Sellers and lessors must provide purchasers and lessees with a federally approved lead hazard information pamphlet (USAF Disclosure Policy, 19 August 1996, para c).

T4.10.15.OCAF. Sellers must provide an opportunity to conduct a risk assessment or inspection for the presence of LBP and/or LBP hazards (USAF Disclosure Policy, 19 August 1996, para d).

T4.10.16.OCAF. Sales and leasing contracts must include disclosure and acknowledgment language (USAF Disclosure Policy, 19 August 1996, para f).

\section{REVIEWER CHECKS: September 2009}

(NOTE: This requirement does not apply to:

- housing built after 1977

- 0-bedroom dwellings [dormitory housing and military barracks]

- commercial lodging [e.g., Visiting Officer Quarters, Visiting Airmen Quarters, Transient Lodging Facilities].)

Verify that the installation provides purchasers and lessees with a federally approved lead hazard information pamphlet.

(NOTE: This requirement does not apply to:

- housing built after 1977

- 0-bedroom dwellings [dormitory housing and military barracks]

- commercial lodging [e.g., Visiting Officer Quarters, Visiting Airmen Quarters, Transient Lodging Facilities].)

Determine whether the installation is selling residential property.

Verify that the installation provides an opportunity to conduct a risk assessment or inspection for the presence of LBP and/or LBP hazards before the purchaser becomes obligated under contract to purchase the housing.

(NOTE: This is usually a 10-day period or another mutually agreed upon period of time.)

(NOTE: This requirement does not apply to:

- housing built after 1977

- 0-bedroom dwellings [dormitory housing and military barracks]

- commercial lodging [e.g., Visiting Officer Quarters, Visiting Airmen Quarters, Transient Lodging Facilities].)

Verify that sales and leasing contracts include disclosure and acknowledgment language.

(NOTE: This requirement does not apply to:

- housing built after 1977

- 0-bedroom dwellings [dormitory housing and military barracks]

- commercial lodging [e.g., Visiting Officer Quarters, Visiting Airmen Quarters, Transient Lodging Facilities].) 


\section{Appendix 11-1}

\section{Summary of Likelihood of Lead-Based Paint Being Present and Regulation/Guidelines Which \\ Normally Must Be Followed}

(USAF/CC Policy Letter 24 May 1993)

\section{High-Priority Facilities}

\begin{tabular}{|l|c|c|c|c|c|}
\hline \multicolumn{1}{|c|}{ Facility Type } & LBP Likely & HUD & OSHA & RCRA & AIR \\
\hline \hline $\begin{array}{l}\text { MFH/Day Care Home, } \\
\text { Before 1980 }\end{array}$ & Yes & Yes & Yes & Yes & No \\
\hline $\begin{array}{l}\text { MFH/Day Care Home, } \\
\text { During/After 1980 }\end{array}$ & No & Yes & No & No & No \\
\hline $\begin{array}{l}\text { Other High Priority } \\
\text { Facilities Before 1980 }\end{array}$ & Yes & Yes & Yes & Yes & No \\
\hline $\begin{array}{l}\text { Other High Priority } \\
\text { Facilities During/After } \\
\begin{array}{l}\text { 1980, Ferrous Metal } \\
\text { Surface }\end{array}\end{array}$ & Yes* & Yes & Yes & Yes & No \\
\hline $\begin{array}{l}\text { Other High Priority } \\
\text { Facilities, During/After } \\
\text { 1980, Other Surfaces }\end{array}$ & No** & Yes & No & No & No \\
\hline
\end{tabular}

\section{Other Facilities (Not High-Priority)}

\begin{tabular}{|l|c|c|c|c|c|}
\hline \multicolumn{1}{|c|}{ Facility Type } & LBP Likely & HUD & OSHA & RCRA & AIR \\
\hline \hline Steel Structures & Yes & No & Yes & Yes & Yes \\
\hline Industrials & Yes & No & Yes & Yes & No \\
\hline $\begin{array}{l}\text { Painted Yellow Pavement } \\
\text { Markings }\end{array}$ & Yes & No & Yes & Yes & No \\
\hline $\begin{array}{l}\text { Nonindustrials, Ferrous } \\
\text { Metal Surfaces }\end{array}$ & Yes* & No & Yes & Yes & No \\
\hline $\begin{array}{l}\text { Nonindustrials, } \\
\text { During/After 1980, } \\
\text { Other Surfaces }\end{array}$ & No** & No & No & No & No \\
\hline
\end{tabular}

* Consumer Product Safety Act (CPSA) restrictions uncertain, but common practices favor lead present.

** CPSA restrictions uncertain, but common practices favor lead absent.

HUD - Housing and Urban Development Interim Guidelines 
OSHA - Occupational Safety and Health Administration

RCRA - Resource Conservation and Recovery Act

AIR - National Primary and Secondary Ambient Air Quality Standards

(NOTE: Likelihood of finding LBP on a particular surface in a facility is based on when it was constructed (before 1980 or during/after 1980), applicability of CPSA restrictions on use of LBP, and common painting practices.)

(NOTE: Although LBP may not be likely, some precautions described in the HUD guidelines will normally be considered in high priority facilities since children are potentially at risk and there is some possibility the LBP is present.) 


\title{
SECTION 12
}

\section{WASTEWATER MANAGEMENT}

\section{Overseas ESOHCAMP}

\author{
September 2009
}

\section{A. Service-specific Regulations and Policies}

- Air Force Instruction (AFI) 32-1067, Water Systems, 25 March 1994, provides guidelines for managing water and wastewater systems at AF installations.

- AFI 32-7041, Water Quality Compliance, 10 December 2003, provides details of the Air Force Water Quality Compliance Program. It applies to all permanent Air Force installations and facilities generating, collecting, treating, reusing, and disposing of domestic and industrial wastewater, stormwater, non-point source runoff, biosolids, and water treatment residuals, including disposal by underground injection. For DOD components at installations outside the United States, its territories, and possessions, i.e. overseas, the applicable portions of this AFI are to be implemented in accordance with international agreements and the applicable Final Governing Standards (FGS) or, in their absence, the Overseas Environmental Baseline Guidance Document (OEBGD). See AFI 327006, EnvironmentalProgram in Foreign Countries for additional environmental guidance for overseas installations.

- HQ USAF/ILEV Memorandum, Revised Environmental Quality Metrics, 14 February 2005, requires immediate implementation across the AF (including overseas installations and government-owned/contractor-operated (GOCO) facilities of Under Secretary of Defense Memorandum, Revised Pollution Prevention and Compliance Metrics, dated 12 October 2004.

\section{B. Department of Defense (DOD) Directives/Instructions}

- Under Secretary of Defense Memorandum, Revised Pollution Prevention and Compliance Metrics, dated 12 October 2004, publishes pollution prevention (P2) metrics and definitions. Implementation begins in 2005. The following goals for wastewater are established in the memorandum:

1. Manage domestic and industrial wastewater and storm water effectively to protect public health, meet clean water standards, and maximize operational flexibility

2. Protect watersheds and ensure availability of discharge capacity to support mission

3. Leverage water conservation opportunities.

\section{Service-specific/DOD Definitions}

- Best Management Practices (BMP) - measures or practices to eliminate or reduce pollutants entering surface water, air, land, or groundwater. A Best Management Practice can be a process, activity, or physical structure. Structural BMPs include infiltration devices, ponds, filters and constructed wetlands. Non-structural BMPs include low impact development practices and management measures such as maintenance practices, street sweeping, public education and outreach programs (AFI 32-7041, Attachment 1).

- Biosolids - the byproduct of municipal wastewater treatment, also are known as sewage sludge (AFI 32-7041, Attachment 1).

- Closed Enforcement Action - an open enforcement action for water quality compliance closes when (AFI 327041, Attachment 1): 
(1) the regulatory agency sends a letter confirming that the enforcement action was resolved, rescinded, or superseded;

(2) the Regional Compliance Office determines that the regulators are not carrying out the open enforcement action; or

(3) for overseas installations, when the Major Command determines the open enforcement action is closed.

- Combined Sewer - a wastewater collection system that collects stormwater and wastewater (AFI 32-7041, Attachment 1).

- Combined-Sewer Overflow - direct discharge of untreated wastewater from a combined sewer (AFI 32-7041, Attachment 1).

- Cost of Wastewater Management - for tracking purposes of this metric, this cost is listed in the PB-28 and is the non-recurring investment needed to maintain compliance with Final Governing Standards. As noted, this nonrecurring cost is only part of the overall management cost for wastewater management. Recurring and routine operation and maintenance are not included in the metric (Attachment 2, Under Secretary of Defense Memorandum, Revised Pollution Prevention and Compliance Metrics, 12 October 2004).

- Crossconnection - interconnecting separate wastewater collection systems, such as (AFI 32-7041, Attachment 1):

(1) Industrial wastewater collection systems to domestic or storm sewers;

(2) Stormwater collection systems to domestic or industrial sewers;

(3) Domestic wastewater collection systems to storm or industrial sewers; and

(4) Unregulated non-stormwater discharges.

- Direct Discharge - a wastewater or stormwater discharge to waters of United States, as opposed to a discharge to a publicly-owned treatment works (POTW) or other permitted treatment system (AFI 32-7041, Attachment 1).

- Discharge Limit - the maximum pollutant concentration that a discharge permit allows (AFI 32-7041, Attachment 1).

- Discharge Permit - a permit that authorizes discharging wastewater or stormwater to the waters of the United States, or host nation, or to a POTW. There are two types of discharge permits, individual and general, and many permits include maximum contaminant levels allowed in the discharge (AFI 32-7041, Attachment 1).

- DOD-Managed Treatment Works - for overseas installation, wastewater treatment works that are operated by Department of Defense (DOD) personnel, may or may not be owned by DOD, and are regulated under the FGS, the OEBGD, and/or host nation discharge permit (AFI 32-7041, Attachment 1).

- Domestic Sewer - a conveyance system for domestic or pretreated industrial wastewater collection (AFI 32-7041, Attachment 1).

- Domestic Wastewater - wastewater that contains human wastes and wastewater from food preparation, laundry, bathing, and similar activities. Domestic wastewater typically includes wastewater from housing units and wastewater from commercial or industrial facilities that is similar to that from housing units. Domestic wastewater does not include industrial process wastewater (AFI 32-7041, Attachment 1).

- Exfiltration - flow out of a sewer to the subsurface due to sewer pipe leakage from breaks or joints (AFI 32-7041, Attachment 1).

- Facility - all buildings, equipment, structures, and other stationary items which are located on a single site or on contiguous or adjacent sites and which are owned or operated by the same person (or by any person which controls, is controlled by, or under common control with, such person) (AFI 32-7041, Attachment 1).

- Industrial Sewer - a conveyance system for collecting industrial wastewater (AFI 32-7041, Attachment 1). 
- Industrial Sludge - sludge from and wastewater treatment process or works that is not part of a domestic wastewater treatment system (AFI 32-7041, Attachment 1).

- Industrial Wastewater - wastewater from industrial activities such as electroplating, metal finishing, aircraft maintenance, corrosion control, vehicle maintenance, and other industrial processes at Air Force installations (AFI 32-7041, Attachment 1).

- Infiltration - groundwater that leaks into wastewater collection systems due to leakage through pipe breaks or joints (AFI 32-7041, Attachment 1).

- Inflow - stormwater flow into wastewater collection systems (AFI 32-7041, Attachment 1).

- Installation - a piece of real property owned or controlled by the military (AFI 32-7041, Attachment 1).

- Interference - disrupting a POTW operation or treatment by discharging an incompatible pollutant or waste stream to the POTW (AFI 32-7041, Attachment 1).

- Lift Station - a wastewater collection system that pumps wastewater from a gravity sewer to a sewer or treatment plant at a higher elevation (AFI 32-7041, Attachment 1).

- Nonpoint Source - a pollutant source that does not meet the definition of "point source." Nonpoint source pollution generally results from land runoff, atmospheric deposition, drainage, or seepage (AFI 32-7041, Attachment 1).

- Nonrecurring CWA/Wastewater Compliance Investment - fiscal year costs listed on Exhibit PB-28 (Funds Budgeted for Environmental Quality) of the Presidential Budget for the Clean Water Act/Wastewater. These costs represent Class I/II projects and planning efforts (already out of compliance/will be out of compliance at a specified date in the future) to achieve compliance (Attachment 2, Under Secretary of Defense Memorandum, Revised Pollution Prevention and Compliance Metrics, 12 October 2004).

- Nonrecurring CWA/Wastewater Pollution Prevention Investment - fiscal year costs listed on Exhibit PB-28 (Funds Budgeted for Environmental Quality) of the Presidential Budget for the Clean Water Act/Wastewater. These costs represent Class I/II pollution prevention projects (already out of compliance/will be out of compliance at a specified date in the future) (Attachment 2, Under Secretary of Defense Memorandum, Revised Pollution Prevention and Compliance Metrics, 12 October 2004).

- Notice of Intent - an application to notify the permitting authority of a facility's intention to be covered by a general permit (AFI 32-7041, Attachment 1).

- Notice of Termination - an application used to notify the permitting authority of a facility's termination of coverage under a general permit (AFI 32-7041, Attachment 1).

- Open Enforcement Actions - written notices indicating one or more violations of environmental regulations issued by a host nation, Federal, state, local, or other regulatory agency (AFI 32-7041, Attachment 1).

- Operator - an owner or operator of any "facility or activity" subject to regulation under the NPDES program (AFI 32-7041, Attachment 1).

- Outfall - a structure through which treated or untreated stormwater or wastewater is discharged to the waters of the United States (AFI 32-7041, Attachment 1).

- Overseas - outside any territory, possession, or commonwealth of the United States. This does not include contingency operations, training deployments, or the operations of military vessels and aircraft (Attachment 2, Under Secretary of Defense Memorandum, Revised Pollution Prevention and Compliance Metrics, 12 October 2004). 
- Overseas Installations - permanent, base force structure facilities under the operational control of the Secretary of a military department or the Department of Defense that is located outside the United States and outside any territory, commonwealth or possession of the United States. Installations overseas do NOT include temporary, contingency operation or deployment support facilities. Tenants on overseas installations should report through their component headquarters reporting systems (Attachment 2, Under Secretary of Defense Memorandum, Revised Pollution Prevention and Compliance Metrics, 12 October 2004).

(NOTE: Include Government-owned, Contractor-operated [GOCO] installations.)

- Pass-Through - a discharge of pollutants to a POTW collection system which passes untreated through the POTW into United States waters (AFI 32-7041, Attachment 1).

- Point Source - any discernible confined and discrete conveyance from which pollutants are or may be discharged, excluding agricultural stormwater discharges and return flows from irrigated agriculture. Point sources include (AFI 32-7041, Attachment 1):

(1) Pipes

(2) Ditches

(3) Channels

(4) Tunnels

(5) Conduits

(6) Wells

(7) Discrete fissures

(8) Containers

(9) Rolling stock

(10) Concentrated animal feeding operations

(11) Landfill leachate collection systems

(12) Vessel or other floating crafts.

- Pretreatment - treatment of industrial wastewater required under federal, state or POTW pretreatment regulations to meet contaminant concentration limits (AFI 32-7041, Attachment 1).

- Pretreatment Permit - authorization to discharge untreated or pretreated industrial wastewater to a POTW. Permit prescribes maximum contaminant concentration limits in wastewater (AFI 32-7041, Attachment 1).

- Publicly-Owned Treatment Works (POTW) - a treatment plant belonging to a state, county, regional agency, or municipality that treats domestic wastewater or pretreated industrial wastewater (AFI 32-7041, Attachment 1).

- Pump Station - See Lift Station.

- Regulated Facilities - for overseas, this includes those facilities for which criteria are established under the Final Governing Standards (FGS-regulated), such as domestic wastewater treatment systems, industrial wastewater treatment systems, or storm water systems that discharge to the waters of the host nation. An installation holding host-nation permits will report metric compliance based on discharges regulated by each permit and its requirements. For FGS regulated discharges without a host-nation discharge permit, installations will combine all domestic wastewater, industrial wastewater, and storm water discharges and report as one regulated facility per installation (Attachment 2, Under Secretary of Defense Memorandum, Revised Pollution Prevention and Compliance Metrics, 12 October 2004).

- Sanitary Wastewater - See Domestic Wastewater.

- Source - any building, structure, facility, or installation from which there is or may be the discharge of pollutants (AFI 32-7041, Attachment 1). 
- Stabilization of Site - BMPs used to stabilize the soil, to reduce raindrop impact, to reduce the velocity of surface runoff, and to prevent erosion (AFI 32-7041, Attachment 1).

- Stormwater Discharge Associated with Industrial Activity - stormwater that has contacted manufacturing operations, or stored raw materials or supplies at an industrial activity, as defined. The Environmental Protection Agency defines 11 categories of industrial activities, some of which may apply to Air Force installations, including (AFI 32-7041, Attachment 1):

(1) Air and ground transportation facilities;

(2) Steam electric power generating facilities;

(3) Treatment works treating domestic sewage having a capacity over 1 million gallons per day (MGPD); and

(4) Construction sites.

- Stormwater Pollution Prevention Plan (SWPPP) - a series of steps and activities to identify sources of stormwater pollution at an industrial or construction site, including actions to be taken that will prevent or control stormwater contamination (AFI 32-7041, Attachment 1).

- Technology-Based Effluent Limit - a discharge standard based on an Environmental Protection Agency review of common treatment technologies for treating a type of wastewater. Technology-based effluent limits are the same for each type of wastewater, regardless of the location or quality of the receiving water (AFI 32-7041, Attachment 1).

- Wastewater System - related units or devices and associate conveyances or appurtenances necessary to manage the generation, collection, storage, transportation, distribution, treatment, pollution prevention activities, recycling, reclamation, and disposal of domestic wastewater, industrial wastewater or stormwater runoff. The commonality of treatment characteristics and/or the commonality of classification of all wastewater systems are essential to good management and reporting requirements (AFI 32-7041, Attachment 1).

- Watershed - a geographical area that drains to a specified point on a water course, usually a confluence of streams or rivers. Also known as drainage area, catchment, or river basin (AFI 32-7041, Attachment 1).

- Water Quality-Based Effluent Limit - discharge limit to ensure that discharging the pollutant will not exceed the water quality standard for that pollutant. Water quality-based effluent limits are site-specific and pollutantspecific. As opposed to technology-based limits, water quality-based effluent limits may differ from those in other locations for the same type of wastewater (AFI 32-7041, Attachment 1).

- Water Treatment Residuals - solids (sludge) and waste process water such as sludge dewatering decant water generated at water treatment plants (AFI 32-7041, Attachment 1).

- Wetlands - Areas inundated by surface or groundwater that support plants and animals that need saturated or seasonally saturated soil to grow and reproduce. Wetlands include swamps, marshes, bogs, sloughs, mud flats, and natural ponds (AFI 32-7041, Attachment 1).

\section{Additional Records to Review}

- None

\section{E. Additional Physical Features to Inspect}

- None 


\section{F. Guidance for Checklist Users}

REFER TO CHECKLIST ITEMS:

Missing Checklist Items/Positive Findings

General

Treatment Works

Discharges to Domestic Sanitary Systems

Stormwater Management

Oil/Water Separators

Training and Certification
WA.2.1.OCAF and WA.2.2.OCAF

WA.10.1.OCAF through WA.10.15.OCAF

WA.12.1.OCAF through WA.12.14.OCAF

WA.15.1.OCAF through WA.15.5.OCAF

WA.50.1.OCAF through WA.50.6.OCAF

WA.60.1.OCAF through WA.60.10.OCAF

WA.70.1.OCAF and WA.70.2.OCAF 


\begin{tabular}{|c|c|}
\hline \multicolumn{2}{|r|}{$\begin{array}{l}\text { COMPLIANCE CATEGORY: } \\
\text { WASTEWATER MANAGEMENT } \\
\text { Overseas ESOHCAMP }\end{array}$} \\
\hline $\begin{array}{l}\text { REGULATORY } \\
\text { REQUIREMENTS: }\end{array}$ & $\begin{array}{l}\text { REVIEWER CHECKS: } \\
\text { September } 2009\end{array}$ \\
\hline $\begin{array}{l}\text { WA.2 } \\
\text { MISSING CHECKLIST } \\
\text { ITEMS/POSITIVE } \\
\text { FINDINGS }\end{array}$ & \\
\hline $\begin{array}{l}\text { WA.2.1.OCAF. Installations } \\
\text { must comply with all applica- } \\
\text { ble regulatory requirements } \\
\text { not contained in this checklist } \\
\text { (a finding under this checklist } \\
\text { item will have the citation of } \\
\text { the applied regulation as a } \\
\text { basis of finding) [Added } \\
\text { March 2002]. }\end{array}$ & $\begin{array}{l}\text { Determine whether any new regulations concerning wastewater management have } \\
\text { been issued since the finalization of the manual. } \\
\text { Determine whether the installation has activities or facilities that are regulated but } \\
\text { not addressed in this checklist. } \\
\text { Verify that the installation is in compliance with all applicable and newly issued } \\
\text { regulations. }\end{array}$ \\
\hline $\begin{array}{l}\text { WA.2.2.OCAF. Installations } \\
\text { should go above and beyond } \\
\text { environmental statutory and } \\
\text { regulatory compliance (MP) } \\
\text { [Added March 2002]. }\end{array}$ & $\begin{array}{l}\text { Determine whether the installation has gone above and beyond simply complying } \\
\text { with environmental requirements. } \\
\text { (NOTE: This checklist item is used only to write positive findings.) }\end{array}$ \\
\hline
\end{tabular}




\begin{tabular}{|c|c|}
\hline \multicolumn{2}{|r|}{$\begin{array}{l}\text { COMPLIANCE CATEGORY: } \\
\text { WASTEWATER MANAGEMENT } \\
\text { Overseas ESOHCAMP }\end{array}$} \\
\hline $\begin{array}{l}\text { REGULATORY } \\
\text { REQUIREMENTS: }\end{array}$ & $\begin{array}{l}\text { REVIEWER CHECKS: } \\
\text { September } 2009\end{array}$ \\
\hline $\begin{array}{l}\text { WA.10 } \\
\text { GENERAL }\end{array}$ & \\
\hline $\begin{array}{l}\text { WA.10.1.OCAF. [Moved } \\
\text { March 2002]. }\end{array}$ & Moved to WA.2.1.OCAF. \\
\hline $\begin{array}{l}\text { WA.10.2.OCAF. Installations } \\
\text { must meet requirements con- } \\
\text { tained in MAJCOM supple- } \\
\text { ments to AFIs and policy } \\
\text { documents (a finding under } \\
\text { this checklist item will have } \\
\text { the citation of the MAJCOM } \\
\text { document as a basis of find- } \\
\text { ing). }\end{array}$ & $\begin{array}{l}\text { Determine whether the requirements in MAJCOM supplements to AFIs and pol- } \\
\text { icy documents are within the scope of the environmental compliance assessment. } \\
\text { Verify that the installation is in compliance with MAJCOM requirements. }\end{array}$ \\
\hline $\begin{array}{l}\text { WA.10.3.OCAF. } \quad \text { [Moved } \\
\text { March 2002]. }\end{array}$ & Moved to WA.2.2.OCAF. \\
\hline $\begin{array}{l}\text { WA.10.4.OCAF. Bases out- } \\
\text { side the United States and its } \\
\text { territories must cooperate } \\
\text { with foreign regulatory agen- } \\
\text { cies, consistent with host na- } \\
\text { tion agreements (AFI 32- } \\
\text { 1067, para 14.1). }\end{array}$ & $\begin{array}{l}\text { Verify that the installation cooperates with host nation regulatory agencies, con- } \\
\text { sistent with host nation agreements. }\end{array}$ \\
\hline $\begin{array}{l}\text { WA.10.5.OCAF. [Moved } \\
\text { December 2003]. }\end{array}$ & $\begin{array}{l}\text { Moved to WA.12.4.OCAF upon incorporation of AFI 32-7041 in December } \\
2003 .\end{array}$ \\
\hline $\begin{array}{l}\text { WA.10.6.OCAF. [Moved } \\
\text { December 2003]. }\end{array}$ & $\begin{array}{l}\text { Moved to WA.12.5.OCAF upon incorporation of AFI 32-7041 in December } \\
2003 .\end{array}$ \\
\hline $\begin{array}{l}\text { WA.10.7.OCAF. [Moved } \\
\text { December 2003]. }\end{array}$ & $\begin{array}{l}\text { Moved to WA.12.6.OCAF upon incorporation of AFI 32-7041 in December } \\
2003 .\end{array}$ \\
\hline $\begin{array}{l}\text { WA.10.8.OCAF. [Moved } \\
\text { December 2003]. }\end{array}$ & $\begin{array}{l}\text { Moved to WA.12.7.OCAF upon incorporation of AFI 32-7041 in December } \\
2003 .\end{array}$ \\
\hline $\begin{array}{l}\text { WA.10.9.OCAF. [Moved } \\
\text { December 2003]. }\end{array}$ & $\begin{array}{l}\text { Moved to WA.12.8.OCAF upon incorporation of AFI 32-7041 in December } \\
2003 .\end{array}$ \\
\hline $\begin{array}{l}\text { WA.10.10.0CAF. Installa- } \\
\text { tions must coordinate with the } \\
\text { MAJCOM for consultation }\end{array}$ & $\begin{array}{l}\text { Verify that the installation coordinates with the MAJCOM for consultation with } \\
\text { the DOD Environmental Executive Agent when applying for or renewing a per- }\end{array}$ \\
\hline
\end{tabular}




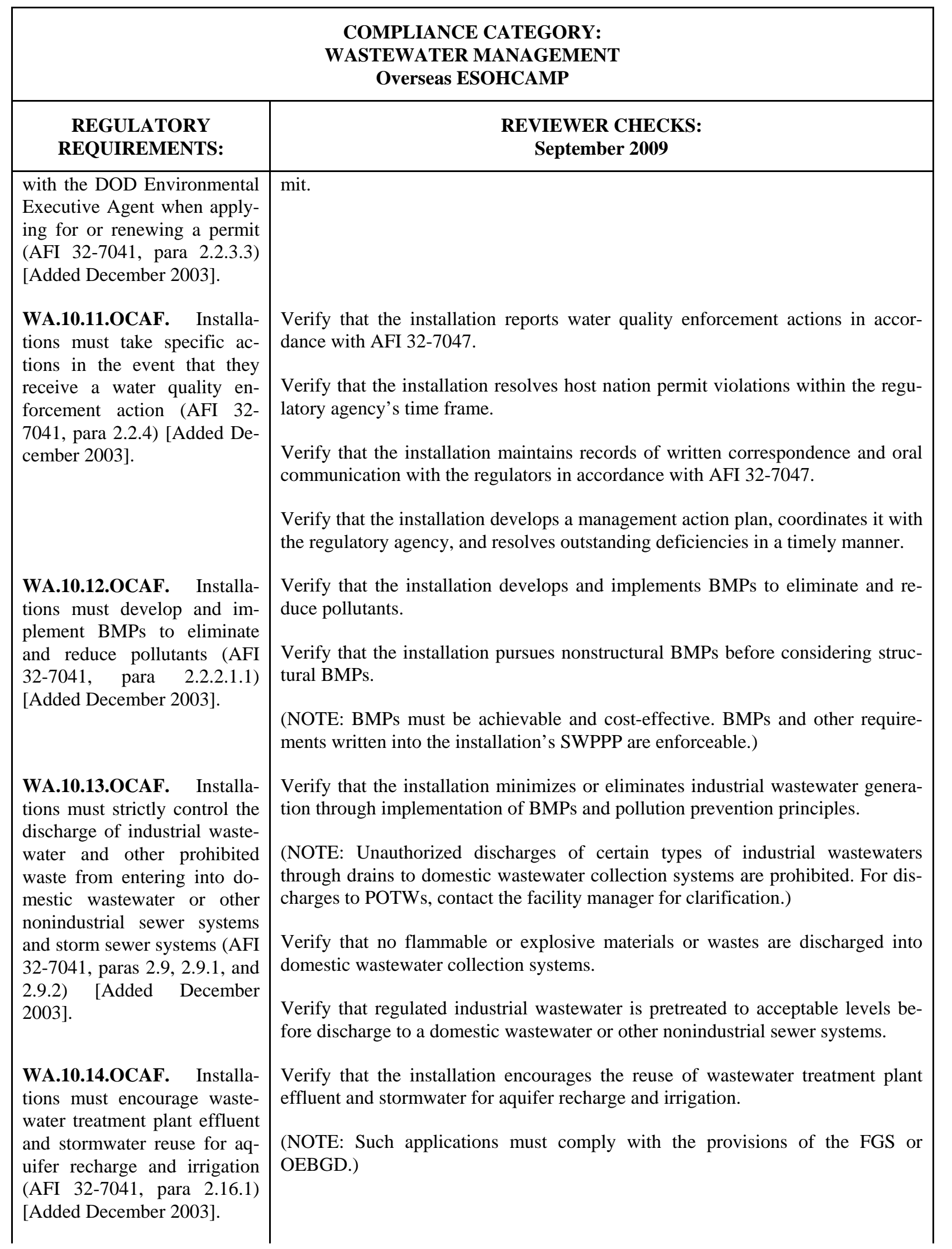




\begin{tabular}{|c|c|}
\hline \multicolumn{2}{|r|}{$\begin{array}{c}\text { COMPLIANCE CATEGORY: } \\
\text { WASTEWATER MANAGEMENT } \\
\text { Overseas ESOHCAMP }\end{array}$} \\
\hline $\begin{array}{l}\text { REGULATORY } \\
\text { REQUIREMENTS: }\end{array}$ & $\begin{array}{l}\text { REVIEWER CHECKS: } \\
\text { September } 2009\end{array}$ \\
\hline $\begin{array}{l}\text { WA.10.15.OCAF. All instal- } \\
\text { lations with on-base facilities } \\
\text { that discharge regulated } \\
\text { wastewater into the waters of } \\
\text { the host nation must report } \\
\text { specific information on a cal- } \\
\text { endar year basis (HQ } \\
\text { USAF/ILEV Memorandum, } \\
\text { Revised Environmental Qual- } \\
\text { ity Metrics, 14 February 2005, } \\
\text { para 1; Under Secretary of } \\
\text { Defense Memorandum, Re- } \\
\text { vised Pollution Prevention } \\
\text { and Compliance Metrics, 12 } \\
\text { October 2004; Attachment 1, } \\
\text { paras VII.c.2 and VII.d.2 } \\
\text { through VII.d.3) [Added } \\
\text { March 2005]. }\end{array}$ & $\begin{array}{l}\text { Determine whether the installation has on-base facilities that discharge regulated } \\
\text { wastewater into the waters of the host nation. } \\
\text { Verify that the installation reports: } \\
\text { - total number of facilities discharging regulated wastewater or stormwater } \\
\text { - number of facilities discharging regulated wastewater or stormwater that are } \\
\text { in compliance with effluent limitations } \\
\text { - cost of wastewater (includes domestic, industrial, and storm water) man- } \\
\text { agement as reported in President's Budget, Exhibit PB-28 in thousands of } \\
\text { dollars (\$) for: nonrecurring compliance investment, and non-recurring } \\
\text { pollution prevention investment, Clean Water Act. } \\
\text { (NOTE: Potential sources of data include the President's Budget [Exhibit PB- } \\
\text { 28].) } \\
\text { (NOTE: If you answer "yes" to any of the following questions, you are consid- } \\
\text { ered out of compliance. During the 6-mo reporting period, has your installation: } \\
\text { - exceeded any permit or effluent limit for two or more consecutive months at } \\
\text { any given discharge point? (Yes/No) If yes, identify parameter(s). } \\
\text { - had any prohibited bypass event, unpermitted discharge, or pass-through of } \\
\text { pollutants to a water body? (Yes/No) } \\
\text { - failed to develop and/or implement a required program or plan such as a } \\
\text { stormwater pollution prevention plan or pretreatment program? (Yes/No) } \\
\text { - failed to satisfy sampling, monitoring, and testing requirements? (Yes/No) } \\
\text { If you answered yes to any question above, provide a written explanation for the } \\
\text { reasons for noncompliance or not meeting requirements and the corrective actions } \\
\text { taken.) } \\
\text { (NOTE: Begin collecting this data in Calendar Year 2005.) }\end{array}$ \\
\hline
\end{tabular}


12-12

Wastewater 


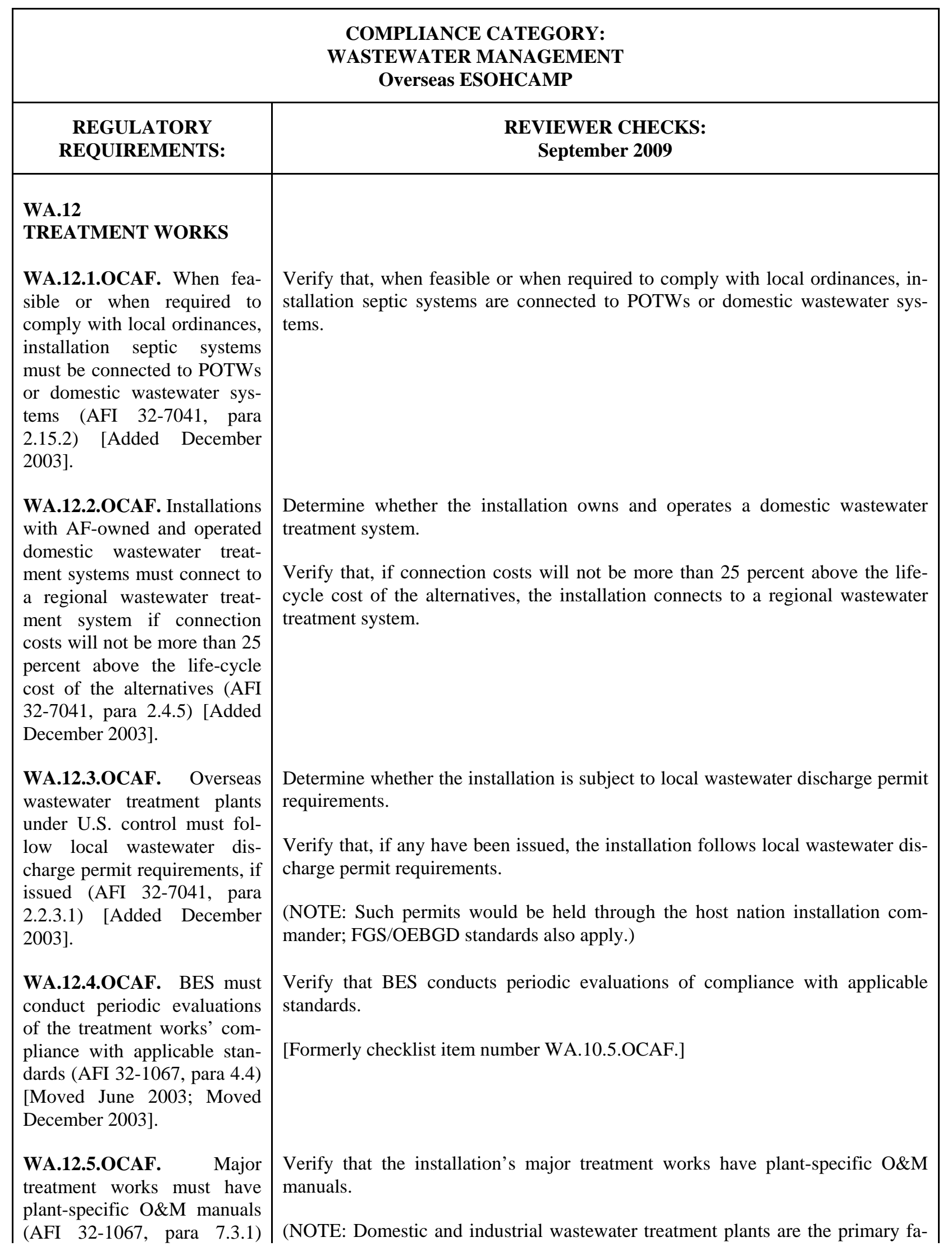




\section{COMPLIANCE CATEGORY: \\ WASTEWATER MANAGEMENT \\ Overseas ESOHCAMP}

\section{REGULATORY REQUIREMENTS:}

[Moved June 2003; Moved December 2003].

WA.12.6.OCAF. Specific physical facility information must be developed, maintained, and kept available at treatment facilities (AFI 321067, para 10.2) [Moved June 2003; Moved December 2003].

WA.12.7.OCAF. Installations must develop and maintain effective maintenance plans that address specific topics (AFI 32-1067, para 10.3) [Moved June 2003].

\section{REVIEWER CHECKS: \\ September 2009}

cilities covered by this instruction.)

Verify that, if the facilities are present on the installation, plant-specific manuals address the following areas of concern:

- metal finishing and electroplating

- vehicle and aircraft wash facilities

- aircraft maintenance:

- paint stripping

- nondestructive inspection

- painting

- solvent cleaning

- battery shops

- photo labs

- hospitals

- aircraft deicing

- fire training.

Verify that plant-specific manuals address the proper operation and maintenance of oil/water separators and lift stations.

[Formerly checklist item number WA.10.6.OCAF.]

Verify that the following information is developed, maintained, and kept available at the treatment facilities:

- required plant-specific O\&M manuals and applicable AF publications

- system operating instructions with single-line drawings, including operational and compliance monitoring procedures

- up-to-date system as-built drawings along with other system plans and blue prints, including hydraulic water elevation profiles and a drawing of the entire collection and distribution systems

- shop drawings, catalogue cuts, and any other equipment information or literature.

[Formerly checklist item number WA.10.7.OCAF.]

Verify that the installation develops and maintains effective maintenance plans that include:

- a recurring work schedule

- a maintenance history for each major piece of equipment

- an essential spare parts list, with spare parts stocked at the treatment facility or other accessible location

- a long-range maintenance and improvement plan.

[Formerly checklist item number WA.10.8.OCAF.] 


\section{COMPLIANCE CATEGORY: WASTEWATER MANAGEMENT Overseas ESOHCAMP}

\section{REGULATORY REQUIREMENTS:}

WA.12.8.OCAF. Operators of treatment works must prepare pollution control logs (AFI 32-1067, para 10.1.2) [Moved June 2003].

WA.12.9.OCAF. Installations with AF-owned and operated domestic wastewater treatment systems should consider performing an Operations, Maintenance, Training, and Assistance Program (OMTAP) engineering analysis before programming wastewater system upgrades (MP) [Added December 2003].

WA.12.10.0CAF. Installations with AF-owned and operated domestic wastewater treatment systems must obtain applicable permits issued by recognized host nation local governments or authorities prior to projects to upgrade, modify or replace wastewater systems (AFI 32-7041, para 2.4.3) [Added December 2003].

WA.12.11.0CAF. For installations with AF-owned and operated domestic wastewater treatment systems, projects to upgrade, modify or replace wastewater plants must include on-the-job operator training and development of new or revised operations and maintenance manuals (AFI 32-7041, para 2.4.3.2) [Added December 2003].

WA.12.12.0CAF. Wastewa-

\section{REVIEWER CHECKS: September 2009}

Verify that operators prepare the following forms:

- AF Form 1462, Water Pollution Control Utility Operating Log (General)

- AF Form 1463, Water Pollution Control Plant Operating Log-Supplementary.

[Formerly checklist item number WA.10.9.OCAF.]

Determine whether the installation owns and operates a domestic wastewater treatment system.

Verify that the installation considers performing an OMTAP engineering analysis before programming wastewater system upgrades.

(NOTE: For further detail on the OMTAP, see AFCESA A-GRAM 0-25, OMTAP Program for Drinking Water and Wastewater Treatment Plants, October 2001.)

(NOTE: This MP is suggested at AFI 32-7041, para 2.4.3.1.)

Determine whether the installation owns and operates a domestic wastewater treatment system.

Verify that, for projects to upgrade, modify or replace the wastewater system, the installation obtains applicable permits issued by recognized host nation local governments or authorities.

Verify that required permits are obtained from appropriate regulatory agencies prior to commencing construction and before starting plant operations.

Verify that, for installations with AF-owned and operated domestic wastewater treatment systems, projects to upgrade, modify or replace wastewater plants include on-the-job operator training and development of new or revised operations and maintenance manuals.

Verify that major lift stations have two independent power sources at each station 


\section{COMPLIANCE CATEGORY: WASTEWATER MANAGEMENT Overseas ESOHCAMP}

\begin{tabular}{|c|c|}
\hline $\begin{array}{l}\text { REGULATORY } \\
\text { REQUIREMENTS: }\end{array}$ & $\begin{array}{l}\text { REVIEWER CHECKS: } \\
\text { September } 2009\end{array}$ \\
\hline $\begin{array}{l}\text { ter lift stations must continue } \\
\text { to operate during power fail- } \\
\text { ures and have redundant } \\
\text { pumps to provide adequate } \\
\text { pumping capacity for han- } \\
\text { dling the maximum wastewa- } \\
\text { ter flow when one pump is } \\
\text { out of service (AFI } 32-7041 \text {, } \\
\text { paras } 2.5 \text { and } 2.5 .1 \text { through } \\
2.5 .3 \text { ) [Added December } \\
2003 \text { ]. }\end{array}$ & $\begin{array}{l}\text { such as standby or portable power generators. } \\
\text { Verify that standby power is provided in accordance with Military Handbook } \\
\text { (MIL-HDBK) 1005/16, Wastewater Treatment System Design Augmenting Hand- } \\
\text { book, } 31 \text { October 1997. } \\
\text { (NOTE: The MIL-HDBK refers to U.S. Army Corps of Engineers, Engineering } \\
\text { Instructions (EI) 11C201, Wastewater Collection and Pumping, } 1 \text { March 1997, } \\
\text { Chapter 9-7, titled "Standby Power.") } \\
\text { Verify that, for lift stations located in low lying areas, or in areas remote from a } \\
\text { treatment plant, a standby power connection point capability is provided to pre- } \\
\text { vent flooding of lift station, overflows at sewer manholes, backup of wastes into } \\
\text { buildings, or any unauthorized discharges of untreated wastewater. } \\
\text { Verify that, for lift stations located at or in conjunction with treatment facilities, } \\
\text { such as those required for influent pumping, recycling or bypassing of flows, and } \\
\text { pumping of effluent, standby power capability is provided if the pumping is es- } \\
\text { sential to critical treatment processes, plant flow control, or is necessary to main- } \\
\text { tain compliance with the discharge permit. }\end{array}$ \\
\hline $\begin{array}{l}\text { WA.12.13.OCAF. Wastewa- } \\
\text { ter lift stations must have au- } \\
\text { dible and visual alarms at } \\
\text { each pump station to alert } \\
\text { maintenance staff of pump } \\
\text { failures (AFI 32-7041, para } \\
2.5 .4 \text { ) [Added December } \\
\text { 2003]. }\end{array}$ & $\begin{array}{l}\text { Verify that wastewater lift stations have audible and visual alarms at each pump } \\
\text { station to alert maintenance staff of pump failures. } \\
\text { Verify that the alarm systems include equipment to transmit alarm signals to a } \\
\text { central monitoring point, if possible. } \\
\text { Verify that backup batteries or other emergency power sources are installed to } \\
\text { retain alarm data during power failures. }\end{array}$ \\
\hline $\begin{array}{l}\text { WA.12.14.OCAF. Installa- } \\
\text { tions must repair or replace } \\
\text { failed pumps at wastewater } \\
\text { lift stations expeditiously to } \\
\text { maintain redundancy (AFI 32- } \\
\text { 7041, para 2.5.5) [Added De- } \\
\text { cember 2003]. }\end{array}$ & $\begin{array}{l}\text { Verify that failed pumps at wastewater lift stations are repaired or replaced expe- } \\
\text { ditiously to maintain redundancy. }\end{array}$ \\
\hline
\end{tabular}




\begin{tabular}{|c|c|}
\hline \multicolumn{2}{|r|}{$\begin{array}{l}\text { COMPLIANCE CATEGORY: } \\
\text { WASTEWATER MANAGEMENT } \\
\text { Overseas ESOHCAMP }\end{array}$} \\
\hline $\begin{array}{l}\text { REGULATORY } \\
\text { REQUIREMENTS: }\end{array}$ & $\begin{array}{l}\text { REVIEWER CHECKS: } \\
\text { September } 2009\end{array}$ \\
\hline $\begin{array}{l}\text { WA.15 } \\
\text { DISCHARGES TO } \\
\text { DOMESTIC SANITARY } \\
\text { SYSTEMS }\end{array}$ & \\
\hline $\begin{array}{l}\text { WA.15.1.OCAF. Installa- } \\
\text { tions must develop a base } \\
\text { standard wastewater treatment } \\
\text { procedure to govern the dis- } \\
\text { charge of industrial and non- } \\
\text { domestic waste to the sanitary } \\
\text { system by generating activi- } \\
\text { ties (AFI 32-1067, para 7.3.2) } \\
\text { [Moved June 2003]. }\end{array}$ & $\begin{array}{l}\text { Verify that the installation has a base standard wastewater treatment procedure to } \\
\text { govern the discharge of industrial and nondomestic waste to the sanitary system } \\
\text { by generating activities. } \\
\text { Verify that BCE outlines procedures for discharging industrial wastes to the sani- } \\
\text { tary system. } \\
\text { Verify that the procedures describe the following: } \\
\text { - pretreatment requirements } \\
\text { - discharge procedures } \\
\text { - effluent limitations for industrial waste. } \\
\text { (NOTE: The base commander or the municipal wastewater authority can impose } \\
\text { these requirements.) } \\
\text { Verify that generators follow the instructions given by BCE. } \\
\text { [Formerly checklist item WA.40.1.OCAF.] }\end{array}$ \\
\hline $\begin{array}{l}\text { WA.15.2.OCAF. Generators } \\
\text { must use pollution control } \\
\text { techniques to minimize pol- } \\
\text { lutant discharges (AFI 32- } \\
\text { 1067, para 7.3.2) [Moved } \\
\text { June 2003]. }\end{array}$ & $\begin{array}{l}\text { Verify that generators of discharges minimize the discharge of pollutants using } \\
\text { the pollution control techniques in AFI 32-7080. } \\
\text { (NOTE: See the pollution prevention subsection of Section 6, Other Environ- } \\
\text { mental Issues.) } \\
\text { [Formerly checklist item WA.40.2.OCAF.] }\end{array}$ \\
\hline $\begin{array}{l}\text { WA.15.3.OCAF. Hazardous } \\
\text { waste must not be discharged } \\
\text { to the collection system (AFI } \\
\text { 32-1067, para 7.3.2) [Moved } \\
\text { June 2003]. }\end{array}$ & $\begin{array}{l}\text { Verify that no hazardous waste is discharged to the collection system. } \\
\text { [Formerly checklist item WA.40.3.OCAF.] }\end{array}$ \\
\hline $\begin{array}{l}\text { WA.15.4.OCAF. Industrial } \\
\text { wastewater must not be dis- } \\
\text { charged to septic systems } \\
\text { (AFI 32-7041, para 2.15.1) } \\
\text { [Added December 2003]. }\end{array}$ & Verify that no industrial wastewater is discharged to a septic system. \\
\hline WA.15.5.OCAF. Installations & Determine whether the installation is subject to any applicable local regulations \\
\hline
\end{tabular}




\begin{tabular}{|c|c|}
\hline \multicolumn{2}{|r|}{$\begin{array}{l}\text { COMPLIANCE CATEGORY: } \\
\text { WASTEWATER MANAGEMENT } \\
\text { Overseas ESOHCAMP }\end{array}$} \\
\hline $\begin{array}{l}\text { REGULATORY } \\
\text { REQUIREMENTS: }\end{array}$ & $\begin{array}{l}\text { REVIEWER CHECKS: } \\
\text { September } 2009\end{array}$ \\
\hline $\begin{array}{l}\text { must comply with local regu- } \\
\text { lations regarding septic sys- } \\
\text { tems (AFI 32-7041, para } \\
\text { 2.15.3) [Added December } \\
\text { 2003]. }\end{array}$ & $\begin{array}{l}\text { regarding septic systems. } \\
\text { Verify that the installation complies with the provisions of applicable local regula- } \\
\text { tions regarding septic systems. }\end{array}$ \\
\hline
\end{tabular}


12-20

Wastewater 


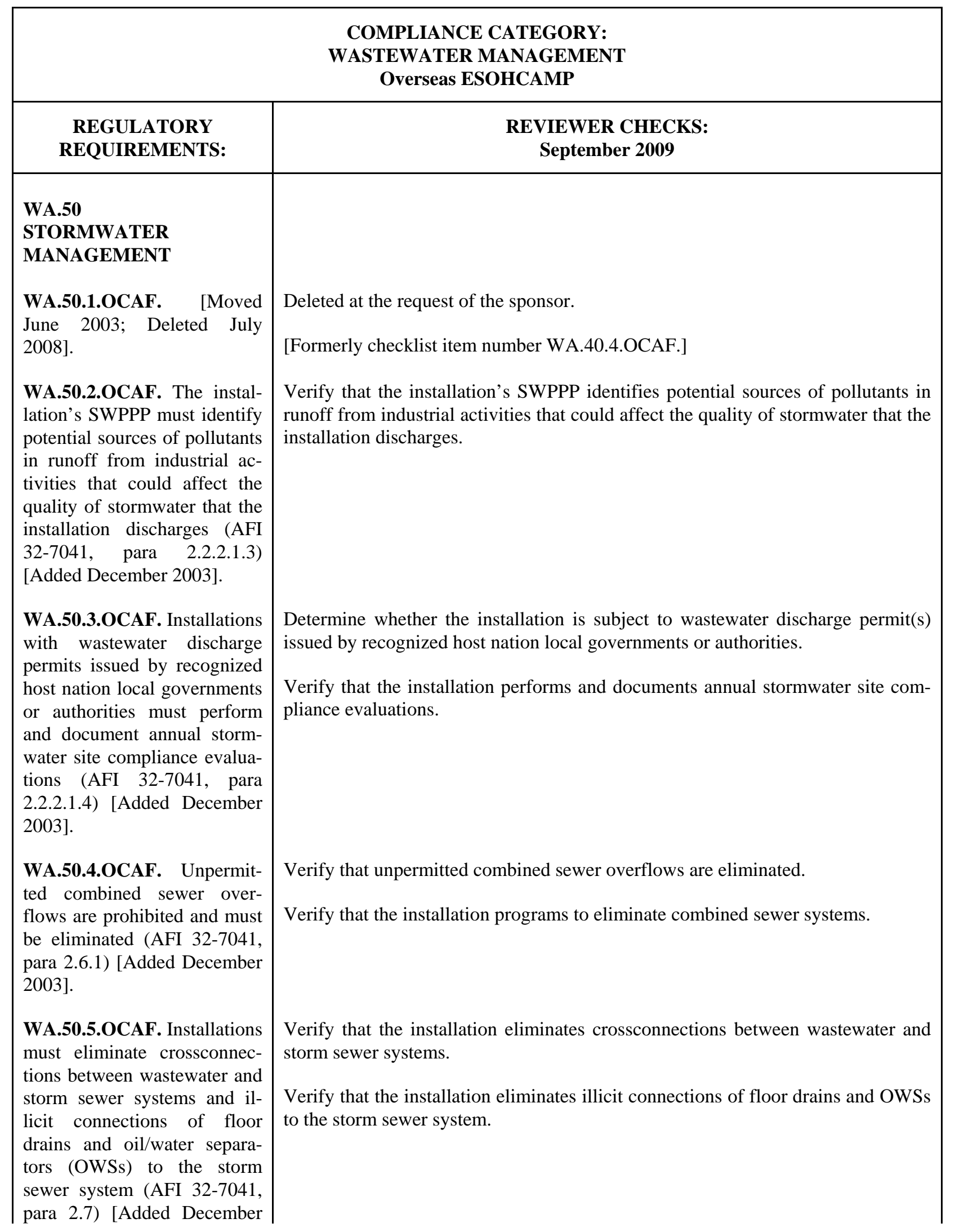




\begin{tabular}{|l|c|}
\hline \multicolumn{2}{|c|}{$\begin{array}{c}\text { COMPLIANCE CATEGORY: } \\
\text { WASTEWATER MANAGEMENT } \\
\text { Overseas ESOHCAMP }\end{array}$} \\
\hline $\begin{array}{c}\text { REGULATORY } \\
\text { REQUIREMENTS: }\end{array}$ & $\begin{array}{c}\text { REVIEWER CHECKS: } \\
\text { September 2009 }\end{array}$ \\
\hline $\begin{array}{l}\text { 2003]. } \\
\text { WA.50.6.OCAF. Installations } \\
\text { must minimize infiltration and } \\
\text { inflow to wastewater collec- } \\
\text { tion systems (AFI 32-7041, } \\
\text { para 2.8) [Added December } \\
\text { 2003]. }\end{array}$ & $\begin{array}{l}\text { Verify that the installation minimizes infiltration and inflow to wastewater collec- } \\
\text { tion systems. }\end{array}$ \\
\hline
\end{tabular}




\begin{tabular}{|c|c|}
\hline \multicolumn{2}{|r|}{$\begin{array}{l}\text { COMPLIANCE CATEGORY: } \\
\text { WASTEWATER MANAGEMENT } \\
\text { Overseas ESOHCAMP }\end{array}$} \\
\hline $\begin{array}{l}\text { REGULATORY } \\
\text { REQUIREMENTS: }\end{array}$ & $\begin{array}{l}\text { REVIEWER CHECKS: } \\
\text { September } 2009\end{array}$ \\
\hline $\begin{array}{l}\text { WA.60 } \\
\text { OIL/WATER } \\
\text { SEPARATORS }\end{array}$ & \\
\hline $\begin{array}{l}\text { WA.60.1.OCAF. [Deleted } \\
\text { December 2003]. }\end{array}$ & $\begin{array}{l}\text { This checklist item, based on HQ USAF/CE Oil/Water Separator Letter of } 21 \\
\text { October 1994, was deleted upon incorporation of AFI 32-7041 in December } \\
2003 \text {. }\end{array}$ \\
\hline $\begin{array}{l}\text { WA.60.2.OCAF. [Deleted } \\
\text { December 2003]. }\end{array}$ & $\begin{array}{l}\text { This checklist item, based on HQ USAF/CE Oil/Water Separator Letter of } 21 \\
\text { October 1994, was deleted upon incorporation of AFI 32-7041 in December } \\
2003 \text {. }\end{array}$ \\
\hline $\begin{array}{l}\text { WA.60.3.OCAF. [Deleted } \\
\text { December 2003]. }\end{array}$ & $\begin{array}{l}\text { This checklist item, based on HQ USAF/CE Oil/Water Separator Letter of } 21 \\
\text { October 1994, was deleted upon incorporation of AFI 32-7041 in December } \\
2003 \text {. }\end{array}$ \\
\hline $\begin{array}{l}\text { WA.60.4.OCAF. Installations } \\
\text { must not install any new } \\
\text { OWSs until all alternatives } \\
\text { have been evaluated (AFI 32- } \\
\text { 7041, para 2.10.1) [Added } \\
\text { December 2003]. }\end{array}$ & $\begin{array}{l}\text { Verify that the installation does not install any new OWSs until all alternatives } \\
\text { have been evaluated. } \\
\text { (NOTE: See Multiservice Oil/Water Separator Guidance Document, SFIM-AEC- } \\
\text { EQ-CR-200010). }\end{array}$ \\
\hline $\begin{array}{l}\text { WA.60.5.OCAF. Installations } \\
\text { must perform an OWS survey } \\
\text { to locate all existing OWS, } \\
\text { evaluate the need for them, } \\
\text { and identify opportunities to } \\
\text { consolidate or eliminate } \\
\text { OWSs (AFI 32-7041, para } \\
2.10 .2 \text { ) [Added December } \\
2003 \text { ]. }\end{array}$ & $\begin{array}{l}\text { Verify that the installation performs an OWS survey to locate all existing OWSs, } \\
\text { evaluates the need for them, and identifies opportunities to consolidate or elimi- } \\
\text { nate OWSs. } \\
\text { Verify that the installation implement pollution prevention principles and uses } \\
\text { BMPs to minimize the requirement for OWSs. }\end{array}$ \\
\hline $\begin{array}{l}\text { WA.60.6.OCAF. Installations } \\
\text { must eliminate unauthorized } \\
\text { waste discharges (AFI 32- } \\
\text { 7041, para 2.10.3) [Added } \\
\text { December 2003]. }\end{array}$ & $\begin{array}{l}\text { Verify that the installation eliminates unauthorized waste discharges. } \\
\text { Verify that, where feasible, floor drains are plugged to eliminate potential illicit } \\
\text { discharge points. } \\
\text { Verify that no one intentionally discharges or disposes of fuel, oil, grease, oily } \\
\text { waste, solvents, cleaning compounds, corrosion-control facility waste, or other } \\
\text { contaminants into OWSs. }\end{array}$ \\
\hline $\begin{array}{l}\text { WA.60.7.OCAF. OWSs must } \\
\text { not be used as containment } \\
\text { devices (AFI 32-7041, para } \\
2.10 .3 \text { ) [Added December }\end{array}$ & Verify that no OWS is used as a containment device. \\
\hline
\end{tabular}




\begin{tabular}{|c|c|}
\hline \multicolumn{2}{|r|}{$\begin{array}{l}\text { COMPLIANCE CATEGORY: } \\
\text { WASTEWATER MANAGEMENT } \\
\text { Overseas ESOHCAMP }\end{array}$} \\
\hline $\begin{array}{l}\text { REGULATORY } \\
\text { REQUIREMENTS: }\end{array}$ & $\begin{array}{l}\text { REVIEWER CHECKS: } \\
\text { September } 2009\end{array}$ \\
\hline 2003]. & \\
\hline $\begin{array}{l}\text { WA.60.8.OCAF. New in- } \\
\text { ground separators, including } \\
\text { associated oil recovery tanks, } \\
\text { must be installed over a dou- } \\
\text { ble liner or have double walls } \\
\text { and be equipped with a leak } \\
\text { detection system (AFI 32- } \\
7041 \text {, para 2.10.4) [Added } \\
\text { December 2003]. }\end{array}$ & $\begin{array}{l}\text { Verify that new in-ground separators, including associated oil recovery tanks, are } \\
\text { installed over a double liner or have double walls. } \\
\text { Verify that new in-ground separators, including associated oil recovery tanks, are } \\
\text { equipped with a leak detection system. } \\
\text { (NOTE: Separate oil recovery tanks may be regulated as underground storage } \\
\text { tanks.) }\end{array}$ \\
\hline $\begin{array}{l}\text { WA.60.9.OCAF. Installations } \\
\text { must perform regular sched- } \\
\text { uled inspections and mainte- } \\
\text { nance of all OWSs (AFI 32- } \\
\text { 7041, para 2.10.5) [Added } \\
\text { December 2003]. }\end{array}$ & $\begin{array}{l}\text { Verify that all OWSs are regularly inspected and maintained. } \\
\text { Verify that the installation has an inspection and maintenance schedule for all its } \\
\text { OWSs. }\end{array}$ \\
\hline $\begin{array}{l}\text { WA.60.10.0CAF. The instal- } \\
\text { lation must obtain an appro- } \\
\text { priate host nation wastewater } \\
\text { discharge permit if a non- } \\
\text { stormwater discharge from an } \\
\text { OWS to a wastewater treat- } \\
\text { ment plant is not possible } \\
\text { (AFI 32-7041, para 2.10.6) } \\
\text { [Added December 2003]. }\end{array}$ & $\begin{array}{l}\text { Verify that, if a nonstormwater discharge from an OWS to a wastewater treatment } \\
\text { plant is not possible, the installation obtains an appropriate host nation wastewater } \\
\text { discharge permit. }\end{array}$ \\
\hline
\end{tabular}




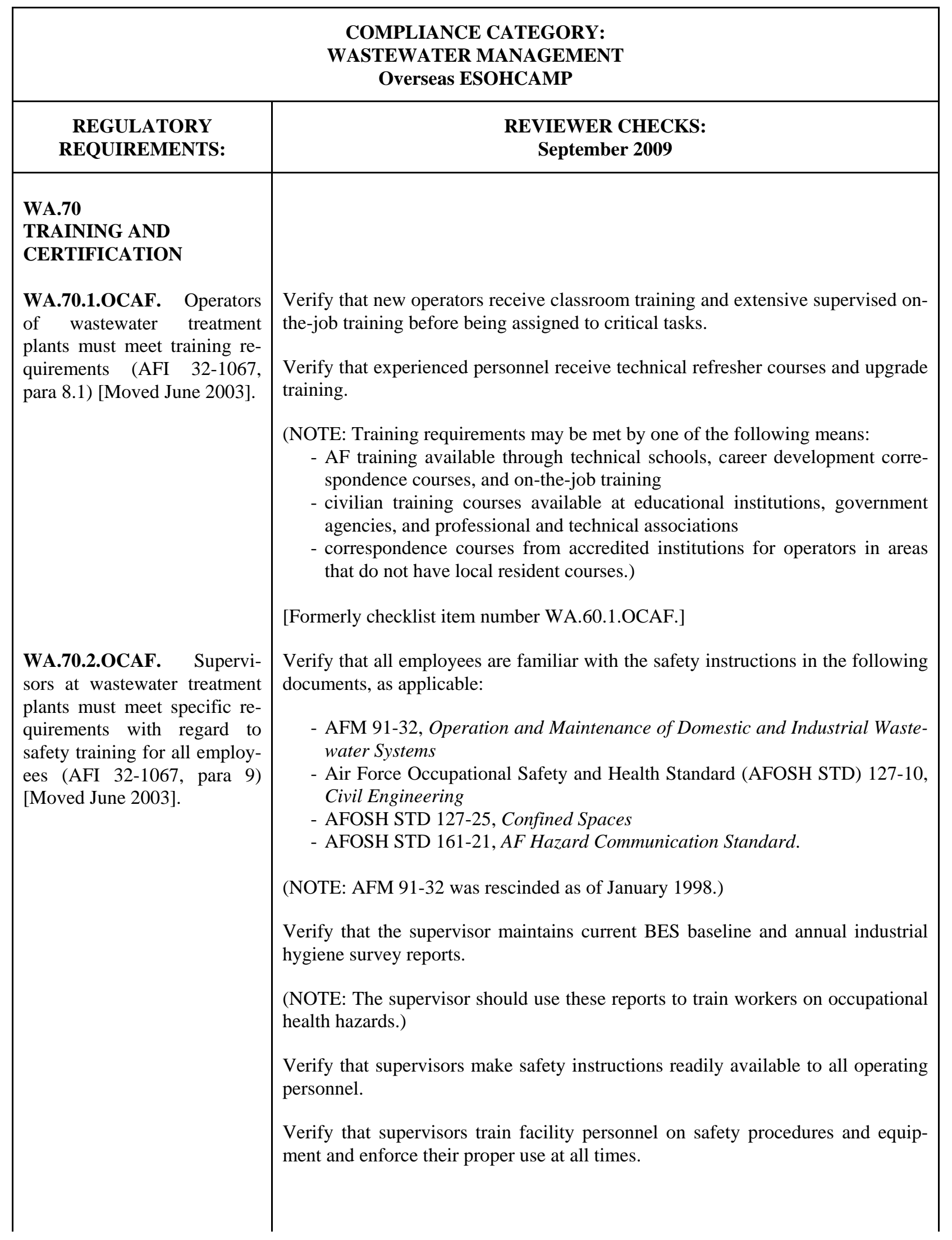




\begin{tabular}{|c|c|}
\hline \multicolumn{1}{|c|}{$\begin{array}{c}\text { COMPLIANCE CATEGORY: } \\
\text { WASTEWATER MANAGEMENT } \\
\text { Overseas ESOHCAMP }\end{array}$} \\
\hline $\begin{array}{c}\text { REGULATORY } \\
\text { REQUIREMENTS: }\end{array}$ & \multicolumn{1}{c|}{$\begin{array}{c}\text { REVIEWER CHECKS: } \\
\text { September 2009 }\end{array}$} \\
\hline & $\begin{array}{l}\text { (NOTE: Once trained, individual workers are personally responsible for following } \\
\text { safe procedures.) } \\
\text { [Formerly checklist item number WA.60.2.OCAF.] }\end{array}$ \\
\hline
\end{tabular}




\title{
SECTION 13
}

\section{WATER QUALITY MANAGEMENT}

\section{Overseas ESOHCAMP}

\author{
September 2009
}

\section{A. Service-Specific Regulations and Policies}

- Air Force Regulation (AFR) 91-26, Maintenance and Operation of Water Supply, Treatment, and Distribution Systems, 30 August 1984, provides guidance for personnel who maintain and operate water supply, treatment, and distribution systems on U.S. Air Force (AF) installations.

- AF Instruction (AFI) 32-1066, Backflow Prevention Program, 17 October 2007, provides guidance for personnel who maintain and operate plumbing systems on USAF installations. Through release of this AFI, the AF adopts the backflow requirements of the Uniform Plumbing Code (UPC) (2006 edition) and the UPC Illustrated Training Manual, published by the International Association of Plumbing and Mechanical Officials (IAPMO), $5001 \mathrm{E}$. Philadelphia Street, Ontario CA 91761 (909-472-4100/4208). IAPMO updates and republishes these publications every 3 yr. When an updated version of the UPC or UPC Illustrated Training Manual is published by IAPMO, the backflow requirements in these updated publications become a part of AFI 32-1066.

- AFI 32-1067, Water Systems, 25 March 1994, provides guidelines for managing water and wastewater systems at USAF bases.

- Headquarters (HQ) USAF/SG Policy Letter, Water Testing in Child Development Centers (CDCs), 21 October 1992, provides guidelines for monitoring drinking water at AF CDCs.

- HQ USAF/SGO Memorandum, AF Policy on Potable Water Vulnerability Assessment and Emergency Response Plans, dated 6 October 2003, implements DOD requirements (Policy Letter: 3 Jul 2003) and establishes AF requirements for Water Vulnerability Assessments (WVAs) and Emergency Response Plans (ERPs).

- HQ USAF/ILEV Memorandum, Revised Environmental Quality Metrics, 14 February 2005, requires immediate implementation across the AF (including overseas installations and government-owned/contractor-operated (GOCO) facilities of Under Secretary of Defense Memorandum, Revised Pollution Prevention and Compliance Metrics, dated 12 October 2004.

\section{B. DOD Directives and Instructions}

- Under Secretary of Defense Memorandum, Revised Pollution Prevention and Compliance Metrics, dated 12 October 2004, publishes pollution prevention (P2) metrics and definitions. Implementation begins in 2005. The following goals for drinking water are established in the memorandum:

1. Ensure we consistently provide safe drinking water to protect the health of people living and working on our installations.

2. Protect, restore, and sustain water resources to ensure long term capability at installations

3. Support readiness by conserving resources through efficient management of drinking water assets.

\section{Service-specific/DOD Definitions}

- Appropriate DOD Medical Authority - the medical professional designated by the in-theater component commander (overseas) or the installation commander (U.S.) to be responsible for resolving medical issues necessary 
to provide safe drinking water at the component's installations (Attachment 2, Under Secretary of Defense Memorandum, Revised Pollution Prevention and Compliance Metrics, 12 October 2004).

- Approved Device - an approved device is a device that has been tested and approved by the International Association of Plumbing and Mechanical Officials (IAPMO) laboratory. IAPMO-approved devices carry an attached or imprinted IAPMO seal of approval. Alternately, acceptable devices are those approved by the Foundation for Cross-Connection Control and Hydraulic Research (FCCCHR) or the American Society of Sanitary Engineering (ASSE) (AFI 32-1066, para 5.1).

(NOTE: The Base Civil Engineer [BCE], with Bioenvironmental Engineer [BEE] and command backflow prevention manager [BPM] coordination, may authorize the use of new devices not yet approved by IAPMO, FCCCHR, or ASSE; however, the BCE must be confident that the use of these devices and their installation location and orientation will provide adequate protection.)

- Backflow Preventer (Device or Assembly) - a device or assembly to prevent backflow into the potable water system. The terms "backflow preventer," "backflow device," and "backflow assembly" are used interchangeably in the industry and in AFI 32-1066 (AFI 32-1066, para 5.2).

- Backflow Prevention/Cross-Connection Survey (Survey) - the survey and related tasks are described in AFI 321066, paras 7 through 7.4. The survey of backflow prevention assemblies and cross-connections will be conducted at least every 5 yr by qualified personnel in accordance with AFI 32-1066, para 9.4 (AFI 32-1066, para 5.3).

- Backflow Prevention Test and Inspection (Test) - this term refers to an annual inspection and testing of backflow prevention assemblies by certified technicians. AFI 32-1066, paras 8 and 9 detail testing and technician certification requirements, respectively (AFI 32-1066, para 5.4).

- Critical Water System - a facility or piece of equipment where a temporary loss of water service would directly and significantly impact military operations and where no alternative "work-arounds" or mitigation measures are feasible (AFI 32-1066, para 5.9).

- Cross-Connection - any connection between a potable water supply system and any system, fixture, or other device through which it may be possible for nonpotable, polluted or contaminated water, or other substances to enter the potable water system under any condition (AFI 32-1066, para 5.8).

- Drinking Water Management Costs - drinking water management is defined as nonrecurring environmental compliance costs, noting that this is only one part of the management costs. Drinking water management does not include permitting, sampling/analysis/monitoring; inspections; and training (Attachment 2, Under Secretary of Defense Memorandum, Revised Pollution Prevention and Compliance Metrics, 12 October 2004).

- DOD Population Served - the number of people who are provided water by a DOD public water system (regulated and unregulated). To determine a fixed number for the population served by an unregulated DOD public water system, use the highest daily average population served by that system during the year. Determine the public water system population by counting the total number of year-round residents plus the average number of regular consumers served (same persons), per day, during the month plus the average number of transient consumers served per day, during the month (Attachment 2, Under Secretary of Defense Memorandum, Revised Pollution Prevention and Compliance Metrics, 12 October 2004).

- High Hazard - a high hazard is also defined as "contamination" and is an impairment of the quality of the potable water that creates an actual hazard to public health through poisoning or through the spread of disease by sewage, industrial fluids, chemicals, or wastewaters (AFI 32-1066, para 5.6).

- Low Hazard - a low hazard is also defined as "pollution" and is an impairment of the quality of the potable water to a degree that does not create a significant hazard to the public health, but that does adversely and unreasonably affect the aesthetic quality of potable water for potable use (AFI 32-1066, para 5.7). 
- Notification Requirements Overseas - when a DOD public water system is out of compliance as set forth in the OEBGD/FGS potable water criteria, the operator will notify the appropriate DOD medical authority and installation personnel (U.S. and host nation). The notice will provide a clear and readily understandable explanation of the violation, any potential adverse health effects, the population at risk, the steps taken to correct the system violation, the necessity for seeking alternative water supply, if any, and any preventive measures the consumer should take until the violation is corrected. The appropriate DOD medical authority will coordinate notification of host authorities in cases where off-installation populations are at risk (Attachment 2, Under Secretary of Defense Memorandum, Revised Pollution Prevention and Compliance Metrics, 12 October 2004).

- Overseas - outside any territory, possession, or commonwealth of the United States. This does not include contingency operations, training deployments, or the operations of military vessels and aircraft (Attachment 2, Under Secretary of Defense Memorandum, Revised Pollution Prevention and Compliance Metrics, 12 October 2004).

- Overseas Installations - permanent, base force structure facilities under the operational control of the Secretary of a military department or the Department of Defense that is located outside the United States and outside any territory, commonwealth or possession of the United States. Installations overseas do NOT include temporary, contingency operation or deployment support facilities. Tenants on overseas installations should report through their component headquarters reporting systems (Attachment 2, Under Secretary of Defense Memorandum, Revised Pollution Prevention and Compliance Metrics, 12 October 2004).

(NOTE: Include Government-owned, Contractor-operated [GOCO] installations.)

- Nonrecurring Compliance Cost - environmental compliance costs identified as obligated/executed for the Safe Drinking Water Act entry at Tab E of the POM Preparation Instructions. This includes, but is not limited to, investments for new requirements or upgrades to existing systems that meet or maintain existing compliance with the Safe Drinking Water Act (Attachment 2, Under Secretary of Defense Memorandum, Revised Pollution Prevention and Compliance Metrics, 12 October 2004).

- Provide Drinking Water - DOD public water systems that produce, procure, or distribute drinking water for human consumption. This specifically excludes nonpublic water systems (Attachment 2, Under Secretary of Defense Memorandum, Revised Pollution Prevention and Compliance Metrics, 12 October 2004).

- Readily Accessible - a device that is readily accessible is one that is located to within 1 to $5 \mathrm{ft}$ above the floor or grade to provide access with adequate clearance for testing, maintenance, and repair (AFI 32-1066, para 5.5).

(NOTE: In addition, devices should be installed at least $1 \mathrm{ft}$ from the back wall, have at least $1 \mathrm{ft}$ above for maintenance, and have a minimum of $2 \mathrm{ft}$ clearance on the side of the valve on which the test cocks are located. If a new or existing device is located higher than $5 \mathrm{ft}$ above the grade or floor, a permanent platform or structure shall be provided for safely inspecting, testing, and maintaining the device.)

- Regulated Public Water System (PWS) - for overseas, a DOD PWS subject to FGS or international treaty (Attachment 2, Under Secretary of Defense Memorandum, Revised Pollution Prevention and Compliance Metrics, 12 October 2004). 


\section{Additional Records To Review}

- Facility survey of plumbing devices and systems

- Backflow prevention documentation

- Training and certification documentation

- Treatment plant operating logs

- Records for wells and pumping stations

- Local operating procedures for the treatment plant

\section{E. Additional Physical Features To Inspect}

- Potential cross-connections

- Backflow prevention devices

- Water supply sources and well heads

- Current BES baseline and annual industrial hygiene survey reports

\section{F. Guidance for Checklist Users}

\section{REFER TO CHECKLIST ITEMS:}

Missing Checklist Items/Positive Findings

General

Backflow Prevention

Child Development Centers (CDCs)

Recordkeeping and Notification Requirements

Training and Certification
WQ.2.1.OCAF and WQ.2.2.OCAF

WQ.10.1.OCAF through WQ.10.12.OCAF

WQ.15.1.OCAF through WQ.15.40.OCAF

WQ.35.1.OCAF through WQ.35.5.OCAF

WQ.40.1.OCAF through WQ.40.7.OCAF

WQ.80.1.OCAF and WQ.80.2.OCAF 


\begin{tabular}{|c|c|}
\hline \multicolumn{2}{|r|}{$\begin{array}{l}\text { COMPLIANCE CATEGORY: } \\
\text { WATER QUALITY MANAGEMENT } \\
\text { Overseas ESOHCAMP }\end{array}$} \\
\hline $\begin{array}{l}\text { REGULATORY } \\
\text { REQUIREMENTS: }\end{array}$ & $\begin{array}{l}\text { REVIEWER CHECKS: } \\
\text { September } 2009\end{array}$ \\
\hline $\begin{array}{l}\text { WQ.2 } \\
\text { MISSING CHECKLIST } \\
\text { ITEMS/POSITIVE } \\
\text { FINDINGS }\end{array}$ & \\
\hline $\begin{array}{l}\text { WQ.2.1.OCAF. Installations } \\
\text { must comply with all applica- } \\
\text { ble regulatory requirements } \\
\text { not contained in this checklist } \\
\text { (a finding under this checklist } \\
\text { item will have the citation of } \\
\text { the applied regulation as a } \\
\text { basis of finding) [Added } \\
\text { March 2002]. }\end{array}$ & $\begin{array}{l}\text { Determine whether any new regulations concerning water quality management } \\
\text { have been issued since the finalization of the manual. } \\
\text { Determine whether the installation has activities or facilities that are regulated but } \\
\text { not addressed in this checklist. } \\
\text { Verify that the installation is in compliance with all applicable and newly issued } \\
\text { regulations. }\end{array}$ \\
\hline $\begin{array}{l}\text { WQ.2.2.OCAF. Installations } \\
\text { should go above and beyond } \\
\text { environmental statutory and } \\
\text { regulatory compliance (MP) } \\
\text { [Added March 2002]. }\end{array}$ & $\begin{array}{l}\text { Determine whether the installation has gone above and beyond simply complying } \\
\text { with environmental requirements. } \\
\text { (NOTE: This checklist item is used only to write positive findings.) }\end{array}$ \\
\hline
\end{tabular}




\begin{tabular}{|c|c|}
\hline \multicolumn{2}{|r|}{$\begin{array}{c}\text { COMPLIANCE CATEGORY: } \\
\text { WATER QUALITY MANAGEMENT } \\
\text { Overseas ESOHCAMP }\end{array}$} \\
\hline $\begin{array}{l}\text { REGULATORY } \\
\text { REQUIREMENTS: }\end{array}$ & $\begin{array}{l}\text { REVIEWER CHECKS: } \\
\text { September } 2009\end{array}$ \\
\hline $\begin{array}{l}\text { WQ.10 } \\
\text { GENERAL }\end{array}$ & \\
\hline $\begin{array}{l}\text { WQ.10.1.OCAF. } \quad \text { [Moved } \\
\text { March 2002]. }\end{array}$ & Moved to WQ.2.1.OCAF. \\
\hline $\begin{array}{l}\text { WQ.10.2.OCAF. Installations } \\
\text { must meet requirements con- } \\
\text { tained in MAJCOM supple- } \\
\text { ments to AFIs and policy } \\
\text { documents (a finding under } \\
\text { this checklist item will have } \\
\text { the citation of the MAJCOM } \\
\text { document as a basis of find- } \\
\text { ing). }\end{array}$ & $\begin{array}{l}\text { Determine whether the requirements in MAJCOM supplements to AFIs and pol- } \\
\text { icy documents are within the scope of the environmental compliance assessment. } \\
\text { Verify that the installation is in compliance with MAJCOM requirements. }\end{array}$ \\
\hline $\begin{array}{l}\text { WQ.10.3.OCAF. [Moved } \\
\text { March 2002]. }\end{array}$ & Moved to WQ.2.2.OCAF. \\
\hline $\begin{array}{l}\text { WQ.10.4.OCAF. OCONUS } \\
\text { installations must cooperate } \\
\text { with foreign regulatory agen- } \\
\text { cies (AFI 32-1067, para 14.1). }\end{array}$ & $\begin{array}{l}\text { Verify that the installation cooperates with host nation regulatory agencies, con- } \\
\text { sistent with host nation agreements. }\end{array}$ \\
\hline $\begin{array}{l}\text { WQ.10.5.OCAF. Bases must } \\
\text { not have dual water supply } \\
\text { systems for potable and non- } \\
\text { potable water unless certain } \\
\text { conditions have been met } \\
\text { (AFI 32-1067, para 12.1). }\end{array}$ & $\begin{array}{l}\text { Verify that the following conditions are met by bases with dual water supply sys- } \\
\text { tems: } \\
\text { - BCE establishes and maintains a clearly defined separation of the two sys- } \\
\text { tems so that nonpotable water cannot contaminate the potable water system } \\
\text { - the systems have approved backflow prevention devices to prevent contami- } \\
\text { nation of potable water } \\
\text { - the MAJCOM approves the dual system before construction and operation } \\
\text { - connections between systems are avoided. }\end{array}$ \\
\hline $\begin{array}{l}\text { WQ.10.6.OCAF. Installa- } \\
\text { tions must use municipal or } \\
\text { regional water supply systems } \\
\text { where feasible (AFI 32-1067, } \\
\text { para 2) [Moved June 2003]. }\end{array}$ & $\begin{array}{l}\text { Verify that the installation uses a municipal or regional water system where feasi- } \\
\text { ble. } \\
\text { Verify that a life-cycle cost analysis is performed to determine the most cost- } \\
\text { effective approach. } \\
\text { [Formerly checklist item number WQ.30.1.OCAF.] }\end{array}$ \\
\hline $\begin{array}{l}\text { WQ.10.7.OCAF. BCE must } \\
\text { develop local operating in- } \\
\text { structions that address specific } \\
\text { topics (AFI 32-1067, para 4.3) }\end{array}$ & $\begin{array}{l}\text { Verify that BCE has developed local operating instructions that include the fol- } \\
\text { lowing: } \\
\text { - operational monitoring for process control }\end{array}$ \\
\hline
\end{tabular}




\section{COMPLIANCE CATEGORY: \\ WATER QUALITY MANAGEMENT \\ Overseas ESOHCAMP}

\begin{tabular}{|l|}
\hline $\begin{array}{c}\text { REGULATORY } \\
\text { REQUIREMENTS: }\end{array}$ \\
\hline [Moved June 2003]. \\
\\
WQ.10.8.OCAF. Each sepa- \\
rate water supply source must \\
have a water meter and a raw \\
water sampling point (AFI 32- \\
1067, para 6) [Moved June \\
2003].
\end{tabular}

WQ.10.9.OCAF. Each active well should have an air line or electric depth gauge to measure drawdown, static level, and pumping level (MP) [Moved June 2003].

WQ.10.10.OCAF. All drinking water systems that serve more than 25 people must undergo a water vulnerability assessment (HQ USAF/SGO Memorandum, AF Policy on Potable Water Vulnerability Assessment and Emergency Response Plans, Attachment 1) [Added March 2005].
REVIEWER CHECKS: September 2009

- sampling and testing procedures

- emergency operations

- maintenance

- regulatory compliance requirements.

[Formerly checklist item number WQ.30.2.OCAF.]

Verify that each separate water supply source has a water meter and a raw water sampling point for water quality monitoring.

[Formerly checklist item number WQ.30.3.OCAF.]

Verify that each active well has an air line or electric depth gauge to measure draw down, static level, and pumping level.

(NOTE: This MP is drawn from AFI 32-1067, para 6.)

[Formerly checklist item number WQ.30.4.OCAF.]

(NOTE: This checklist item applies to all AF drinking water systems that serve more than 25 consumers, including overseas systems that produce water and/or are provided water by a local supplier.)

(NOTE: Privatized systems and single buildings [such as an office building] connected to a municipal water system do not require a separate WVA. Security and water managers of these systems are encouraged to work with their suppliers to obtain relevant vulnerability assessment information and are encouraged to perform abbreviated WVAs that address the applicable criteria contained in Appendix 13-1.)

Verify that the WVA is conducted by a team of functional experts that includes, at a minimum, Bioenvironmental Engineering (BE) and Civil Engineering (CE) and is supported by the installation Antiterrorism Officer (ATO).

(NOTE: In accordance with current AF policy, BE is responsible for WVA requirements and CE is responsible for updating water-system-related ERP requirements.)

Verify that system WVAs are completed according to AF-developed criteria as outlined in Appendix 13-1.

(NOTE: Individual MAJCOMs may maintain their own requirements for WVAs and subsequent reports; at a minimum they must include the criteria specified in all sections of Appendix 13-1.) 


\section{COMPLIANCE CATEGORY: \\ WATER QUALITY MANAGEMENT \\ Overseas ESOHCAMP}

\section{REGULATORY REQUIREMENTS:}

WQ.10.11.OCAF. After the completion of a WVA, the installation's water-systemrelated ERP must be updated (HQ USAF/SGO Memorandum, AF Policy on Potable Water Vulnerability Assessment and Emergency Response Plans, Attachment 1) [Added March 2005].

\section{REVIEWER CHECKS: September 2009}

Verify that system WVAs are completed in accordance with the AF-unique deadlines in Appendix 13-2.

Verify that data collected during the WVA process is controlled for security reasons.

Verify that the final WVA is appropriately classified.

Verify that the installation submits its WVA and certifications to the MAJCOM Bioenvironmental Engineer (BEE).

(NOTE: The MAJCOM BEE submits WVAs to a single account at SGZE.group@af.pentagon.smil.mil and WVA certifications to SGZE.group@pentagon.af.mil. All WVAs and certifications are to be sent to AFMSA/SGPE, no later than three weeks prior to the AF deadlines established in Row 1 of Appendix 13-2.)

Verify that all vulnerabilities related to intentional water system threats are provided to the local FPWG and ATO for potential loading into the Vulnerability Assessment Management Program (VAMP) to ensure the findings are appropriately tracked and monitored.

(NOTE: Findings are specific issues or circumstances that can be exploited to cause the installation to suffer a definite degradation of public health or mission capability as a result of having been subjected to intentional or unintentional acts.)

(NOTE: This checklist item applies to all drinking water systems that serve more than 25 consumers, including overseas systems that produce water and/or are provided water by a local supplier.)

(NOTE: Privatized systems and single buildings [such as an office building] connected to a municipal water system do not require a separate WVA. Security and water managers of these systems are encouraged to work with their suppliers to obtain relevant vulnerability assessment information and are encouraged to perform abbreviated WVA(s) that address the applicable criteria contained in Appendix 13-1.)

Verify that CE updates the installation contingency response plan for water utility actions in response to man-made or natural/sanitary findings identified by the WVA Team.

Verify that CE incorporates this guidance into the installation's local watersystem-related ERP.

Verify that the ERP delineates the organizational structure within the installation that will be responsible for incident response and management.

Verify that this structure identifies specific roles and responsibilities for decision- 


\section{COMPLIANCE CATEGORY: \\ WATER QUALITY MANAGEMENT \\ Overseas ESOHCAMP}

\begin{tabular}{|c|c|}
\hline $\begin{array}{l}\text { REGULATORY } \\
\text { REQUIREMENTS: }\end{array}$ & $\begin{array}{l}\text { REVIEWER CHECKS: } \\
\text { September } 2009\end{array}$ \\
\hline $\begin{array}{l}\text { WQ.10.12.OCAF. All instal- } \\
\text { lations that provide drinking } \\
\text { water under the Final Govern- } \\
\text { ing Standards or international } \\
\text { treaties must report specific } \\
\text { information on a calendar year } \\
\text { basis (HQ USAF/ILEV } \\
\text { Memorandum, Revised Envi- } \\
\text { ronmental Quality Metrics, } 14 \\
\text { February 2005, para 1; Under } \\
\text { Secretary of Defense Memo- } \\
\text { randum, Revised Pollution } \\
\text { Prevention and Compliance } \\
\text { Metrics, 12 October 2004; } \\
\text { Attachment 1, paras I.c.2 and } \\
\text { I.d.1 through I.d.3) [Added } \\
\text { March 2005]. }\end{array}$ & 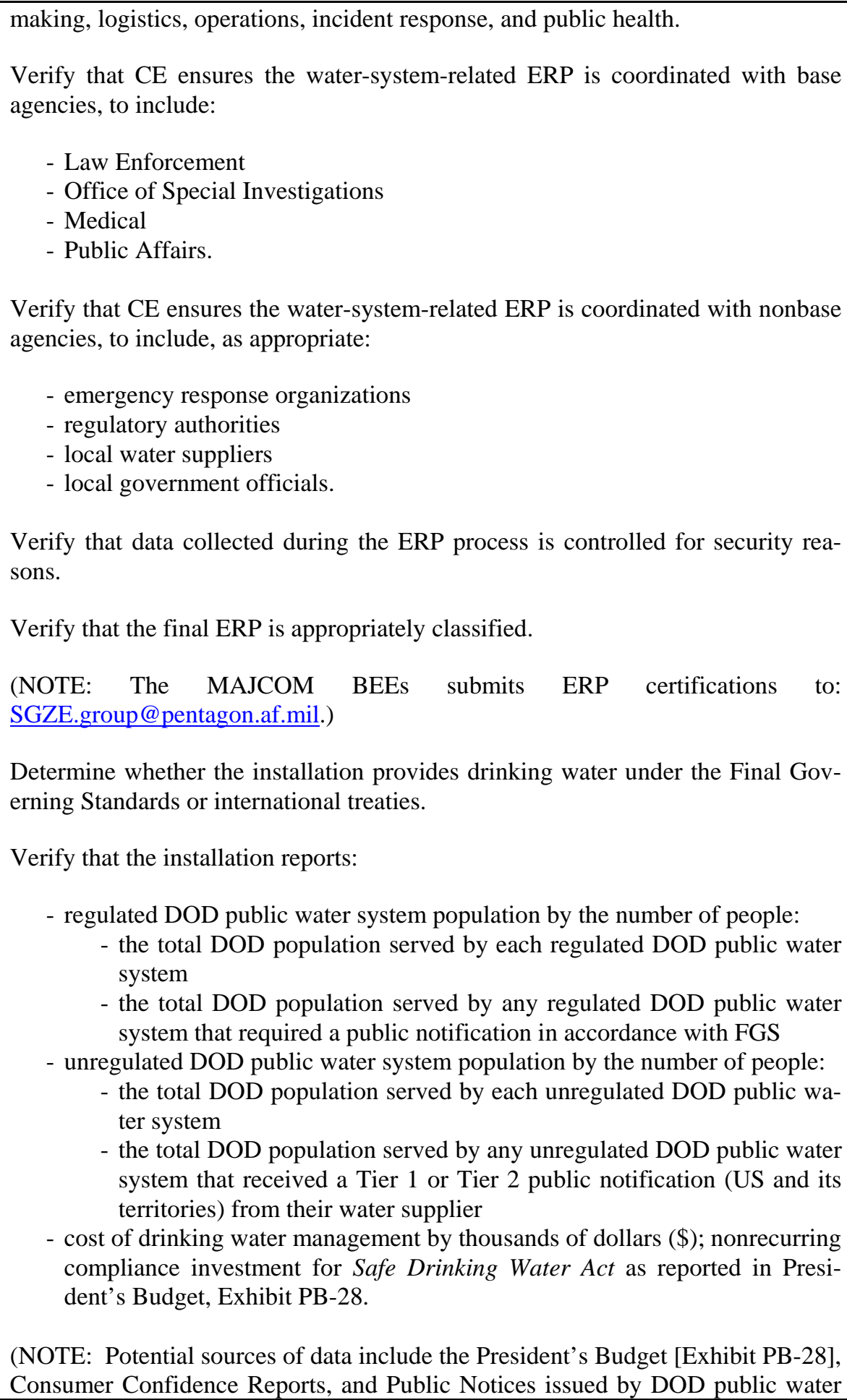 \\
\hline
\end{tabular}




\begin{tabular}{|c|c|}
\hline \multicolumn{2}{|c|}{$\begin{array}{c}\text { COMPLIANCE CATEGORY: } \\
\text { WATER QUALITY MANAGEMENT } \\
\text { Overseas ESOHCAMP }\end{array}$} \\
\hline $\begin{array}{c}\text { REGULATORY } \\
\text { REQUIREMENTS: }\end{array}$ & $\begin{array}{c}\text { REVIEWER CHECKS: } \\
\text { September 2009 }\end{array}$ \\
\hline & system or its supplier.) \\
& (NOTE: Begin collecting this data in Calendar Year 2005.) \\
\hline
\end{tabular}




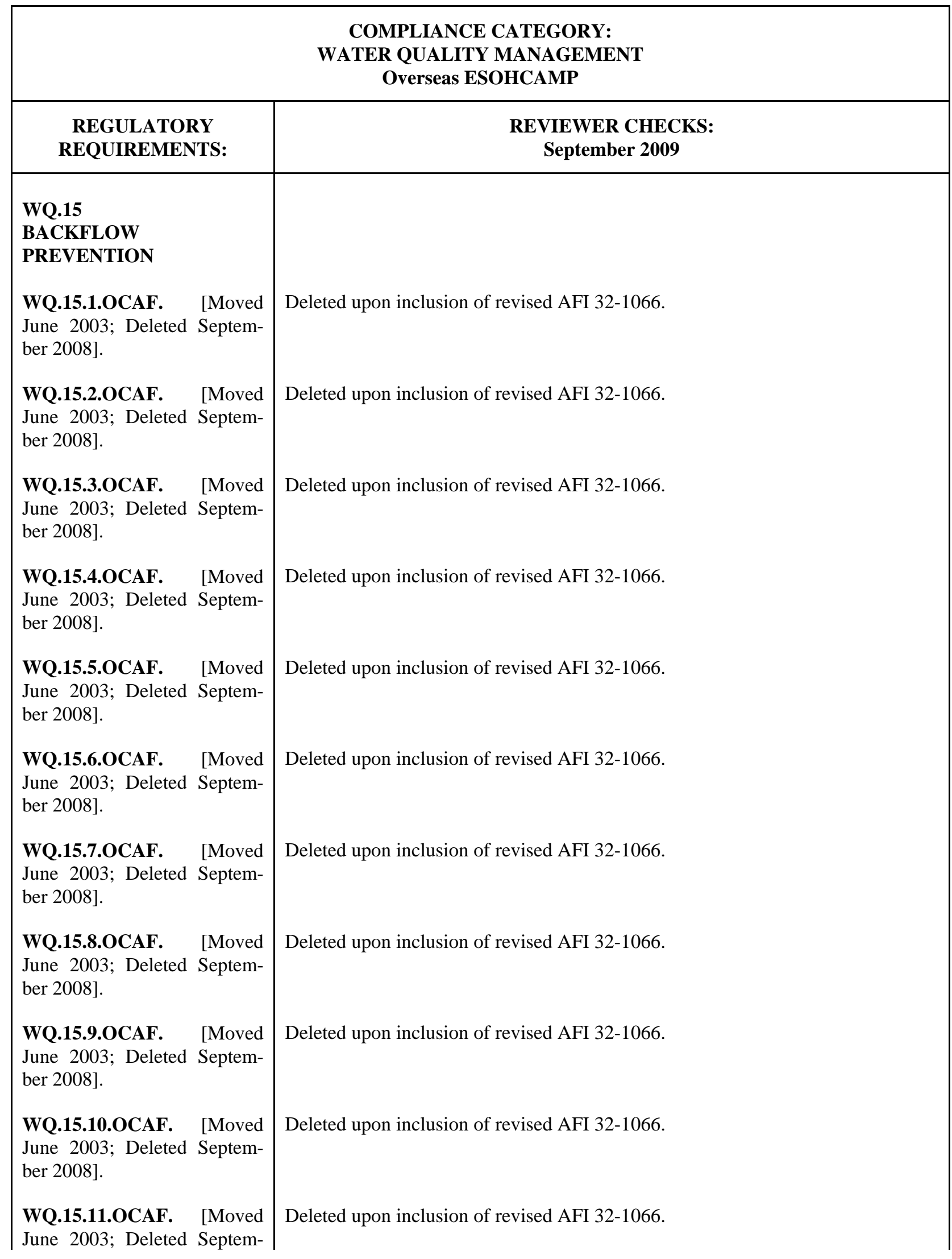




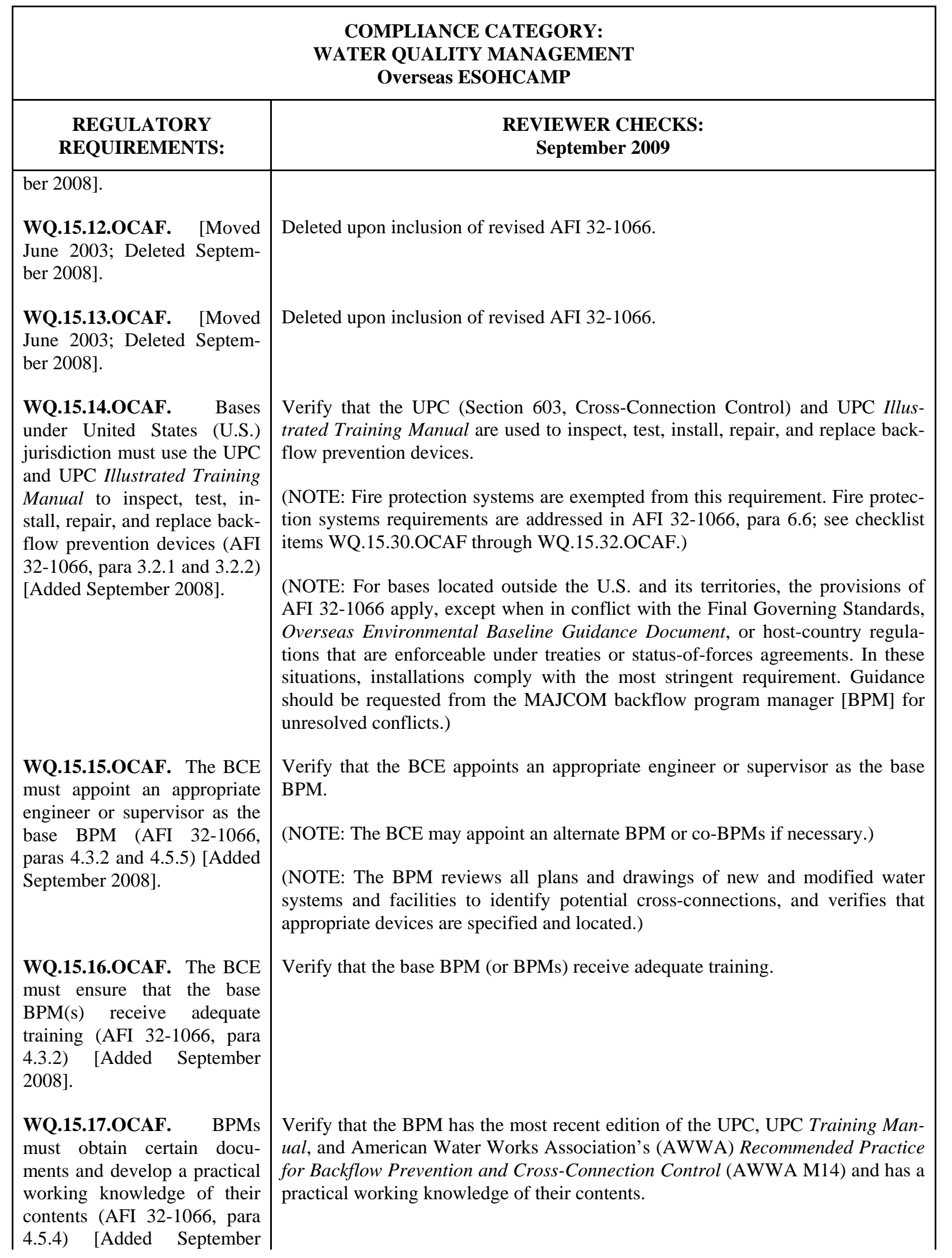




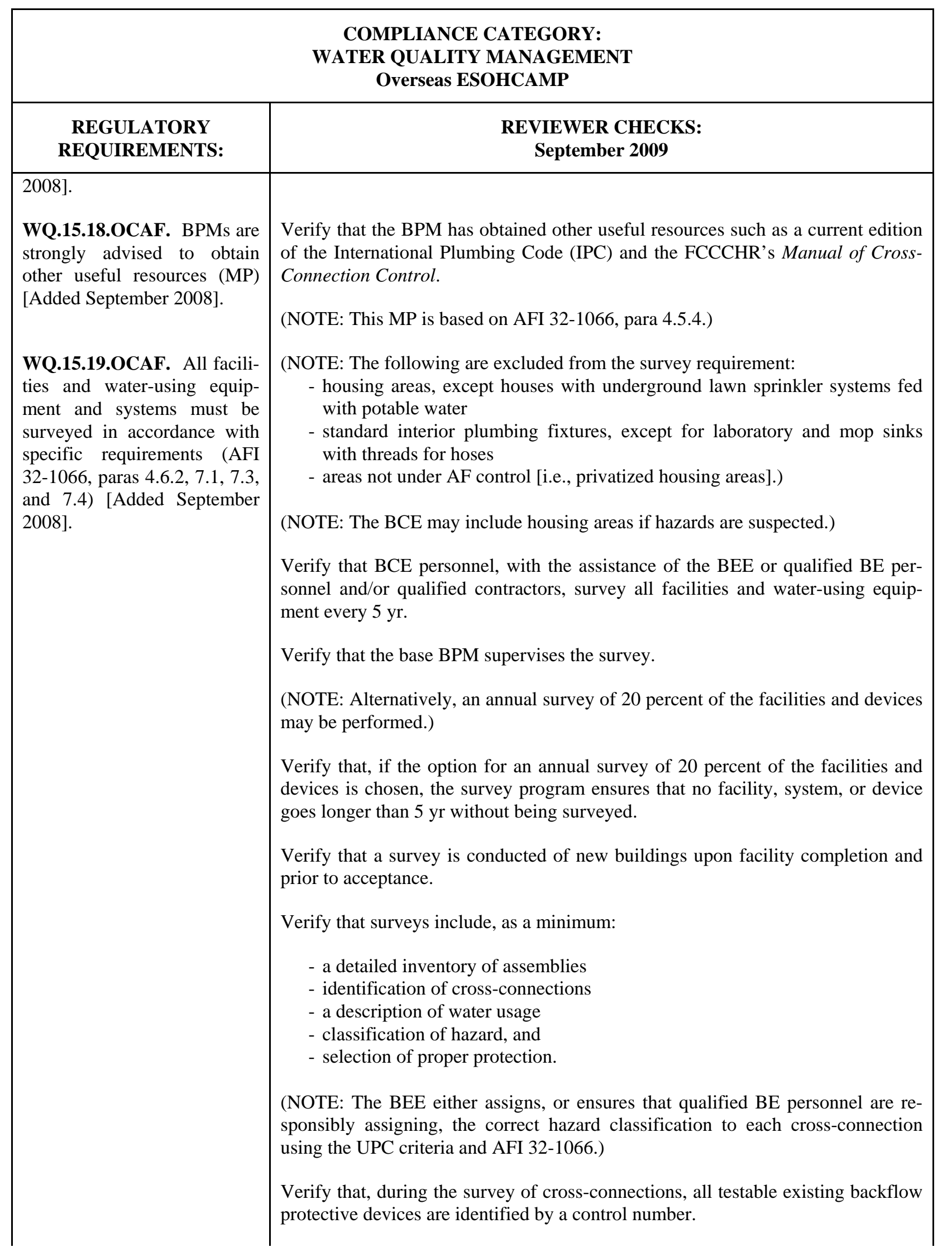




\section{COMPLIANCE CATEGORY: \\ WATER QUALITY MANAGEMENT \\ Overseas ESOHCAMP}

\begin{tabular}{|c|c|}
\hline $\begin{array}{l}\text { REGULATORY } \\
\text { REQUIREMENTS: }\end{array}$ & $\begin{array}{l}\text { REVIEWER CHECKS: } \\
\text { September } 2009\end{array}$ \\
\hline $\begin{array}{l}\text { WQ.15.20.OCAF. Cross- } \\
\text { connection/backflow survey- } \\
\text { ors must meet specific re- } \\
\text { quirements (AFI 32-1066, } \\
\text { paras 7.1, 9, and 9.4) [Added } \\
\text { September 2008]. }\end{array}$ & $\begin{array}{l}\text { Verify that, during the survey of cross-connections, all unapproved or nontestable } \\
\text { devices are listed for replacement. } \\
\text { (NOTE: In accordance with the HQ USAF/ILEV policy letter dated } 9 \text { August } \\
\text { 2002, backflow surveys are not eligible for environmental funding.) } \\
\text { Verify that cross-connection/backflow surveyors either meet AF surveyor re- } \\
\text { quirements or are certified by the state as a backflow/cross-connection surveyor. } \\
\text { Verify that AF surveyors have satisfactorily completed a training program such } \\
\text { as: } \\
\text { - a survey course addressing Federal and state regulations, cross-connection } \\
\text { identification, and types and uses of backflow prevention devices recognized } \\
\text { by the host state } \\
\text { - a survey course addressing Federal and state regulations, cross-connection } \\
\text { identification, and types and uses of backflow prevention devices sponsored } \\
\text { by a nationally or internationally recognized professional organization with } \\
\text { written and performance examinations } \\
\text { - graduation from an appropriate Bachelor-level engineering program ap- } \\
\text { proved by the Accreditation Board for Engineering and Technology, along } \\
\text { with backflow training. }\end{array}$ \\
\hline
\end{tabular}

[Author's Note: AFI 32-1066, para 9.4, does not specifically address how the qualifications of backflow prevention surveyors are to be evaluated on installations in a foreign country or territory. In the event that a means of demonstrating surveyor qualifications other than those presented in the AFI seems appropriate, BPMs on installations in foreign countries or territories should consider reviewing the qualifications of their surveyors with the MAJCOM BPM prior to conducting a survey.]

WQ.15.21.OCAF. The results of the backflow prevention/cross-connection survey must be documented (AFI 321066, para 7.2) [Added September 2008].

WQ.15.22.OCAF. The BPM must centrally maintain documentation related to the backflow prevention program (AFI 32-1066, paras 4.5.1, 7.2, and 8.4.2) [Added Sep-

Verify that the results of the survey are documented on AF Form 848 or a computerized maintenance management system (CMMS).

(NOTE: CMMS records must record information that is equivalent to the information on the AF form. With adequate information, these documents are a suitable substitute to using the prescribed AF form. The BPM uses this information to maintain other records for installed devices and to set testing schedules.)

Verify that the survey team documents the requirements for new or additional backflow prevention devices.

Verify that the BPM centrally maintains inspection records and the status of installation and upgrade actions.

(NOTE: BPMs are responsible for following up corrective actions identified in the backflow prevention device and cross-connection survey and assisting techni- 


\section{COMPLIANCE CATEGORY: \\ WATER QUALITY MANAGEMENT \\ Overseas ESOHCAMP}

\begin{tabular}{|l|}
\hline \multicolumn{1}{|c|}{ REGULATORY } \\
REQUIREMENTS: \\
\hline tember 2008]. \\
\\
WQ.15.23.0CAF. Immedi- \\
ate actions must be taken to \\
eliminate high (i.e., contami- \\
nation) cross-connection haz- \\
ards (AFI 32-1066, para 7.2) \\
[Added September 2008]. \\
WQ.15.24.OCAF. If it is not \\
feasible to eliminate a cross- \\
connection, an approved \\
backflow prevention device- \\
must be installed (AFI 32- \\
1066, para 6.1) [Added Sep- \\
tember 2008].
\end{tabular}

WQ.15.25.OCAF. If the water use served by a backflow preventer is deemed critical by the BCE, approved backflow preventers must be installed in parallel (AFI 321066, para 6.1) [Added September 2008].

WQ.15.26.OCAF. New and existing backflow devices must be planned for and installed to be readily accessible (AFI 32-1066, para 6.2) [Added September 2008].

cians in addressing corrective actions.)

Verify the base BPM maintains backflow prevention and cross-connection control program documents at a central location.

Verify that the BPM maintains and updates inventory records of all device locations (AF Form 848) and copies of individual records (AF Form 845) for each assembly.

(NOTE: Upon implementation of ACES-PM, backflow assembly information should be entered and subsequently managed via this module. Although ACESPM will be available to installations, the base BPM may approve use of a different CMMS for data management. It is the responsibility of the base BPM to ensure that technicians' records are complete and current.)

Verify that immediate actions are taken to eliminate high (i.e., contamination) cross-connection hazards.

(NOTE: BCE personnel must first consider designing a solution to eliminate the potential for a cross-connection.)

Verify that, if it is not feasible to eliminate a cross-connection, an approved backflow prevention device has been installed.

(NOTE: The purpose of the device is to prevent contamination of potable water supplies susceptible to backpressure or back-siphonage from any contamination source.)

Verify that, if the water use served by a backflow preventer is deemed critical by the BCE, approved backflow preventers are installed in parallel.

(NOTE: Installation in parallel is intended to allow maintenance or repair of the backflow preventer without system shutdown.)

Verify that new and existing backflow devices are planned for and installed to be readily accessible.

(NOTE: See the definition of 'readily accessible' in AFI 32-1066, para 5.5 or, in the manual, above.)

(NOTE: The BPM may exempt a device from being located in a readily accessible 


\section{COMPLIANCE CATEGORY: \\ WATER QUALITY MANAGEMENT \\ Overseas ESOHCAMP}

\begin{tabular}{|l|}
\hline \multicolumn{1}{|c|}{ REGULATORY } \\
REQUIREMENTS: \\
\hline WQ.15.27.OCAF. Backflow \\
prevention devices must be \\
located in safe places (AFI \\
32-1066, para 6.3) [Added \\
September 2008]. \\
\\
\\
WQ.15.28.0CAF. Backflow \\
prevention devices should be \\
protected (MP) [Added Sep- \\
tember 2008].
\end{tabular}

REVIEWER CHECKS:
September 2009

position if no safe, reasonable, or feasible location can be provided.)

Verify that backflow devices under the above exemption are documented on AF Form 845.

Verify that backflow prevention devices are outside of areas containing toxic, poisonous, or corrosive fumes.

(NOTE: The Command BPM may approve placement in such locations.)

Verify that, in addition, no reduced-pressure or other venting devices are installed immediately above electrical panels and chemical storage areas.

(NOTE: The BPM may approve placement in such locations.)

Verify that no relief ports, collector assemblies, or drainage piping connected to venting devices are located in or drained to locations that potentially create flooding hazards.

Verify that drainage piping is twice the pipe diameter of the piping to the backflow device.

Verify that enclosures are installed to secure exterior backflow preventers that serve critical or high-risk facilities.

(NOTE: Examples of critical or high-risk facilities are those identified in the installation's Water Vulnerability Assessment and other force protection documents.)

Verify that enclosures are designed to prevent tampering and to prevent adversaries from using the backflow preventer to introduce contaminants into the building's drinking water system.

(NOTE: Backflow preventers serving only nonpotable uses [i.e., fire protection systems] are excluded.)

(NOTE: This MP is found at AFI 32-1066, para 6.3.)

WQ.15.29.OCAF. Hose bibb devices are subject to specific requirements (AFI 32-1066, para 6.5) [Added September 2008].
Verify that atmospheric vacuum breaker-type devices that meet ASSE Standard 1011-2004, Performance Requirements for Hose Connection Vacuum Breakers, at a minimum, are specified.

Verify that, in commercial, industrial, and recreational areas, nonremovable hose bibb-type backflow devices are installed on potable water outlets when there is the potential for contaminants or pollutants to enter through hoses.

Verify that protection is provided where attached hoses can be submerged or are normally unattended when used. 


\section{COMPLIANCE CATEGORY: \\ WATER QUALITY MANAGEMENT \\ Overseas ESOHCAMP}

\section{REGULATORY REQUIREMENTS:}

WQ.15.30.OCAF. Backflow protection on AF fire suppression systems must be in accordance with Chapter 6 of AWWA Manual M14 (AFI 32-1066, para 6.6) [Added September 2008].

WQ.15.31.OCAF. New fire suppression systems are subject to specific requirements (AFI 32-1066, paras 6.6.1 and 6.6.3) [Added September 2008].

\section{REVIEWER CHECKS: September 2009}

(NOTE: In freezing climates, self-draining, frost-proof hose bibbs with integral backflow preventers or vacuum breakers are highly recommended.)

(NOTE: Hose bibbs in housing areas are not required to have backflow devices unless documented hazards exist.)

Verify that backflow protection on AF fire suppression systems is in accordance with Chapter 6 of AWWA Manual M14.

(NOTE: Backflow protection on AF fire suppression systems is not subject to the provisions of the UPC.)

(NOTE: UFC 3-600-01, Fire Protection Engineering for Facilities, requires that fire suppression systems be in accordance with National Fire Protection Association [NFPA] 13, Standard for the Installation of Sprinkler Systems. NFPA 13 requires backflow preventers to be approved and listed for fire protection use by acceptable testing agencies such as Underwriters Laboratories Inc. ${ }^{\circledR}$ or Factory Mutual Research Corporation.)

Verify that backflow preventers are approved and listed for fire protection use by acceptable testing agencies such as Underwriters Laboratories Inc. ${ }^{\circledR}$ or Factory Mutual Research Corporation.

Verify that the rated working flow rate of the backflow prevention device selected or installed meets the flow requirements of the system.

(NOTE: This requirement is typically addressed as part of design and submittal acceptance.)

Verify that, if a backflow device must be mounted in a vertical position, the device is rated and approved for vertical installation.

(NOTE:Fire protection systems that use nonpotable water are exempt from backflow requirements.)

Verify that all new fire suppression systems using potable water have backflow prevention installed.

Verify that a double check valve backflow preventer is installed on new dry/wet fire suppression systems that use only water as a fire suppressant (with or without fire department [Siamese] connections).

Verify that a reduced pressure-type backflow device is used only where antifreeze, foam, or other hazardous chemicals are added.

(NOTE: Pressure losses through a backflow prevention device will degrade the effectiveness of a fire protection system. Design and submittal acceptance by a registered PE must be completed to ensure that the rated working flow rate of the 


\section{COMPLIANCE CATEGORY: \\ WATER QUALITY MANAGEMENT \\ Overseas ESOHCAMP}

\section{REGULATORY REQUIREMENTS: \\ WQ.15.32.0CAF. Existing fire suppression systems are subject to specific require- ments (AFI 32-1066, paras 6.6.2 and 6.6.3) [Added Sep- tember 2008].}

WQ.15.33.OCAF. The BPM ensures that a schedule is developed and used by certified technicians to inspect and test backflow assemblies (AFI 321066, para 8.1) [Added September 2008].

WQ.15.34.OCAF. Certified backflow technicians must complete specific annual in-

\section{REVIEWER CHECKS: September 2009}

selected valve will meet the flow requirements of the system. In some cases, significant modifications to the fire protection system are required to offset the pressure loss caused by the backflow device.)

(NOTE: Existing fire suppression systems using only water as a fire suppressant are exempted from the backflow requirements for new systems if they met the existing backflow requirements at the time they were installed.)

Verify that systems that use antifreeze, foam, or other hazardous chemicals are retrofitted with a reduced pressure backflow device.

Verify that a double check valve backflow preventer is installed on dry/wet fire suppression systems that use only water as a fire suppressant when:

- replacing or upgrading backflow protection on existing systems

- making significant modifications to the fire suppression system.

Verify that a reduced pressure-type backflow device is installed only where antifreeze, foam, or other hazardous chemicals are added, or where the local, state, or water provider codes specifically require existing water-only fire protection systems to be retrofitted with such a device.

(NOTE: When there is a valid requirement to upgrade, install, or change a backflow device on a fire protection system, increased pressure losses and resulting lower flow rates must be considered.)

Verify that a registered Professional Engineer (PE) (preferably a fire protection engineer) approves the design and all submittals for any additions or changes to the backflow protection devices installed on fire protection systems.

(NOTE: Pressure losses through a backflow prevention device will degrade the effectiveness of a fire protection system. Design and submittal acceptance by a registered PE must be completed to ensure that the rated working flow rate of the selected valve will meet the flow requirements of the system. In some cases, significant modifications to the fire protection system are required to offset the pressure loss caused by the backflow device.)

Verify that a schedule is developed for the testing and inspection of backflow assemblies.

Verify that certified technicians use this schedule to inspect and test backflow assemblies.

Verify that certified backflow technicians inspect identified cross-connection locations to ensure that: 


\begin{tabular}{|c|c|}
\hline \multicolumn{2}{|r|}{$\begin{array}{c}\text { COMPLIANCE CATEGORY: } \\
\text { WATER QUALITY MANAGEMENT } \\
\text { Overseas ESOHCAMP }\end{array}$} \\
\hline $\begin{array}{l}\text { REGULATORY } \\
\text { REQUIREMENTS: }\end{array}$ & $\begin{array}{l}\text { REVIEWER CHECKS: } \\
\text { September } 2009\end{array}$ \\
\hline $\begin{array}{l}\text { spection tasks (AFI 32-1066, } \\
\text { para 8.2) [Added September } \\
\text { 2008]. }\end{array}$ & $\begin{array}{l}\text { - proper air gaps are maintained } \\
\text { - backflow prevention devices are in good condition and readily accessible } \\
\text { - newly installed devices were installed correctly and are free of debris that } \\
\text { could interfere with their testing or functioning } \\
\text { - devices have been properly insulated and protected against freezing weather } \\
\text { conditions and that test ports are accessible. } \\
\text { (NOTE: Per AFI 32-1066, para 5.2, a backflow preventer is a device or assembly } \\
\text { to prevent backflow into the potable water system. The terms "backflow pre- } \\
\text { venter," "backflow device," and "backflow assembly" are used interchangeably in } \\
\text { the industry and in AFI 32-1066.) }\end{array}$ \\
\hline $\begin{array}{l}\text { WQ.15.35.OCAF. Backflow } \\
\text { prevention devices must be } \\
\text { tested in accordance with spe- } \\
\text { cific requirements (AFI 32- } \\
\text { 1066, para 8.3) [Added Sep- } \\
\text { tember 2008]. }\end{array}$ & $\begin{array}{l}\text { Verify that all backflow prevention devices are tested in accordance with } \\
\text { FCCCHR's Manual of Cross-Connection Control, Section 9, or the manufac- } \\
\text { turer's instructions for the particular device, or using procedures recognized by } \\
\text { the tester's certifying agency. } \\
\text { Verify that, at a minimum, testable devices are tested after installation, cleaning, } \\
\text { repair or relocation, and at least annually. } \\
\text { (NOTE: Per AFI 32-1066, para 5.2, a backflow preventer is a device or assembly } \\
\text { to prevent backflow into the potable water system. The terms "backflow pre- } \\
\text { venter," "backflow device," and "backflow assembly" are used interchangeably in } \\
\text { the industry and in AFI 32-1066.) }\end{array}$ \\
\hline $\begin{array}{l}\text { WQ.15.36.OCAF. Inspec- } \\
\text { tion and testing of backflow } \\
\text { prevention devices must be } \\
\text { documented in accordance } \\
\text { with specific requirements } \\
\text { (AFI 32-1066, para 8.4.1) } \\
\text { [Added September 2008]. }\end{array}$ & $\begin{array}{l}\text { Verify that technicians record test data on AF Form } 843 \text { and AF Form 845, state } \\
\text { mandated forms, the Automated Civil Engineer System Program Management } \\
\text { module (ACES-PM), or another CMMS system approved by the base BPM. }\end{array}$ \\
\hline $\begin{array}{l}\text { WQ.15.37.OCAF. Only cer- } \\
\text { tified military or civilian per- } \\
\text { sonnel or contractors are au- } \\
\text { thorized to test and maintain } \\
\text { backflow prevention devices } \\
\text { (AFI 32-1066, para 9) [Added } \\
\text { September 2008]. }\end{array}$ & $\begin{array}{l}\text { Verify that only certified military or civilian personnel or contractors test and } \\
\text { maintain backflow prevention devices. }\end{array}$ \\
\hline $\begin{array}{l}\text { WQ.15.38.OCAF. Backflow } \\
\text { technicians must meet certifi- } \\
\text { cation requirements (AFI 32- } \\
\text { 1066, paras 9.1 and 9.2) } \\
\text { [Added September 2008]. }\end{array}$ & $\begin{array}{l}\text { Verify that backflow technicians have either a current backflow/cross-connection } \\
\text { certification from the state or a certification issued by the MAJCOM. } \\
\text { (NOTE: MAJCOMs certify and recertify backflow prevention technicians as- } \\
\text { signed to their command using database systems such as the ACES-PM module, a } \\
\text { CMMS, or AF Form 483.) }\end{array}$ \\
\hline
\end{tabular}




\section{COMPLIANCE CATEGORY: \\ WATER QUALITY MANAGEMENT \\ Overseas ESOHCAMP}

\section{REGULATORY REQUIREMENTS:}

\section{REVIEWER CHECKS: September 2009}

(NOTE: All MAJCOM certifications expire after 3 yr. Transfer of personnel between MAJCOMs does not require recertification until the certificate expires. Similar certificates obtained by technicians from states or other governmental agencies or organizations are valid until they expire.)

(NOTE: Backflow technician certifications are issued by the MAJCOM BPM based on the recommendation of the BCE.)

Verify that individuals recommended by the BCE for MAJCOM certification have:

- at least a 5-level or equivalent experience

- have received on-the-job training and experience in inspecting and testing the types of devices installed at the installation

- satisfactorily completed an approved training program such as:

- Sheppard Technical Training Center's Backflow Prevention Devices course

- a backflow prevention course recognized by the host state

- a backflow prevention course sponsored by a nationally or internationally recognized professional organization with written and performance examinations.

(NOTE: Technicians who take a state-recognized course must also have passed the state's backflow device tester's examination.)

(NOTE: After evaluating the circumstances, and based on a unique situation, specific location, or other factors, the BCE may decide to certify a skill level lower than 5-level.)

[Author's Note: AFI 32-1066, para 9, does not specifically address how the certifications of backflow prevention technicians are to be evaluated on installations in a foreign country or territory. In the event that a means of demonstrating technician certification other than those presented in the AFI seems appropriate, BPMs on installations in foreign countries or territories should consider reviewing the certifications of their technicians with the MAJCOM BPM.]

(NOTE: Backflow technicians obtain a MAJCOM recertification using data furnished by the BCE; see checklist item number WQ.15.39.OCAF.)

Verify that the BCE requests recertification and provides the following information at least 60 days prior to the 3-yr anniversary date listed on AF Form 483:

- date the technician completed an approved retraining course, unless the technician has inspected and tested a number (usually 50) of representative backflow device types since he or she was last certified

- date and description of supplemental backflow prevention courses and training completed

- device types and frequency of tests, inspections, and maintenance tasks 


\begin{tabular}{|c|c|}
\hline \multicolumn{2}{|r|}{$\begin{array}{c}\text { COMPLIANCE CATEGORY: } \\
\text { WATER QUALITY MANAGEMENT } \\
\text { Overseas ESOHCAMP }\end{array}$} \\
\hline $\begin{array}{l}\text { REGULATORY } \\
\text { REQUIREMENTS: }\end{array}$ & $\begin{array}{l}\text { REVIEWER CHECKS: } \\
\text { September } 2009\end{array}$ \\
\hline September 2008]. & $\begin{array}{l}\text { - a statement attesting to the technician's proficiency maintaining said de- } \\
\text { vices. }\end{array}$ \\
\hline $\begin{array}{l}\text { WQ.15.40.OCAF. The BCE } \\
\text { must provide the MAJCOM a } \\
\text { list of assigned certified tech- } \\
\text { nicians and must update the } \\
\text { list annually (AFI 32-1066, } \\
\text { para 9.3) [Added September } \\
\text { 2008]. }\end{array}$ & $\begin{array}{l}\text { Verify that the BCE provides the MAJCOM a list of assigned certified techni- } \\
\text { cians. } \\
\text { Verify that the BCE updates the list annually. } \\
\text { (NOTE: The MAJCOM tracks the number of certified technicians for each of its } \\
\text { bases.) }\end{array}$ \\
\hline
\end{tabular}


13-24

Water Quality 


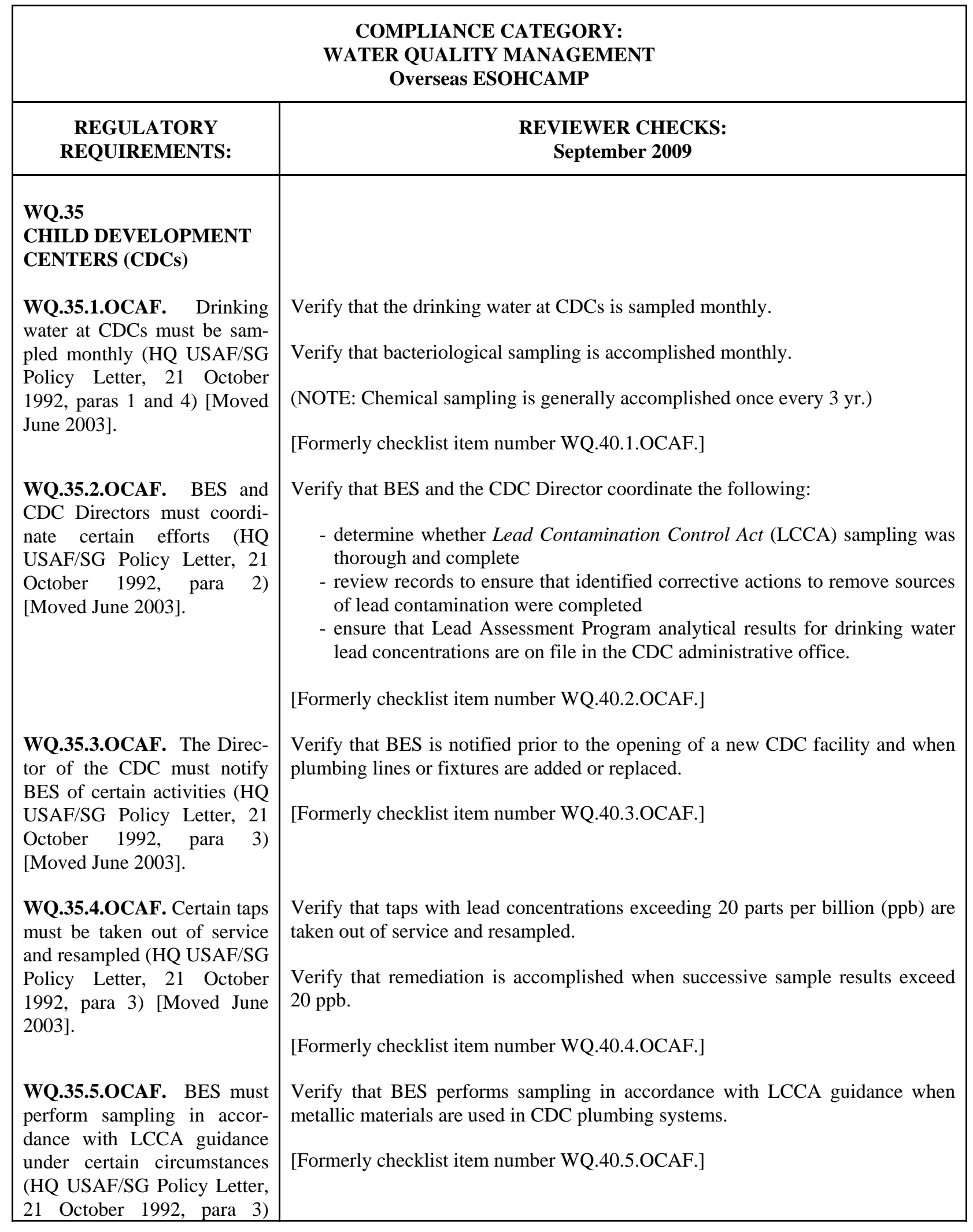




\begin{tabular}{|c|c|}
\hline \multicolumn{1}{|c|}{$\begin{array}{c}\text { COMPLIANCE CATEGORY: } \\
\text { WATER QUALITY MANAGEMENT } \\
\text { Overseas ESOHCAMP }\end{array}$} \\
\hline $\begin{array}{c}\text { REGULATORY } \\
\text { REQUIREMENTS: }\end{array}$ & $\begin{array}{c}\text { REVIEWER CHECKS: } \\
\text { September 2009 }\end{array}$ \\
\hline [Moved June 2003]. & \\
\hline
\end{tabular}




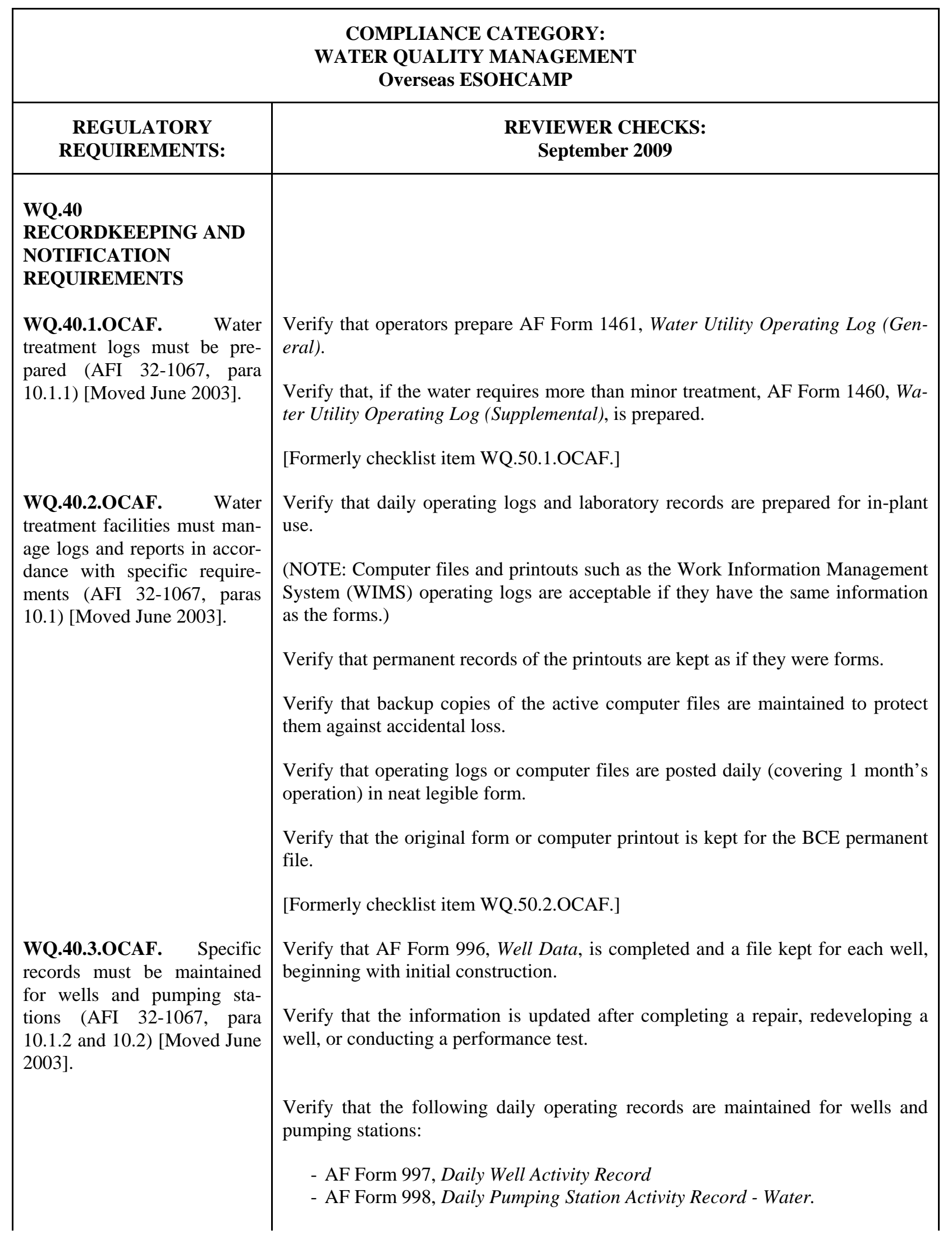




\section{COMPLIANCE CATEGORY: \\ WATER QUALITY MANAGEMENT \\ Overseas ESOHCAMP}

\section{REGULATORY REQUIREMENTS:}

WQ.40.4.OCAF. Facilities should establish local procedures for preparing coordinating, reviewing, and approving logs and reports (MP) [Moved June 2003].

WQ.40.5.OCAF. Specific physical facility information must be developed, maintained, and kept available at treatment facilities (AFI 321067, para 10.2) [Moved June 2003].

WQ.40.6.OCAF. Installations must develop and maintain effective maintenance plans that address specific topics (AFI 32-1067, para 10.3) [Moved June 2003].

WQ.40.7.OCAF. BCE must notify MAJCOM A7C and the base bioenvironmental engineer when the potable water supply becomes contaminated or polluted (AFI 32-1066, para 4.3.3) [Moved June 2003; Revised September 2008; Citation Revised September 2008].

\section{REVIEWER CHECKS: September 2009}

[Formerly checklist item WQ.50.3.OCAF.]

Verify that water treatment and wastewater treatment facilities establish local procedures for preparing coordinating, reviewing, and approving logs and reports.

(NOTE: This MP is found in AFI 32-1067, para 10.1.3.)

[Formerly checklist item WQ.50.4.OCAF.]

Verify that the following information is developed, maintained, and kept available at the treatment facilities:

- required plant-specific Operations and Maintenance (O\&M) manuals and applicable AF publications

- system operating instructions with single-line drawings, including operational and compliance monitoring procedures

- up-to-date system as-built drawings along with other system plans and blue prints, including hydraulic water elevation profiles and a drawing of the entire collection and distribution systems

- AF Form 996, Well Data

- shop drawings, catalogue cuts, and any other equipment information or literature.

[Formerly checklist item WQ.50.5.OCAF.]

Verify that the installation develops and maintains effective maintenance plans that include:

- a recurring work schedule

- a maintenance history for each major piece of equipment

- an essential spare parts list, with spare parts stocked at the treatment facility or other accessible location

- a long-range maintenance and improvement plan.

[Formerly checklist item WQ.50.6.OCAF.]

Verify that MAJCOM/CE is notified when the potable water supply becomes contaminated or polluted.

(NOTE: See the definitions for High Hazard and Low Hazard in the introductory matter to this section of the manual.)

[Formerly checklist item WQ.50.7.OCAF.] 


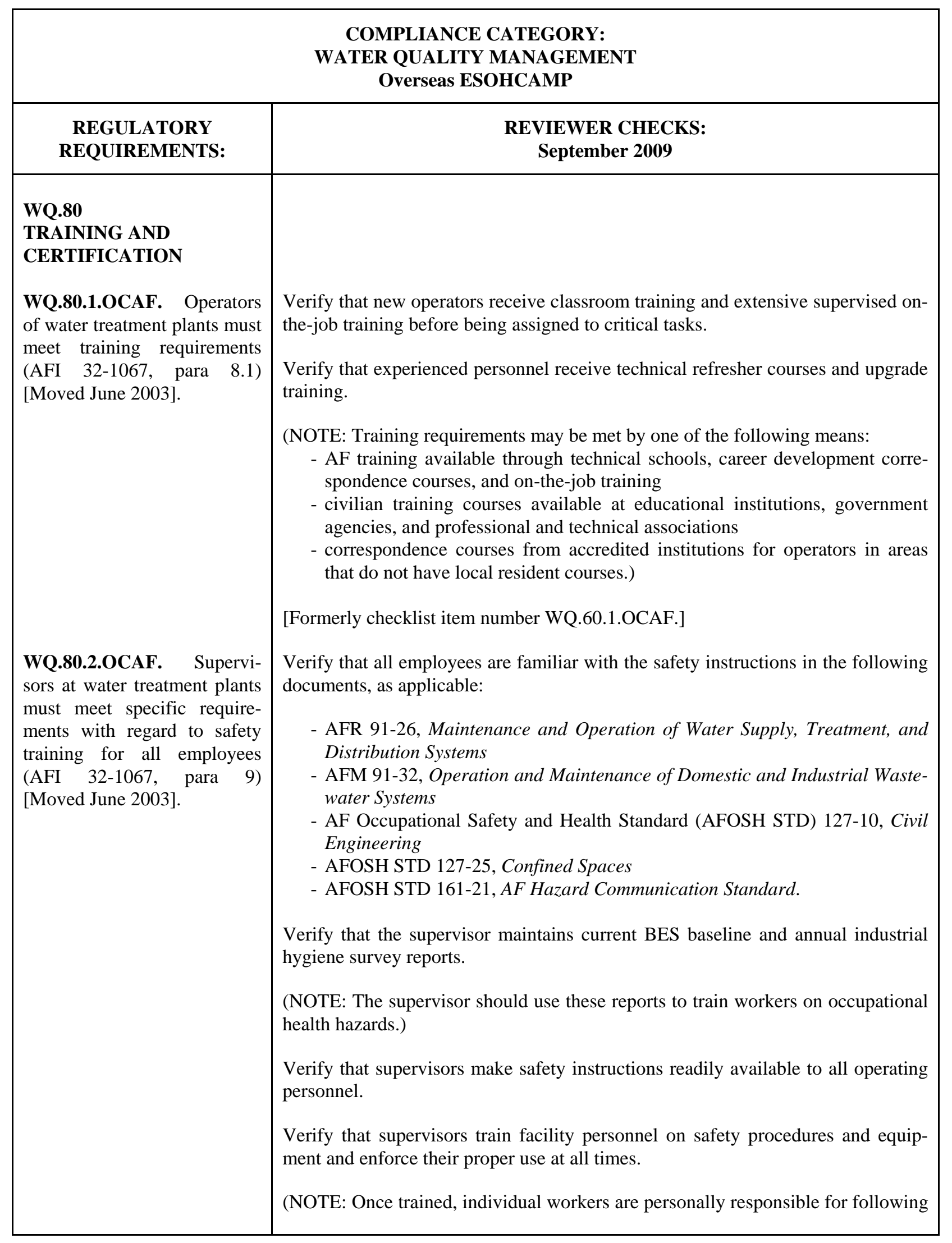




\begin{tabular}{|c|l|}
\hline \multicolumn{2}{|c|}{$\begin{array}{c}\text { COMPLIANCE CATEGORY: } \\
\text { WATER QUALITY MANAGEMENT } \\
\text { Overseas ESOHCAMP }\end{array}$} \\
\hline $\begin{array}{c}\text { REGULATORY } \\
\text { REQUIREMENTS: }\end{array}$ & \multicolumn{1}{c|}{$\begin{array}{c}\text { REVIEWER CHECKS: } \\
\text { September 2009 }\end{array}$} \\
\hline & safe procedures.) \\
& [Formerly checklist item number WQ.60.2.OCAF.] \\
\hline
\end{tabular}




\section{Appendix 13-1}

Potable Water Vulnerability Assessment Criteria

(HQ USAF/SGO Memorandum, AF Policy on Potable Water Vulnerability

Assessment and Emergency Response Plans, Attachment 2)

\section{ANTITERRORISM/FORCE PROTECTION (Intentional Threats)}

\section{CHARACTERIZE THE DRINKING WATER SYSTEM (Permanent or Temporary)}

1.1 Determine the potable water mission objectives and prioritize them:

- Mission-Critical Operations

- Force Protection

- Firefighting

- Potability (what drinking water standards must be met)

- Sanitation

- Other (e.g., non-critical industrial processes, irrigation, etc.)

1.2 Identify Each System's Critical Assets

- Water Sources (groundwater, surface water, purveyor supply)

- Transmission System

- Treatment Processes

- Storage (raw, treated, and firefighting)

- Distribution

- Supplemental Support Systems (power, personnel, communications, Supervisory Control and Data Acquisition (SCADA), transportation)

1.3 Describe How the System Operates (Overview)

- $\quad$ System Configuration

- System Integrity (e.g., component ages, structural condition and associated problems)

- Operational Parameters (e.g., pressure and disinfectant residual ranges)

- O\&M and Monitoring Programs

- Supply and Demand (total and firefighting)

- Chemical Use, Handling and Storage

- $\quad$ Projected Capital Improvements

- Projected Changes to Operations and Maintenance

\section{DETERMINE CRITICAL ASSETS SUBJECT TO INTENTIONAL ACTS AND ADVERSE CONSEQUENCES}

2.1 Identify Critical Control Points (CCPs) Subject to Contamination and/or Service Disruption

- Water Sources (groundwater, surface water, purveyor supply)

o Facilities

o Intake/pump equipment

o Controls

o Purveyor transmission lines

- Transmission System

o Pipelines

o Transmission Pumps

o Valves

o Appurtenances (hydrants, backflow prevention devices, blow-offs, taps, couplings, etc.) 
- $\quad$ Treatment Processes

o Facilities

o Process equipment

o Controls

o Chemicals

- $\quad$ Storage (raw, treated, and firefighting)

o Tanks/Containers (fixed or temporary)

o Controls

o Valves

o Appurtenances (hatches, vents, overflow pipes, etc.)

- Distribution

o Pipelines (mains, laterals, service lines, building plumbing, mobile transport)

o Booster Pumps

o Valves

o Appurtenances (hydrants, backflow prevention devices (BPDs), blow-offs, taps, couplings, etc.)

- $\quad$ Supplemental Support Systems

o Power

o Supervisory Control and Data Acquisition (SCADA)

o Personnel

o Communications

o Transportation

\section{EVALUATE EXISTING COUNTERMEASURES}

3.1 Assess Potable Water Critical Asset Security Programs, as a Minimum:

- Civil Engineering

o Facilities Staffing and Hours of Manned Coverage

o Access/Entry Control Procedures

o Site Inspection Frequencies and Procedures

o Employment Security Screening Procedures

o Security System SCADA Operations and Maintenance

- Security Forces

o Knowledge of Critical Assets, Locations, and Authorized O\&M Personnel

o Inclusion of Critical Assets on Patrol Routes

3.2 Assess Physical Security Measures for all Critical Assets (Site Survey)

- Deterrence

- Detection

- Delay

- Response

3.3 Assess Contamination and Disruption Factors for each Critical Control Point (Site Survey)

- Contaminant Routes of Entry

- Route of Entry Accessibility (e.g., pressurized/unpressurized access point, availability of hatches, vents and other openings, tools, etc.)

- Contaminant Attenuation Factors

o CCP Location Relative to Treatment Process

o Type of Treatment

o Contact Time (if applicable)

o Dilution (e.g., storage volume, interconnections with other supply water, etc.)

- Contaminant Delay Factors

o Proximity to Consumers

o Estimated Travel Time Between Introduction Point and Consumer Point of Use (POU) 
- Contaminant Detection Capability (e.g., in-line continuous monitor)

- Isolation Valves

- Emergency Bypasses

- Redundant Components and Backup Systems

\section{IDENTIFY ADVERSE CONSEQUENCES TO AVOID}

4.1 Determine Likely Contamination and Disruption Threats and Associated Hazards

- Sabotage (contaminant introduction, manipulation of treatment process, physical destruction, cyber attack)

- Wartime Attack (weapons of mass destruction, secondary contamination from conventional weapons, physical destruction from munitions impacts)

4.2 Perform Adverse Consequences Analysis for Each Credible Threat; Identify:

- Critical Assets Most Vulnerable to the Threat

- Potential Magnitude of Effects on the Potable Water System, Mission and People

- Likely Service Disruption Hazards and Consequences on Mission and People

- Likely Contamination Hazards and Consequences on Mission and People

\section{ASSESS LIKELIHOOD OF ATTACK FOR EACH VULNERABLE CCP}

5.1 Consider Intentional Threat Types:

- Enemy States

- Terrorist Operatives or Extremist Groups (e.g., militants)

- Disenfranchised Individuals (e.g., fanatics, revenge-seekers)

- Insiders or Collusion (insider and outsider)

- Vandals

5.2 Evaluate the Following Items, as a Minimum:

- Criticality of Asset (real or "perceived")

- Local Threat Information and Intrusion History

- Location (on/off base, remoteness, etc.)

- Accessibility (by foot and by vehicle)

- Staff Presence and/or Regularity of Operator Visits and Security Patrols

- Lighting

- Observable Barriers and Intrusion Detection System

- Evidence of Vandalism/Signs of Intrusion

6. ANALYZE RISK AND DEVELOP A PRIORITIZED RISK REDUCTION PLAN

6.1 Conduct a Risk Assessment for Each Vulnerable Critical Control Point, Factoring:

- Likelihood (Probability) of Attack

- Effectiveness of Existing Countermeasures (Controls)

- Potential Consequences of Attack on People and Mission

6.2 Rank Vulnerable Critical Control Points by Relative Risk Level

6.3 Identify Suggested Corrective Control Actions for Each Vulnerable CCP

\section{SANITARY SURVEY (Unintentional Threats)}

1. CHARACTERIZE THE DRINKING WATER SYSTEM (Permanent or Temporary) 
1.1 Determine the potable water mission objectives and prioritize them:

- Mission-Critical Operations

- Force Protection

- Firefighting

- Potability (what drinking water standards must be met)

- Sanitation

- Other (e.g., non-critical industrial processes, irrigation, etc.)

1.2 Identify Each System's Critical Assets

- Water Sources (groundwater, surface water, purveyor supply)

- Transmission System

- Treatment Processes

- Storage (raw, treated, and firefighting)

- Distribution

- Supplemental Support Systems (power, personnel, communications, Supervisory Control and Data Acquisition (SCADA), transportation)

1.3 Describe How the System Operates (Overview)

- System configuration

- $\quad$ System Integrity (e.g., component ages, structural condition and associated problems)

- Operational Parameters (e.g., pressure and disinfectant residual ranges)

- O\&M Programs

- Monitoring Program

- Supply and Demand (total and firefighting)

- Chemical Use, Handling and Storage

- $\quad$ Projected Capital Improvements

- Projected Changes to Operations and Maintenance

\section{DETERMINE CRITICAL ASSETS SUBJECT TO NONINTENTIONAL ADVERSE CONSEQUENCES}

2.1 Identify Critical Control Points (CCPs) Subject to Contamination and/or Service Disruption

- Water Sources (groundwater, surface water, purveyor supply)

0 Facilities

o Intake and pump equipment

o Controls

o Purveyor transmission lines

- Transmission System

o Pipelines

o Transmission Pumps

o Valves

o Appurtenances (hydrants, backflow prevention devices (BPDs), blow-offs, taps, couplings, etc.)

- Treatment Processes

o Facilities

o Process equipment

o Controls

o Chemicals

- $\quad$ Storage (raw, treated, and firefighting)

o Tanks/Containers (fixed or temporary)

o Controls

o Valves 
o Appurtenances (hatches, vents, overflow pipes, etc.)

-Distribution

o Pipelines (mains, laterals, service lines, building plumbing, mobile transport)

o Booster Pumps

o Valves

o Appurtenances (hydrants, backflow prevention devices (BPDs), blow-offs, taps, couplings, etc.)

- Supplemental Support Systems

o Power

o Personnel

o Communications

o Supervisory Control and Data Acquisition (SCADA)

o Transportation

\section{EVALUATE EXISTING COUNTERMEASURES}

3.1 Assess Potable Water Protection Programs, as a Minimum:

- Operations and Maintenance

o Training and Resources

o Source Water and Wellhead Protection Program

o Cross-connection Control and Backflow Prevention

o Mains Flushing and Fireflow Testing

o Pipeline Breaks, Installations, and Disinfection

o Valve Inspections and Exercising

o Storage Tank Operation (e.g., turnover), Inspections and Maintenance

o Treatment Processes O\&M

o SCADA/Telemetry Systems O\&M

o Capital Improvements Roadmap

- Monitoring

o Environmental Sampling, Analysis and Monitoring (ESAM) Plan

o Quality Assurance/Quality Control

o Outside Laboratory Support

o Maximum Contaminant Level (MCL) Exceedence Procedures (e.g., follow-up monitoring and reporting)

3.2 Assess Contamination and Disruption Factors for each Critical Control Point (Site Survey)

- Contaminant Sources (e.g., POL/hazmat storage, agricultural/industrial activities, sewage lines, injection wells, RCRA sites, birds/rodents/farm animals/pests, vehicle transport and parking, etc.)

- Potential Contaminants and Routes of Entry

- $\quad$ Route of Entry Accessibility (e.g., pressurized/unpressurized point, effective/deteriorated hatch seals or vent screens, presence/absence of proper backflow protection, permeable/impermeable geology, etc.)

- Contaminant Attenuation Factors

o CCP Location Relative to Treatment Process

o Type of Treatment

o Contact Time (if applicable)

o Dilution (e.g., storage volume, interconnections with other supply water, etc.)

- Contaminant Delay Factors

o Proximity to Consumers

o Estimated Travel Time Between Introduction Point and Consumer Point of Use (POU)

- Contaminant Detection Capability (e.g., in-line continuous monitor)

- Isolation Valves

- Emergency Bypasses

- Redundant Components and Backup Systems 


\section{IDENTIFY ADVERSE CONSEQUENCES TO AVOID}

4.1 Determine Credible Contamination and Disruption Threats, and Associated Hazards

- Insufficient O\&M

- Contaminant Spills, Leaks and Runoff

- $\quad$ Natural Event (e.g., flooding, high winds, drought)

- Major Accident (e.g., POL or munitions detonation, fire, aircraft mishap)

4.2 Perform Adverse Consequences Analysis for Each Credible Threat; Identify:

- Critical Assets Most Vulnerable to the Threat

- Potential Magnitude of Effects on the Potable Water System, Mission and People

- Likely Service Disruption Hazards and Consequences on Mission and People

- Likely Contamination Hazards and Consequences on Mission and People

\section{ASSESS LIKELIHOOD OF NONINTENTIONAL INCIDENT FOR EACH VULNERABLE CCP}

5.1 As a Minimum, Consider the Following Items:

- All Contamination and Disruption Hazards

- Incident/Analytical History

- Effectiveness of Existing Countermeasures (administrative and engineering)

\section{ANALYZE RISK AND DEVELOP A PRIORITIZED RISK REDUCTION PLAN}

6.1 Conduct a Risk Assessment for Each Vulnerable Critical Control Point, Factoring:

- Likelihood (Probability) of Incident

- Effectiveness of Existing Countermeasures (Controls)

- Potential Consequences of Incident on People and Mission

6.2 Rank Vulnerable Critical Control Points by Relative Risk Level

6.3 Include Suggested Corrective Control Actions for Each Vulnerable CCP

\section{POTABLE WATER EMERGENCY (CONTINGENCY) RESPONSE PROGRAM FOR INTENTIONAL AND UNINTENTIONAL THREATS}

1. Validate CE Readiness Flight (CEX) Elements

- Determines the types of manmade and natural disasters that threaten the installation

- Develops, in conjunction with BE, the WMD incident detection and monitoring program.

- As owner of the CE Contingency Response Plan, ensures the plan is periodically updated by appropriate subject matter experts (i.e., CEO, CE Fire Department (CEF), etc.)

- Assists the exercise evaluation team (EET) chief in developing response exercises

o Advocate to include scenarios involving water asset/infrastructure, to allow CE Control Center personnel (CEO), Water Utilities (CEOIU), CEF, and BE to exercise contingency response duties, scenarios should include local supplies if the water source is off-base.

- Ensures planning coordination, with the Local Emergency Planning Committee (LEPC)

2. Validate Civil Engineering Operations Flight (CEO) Elements

- Has established effective relationships with commercial infrastructure providers to address all vulnerability issues and ensure infrastructures are available as required

- Ensures an effective Utility Contract/Agreement exists with purveyors that addresses vulnerability cooperation, supply assurances, and accessibility (if necessary) 
- The CEO EET member, in coordination with Bioenvironmental Engineering and Fire Dept EET members, develops and submits scenario inputs involving water assets and infrastructure to the EET Chief for inclusion in wing and unit exercises

- As the primary technical developer of the potable water component of the CE Contingency Response Plan (CRP), periodically reviews and updates the component

- The CRP incorporates applicable information from Vulnerability Assessments that meet the criteria of the SDWA, Section 1433, "Terrorist and Other Intentional Acts".

- The CRP provides sufficient guidance and information to enable CE personnel to respond quickly and effectively to all contingencies, in order to maintain or restore the installation's operational capability to meet its wartime or peacetime missions

- The CRP includes actions, procedures, and identification of equipment that can obviate or lessen the impact of terrorist attacks, other intentional actions, and non-intentional incidents on the safety and supply of potable water provided to consumers. As a minimum, the CRP:

o Identifies all viable/approved primary, alternate, and emergency potable water sources (including mutual aid from nearby DoD facilities)

o Identifies all primary and alternate nonpotable water sources, both on and nearby off base

o Includes accurate utility distribution system drawings showing locations of critical isolation valves and emergency bypasses

o Details system mitigation and restoral actions, including response team ' $G r a b-n-G o$ "' checklists

o Lists specific contacts at other DoD installations, local contractors, or other sources, and the types and quantities of equipment they possess, and restrictions on their availability

o Includes appropriate contracts, agreements, and memorandums of understanding (MOU)

o Includes a Water Demand Reduction Plan (AFPAM 10-219 Vol I A3.18.6 Contingency Disaster Planning) and a Priority Facilty Return-to-Service Plan

3. Validate CE Water Utilities (CEOIU) Elements

- Personnel (both military and civilian) are sufficiently trained to respond to potable water disruption and contamination contingencies (i.e., identifying critical valve locations, operating and maintaining reverse osmosis water purification units (ROWPUs), etc.)

- Retains appropriate staffing and procedures (e.g., on-call) to quickly and effectively respond to potable water contingencies $24 / 7$

- Maintains sufficient equipment and material (e.g., spares, emergency back-up, emergency treatment, communications equipment, transportation, etc.) to respond quickly and effectively to all credible potable water contingencies

- Keeps up-to-date system maps showing critical valve and emergency bypass locations, and appropriate contingency response checklists on hand (e.g., within response vehicles)

- Assists CEO with updating the CE CRP as necessary, and voice concerns if provisions for appropriate support elements are not in place (e.g., contractors

- Ensures emergency generators, generator fuel, communications equipment (e.g., radios, SCADA), and other contingency response equipment and material are being maintained as required by outside offices (i.e., Power production, Communications Squadron, etc.)

- Ensures proper procedures are followed for disinfection and notifying Bioenvironmental Engineering after main breaks and installations.

- Ensures the Fire Alarm Center is alerted when mains or Fire Suppression Systems are out of service due to scheduled work or unforeseen events (e.g., line breaks)

4. Validate CE Fire Department (CEF) Elements

- Has determined, in conjunction with CEO or CE Engineering (CEC), peak fire flow demand requirements for the installation

- Ensures hydrant flow tests are conducted annually, and that results are reviewed to identify pressure and flow problems in particular areas of the installation 
- Is aware of potable water system deficiencies that do not meet peak fire flow demands overall, or for particular installation facilities

- Has taken appropriate steps to advocate system upgrades, as necessary

- Has identified and listed alternate, nonpotable water sources for firefighting (e.g., emergency water storage (EWS) tanks, swimming pools, ponds, lakes, rivers, ocean, wells, etc.)

- Is equipped and trained to quickly draft from emergency water sources

- Ensures that EWS tanks are properly maintained and topped off

- Maintains written mutual aid agreements with neighboring community or DoD fire departments

- Ensures new facility and water system construction designs are being coordinated and reviewed through the Fire Dept to ensure firefighting requirements are being addressed

- Ensures the Fire Alarm Center is being alerted when mains or Fire Suppression Systems are out of service due to scheduled work or unforeseen events (e.g., line breaks)

5. Validate Bioenvironmental Engineering (BE) Elements

- Personnel (both military and civilian) are sufficiently trained to respond to potable water contamination contingencies

- $\quad$ Retains appropriate staffing and procedures (e.g., on-call) to quickly and effectively respond to potable water contingencies 24/7

- Maintains the BE Team Annex for the Medical Contingency Response Plan (MCRP), which outlines support to the base:

o Monitoring of base water supply to ensure potability, vulnerability and survivability

o Monitoring of chemical, biological, and radiological hazards

- Updates and maintains MCRP Annex checklists, designed as quick reference, chronological lists of actions required in any given situation (e.g., water contamination incidents, suspected or actual, intentional or accidental)

- Maintains appropriate equipment and supplies to sample and analyze water for known or unknown contaminants in the event of a suspected or actual contamination incident (e.g., appropriate screening kits, sample containers and preservatives, bomb or Kemmerer discrete samplers for stratified tank sampling, etc.)

- Ensures provisions are in place with base agencies and support lab(s) to expedite contingency monitoring, shipping, analysis, and appropriate funding 24/7

- Has established provisions for sample chain-of-custody handling and evidence preservation 


\section{Appendix 13-2}

AF Deadlines for Initial Comprehensive WVA

(HQ USAF/SGO Memorandum, AF Policy on Potable Water Vulnerability Assessment and Emergency Response Plans, Attachment 4)

\begin{tabular}{|l|c|c|c|c|}
\hline $\begin{array}{l}\text { Type of Drinking Water System } \\
\text { (serving }>\text { 25 people) }\end{array}$ & $\begin{array}{c}\text { WVA Re- } \\
\text { quired by }\end{array}$ & $\begin{array}{c}\text { WVA Report } \\
\text { Deadline }\end{array}$ & ERP Deadline & $\begin{array}{c}\text { Approximate \# } \\
\text { of AF Systems }\end{array}$ \\
\hline $\begin{array}{l}{ }^{2} \text { Regulated and unregulated Community Wa- } \\
\text { ter System (CWS) and consecutive CWS } \\
\text { serving }>3300 \text { people }\end{array}$ & $\begin{array}{c}\text { EPA and AF } \\
\text { policy }\end{array}$ & 30 Jun 04 & $\begin{array}{c}31 \text { Dec 04 (Certifi- } \\
\text { cation Due to EPA) }\end{array}$ & 79 \\
\hline $\begin{array}{l}{ }^{3} \text { Overseas Public Water System (PWS) that } \\
\text { produce water and/or are provided water by a } \\
\text { local supplier }\end{array}$ & AF Policy & 31 Dec 05 & 30 Jun 06 & 42 \\
\hline $\begin{array}{l}\text { All other regulated CWS (serving }<3300 \\
\text { people) }\end{array}$ & AF Policy & 31 Dec 06 & 31 Dec 07 & 15 \\
\hline $\begin{array}{l}{ }^{4} \text { Unregulated PWS (e.g., customer-only sys- } \\
\text { tems) }\end{array}$ & AF Policy & 30 Jun 07 & 30 Jun 08 & 96 \\
\hline $\begin{array}{l}\text { Regulated consecutive PWS serving >25 } \\
\text { people (including: consecutive CWS, con- } \\
\text { secutive Non-Transient Non-Community Wa- } \\
\text { ter System (NTNCWS), and consecutive } \\
\text { Transient Non-Community Water System } \\
\text { (TNCWS) }\end{array}$ & AF Policy & 30 Jun 07 & 30 Jun08 & \\
\hline $\begin{array}{l}\text { Other non-transient, non-community water } \\
\text { PWS (NTNCWS) }\end{array}$ & AF Policy & 30 Jun 08 & 30 Jun 09 & \\
\hline $\begin{array}{l}\text { Other transient, non-community water PWS } \\
\text { (TNCWS) }\end{array}$ & AF Policy & 30 Jun 09 & 30 Jun 10 & 13 \\
\hline Total & & & & \\
\hline
\end{tabular}

Notes:

1. Standard water system definitions can be found in 40 CFR 141.2 or Chapter 3 of the DOD 4715.5-G "Overseas Environmental Baseline Guidance Document"

2. Regulated - A system that is subject to EPA NPDWR requirements and located within the U.S. and its territories.

3. Overseas - A system that is not located within the U.S. and its territories.

4. Unregulated - A system that is within the U.S. and its territories but is not subject to EPA NPDWR requirements because it does not sell or treat drinking water and buys all drinking water from another supplier (a.k.a. "customer-only").

5. Consecutive - A regulated system that buys all or some of its water from another supplier and treats/sells drinking water to consumers. 
